\title{
PLEISTOCENE STRATIGRAPHY AND GLACIAL HISTORY OF THE CENTRAL PART OF DENMARK
}

\author{
Michael Houmark-Nielsen
}

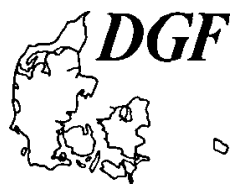

Houmark-Nielsen, M.: Pleistocene stratigraphy and glacial history of the central part of Denmark. Bull. geol. Soc. Denmark, vol. 36, pp. 1-189. Printed 9-10-1987. https://doi.org/10.37570/bgsd-1988-36-01

The Pleistocene deposits of Denmark are largely composed of two major facies that interfinger with each other: 1) tills, and 2) waterlaid outwash material. The two facies are occasionally interbedded with interglacial or interstadial deposits.

By applying lithostratigraphy combined with structural analysis in open exposures, a glacial stratigraphy of the Pleistocene has been established, and the glacial history interpreted. Only till units are classified lithostratifically because of their high regional consistency compared to waterlaid outwash deposits. Correlation of till units is based on three basic properties: lithology, stratigraphic position and associated glaciotectonic boundaries.

Lithic characteristics, some of which have local value whilst others indicate regional properties, include data on local glacier flow directions from fabric analyses and the contents of provenance dependent compositional features, the latter may provide information on the long range path of glaciers. Fine gravel analyses and stone counts demonstrate, that distinct stratigraphical relationships exist between tills rich and poor in quartz as well as between tills of Fennoscandian and Baltic provenance primarily indicated by the quantities of Paleozoic limestone clasts. The contests of re-deposited Quaternary foraminifera primarily serve as lithic characteristica and secondly as a guide line to estimate the possible age of a till unit.

Bounding relations between till units are studied with special emphasis on glaciotectonic unconformaties. They not only serve as supreme marker horizons on a regional scale, but they also supply high rank information on the local direction of glacier movement. Analysis of glaciotectonic structures often constitutes the implement by which the stratigraphy of a dislocated glacial sequence can be recognized.

Using a combined set of glacial-stratigraphic methods, about 200 selected localities in the central part of Denmark have been investigated over the past ten years.

Studies at eight principal localities and two key localities, some of which are classical exposures, provide the foundation for a litho-stratigraphic model for the till units.

The Elsterian glaciaiton is represented by three till units (SØNDER VISSING TILL, PALSGÅRD TILL, SNOGHØJ TILL) of Norwegian, Middle Swedish and Baltic provenance respectively. The Saalian comprise three till units (TRELDE NÆS TILL, ASHOVED TILL, LILLEB/ELT TILL), the two former are of Fennoscandian provenance and the latter of Baltic provenance; deposited in the above mentioned order by icesheets from the north, the northeast and from the east respectively. The Weichselian is build up of six till units, the oldest of which (RISTINGE KLINT TILL) was most probably deposited later than 36800 BP. This Baltic till is followed by three tills of Fennoscandian provenance (KATTEGAT TILL, MID DANISH TILL, NORTH SJELLAND TILL) deposited respectively from the north, the northeast, and the east. The two youngest Weichselian till units are of Baltic provenance (EAST JYLLAND TILL, BAELTHAV TILL) and they were deposited from south-easterly directions before 13500 BP.

Till beds are erected into formal lithostratigraphic units of Formation rank and they are extended to cover extraregional till units, correlation is based on stratigraphic position, lithology and boundaries.

The following glacial history can be outlined.

During the Elsterian the Sønder Vissing till, the Palsgård till and the Snoghøj till were deposited by three glacial advances probably in the chronological order as mentioned above. During the Holsteinian interglacial, marl and diatomite were deposited in lake basins in the central part of the region.

The Saalian glaciation was initiated with the deposition of outwash material by southerly to southwesterly directed meltwater streams and succeeded by an ice-stream from southern Norway, which deposited the Trelde Næs Till. After deposition of this till, interstadial conditions prevailed, and outwash material was deposited by westward flowing meltwater streams. This interstadial phase was followed by the second Saalian glacial advance during which the Ashoved Till was laid down by an ice-sheet from Middle Sweden. Prior to the last Saalian glacial phase, outwash material was deposited by generally westward flowing meltwater streams, that probably emerged from the Palaeobaltic ice. This latter deposited the Lillebælt Till and invaded the country from the western part of the Baltic.

During the Eemian, lake sediments were formed in kettle bogs on the surface of the Lillebælt Till, while at the same time, marine sediments were deposits in the southem and northern part of the examined region.

Tundra vegetation developed in a dry polar climate characterize the Early- and the larger part of the Middle Weichselian. Interstadial deposits with an age of about 36800 BP were formed on Sejer $\varnothing$ - probably prior to the Old Baltic ice advance, which in the southern and eastern part of the region deposited 
the Ristinge Klint Till from the Baltic. The Old Baltic advance was succeeded by the Norwegian advance which came from southern Norway crossing the Kattegat depression and deposited the Kattegat Till in the northern part of the region. After deposition of the previously mentioned two till units, interstadial conditions re-occurred and meltwater streams transported outwash material northward into the Kattegat basin.

A change in meltwater palaeocurrent direction towards the west indicates the approach of the Main Weichselian advance. This advance crossed Middle Sweden and deposited the Mid Danish Till, and it probably reached its maximum extension along the Main Stationary Line at around 20000 BP. A readvance during the general retreat of the Main Weichselian icestream crossed Fyn from the NE, and outwash streams were generally directed towards the north until a younger re-advance from easterly directions deposited the North Sjalland Till in the eastern part of Denmark. This re-advance may have occupied the northeastern part of Denmark and Kattegat before giving way to the transgression of the Younger Yoldia Sea, which was initiated about $15000 \mathrm{BP}$ in Vendsyssel. Whilst this transgression was progressing the Main Weichselian ice sheet retreated to a probable position along the Swedish west coast. Northward flowing meltwater streams prevailed, at this time, in the central Danish region, until the Young Baltic icesheet advanced from the Baltic depression and deposited the East Jylland Till. This advance formed the East Jylland ice border line, probably around 14000 BP. During the East Jylland advance, northward directed drainage patterns prevailed in the northern part of the region, whereasoutwash material was deposited by westward flowing streams in southern Jylland.

The East Jylland ice sheet retreated to a position south-east of the examined region before the Bælthav re-advance deposited the Bælthav Till. Still supplied from the Baltic this readvance reached the classical Odsherred ice marginal zone of Northwest Sjzlland and gave rise to the final molding of the ice marginal hills of North Samsø and the archshaped shoals in Storebælt.

During the Weichselian, the Saalian, and probably also the Elsterian, the direction of the majority of ice sheet advance that invaded Denmark changed in a "clockwise" manner. During each glacial, an initial advance from the north was succeeded by one from northeast ending up with one from the east and southeast. The change in direction of advance is accompanied by a corresponding change in the provenance dependent elements of the till units. Hence, the "clockwise" pattern established for the Danish region can reflect a fundamental trend in the dynamic evolution of consecutive Scandinavian ice sheets. The present study therefore, may provide important guide lines for future attempts to establish more detailed theoretical glaciological models for the dynamics of these former Scandinavian ice sheets.

Houmark - Nielsen, Michael. Institut of General Geology, University of Copenhagen, Østervoldgade 10, DK-1350 København K., Denmark. June 16th 1987. 


\section{Contents}

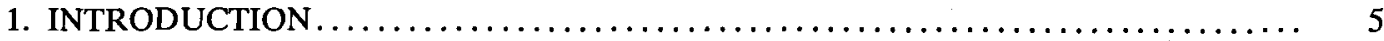

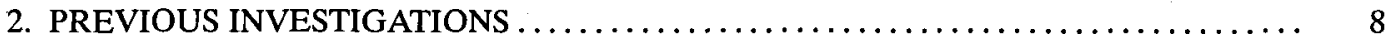

3. METHODS OF STUDY: LITHOSTRATIGRAPHY $\ldots \ldots \ldots \ldots \ldots \ldots \ldots \ldots \ldots \ldots \ldots \ldots \ldots \ldots$

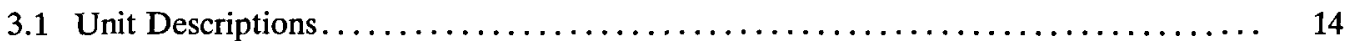

3.2 Lithic Characteristics......................................... 15

3.3 Textural Properties............................................. 15

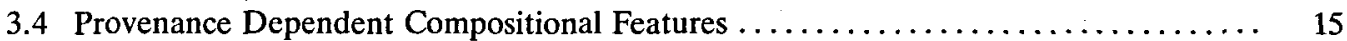

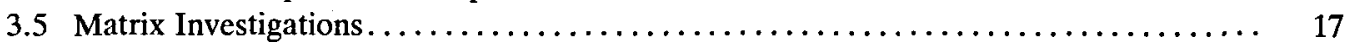

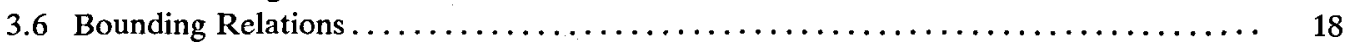

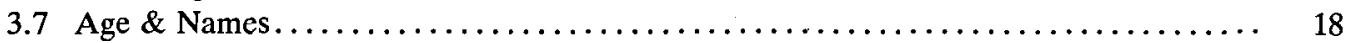

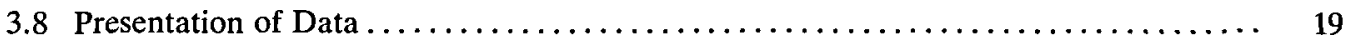

4. GLACIAL STRATIGRAPHY OF PRINCIPAL LOCALITIES $\ldots \ldots \ldots \ldots \ldots \ldots \ldots \ldots \ldots 22$

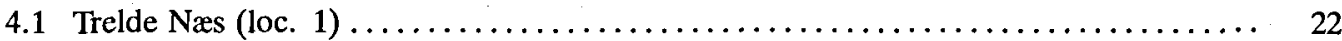

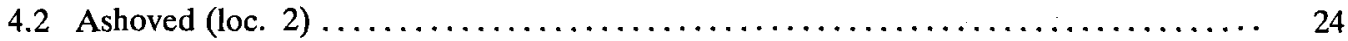

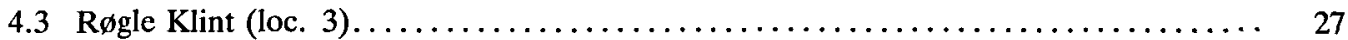

4.4 Ebelø (loc. 4) .............................................. 33

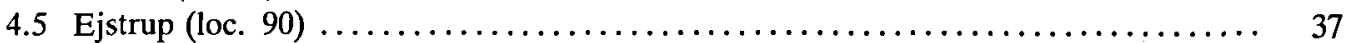

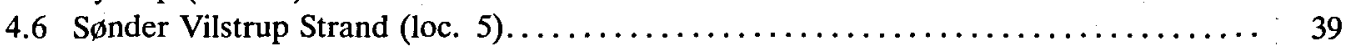

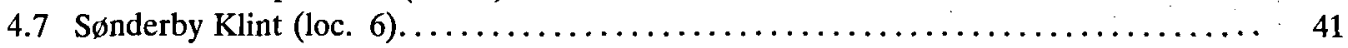

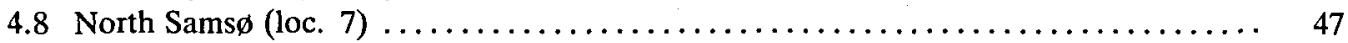

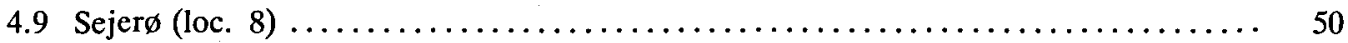

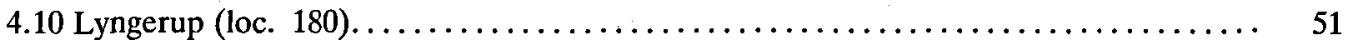

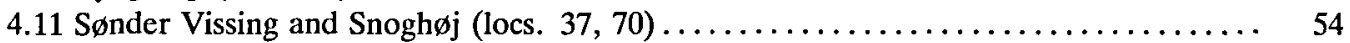

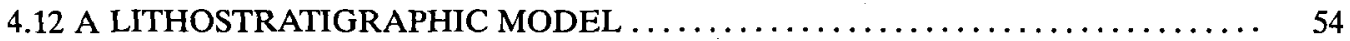

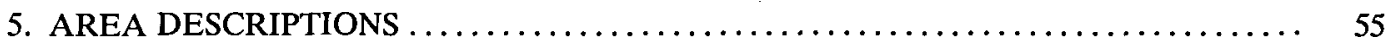

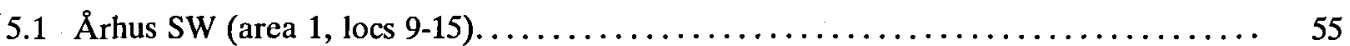

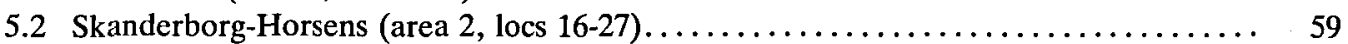

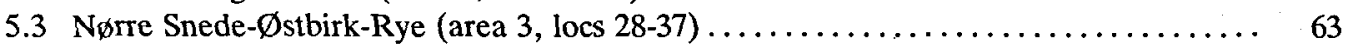

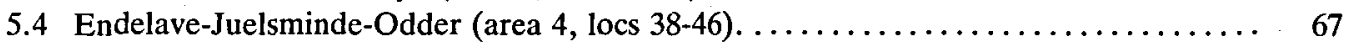

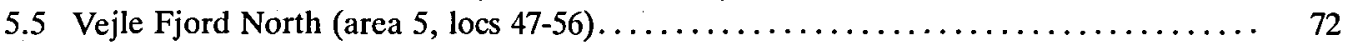

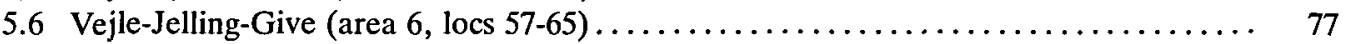

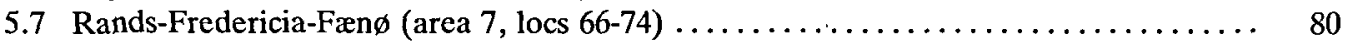

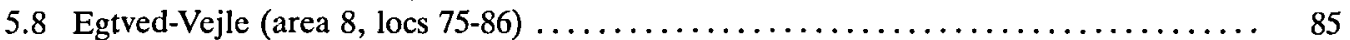

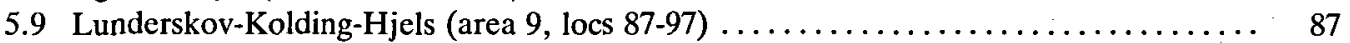

5.10 Western Southeast Jylland (area 10, locs $98-106) \ldots \ldots \ldots \ldots \ldots \ldots \ldots \ldots \ldots$

5.11 Eastern South Jylland (area 11 , locs 107-115) ....................... 94

5.12 North Western Fyn (area 12, locs $116-125) \ldots \ldots \ldots \ldots \ldots \ldots \ldots \ldots \ldots \ldots \ldots . \ldots \ldots$

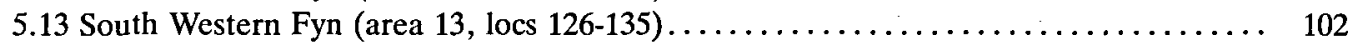

5.14 Mols-Helgenæs-Tun $\emptyset-N o r t h$ Sams $\emptyset$ (area 14, locs 136-144) . . . . . . . . . . . . 105

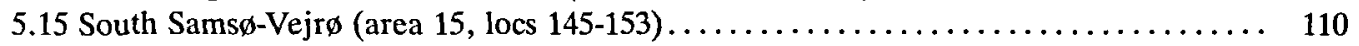

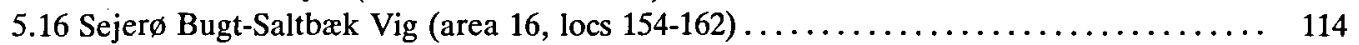

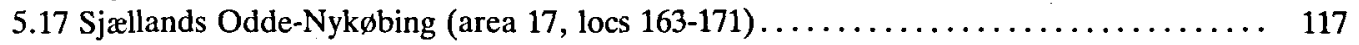

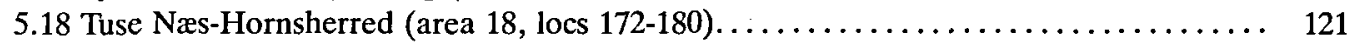

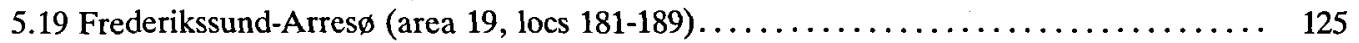

6. PLEISTOCENE STRATIGRAPHY IN THE CENTRAL PART OF DENMARK $\ldots \ldots \ldots$

Lithostratigraphic classification of Till Formations....................... 129

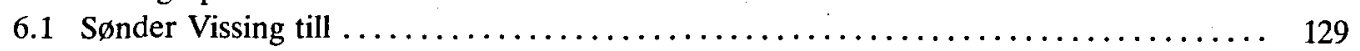

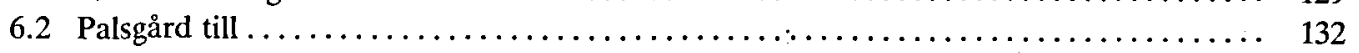

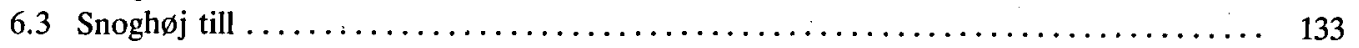




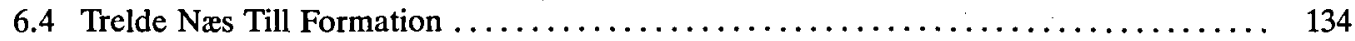

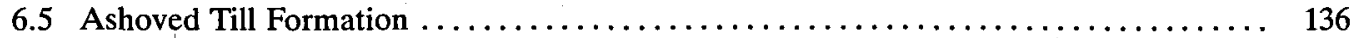

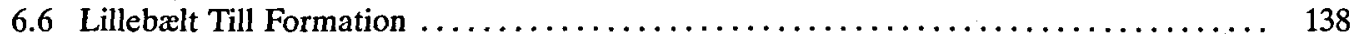

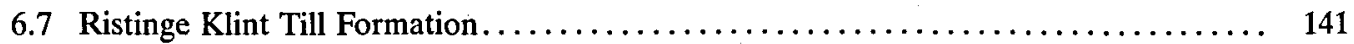

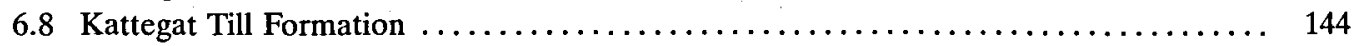

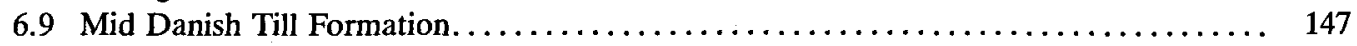

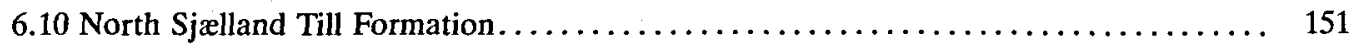

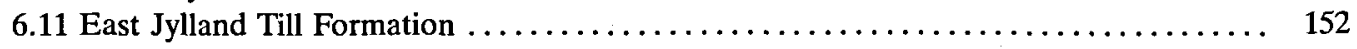

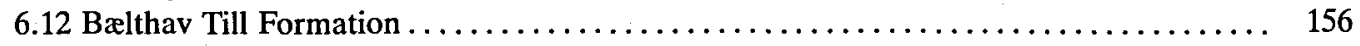

7. REGIONAL STRATIGRAPHY OF PLEISTOCENE TILL FORMATIONS $\ldots \ldots \ldots \ldots, 159$

8. GLACIAL HISTORY OF THE CENTRAL PARTS OF DENMARK $\ldots \ldots \ldots \ldots \ldots \ldots . \ldots$

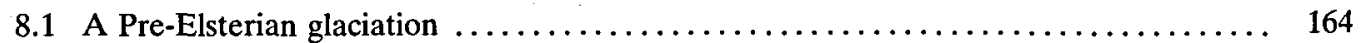

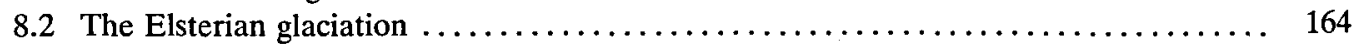

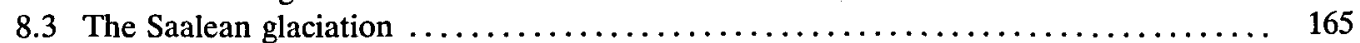

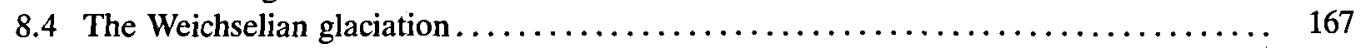

8.5 Age of the first Weichselian glaciation in Denmark $\ldots \ldots \ldots \ldots \ldots \ldots \ldots \ldots \ldots \ldots . \ldots \ldots$

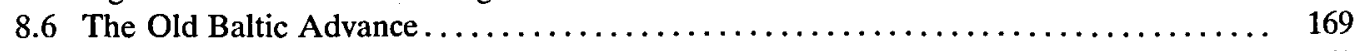

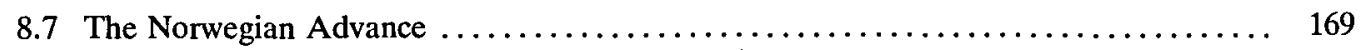

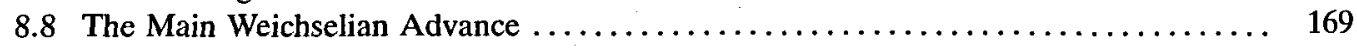

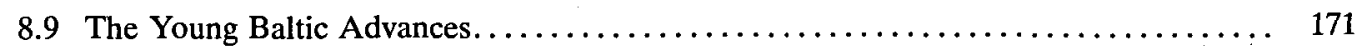

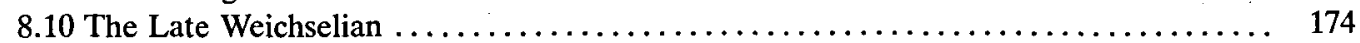

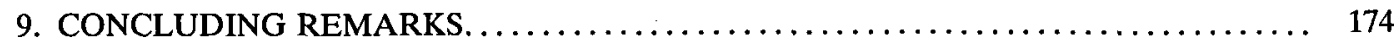

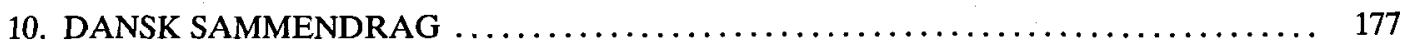

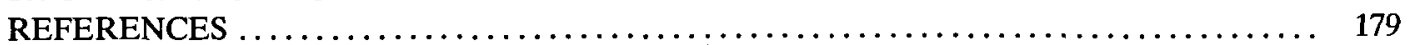




\section{INTRODUCTION}

Denmark is part of the North European midlatitude lowlands (fig. 1), which suffered repeated glaciations during the Pleistocene. Glaciers originating in the Scandinavian highlands in- vaded the country from northerly, northeasterly and southeasterly directions. The mixing during glacial transport of erratics respectively from southern Norway, middle Sweden and the Baltic Sea with more locally derived rocks and fine grained material eventually led to the successive

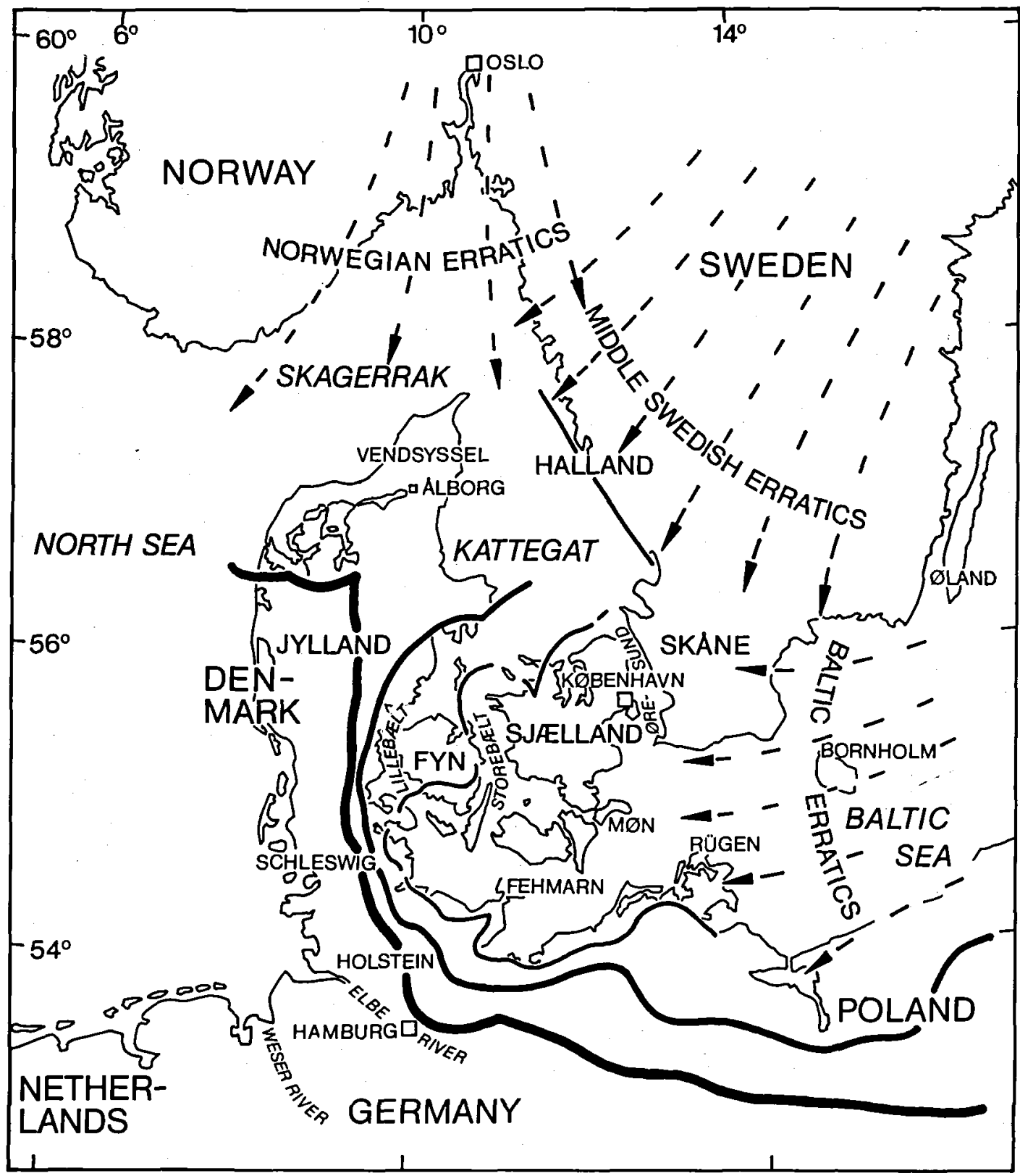

Fig. 1: Key map of Denmark and surrounding countries with major glaciation trends, dispersal of erratics and prominent Weichselian icemarginal positions. 
deposition of tills and outwash sediments. The resultant glacial sequences are found throughout Denmark and are occasionally interbedded with interglacial/interstadial deposits.

Owing to the erosive power of glaciers, exposures show local as well as regional "gaps". In addition, glaciotectonic deformation often caused a complex structural setting of the sequences now exposed. Thus, a structural chronology is added to the depositional succession and it is recognized, that the more tectonically composite exposures are, the more units can often be studied along cliff sites or excavations of restricted size.

The central Danish region has been subjected to intense glaciostratigraphic studies during the last century. One object of the present investigation was to test out and to continue development of classical as well as modern glacialstratigraphic methods within a kinetostratigraphic framework as presented by HoumarkNielsen \& Berthelsen (1981), and Houmark-Nielsen (1983b). Another object was to identify and give a formal classification of lithostratigraphic till units and to map their distribution within the examined region. A historical presentation of previous works is followed by the establishment of a lithostratigraphical model from studies of ten principal, key localities. This model is tested out and adjusted accordingly by examination of a dense network of 190 localities in the examined region before a lithostratigraphic classification of 12 till formations is errected. Thirdly, these studies have led to an increased knowledge of the glacial history of Denmark in general and the examined region in particular.

It is recognized that the Pleistocene of Denmark consists of an interfingering system of two major facies. 1) diamicton facies of glacial origin deposited as till; and 2) waterlaid facies comprising gravel, sand and mud mainly deposited by glacial outwash. The two facies are occasionally interconnected by transitional facies types (Houmark-Nielsen 1983a), but usually the facies boundaries are non-gradational and erosive on both a local and a regional scale. Biogenic, interglacial/interstadial deposits have been preserved locally and serve as important marker beds.

The concept of kineto-stratigraphy (Berthelsen 1973, 1978), which has been applied by several Danish geologists over the past decade (cf. Houmark-Nielsen \& Berthelsen 1981), pays special attention to the directional elements of tills and to glacier-induced deformations. A basic requirement in the use of kineto-stratigraphy and one which has been subsequently confirmed (cf. Berthelsen 1978, Petersen 1978, Sjørring 1981), is that each of the Pleistocene glaciers which reached Denmark possessed a characteristic and regular pattern of ice flow. The main emphasis in correlation of kineto-stratigraphic till units is therefore based on similarities in the kinetic pattern. However, if the direction of movement of a given ice sheet changes during the advance or retreat of the glacier, or the glacier splits up into lobes of independent directions of movement, or successive advances show similar directional patterns in the area of observation, difficulties arise in defining the individual till stratigraphic units on the basis of kinetics alone. In such cases the lithic characteristics of till, such as provenance dependent compositional features, may constitute the only valuable data for correlation.

By employing kineto-stratigraphy (HoumarkNielsen 1976a,b,c, 1980, 1981, Houmark-Nielsen \& Berthelsen 1981) and other sedimentary as well as morphological methods (Houmark-Nielsen 1983a, 1983b, 1983c, Houmark-Nielsen \& Kolstrup 1981, Clemmensen \& Houmark-Nielsen 1981) in the study of glacial deposits in the Central Danish region, a more conclusive stage has been reached where a formal lithostratigraphy of till units from the Pleistocene of Denmark can be established. The lithostratigraphic classification thus applied is founded on the North American Stratigraphic Code (North American Commission on Stratigraphic Nomenclature 1983), which is regarded as an up to date, readily accessible and more schematic presentation of the recommendations laid down in the International Stratigraphic Guide (International Subcommission on Stratigraphic Classification 1976). Lithostratigraphic classification combined with structural analyses on the deposits of former ice sheets provides information of the same character as a kineto-stratigraphic approach; and moreover it facilitates correlation with till units that have not been or can not be classified kineto-stratigraphically. It should however be mentioned, that a kineto-stratigraphic evaluation is given as well for a number of tills.

It has not been regarded advantageous to follow the North American Commission on Strat- 

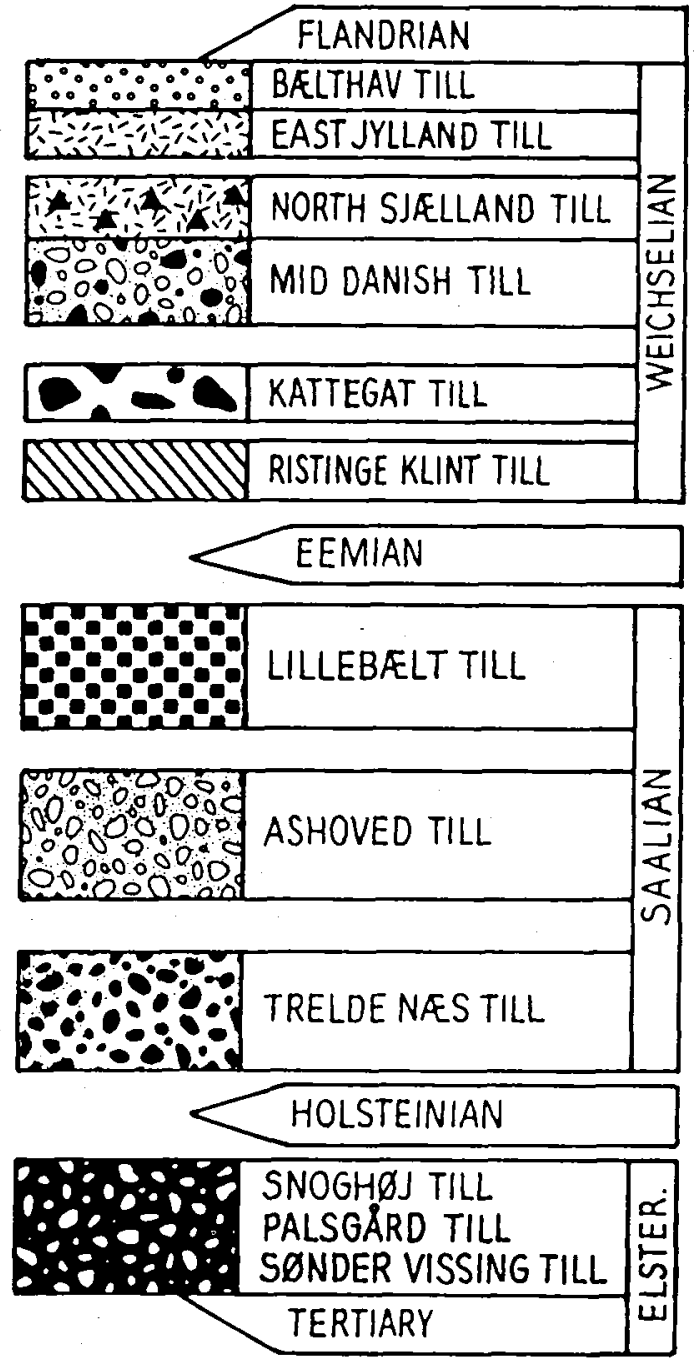

Fig. 2: Till-stratigraphic framework, central Danish region. Till signatures and names will appear throughout the present volume.

igraphic Nomenclature (1983) in applying an allostratigraphic classification as supplementary to the established kinetostratigraphy of glacigenetic deposits in Denmark. Allostratigraphic units are defined and identified on the basis of bounding discontinuities alone, thus internal characters, which play no role in allostratigraphic classification, may vary greatly both laterally and vertically throughout a unit.
As stated in the above mentioned stratigraphic codes, glacial deposits such as tills and outwash sediments may constitute valid lithostratigraphic units. Such deposits conform to the law of superposition and they can be classified according to lithic characters and stratigraphic position.

As a natural and readily applied substitute for the more formally correct and neutral term "diamicton", the word "till" is used to name diamict units, even though such a term would imply some genetic properties. This is considered to be justified because the diamict units classified lithostratigraphically in the present paper show a wide range of glacially imprinted characteristics which distinguishes them from diamictons deposited in environments not influenced by glaciation. To all appearances, the definition given by Francis (1975), that till is a diamicton deposited directly from or by glacier ice without intervention of running water, can be applied in the present classification. Therefore the word till is used here as a term for glacigenetic diamictons without any preference to mode of deposition such as lodging, basal meltout etc.

In the present study till units form the basic framework in glacial stratigraphy. They are deposited by large inland glaciers of high regional uniformity, whereas the waterlaid deposits often show local distribution, they hold inconsistant lithic characters and their paleocurrent patterns are governed by local topography.

The till-stratigraphic framework thus erected in the central part of Denmark is built up of 12 formations (fig. 2). Three older, Elsterian till units: Sønder Vissing till, Palsgård till and Snoghøj till underlie the Saalian Trelde Næs Till, Ashoved Till and Lillebælt Till. These are in turn overlain by six younger Weichselian formations comprising Ristinge Klint Till, Kattegat Till, Mid Danish Till, North Sjælland Till, East Jylland Till and Balthav Till.

The signatures for individual till-formations shown in fig. 2 are used as a leitmotif of the present thesis. The formations they represent appear throughout the central part of Denmark, but they can readily be extended to cover the whole of the country. 


\section{PREVIOUS INVESTIGATIONS}

This section is a historical review of glaciostratigraphic- and glaciomorphological studies in Denmark, with special attention upon the two fundamentally different lines of thinking, that is, the monoglacial and polyglacial models for the course of events during individual glacial stages. For geographical location of sites, regions and geological features mentioned in the text see fig. 3 .

Previous investigations of regional significance for stratigraphic studies in the central Danish region was initiated by the publication of map sheets by the Geological Survey of Denmark at the end of the last century.

Contrary to the view of Rørdam (1893) who favoured a polyglacial model for the Pleistocene it was Ussing's (1899) opinion, that a stratigraphic sequence of two till beds separated by water laid deposits was simply the product of oscillations of the same ice sheet and not evidence of two independent glacial phases. It was Ussing (1899) who gave the first meaningfull explanation of the main features of the Danish glacial landscape; his starting point was the glaciation model presented by Torell $(1872,1873)$ and DeGeer (1884). The great contribution of Ussing $(1903,1907)$ was to outline the Main Stationary Line (Hovedopholdslinien) through central Jylland. The course of this line was defined as the junction between the sand and gravel planes in the west and hilly country with boulder clay deposits towards the east. Ussing interpreted this morphological dividing line as being formed during a stationary period of a large inland ice sheet, which had previously covered the whole of Jylland. This ice sheet consisted of merging ice streams from Norway, Sweden and the Baltic, and during this stationary period northern and eastern Jylland, the Kattegat region and the Danish Islands were covered simultaneously by ice from the north, north-east and the east respectively. At this state the large sandur plains of western Jylland were formed. At a later stage the ice cap melted north-eastwards forcing the outwash to follow more northerly directed routes, through the western Limfjord region.

In a later edition Ussing (1913) implied that the East Jylland Ice-border line, described by Harder (1908) and the terminal moraines of Northwestern Sjalland (Odsherred buerne) described by
Milthers (1900), were younger features developed during halts in the general retreat of the joint ice cap, that previously had its position along the Main Stationary Line.

In contradiction to Ussing, Harder (1908) stated that the East Jylland Ice-border line represented the maximum extension of a younger and independent ice advance and he argued that the larger part of the previously ice covered Jylland was ice-free (except for isolated, dead ice masses) before the advance of the East Jylland ice. Meltwater streams from this ice advance were directed into the Kattegat depression, indicating that the larger parts of northern Denmark had become ice free. The pronounced difference in clast composition between the till deposited during the Main stationary state (characterized by Norwegian and other Fennoscandian indicators) and the till of the East Jylland advance (dominated by rock fragments of the Baltic) would, according to Harder, indicate that direction of glacier movement and region of provenance had shifted away from the Fennoscandian Shield towards a unified supply from the Baltic depression during the East Jylland advance.

Rørdam $(1893,1899)$ and Rørdam \& Milthers (1900) were the first to recognize two individual till beds separated by waterlaid deposits covering the larger part of North Sjælland. Rørdam described a lower till characterized by Norwegian indicators and re-deposited molluscan fragments derived from the Older Yoldia clay of Vendsyssel, as distinct from an upper till dominated by Baltic and Dala indicators. The waterlaid deposits, with amber and twig bearing sands and redeposited molluscan fragments similar to those found in the lower till was, in Rørdams opinion, of interglacial origin.

Supplemented by information from published mapsheets (Jessen 1899, 1907, Madsen 1897, 1900 , Milthers 1908, Ussing \& Madsen 1897) and descriptions of marine (Madsen et al. 1908) and limnic (Hartz \& Østrup 1899) deposits, Rørdam (1909) outlined the Quaternary stratigraphy of Denmark stating that tills from three glacials were separated by deposits of two interglacials.

According to Rørdam (1909) an Older Baltic ice age was succeeded by the First Interglacial, during which the Older Yoldia clay of Vendsyssel could have been deposited. During "the Great Ice age" an icesheet coming from the north 


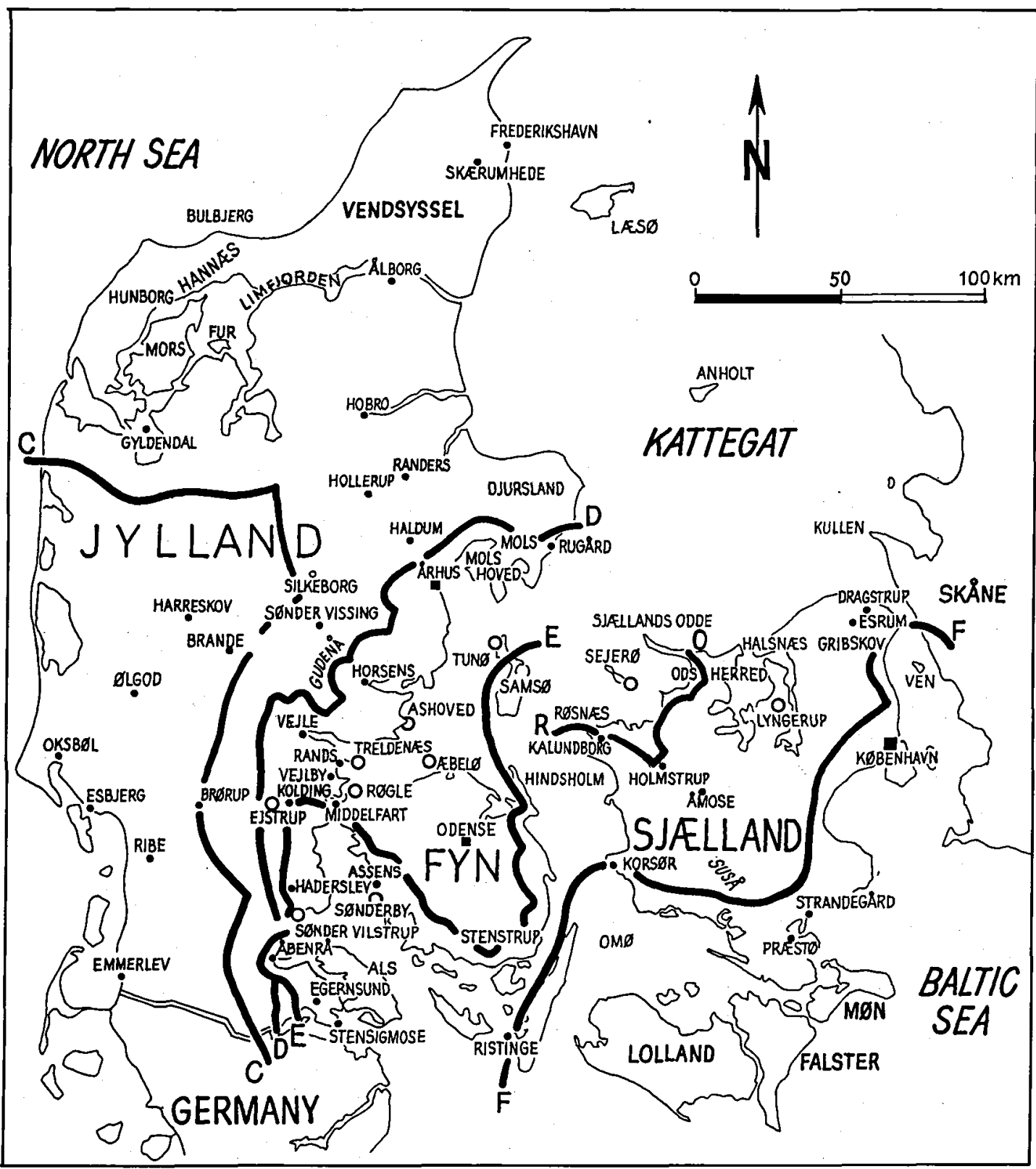

Fig. 3: Location map of Denmark with names mentioned in the text. Icemargins compiled after Madsen et al. (1928) and Ussing (1913) (C: Main Stationary Line, D: East Jylland Stage, E: Bælt Stage, F: Langeland-Øresund Stage, O: Odsherred Margin, R: Røsnæs Margin).

(whose extension is equivalent with that of the largest Saalian icesheet; Rørdam 1909, vol. 1, p. 337), led to the deposition of the so called lower till, which was dominated by Norwegian indicators, in North Sjalland and Eastern Jylland. The Great Ice age was succeeded by the Second Interglacial, during which marine Cyprina clay (referred to as Eemian clay), was deposited in the southern part of the country, while at the same time interglacial, freshwater deposits around Brørup and Kolding and other areas in Jylland were formed in lake basins.

The third glacial was termed the Younger Baltic ice age during which the inland ice had its maximum extension along the Main Stationary Line (Rørdam 1909, vol. 2, p. 154) and a Baltic 
till was deposited in eastern Denmark. During the deglaciation major recessional advances gave rise to the formation of the East Jylland Iceborder line, the Odsherred terminal moraines and the recessional lines southwards through Storebælt towards Langeland.

V.Milthers (1909) extended the chronology of ice sheets from the three glaciations by making extensive use of counts of indicator erratics. Apart from a possible ice advance before the first interglacial, the "Great Ice age" was divided into two individual advances. First an advance from the north that gave rise to outwash deposits dominated by Norwegian indicators in western Jylland. The Norwegian outwash was covered by a Baltic till during the following advance, which covered the whole of Jylland. This Baltic till forms the substratum of the interglacial bogs of Eemian age around Brørup and Kolding.

The third (last) glaciation, the maximum extension of which was placed along the Main Stationary Line or at times was lying slightly beyond it, was initiated by a Norwegian ice sheet in the northern part of the country, and may have advanced south of the E-W lying part of the Main Stationary Line. The Norwegian advance was gradually succeeded by a Baltic advance, which reached the N-S lying section of the Main Stationary Line or slightly more westward. A clockwise rotation in the overall direction of movement of the ice cap was recorded in the age relations of glacial striations on bedrock and the intermixture of indicator erratics with Norwegian, Middle Swedish and Baltic provenance. During deglaciation, icestreams of purely Baltic origin prevailed forming the East Jylland- and Odsherred Ice-border lines.

After two decades of intense stratigraphic study of the Pleistocene deposits, Rørdam's "triple-glacial" model could be amended, and a stratigraphical model combining all new information was presented by Madsen et al. (1928).

The first glacial was divided into an early Norwegian and a younger Baltic stage (Milthers 1909, 1913, Nordmann et al. 1923). Tills of these stages (termed till A) overlie Tertiary deposits at Røgle Klint and in the Esbjerg area, and are in turn overlain by the Tellina clay at Røgle and the Older Yoldia clay in Esbjerg (Jessen 1922).

The first interglacial is represented by the arctic to boreo-lucitanic Older Yoldia clay of Esbj- erg (Jessen 1922). This marine clay in the Esbjerg area is overlain by till deposits which are in turn overlain by undisturbed marine Eemian clay (Nordmann 1922, 1928) indicating that deposition of the Esbjerg Yoldia clay took place during the first interglacial. Limnic deposits were ascribed to the same interglacial on the indirect stratigraphic evidence of a specific floral evolution (Jessen \& Milthers 1928).

The second glaciation deposited the surface tills of western Jylland and the "lower" till of eastern Denmark overlying the previously mentioned interglacial deposits. The till of the second glaciation is termed till B. From data obtained at Røgle Klint and according to Jessen $(1922,1925)$ and Milthers (1925) till B has a rather complex clast and granulometric composition; it ranges from a sandy till dominated by Norwegian indicators (B1) to a chalk rich clayey till of Baltic composition (B2). With the works of Milthers (1909), Jessen et al. (1910) and Jessen \& Milthers (1928) in mind, Madsen et al. (1928) concluded, that the second glaciation was initiated by a Norwegian advance and succeeded by a Baltic advance both of which covered the whole of Jylland. A later Norwegian advance which covered at least the northern part of the country ends this glaciation.

During the second interglacial, boreo-lucitanic marine clay, the so called Cyprina Clay, (Madsen et al. 1908, Nordmann 1928) was deposited in the southern part of the country. The lower (boreal) part of the Skærumhede sequence (Jessen et al. 1910) was deposited simultaneously in northern Jylland, where it rests upon the Baltic facies of till B. Floral, faunal and stratigraphical descriptions and zonation of limnic deposits from western Jylland which rest upon till $B$ were published by Jessen \& Milthers (1928).

During the third glaciation the upper boreoartic to high-artic Older Yoldia clay of Vendsyssel (Jessen et al. 1910) was deposited. A subsequent ice advance to the Main Stationary Line dislocated these deposits from northerly directions (Jessen 1918). According to Madsen et al. (1928) it had become clear that the Main Stationary Line marked the limit of the last glaciation. Outside (west and south of) this line sketched by Ussing the undisturbed bogs of the previous (Eemian) interglacial were only covered by solifluction and outwash material (Jessen et al. 1918), whereas east of the line bogs were disturbed by glacial ac- 
tivity and often covered by till deposits (Jessen \& Milthers 1928). Also the pronounced morphological differences either side of the line (cf. Madsen 1921) was a strong argument in the discussion, and the idea of the Main Stationary Line marking the outer limit (with minor oscillations, Milthers 1925) of the ice cover of the last glaciation was generally accepted. Recently Marcussen \& Østergaard $(1977,1978)$ have questioned this accepted model of Danish glacial geology, but their views have been strongly rejected by Humlum et al. (1978).

The traditional concept of the retreat of the ice sheet from the Main Stationary Line as sketched by Ussing (1913) and Rørdam (1909) was adapted and extended by Madsen et al. with the modification that, between the major readvances, relatively ice free conditions prevailed over large parts of at least the central Danish regions as had already been proposed by Harder (1908).

Stratigraphic studies of key localities like Ristinge Klint (Madsen 1916) and Røgle Klint, supplemented with clast petrographic evidence from published mapsheets, enabled Madsen et al. (1928) to correlate individual till units on the basis of the flint quotient (Flint/Crystalline relationship). They set up a till stratigraphy for the last glaciation, where tills termed C, D, E and F were ascribed to glacial phases reaching the Main Stationary Line, the East Jylland Ice-border, the Bælt stage and the Langeland stage respectively (fig. 3). The flint quotient method of correlating till units was objected to by Jessen (1930) and Andersen (1945) and subsequently by Madsen \& Nordmann (1940) and Nordmann (1958).

Once this general Pleistocene stratigraphy was established, attention was focussed on the deglaciation pattern of the last glaciation.

V.Milthers (1932) used morphological observations and studies of indicator boulder erratics, mainly along the coasts of the central, Danish regions, to outline the glaciation pattern and particularly to focus on the retreat of the ice sheet from the East Jylland Ice-border line. V.Milthers saw the marked contrasts in morphology and indicator boulder content between the central parts and coastal areas of Fyn as the result of an older "Meridian" ice dominated by Norwegian indicators being succeeded by a Baltic ice sheet reaching the East Jylland Ice-border. Before reaching the stage of stagnation, which led to the creation of the central Fyn dead ice landscape, the East Jylland stage ice sheet would locally incorporate large amounts of material from the former "Meridian" ice. The Dala-Baltic ice sheet was still active in coastal areas, but upstream it had changed its direction of movement. This resulted in a change of erratic content in the till supposedly deposited by the East Jylland ice, from originally being dominated by red Baltic quartz porphyry it became dominated by brown quartz porphyry in southerly and coastal areas. V.Milthers extended the East Jylland Ice-border line south of Vejle and sketched recessional lines across South Jylland and Fyn using the ice border lines of Nordmann (1927). The recessional lines drawn through Storebalt were in strong opposition to those outlined by Rørdam (1909), Andersen (1927) and Madsen et al. (1928). This was especially true for the Røsnæs line, which Andersen (1927) on morphological grounds had shown to be the result of a glacier lying south of the peninsula, and which was in Milthers opinion moulded by a glacier lying north of Røsnæs. Milthers' result here was based on changes in the indicator erratic content of beach gravels.

K.Milthers (1942) used indicator boulder counts combined with morphological observations to outline the chronology of Pleistocene ice sheets over Denmark. With minor adjustments K.Milthers referred to V.Madsen et al. (1928), and V.Milthers (1909) in describing the course of events during the early glaciations, and much of V.Milthers' (1932) work forms the foundation of K.Milthers' interpretation of the last (Weichselian) glaciation. The interpretation divides this glacial period into three major phases. The oldest phase is a Norwegian ice sheet reaching the E-W lying part of the Main Stationary Line and possibly somewhat beyond it in the eastern part of Jylland. This ice sheet apparently never reached the northern coast of Sjælland. The second glacial phase of the last glaciation was a Dala-Baltic ice advancing from an easterly direction, which joined the older (Norwegian) ice sheet along the $\mathrm{N}-\mathrm{S}$ lying part of the Main Stationary Line. During deglaciation of this icesheet large dead ice masses were left on central Fyn. Hereafter a younger Dala-Baltic ice sheet reached the East Jylland Ice-border line without covering the dead ice massses of central Fyn. The third glacial phase was the Baltic ice sheet, which advanced along 
either side of the dead ice masses of Fyn to the Mols area, along the east coast of Jylland. Based on marked differences in quantities of red and brown Baltic quartz porphyry, K.Milthers sketched the same recessional phase as V.Milthers (1932) along the East Jylland coast to Horsens, eastwards over Tunø and South Samsø and further on to Sejerø and Sjælland. The splitting up into two independent ice lobes (one on Sjælland and another in the Bælt area) of the Baltic icesheet was initiated at its outermost position on Mols and retained during deglaciation over Samsø, Kalundborg Fjord, Åmosen and the Suså area almost to Præst $\varnothing$ in southern Sjælland.

Even though K.Milthers mentions the existence of waterlaid deposits between tills of the individual advances of the last glaciation, he could only explain these sediments as the product of subglacial meltwater deposition, even though their large lateral distribution seemed quite troublesome (K.Milthers 1942, p. 110). In the view of his opponents the existence of the waterlaid deposits between the tills is the key to the argument, that relatively ice free conditions with subaerial sedimentation of outwash material prevailed between the major ice advances of the last glaciation.

G.Wennberg $(1943,1949)$ who shared K.Milthers' views on the inter-till, waterlaid sediments, explained the changing indicator boulder content in the South Swedish and Danish glacial deposits as the result of differential movements in the periphery of the icesheet during deglaciation. Wennberg (1949) correlates the Danish till stratigraphy with that of Skåne and northern Germany mainly on the basis of indicator pebble counts. Wennberg suggests, that till $\mathrm{C}$ is equivalent to the north German Warthe stage and the so called Old Baltic till of Skane, and that this till is younger than the Eemian and older than the cold part of the Skærumhede sequence. After the deposition of this sequence an ice sheet from the $\mathrm{N}$ and NE invaded the country and found its outer limits along the Main Stationary Line. This ice sheet is referred to as the Meridian ice, and should be correlated with till D. The Meridian ice is succeeded by the Småland ice, which reached the East Jylland Ice-border and formed recessional ice-pushed ridges along Mols, Sjællands Odde, Samsø and Røsnæs. During the retreat of the Småland ice a Baltic ice sheet took over first in the western part of the country, but later also covering the eastern part. However, this ice sheet was not able to transgress the dead ice masses of central Fyn left by the Meridian ice.

Andersen (1945) strongly opposed the method of indicator counts from secondary accumulations combined with morphological interpretation as used by V. and K.Milthers to outline the chronology of ice sheets during the last glaciation. By the combined application of stratigraphical methods, observations of glacially striated boulder pavements and Pre-Quaternary bedrock, glaciotectonic pressure directions observed in dislocated sequences and pronounced morphological features Andersen (1933, 1945, 1950, 1957) outlined a (de)glaciation pattern, which radically differed from the one developed by Ussing, V., K.Milthers and Wennberg. According to Andersen the tills of the last glaciation can be grouped into three individual units separated by meltwater deposits supposedly deposited during ice free conditions between advances.

The oldest till is the so called Old Baltic till (of Baltic clast composition), which overlies the marine Eemian beds of Ristinge Klint, and was deposited by an ice sheet that covered the southeastern parts of the country. The next advance reached the Main Stationary Line generally from north-easterly directions (Andersen 1933, p. 143, 1957, p. 234) and deposited the so called NE-till. This is characterized by southwest Swedish indicators and its low content of Palaeozoic (and other Baltic) rock fragments. The NE-till overlies the earlier Old Baltic till and is in turn overlain by the Young Baltic till. The third (Young Baltic) ice sheet of the last glaciation invaded the country generally from south-easterly directions (Andersen 1933, p. 182, 1957, p. 234). It found its maximum extension along the East Jylland Ice-border line, and recessional advances formed the iceborder lines southward through Storebælt, in Odsherred and possibly also on north-eastern Sjælland. The Young Baltic till is characterized by large quantities of Palaeozoic rock fragments and Baltic indicator erratics. With reference to Madsen et al. (1928) Andersen (1933) points out that the presence of beds with limnic interstadial material between the NE-till and the Young Baltic till in eastern Jylland is a clear indication of a climatic amelioration during the time between the two ice advances. Andersen (1957) also proposed 
a connection between the drainage pattern of meltwater merging from the two icestreams. He indicated, that the NE-ice produced west to south moving meltwater streams and that the Young Baltic ice had given rise to west and north moving outwash streams.

K.Milthers (1952) recognized Andersen's criticism, and he allowed more influence of the NEicestream than previously accepted.

Hansen (1965) in his detailed account of the Quaternary of Denmark correlated the main climatic phases of the Pleistocene of Denmark with those of the internationally accepted terminology and stratigraphy of Woldstedt (1954). Hansen collected new data on the glacial and interglacial stratigraphy and presented them after the scheme outlined by Madsen et al. (1928) and K.Milthers (1942). He also related the younger stratigraphic units to morphological features sketched by V.Milthers (1948). The iceborder-lines C, D and E sketched by Madsen et al. (1928) were related to the Brandenburg-, Frankfurt- and Pomeranian stages of northern Germany.

This very comprehensive outline was almost predictably opposed by Andersen (1966), who saw his theories, especially regarding the Weichselian glaciation, somewhat neglected and misinterpreted. The major contrast in opinion came to be as follows. On one side Hansen recognized only one Weichselian ice sheet as having reached the Main Stationary Line before it withdrew from this line with major recessional halts along the East Jylland Ice-border line and other more or less pronounced morphological ridges interpreted as ice border lines (Hansen 1965, p. 41). On the other side Andersen's more dynamic approach allowed three individual ice advances, each having special patterns of movement and characteristic clast petrographic compositions. In contradistinction to Hansen (1965) Andersen (1966, p. 220) related these three glacial phases to the above mentioned North German terminal moraines. The Old Baltic advance, which might have reached slightly farther west than the Main Stationary Line in southern Jylland, was succeeded by the North-east ice, which reached the Main Stationary Line. During its deglaciation the North-east ice left large dead ice masses on Fyn and possibly other areas. The Young Baltic advance reached the East Jylland Ice border line and during deglaciation the remarkable ice pushed terminal moraines in Odsherred and Røsnæs were built up. The three advances were separated in time by "interstadial" climatic conditions during which large sheets of waterlaid outwash sediments were deposited in a relatively icefree environment.

In the beginning of the last decade renewed glacial stratigraphic investigations have taken place (Berthelsen 1971, 1974, Larsen et al. 1972, Petersen 1973, Petersen \& Buch 1974, Petersen \& Konradi 1974, Rasmussen 1973, Sjørring 1973, 1974, Thamdrup 1970). These investigations have directly or indirectly confirmed Andersens (1933, $1945,1950,1957,1966)$ stratigraphical concept and glaciation pattern of the Weichselian. That is, with the addition of Rørdams (1909) lower till of NE-Sjælland (the Norwegian till) with a somewhat similar stratigraphical position in NE-Sjælland as the Old Baltic till has in the southern parts of the country. Advancing the works of Andersen, Berthelsen (1973) formulated the principle of kineto-stratigraphy in an attempt to introduce modern glacio-stratigraphic working methods and a primarily structural line of thinking into the study of Pleistocene deposits in Denmark. Berthelsen (1978, 1979) sums up the Weichselian till stratigraphy developed during the seventies, amongst many others making use of contributions by Berthelsen et al. (1977), Houmark-Nielsen (1976a, b), Frederiksen (1975, 1976), Jacobsen (19796), Jensen (1977), Petersen (1978), Rasmussen (1975), Sjørring (1977). It is indicated that four major glacial phases (the Norwegian adv. from the $\mathrm{N}$; the Old Baltic from the $\mathrm{SE}$; the Main Weichselian advance from the NE; the Young Baltic adv. from the SE) separated by "interstadials" during which deglaciation at least partly took place, occurred between 25000 and 13000 years BP.

Based on stratigraphical observations and fine gravel analyses Sjørring \& Frederiksen (1980) and Sjørring (1981a) recognized three till types of pre-Weichselian age in the south-western part of Jylland. The younger and older Saalian tills of the "Warthe" and "Drenthe" types are characterized respectively by small quantities of quartz, large amounts of flint and erratics of Baltic provenance, and equal amounts of quartz and flint and erratics of Fennoscandian provenance. An Elsterian till type was characterized as having about twice as much quartz as flint. 
Houmark-Nielsen $(1980,1983)$ presented results of glaciostratigraphic studies in the northern Balthav region and related the inferred stratigraphy to works of other authors in the part of the country Iying east of the Main Stationary Line (Houmark-Nielsen 1981). The so called Paleobaltic till (late Saalian) deposited by an ice sheet from south-easterly directions is overlain by marine Eemian deposits. The Norwegian till is proposed as the oldest Weichselian till, it was deposited by an ice sheet from the north and succeeded by the Main Weichselian advance from the northeast. Between these advances run off outwash patterns were first directed northward (from a proposed Old Baltic ice sheet lying south of the region) and later were forced westward in front of the advancing NE-ice. The age of interstadial deposits from Sejer $\varnothing$ indicated that at least the NE-ice transgressed the area after $36800 \mathrm{BP}$ (Houmark-Nielsen \& Kolstrup 1981). During the deglaciation of the NE-ice, readvances from the $\mathrm{NE}$ caused the formation of push moraines on Mols, North Samsø and possibly Sjællands Odde. As the active ice border vanished north-eastwards, meltwater was directed northward into the Kattegat depression before and during the Young Baltic advance. This can be divided into two phases. The first phase (the East Jylland adv.) reached the East Jylland Ice border Line at Mols from the southeast and in a more upstream position over north Sjælland, showed directions of movement from due east. The second phase of the Young Baltic glaciation (Bælthav adv.) reached the ice border lines of Odsherred and its margin covered Sejer $\emptyset$ and South Sams $\emptyset$ invading the eastern part of the region from southwestern to southeastern directions. According to Houmark-Nielsen (1981) the Bælthav advance could correspond to the Bælt phase (E-phase) described by Madsen et al. (1928).

Sjørring (1983) briefly presents the glacial history of Denmark making use of the newest stratigraphic sources as well as the classical ones. Kronborg (1983) finds a complex glacial stratigraphy in the Randers-Århus-Silkeborg area (northern middle and eastern Jylland) and, using slightly different methods than in the present investigations, a stratigraphy supposedly covering the Menapian, the Elsterian, the Saalian and the Weichselian is presented.

\section{METHODS OF STUDY LITHOSTRATIGRAPHY}

During the last decade several attempts have been made in neighouring regions to describe the lithostratigraphy of the glacial deposits.

Larsen et al. (1977) treated units from both a litho and a kinetostratigraphic point of view. Thus outwash material was given the status of formations whereas till units obtained kinetostratigraphic classification. Lagerlund (1980) erected informal, till stratigraphic units and glaciofluvial deposits into common members. Adrielsson (1983) informally applied member rank to individual till- and waterlaid units respectively, and Kronborg (1983) reports of the grouping into a similar hierachy, which groups members into formations.

Even though informal descriptions are quite useful, the need for a formal lithostratigraphic classification is now strongly advocated. In the present case this need has led to the establishment of formal lithostratigraphic till units with rank of formations, where as waterlaid deposits because of their reduced ability of correlation are for the time being left unclassified. Formation rank is attributed because tills form the basic framework used to describe the Pleistocene geology of former glaciated lowlands like the central Danish region, which for the largest part is build up of non-fossiliferous, clastic deposits. Till units show a reasonably high degree of lithic uniformity, and even though not directly mappable, till units can after simple laboratory treatment, be recognized in a large number of exposures also reaching beyond the examined region. Consequently additional and more thorough examinations may cause the separation of Formations into till units of a lower rank including members and beds.

\subsection{UNIT DESCRIPTIONS}

Till units are described in terms of lithic characteristics with emphasis placed on those features which express the direction of glacier flow together with provenance-dependent, compositional features. The bounding relations are examined with special attention to glaciotectonic unconformities, because the study of glaciotectonic structures not only serve as indicators of a given glacier transgression, but also provide valuable information on the direction of active glacier 

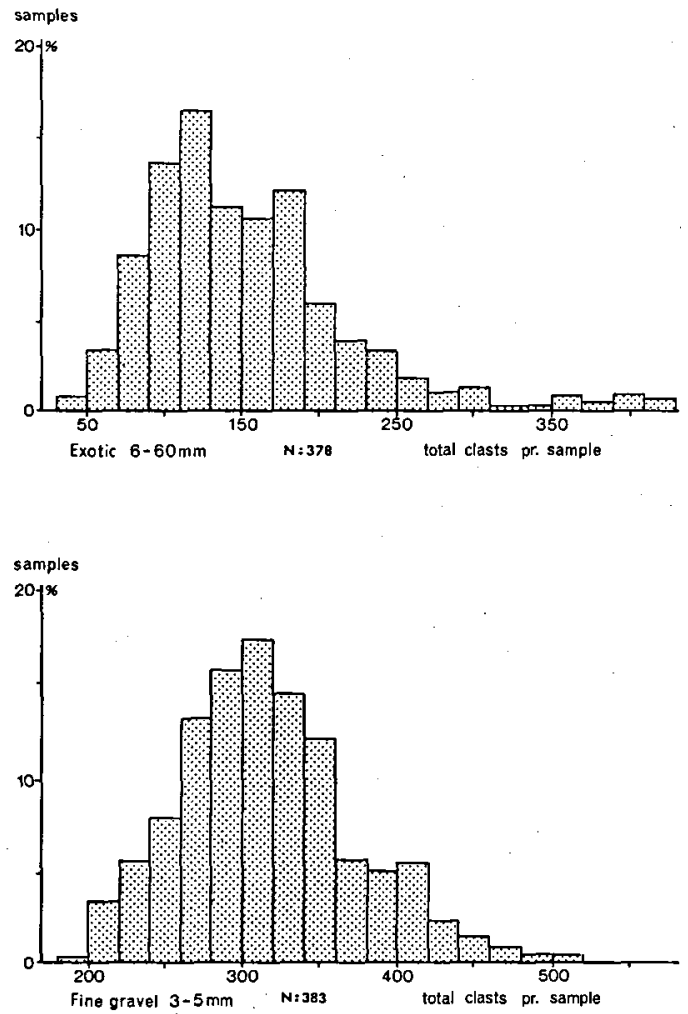

Fig. 4: Distribution of exotic stone counts and finegravel counts indicating the total amount of clasts counted per sample in relation to the number of samples.

movements. Even if a till unit deposited by a glacier can not be recognized at all localities, glaciotectonic unconformities related to the ice sheet which deposited the till may serve as excellent marker horizons in the stratigraphic record.

\subsection{LITHIC CHARACTERISTICS}

The lithic characteristics of tills obtained in the field include colour (usually brown, grey to blackish), granulometric characteristics (discrimination between sandy and clayey tills), and sedimentary - as well as glaciodynamic structures (massive, stratified or banded tills).

\subsection{TEXTURAL PROPERTIES}

The textural properties include macto fabric analysis of tills that may provide information on the local direction of glacier flow, as already pointed out by Richter (1933) and Holmes (1941). Theoretical considerations of the orientation of clasts in a fluid medium or glacier ice (Glenn et al. 1957, Lindsay 1970) have improved the method of interpreting till fabric diagrams in terms of possible glacier movement. Nielsen \& Houmark-Nielsen (1983) summing up the Danish experience in till fabric studies point out that the most common fabric type is one in which the long axes of clasts are alligned parallel to and plunge gently upstream to the flow direction. It was also stressed that fabric data should not be uncritically interpretted in terms of glacier movement, since post-depositional, glaciotectonic deformation, glacier induced reorientation or gravitational remobilization may strongly influence clast orientation.

The fabric analyses from till units of individual sites presented here are based on at least 50 clasts with axial ratios approaching 3:2:1 and, according to the recommendation given by Krüger (1970), long axes that plunge more than 50 degrees from the horizontal have been omitted. Till fabric analyses are performed only in subhorizontally oriented till beds that are envisaged not to have been laid down by gravitational flow- or drop- and dump processes, but rather are thought to have been deposited directly from a glacier. Individual measurements are plotted according to Rasmussen (1974) in equal area nets as minute circles. Clast fabrics of flow till and related deposits or fabrics not showing any prefered orientation are omitted from the data presentation (less than 30 out of a total of 145 clast fabrics).

\subsection{PROVENANCE DEPENDENT COMPOSITIONAL ELEMENTS}

The use of readily apparent petrographic characteristics of clasts in tills has proved to be a valuable tool in distinguishing individual till units in Denmark (Andersen 1945, Berthelsen et al. 1977, Houmark-Nielsen 1980, 1983b, HoumarkNielsen \& Berthelsen 1981, Jacobsen 1976, 1981, Jensen \& Knudsen 1984, Jessen 1930, Madsen 1916, Madsen \& Nordmann 1940, Nielsen 1980, Petersen 1973, Petersen \& Konradi 1974, Petersen \& Buch 1974, Rørdam 1893, Sjørring 1977, Sjørring \& Frederiksen 1980). However examples of the contrary have also been published (Aber 1979, Rasmussen 1975). It is assumed that provenance dependent compositional elements may provide information about the long range path of glacial transport towards and within the Danish region. For further discussion and historical review see Bahnson (1973), Holm (1981), 


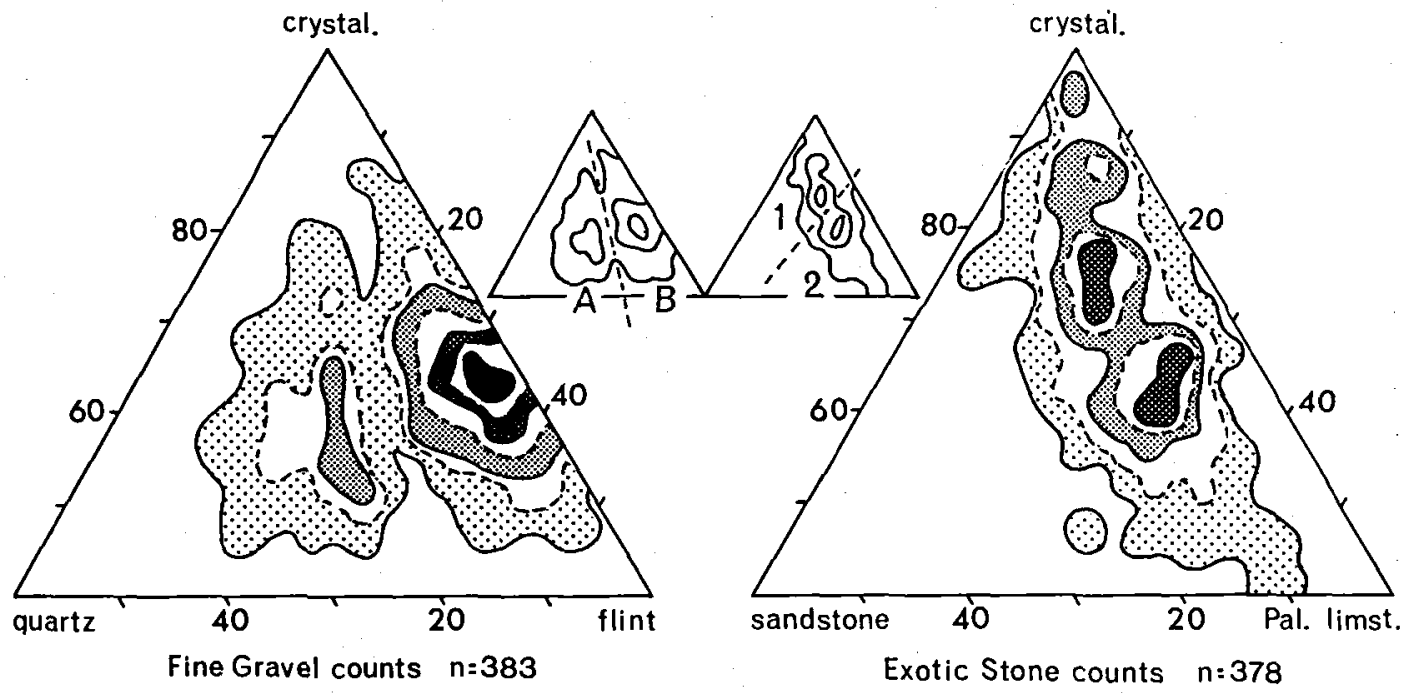

Fig. 5: Left: Fine gravel counts indicating the compositional groups A \& B (respectively high/low contents of quartz and low/high contents of flint. Right: Exotic stone counts indicating the compositional groups 1 \& 2 (respectively low and high amounts of Palaeozoic limestone).

\section{Houmark-Nielsen (1983b) and Marcussen (1974).}

According to Holm (1981) two categories of provenance dependent compositional elements are considered: 1) Exotic rock fragments including crystalline rocks (mostly Precambrian) derived from the Fennoscandian basement and Palaeozoic (abridged: Pal.) sandstone and limestones which cover the basement in the southern Baltic area, 2) local rock sources such as quartz (mainly from Tertiary deposits), flint and limestone (Cretaceous-Paleocene) and other sedimentary rocks. The exotic rock fragments (fig. 4) are counted in the fraction $6-60 \mathrm{~mm}$ in order to compare the results with the stone counts made after the method of Ussing and Madsen (1897). Houmark-Nielsen (1976a, 1980, 1983b) distinguished empirically between two compositional groups of exotic rock fragments: one group poor in Palaeozoic material (Fennoscandian provenance) basically transported from northerly and northeasterly directions, and another group rich in Palaeozoic materal (Baltic provenance) mainly transported from southeasterly directions. In the present investigation 378 samples (table 1, fig. 139) of exotic clast material were counted (fig. 4) and the division of Fennoscandian (group 1) and Baltic (group 2) provenance is shown in fig. 5 .

Fine gravel counts after the Dutch method are, in the present investigation, used for comparison with other authors (cf. Ehlers 1979, Jacobsen
1981, Jensen \& Knudsen 1984, Sjørring \& Frederiksen 1980, Sjørring et al. 1982) working mostly in the southern and western parts of the country. Clasts of quartz, flint, crystalline rocks and chalkfree sediments are considered together with Palaeozoic and Cretaceous-Paleogene limestones.

Sjørring and Frederiksen (1980) examined till samples from south-western Jylland using the method of fine gravel counts applied by Ehlers (1978). They roughly divided the Pre-Weichselian tills into two groups: one poor in quartz and rich in flint, referred to as having a "Warthe" spectrum, and one group with either equal amounts of quartz and flint or with a greater quartz content than flint, which they respectively refered to as the "Drenthe" and "Elster" spectra.

In the present case 383 samples (table 1, fig. 139) have been subjected to fine gravel analysis (figs 4 \& 5) in the fraction $2,80-4,75 \mathrm{~mm}(3-5 \mathrm{~mm}$ approx.) and the two compositional groups of Sjørring and Frederiksen are recognized in the examined regions. In the present investigations the groups rich and poor in quartz are termed $A$ and $B$ respectively.

In a few cases indicator erratic boulders (V.Milthers 1909, K.Milthers 1942) have been found in situ in tills, and indicators from the Oslo region and south central Sweden have been noticed in quantities worth mentioning. The classical Baltic indicator erratics and other rock fragments whose provenance and distribution are less 


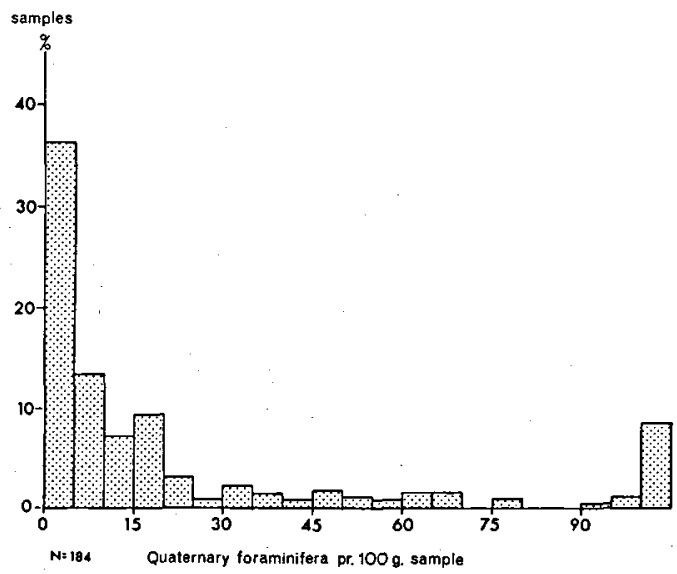

Fig. 6: Distribution of the number of redeposited Quaternary foraminifera in till samples.

well defined have also been considered. Special interest was shown in Palaeozoic limestone and sandstone fragments from the southern Baltic, the so-called "Katholm erratics" (Baartman \& Christensen 1975) which presumably come from along the Fennoscandian Border zone east of Anholt in the Kattegat, and the "Flintconglomerate" described by $\varnothing$ dum (1968) apparently from the Skagerrak Sea. Fragments of cemented, ashbearing diatomite (Fur Formation, Petersen \& Surlyk 1983), also named Moler from the northwestern Limfjord area, have also been noted in reasonable quantities.

\subsection{MATRIX INVESTIGATIONS}

The matrix of tills has been investigated with regard to re-deposited Quaternary foraminifera. A total of 184 samples of $400 \mathrm{~g}$ dry weight have been analysed (fig. 6). The Quaternary foraminifera can be divided into four main groups or accumulations. The most common is one containing quantities too small (less than 15 individuals pr $100 \mathrm{~g}$ sample) for identification and correlation with faunas of known primary marine deposits. However, this group contains quantities of preQuaternary foraminifera large enough to have survived decalcification. The three other accumulations are after Lykke-Andersen (1974) termed $\mathrm{X}, \mathrm{Y} \& \mathrm{Z}$ and correspond to $\mathrm{X}$ ) Eemian-Middle Weichselian Skærumhede sequence (Older Yoldia clay) which indicates a northerly to northeastDanish provenance, Y) Southern Danish Eemian deposits (Cyprina clay) indicating a southerly to central Danish provenance, and Z) Holsteinian deposits of the western Baltic, the North Sea coast, north Jylland and Kattegat (Knudsen 1986).

Modern descriptions of primary foraminifera faunas in the Danish Quaternary are given by Bahnson et al. (1974), Buch (1955), FeylingHanssen \& Knudsen (1979), Knudsen \& FeylingHanssen (1976), Konradi (1976), Petersen \& Buch (1974), Petersen \& Konradi (1974) and the re-deposited accumulations mentioned above are described by A-L.Lykke-Andersen (1979) and Frederiksen (1982). According to Frederiksen, the $\mathrm{X}$-accumulation is dominated by Elphidium excavatum, Cassidulina reniforme and Bulimina marginata ranging in order of number of individuals. Other characteristic species are Elphidium groenlandicum, Islandiella helenae, Islandiella norcrossi and Nonion labradoricum. The Y-accumulation is dominated by either Elphidium excavatum, Nonion orbiculare or Elphidium albiumbilicatum. Other characteristic species are $\mathrm{Bu}-$ cella frigida and occasionally Ammonia batavus. Finally the $\mathrm{Z}$-accumulation is almost totally dominated by Elphidium excavatum supported by minor quantities of Nonion orbiculare, Elphidium subarticum and Ammonia batavus. The foraminiferal accumulations found in connection with the present investigation are presented in table 2 (fig. 140) and will appear as letters X, Y, $\mathrm{Z}$ and $\mathbf{0}$ in the stratigraphical columns.

Previous stratigraphical investigations (for a review see Frederiksen 1982) have applied the method under the assumption that the tills containing $\mathrm{X}$ or $\mathrm{Y}$ accumulations are ascribed to the Weichselian glaciation. This assumption is probably valid for most of the investigations, but present knowledge about the distribution of pre-Eemian marine deposits containing faunas corresponding to $\mathrm{X}$ and $\mathrm{Y}$ accumulations is still very restricted. Lykke-Andersen and Knudsen (1982) have published new results of faunal analyses from pre-Eemian marine beds in the Skærumhede I boring. In this case foraminiferal faunas of supposed Saalian interstadial origin could not be distinguished from the Early to Middle Weichselian foraminifera faunas of the upper Skærumhede sequence. The Saalian deposits, however, seem to have a rather restricted lateral and vertical distribution in comparison with the upper part of the Skærumhede sequence.

In some cases re-deposited molluscan frag- 
ments, strongly resembling the fauna characteristic of the south Danish Eemian deposits, have been reported from the till underlying the classical Eemian bogs at Brørup, central Jylland (V.Milthers 1925, p. 19). Equally it should be mentioned that at only one single locality out of a large number of localities (cf. Lykke-Andersen 1974, Frederiksen 1975, Houmark-Nielsen 1980, Sjørring \& Frederiksen 1980, Kronborg 1983), supposed Saalian tills have been reported to contain re-deposited foraminifera resembling the $X$ \& Y. accumulations (Lykke-Andersen 1974). Most often these tills are either extremely poor in Quaternary species or contain a Z-accumulation.

In the light of this background the contents of re-deposited foraminifera found in the present investigation will serve as 1) a legitimate lithic character of individual tills, 2) as a provenance-dependent element and 3) as a guideline to propose a possible maximum age in connection with other stratigraphical data.

\subsection{BOUNDING RELATIONS}

The recognition of boundaries between units is of prime importance in lithostratigraphic classification, because boundaries are placed between deposits of contrasting lithology. In the present study special emphasis has been placed upon the study of glaciotectonic unconformities because these also give information on the direction of ice transgression as well as the structural chronology of a given body of deformed strata.

Studies of glaciotectonic structures have a long history in Danish geological investigations (cf. Jessen 1918, 1930, Madsen 1897, 1916, Madsen \& Nordmann 1940). It was, Gry (1940) however, who initiated detailed structural analyses to describe the nature of the so-called dislocated cliffs. Gry explained folds and thrust faults in the PreQuaternary as well as Quaternary deposits as the result of active glacier movement, and estimates were made on the direction of glacial pressure.

In central Denmark the method of structural analysis of glaciotectonic features has systematically been applied to stratigraphic investigations for more than a decade (cf. Aber 1979, Berthelsen 1974, 1975, Berthelsen et al. 1977, Frederiksen 1976, Houmark-Nielsen 1976a,b,c, 1980, Houmark-Nielsen \& Berthelsen 1981, HoumarkNielsen \& Kolstrup 1981, Jacobsen 1976, 1981, Jensen 1977, Kronborg 1983, Larsen et al. 1972,
Nielsen 1980, Petersen 1973, 1978, Rasmussen 1973, 1974, 1975, Rasmussen \& Petersen 1980, Sjørring 1974, 1977, 1981, Thamdrup 1970).

Provided a sequence has undergone glaciotectonic deformation, the nature and orientation of structures is either measured or constructed and the vergence of folds and the dip of thrust planes are used as indicators of the direction of ice advance.

Glaciotectonic unconformities are indicated in the data presentation at the stratigraphic level beneath which strata were affected by deformation from a certain direction, and the nature of structures are indicated in stereographic projections.

\section{7 $A G E$}

The inferred age is of course of ultimate importance in stratigraphic studies of glacial and interglacial / interstadial deposits. It must be stressed, though, that the possible age of a unit is not part of the lithostratigraphic classification. However, age is an important object to study for a given unit, even though data from the present investigation are very sparse. It has been possible, in fact, to give certain interglacial / interstadial samples absolute dates. Individual samples of respectively limnic Holsteinian and limnic Eemian and one of presumed late Elsterian marine derivation have been dated by thermoluminiscence (Kronborg 1983, pers.comm.) and a single sample of Pleniglacial origin has been radiocarbon dated (Houmark-Nielsen \& Kolstrup 1981). The samples of Eemian and Pleniglacial age and several others have undergone palynological analysis and have been classified biostratigraphically.

\section{NAMES}

For practical purposes lithostratigraphic till formations are named according to the geographical area of distribution. Only if a unit is confined to one of few localities within a relatively restricted area, the name of the type section is used. In most cases, however, units are observed in many localities over large areas, thus names of more regional significance are favoured. The names chosen for the till units found in the present study are shown in fig. 2 . 


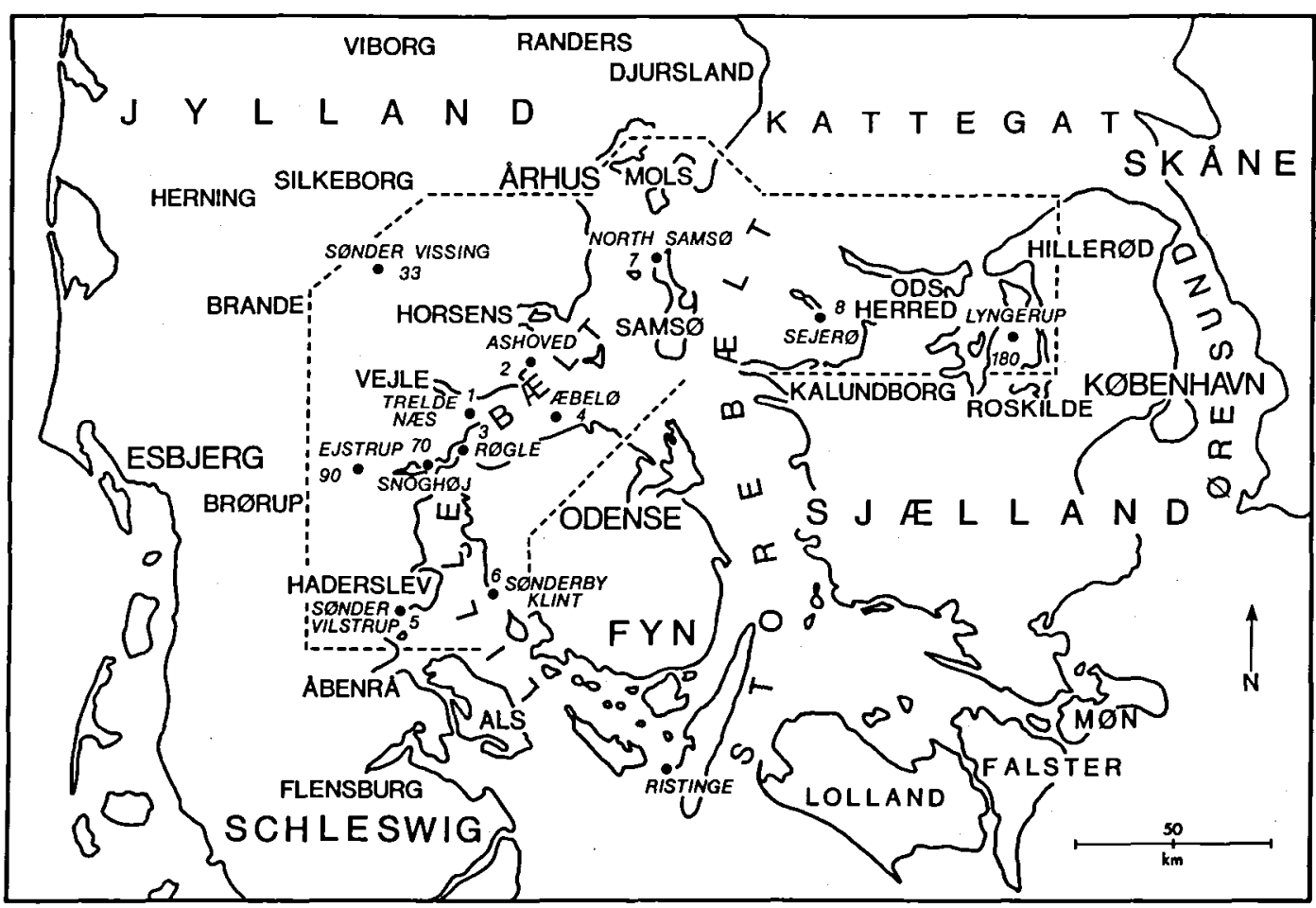

Fig. 7: Examined region (framed) with selected principal and key localities from the central part of Denmark.

\subsection{PRESENTATION OF DATA}

Primary data from selected cliff sections of the principal localities include sketched cross-sections of cliff sites.

Stratigraphical and structural data from composite principal localities (where more than one exposure is studied) or from individual areas (most often containing 9 exposures) are presented in condensed stratigraphical columns.

Data illustrating the combined stratigraphical and tectonic setting of principal localities or the total, representative stratigraphy from each area are shown in glaciostratigraphic data charts, built up after the scheme proposed by Houmark-Nielsen and Berthelsen (1981). The charts contain information on general lithology flanked by special indications of kineto-stratigraphic classification and compositional characteristics of till units by lettering. The range, nature and chronology of glaciotectonic unconformities are indicated in stereographic projections inserted on "deformational logs" that jump "en bayonette" for each generation of deformation. This should not be confused with the delineation of Houmark-Niel- sen and Berthelsen (1981), where the same jumps in the deformational logs indicate a change from domainal to extradomainal deformation. Arrows on the rim of the stereographic projections show the inferred direction of the deformational force refered to as ice-deformation. Till fabric analyses are pictured in equal area nets with open arrows indicating the deduced ice flow direction. The exotic clast composition is represented by dial diagrams with indication of the total number of samples counted from each unit. Fine gravel analyses are presented in the same manner as Ehlers (1978) and Sjørring and Frederiksen (1980). Sample numbers referring to the table 1 (fig. 139) are indicated. The contents of re-deposited Quaternary foraminifera are indicated by letters referring to specific foraminiferal accumulations (fig. 140). 

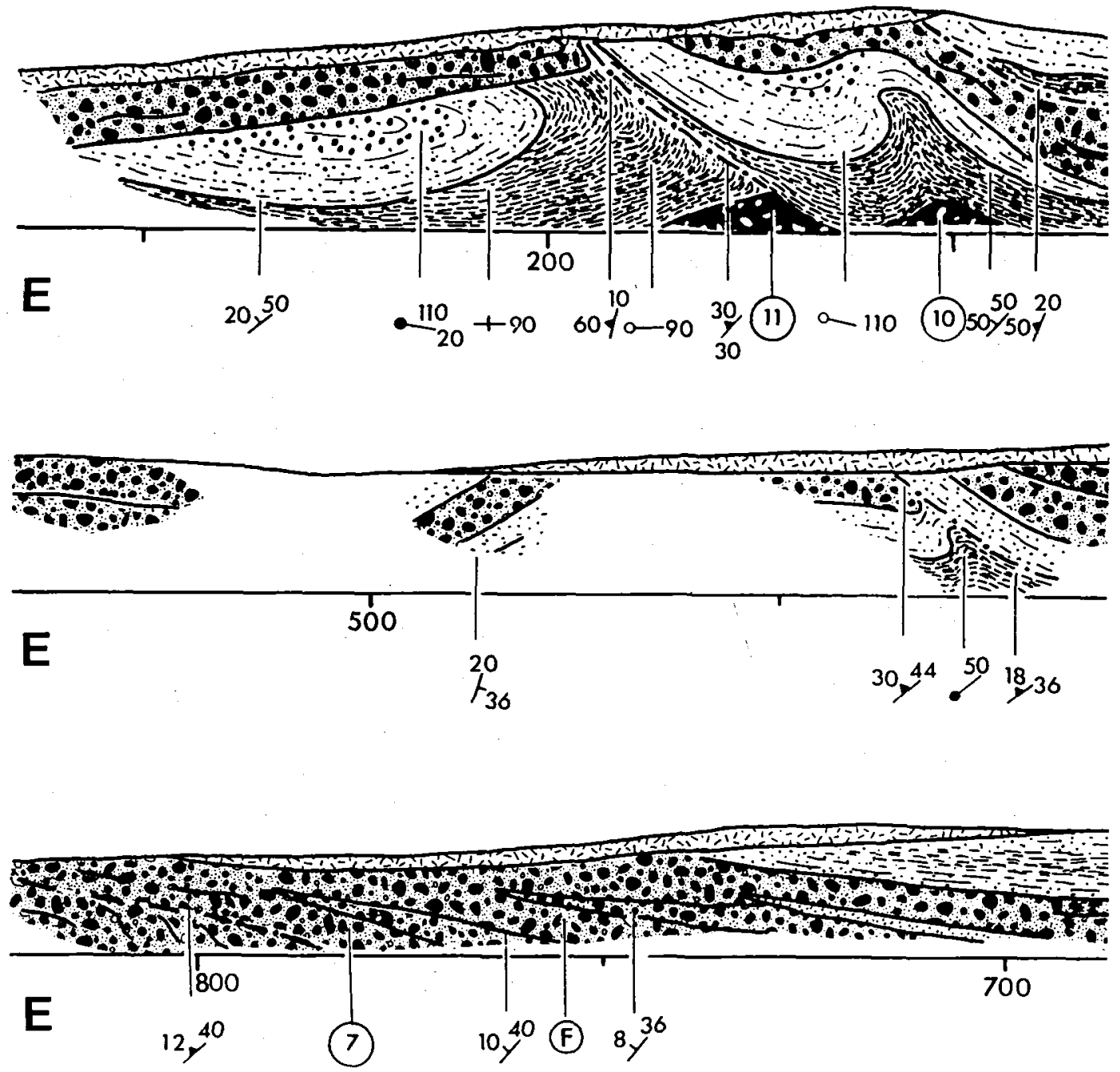

\begin{tabular}{|c|c|c|c|c|c|}
\hline$\therefore \because 8$ & $\begin{array}{l}\text { LOWER TILL } \\
\text { PALSGARD TILL }\end{array}$ & 88 & $\begin{array}{l}\text { MIDDLE TILL } \\
\text { TRELDE NES TILL }\end{array}$ & 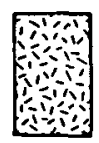 & $\begin{array}{l}\text { UPPER TILL } \\
\text { EAST JYLLAND TILL }\end{array}$ \\
\hline 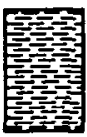 & $\begin{array}{l}\text { HOLSTEINIAN } \\
\text { INTERGLACIAL } \\
\text { DEPOSITS }\end{array}$ & 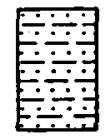 & $\begin{array}{l}\text { WATERLAID } \\
\text { OUTWASH DEPOSITS }\end{array}$ & 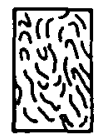 & TERTIARY \\
\hline
\end{tabular}

Fig. 8: Selected cliff section: Trelde Næs (loc. 1). No exaggeration of vertical scale. 

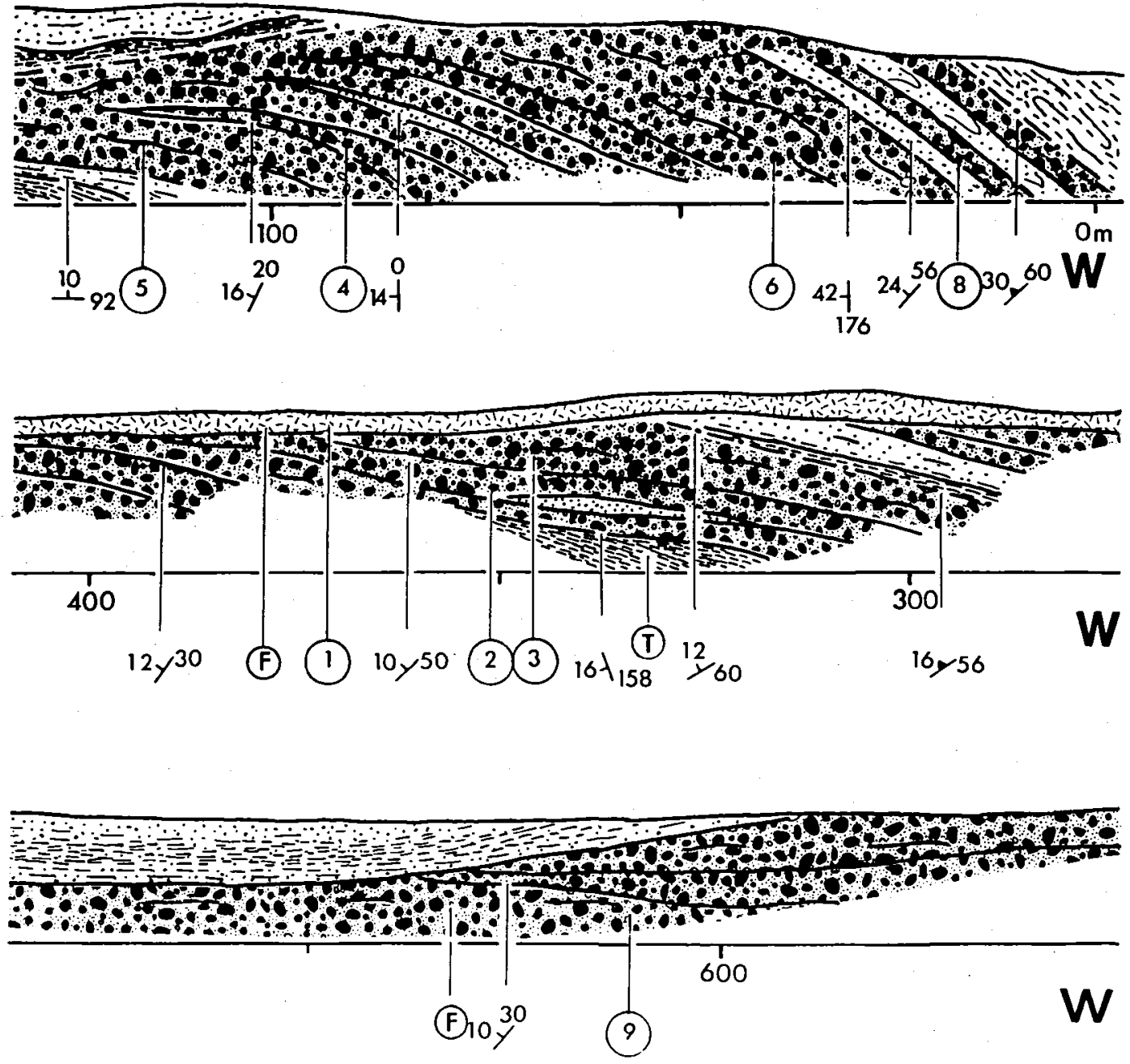

\begin{tabular}{|c|c|c|c|c|c|}
\hline & $\begin{array}{l}\text { THRUST } \\
\text { FAULT }\end{array}$ & & $\begin{array}{l}\text { CONSTRUCTED } \\
\text { FOLD AXIS } \\
\text { MEASURED }\end{array}$ & & $\begin{array}{l}\text { ORIENTATION } \\
\text { OF BEDDING }\end{array}$ \\
\hline (8) & $\begin{array}{l}\text { LOCATION OF } \\
\text { SAMPLE }\end{array}$ & (F) & $\begin{array}{l}\text { TILL FABRIC } \\
\text { MEASUREMENTS }\end{array}$ & (T) & $\begin{array}{l}\text { LOCATION OF } \\
\text { TL DATING }\end{array}$ \\
\hline
\end{tabular}




\section{GLACIAL STRATIGRAPHY OF PRINCIPAL LOCALITIES}

The following paragraph is a presentation of glacialstratigraphic investigations of 8 principal localities (fig. 7) and two key localities within the examined region. These studies eventually led to the establishment of a lithostratigraphic model.

\subsection{LOC. 1: TRELDE NAES}

Loc. 1 is situated on the south coast of Vejle Fjord at Trelde Næs (fig. 7). The cliff section consists of two tills intercalated with interglacial beds and sandy to pebbly waterlaid deposits folded and overthrusted from a northern and northwestern direction. Fine grained waterlaid material and an upper till disconformably overlie the icedeformed sequence.

\section{PREVIOUS INVESTIGATIONS}

An upper- and a lower till interbedded with interglacial lake marl and diatomite was recognized by Hartz and Østrup (1899). They described the flora and fauna of the interglacial deposits and correlated these deposits with the interglacial diatomite of Eemian age found at Hollerup. Madsen \& Nordmann (1928) and Nordmann (1958) stated, that the lower till and the interglacial sequence at Trelde Næs was strongly displaced by ice-deformation from a western direction and overlain by one possibly two discordant tills. S.Th. Andersen (1965) made palynological studies of interglacial diatomite deposits at Vejlby in Rands Fjord $10 \mathrm{~km} \mathrm{SW}$ of Trelde Næs. Andersen concluded that the diatomite at Vejlby was deposited during the Holsteinian interglacial, and he suggests a similar age for the interglacial diatomite at Trelde. Andersen (pers.comm.) confirms this assumption by referring to non published pollen analyses. Sjørring and Frederiksen (1980) correlate on the basis of fine gravel analysis the lower till at Trelde with a supposed Elsterian till from western Jylland.

\section{DESCRIPTION}

More than $800 \mathrm{~m}$ of the well exposed cliff face previously described by Nordmann has been examined, and a section of the site is shown in fig. 8. In the central-western part of the exposure (fig. 9) the Lower till and the interglacial deposits are overlain by a fine sandy to pebbly, coarsen-

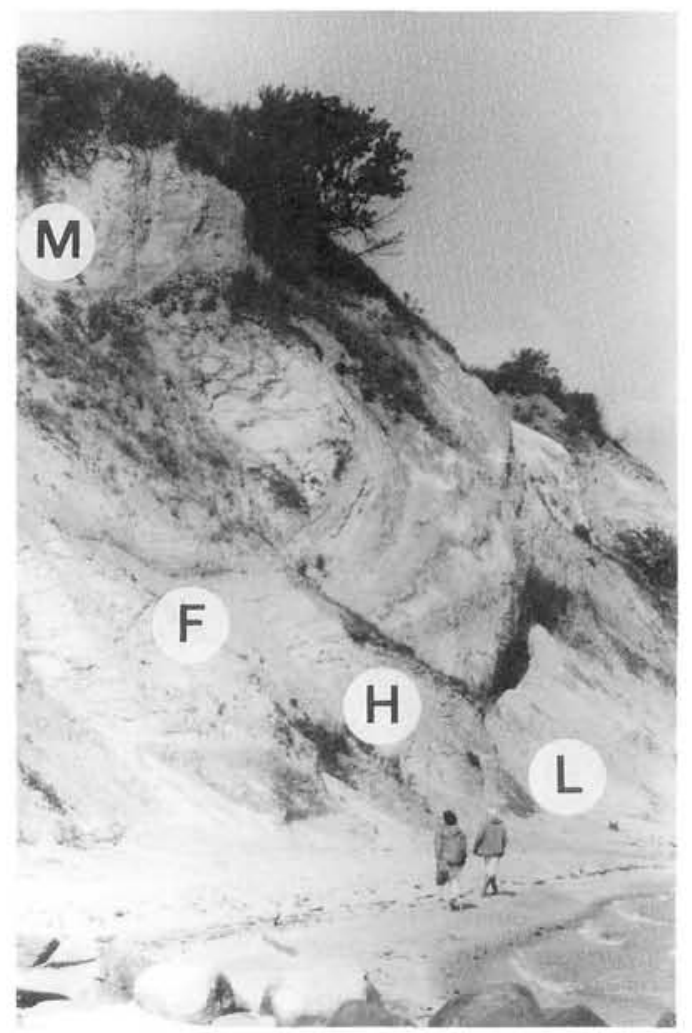

Fig. 9: Lower till (L) Palsgărd Till covered by Holsteinian lake marl $(\mathrm{H})$ and finegrained meltwater material $(\mathrm{F})$ recumbently folded by ice transgression from the north and disconformably overlain by the Middle till (M) Trelde Nas Till, pt. $200 \mathrm{~m}$, Trelde Nas.

ing-upwards sequence. The whole sequence forms a large, cylindrical fold with roughly E-W trending axis generated by ice-deformation from a northerly direction. The Middle till, resting unconformably upon the folded series are, together with this and the underlying Tertiary clay, cut by NW-ward dipping thrust faults and piled up and intensely sheared into floes due to ice-deformation from the NW. The thrust faults and associated drag folds structurally dominate the cliff section. The thrust faults and bedding planes along with numerous shear bands are more steeply inclined in the western part of the section, while to the east the dip approaches sub-horizontal values. This suggests, that the thrusting took place in the SW-NE trending marginal zone of a glacier lying at, or immediately northwest of, Trelde Næs. In the eastern part of the section the more gently dipping thrusted deposits (mostly the Middle till) are overlain by the upper, fine- 


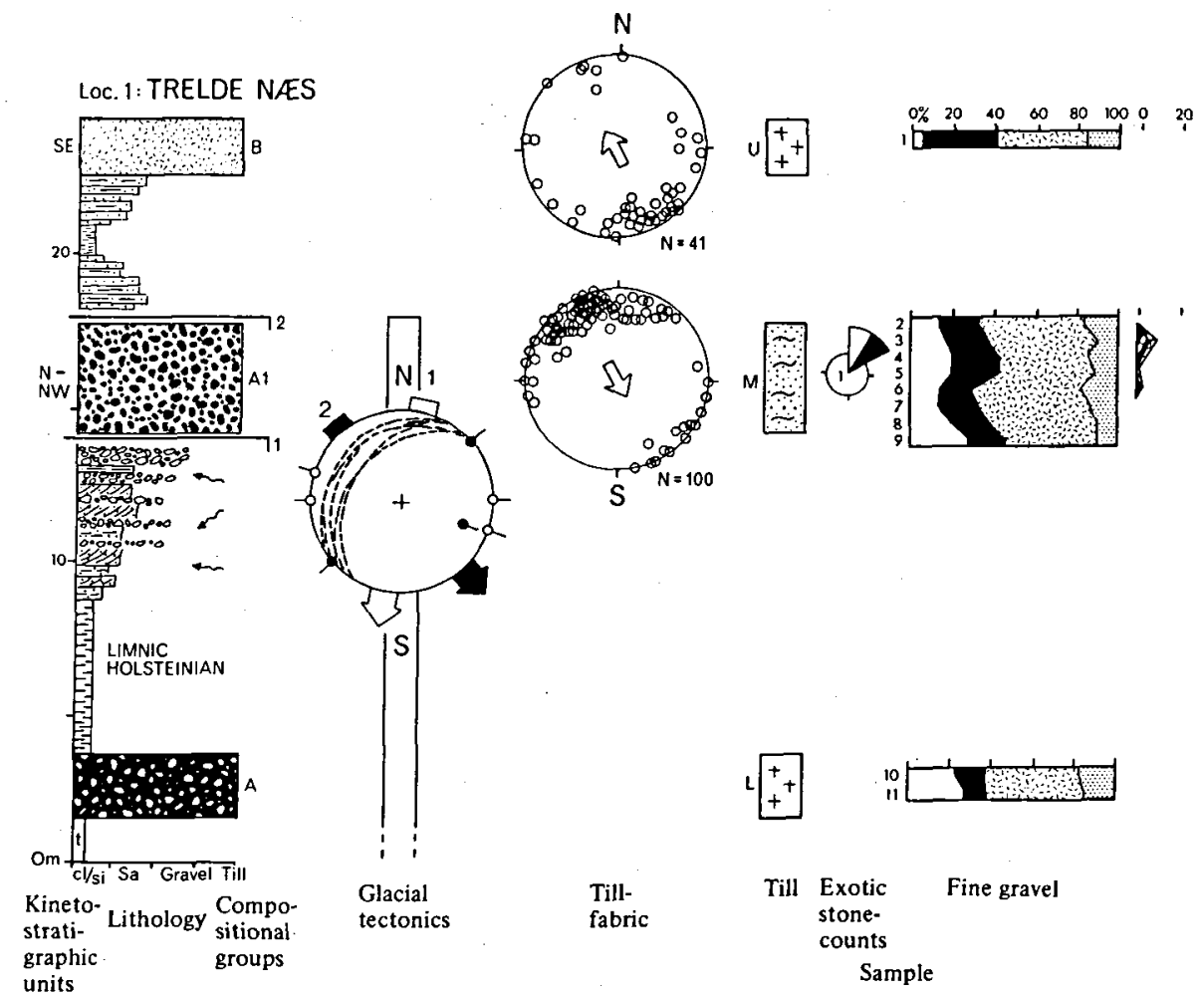

\begin{tabular}{|c|c|c|c|c|c|c|c|c|c|}
\hline $0_{0}^{\circ} 0002_{\text {MEI }}^{\text {MAS }}$ & TIILL & $\begin{array}{l}\text { A: QUART2 } \\
\text { RICH }\end{array}$ & $\begin{array}{l}\text { IHRUST FAULT } \\
\text { FOLDAXIS (MEASURED) }\end{array}$ & $\begin{array}{l}\text { ESTI } \\
\text { OF I }\end{array}$ & & $\because{ }_{0}^{5}$ & $\mid \begin{array}{l}\text { NON CALCEF } \\
-\end{array}$ & & LIMEST. \\
\hline 00 & & $\begin{array}{l}\text { B: QUARIL } \\
\text { POOR }\end{array}$ & FOLDAXISICONSTRUCT & & & & & & \\
\hline 8323085280 , UNO & & 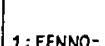 & & & & & $\underline{E}$ & 忌 & 安 \\
\hline $\begin{array}{l}\text { OTABULAR CR } \\
\text { TROUGK CROSS }\end{array}$ & $\frac{\text { BEDD. }}{\text { DING }}$ & $\begin{array}{l}\text { SCANDIAN } \\
\text { 2: BALTIC }\end{array}$ & & & & & $\frac{2}{3}$ & 㤩 & 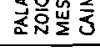 \\
\hline$\because$ MASSIVE & & & & & & & & & $100 \mathrm{~g}$ \\
\hline $\begin{array}{l}\text { PLANAR BEDDING } \\
\text { RIPPLE DRIFT - } \\
\text { LAMINATION } \\
\text { PLANE - }\end{array}$ & 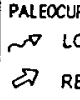 & $\begin{array}{l}\text { OCAL } \\
\text { EGIONAL }\end{array}$ & $\stackrel{+}{+}$ & $\underbrace{}_{\text {EQUAL AREA PROS }} O_{0}$ & & $\begin{array}{l}\text { ER }{ }^{50 \%} \text { PALAEOZOIC } \\
\text { UNTS LIMESTONE }\end{array}$ & $\begin{array}{l}\text { SKARUUMHEDE } \\
\text { SOUTH DANISH E } \\
\text { MOLSTEINIAN AC }\end{array}$ & EMIAN - & $\begin{array}{l}\text { CCUMUL. } \\
\text { TION- } \\
\text { TION }\end{array}$ \\
\hline
\end{tabular}

Fig. 10: Glacialstratigraphic data chart, loc. 1: Trelde Næs. Lower till (L) Palsgård till, Middle till (M) Trelde Næs Till, Upper till (U) East Jylland Till.

grained, meltwater deposits. The Upper till forms a thin cover across the surface of most of the cliff site.

\section{STRATIGRAPHY (fig. 10)}

THE LOWER TILL (L) crops out beneath the interglacial deposits on the lower flank of the older, coast-parallel fold. It is a more than $2 \mathrm{~m}$ thick, massive greyish clayey / sandy till. Fine gravel analysis shows a large amount $(25 \%)$ of quartz, less flint $(15 \%)$ and the original calcium carbonate content of the till has been washed out. The lower till is an A-compositional till type.
THE INTERGLACIAL DEPOSITS (fig. 11) overlying the Lower till consist of laminated lake marl overlain by diatomite with a combined thickness of more than $5 \mathrm{~m}$. Thermoluminiscence-dating of a selected sample of the lake marl (Kronborg 1983) revealed an age of $245000 \mathrm{TL}$ years, thus suggesting deposition during the Holsteinian.

THE LOWER SANDY-PEBBLY DEPOSITS overlying the diatomite, are built up of a more than $5 \mathrm{~m}$ thick coarsening upwards sequence with laminated silt and planar cross-bedded sand and fine gravel showing a gradual increase in gravel content towards the top. The cross-bedding in the 


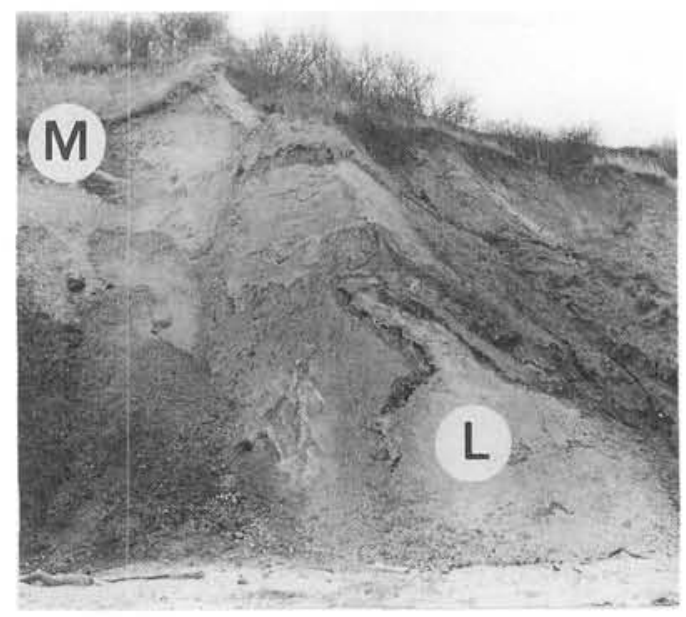

Fig. 11: Folded and thrusted Holsteinian lake marl (L) and diatomite overlain by the Middle Till (M: Trelde Nas Till) pt. 425 m, loc. 1, Trelde Næs.

sandy material and imbrication of pebbles indicate palaeocurrents directed towards the $\mathrm{W}$ and SW.

THE MIDDLE TILL (M): Trelde Næs Till which unconformably overlies the coarsening upwards sequence, is a sandy, strongly banded, to massive till. It is dark-brown to blackish and more than $4 \mathrm{~m}$ thick (fig. 109) with a strong imprint of incorporated Tertiary deposits (quartz sand, lignite and clay) and older till-material especially in sheared condition. Clast orientation measurements made in the eastern part of the cliff section revealed a NNW-dipping, longitudinal fabric, indicating ice-movement from the NNW, partly derived englacially partly reoriented during the younger deformational phase. In most places the original limestone content has been washed out, but in one sample the amount of Pal.limestone from stone counts of exotic materal was $7 \%$ suggesting Fennoscandian provenance. A few Oslo erratics were found in situ. The fine gravel analysis shows an average of nearly equal amounts of quartz and flint $(20 \%$ and $18 \%$ respectively), even though values approaching the Lower till appears. This is probably due to mixing with older till material. The Middle till can be characterized as a NNW-till of $\mathrm{Al}$ composition.

THE UPPER WATERLAID DEPOSITS consist of a sandy, silty and clayey sequence less than $5 \mathrm{~m}$ thick, with most fine material concentrated in the middle section. The individual beds of sand and clay which are about $1 \mathrm{~cm}$ thick, often show normal grading, characteristic of varves. Sets of beds are seen slump-folded in the central part and on the slopes of the less than $200 \mathrm{~m}$ wide basin which is filled by the upper stratified drift.

THE UPPER TILL (U): East Jylland Till forms a thin, discordant cover in the top part of the cliff section. The till is brown, clayey and massive. Measurements of clast orientation show a SE-dipping longitudinal fabric indicating icemovement from the SE. The Upper till is free of limestone and the fine gravel analysis shows small amounts of quartz (5\%) and large amounts of flint $(25 \%)$. The Upper till is a SE-till of B composition.

\section{CONCLUSION}

An ice-stream, the direction of movement and provenance of which are unknown, deposited a (Lower) till of A composition with about twice as much quartz as flint. During the Holsteinian interglacial marl and diatomite was deposited in a lake-basin. The lake-basin was filled up and was covered by fluviatile sediments of increasing grainsize transported by $\mathrm{SW}$ - to $\mathrm{W}$-ward moving meltwater streams probably emerging from an advancing ice-sheet. This ice-sheet dislocated the underlying deposits from a northern direction, and deposited the middle Trelde Næs Till with fabric indicating ice-movement from the NNW and with Oslo erratics and an $\mathrm{Al}$ composition of Fennoscandian provenance. During the retreat of this ice-sheet a readvance caused deformation from the NW. The deposition of varved sediments in a (ice-dammed?) basin was probably controlled by the melting of this readvance. A younger ice-stream deposited a (Upper) till East Jylland Till with fabrics indicating movement from the SE and a B composition with little quartz and much flint.

\subsection{LOC. 2: ASHOVED}

Loc. 2 is situated on the eastern-most point of the area between Horsens fjord and Vejle fjord (fig. 7). The cliff consists of 4 tills interbedded with sandy and gravely waterlaid deposits. The Lower till and the overlying sand and gravel have been subjected to claciotectonic displacement from a northerly direction. 


\section{PREVIOUS INVESTIGATIONS}

V.Madsen (1900) mentions two tills from Ashoved. An upper limestone free till is suggested to be of Baltic origin. The dark, sandy lower till, having limited amounts of Pal.limestone, is claimed to be of Norwegian origin due to large numbers of Oslo-district indicator erratics found in beach gravels where the lower till crops out.

V.Milthers (1932) describes the almost total domination of Oslo indicator erratics among beach gravels at Ashoved. K. Milthers (1942) suggests, that the till material, rich in Norwegian indicator erratics, belongs either to the northern fan of the Main Weichselian ice-stream or a late Saalian, Norwegian ice-advance. According to K.Milthers the young Baltic ice-advance of the Weichselian does not seem to have had any effect on the indicator erratic counts from this locality.

\section{DESCRIPTION}

Only limited portions of the eastern-most part of the cliff at Ashoved have been accessible for study over the last 3 years; a section of about 100 $m$ in length was satisfactorily exposed (fig. 12). In the southern half of the section the lower till and overlying sand and gravel is over-thrusted and folded from a northerly direction. These deposits are unconformably overlain by a Middle till and an Upper till. In the northern part of the section the Uppermost till constitutes the youngest glacial deposit.

\section{STRATIGRAPHY (fig. 13)}

THE LOWER TILL (L): Palsgård Till is a dark blue-greyish, clayey and sandy till more than $2 \mathrm{~m}$ thick, massive in the lower parts and banded towards the top. It rests upon Tertiary clay. Stone counts show limited amounts $(15 \%)$ of Pal.limestone, whilst fine gravel analysis shows large amounts of quartz $(20 \%)$ and small amounts of flint $(10 \%)$. Several in situ indicator boulders of kinnekulle-diabase were observed. No re-deposited Quaternary foraminifera were found in the samples taken. The lower till has an Al-0 composition.

THE LOWER WATERLAID BEDS consist of about $5 \mathrm{~m}$ of pebbly and gravelly stratified sand. This deposit is, together with the underlying till, dislocated by ice-pressure from the north (fig. 14).
THE MIDDLE TILL (M): Trelde Næs Till unconformably overlies the dislocated deposits. It is less than $3 \mathrm{~m}$ thick, greyish black, banded and rather sandy with some clay content. Measurements of clast orientations revealed a northward dipping, longitudinal fabric with some transverse positions indicating ice-movement from the north. Apart from several readily observable Oslo indicator erratics rock fragments of the Fur Formation (cemented ash bearing diatomite) and Flint conglomerates are associated with this unit. The stone counts show restricted quantities of Pal.limestone (15\%) and fine gravel analyses show equal amounts of quartz and flint (15\%). The Middle till contains very limited amounts of re-deposited Quaternary foraminifera. The Middle till can be characterized as a $\mathrm{N}$-till of $\mathrm{Al}-0$ composition.

THE UPPER SANDY GRAVEL BEDS consist of lenticular bodies of tabular cross-bedded sand and fine gravel, interveined by imbricated pebbles and gravel. The orientation of primary sedimentary structures indicate westerly palaeoflow.

THE UPPER TILL (U): Ashoved Till is massive brown to grey, sandy to clayey and more than $2 \mathrm{~m}$ thick (fig. 112). Long axis measurements show a blurred, weakly NE-dipping longitudinal fabric indicating ice-movement from the NE. Stone counts show little Pal.limestone $(14 \%)$, fine gravel analysis shows almost equal amounts of quartz and flint $(17 \%)$ and more than 10 indicator erratics of kinne-diabase were found in situ along the $100 \mathrm{~m}$ long cliffsite. The Upper till does not contain notable amounts of re-deposited Quaternary foraminifera. The Upper till can be characterized as a NE-till of Al-0 composition.

THE UPPERMOST TILL (Um): Mid Danish Till is separated from the Upper till by smaller lenses and smears of sand and gravel. The till is brown massive, clayey and less than $2 \mathrm{~m}$ thick. The results of the stone counts give a limited percentage of Pal.limestone content $(13 \%)$ and the fine gravel analysis shows small amounts of quartz (6\%) and large amounts of flint (24-30\%). The Uppermost till can be characterized as a B1 till. 


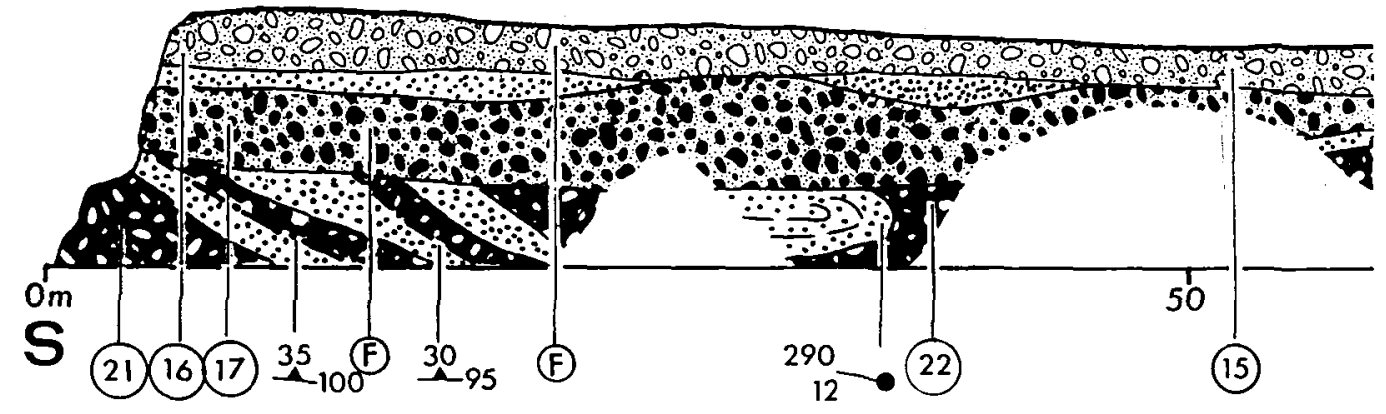

\begin{tabular}{|c|c|c|}
\hline$\because \because$ LOWER TILL & $8 \%$ & $\begin{array}{l}\text { MIDDLE TILL } \\
\text { TRELDE NES TILL }\end{array}$ \\
\hline
\end{tabular}

Fig. 12: Selected cliff section, Ashoved (loc. 2).

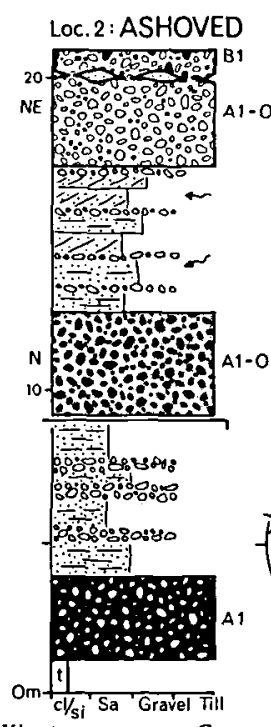

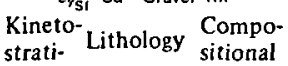
graphic units
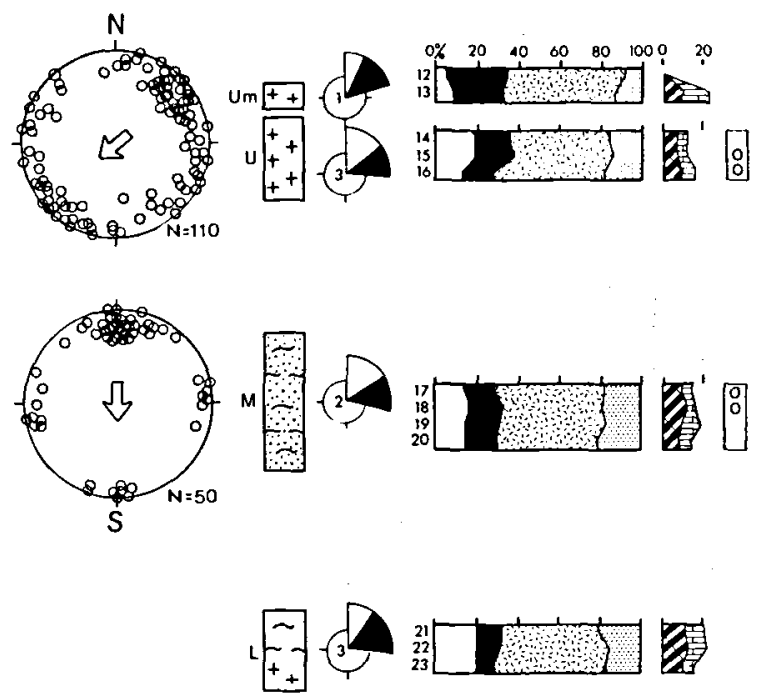

Till-

fabric

\begin{abstract}
Glacial tectonics
\end{abstract} groups

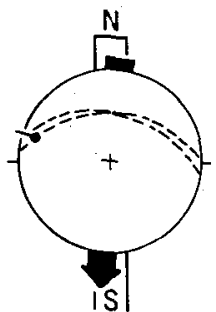

MIDDLE TILL

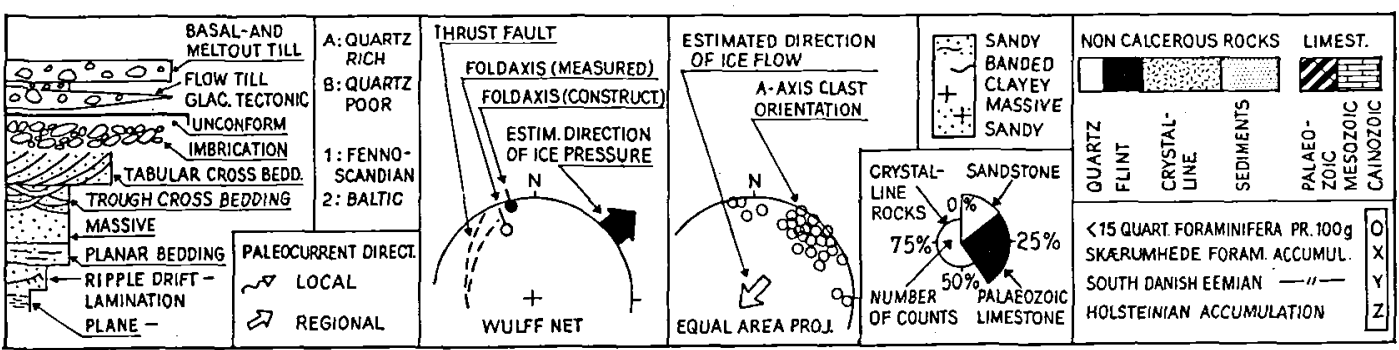

Fig. 13: Glacial stratigraphic data chart, loc. 2, Ashoved. Lower till (L) Palsgård Till, Middle till (M) Trelde Næs Till, Upper till (U) Ashoved till, Uppermost till (Um) Mid Danish Till. 


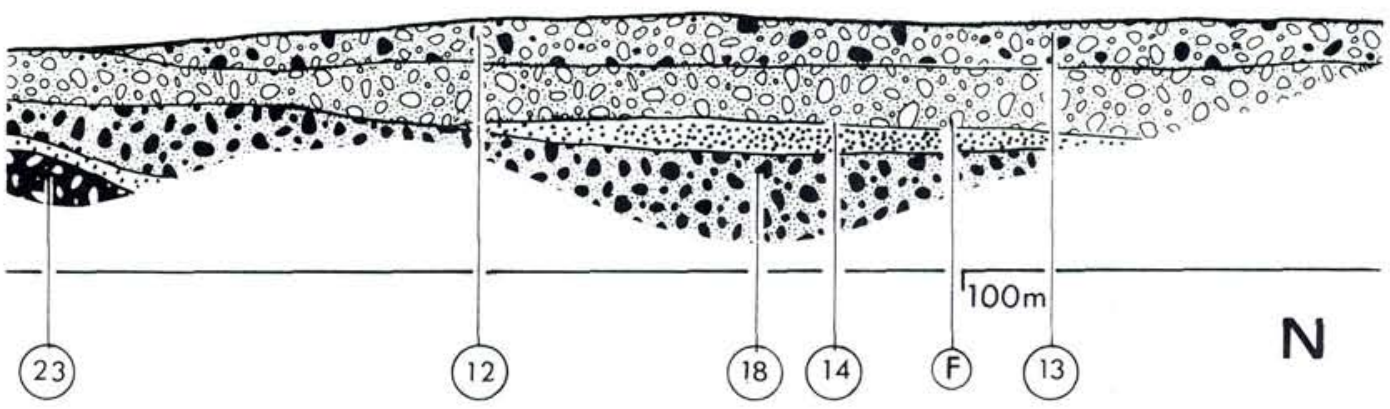

\section{CONCLUSION}

The sequence at Ashoved is related to four major ice-streams. The oldest advance deposited a till (Palsgård Till) of Fennoscandian provenance containing Middle Swedish indicator erratics and with high quartz values compared to the flint content. This till was probably deposited by the same ice sheet which deposited the pre-Holsteinian till at Trelde Næs.

The oldest advance was succeeded by an advance from the north depositing a $\mathrm{N}$-till of Fennoscandian provenance with equal amounts of quartz and flint and with a characteristic content of Oslo indicator erratics and other rocks of northerly derivation (Trelde Næs Till). The glaciotectonic deformation from the north followed by the deposition of a $\mathrm{N}$-till corresponds to what came to pass at Trelde Næs. Deposition of meltwater deposits by westward moving streams separate the $\mathrm{N}$-till from the NE-till of Fennoscandian provenance (The Ashoved Till). It contains equal amounts of quartz and flint and notable amounts of kinne-diabase. The Upper till was deposited by an ice-sheet which advanced from a northeasterly direction. The Uppermost till has a Fennoscandian provenance and low quartz content. Due to the lack of Baltic indicator erratics at Ashoved the Uppermost till is thought to be associated with a younger ice-sheet advancing probably from north-easterly directions.

\subsection{LOC. 3: RØGLE KLINT}

Røgle klint is situated on the Lillebælt coast of western Fyn $8 \mathrm{~km}$ ENE of Middelfart (fig. 7). The cliff section consists of 3 dislocated tills interstratified by glaciofluviatile material and rests upon Tertiary clay and sand. The two older tills are supposedly also separated by interstadial, marine silt and clay (Tellina Clay). In places a discordant till covers the sequence which has been dislocated from the ENE. Only a minor stretch $(500 \mathrm{~m})$ of the main cliff site has been accessible for study over the past 3 years.

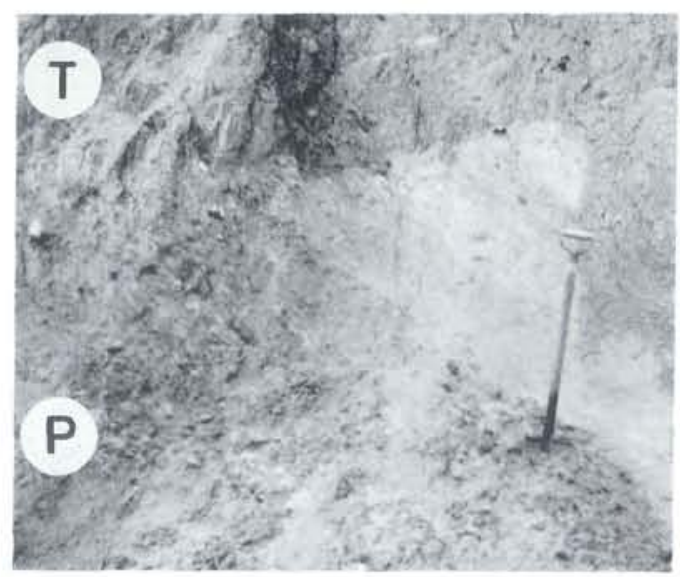

Fig. 14: Palsgard till (P) overlain by waterlaid outwash deposits, thrusted by ice-deformation from the North and unconformably overlain by the Trelde Nas Till (T), loc. 2, Ashoved. 


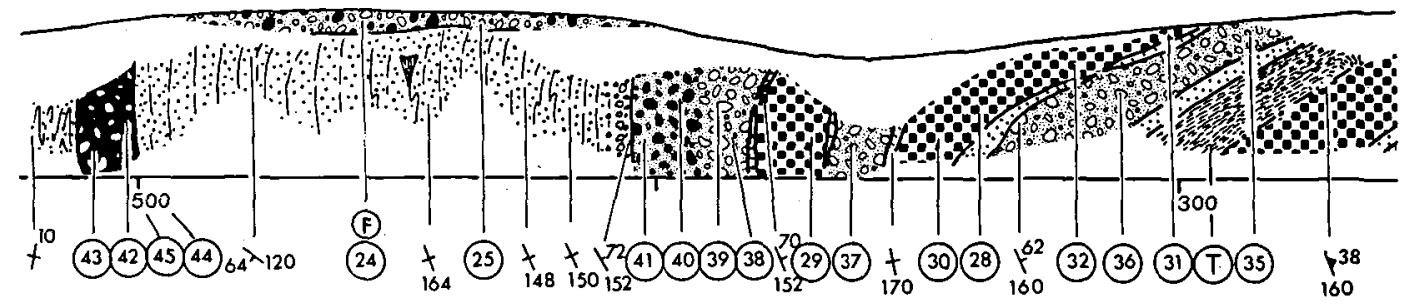

ENE

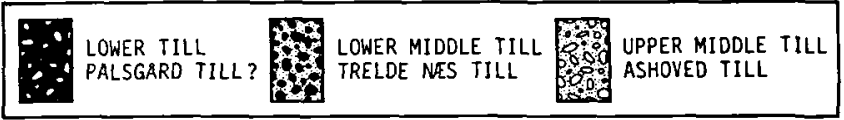

Fig. 15: Selected cliff section, Røgle Klint (loc. 3).

\section{PREVIOUS INVESTIGATIONS}

Prior to the publication of structural and stratigraphical studies at Røgle Klint (Madsen \& Nordmann 1940), a prolonged discussion on the nature of the Quaternary deposits at Røgle and their tectonic setting had taken place. Madsen \& Nordmann (1940) sum up this discussion before presenting the data of their investigations, which resulted in the following glacial stratigraphy: 1 ) till A underlying, 2) the Tellina Clay characterized by a sparse boreoartic molluscan fauna overlain by 3) till B and 4) till C. 5) A discordant till D covers the surface of the cliff. The above mentioned stratigraphical units (1-5) are separated by stratified, waterlaid drift, some of which contain re-deposited clasts of Tellina Clay (sand and gravel separating tills $A$ and $B$ ) or marine molluscan fragments of Eemian age (separating tills C and D). Madsen and Nordmann repeat the glacial chronology of deposits described by Madsen et al. (1928) which are as follows: Till A is of Elsterian age followed by the Tellina Clay deposited during the early Holsteinian interglacial. Till B is of Saalian age and tills $C$ and D belong to the Main Weichselian and the East Jylland advances respectively. The direction of dislocation of the sequence beneath till $D$ is from the ENE. Despite the evidence from other localities (cf. Gry 1940, Jessen 1930, 1931) it is the opinion of Madsen and Nordmann, that the dislocation was caused by deep-seated tectonism, and not glaciotectonic deformation.

Madsen and Nordmann used clast petrographic studies based on the proportion between flint and crystalline rocks (flint quotient) to describe the four major till units, and to sub-divide tills $B$ and C into 2 sub-units.

Lykke-Andersen (1974) proposed the Tellina Clay to be of Early Weichselian age (Brorup?) on the basis of foraminiferal studies of the tills at Røgle. Lykke-Andersen found that till B is characterized by a re-admixed, diluted foraminiferal assemblage of Skærumhede type (X-"fauna") and that till $C$ contains a re-deposited Eemian foraminiferal assemblage (Y-"fauna"). However, this information has not been published, and neither the exact location of samples nor the size of samples is therefore known.

Sjørring and Frederiksen (1980) suggests an Elsterian age for till $\mathrm{A}$ based on fine gravel analysis.

\section{DESCRIPTION}

The main section of the cliff site examined by Madsen and Nordmann (1940) is still accessible for study (Madsens \& Nordmanns parts IX-V) even though the degree of exposure has been rather limited, Also, a minor section of Madsen and Nordmann's section (part I) at the very southwesterly end of the cliff has been studied. Unfortunately the degree of exposure prevents a full investigation of the glaciotectonic and the stratigraphic setting of the cliff section, for which reason the structural model and the glacial stratigraphy proposed by Madsen and Nordmann is still favoured, even though further studies might possibly led to a reinterpretation (fig. 15). 


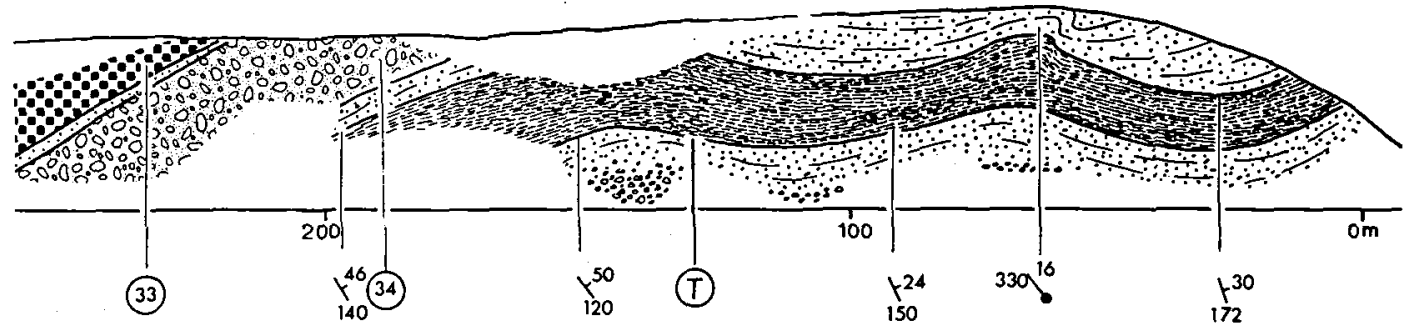

From the WSW the Tellina Clay, with its under- and overlying sandy to gravelly waterlaid deposits, has been folded by ice-pressure from the ENE. Towards the ENE the younger of the sand and gravel deposits is overlain by the Middle till (=B) and the Upper till (=C). The tills are separated by smears and lenses of sand and gravel. The upper part of the above mentioned sequence has been thrust-over upon itself from the ENE giving rise to a repetition of the sequence in the middle part of the cliff site. Further eastwards an intricate intermixture of the two tills (Middle and Upper tills) and waterlaid deposits apparently confuse the simple structural setting. However, the deposits are, at this location, situated in the centre of a large synclinal fold in which the glaciotectonic deformation could have caused the squeezing and intermixing of the deposits. On the left flank of the synclinal fold the Middle till overlies a coarsening upwards sequence of waterlaid sand and pebbles of great thickness resting upon the Lower till. This sequence, in which a $1 / 2 \mathrm{~m}$ size lens of Tellina Clay (described by Madsen $\&$ Nordmann 1940) still can be observed, has undergone intese isoclinal folding obscuring the true thickness and most primary sedimentary structures of the deposits.

\section{STRATIGRAPHY (fig. 16)}

THE LOWER TILL (L) is a dark, greyish brown, sandy banded till more than $5 \mathrm{~m}$ thick, resting on intensly folded sand (fig. 17). It contains limited amounts of Pal.limestone (11-18\%) and roughly equal amounts of quartz and flint
$(14 \%)$. The till contains hardly any Quaternary foraminifera. The lower till can be characterized as an A1-0 till.

THE LOWER WATERLAID BEDS are more than $15 \mathrm{~m}$ in thickness and consist of a sequence gradually fining upwards from gravel to heterolithic silty sand and clay in the western part of the cliff section where it underlies the Tellina Clay. According to Madsen and Nordmann it is assumed to rest upon the Lower till even though not exposed in this part of the cliff section. In the eastern part of the section, the lower half of the sandy stratified drift separating the Lower and the Middle tills is supposed also by Madsen and Nordmann (1940) to be part of the lower stratified drift.

THE TELLINA CLAY is a dark brown laminated marine clay of at least $10 \mathrm{~m}$ in thickness and with a strong imprint of re-deposited Tertiary clay and fine sand. Towards the southwest the lower waterlaid beds changes gradually upwards into the Tellina Clay. This is characterized by a sparse artic to boreoartic molluscan fauna dominated by Macoma (Tellina) calcarea and Saxicava rugosa (Madsen \& Nordmann 1940). Two samples of the Tellina Clay were thermoluminiscence dated and the results obtained showed ages between 600.000 and 300.000 TL-years (Kronborg pers.comm.).

THE UPPER WATERLAID DEPOSITS, in the western part of the section, consist of a coarsening upwards sequence more than $10 \mathrm{~m}$ thick with a gradual transition from the underlying Tellina Clay. In the eastern part of the section, 


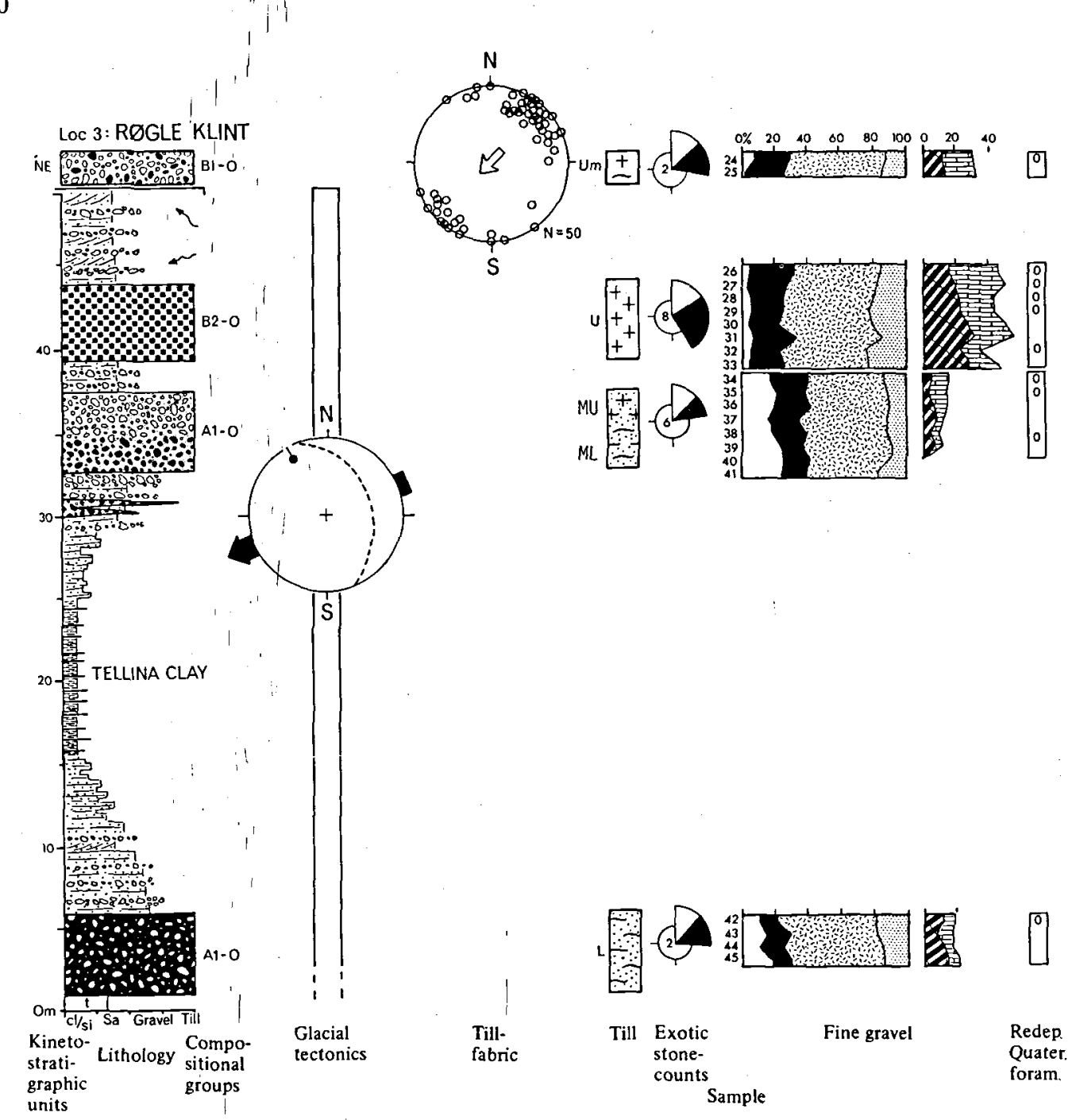

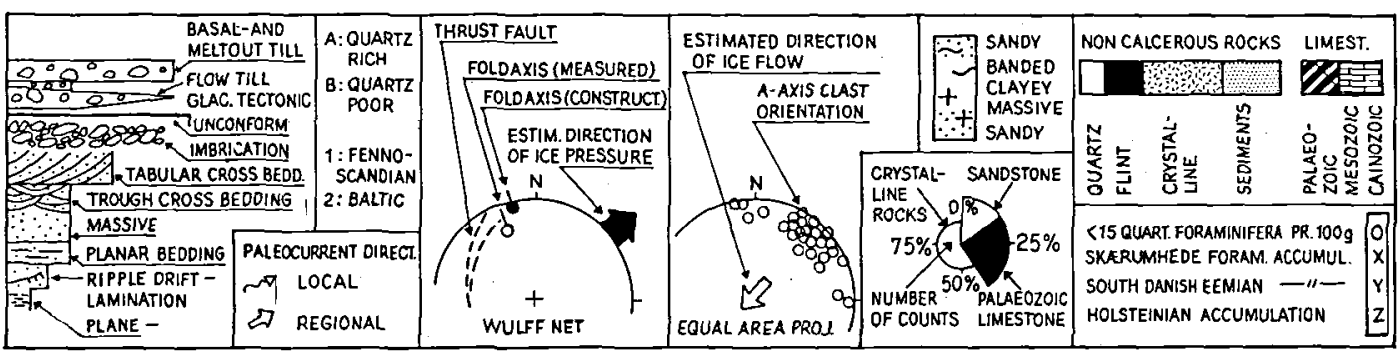

Fig. 16: Glacial stratigraphic data chart, loc. 3. Røgle Klint. Lower till (L) Palsgård till, Lower Middle till (LM) Trelde Næs Till, Upper Middle till (UM) Ashoved Till, Upper till (U) Lillebalt Till, Uppermost till (Um) Mid Danish Till.

the sandy drift containing clasts of Tellina Clay coarses upwards into coarse gravel with minor lenses of flow-till immediately beneath the Middle till.

THE MIDDLE TILL (M): Trelde Næs Till Ashoved Till is banded and blackish in the lower parts (fig. 18) and it appears brown, and massive in the upper parts. The till unit is sandy and more than $5 \mathrm{~m}$ in thickness. The clast composition shows small amounts of Pal.limestone (9\%) and roughly equal amounts of quartz and flint $(20 \%)$. However, the samples taken in the eastern part 


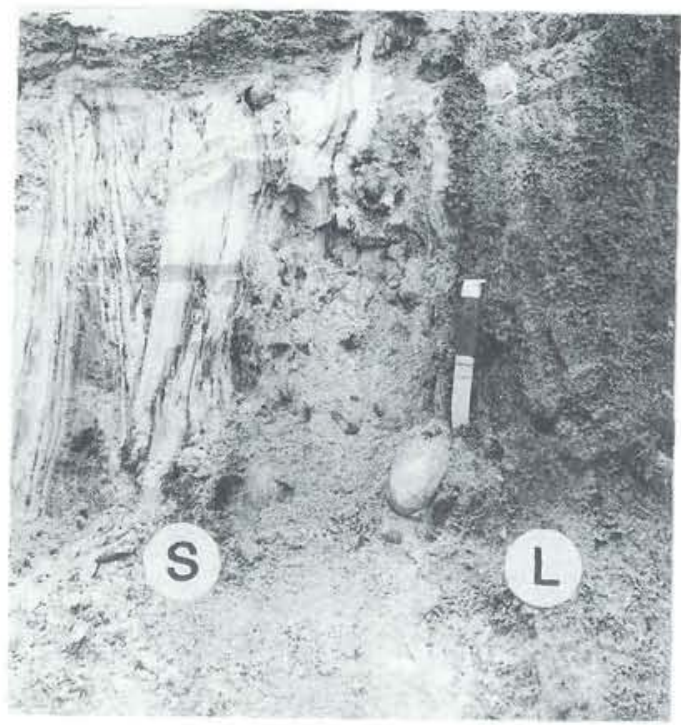

Fig. 17: Lower till (L) at pt. $500 \mathrm{~m}$ overlying intensily floded meltwater sand (S) with a strong imprint of Tertiary material, loc. 3, Røgle Klint.

of the section, presumably in the lower part of the till, show somewhat higher values of quartz $(25 \%)$. On similar grounds Madsen and Nordmann mentiones a bipartiation of till B from this section of the cliff. One lower part (B1) is rich in crystalline rocks and poor in chalk and flint and an upper part (B2) rich in chalk and flint and poorer in crystalline material. The Middle till contains very limited amounts of Quaternary for-

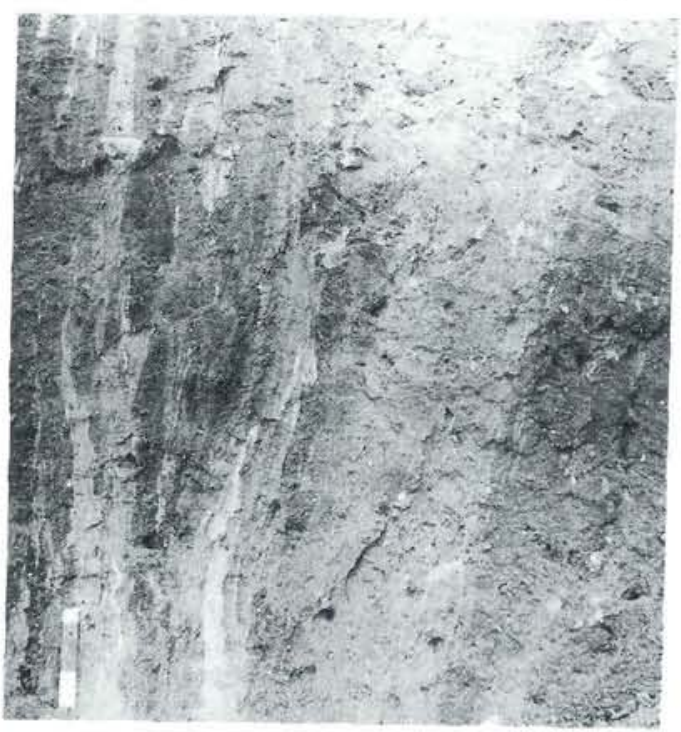

Fig. 18: Middle till (lower part $=$ Trelde Nas Till) at pt. $400 \mathrm{~m}$, loc. 3, Røgle Klint.
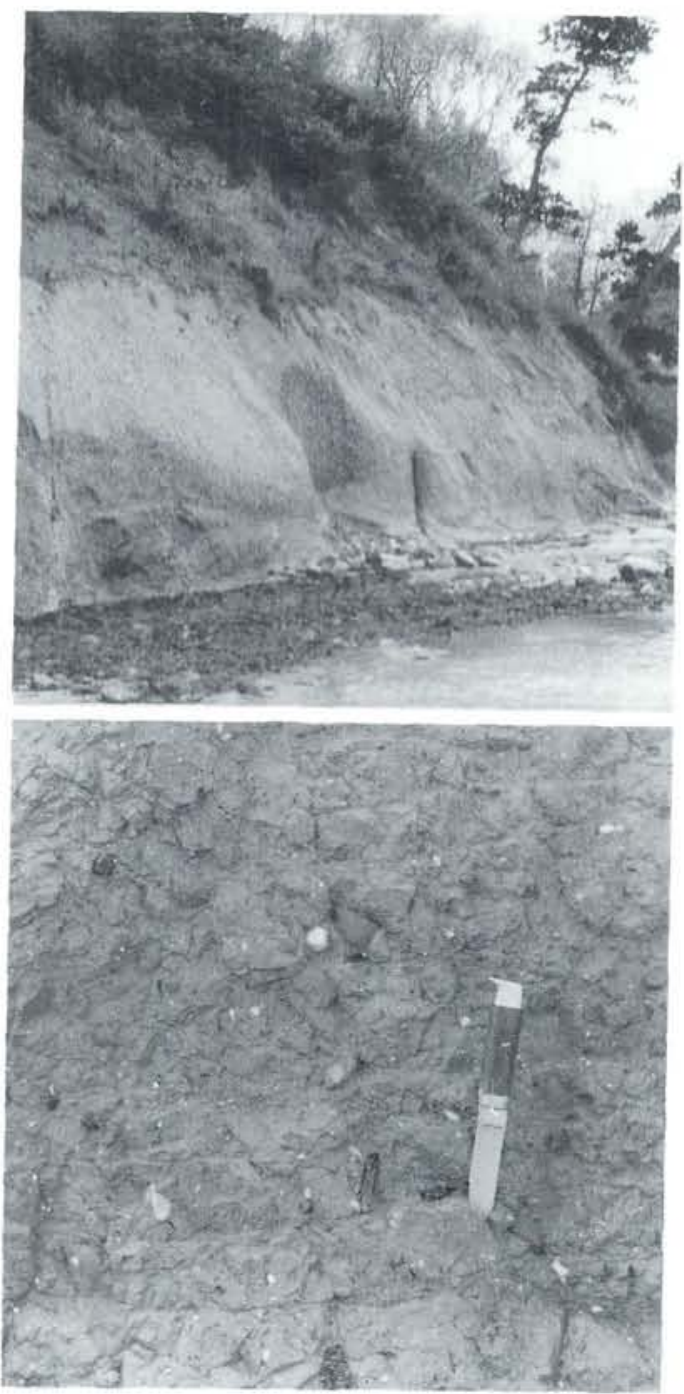

Fig. 19: Upper part: Lillebalt Till overlain by stratified, waterlaid sand and gravel at the extreme southern end of Røgle Klint. Lower part: detail of the Lillebalt Till (Upper till).

aminifera. In accordance with its composition the Middle till is classified as an A1-0 till.

THE UPPER TILL (U): Lillebælt Till is separated from the Middle till by lenses and smears of sand and gravel. The till is grey, clayey, massive and about $4 \mathrm{~m}$ in thickness and it can also be observed outside the main profile at Madsen and Nordmann's part I (fig. 19). It contains about $26 \%$ Pal. limestone, small amount of quartz $(6 \%)$ and much flint $(22 \%)$ and the content of re-deposited Quaternary foraminifera is insignificant. The Upper limestone rich till is compositionally characterized as a B2-0 till. 


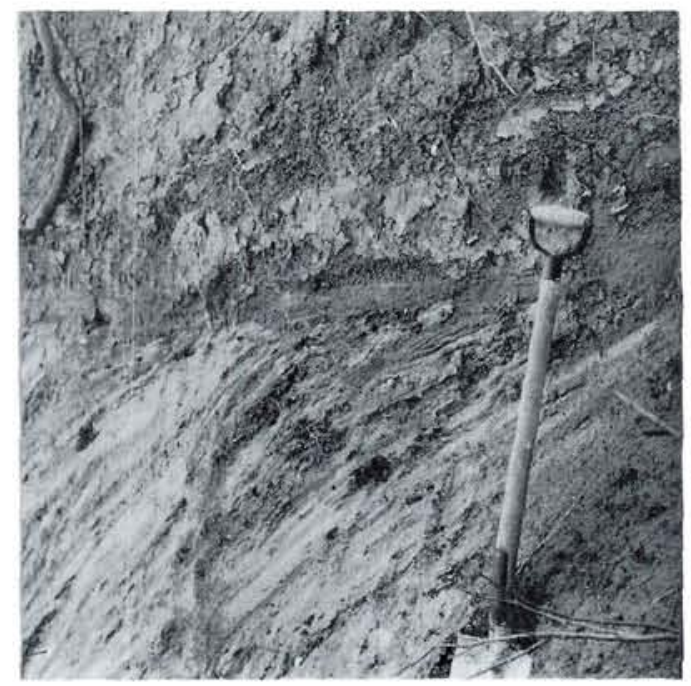

Fig. 20: Uppermost till (Mid Danish Till) unconformably overlying fine grained waterlaid material, pt. 450 , loc. 3 , Røgle Klint.

THE UPPERMOST STRATIFIED DRIFT consists of more than $5 \mathrm{~m}$ of plane- or tabularand trough crossbedded sand, interbedded with decimetre thick sheets of gravel overlying the Upper Till (fig. 19). Palaeocurrents were directed westward. The stratified drift contains numerous shell-fragments of re-deposited Eemian marine molluses (Madsen \& Nordmann 1940).

THE UPPERMOST TILL (Um): Mid Danish Till lying unconformably upon the dislocated sequence, is brown massive, clayey and less than 2 $\mathrm{m}$ in thickness (fig. 20). Long axis measurements of clasts revealed a north-eastward dipping longitudinal fabric, indicating icemovement from the NE. It contains roughly $16 \%$ Pal.limestone, about $6 \%$ quartz, and little less than $25 \%$ flint, and it does not contain noteworthy amounts of Quaternary foraminifera. The Uppermost till is characterized as a NE-till of B1-0 composition.

\section{DISCUSSION}

When Madsen et al. (1928) described tills of the previous 3 glaciations (Elsterian, Saalian and Weichselian) they used the flint quotient to correlate individual tills over considerable distances (more than $100 \mathrm{~km}$ ). As Røgle Klint played a major role in these correlations, it should be mentioned, that till $\mathrm{C}$ is clearly of Baltic provenance (cf. Madsen \& Nordmann 1940) and therefore unlikely to have been deposited by the Main Weichselian (NE) ice sheet as suggested by them.
Equally till D with Fennoscandian provenance was most probably not deposited by the East Jylland advance.

The results of Lykke-Andersen's (1974) examination of re-deposited Quaternary foraminifera in the tills of Røgle Klint are not confirmed by foraminifera analysis carried out in connection with the present investigation. In the present case 10 samples, taken chiefly from the Middle and Upper tills (B \& C), contained quantities of redeposited Quaternary foraminifera that were too small for faunal comparison, i.e. less than $15 \mathrm{pr}$ $100 \mathrm{~g}$.

\section{CONCLUSION AND CORRELATION}

The TL-datings of the marine, interstadial clay suggests, that an age higher than the Holsteinian interglacial is to be expected for the till apparently underlying the Tellina Clay. The boreoartic clay itself could have been deposited during the late Elsterian glaciation as proposed by Madsen et al. (1928) an assumption recently favoured by Knudsen (1986). Consequently the lower till (till A) must be grouped together with other presumably pre-Holsteinian tills in the region. The Middle till could correspond to either one of the postHolsteinian, quartz rich tills previously described (Trelde Næs Till, Ashoved Till). However, a division of the Middle till-unit related to both postHolsteinian, quartz rich tills is suggested at present partly on the basis of Madsen and Nordmann's stone counts.

The Upper till and the Uppermost NE-till belong to the quartz poor group (B-group). The upper till is rich in $\mathrm{Pal}$. limestone but the uppermost till is not. Due to differences in quartz content and stratigraphic position, the NE-tills of Ashoved and Røgle can not be correlated with one another, and therefore presumably belong to different NE-ice-streams, separated in time, at least by the deposition of the Upper (Baltic) till and the Uppermost waterlaid deposits. The younger quartz rich tills (Middle till) could have been deposited by two individual ice sheets presumably after the Holsteinian interglacial. The Upper, Baltic till (Lillebælt Till) is younger than the quartz rich tills and older than the deformation from NE. Moreover, the Upper till is overlain by stratified drift containing re-deposited, marine Eemian shell fragments, indicating a Weichselian age for the Uppermost NE-till. The youngest re- 


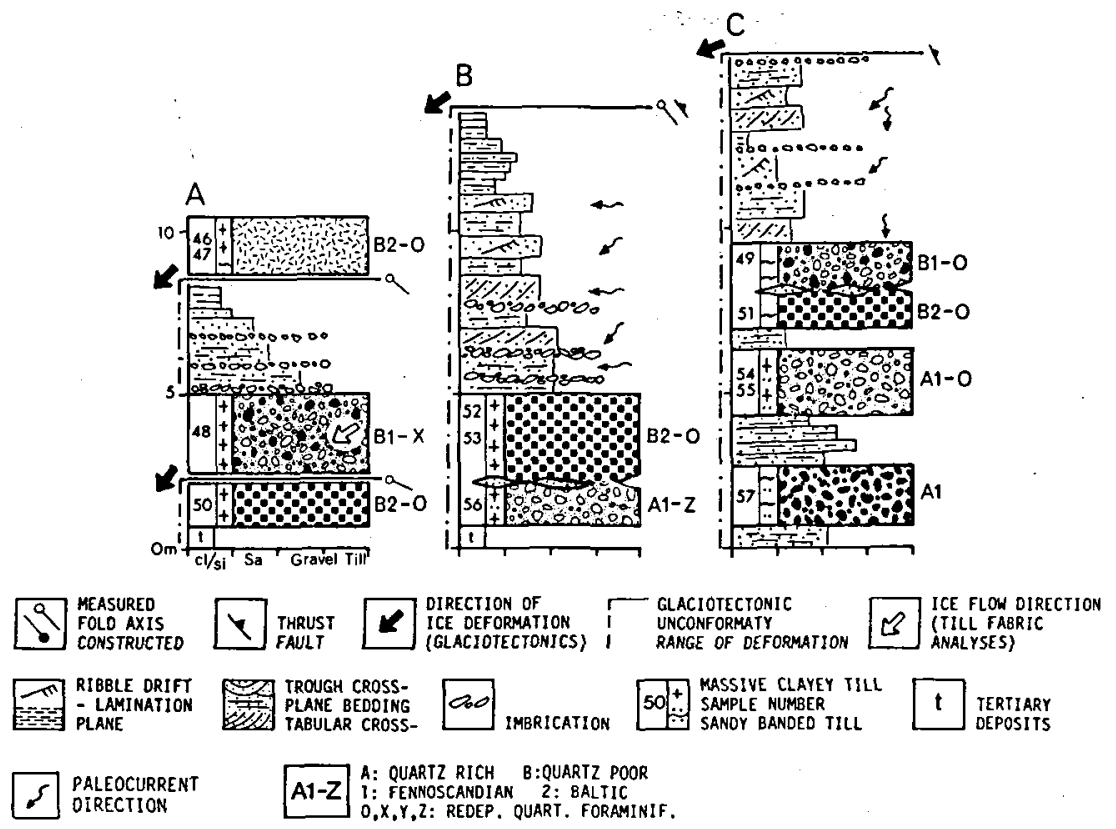

Fig. 21: Simplified lithological logs, loc. 4, Æbelø. A: Æbelø Bådehavn, B: Tjørnehule, C: Nodrebråd.

corded ice sheet deposited the Uppermost NE-till of Fennoscandian provenance (Mid Danish Till).

\subsection{LOC. 4: $A B E L \emptyset$}

Æbel $\varnothing$ is an island less than $3 \mathrm{~km}^{2}$ in size lying approximately $5 \mathrm{~km}$ north of the island of Fyn (fig. 7). Three cliff sites (A, B \& C) on the island have been investigated. As a whole the glacial sequence at the three sites consists of four tills, some of which are separated by stratified sand and gravel, glaciotectonically folded and overthrusted from northeasterly directions and overlain by a discordant till.

\section{PREVIOUS INVESTIGATIONS}

V.Madsen (1900) mentions the complicated structural conditions in the cliffs of $Æ$ belø, where Tertiary clay and glacial deposits are exposed in "a somewhat disorderly fashion" (translated from Madsen 1900). Because of the change in the degree of exposure Madsen's glacial stratigraphic units cannot be demonstrated, at present. He recognized two tills however, one rich and one extremely poor in Pal. limestone. No clear indication was given regarding the relative age of the tills, only that they are older than the youngest till cropping out on the island's surface.

V.Milthers (1932) conducted indicator erratic counts on the beach gravels on the north coast of Æbelø, and the dominance of Norwegian over Baltic indicators is ascribed by K.Milthers (1942) to the presence of an older Norwegian till the indicator erratic content of which has not been dimmed by younger Baltic tills.

\section{DESCRIPTION}

Three main sites have been chosen for glacial stratigraphic studies. Site A (Bådehavn) (fig. 21) is situated around, and to the northeast of, the landing-stage on the SW side of the island. It is built up of the Middle till folded by ice pressure from the NE, unconformably overlain by the Upper till which in turn is overlain by a generally sandy, fining upwards sequence. These deposits have undergone glaciotectonic deformation from the NE. A discordant till (Uppermost till) rests unconformably upon the dislocated deposits.

Site B (Tjørnehule) is a cliff section more than $400 \mathrm{~m}$ long in the central part of the SE coast of the island (figs 21, 22). Site B consists of Tertiary clay, the Lower till, the Middle till, and is overlain by the fining upwards sequence. This series of strata has been overthrusted and folded by icedeformation from north-easterly directions (fig. 25).

Site C (figs 21,23 ) is situated on the north- 

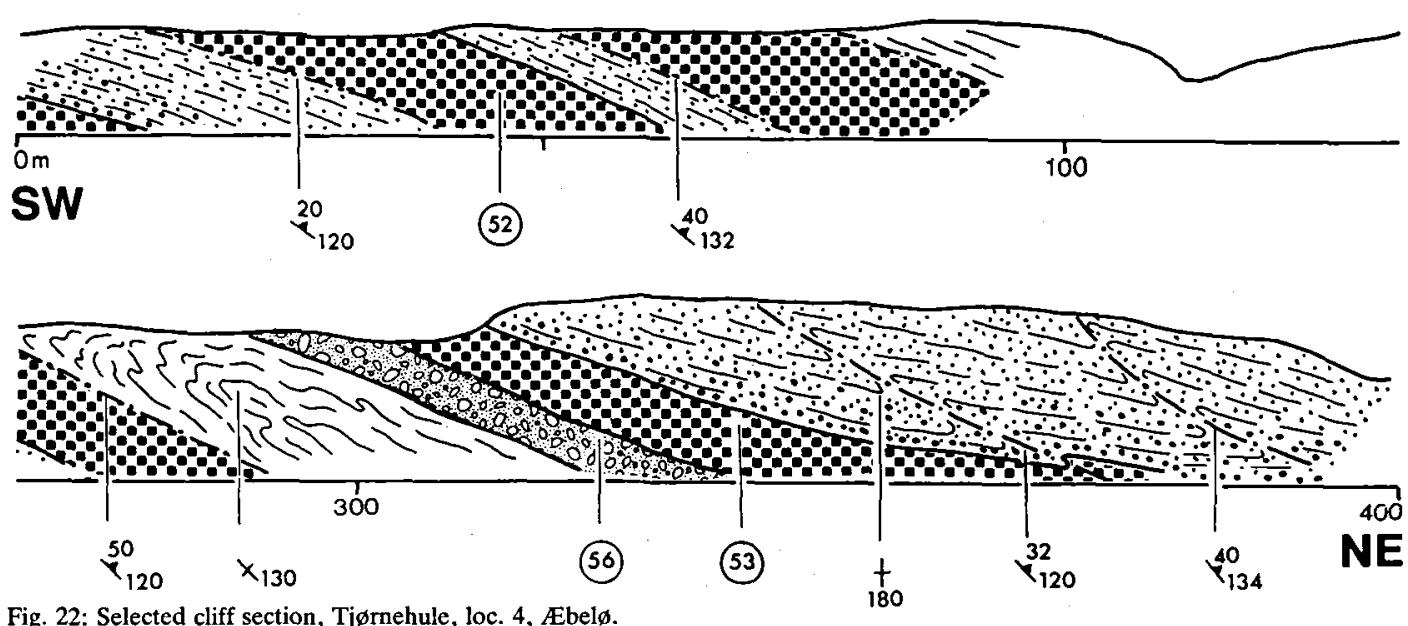

Fig. 22: Selected cliff section, Tjørnehule, loc. 4, Æbelø.

western tip of $Æ$ Ebelø (Nordrebråd) and consists of the Lowermost till, overlain by fine grained waterlaid deposits and the lower till. The Middle and the Upper tills have been thrusted upon this vertically inclined sequence from a north-easterly direction. The glacial sequences from the three sites are correlated with each other and illustrated in the data-chart (fig. 24).

\section{STRATIGRAPHY}

THE LOWERMOST TILL (Lm): Trelde Nas Till is a sandy, banded, dark brown to blackish till of less than $3 \mathrm{~m}$ in thickness. Clast composition shows little Pal.limestone (12\%) and roughly equal amounts of quartz and flint (16\%). The lowermost till is an A1-till.

THE LOWER TILL (L): Ashoved Till is dark brown to blackish, sandy and massive. It is more than $3 \mathrm{~m}$ thick and contains small amounts of Pal. limestone (10-16\%) and equal amounts of quartz and flint $(15 \%)$. The content of re-deposited Quaternary foraminifera is low except for one sample which contains a rich $(Z)$ accumulation of foraminifera resembling the fauna of the marine Holsteinian. The lower till is characterized as an A1-Z till.

THE MIDDLE TILL (M): Lillebælt Till is separated from older tills by lenses of fine grained sand. The Middle till is more than $3 \mathrm{~m}$ in thickness, grey, massive and clayey. It contains large amounts of Pal.limestone $(20-40 \%)$, small amounts of quartz $(4 \%)$ and large quantities of flint $(30 \%)$. The Middle till does not contain noteworthy amounts of re-deposited Quaternary foraminifera. The Middle till is characterized as a B2-0 till.

THE UPPER TILL (U): Mid Danish Till unconformably overlies the Middle till and Tertiary deposits at site A. Here its substratum has been folded from the north-east. The Upper till is a grey, clayey, massive till and clast long axes dip gently towards the NE giving a longitudinal fabric, indicating ice-movement from the NE. The Upper till is poor in Pal.limestone (8-13\%) and

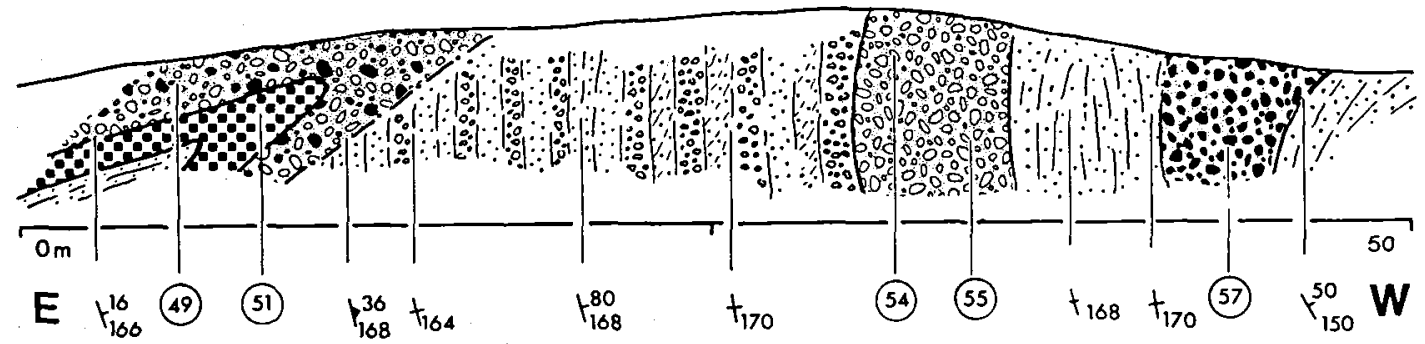

Fig. 23: Selected cliff section, Nordrebråd, loc. 4, Ebelø. Further explation fig. 22. 


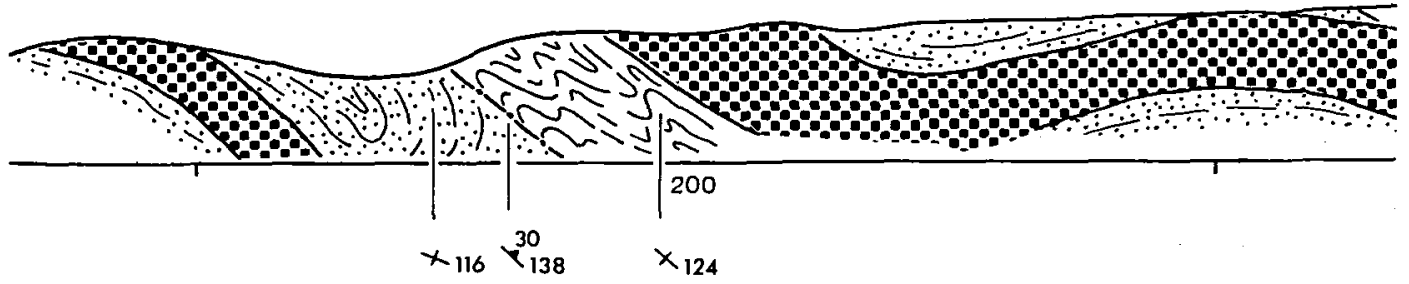

\begin{tabular}{|c|c|c|c|}
\hline $\begin{array}{l}\text { 89 LOWERMOST TILL } \\
\text { TRELDE NES TILL }\end{array}$ & $\begin{array}{l}809 \\
60 \% \text { LOWER TILL } \\
6 \% \text { ASHOVED TILL }\end{array}$ & LIDDLE TILL & $\begin{array}{l}80 . \\
0 \% \text { UPPER TILL } \\
0 \% 9 \text { MID DANISH TILL }\end{array}$ \\
\hline
\end{tabular}

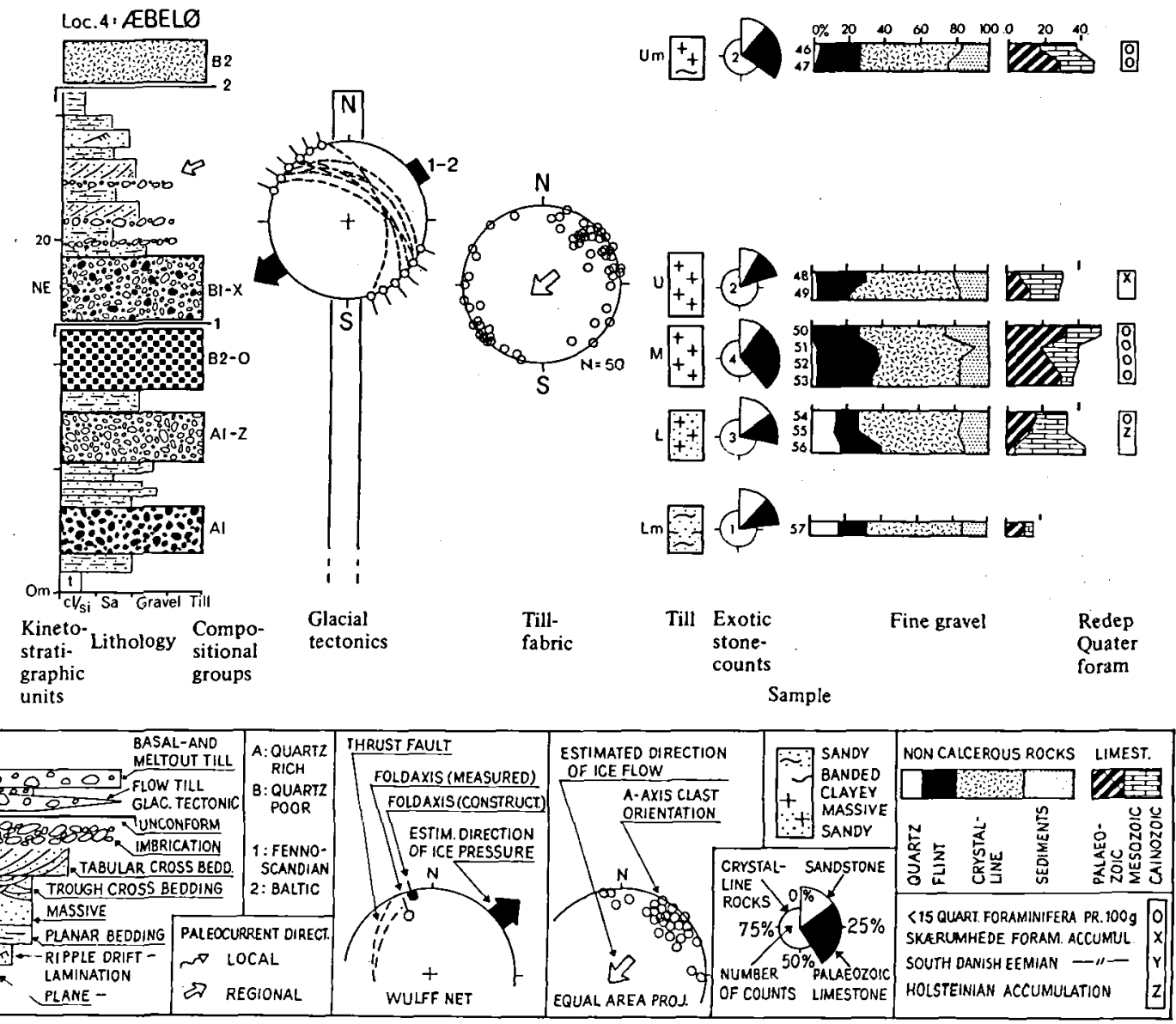

Fig. 24: Glacial stratigraphic data chart loc. 4, Abbelø. Lowermost till (Lm) Trelde Næs Till, Lower till (L) Ashoved Till, Middle till (M) Lillebælt Till, Upper till (U) Mid Danish Till, Uppermost till (Um) East Jylland Till. 


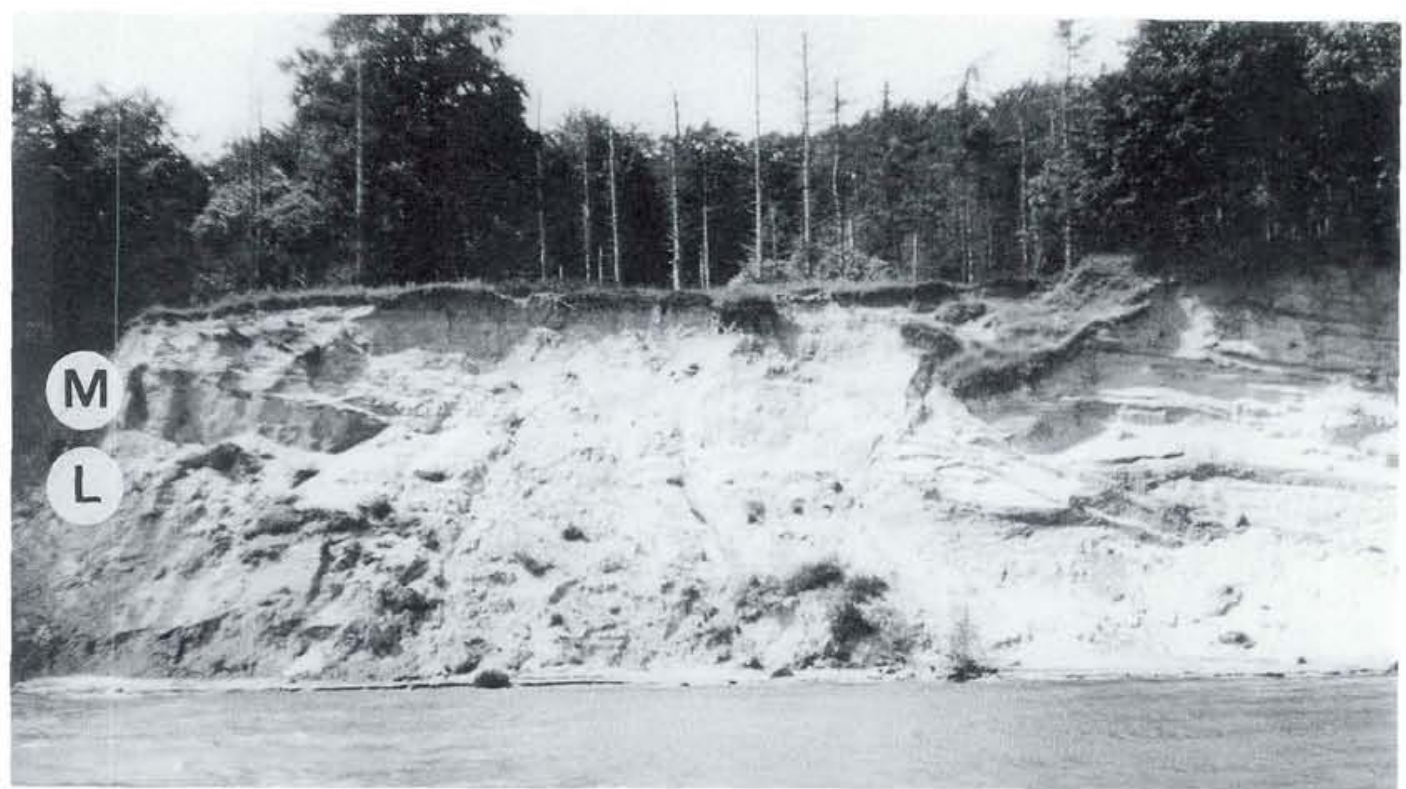

Fig. 25: SW-NE oriented section showing the Lower till (L) Ashoved Till overlain by the Middle till (M) Lillebælt Till and waterlaid outwash thrusted from the NE, pt. $350 \mathrm{~m}$, Tjørnehule, loc. 4, Æbelø.

quartz (4\%). Apart from numerous kinnekullediabase erratics the till is also characterized by many of the so-called Katholm erratics, which are indicators of ice movement from the NE as described by Baartman and Christensen (1975). The upper till also contains a re-deposited foraminiferal accumulation, resembling the Skærumbede fauna $(\mathrm{X})$ and suggesting a Weichselian age. The Upper till can be characterized as a NEtill of B1-X composition.

THE WATERLAID, FINING UPWARDS SEQUENCE is deposited upon the Upper till at site $\mathrm{A}$ but it overlies the Middle till at site B, and it apparently overlies the Lower till at site C. It is a sequence, more than $10 \mathrm{~m}$ thick, fining upwards and characterized by imbricated pebble and gravel sheets interbedded with plane-bedded and tabular cross-bedded sand. Higher up in the sequence climbing ripples laminated sand and silt dominate, ending with varved silt and clay. The current-bedding indicates palaeocurrents moving west- and south-westward. This sequence and underlying deposits have been subjected to glaciotectonic deformation from the NE (fig. 25).

THE UPPERMOST TILL (Um): East Jylland Till is found at site A, where it unconformably overlies the top of the fining upwards sequence which is folded from the NE. The Uppermost till is less than $2 \mathrm{~m}$ thick, massive clayey and brown. It contains rather large amounts of Pal.limestone $(20-24 \%)$ and little quartz (3\%), and very limited amounts of re-deposited Quaternary foraminifera. The Uppermost till is characterized as a B2-0 till.

\section{CORRELATION AND CONCLUSION}

The Lowermost and the Lower tills (Trelde Næs Till, Ashoved Till), are both characterized by equal amounts of quartz and flint and with Fennoscandian provenance, and in the Lower till, a content of re-deposited Holsteinian foraminifera. They are correlated with the two older, postHolsteinian from Trelde Næs and Ashoved and they assumingly correspond to the middle till from Røgle with similar clast composition. The Middle till at Æbelø (Lillebælt Till) is characterized by small quantities of quartz and has a Baltic provenance and is correlated with the Upper, Baltic till at Røgle which possesses similar compositional properties. Both tills are glaciotectonically disturbed from the NE, and their relationship in age will be further examined in the description of the next locality. The Upper till (Mid 


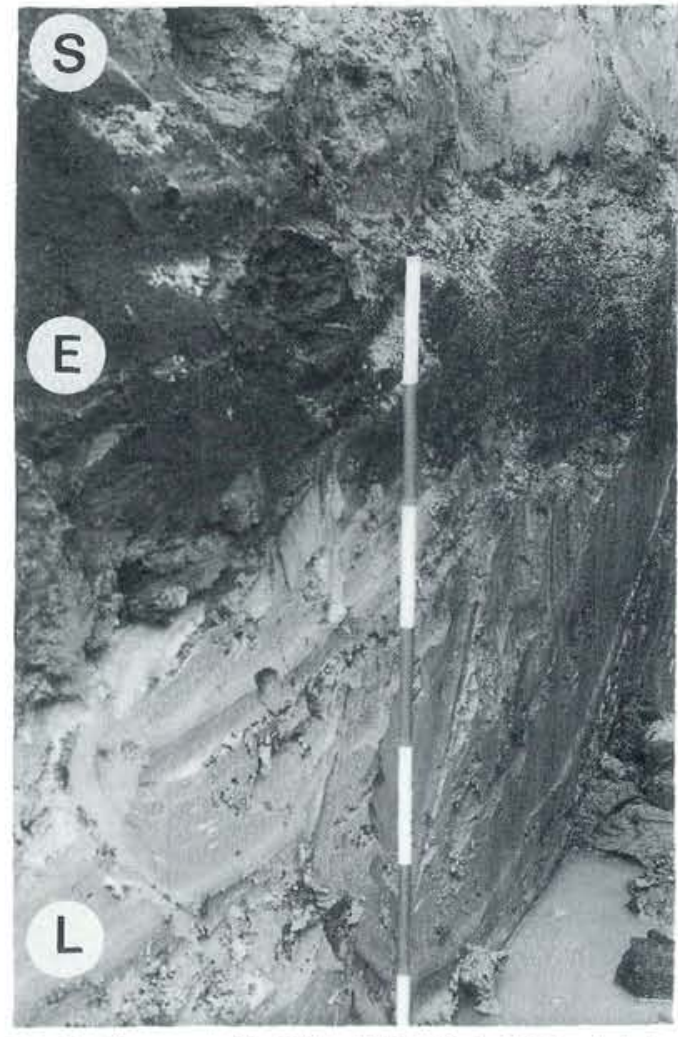

Fig. 26: Limestone rich, Baltic till (L) Lillebælt Till underlying limnic, Eemian deposits (E) and solifluction material (S), loc. 90. Ejstrup (scale $20 \mathrm{~cm}$ interval).

Danish Till) is correlated with the Uppermost till at Røgle, they are both NE-tills with low quartz contents and of Fennoscandian provenance. Readmixed quaternary foraminifera of $\mathrm{X}$ association at Æbelø suggests a Weichselian age for the till. The Uppermost till (East Jylland Till) is of Baltic provenance and has a low quartz content. It was most probably deposited by the youngest Weichselian icestream that covered Æbelø.

\subsection{LOC 90: EJSTRUP}

Even though this site (fig. 7) is not characterized as a principal locality, it is the only locality in the region where a Baltic, probably late Saalian till, is found overlain by limnic deposits from the Eemian Interglacial. The description of this locality will appear together with the other localities of area 9 , but a few principal features concerning the glacial stratigraphy of the whole region are connected with this locality at Ejstrup as well as the classical localities at Brørup $20 \mathrm{~km}$ west of the region examined.

\section{PREVIOUS INVESTIGATIONS}

Hartz (1909) described the flora and fauna of interglacial beds overlying meltwater deposits and till at Ejstrup Station about $1 \mathrm{~km}$ east of the present locality. Hartz concluded that the Ejstrup bog could be correlated with other interglacial bogs at Brørup and he estimated them to belong to the Eemian Interglacial.

V.Milthers (1925) described the substratum of the Eemian bogs in the Ejstrup-Brørup area and indicated that this substratum mainly consists of a clayey till, rich in limestones, occasionally overlain by meltwater clay. The limnic deposits are situated in numerous hollows (kettles) the origin of which may be found in the dead-ice masses of the late Saalian ice-sheet which deposited the limestone-rich till. According to petrographic stone counts made by Milthers in the till underlying the "kettle bogs" at Brørup, the clast composition is of Baltic provenance (22-23\% Pal. limestone in the exotic components). V.Milthers concluded on the basis of indicator erratic counts, that the limestone-rich till underlying the Eemian bogs at Brørup makes up large parts of the surface deposits in the pre-Weichselian glacial landscape west of the Main Stationary Line and that this till was deposited by a Baltic ice sheet probably in the later part of the Saalian.

Regarding the content of re-deposited, marine shells at Brørup, V.Milthers (1925) referred to the samples collected by Hartz from the till underlying the Eemian bogs and found that the till is characterized by re-deposited and fragmented, marine molluscans dominated by boreal species but also containing shell fragments of arctic derivation. The content of shell material had in V.Milther's opinion, its origin in the well described marine Eemian beds from the southern part of Denmark (Madsen et al. 1908).

\section{DESCRIPTION}

The present site is a gravel pit situated on the northern rim of the Kolding A valley at Ejstrup. Beneath more than $8 \mathrm{~m}$ of sandy and gravely, waterlaid outwash deposits a "floor" of grey, calcareous, clayey till is present. A trench about $m$ wide was dug into this floor in an attempt to find more gravel beneath the till. Fortunately, the place chosen revealed a depression in the tillsurface, where interglacial, limnic gyttja and peat deposited upon the till and overlain by solifluc- 


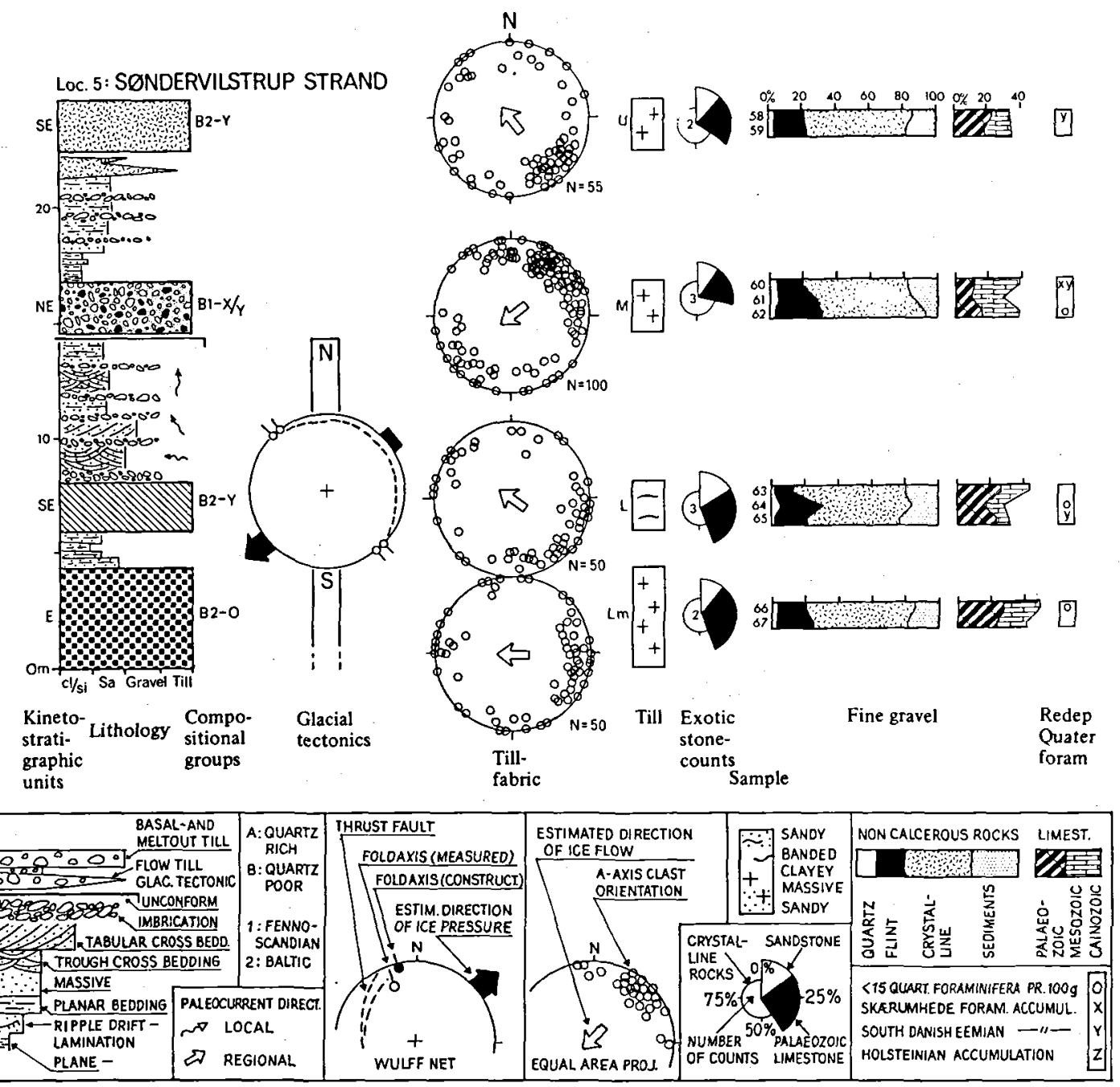

Fig. 27: Glacial stratigraphic data chart, loc. 5, Søndervilstrup Strand. Lowermost till (Lm) Lillebalt Till, Lower till (L) Ristinge Klint Till, Middle till (M) Mid Danish Till, Upper till (U) East Jylland Till.

tion material was found (fig. 26). The combined thickness is more than $2 \mathrm{~m}$. This sequence beneath the meltwater deposits has been folded around an axis trending roughly N-S with a western vergence.

\section{STRATIGRAPHY}

THE TILL: Lillebælt Till is grey, massive, clayey and more than $2 \mathrm{~m}$ in thickness and it rests upon sand and gravel beds. It is rich in Pal.limestone $(21-26 \%)$ and poor in quartz $(5 \%)$. It contains insignificant amounts of re-deposited Quaternary foraminifera, and it is, on compositional grounds, characterized as a B2-0 till.

THE INTERGLACIAL LIMNIC DEPOSITS consist of sandy gyttja deposited upon the till and overlain by peat, and has a combined thickness of about $1 \mathrm{~m}$. Overlying the peat more than $1 \mathrm{~m}$ of re-deposited gyttja, peat and till make up a solifluction deposit filling the former lake-depression. A palynological analysis of a sample of the undisturbed peat revealed a pollen spectrum characteristic of Eemian pollen zone 4 as defined by S.Th.Andersen (1961). In the same peat-bed a thermoluminiscence dating was undertaken, the result of which gave an age of 93100 TL-years (Kronborg 1983).

THE UPPER WATERLAID BEDS consist of more than $8 \mathrm{~m}$ of trough-, tabular cross-bedded and plane bedded sand and pebbles interveined 


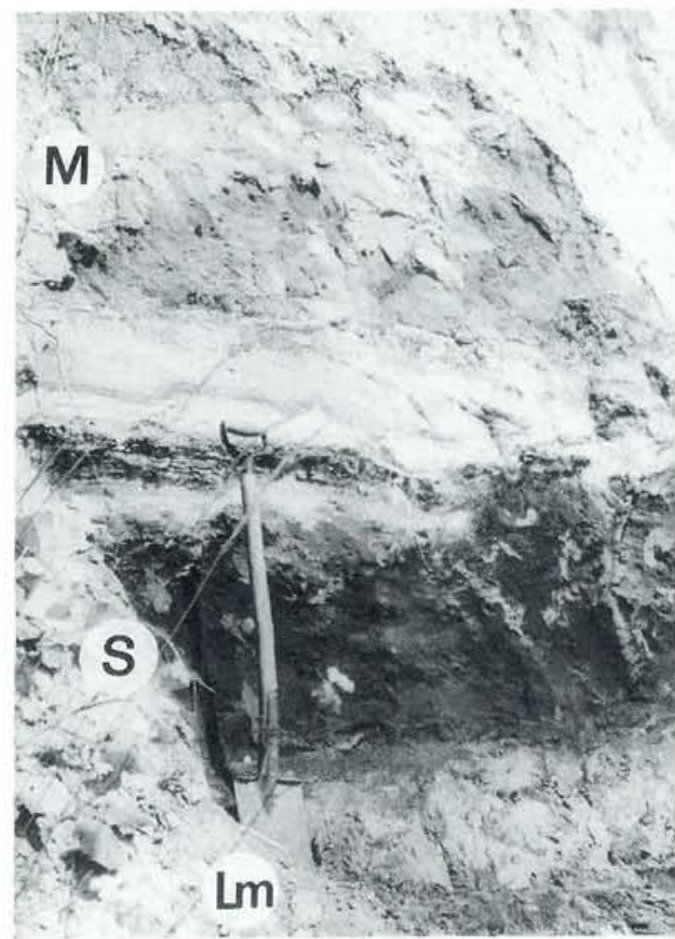

Fig. 28: Precipitated ironoxides on the surface of the lowermost till (Lm) Lillebæit Till and in a cover of meltwater sand (S). The Middle till (M) Mid Danish Till overlies this presumably Eemian paleosol. Søndervilstrup Strand, loc. 5.

by imbricated sheets of coarse gravel. The sedimentary structures indicate westward moving palaeocurrents. The Upper stratified drift has a characteristic content of re-deposited Eemian floral and faunal fragments described by Nordmann (1958).

\section{DISCUSSION AND CONCLUSION}

From a comparison of the data presented by Hartz (1909) and V.Milthers (1925), it is highly probable that the till underlying the Eemian bogs at Brørup is identical with the till underlying the Eemian bog at Ejstrup. The till is poor in quartz and of Baltic provenance and also rich in Cretaceous-Paleocene limestone and a chalk. The samples treated in connection with this investigation have revealed small, but insignificant amounts of re-deposited Quaternary foraminifera. The till at Ejstrup (Lillebælt Till) is correlated with the Baltic till at Røgle, both of which are overlain by glaciofluvatile deposits contaning re-deposited biogenetic fragments of Eemian derivation. The contents of re-deposited Quaternary foraminifera resembling the Y-foraminiferal assemblage reported from the Upper till at Røgle (Lykke-Andersen 1973) could in fact have the same origin as the molluscan fragments from Brørup. This would suggest that marine deposits of pre-Eemian age, strongly resembling the marine Eemian faunas is present in Saalian tills, but apparently in a much more diluted state than is found in Weichselian tills with re-deposited Eemian and Early Weichselian material. The dislocation of the sequence (till, the Eemian deposits and the solifluction material) from an eastern direction could suggest correspondance to the NE-dislocations from Æbelø and Røgle, but it could also have originated during an earlier glacial phase of the Weichselian.

\subsection{LOC 5: SØNDERVILSTRUP STRAND}

Loc. 5 is a cliff section more than $5 \mathrm{~km}$ long, with a varying degree of exposure, situated on the Lillebælt coast $10 \mathrm{~km} \mathrm{SE}$ of Haderslev (fig. 7). In the cliff section 4 tills interbedded with stratified sand and gravel can be observed. Glaciotectonic structures at the base of the Middle till indicate ice-deformation from north-easterly directions.

\section{PREVIOUS INVESTIGATIONS}

Jessen (1935) mentions the presence of 3 tills interbedded with glaciofluviatile material, all assumed to be of Weichselian age. Frederiksen's $(1975,1976)$ investigations show that the upper till has a fabric indicating ice movement from the $\mathrm{SE}$, whilst the middle till has associated glaciotectonic deformations from the NE. Frederiksen concluded that the lower till can be correlated with the lower till at Halk Hoved (loc. 112) described by Jessen (1930), and that this till is probably of Saalian age. The middle and upper tills are ascribed to the Main Weichselian and the Young Baltic glacial phases respectively.

\section{DESCRIPTION AND STRATIGRAPHY (fig. 27)}

THE LOWERMOST TILL (Lm): Lillebælt Till is less than $5 \mathrm{~m}$ thick, grey clayey and massive. Measurements of clast long axes orientation revealed an eastward dipping, longitudinal fabric indicating ice movement from an easterly direction. Clast composition shows high values of $\mathrm{Pal}$. limestone $(24-40 \%)$, low quartz content $(4 \%)$ 

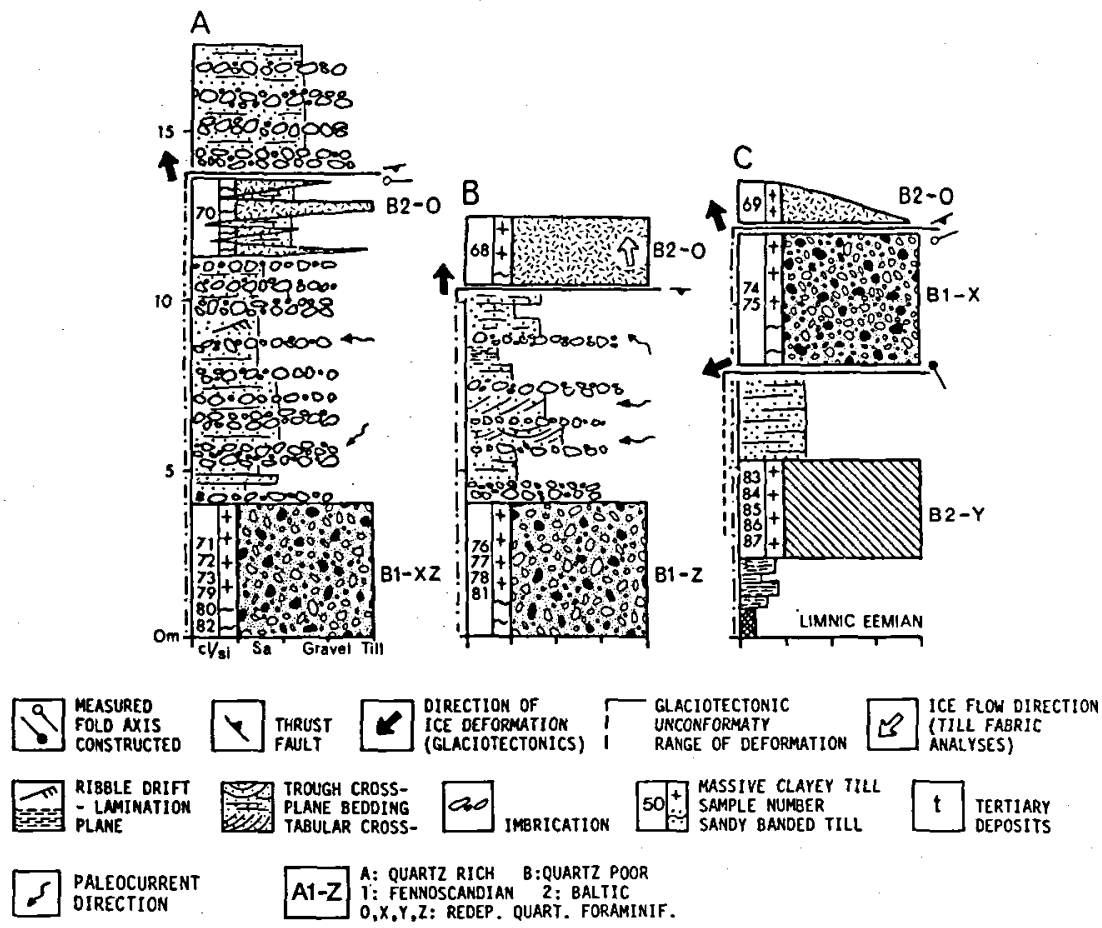

Fig. 29: Simplified lithological logs, sites A, B, C, loc. 6, Sønderby Klint. Stratigraphy compiled in datachart fig. 36.

and high flint content $(20 \%)$. The amount of redeposited Quaternary foraminifera is insignificant. The lowest till is an E-till of B2-0 composition.

THE LOWER WATERLAID MATERIAL is deposited upon the lowermost till and consist of less than $1 \mathrm{~m}$ of sand. In the sand a leached horizon overlying a rust-cemented zone of precipitated iron-oxides has been interpreted as a podsolic palaeosoil (fig. 28).

THE LOWER TILL (L): Ristinge Klint Till is about $1 \mathrm{~m}$ thick, brown, banded and clayey, and it overlies the lowermost till. Clast orientation measurements revealed a south-eastward dipping, longitudinal fabric indicating ice movement from the SE. The till has a high amount of Pal. limestone $(29 \%)$, a low content of quartz $(4 \%)$, moderate to high values of flint (13-26\%) and a characteristic content of re-deposited Quaternary foraminifera of Y-accumulation. The lower till is characterized as a SE-till of B2-Y composition.

THE MIDDLE WATERLAID DEPOSITS consist of a fining upwards sequence of more than $5 \mathrm{~m}$ of current bedded sand and fine gravel interbedded with sheets of coarser material. Palaeocurrent measurements indicate water-flow towards the NW.
THE MIDDLE TILLE (M): Mid Danish Till is grey, massive, clayey and less than $2 \mathrm{~m}$ thick. At its base glaciotectonic structures indicating ice deformation from the NE were observed. Measurements of clast long axes orientation revealed a north-eastward dipping, somewhat diffuse longitudinal fabric, indicating ice movement from the NE. The clast composition shows restricted amounts of Pal.limestone (18\%), little quartz $(4 \%)$, considerable quantities of flint $(16-28 \%)$ and the content of re-deposited Quaternary foraminifera shows a mixture of $\mathrm{X}$ and $\mathrm{Y}$ accumulations. The Middle till is characterized as a NE-till of B1-X/Y composition.

THE UPPER WATERLAID BEDS consist of a coarsening upwards sequence with laminated clay and silt at the base and coarse gravel and lenses of flow-till at the top.

THE UPPER TILL (U): East Jylland Till is brown, massive, clayey and more than $2 \mathrm{~m}$ thick. Clast long axes measurements revealed a southeastward dipping longitudinal fabric, indicating ice movement from the SE. The clast composition is rich in Pal.limestone (22-25\%), low in quartz $(3 \%)$ and shows a moderate flint content $(19 \%)$. The Upper till contains re-deposited Quaternary foraminifera of Y-accumulation. The 
Upper till is termed a SE-till of B2-Y composition.

\section{DISCUSSION AND CORRELATION}

Frederiksen (1975) argued, mainly on the basis of re-deposited Quaternary foraminifera, that the oldest till in the Søndervilstrup cliff section (Lowermost till) is of Saalian age and that the clast composition is an indication of Baltic heritage. The present investigation shows that this till is overlain by another Baltic till (Lower till), which only differs noticeably from the former by its content of re-deposited Quaternary foraminifera of Eemian derivation. However, they have not been seen separated from each other by the presumed podsolic horizon. It is therefore suggested, in accordance with Frederiksen, that the Lower till (Ristinge Klint Till) is of Weichselian age and the Lowermost (Lillebæit Till) is of late Saalian age. The latter is correlated with the till underlying the Eemian bog at Ejstrup and the Middle till of Æbelø. The Middle (NE) till (Mid Danish Till) and the Upper (SE) till (East Jylland Till) of Søndervilstrup Strand are correlated with the Upper (NE) till and the Uppermost till of Æbelø respectively.

\subsection{LOC. 6: SØNDERBY KLINT}

Sønderby Klint is situated about $5 \mathrm{~km}$ SE of Assens on the Lillebælt coast of SW-Fyn (fig. 7). It is a cliff site consisting of 2 tills (Lower and Middle tills) separated by meltwater deposits, folded and thrusted from a southerly direction, and overlain by a third, discordant (Upper) till or stratified gravely deposits. The entire sequence is of Weichselian age.

\section{PREVIOUS INVESTIGATIONS}

V.Milthers (1940) mentions the presence of peat beds beneath $12 \mathrm{~m}$ of till material in the central part of Sønderby Klint cliff. Samples of the peat were subjected to palynological analysis and the results indicate Eemian age (V.Milthers 1940, p. 53).

K.Milthers (1942) published indicator erratic counts from beach gravels and a gravel pit at Sønderby Klint. Both sites are dominated by Åland indicator erratics and to a lesser extend by Dalar rocks. The beach gravels, which accumulated from the whole of the cliff section, show small but equal amounts of Baltic quartz-porphyry and
Kinne-diabase. The gravel pit shows a somewhat higher content of Baltic indicators.

Schwann \& van Loon (1979) and Schwann \& Rizema (1982) described sedimentary facies in the cliff face and divided the glacial sequence into 4 major lithostratigraphic units: an upper (flow-) and a lower (basal-) till separated by, as well as overlain by, sand and gravel beds of glaciolacustrine and glaciofluviatile origin. Prior to the deposition of the upper meltwater sand and gravel the older deposits were folded and thrusted by ice pressure from the south. Schwann \& van Loon and Schwann \& Rizema concluded that the entire sequence in Sønderby Klint was deposited during oscillations of the Lillebælt glacier; presumably a late phase of the Young Baltic (Weichselian) ice-cover.

\section{DESCRIPTION}

Three sites of the more than $3 \mathrm{~km}$ long and rather well exposed cliff section have been chosen for glaciostratigraphic studies. Site A: (fig. 29), also described by Schwann \& van Loon corresponds to section II of Schwann \& Rizema and consists of thrusted and folded slices of the Middle till, the overlying meltwater material and the Upper till. Coarse waterlaid deposits unconformably overlie this sequence. Site B: (fig. 29) (situated immediately east of Schwann \& Rizemas section II) is shown in fig. 30. The Middle till and the middle waterlaid deposits are cut by southward dipping thrust planes and are folded along roughly E-W trending axes (fig. 34). Site C: (fig. 29) (Schwann \& Rizemas section III s. 8) is shown in fig. 31. It consists of the lowermost waterlaid mud and sand which presumably overlies the limnic Eemian deposits described by V.Milthers. The mud and sand is overlain by the Lower till, which in turn is overlain by the lower stratified sand. At the base of the Middle till these deposits have been isoclinally folded, by ice pressure from the ENE, along an inclined axis dipping towards the SSE (figs 31, 33). The middle till and the underlying deposits have been thrusted from the SSE and folded by associated drag along ENE-WSW trending axes and overlain by the Upper (discordant) till. The stratigraphic columns from the three sites have been put together in the data chart (fig. 36). 

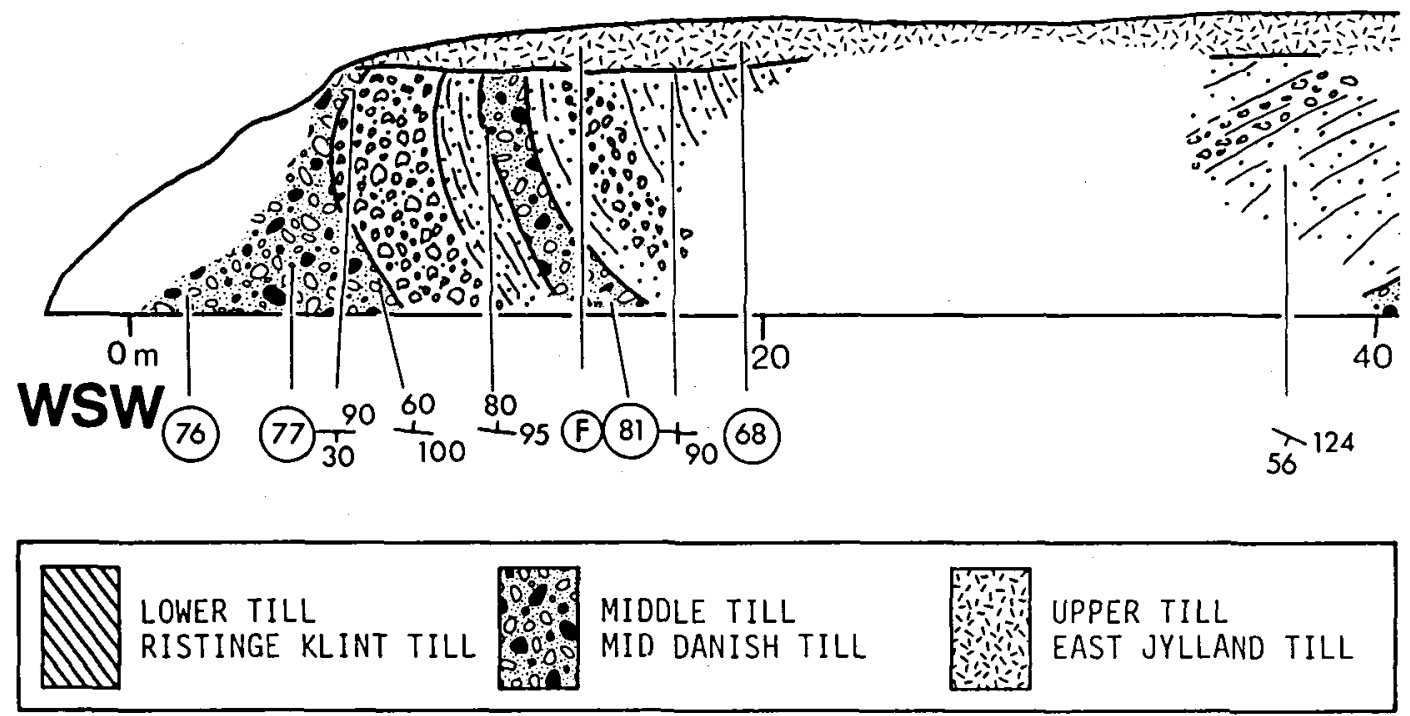

Fig. 30: Selected cliff section B, Sønderby Klint.

\section{STRATIGRAPHY (fig. 36)}

THE LOWERMOST WATERLAID MATERIAL consist of at least $2 \mathrm{~m}$ of laminated silt and clay with a tendency to coarsen upwards.

THE LOWER TILL (L): Ristinge Klint Till is less than $2 \mathrm{~m}$ thick, grey, clayey and massive. The clast composition shows large amounts of $\mathrm{Pal}$. limestone $(25 \%)$, little quartz $(4 \%)$ and a high flint content (24\%). Analysis of re-deposited Quaternary foraminifera shows that the lower till is dominated by the Y-foraminiferal accumulation with a secondary content of $Z$-accumulation. The Lower till is characterized by its composition as a B2-Y till.

THE LOWER WATERLAID BEDS consist of rather well sorted, generally plane-bedded, white and yellow sand of more than $3 \mathrm{~m}$ thickness. Its deposition was succeeded by the older deformational phase due to ice transgression from the ENE.
THE MIDDLE TILL (M): Mid Danish Till lying unconformably upon the older deposits is up to $5 \mathrm{~m}$ thick, grey and brown, and clayey appearing massive in its upper parts and banded towards the base. The clast composition shows limited quantities of Pal. limestone (15\%) little quartz $(2-9 \%)$ and much flint $(22-40 \%)$. Where the content of re-deposited Quaternary foraminifera is sufficient, it is dominated by $\mathrm{X}$ and $\mathrm{Z}$ foraminiferal accumulations or mixtures of these with a secondary content of $\mathrm{Y}$-accumulation. Occasionally the Middle till contains large (meter size) clasts of older till material with very small quantities of limestone and equal amounts of quartz and flint (18-20\%). The Middle till can be characterized as a $\mathrm{B} 1-\mathrm{X}(\mathrm{OZ})$ till.

THE UPPER WATERLAID BEDS consist of more than $10 \mathrm{~m}$ of coarse gravel interbedded by lenses and beds of sand. Only very few cross bedded primary sedimentary structures have been

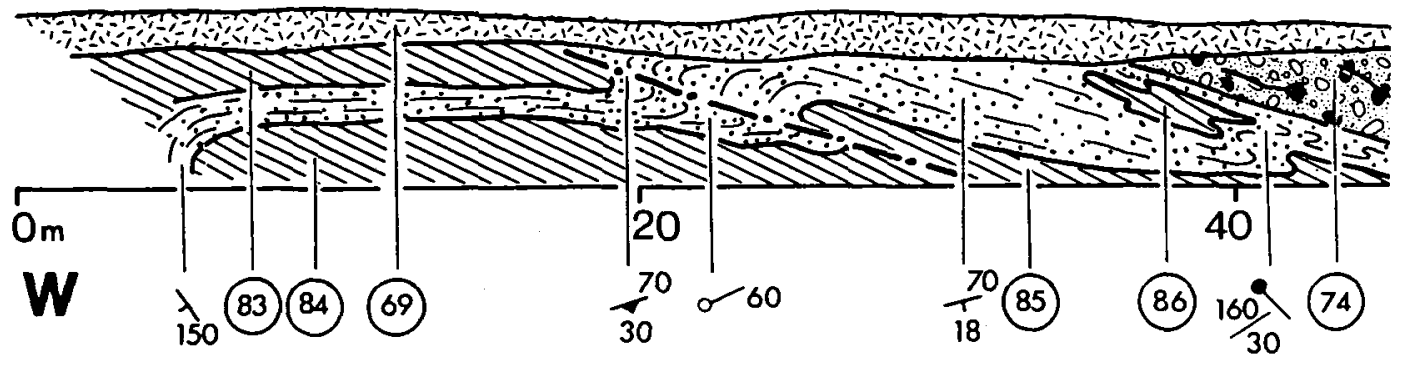

Fig. 31: Selected cliff section C. Sønderby Klint. Further explanation fig. 30. 


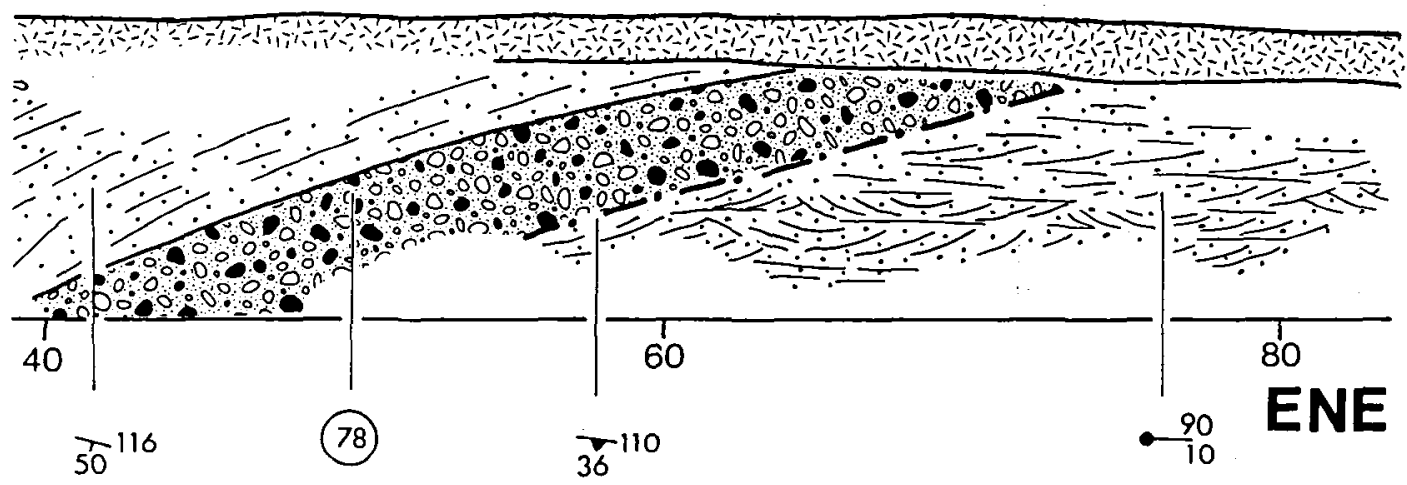

observed at site 1 but at site 2 this stratified drift is dominated by trough and tabular cross bedding that indicate westward moving palaeocurrents.

THE UPPER TILL (U): East Jylland Till can be divided into 2 sub-units; a) one unit up to $3 \mathrm{~m}$ thick consists of tongues of flow-till interveined by well-sorted sand and gravel, which have participated in the last deformational phase, b) the second unit is also brown, about $2 \mathrm{~m}$ thick, banded in the lower section and massive in the upper (fig. 35) lying unconformably upon the icedeformed sequence. In the discordant subunit of the Upper till, measurements of clast long axis orientation revealed a southward dipping, longitudinal fabric which implies ice movement from the south. The clast composition of both subunits is rich in Pal. limestone (34\%), poor in quartz (1-4\%) and contains considerable amounts of flint (18-29\%). The Upper till can be characterized as a S-till of B2-0 composition.
THE UPPERMOST STRATIFIED MATERIAL is found at site A where it unconformably overlies the flow-till subunit of the Upper till. It is more than $5 \mathrm{~m}$ in thickness and consists of coarse gravel, interbedded with more fine grained, mostly sandy, deposits.

\section{DISCUSSION AND CORRELATION}

The results of K.Milthers' (1942) indicator erratic counts imply that the sequence from which the indicators are derived must be of a composite nature, though dominated by material of Baltic provenance. The presence of Kinne-diabase in the same quantities as the Baltic quartz-porphyries suggests the presence of till-material of Fennoscandian provenance. Schwann \& van Loon (1979) ascribe the Middle till (= basal till) at site A to the northward moving Lillebælt stage of the Young Baltic ice sheet, even though they state

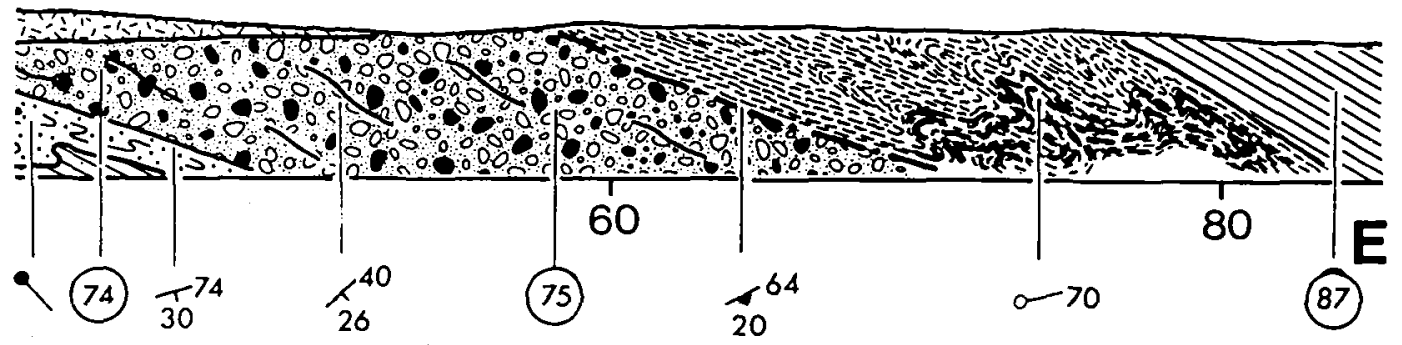




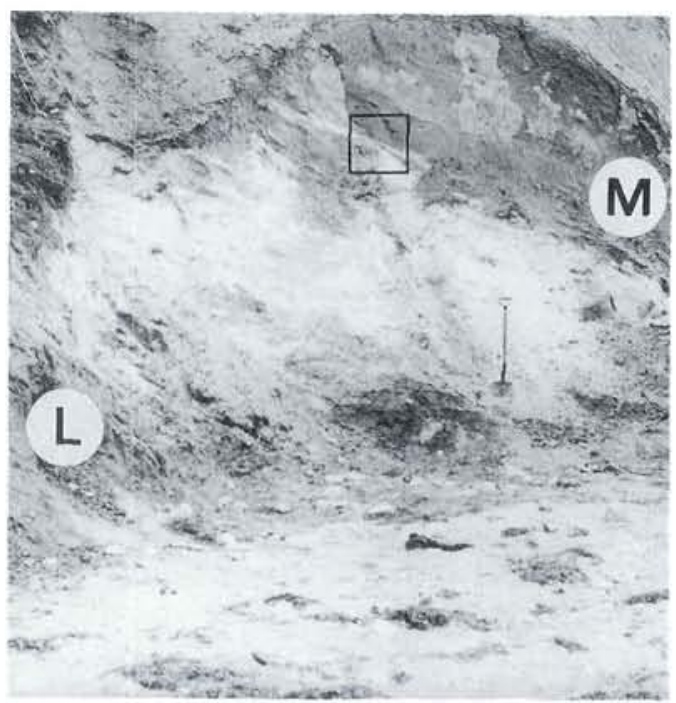

Fig. 32: Detail of section C, Sønderby Klint (pt. 40 m, fig. 31). Lower till (L) Ristinge Klint Till covered by sand and uncorformably overlain by the Middle till (M) Mid Danish Till. Incert see fig. 33 .

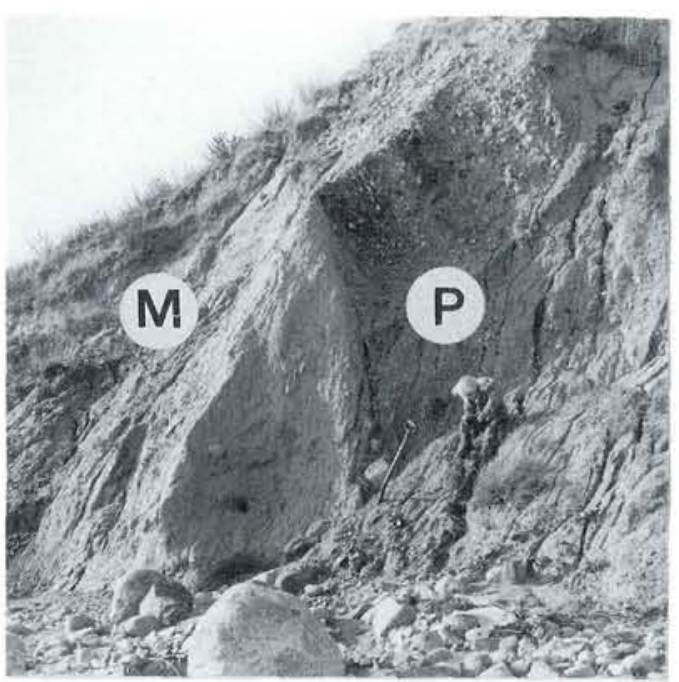

Fig. 34: Detail of section B (pt. 10 m, fig. 30) Sønderby Klint. Middle till (M) Mid Danish Till overlain by proximal outwash (P).

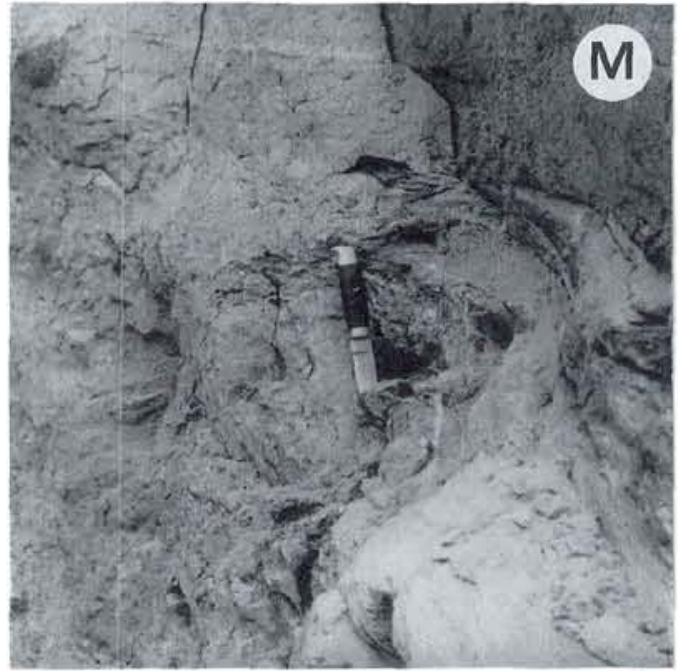

Fig. 33: Folded sand at the base of the Middle till (M) Mid Danish Till, section C. pt. 40 m, Sønderby Klint. Axial properties $160 / 30$, vergence towards the southwest.

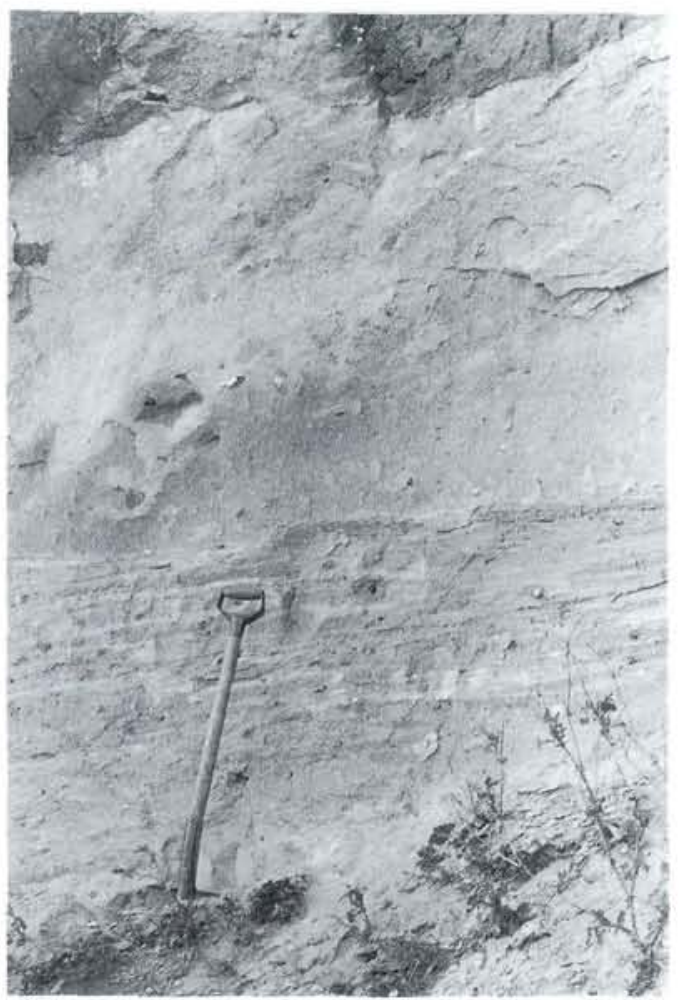

Fig. 35: Upper till: East Jylland Till (pt. 20 m, fig. 30) Sønderby Klint. 
Loc. 6: SONDERBY KLINT

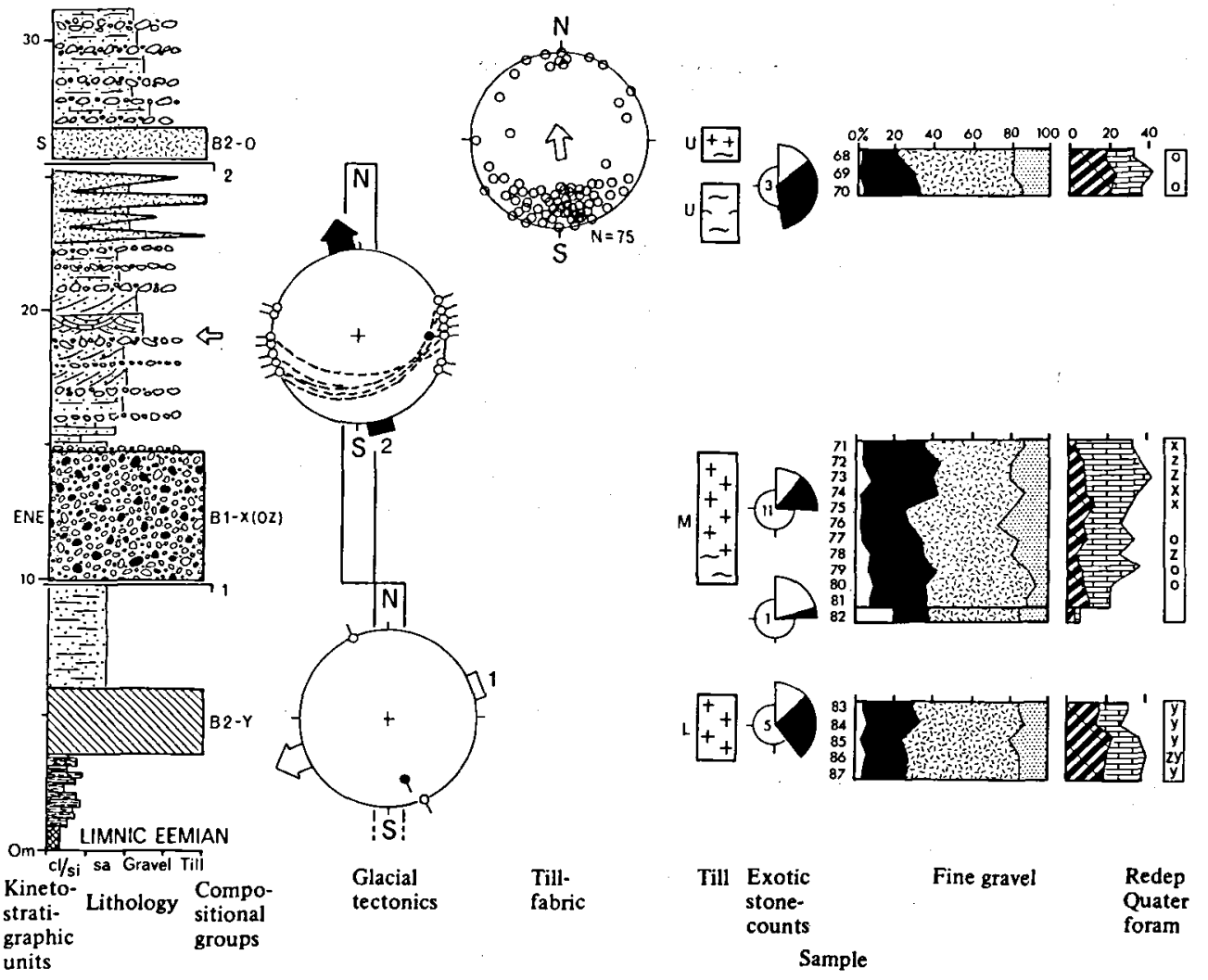

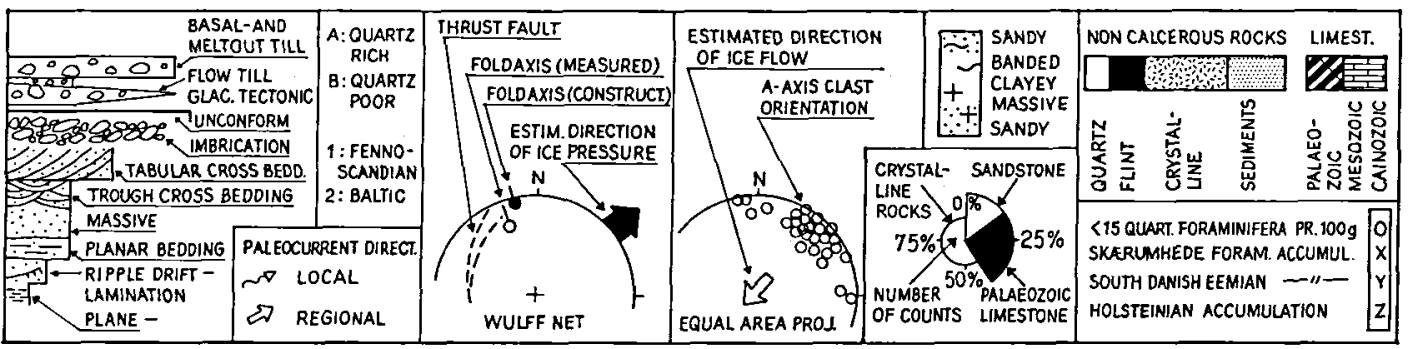

Fig. 36: Glacial stratigraphic data chart, loc. 6, Sønderby Klint. Lower till (L) Ristinge Klint Till, Middle till (M) Mid Danish Till, Upper till (U) East Jylland Till. 
that the clast content of the basal till is "quite unbaltic".

The somewhat conflicting evidence of the indicator erratics can be explained by the presence of 3 till units representing 3 individual icestreams, with particular directions of movement and provenance dependent features. The supposed stratigraphic position of the Lower till upon interglacial, limnic beds of Eemian age is in agreement with its content of re-deposited Quaternary foraminifera, thus it contains readmixed foraminifera of Eemian derivation (Y-accumulation). The Middle till mostly shows and EarlyMiddle Weichselian (X-) accumulation. The clast composition of the 3 tills indicates that the Lower- and the Upper till are of Baltic provenance whereas the Middle till is of Fennoscandian provenance. The deformational pattern can be grouped into two phases. An early phase of ice transgression from the ENE produced the first deformational phase and the subsequent deposition of the Middle till. This was succeeded by the second glaciotectonic phase with thrusting and folding from a southerly direction by the ice sheet which deposited the Upper till. The three tills of Sønderby Klint are correlated with the three upper tills at Søndervilstrup because they possess similar directional properties, compositional elements and are all of post-Eemian age.

The three till units can be correlated with extraregional till-units from the glacial sequence at the principal locality Ristinge Klint (cf. Sjørring et al. 1983). In the Ristinge section four tills of Weichselian age are described in terms of lithology and structural setting (Madsen 1916, Rosenkrantz 1944), till fabric measurements (Ehlers 1979, Sjørring et al. 1983), stone counts (Madsen 1916), fine gravel-analysis (Ehlers 1979, Sjørring et al. 1983) and re-deposited Quaternary foraminifera (Sjørring et al. 1983). Additional methods applied by these authors are not used in this correlation. The four till units of Ristinge Klint of which the older two are dislocated from the SE, are separated by waterlaid deposits and rest upon marine beds of Eemian age. The tills are 1) a "thin" (Old Baltic) till with fabrics indicating icemovement from the SE. It is of Baltic composition and with insignificant quartz contents. 2) a "thick" biparted NE-till of B1-X composition and $3 \& 4$ ) a lower and an upper, discordant till with low quartz contents, and for the lower one with fabric indicating ice-movement from the SE. Consequently the lower till at Sønderby Klint is correlated with the lower till at Ristinge, the NEtills of B1-X composition are correlated with one another and the upper, S-till of B2 composition is correlated with the lower of the discordant tills at Ristinge Klint.

\section{CONCLUSION}

With reference to the principal locality of Ristinge Klint the glacial sequence at Sønderby can be divided into 3 major lithostratigraphic till units deposited by 3 major Weichselian ice-streams: 1) the Lower, Baltic till (Ristinge Klint Till) with a content of re-deposited foraminifera of Eemian derivation, probably deposited by the Old Baltic ice-stream. 2) The middle till of Fennoscandian provenance (Mid Danish Till) containing EarlyMiddle Weichselian foraminifera of northerly provenance was most probably deposited by the Main Weichselian advance. The Upper till (East Jylland Till) deposited by an ice-stream locally from the south, has a Baltic clast provenance and was probably deposited by the Young Baltic icestream. 


\subsection{LOC. 7: NORTH SAMS $\varnothing$}

The cliff sections of North Sams $\emptyset$ are situated on the NW coast of Sams $\emptyset$ island (fig. 7). The sections are built up of 3 major till-units separated by waterlaid deposits. Glaciotectonic structures generated by ice-pressure from the NE dominate the sections.

\section{PREVIOUS INVESTIGATIONS}

V.Madsen (1897) carried out the geological mapping of the island of Sams $\emptyset$ using the newly established stone count method in stratigraphic correlation. V.Madsen outlined a glacial stratigraphy built up of two tills separated by a series of meltwater deposits. The lower grey till has a lower flint/crystalline rock fragment ratio than the brown upper till, which has a higher flint content.

V.Milthers (1932) counted indicator erratics in beach gravels and found that North Sams $\varnothing$, in contrast to adjacent areas, is dominated by Norwegian indicators. K.Milthers (1942) explained this relationship by the presence of an older Norwegian till of either late Saalian or early Weichselian age, penetrating younger deposits of Baltic provenance.

Houmark-Nielsen (1976a, b, c) examined the cliff sites and described the glacial stratigraphy of North Sams $\varnothing$, and Houmark-Nielsen \& Berthelsen (1981) published the results of these investigations focussing on the kineto-stratigraphic division of the glacial sequence. The following description is a condensed presentation of these works.

\section{DESCRIPTION}

About $3 \mathrm{~km}$ of the more than $7 \mathrm{~km}$ long west coast of North Sams $\varnothing$ is well exposed and suitable for glaciostratigraphic studies. In the cliff sections (Houmark-Nielsen \& Berthelsen 1981, p. 114$115)$ the three lower tills are interbedded with sandy and gravely sandur deposits and are strongly folded and thrusted from a north-easterly direction and subsequently from more eastnorth-easterly directions. The entire glacial sequence was then folded from a south-easterly direction. Glaciotectonic features, related to this later phase of ice transgression are however less distinct. The two generations of glaciotectonic events are separated in time by the deposition of the upper waterlaid deposits.
STRATIGRAPHY (fig. 37)

THE LOWER TILL (L): Kattegat Till is a mostly massive, more than $2 \mathrm{~m}$ thick, grey, clayey till, banded in the uppermost parts. The clast composition is low in Pal.limestone (15\%), it has little quartz and much flint and the till contains an accumulation of re-deposited Quaternary foraminifera comparable with the Early- to Middle Weichselian "Skærumhede" deposits. The lower till is termed a Fennoscandian B1-X till.

THE LOWER WATERLAID DEPOSITS overlying the lower till (fig. 38) are divided into 3 units. The lower unit is a less than $2 \mathrm{~m}$ thick sequence of sand and gravel fining upwards, with lenses of laminated clay containing a similar foraminiferal accumulation as the lower till. The middle unit consists of a sandy and pebbly more than $4 \mathrm{~m}$ thick, deltaic sequence in which palaeocurrent measurements indicate infilling from the south. The upper unit consists of $4-5 \mathrm{~m}$ of imbricated coarse gravel interveined by more sandy beds. Palaeocurrent directions are directed westand southwestwards.

THE MIDDLE TILL: Mid Danish Till is divisible into 2 beds ( $\mathrm{Lm} \mathrm{Um}$ ), separated by coarse gravel deposited by westward moving proximal meltwater streams. The Middle tills are characterized by longitudinal and transverse fabrics indicating ice-movement from the NE, small quantities of Pal. limestones, little quartz and high flint values, and by re-deposited Quaternary foraminifera of the $\mathrm{X}$-accumulation. The Middle till unit (fig. 39) is termed a NE-till of B1-X composition.

THE UPPER WATERLAID DEPOSITS are divided into 2 units. 1) a lower, sequence fining upwards glaciotectonically deformed from the NE along with the middle tills, and 2) a younger, sequence coarsening upwards dislocated by the younger glaciotectonic phase, indicating ice-advance from the SE.

THE UPPER TILL (U): East Jylland Till is partly bounded by glaciotectonic unconformaties indicating deformation from the SE, whilst the lower bounding units consists of either waterlaid material or the middle till. The Upper till is brown, massive, clayey and less than $2 \mathrm{~m}$ thick. Fabric studies indicate ice movement from the SE and the clast composition shows intermediate 


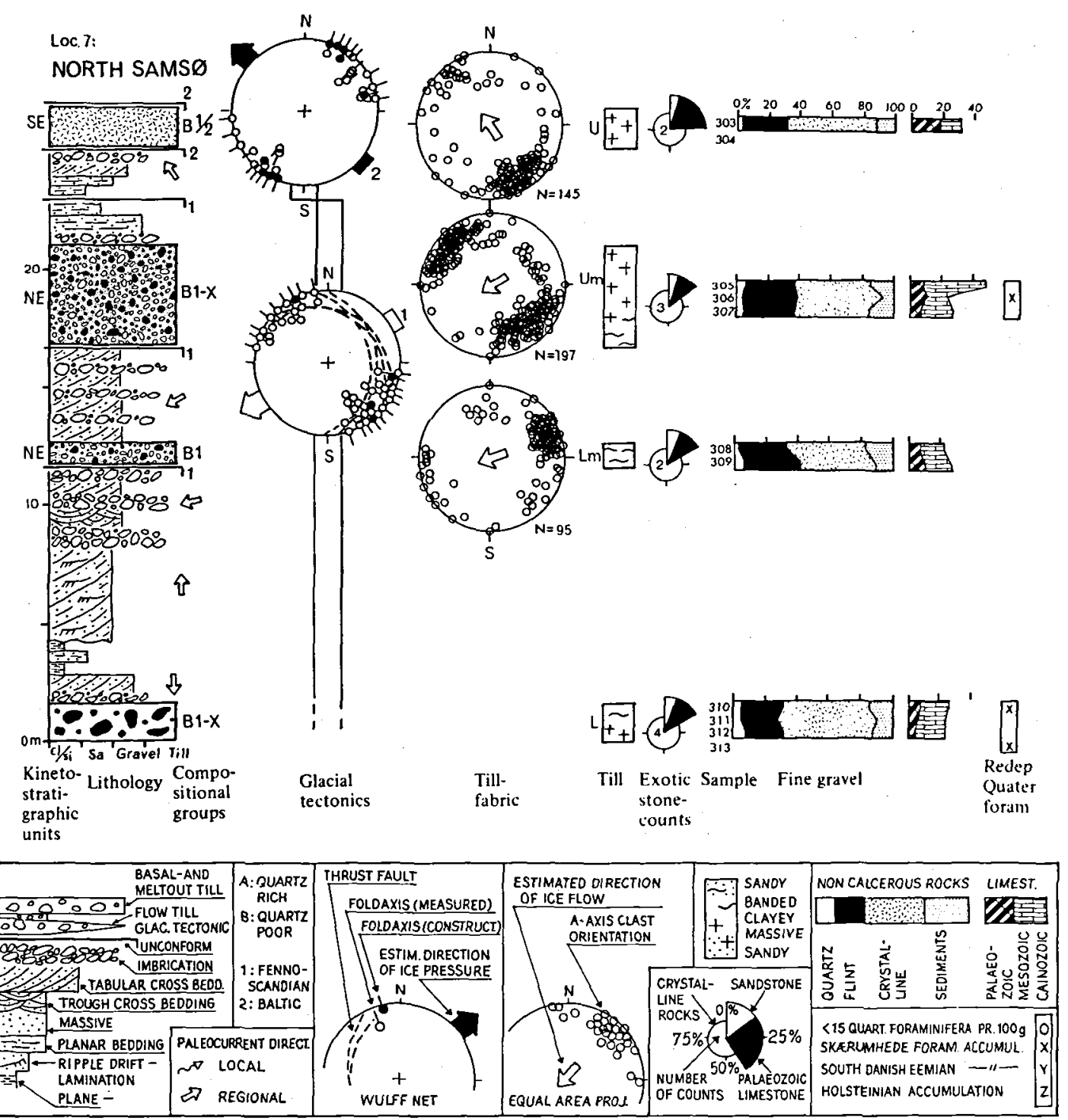

Fig. 37: Glacial stratigraphic data chart, loc. 7, North Samsø. Lower till (L) Kattegat Till, Middle tills (Lm, Um) Mid Danish Till, Upper till (U) East Jylland Till. 
amounts of Pal.limestone (20\%), low quartz and high flint values. The upper till is termed a SE-till of $\mathrm{B} 1 / 2$ composition.

\section{CORRELATION}

The four till units of North Sams $\emptyset$ were apparently deposited by three individual ice-streams. The lower, Fennoscandian till (Kattegat Till) from which the Norwegian indicators supposedly have originated is correlated with the lower "Norwegian"-till of Halsnæs (Rørdam 1893, Sjørring 1974, Jensen 1977) which is characterized by fabrics indicating ice movement from the north, Fennoscandian provenance and a pronounced content of re-deposited Quaternary foraminifera of the X-accumulation. The two middle NE-tills of Fennoscandian provenance and low quartz content (Mid Danish Till) are correlated with NE-tills of similar composition from locs 4,5 \& 6 (Æbelø, Søndervilstrup and Sønderby). Even though the upper till (East Jylland Till) shows an intermediate exotic clast composition with low flint content, fabrics indicate ice-flow from the $\mathrm{SE}$ and it is correlated with the younger Baltic SE-tills of locs 5 \& 6 (Søndervilstrup and Sønderby).

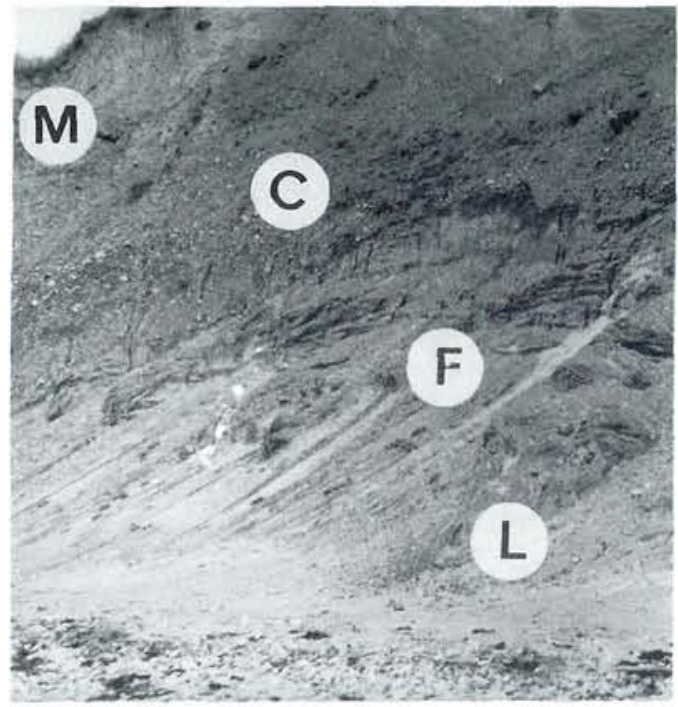

Fig. 38: Lower till (L) Kattegat Till covered by fine grained (F) and coarse (C) meltwater deposits unconformably overlain by the upper Middle till (M) Mid Danish Till, North Samsø.

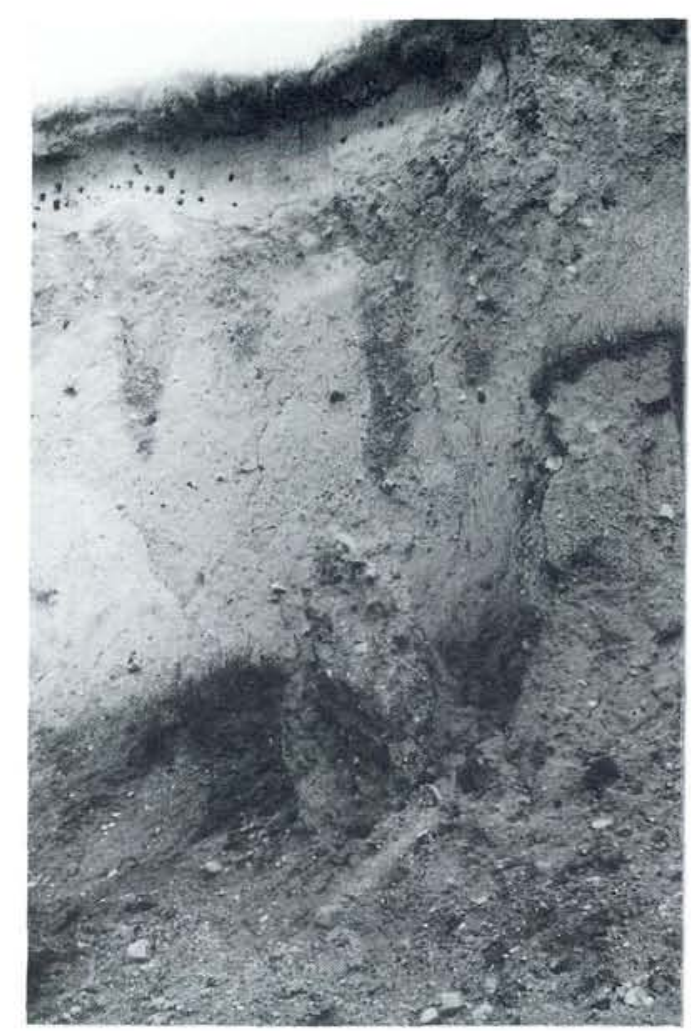

Fig. 39: Upper Middle till, Mid Danish Till, North Samsø. 


\subsection{LOC. 8: SEJER $\varnothing$}

Sejer $\varnothing$ is situated between Sams $\emptyset$ and NW-Sjælland (fig. 7) and the cliff site discussed lies at Kongsh $\varnothing j$ on the south-easternmost tip of the island. The cliff section consists of 4 tills, the 3 youngest separated by waterlaid material. They overlie limnic deposits of Middle Weichselian age. Houmark-Nielsen (1980) described the cliff section, and Houmark-Nielsen \& Kolstrup (1981) published results of glaciostratigraphic- and palynological investigations.

\section{STRATIGRAPHY (fig. 40)}

THE INTERSTADIAL DEPOSITS (fig. 41), the lower boundary of which is not exposed, consist of at least $3 \mathrm{~m}$ of laminated organic rich, sand and silty clay bounded upwards by the Lower till. The organic material is dominated by fragments of Cyperaceae and Gramineae. Radiocarbon dates revealed an age between 36900 - and 36710 \pm 460 years BP. These properties suggest that the Sejer $\varnothing$ interstadial beds was deposited most probably during the Hengelo Chronozone.
THE LOWERMOST TILL (Lm): Ristinge Klint Till is less than $2 \mathrm{~m}$ thick, grey, clayey and appears both banded and massive. It has a lower, unconformable boundary in contact with the interstadial deposits. Upwards it grades into the lower till, or is separated from this by smears and lenses of sand. The clast composition is of Baltic provenance ( $28 \%$ Pal. limestone), the quartz content is low and the matrix is characterized by re-deposited Quaternary foraminifera of the Yaccumulation. The lowermost till is termed a B2-Y till in accordance with its compositional characteristics.

THE LOWER TILL (L): Mid Danish Till is about $2 \mathrm{~m}$ thick, brown and banded in the upper sections, grey and massive towards the base. Fabric studies indicate ice movement from the NE and clast composition shows and average of $16 \%$ Pal.limestone, and little quartz when compared to flint content. It contains insignificant quantities of re-deposited Quaternary foraminifera. The lower till is termed a NE-till of B1 composition.

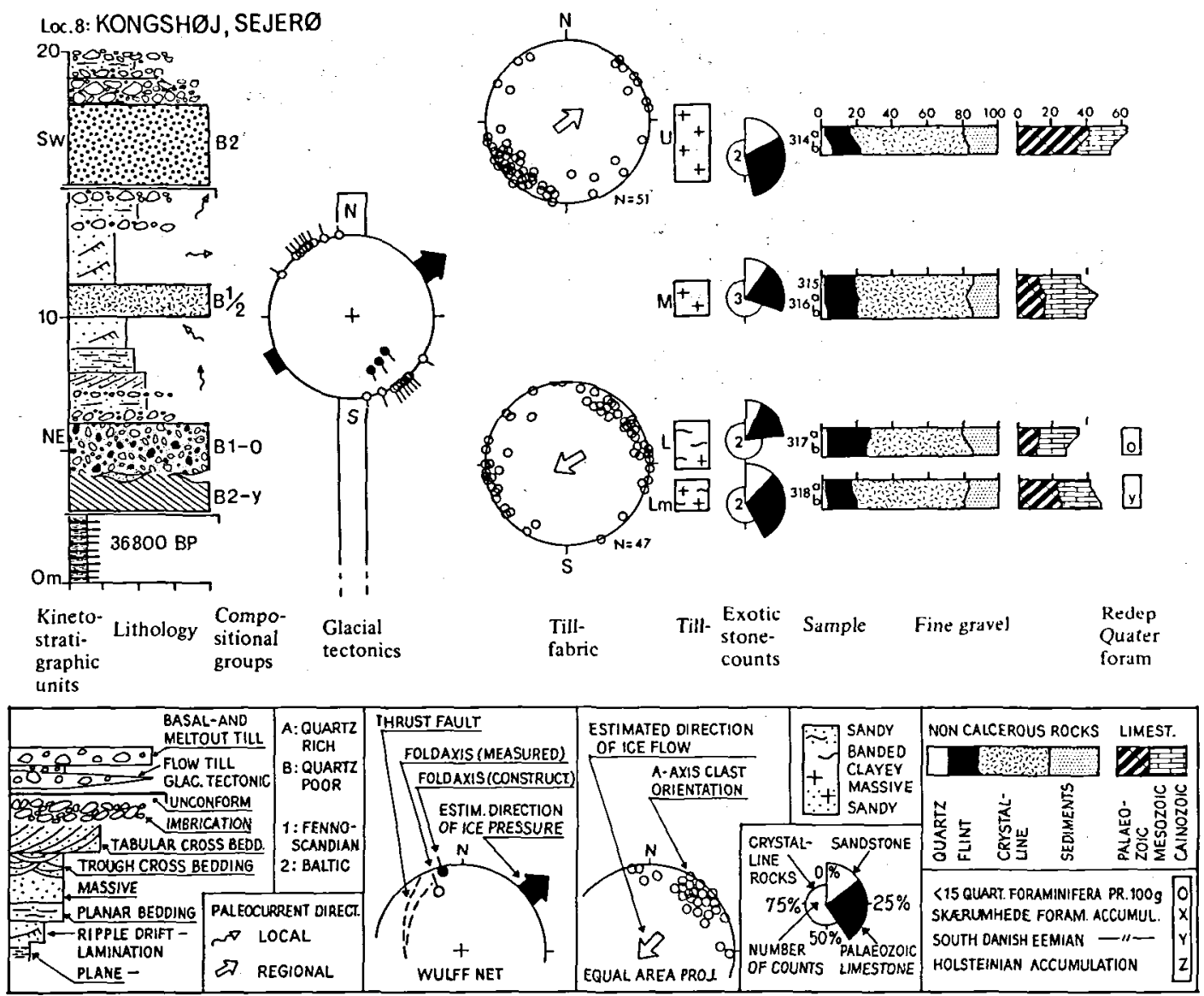

Fig. 40: Glacial stratigraphic data chart, loc. 8, Kongshøj, Sejerø. Lowermost till (Lm) Ristinge Klint Till, Lower (L) Mid Danish Till, Middle till (M) East Jylland Till, Upper till (U) Balthav Till. 
THE MIDDLE TILL (M): East Jylland Till is separated from the lower till by more than $2 \mathrm{~m}$ of waterlaid gravel, grading upwards into cross-bedded and cross-laminated sand deposited by northward moving palaeocurrents. The middle till is about $1 \mathrm{~m}$ thick, brown, clayey and massive. Fabric analysis was previously (Houmark-Nielsen \& Kolstrup 1981) suggested to indicate ice-movement from the E. A reconsideration has, however, omitted this fabric as being suitable for analysis because of its vague character. Clast composition is weakly Baltic $(20 \%$ Pal. limestone) and the quartz content is insignificant. The middle till is termed a till of $\mathrm{B} 1 / 2$ composition.

THE UPPER TILL (U): Bælthav Till is separated from the Middle till by more than $2 \mathrm{~m}$ of sand with climbing ripples and planar- and trough- cross-bedded sand and gravel deposited by eastward and northward flowing meltwaterstreams. It unconformably overlies the previously mentioned deposits. The older deposits are separated from the Upper till by a glaciotectonic disconformity which indicates ice advance from the SW. Fabric studies in the till show a longitudinal, southwestward dipping orientation indicating ice movement from SW and the clast composition is of Baltic provenance ( $28 \%$ Pal.limestone) with little quartz. The upper till is termed a SW-till of B2 composition.

The upper till is overlain by coarse grained flow till deposits, which in turn are overlain by sandy waterlaid gravel, the combined thickness of which is at least $3 \mathrm{~m}$.

\section{CORRELATION}

It has been shown that the described glacial sequence from Sejerø appears to be younger than about 36800 years BP.

Owing to its compositional characteristics the lowermost till (Ristinge Klint Till) is correlated with the lower tills of locs 5 and 6 (Søndervilstrup and Sønderby) both overlain by NE-tills.

The Lower Fennoscandian NE-till (Mid Danish Till) and the Middle Fennoscandian to Baltic E-till (East Jylland Till) of Sejerø is correlated with the NE- and SE tills of North Samsø and Æbel $\emptyset$ as they occupy similar stratigraphic positions. The Upper SW-till of Baltic provenance (Bælthav Till) is correlated with the upper discordant till from Ristinge Klint and its deposition is probably related to the youngest of the defor- mational phases from the SE recorded at North Samsø.

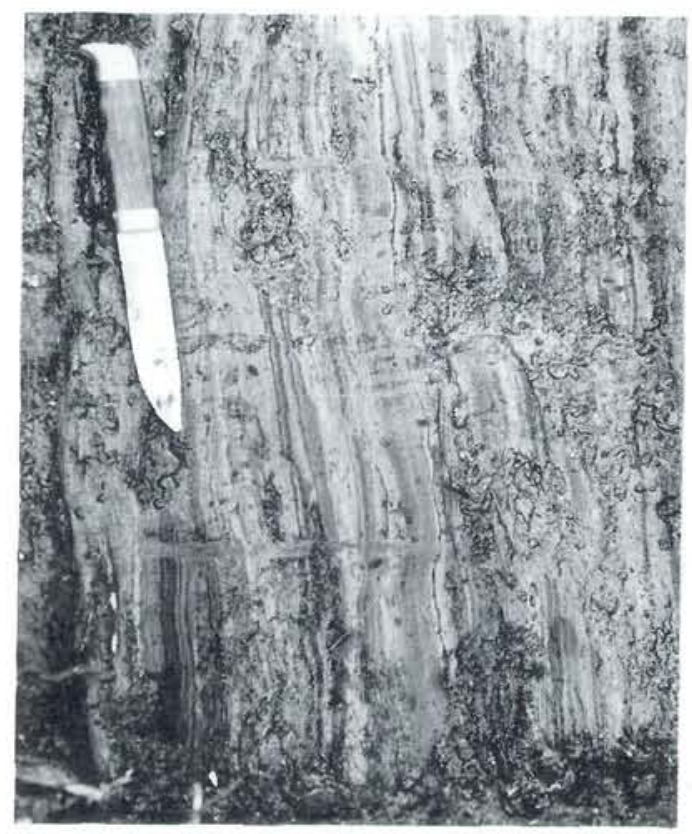

Fig. 41: Limmic, interstatial deposits, Sejerø Interstatial, loc. 8 , Kongshøj, Sejerø.

\subsection{LOC. 180: LYNGERUP}

Like Ejstrup this locality is not a principal one, however it provides valuable information regarding the stratigraphic relationship of the younger tills in the eastern part of the region examined. The gravel pit at Lyngerup, which is pictured under Area 18 (fig. 100) is no longer accessible to study, it was however described by HoumarkNielsen (1980). It consists of 3 tills, interbedded with waterlaid material. The deposits beneath the Middle till have been subjected to glaciotectonic folding from an easterly direction (fig. 42).

\section{STRATIGRAPHY}

THE LOWER TILL: Mid Danish Till is grey, clayey and massive at the base, and banded and brown at the top and more than $2 \mathrm{~m}$ thick. Its lower boundary is not exposed. The clast composition is poor in Pal.limestone $(5 \%)$ and the lower sections contain re-deposited Quaternary foraminifera of the $\mathrm{X}$-accumulation. It is 


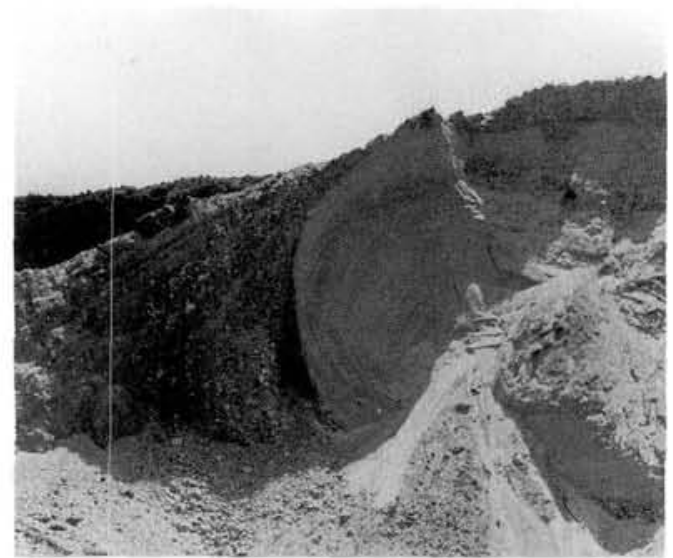

Fig. 42: Lower waterlaid deposits folded by ice-deformation from the E (axial properties 4/0) loc. 180, Lyngerup. Upper tills (North Sjælland Till and Brithav Till) removed. See also fig. 102, page 7).
THE LOWER WATERLAID deposits consist of a more than $5 \mathrm{~m}$ thick fining upwards sequence of imbricated gravel and trough- and planar cross-bedded sand and pebbles. Palaeocurrents were directed northward.

THE MIDDLE TILL: North Sjælland Till is about $1 \mathrm{~m}$ thick, brown, massive and clayey (fig. 102). Clast fabric analysis indicates ice movement from the $\mathrm{E}$ and the clast composition shows limited amounts of Pal.limestone $(12 \%)$. The lower boundary is a glaciotectonic unconformity where the lower waterlaid deposits and the lower till have been folded from an easterly direction (fig. 42). The middle till is an E-till of Fennoscandian clast composition.

bounded upwards by the lower waterlaid sand and gravel, which in turn is overlain discordantly by the Middle till. The lower till is termed a Fennoscandian X-till.

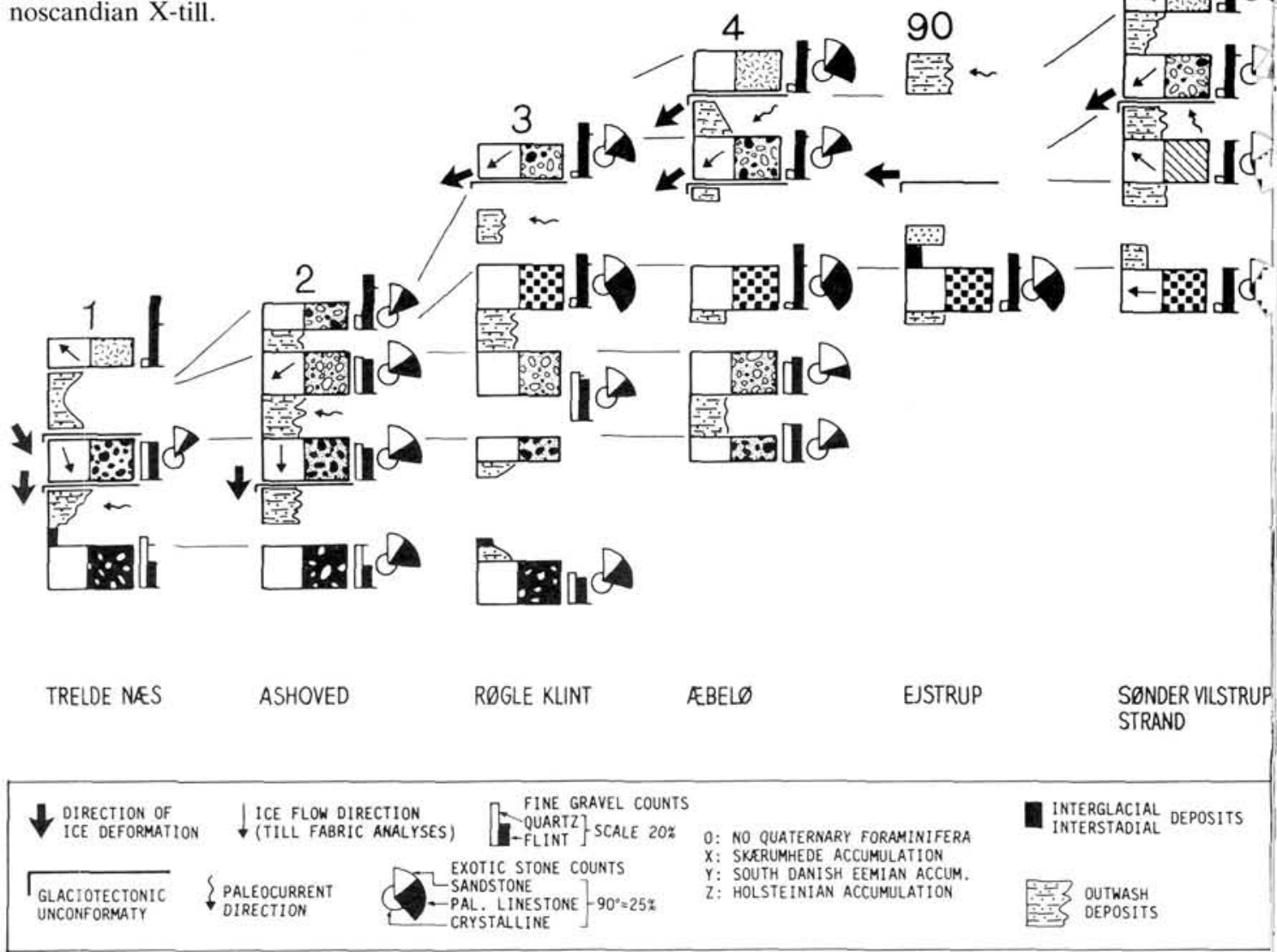

Fig. 43: Correlation chart and stratigraphic model based on ten principal and key localities, central Denmark. 
The UPPER TILL: Bælthav Till is separated from the Middle till by up to $1.5 \mathrm{~m}$ of laminated clay, silt and fine sand. The Upper till is brown, clayey, massive, and more than $2 \mathrm{~m}$ thick. Clast fabric analysis indicates ice movement from the SSE and clast composition is of Baltic provenance, (23\% Pal. limestone) with a low quartz content. The Upper till is termed a SSE-till of B2 composition. re-deposited foraminifera of the $\mathrm{X}$-accumulation (Mid Danish Till) is correlated with the NE-tills of similar composition from Sejerø, North Samsø, Sønderby Klint and Æbelø. The Middle E-till (North Sjælland Till) is regarded as previously unmentioned till unit characterized by Fennoscandian clast composition and directional properties indicating deposition by an ice sheet

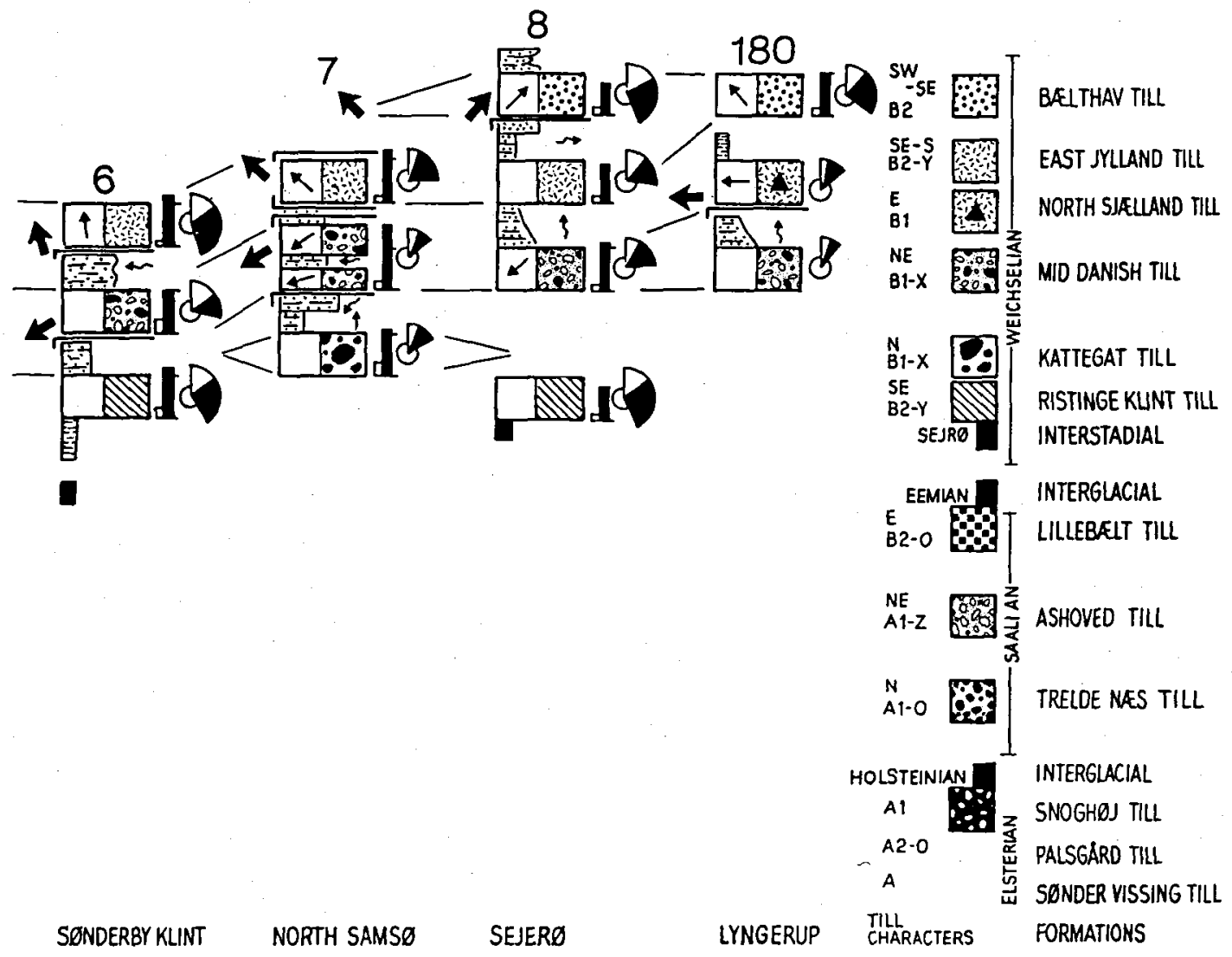

\section{CORRELATION}

Because of the presence of considerable amounts of large blocks of kinne-diabase apparently associated with the Lower till in the gravel pit, this till with Fennoscandian clast composition and with from easterly directions. The Upper SE-till (Bælthav Till) is only indirectly correlated with the SW-till of Sejerø, because of the difference in the deduced patterns of their movement. 


\subsection{LOCS. 37 \& 70: SøNDER VISSING AND SNOGHØJ}

These two sites, located in central Jylland (Area 3, fig. 44) and by the narrowest part of Lillebælt (Area 7, fig. 44), are neither principal- nor key localities. However, they probably hold some of the oldest tills observed in the examined region. It is demonstrated (figs $51 \& 66$ ) that respectively a sandy till with in situ Norwegian erratics ( $\mathbf{n} \emptyset$ der Vissing Till) and a clayey, Baltic till (Snoghøj Till); both holding about twice the amount of quartz compared to the flint content; is overlain by a till corresponding to the (Middle-) tills of northerly.derivation and Norwegian provenance (Trelde Næs Till) described from Trelde Næs (loc. 1) and Ashoved (loc. 2).

\subsection{A LITHOSTRATIGRAPHIC MODEL}

The combination of structural chronology and lithostratigraphic correspondance between till units observed at principal - and key localities suggest, that 12 till formations can be established. A lithostratigraphic model comprising till formations deposited during the last three glaciations interfingering with outwash units and interglacial-interstadial deposits have been constructed (fig. 43).

Two Fennoscandian tills of respectively Norwegian and Middle Swedish provenance and a Baltic till are respectively named Sønder Vissing till, Palsgård till and Snoghøj till. All three show a larger quartz content compared to flint and they are found to be older than the first Saalian till or deposits of the Holstenian Interglacial, thus the tills were most probably deposited during the Elsterian glaciation.

Bound by interglacial, limnic deposits of respectively Holsteinian (lower boundary) and the Eemian (upper boundary) two quartz rich, Fennoscandian tills and a quartz poor, Baltic till has been recognized. The two older formations are characterized as a $\mathrm{N}$-till of Norwegian provenance overlain by a NE-till of Middle Swedish provenance, respectively named Trelde Næs Till and Ashoved Till. They are in turn covered by an Etill of Baltic provenance called Lillebalt Till. Most samples of these supposedly Saalian till units show negligible amounts of re-deposited Quaternary foraminfera.
Six quartz poor till formations overlie limnic Eemian deposits or hold a foraminiferal association most likely incorporated from Eemian to Middle Weichselian marine beds; thus these tills were deposited during the Weichselian glaciation. Ristinge Klint Till a SE-till of Baltic provenance with re-deposited south Danish Eemian foraminifera overlie the limnic sequence of the Sejer $\emptyset$ interstadial ( 36800 y BP). It is succeeded by three Fennoscandian tills: Kattegat Till, a N-till of Norwegian provenance; Mid Danish Till, a NE-till of Middle Swedish provenance; and North Sjælland Till, an E-till of Southwest to Middle Swedish provenance. The Fennoscandian tills are overlain by two respectively SE-S and SE-SW-tills of Baltic provenance. They are named East Jylland Till and Bælthav Till, and the older contains re-deposited Quaternary foraminifera of South Danish, Eemian derivation. 


\section{AREA DESCRIPTIONS}

The examined region in the central part of Denmark has been divided into 19 areas containing slightly less than 200 investigated localities (fig. 44). From each area about 9 single- or combined localities are described and with reference to the lithostratigraphic model data are presented in glacial stratigraphic data charts. Data from possible principal localities within a given area are not pictured in the charts, but will naturally be considered in the stratigraphic descriptions from each area. Condenced stratigraphic columns from each of the 19 areas will appear (fig. 105).

\subsection{AREA 1: ARHUS SW (locs 9-15, fig. 44) MORPHOLOGY AND LOCATION}

Area 1, lying between Århus, Skanderborg and Odder is dominated by the SW-NE elongated ridges of Jelshøj, Malling-Odder and the hills east of Skanderborg. The landscape is cut by the Århus-, Skanderborg- and Odder Valleys. The localities investigated lie on the coast cutting the Jelsh $\varnothing j$ ridge (locs $9,10,11)$ and further southwards around Kysing Fjord $(13,14)$. Inland localities 12 and 15 disect the Odder-Malling ridge and the hills east of Skanderborg.

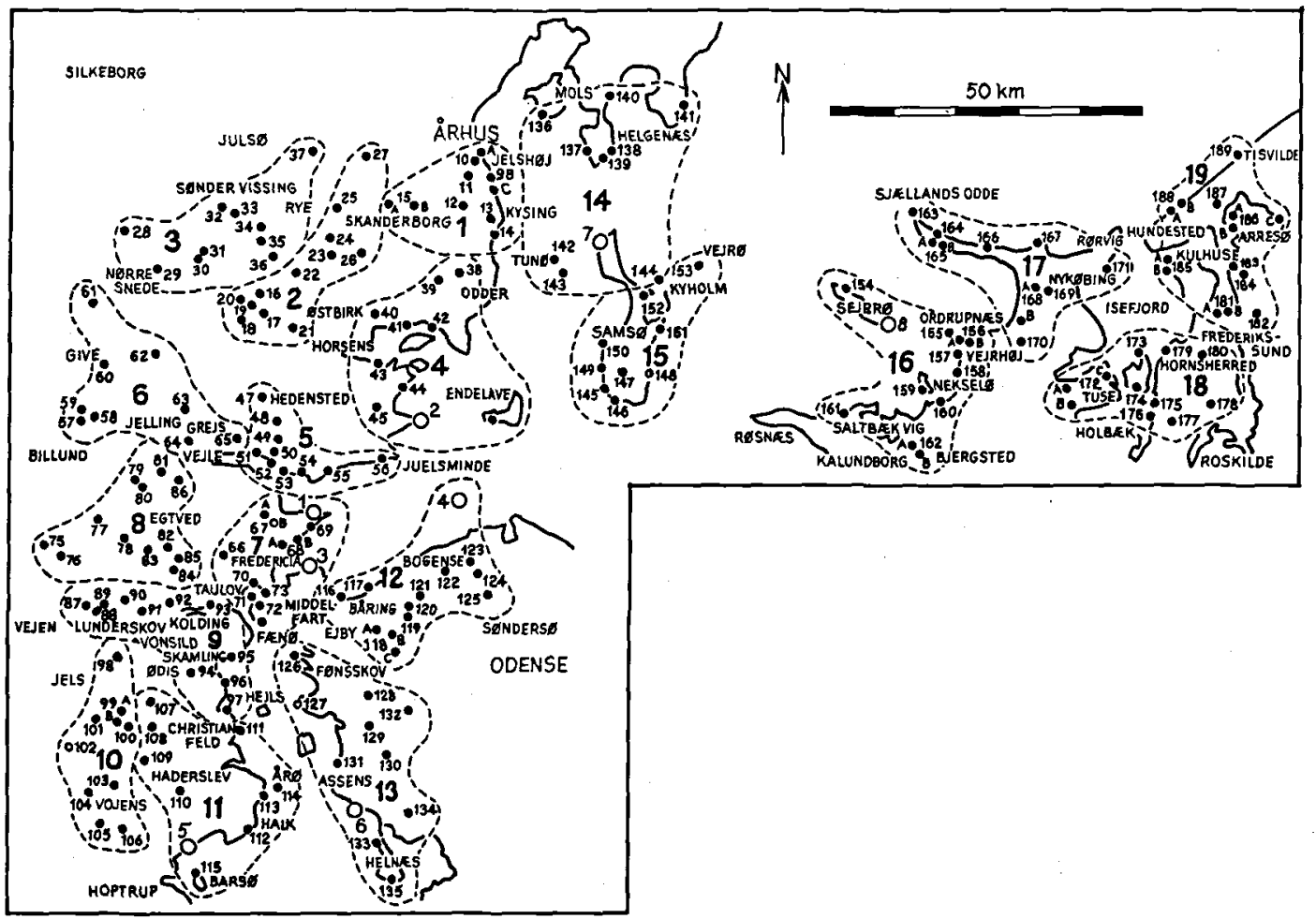

Fig. 44: Central Danish region with position of investigated localities distributed in 19 areas. 


\section{PREVIOUS INVESTIGATIONS}

Harder (1908) demonstrated that the till covering the surface of the area, was deposited by the East Jylland Icestream and is characterized by a Baltic clast composition. V.Milthers (1932) and K.Milthers (1942) studied indicator erratic boulders from beach gravels and found a predominance of Baltic indicators. They saw the presence of Baltic indicators as the result of the (Baltic) East Jylland Ice cover, which was also responsible for the formation of the elongated morphological ridges of the area, interpreted as recessive ice border lines. Lykke-Andersen (1968) points out, that the hills of Jelsh $ø j$ are ice pushed ridges comparable in size with the classical ridges of Odsherred. During the retreat of the East Jylland Icesheet, local glacier tongues first from the southeast later from eastern directions formed the Jelshøj ridges.

\section{STRATIGRAPHY}

Simplified lithological logs of each locality are shown in fig. 45. The till units are correlated and pictured for the whole area in the data chart fig. 46.

The oldest till which has been observed in area 1 , is a grey, clayey, massive, quartz poor Baltic till (fig. 47) with insignificant amounts of re-deposited Quaternary foraminifera (B2-0): The Lillebælt Till. It often overlies Tertiary clay but at loc. 15a, however it overlies waterlaid sand and gravel deposited by southward moving palaeocurrents. The Lillebælt Till is locally overlain by waterlaid sand and gravel deposited by northward moving meltwater streams. The sand and gravel beds are overlain by a grey, massive quartz poor till of Fennoscandian clast composition and with an X-foraminiferal accumulation (B1-X): The Kattegat Till. It is overlain by a waterlaid fin-

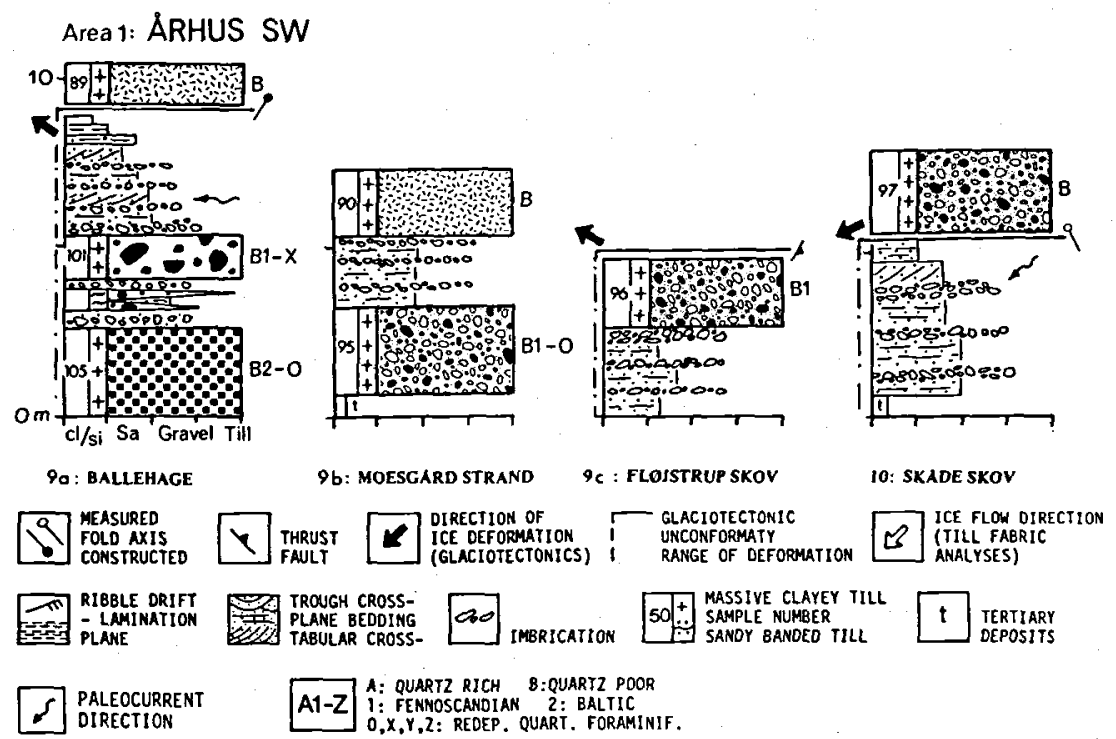

Fig. 45: Simplified lithological logs, area 1, Århus southwest. 
ing upwards sequence with primary sedimentary structures indicating westward moving palaeocurrents. These strata have suffered glaciotectonic deformation from the NE (locs $10,12,14$ ) and are unconformably overlain by a brown, massive, quartz poor Fennoscandian till (locs 8, 9, 10, 12, 14) with an $X$-foraminiferal accumulation (B1-X): The Mid Danish Till (fig. 47). It is overlain by waterlaid sand and gravel beds occasionally coarsening upwards with bedding structures indicating north- and westward moving meltwater streams. The above mentioned deposits have undergone glaciotectonic deformation from the

\section{DISCUSSION}

Clast petrographic analysis of the youngest till in the area confirms Harders (1908) view of its Baltic provenance and fabric analysis and glaciotectonic disturbances connected with the deposition of the East Jylland Till indicate ice movement from south-easterly directions. The deformation chronology of the Jelsh $\varnothing j$ Hills proposed by Lykke-Andersen (1968) can not be recognized, on the contrary it seems highly probable, that an older phase of glacial deformation from the ENE took place in connection with the ice-stream which deposited the Mid Danish Till and that this

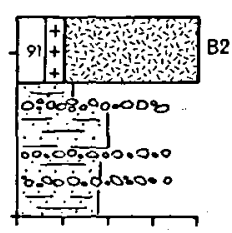

II: LANGBALLE

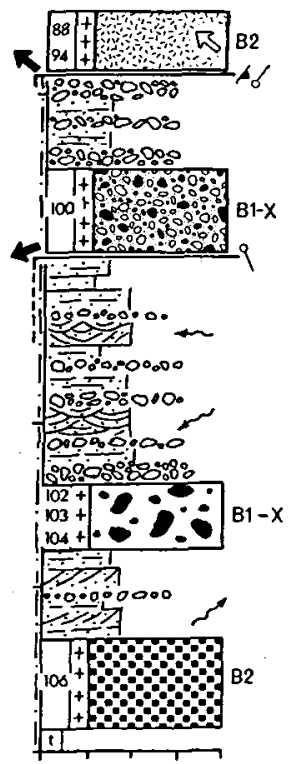

12: MALLING STEN \& GRUS

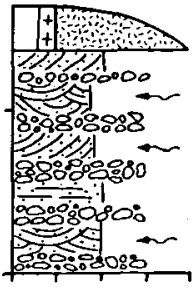

13: NORSMINDE

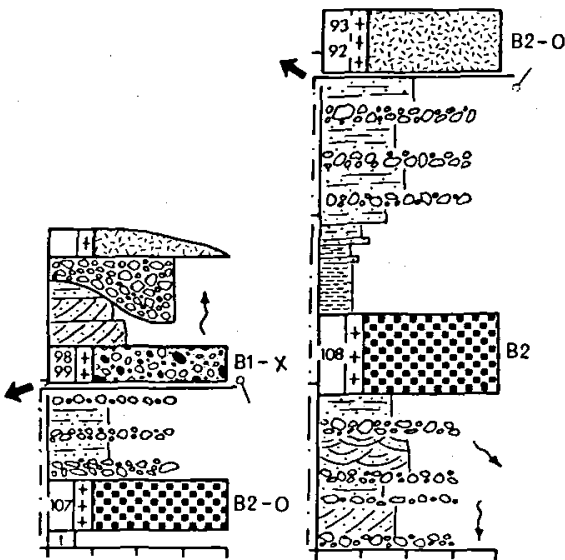

14: KYSING STRAND

IS * \& b: FRUERING - SOLBJERG
SE (locs 9a, 9c, 12, 15a) and are unconformably overlain by a brown, massive, quartz poor Baltic till (locs 11, 12,15) apparently without significant amounts of re-deposited Quaternary foraminifera SE-(B2-0): The East Jylland Till (fig. 47). Fabric measurements indicate ice movement from the southeast (loc. 12). phase was succeeded by the deformations caused by the transgression of the East Jylland Icecap. This ice-sheet is also responsible for the formation of the Malling-Odder ridges, the internal structure of which indicate thrusting from the SE. It must be emphasized, that the domination of in- 
Area 1: ÅRHUS SW

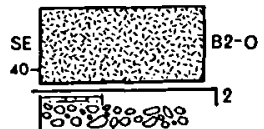

209000090

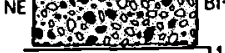

00000

f0000000 \&

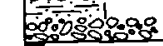

$10-$
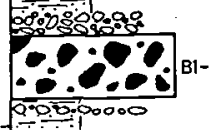

政
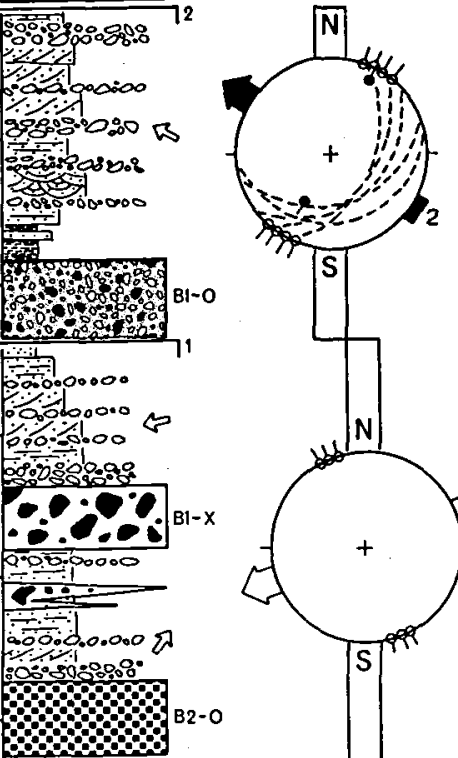

$00 \div \div 00.00$

cosognoon \&

p.

Om $\frac{\mathrm{tl}}{\mathrm{c} \mathrm{y}_{\mathrm{si}} \text { sa 'Gravel Till }}$

Kineto- Compo-

strati- Lithology sitional

graphic

units
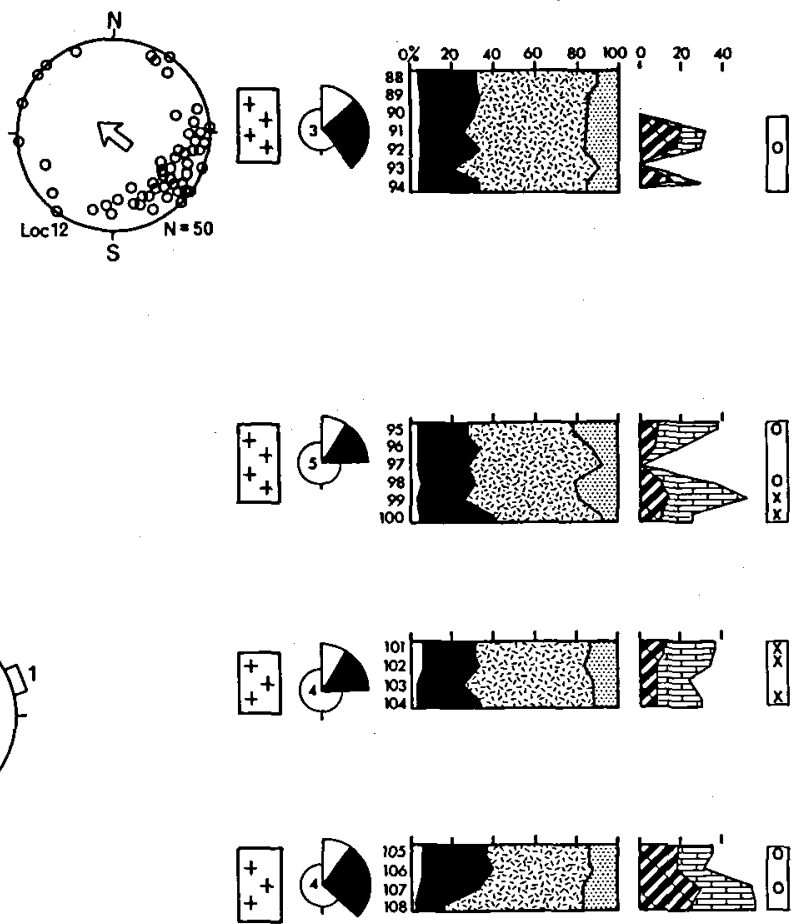

Till-
fabric
Till Exotic counts

Sample
Fine gravel

Redep.

Quater

foram.

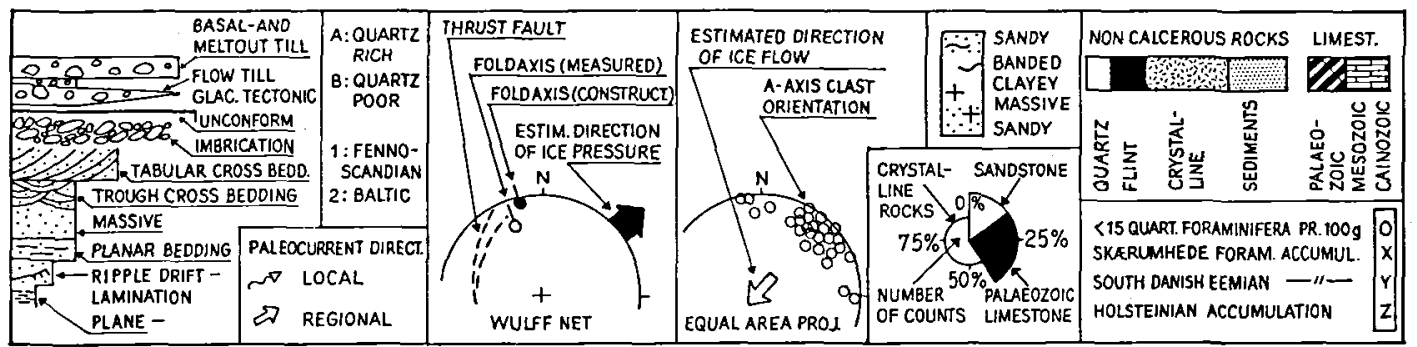

Fig. 46: Glacial stratigraphic data chart, area 1, Århus southwest. Till units shown in fig. 43. 
dicator erratics from the Baltic Sea in beach gravels is most probably due to the presence of two Baltic tills in the cliff sites south of Århus, the Lillebælt Till and the East Jylland Till, thus erratics do not originate exclusively from the East Jylland Till as estimated by V. and K.Milthers.

\section{CONCLUSION}

The stratigraphy of area 1 (fig. 105) is characterized by four till units separated by waterlaid deposits: 1) The Lillebælt Till of Saalian age, 2) The Kattegat Till of the Weichselian, 3) The Mid Danish Till with associated glaciotectonic deformations from the ENE and 4) The East Jylland Till with associated movement from the SE. Recessional advances from the East Jylland icecap formed the NE-SW elongated hills of Jelshøj and around Malling-Odder.

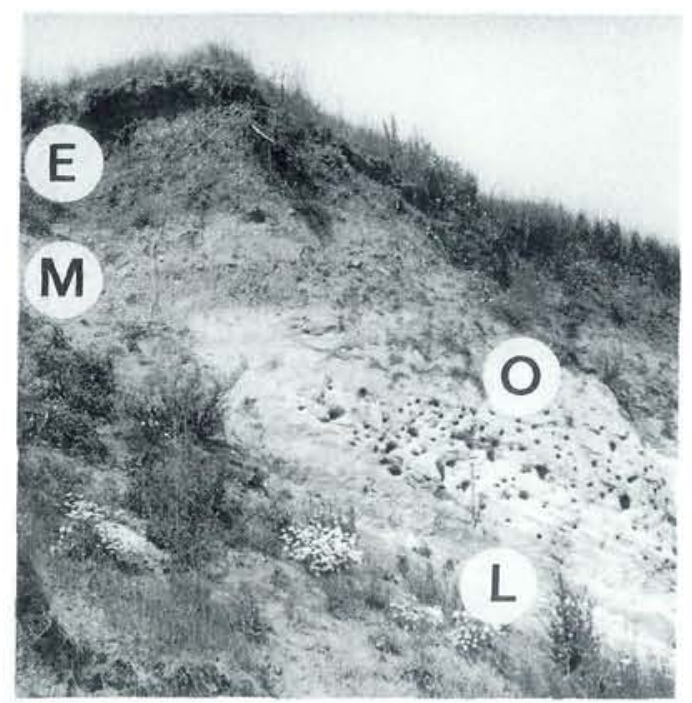

Fig. 47: Lillebalt Till (L) overlain by outwash deposits (O) dislocated from the NE. Unconformably overlain by the Mid Danish Till (M) and the East Jylland Till (E). Loc. 14, Kysing Strand.

\subsection{AREA 2: SKANDERBORG-HORSENS (locs 16-27, fig. 44) MORPHOLOGY AND LOCATION}

Area 2 lying between Horsens and Skanderborg is bound to the west by the Gudena valley and the Århus valley to the north. The localities are situated in the high lying and hilly country along or immediately beyond the East Jylland Ice border line (locs 16, 17, 18, 19, 20, 24, 25, 26) or a few $\mathrm{km}$ east of the ice border line (locs 21, 22, 23, 27).

\section{PREVIOUS INVESTIGATIONS}

The East Jylland Ice border line was described by Harder (1908) and can in several areas be defined by elongated ridges consisting of gravel-till (morænegrus) west of which proximal valley-sandur deposits are found, and a Baltic till cover can be mapped behind (east of) the ice border line. Houmark-Nielsen (1983a) described the sedimentary facies of ice marginal deposits west of Horsens previously dealt with by Harder. The indicator erratic counts presented by K.Milthers (1942) are from gravel pits situated on or slightly behind the East Jylland ice border. They show a predominance of Dala- over Baltic erratics and few Norwegian indicators; according to Milthers these results are typical of the area covered by the East Jylland icesheet. K.Milthers' erratic counts in the gravel pit of Stjær (loc. 27) are dominated by Norwegian indicators and contain restricted amounts of Baltic material, this is assumed to be an admixture of the deposits of the older Norwegian and the younger Dala-Baltic ice-stream of the last glaciation. Kronborg (1983) recognizes four till units at loc. 27 (Stjær): 1) an Elsterian(?), sandy $\mathrm{N}$-till lying unconformably upon waterlaid deposits folded by ice pressure from the north, 2) a clayey ENE-till of Saalian age separated from the overlying 3) residual gravel interpreted as a Weichselian till by waterlaid material and a glaciotectonic unconformity indicating ice push from the NE. The residual till is overlain by 4) a clayey SE-till deposited by the East Jylland icesheet. 


\section{STRATIGRAPHY}

Symbolic logs of each locality are shown in fig. 48. The till units are correlated and pictured for the whole area in the data chart fig. 49.

The oldest till unit found in area 2 (loc. 27, fig. 50 ) is a sandy, brown, massive Fennoscandian till with equal amounts of quartz and flint and characterized by Norwegian indicator erratics (A1): The Trelde Næs Till. It overlies waterlaid material with sedimentary structures indicating that palaeocurrents were directed towards the west and north-west. At the same locality a thin sheet of waterlaid material separates the Trelde Næs
Till from the overlying brownish, sandy to clayey, limestone free till which has equal amounts of quartz and flint (A): The Ashoved Till. The stratigraphic relationship between these tills and the younger tills (except for the youngest) of the area has not been observed, however, the model (fig. 43) predicts that the tills of loc. 27 are separated by outwash deposits from the overlying grey, clayey, massive, quartz poor, Baltic till (locs 17, $23,25)$ which does not contain noteworthy amounts of re-deposited Quaternary foraminif-

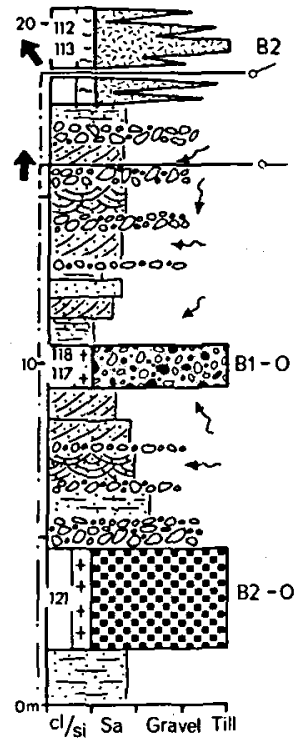

16. 17. 18: NIM - HVIRRING

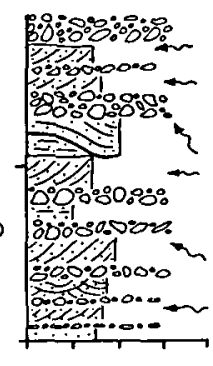

19. 20: NIM MARX

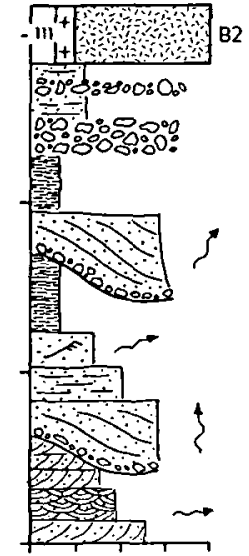

21: ARUPGARD

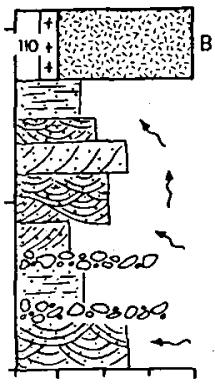

22: SATTRUP STEN \& GRUS

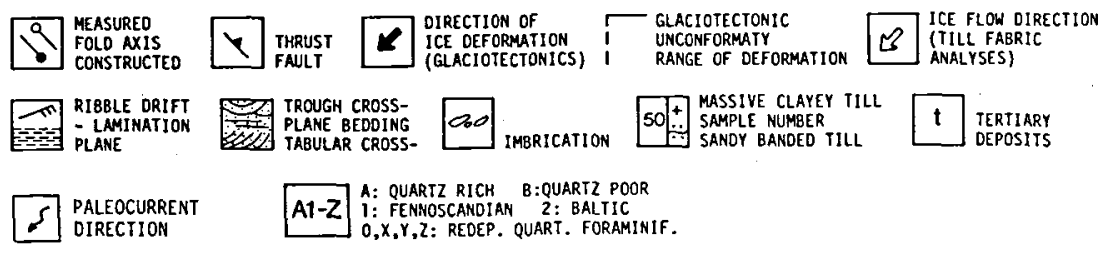

Fig. 48: Simplified lighological logs, area 2, Skanderborg-Horsens. 
era (B2-0): The Lillebælt Till. This till is overlain by waterlaid sand and gravel, occasionally fining upwards, deposited by north-westward moving meltwater streams. At loc. 17 this outwash is overlain by a sandy to clayey, brown, massive Fennoscandian till, with low quartz content and very few re-deposited Quaternary foraminifera (B1-0): The Mid Danish Till. The glaciotectonic deformation affecting the old, sandy tills at loc. 27, which indicate ice pressure from the NE, is related to the glacier advance, which deposited the Mid Danish Till. This till is overlain by waterlaid material deposited by generally westward moving meltwater streams. The waterlaid sequence and older deposits are folded by glaciotectonic deformation from the south and southeast at the edge of the East Jylland Ice border (locs 17, 18). The youngest till of area 2 is a brown, clayey, banded and massive Baltic till with fabrics indicating ice movement from the southeast, SE-(B2): The East Jylland Till. The waterlaid material at locs $19,20,24$ are sandur sediments deposited in front of the East Jylland ice border.

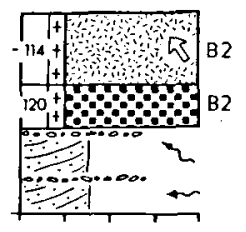

23: BAVNEHOJ

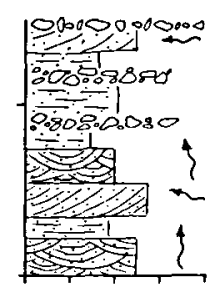

24: TANING SE

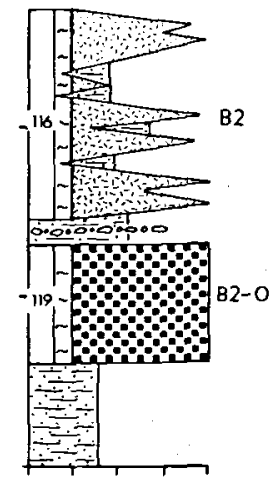

25: LEGARDSLYST

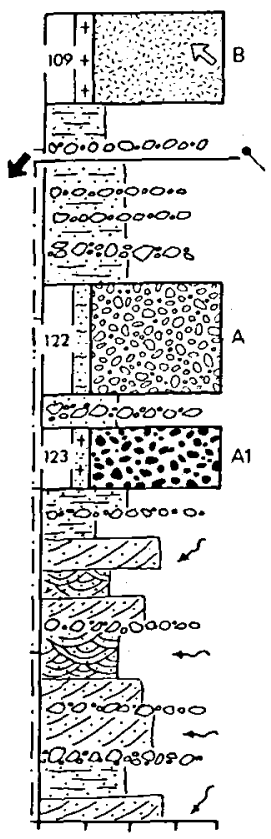

27: STJER GRUSGRAV 


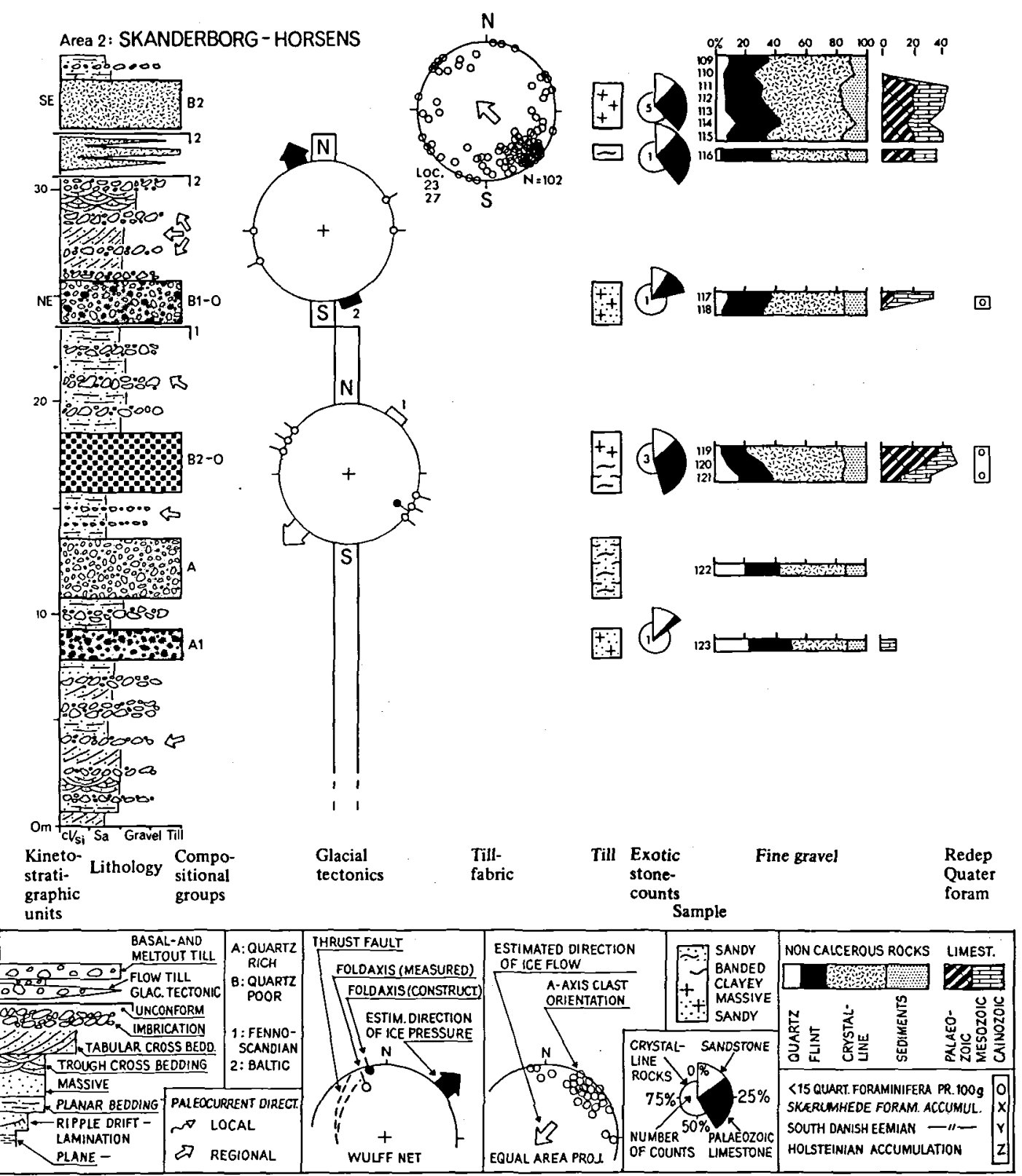

Fig. 49: Glacial stratigraphic data chart, area 2, Skanderborg-Horsens. Till units shown in fig. 43. 


\section{DISCUSSION}

As pointed out by Harder (1908) and K.Milthers (1942) the surface till and youngest outwash deposits were deposited by the East Jylland ice and characterized by Baltic clast material. Its petrographic composition contrasts the subsurface material, found in deep gravel pits, which is dominated by Norwegian indicators (cf. loc. 27). It seems however, that this deep lying material of Norwegian provenance is older than the last glaciation, even though it can only be indirectly verified, that the Norwegian clast material is older than the Weichselian ice transgression from the $\mathrm{N}$. On the other hand, it can not be proved that this material is older than the Saalian as claimed by Kronborg (1983).

\section{CONCLUSION}

Five till units, separated by waterlaid deposits generally deposited by westward moving palaeostreams, have been recognized in area 2 (fig. 105): 1) The Trelde Næs Till, 2) The Ashoved Till, 3) The Lillebælt Till, 4) The Mid Danish Till and its associated glaciotectonic deformations from the NE and 5) The East Jylland Till deposited as flow till along the ice margin and asso- ciated with glaciotectonic deformation indicating ice deformation from the south and southeast. The Baltic till deposited behind the East Jylland Ice border shows fabrics indicating ice movement from the SE.

\subsection{AREA 3: NØRRE SNEDE-ØSTBIRK-RYE (locs 28-37, fig. 44) MORPHOLOGY AND LOCATION}

Area 3, lying between Nørre Snede, $\emptyset_{\text {stbirk and }}$ Rye, is bound to the west by the sandur plains that begin at the Main Stationary Line, northward by the Julsø-Århus valley and eastward by the Gudena valley. The examined localities are situated in an area characterized by NE-SW trending valleys that dissect the young glacial landscape between the Main Stationary Line and the East Jylland Ice border line.

\section{PREVIOUS INVESTIGATIONS}

K.Milthers (1942) presents indicator erratic counts from gravel pits and rocks collected in fields, his results show a domination of Norwegian indicators and restricted amounts of Baltic rocks. Milthers regards this area as the extreem

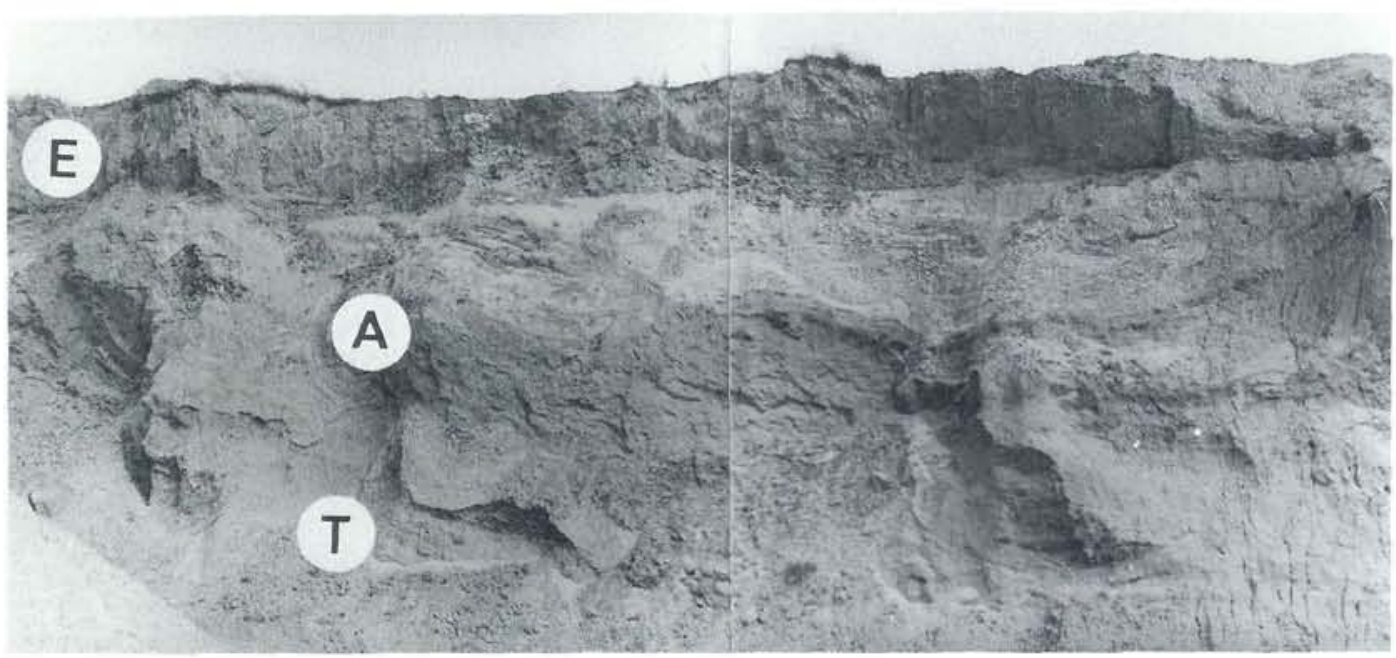

Fig. 50: Trelde Nas Till (T) overlain by Ashoved Till (A) and covered by glaciofluvial material folded by ice-deformation from the northeast and unconformably overlain by the East Jylland Till (E), loc. 27, Stjær. 


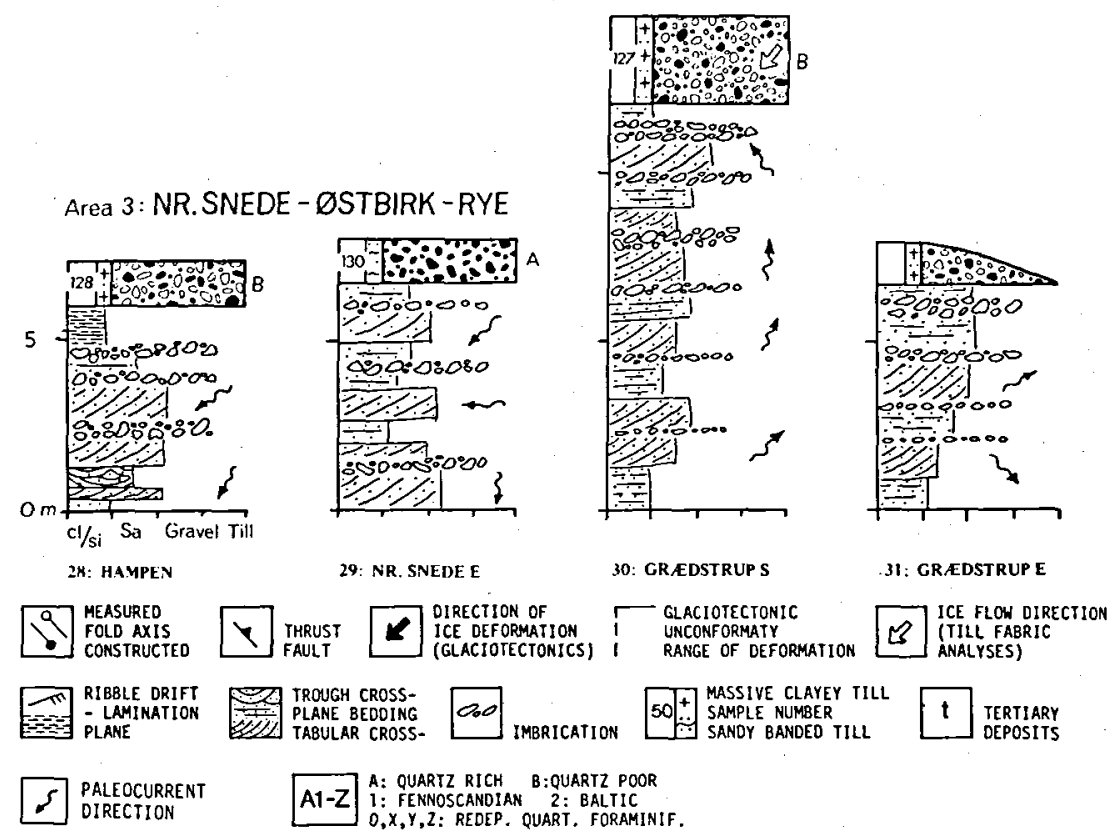

Fig. 51: Simplified lithological logs, area 3, Nørre Snede- $\emptyset$ stbirk-Rye.

westerly location where deposits from the Norwegian and Dala-Baltic ice sheets are found mixed. On morphological grounds V.Milthers (1948) and Larsen et al. (1979) sketched a number of roughly $\mathrm{N}-\mathrm{S}$ trending recessional ice border lines from the icesheet that reached the Main Stationary Line.

\section{STRATIGRAPHY}

The symbolic logs of each locality are shown in fig. 51. The till units are correlated and pictured for the whole area in the data chart fig. 52.

The oldest till of this area was found at loc. 33: Sønder Vissing Sand. It is a very sandy, massive, limestone free till with twice as much quartz as flint (A) and with a pronounced content of Norwegian indicator erratics: Sønder Vissing Till. It overlies Pleistocene, wateralid material, containing several horizons of large $(5-50 \mathrm{~cm})$ ventifacts, which again overlies Tertiary quartz sand. The Sønder Vissing Till is separated from the over-
30: GREDSTRUP S 


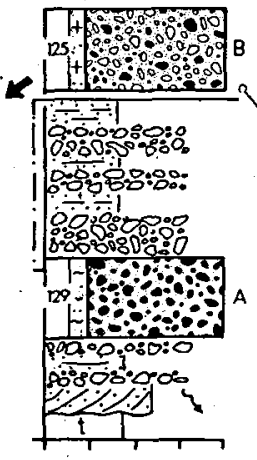

32: ADDIT SAVVARK

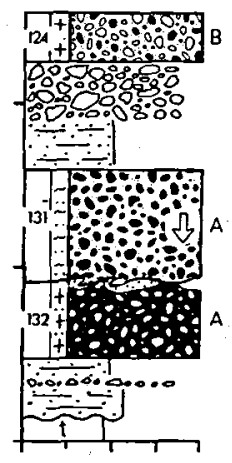

33: SDR. VISSINC SAND

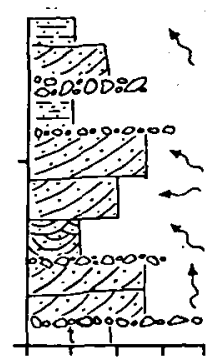

34: VOERVADS BRO

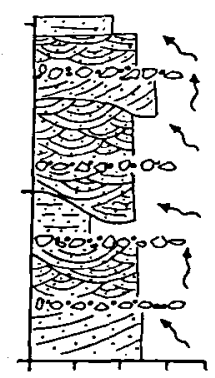

35. 36: OSTBIRK - GUDENA

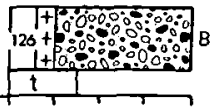

37: JAVNGYDE

\section{DISCUSSION}

As mentioned in connection with area 2 , the clast material dominated by Norwegian indicators (K.Milthers 1942) most probably does not originate from the last glaciation, but must be older. The stratigraphical analyses from principal loc. 1 indicates that the $\mathrm{N}$-till with an $\mathrm{A}$ composition, Trelde Næs Till, is of Saalian age. This is separated by Holsteinian deposits from the underlying quartz rich, Palsgård Till. It is therefore highly probable, that the Sønder Vissing Till underlying the Trelde Næs Till at Sønder Vissing Sand is also of Elsterian age however, with the same reservations regarding a greater age as for the $\mathrm{Pal}$ sgård Till. Differences in other lithic characteristics than quartz content prevents correlation between these two quartz rich tills. The waterlaid sand and gravel deposits separating the Trelde Næs Till and the Sønder Vissing Till is thought to be equivalent to the so-called "Norwegian" gravel, which is assumed to be of early Saalian age and has been described by V.Milthers (1939) from the geological mapsheet lying immediately west of area 3 .

\section{CONCLUSION}

Three till units separated by outwash material can be recognized in area 3 (fig. 105). The oldest is the Sønder Vissing Till with northerly clast provenance probably of Elsterian age separated from the overlying Trelde Næs Till by sand and gravel with northerly clast provenance deposited by southward moving meltwater streams. The Trelde Næs Till with fabric indicating ice movement from the north is overlain by meltwater material with northward moving palaeocurrents overlain by the Mid Danish Till with fabric and associated glaciotectonic deformation indicating ice movement from the northeast. During the recession of the NE-icesheet and the advance of the East Jylland Ice cap meltwater material was deposited as valley sandurs in the Gudenå valley and adjoining valleys. 


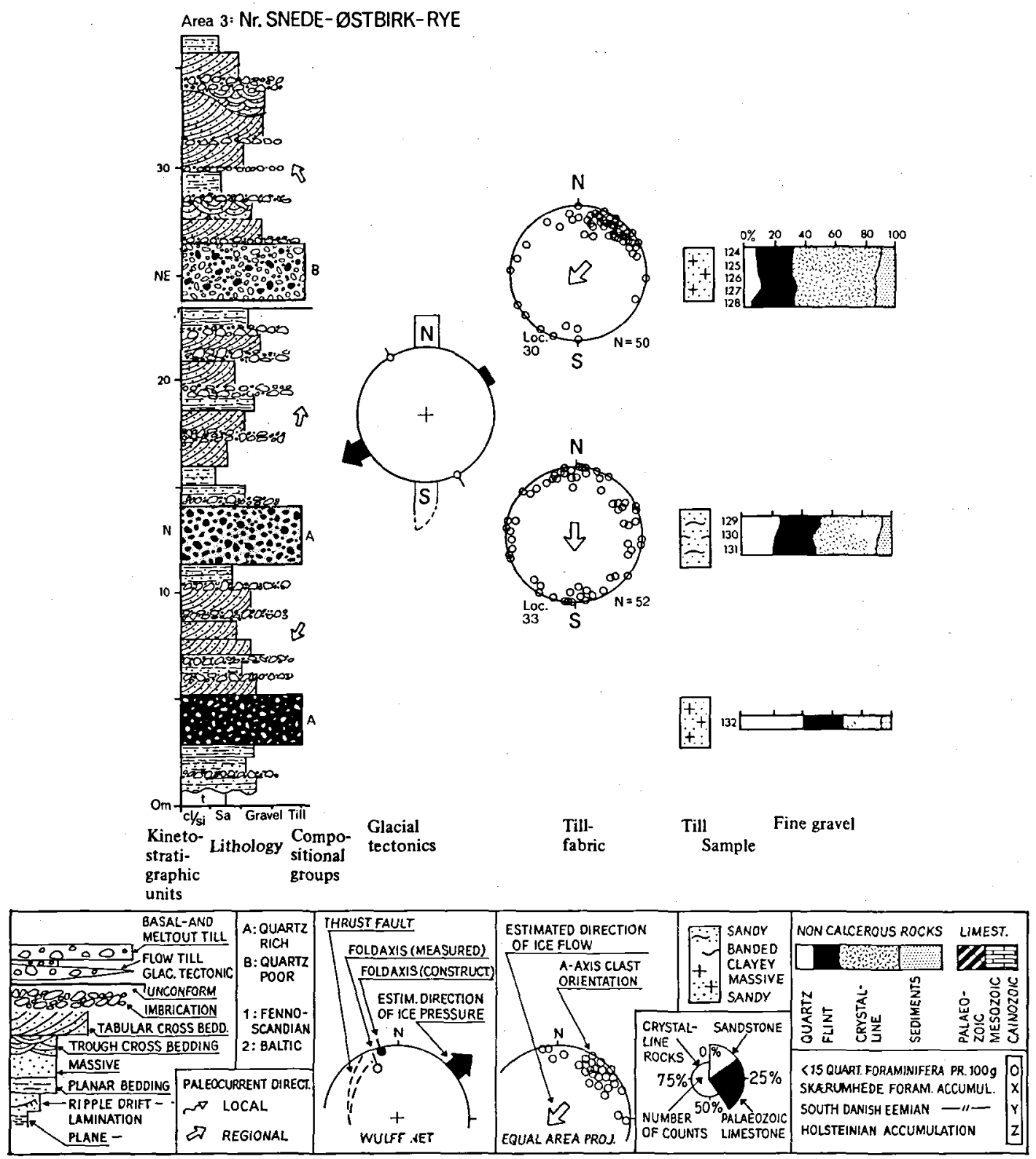

Fig. 52: Glacial stratigraphic data chart, area 3, Nørre Snede- Østbirk-Rye. Till units shown in fig. 43. 


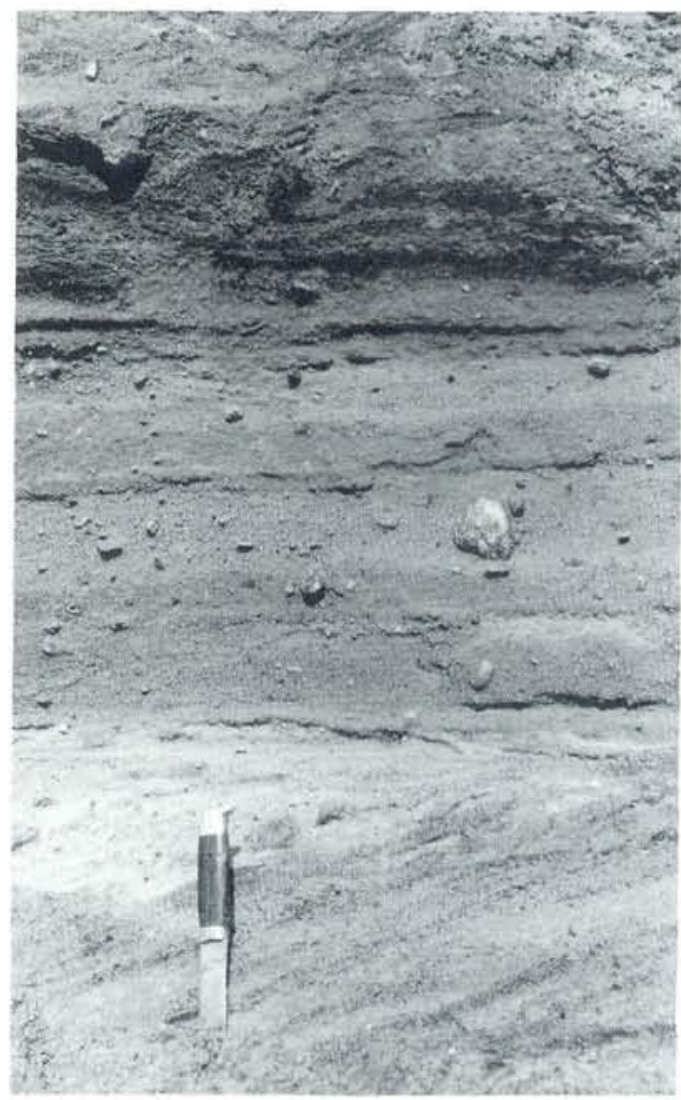

Fig. 53: Trelde Nas Till overlying waterlaid material, loc. 29. Nørre Snede. (Note in situ Oslo-erratic).

\subsection{AREA 4: ENDELAVE-JUELSMINDE- ODDER (locs 38-46, fig. 44) MORPHOLOGY AND LOCATION}

Area 4 lying east of Horsens between OdderJuelsminde and Endelave is characterized by E-W lying elongate hills north of Horsens fjord situated in a rather smooth landscape and cut by the $\mathrm{N}-\mathrm{S}$ trending Odder valley. The localities are placed at coastal cliffs (locs 41, 42, 43, 44, 46) or in gravel pits close to the Odder valley (locs 38 , $39,40,45)$. The principal locality 2: Ashoved lies in the southern part of the area.

\section{PREVIOUS INVESTIGATIONS}

V.Madsen (1900) suggests that two tills are present in the area; an upper brown till of Baltic (and Fennoscandian) provenance with an associated Dala-Baltic indicator erratic association is found over the whole of the mapsheet. The lower till exposed in cliff sites is a blackish, Fennoscandian till, the appearance of which is connected with the presence of Norwegian indicator erratics. Harder (1908) characterized the surface till of the area as Baltic presumably deposited by the East Jylland icesheet.

V.Milthers (1932) and K.Milthers (1942) indicate, that the youngest till of the area is characterized by Baltic indicators; whereas the subsurface deposits are dominated by Norwegian indicators. The surface till is divided into two facies, one dominated by Red Baltic quartzporphyries north of the Horsens Fjord ice marginal hills and another dominated by brown Baltic quartzporphyries south and east of the hills. This division indicates, in K.Milthers opinion, that the Dala-Baltic dominated East Jylland ice was succeeded by a purely Baltic, Lillebælt glacier confined to the coastal areas of East Jylland carrying the brown Baltic quartz-porphyries.

A.Berthelsen (1949) also recognized the dominance of Norwegian indicators in the subsurface deposits and established the fact, that in the area between the East Jylland Ice border west of Horsens and the Lillebælt coast the surface till carries a rather homogeneous, Baltic indicator association and that the division based on the contents of different Baltic quartzporphyries as described by K. Milthers no longer can be maintained.

\section{STRATIGRAPHY}

Simplified lithological logs from the individual localities are shown in fig. 54 and correlated for the whole area in the glaciostratigraphic data chart (fig. 55).

The oldest till of area 4 (excluding the principal locality 2: Ashoved) is a brown, sandy to clayey, banded and massive, Fennoscandian till (locs 39, 45) with equal amounts of quartz and flint (A1): The Ashoved Till, at the base of which glaciotectonic unconformities (loc. 45) indicate folding and thrusting north-eastern directions (fig. 56) affecting the underlying waterlaid material which is characterized by Norwegian indicators. 


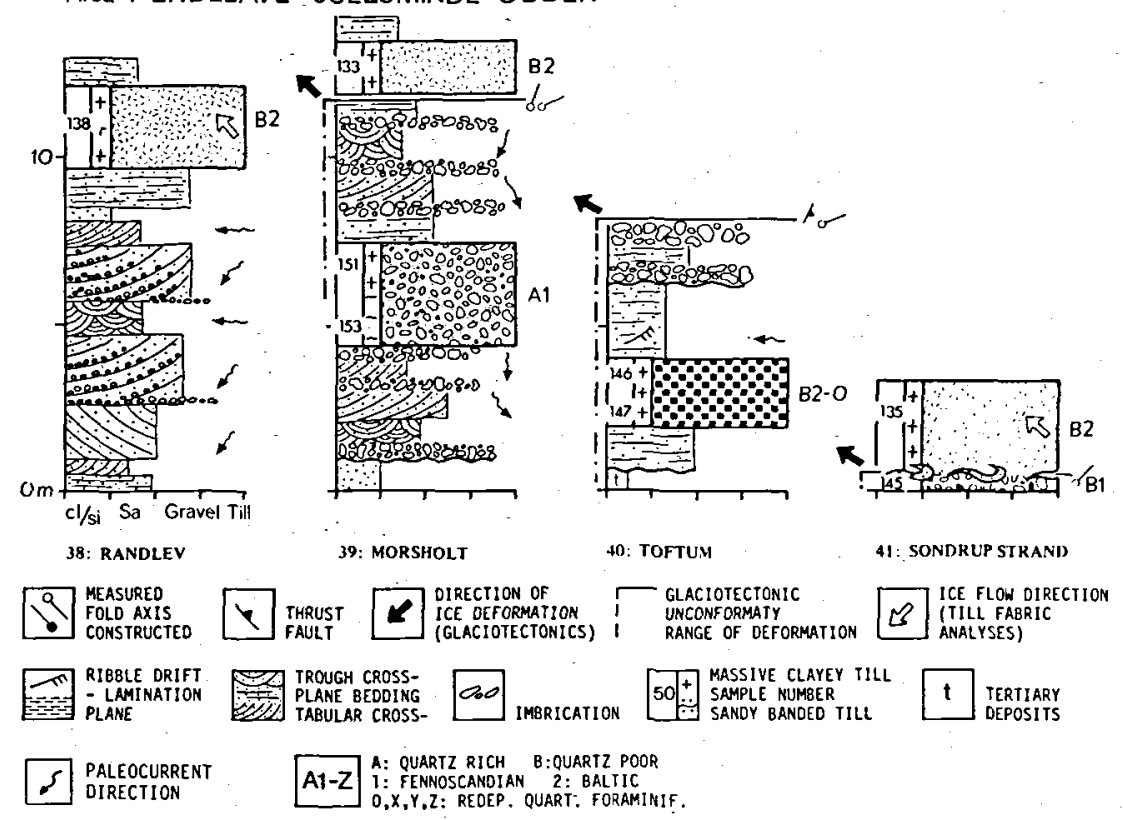

Fig. 54: Simplified lithological logs, area 4, Endelave-Juelsminde-Oder.

overlain by fine grained outwash, deposited by westward moving palaeocurrents, (loc. 40 ) or observed in direct contact with the overlying brown to grey, clayey, massive and banded, quartz poor, Fennoscandian till (locs 44,46 ). This till also occasionally contains an $\mathrm{X}$-foraminiferal accumulation and has a fabric (loc. 42) which indicate ice flow from the northeast, NE-(B1-X): The Mid Danish Till. A lower member of the Mid Danish Till is separated from an younger subunit (B1) by sandy outwash and glaciotectonic unconformities which indicate ice deformation from the NE (loc. 44). The Mid Danish Till is separated from the overlying till by sand and gravel deposited by west and south-westward directed melt-

Any direct relationship between the Ashoved Till and younger tills of the area has not been observed, but according to the stratigraphical model and observations from localities in the adjoining area (5) the Ashoved Till is separated by waterlaid material from the overlying till. This till is grey, clayey, mostly massive, quartz poor, of Baltic provenance (locs $40,44,46)$ and with insignificant amounts of re-deposited Quaternary foraminifera (B2-0): The Lillebælt Till. It is either water streams (locs $38,39,43,44$ ). At the base of the overlying till glaciotectonic unconformities indicate ice deformation from the southeast (loc. 41). Additional ice pushed structures also indicating ice deformation from the SE are observed at locs 39, 40, 45. The youngest till, is at Endelave (loc. 46) separated from the Mid Danish Till by a blurred boulder pavement with glacial striations, which trend in NW-SE oriented directions (fig. 57). The youngest till is brown, mostly massive, quartz poor and Baltic containing fabrics which indicate ice movement from the southeast, SE-(B2): The East Jylland Till. At several localities this till is overlain by sandy outwash. 


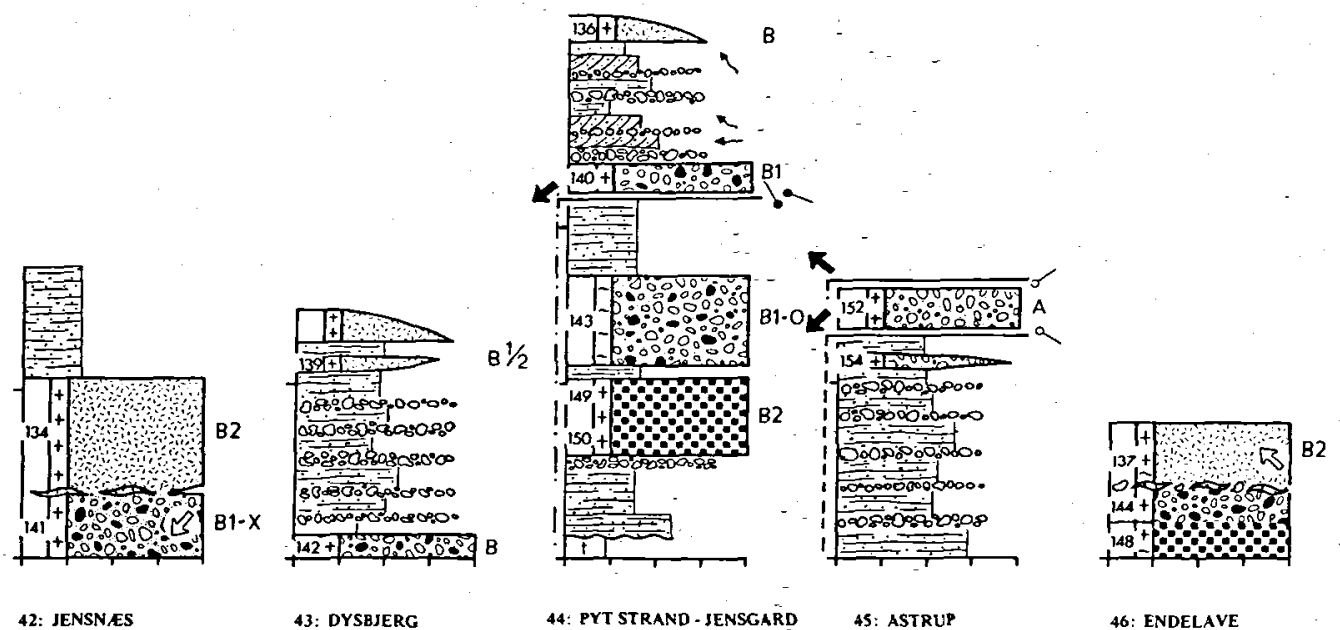

\section{DISCUSSION}

From the indicator erratic counts published by Madsen (1899), Madsen et al. (1928), K.Milthers (1942) and Berthelsen (1949) it must be argued, that the content of Norwegian indicators in subsurface deposits most probably originate from the Trelde Næs Till or the waterlaid outwash deposited in connection with this early Saalian till. This implies, that the maximum extension of the Weichselian ice-sheet, which deposited the $\mathrm{Ka}^{-}$ ttegat till from northerly directions, must be found north of the localities of area 4 and 5 where Norwegian clast material of supposed Saalian age constitute the subsurface deposits.

\section{CONCLUSION}

Including the data from the principal locality 2: Ashoved six till units separated by outwash, deposited from southward and westward moving meltwater streams, are present in area 4 (fig. $105)$.

The oldest till is the Palsgård Till which is presumed to be of Elsterian age and is separated from the older Saalian Trelde Næs Till by outwash deposits and glaciotectonic unconformities which indicate ice deformation from the north. The Trelde Nas Till with fabrics indicating ice flow from the north is succeeded by the Ashoved Till with-associated glaciotectonic deformation and fabrics indicating ice movement from the NE. The Lillebælt Till constitutes the till deposited by the final Saalian ice advance from the Baltic region and it is overlain by the Mid Danish Till (Weichselian) which contains fabrics indicating ice movement from the NE. A recessional advance of the ice-sheet which deposited the Mid Danish Till gave rise to glaciotectonic disturbances from the NE in the coastal areas and deposited an upper subunit of the Mid Danish Till. The East Jylland Till represents the youngest ice advance in the area with fabrics and associated glaciotectonic deformations indicating ice movement from the SE. 


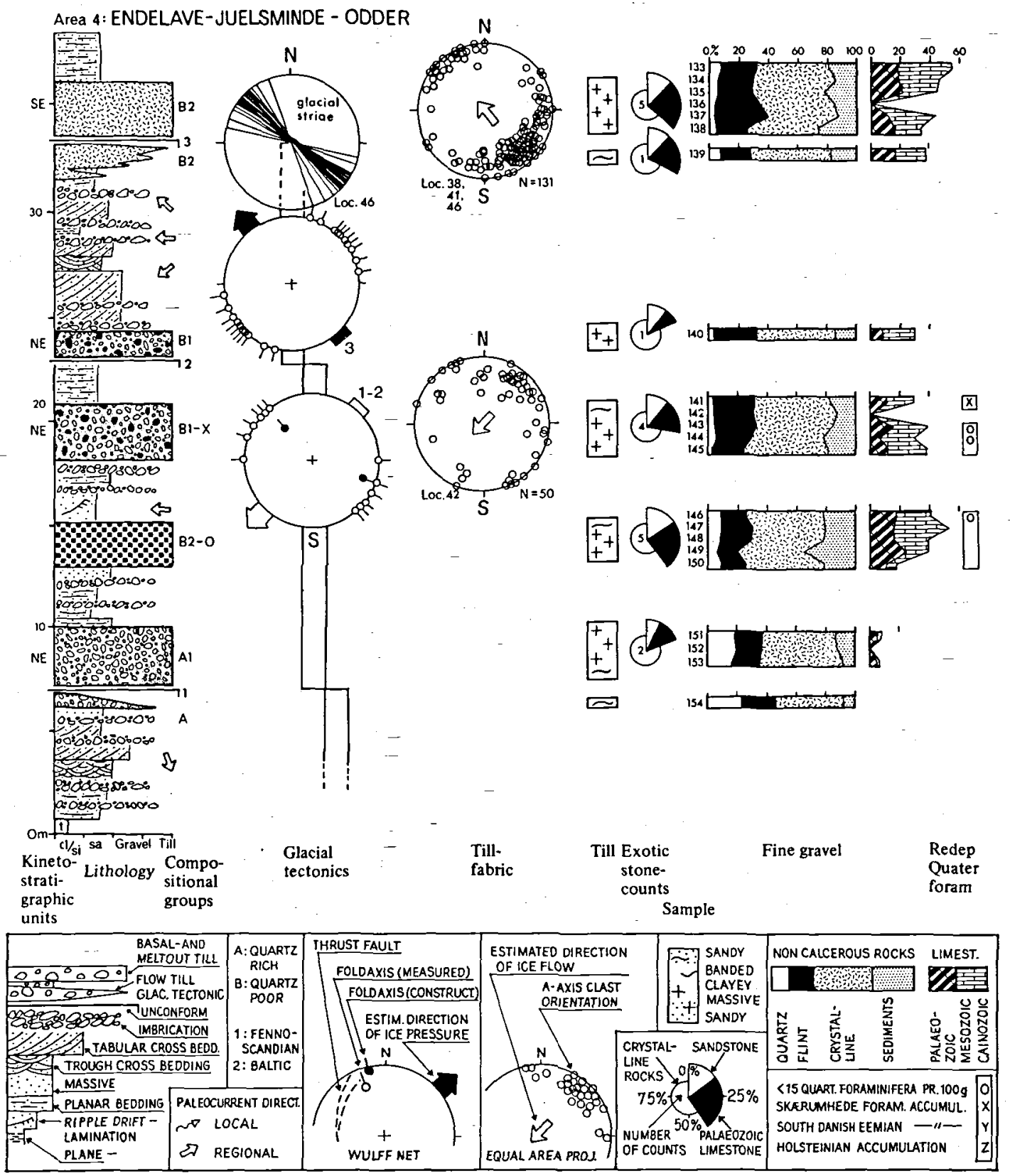

Fig. 55: Glacial stratigraphic data chart, area 4, Endelave-Juelsminde-Odder. Till units shown in fig. 43. 


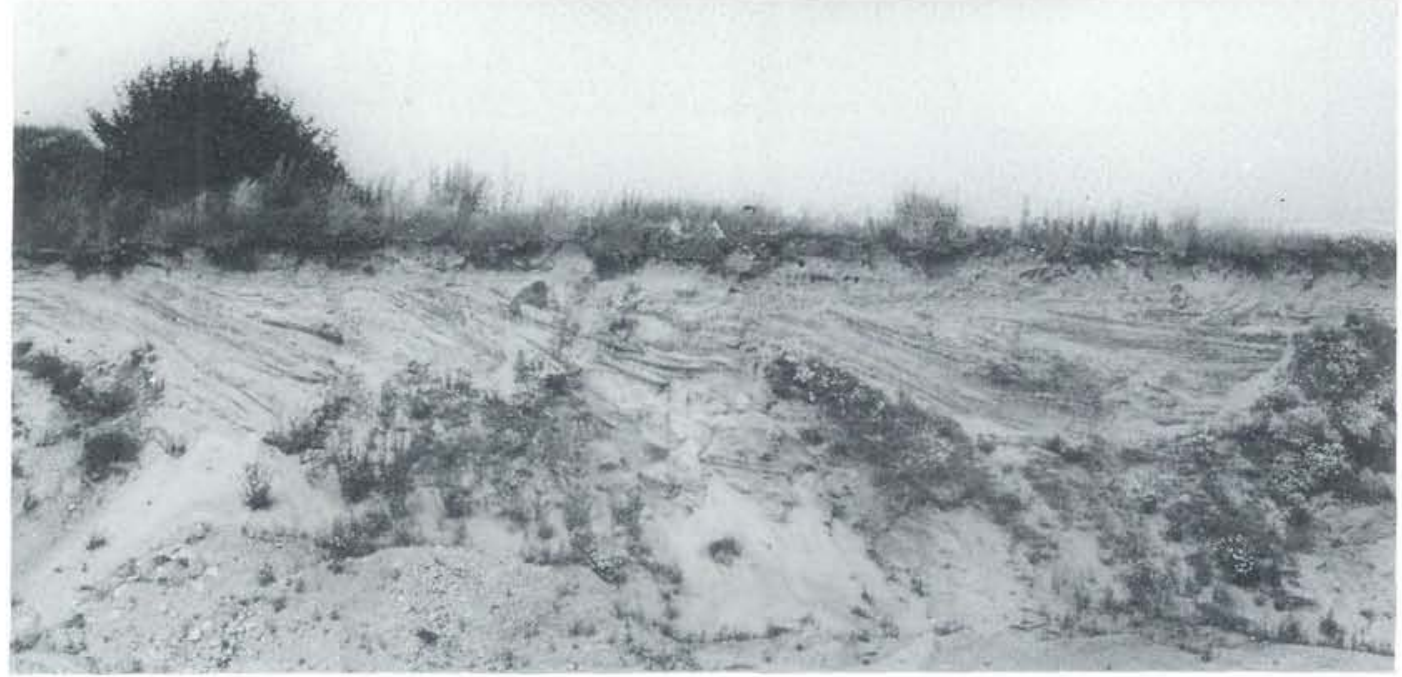

Fig. 56: Lower waterlaid deposits rich in Oslo erratics dislocated from the NE and unconformably overlain by the Ashoved Till (partly removed), loc. 45, Asstrup.
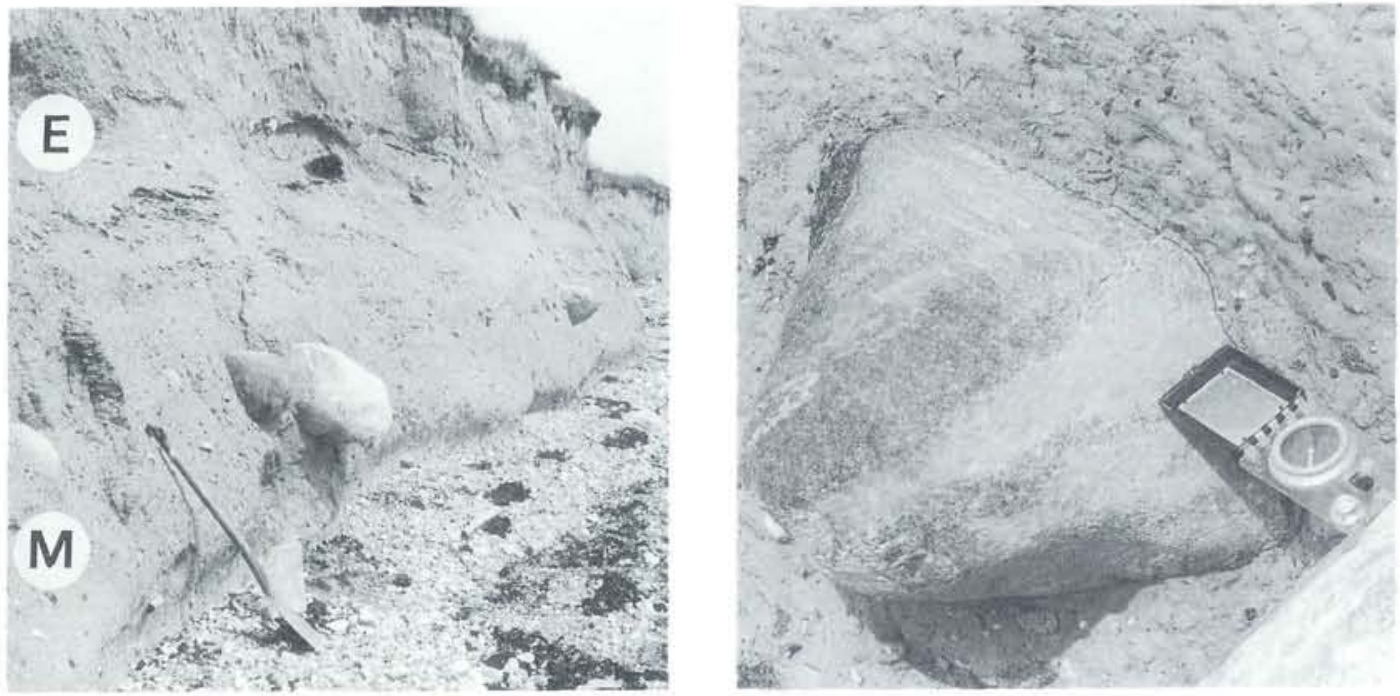

Fig. 57: Glacial striations right on boulder pavement left separating the Mid Danish Till (M) and the East Jylland Till (E) (a banded and massive subunit is overlain by a massive subunit) loc, 46, Endelave. 


\subsection{AREA 5: VEJLE FJORD NORTH (locs 47-56, fig. 44) MORPHOLOGY AND LOCATION}

Area 5 is situated in the strip of land between the southern part of the East Jylland Ice border line at Hedensted and Juelsminde at the mouth of the Vejle fjord. Most of the localities are placed at coastal cliff sites on the Vejle Fjord coast $(51,52$, $53,54,55,56)$, the remainder are gravel pits between the coast and the East Jylland Ice border line $(47,48,49,50)$.

\section{PREVIOUS INVESTIGATIONS}

Harder (1908) studied the ice marginal deposits at Remmerslund by Hedensted on the southern edge of the East Jylland Ice border line north of Vejle. V.Milthers (1932) and K.Milthers (1942) conclude in accordance with Harder, that the till cover of the area east of the East Jylland Ice border line is dominated by Baltic indicators. They also conclude, that the subsurface deposits are characterized by Norwegian indicators, which in
K.Milthers' opinion, have been deposited either by a late Saalian or early Weichselian advance. V.Nordmann (1958) sketched a SW-NE trending recessional ice border line behind the East Jylland Ice border and indicates, that on the basis of stone counts individual till beds can be recognized. These stone counts have however not been published. Nordmann does point out however, that it cannot be concluded whether the individual till beds have been deposited by one and the same ice-sheet or whether they have been laid down during several glaciations.

\section{STRATIGRAPHY}

Symbolic logs of each locality are shown in fig. 58 , and complete lithologies are shown and correlated in the glacial stratigraphic data chart (fig. 59).

The oldest till found at the examined localities (loc. 52) is a dark brown, sandy, banded, Fennoscandian till (fig. 60) with equal amounts of quartz and flint and with a fabric indicating ice

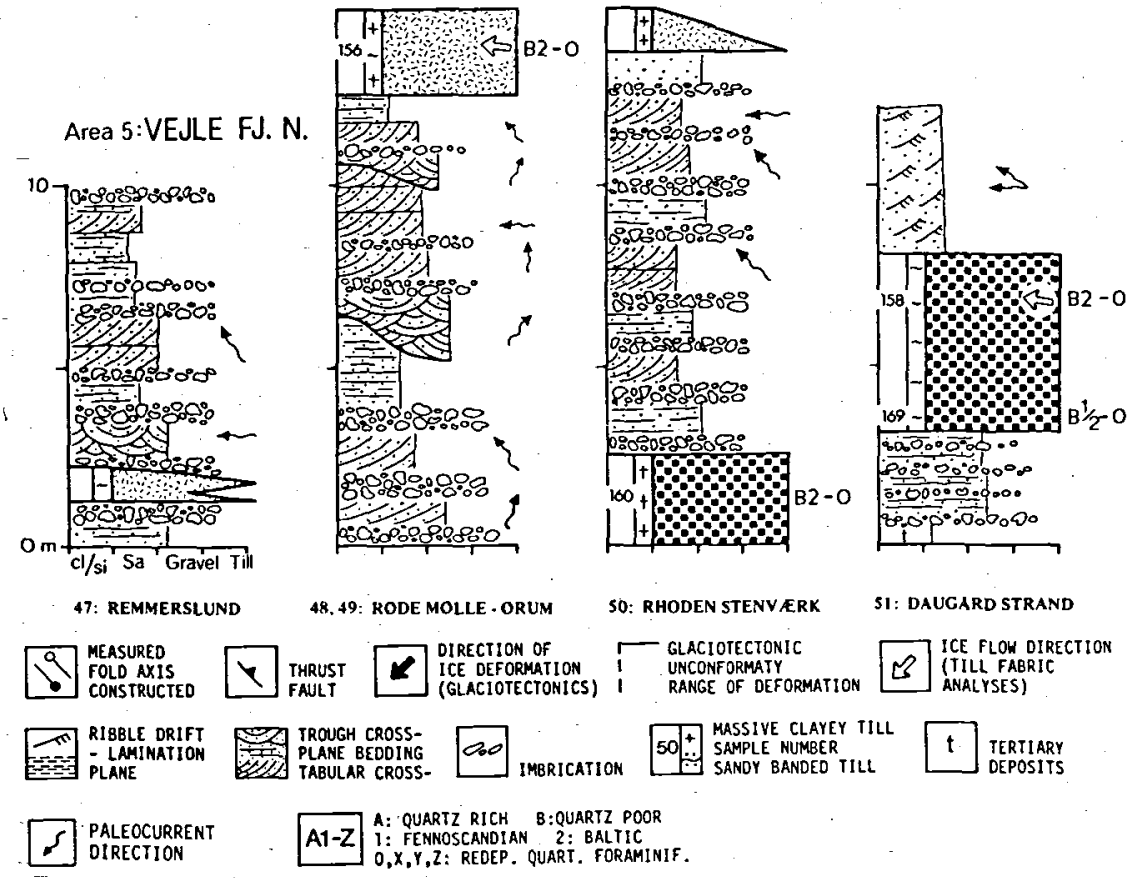

Fig. 58: Simplified lithological logs, area 5, Vejle Fjord North. 
movement from the northeast, NE-(A1): The Ashoved THl. This till is separated from underlying Tertiary sand by meltwater sand and gravel. The Ashoved Till is often separated by outwash material from the overlying grey, clayey, mostly massive, quartz poor, Baltic till (locs 50, 51, 52, $53,54,55,56)$. This till contains insignificant amounts of re-deposited Quaternary foraminifera and shows fabrics indicating ice movement from an east-south-easterly direction, ESE-(B2$0)$ : The Lillebælt Till. This till can be divided into several sub-facies. Apart from the general attitude of the till outlined above, a lower sub-facies is characterized by a Fennoscandian clast provenance and another, apparently upper sub-facies is extremely rich in Cretaceous/Tertiary limestone. The Lillebælt Till and associated outwash, deposited on the surface of the till by westward moving meltwater streams (locs 51,53,55) has been folded and thrusted from north-easterly directions (fig. 61). These deposits are unconformably overlain by generally coarse grained, current bedded and imbricated outwash material, with a tendency to fine upwards and deposited by generally north-westward flowing meltwater streams (locs 48, 49, 50, 55). East of the East Jylland Ice border line this waterlaid sequence is overlain by a banded and massive, brown, clayey, quartz poor, Baltic till (fig. 62) containing insignificant quantities of re-deposited Quaternary foraminif-

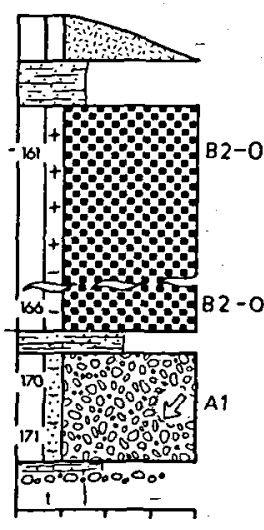

S2: RHODEN STRAND

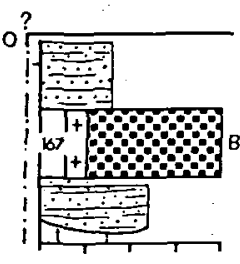

53: TRESKOHACE

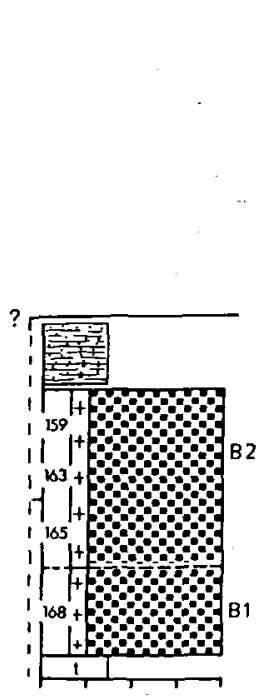

54: AHUSE

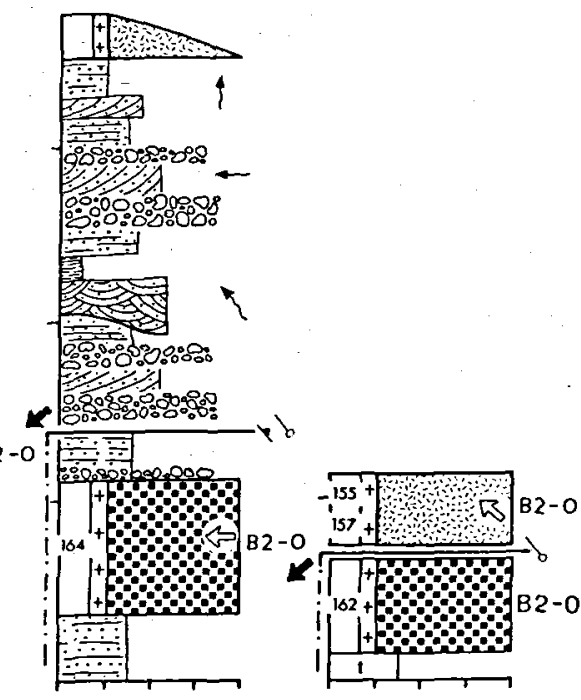

55: STAKSRODE STRAND

56: XLAKRING STRAND 


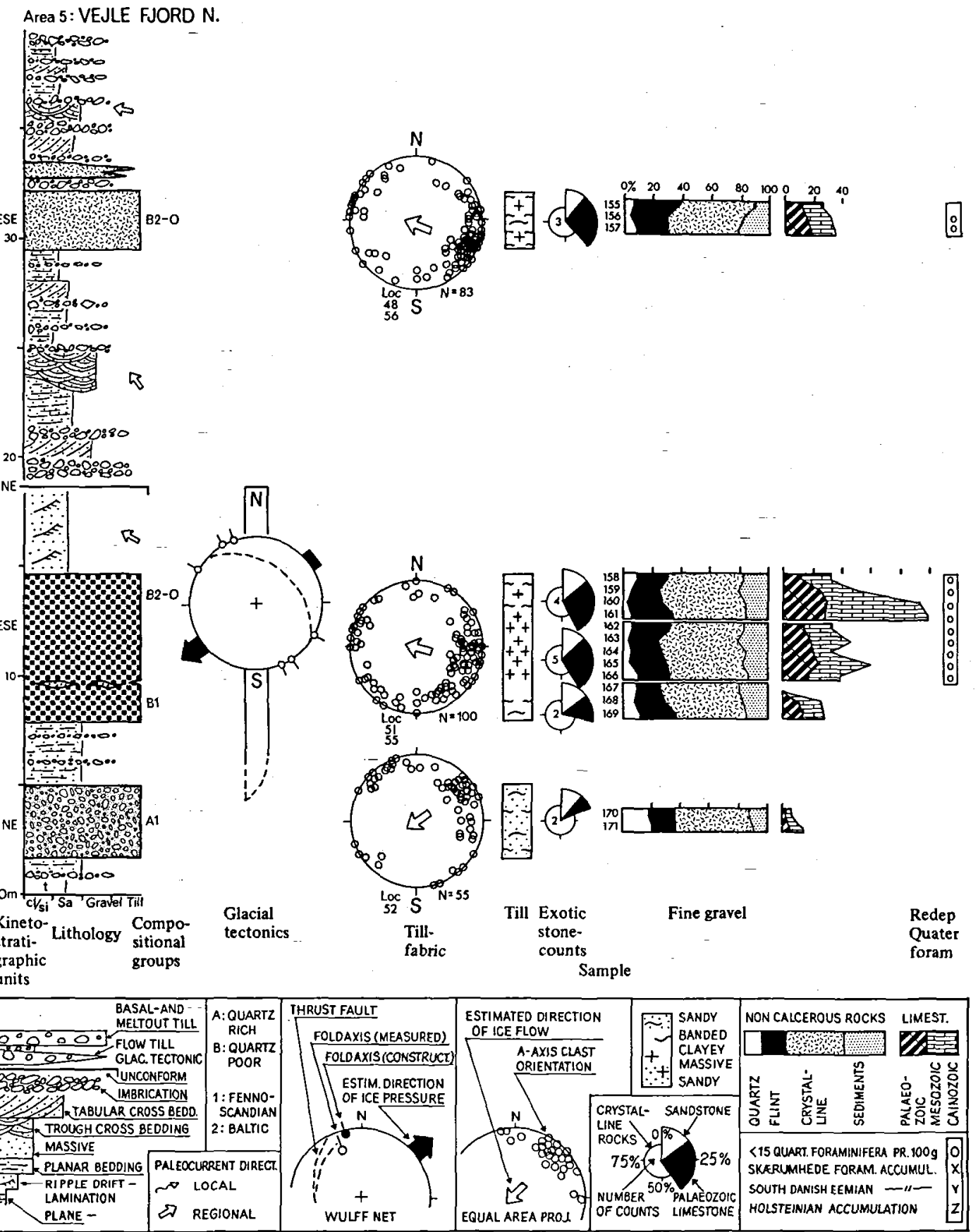

Fig. 59: Glacial stratigraphic data chart, area 5, Vejle Fjord North. Till units shown in fig. 43. 


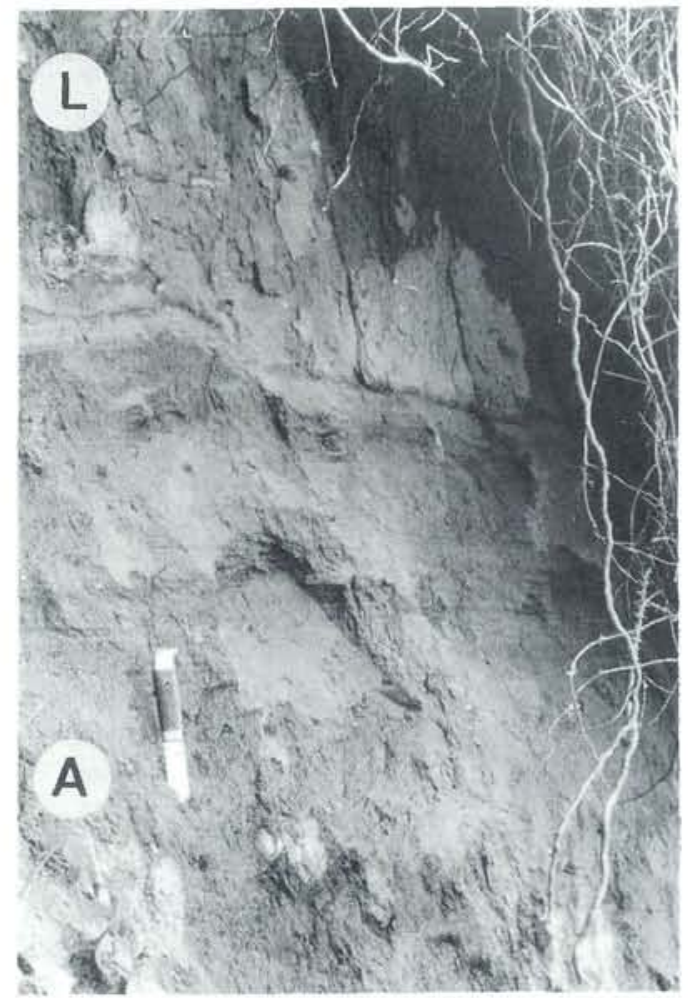

Fig. 60: Banded Ashoved Till (A) overlain by the massive Lillebalt Till (L), loc. 52, Rhoden Strand. era and with fabrics (locs 48, 56) which indicate ice movement from the eastsoutheast, ESE-(B10): The East Jylland Till. In proximal outwash deposits (loc. 47) which lie on the East Jylland Ice border line, the East Jylland Till appears as tongues and lenses of flow till overlain by waterlaid material fining upwards.

\section{DISCUSSION}

The indicator erratic counts presented by K.Milthers (1942) indicate, that the subsurface deposits are dominated by Norwegian indicators in the eastern part of the area. As previously mentioned these counts were made in beach gravels adjacent to coastal cliffs which presumably contain older till material. Further west (between locs 54 and 55) counts suggest the presence of deep lying Baltic sources along with the Norwegian indicators, this is however, not taken into consideration by K.Milthers. It seems highly probable, that a large portion of the Baltic contribution to Milthers' counts originates from the Baltic, Lillebælt Till.

The Fennoscandian, lower sub-unit of this till (loc. 52) is not interpreted as the result of an independent ice stream, but merely due to local incorporation of older till material situated beneath the glacier, which deposited the Lillebælt Till.

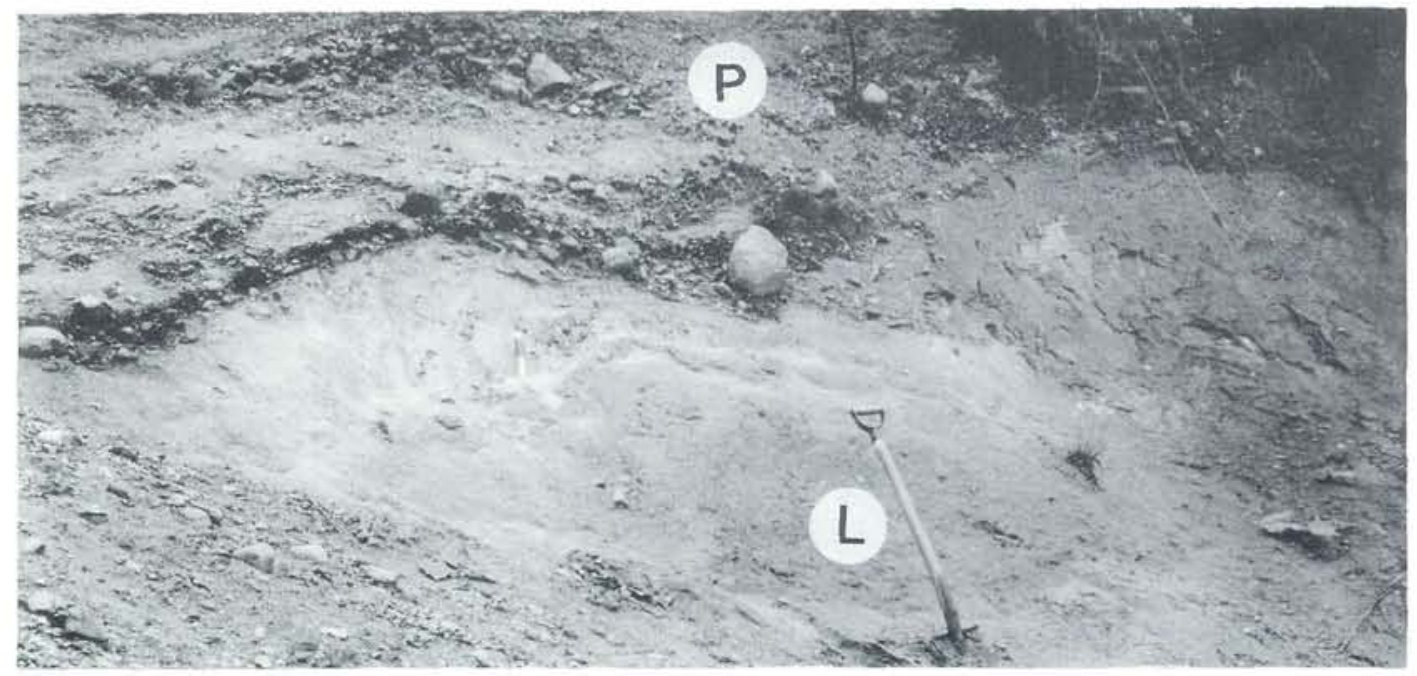

Fig. 61: Lillebalt Till (L) overlain by sand outwash material dislocated from the NE and unconformably overlain by proximal meltwater deposits (P), loc. 55, Starksrode Strand. 
The calcium carbonate rich sub-facies has probably originated from large rafts of chalk picked up in the eastern part of the country, which gradually disintegrated into smaller clasts during glacial transport.

The Mid Danish Till has not been found in the investigated localities of area 5 . The glacialtectonic unconformities, which affect the Lillebælt Till, and indicate ice pressure from the NE are, however, most probably associated with the ice sheet which deposited the Mid Danish Till.

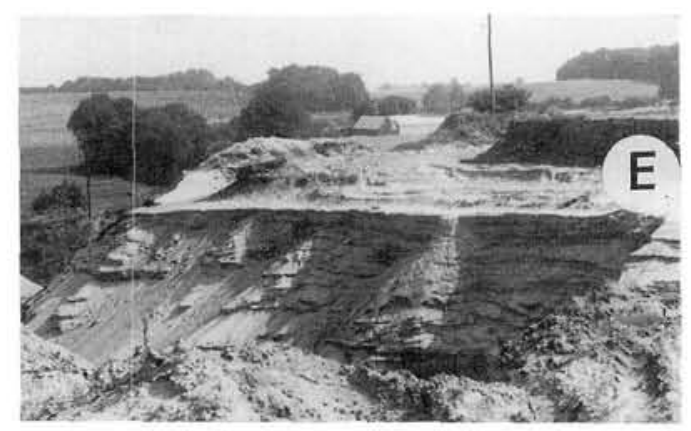

Fig. 62: Partly removed East Jylland Till (E) overlying outwash deposits, loc. 48, Røde Mølle.

\section{CONCLUSION}

The oldest till observed in area 5 (fig. 105) is the Ashoved Till deposited by an ice stream from the northeast and separated from the overlying Lillebælt Till by outwash deposits. The Lillebælt Till was deposited by an ice stream from the ESE. Glacialtectonic unconformaties affecting this till and the overlying fine grained outwash, which was deposited by northwestward flowing meltwater streams, indicate transgression during the Weichselian of an ice sheet from the NE. This ice stream was succeeded by north-westward flowing outwash and is overlain by the youngest till, deposited from the ESE by the East Jylland Icesheet.

Area 6: VEJLE -JELLING - GIVE
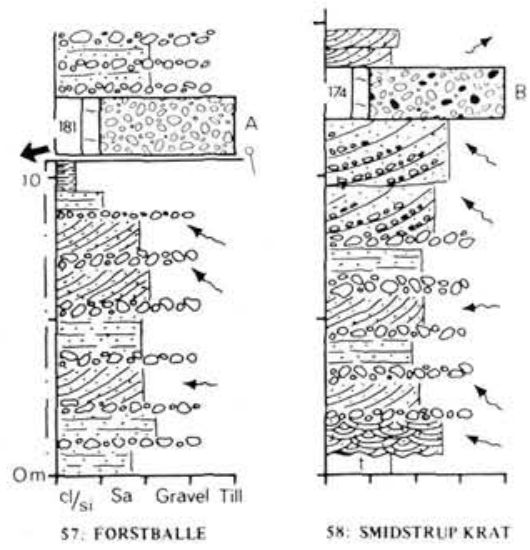

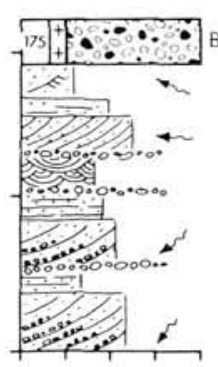

58: SMIDSTRUP KRAT

59: GRONBJERG

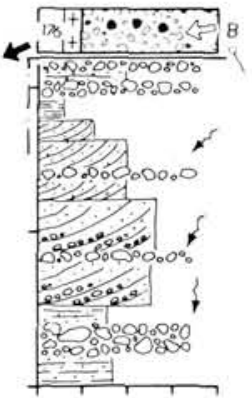

60 RIS-GIVSKUD
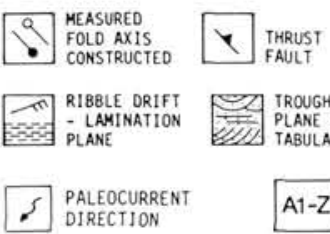

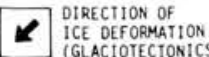

M ICE FLOW DIRECTION

GLACIOTECTONIC UNCONFORMATY

3 (TILL FABRIC 000 MasSIVE ClaYey tILL $t \quad \begin{aligned} & \text { TERTIARY } \\ & \text { DEPOSITS }\end{aligned}$

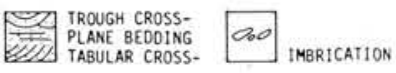

SANDY BANDED THLL

A1-Z A: QUART2 RICH B: QUARTZ POOR

1: FENNOSCANDIAN 2: BALTIC
$0, X, Y, Z:$ REDEP QUART. FORAMINIF.

Fig. 63: Simplified lithological logs, area 6, Vejle-Jelling -Give. 
5.6 AREA 6: VEJLE-JELLING-GIVE (locs 57-65, fig. 44) MORPHOLOGY AND LOCATION

Area 6 lies in a triangle between the Main Stationary Line and the East Jylland Ice border line northwest of Vejle. The landscape is composed of roughly $\mathrm{N}-\mathrm{S}$ oriented ice marginal hills which in the west lie on a rather plane surface dissected by generally E-W oriented valleys, that are partly filled with sandur deposits. The localities (all gravel pits) are placed in the ice marginal hills to the west $(57,58,59,60,61)$, the intermediate area west of Vejle $(62,63,64)$ and just south of the East Jylland Ice border line east of Vejle (65).

\section{PREVIOUS INVESTIGATIONS}

On the basis of morphological features V.Milthers (1925) and Nordmann (1927) extended the East Jylland Ice border line described by Harder (1908), from the Hedensted area in an arch shaped lobe north and west of Jelling. In contrast to Harders (1908) works Milthers and Nordmann
Norwegian and Dala erratic material. He suggests further that the western limit of the East Jylland Ice border should be drawn along the marked N-S trending line separating the young glacial landscape in the east from the old glacial landscape in the west. According to V.Milthers (1932), this border line also defines the division between the area towards the west characterized by large quantities of Scanian basalt erratics in the surface deposits and the Norwegian-Dala erratic dominated area to the east.

K.Milthers (1942) referring mainly to earlier counts by V.Milthers, acknowledges the lack of Baltic indicators in the area west of Hedensted. Even so, K.Milthers chose the same outline for the East Jylland Ice border line as that previously drawn by V.Milthers and Nordmann.

Nordmann (1958) sketches recessional positions of the East Jylland Ice border line immediately west of Vejle, and associated one recessional state with the deposition of sandy and silty clay in ice damed lake basins in the valleys $3-5 \mathrm{~km}$ north and west of Vejle.

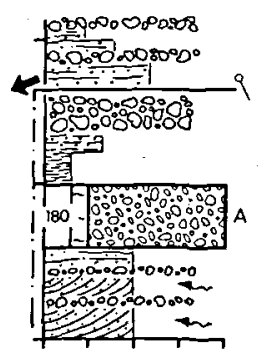

61: HOLMOSEGARD - TYREGOD

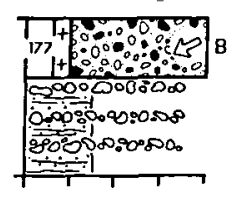

62: ALSTED MOLLE

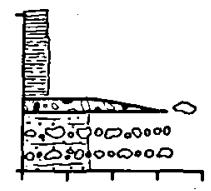

63 a \& b: FLOJSTRUP

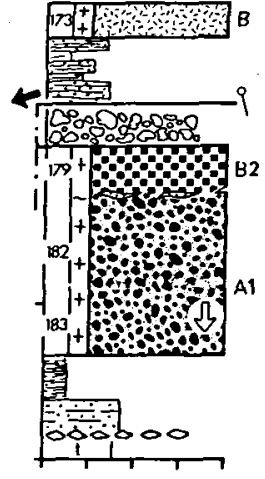

64: GREJSDAL

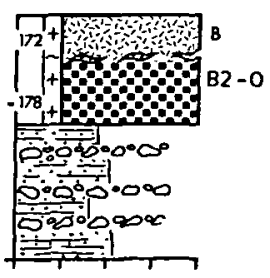

65: ASSENDRUP did not find the Baltic indicator association, described as characteristic of the land covered by the East Jylland Icesheet in the area west and north of Vejle (Harder 1908). V.Milthers (1925, $1932,1948)$ ascribes the reduced quantity of Baltic indicators to strong incorporation of older

\section{STRATIGRAPHY}

The symbolic logs of each locality are shown in fig. 63. The till units are correlated and pictured on for the whole area in the data chart fig. 64 .

The oldest till found in area 6 (loc. 64) is a grey, clayey and sandy, mostly massive, Fennos- 
Area 6:VEJLE-JELLING - GIVE

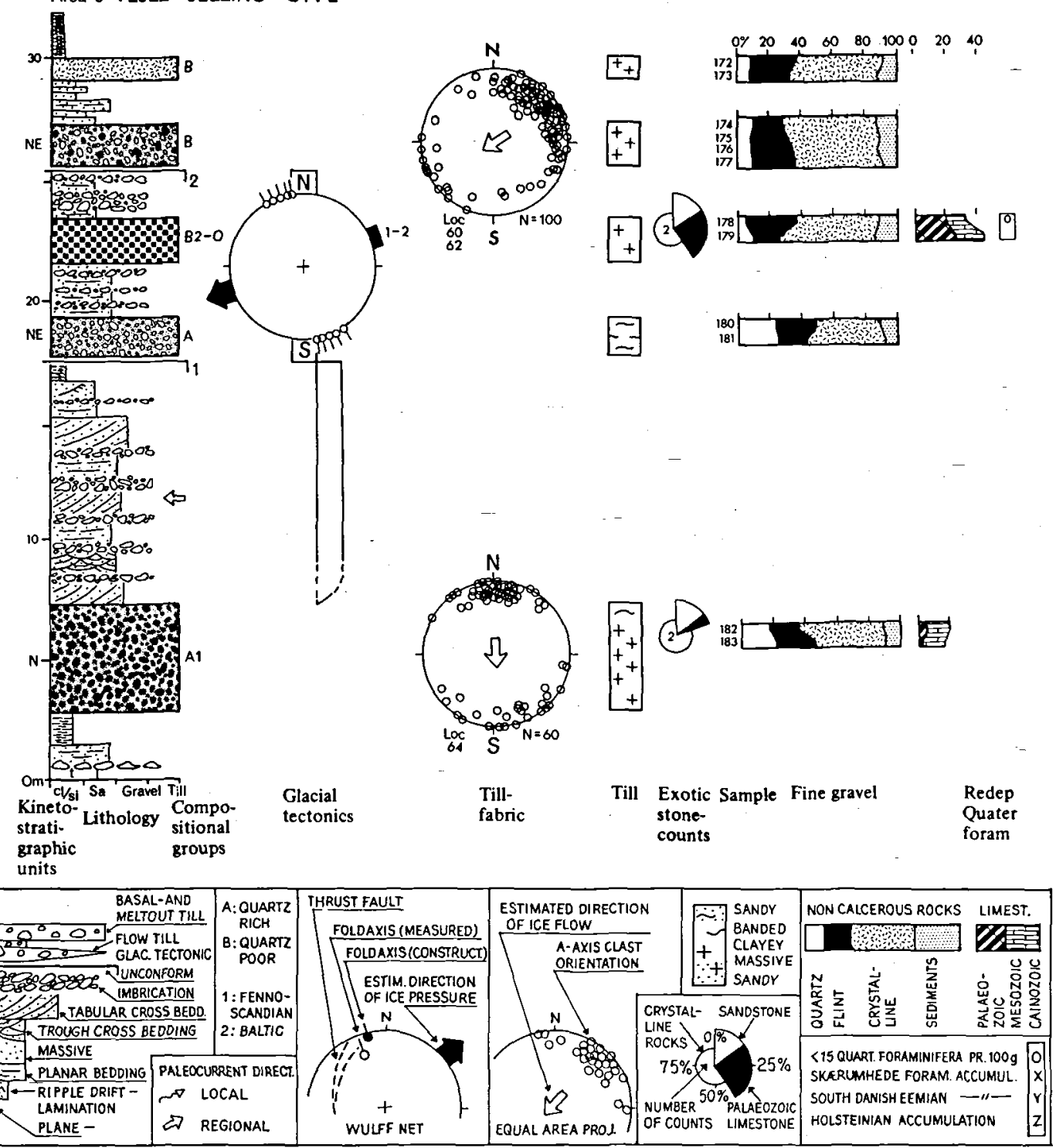

Fig. 64: Glacial stratigraphic data chart, area 6, Vejle -Jelling-Give. Till units shown in fig. 43. 
candian till containing equal amounts of quartz and flint with a fabric indicating ice movement from the north, $\mathrm{N}-(\mathrm{A} 1)$ : The Trelde Næs Till. The till overlies meltwater clay and sand, which is separated from the underlying Tertiary quartz sand by a distinct horizon of ventifacted gravel and boulders. The Trelde Næs Till is not found overlain by the younger Ashoved Till, however, this till seems to be present in the western part of the area (locs 57,61$)$ where it overlies a waterlaid sequence which has a tendency to fine upwards and was deposited by south-westward flowing palaeocurrents. The sequence has been subjected to glaciotectonic folding (loc. 57) from the northeast, and is unconformably overlain by a sandy to clayey, brown, banded, limestone free till. This till contains equal amounts of quartz and flint, and was presumably deposited by the ice sheet responsible for the dislocation of the underlying strata from the northeast, NE-(A): The Ashoved Till. According to the stratigraphic model and evidence from other areas (cf. area 5) the Ashoved Till is separated by waterlaid deposits from the overlying grey, clayey, massive, Baltic till. This till contains small amounts of quartz and hardly any re-deposited Quaternary foraminifera, (B2-0): The Lillebælt Till, which is present at locs 64 and 65 . This till and the overlying proximal outwash deposits have been subjected to glaciotectonic disturbances from north easterly directions (locs 60, 61, 64). The sequence is unconformably overlain by a brown, massive, clayey limestone free, quartz poor till (fig. 65) with fabrics indicating ice flow from the north east, and is found at locs 58, 59, 60, 62, 63, NE-(B): The Mid Danish Till.

The Mid Danish Till or glaciotectonic unconformities associated with the deposition of this till is, are at some localities in the west, covered by proximal outwash or laminated sandy and silty clay which was deposited in the ice dammed lakes north of Vejle (locs 63, 64) described by Nordmann (1958). At loc. 64: Grejsdal north of Vejle, the laminated clay is overlain by a brown, massive, quartz poor, limestone free till which is also present at loc. 65 . This till is supposed to be the East Jylland Till, however no lime bearing surface-till has been found in the area around the Grejsdal and west of Hedensted, thus the Baltic provenance of the till can not be demonstrated by stonecounts.

\section{DISCUSSION}

Unfortunately the lower part of the stratigraphic column can not be established from evidence of area 6 only. The presence of the Ashoved Till in the area is founded upon the quartz/flint relationship alone, thus being younger than the fining upwards sequence beneath the till (at loc. 57) and ascribing the glaciotectonic unconformity which indicates ice pressure from the NE, to the icesheet which deposited the Ashoved Till. It could be argued, that the Ashoved Till assumed to be present in the western part of the area is in fact a subfacies of the Mid Danish Till with an extreme enrichment in quartz content. This means, that the waterlaid sequence beneath the till could be considerably younger. However, if a consistent line of reasoning is to be maintained, tills with equal amounts of quartz and flint which are presumably deposited by an icesheet from the NE, must correspond to the Ashoved Till.

With regard to the East Jylland Ice border line, it is the opinion of the present author, that the arguments held by V.Milthers $(1925,1932,1948)$, K.Milthers (1942) and Nordmann $(1927,1958)$ in favour of extending this ice advance to the area north and west of Jelling have little validity. The area between the East Jylland Ice border and the Main Stationary Line is characterized by the indicator erratic association described from area 6 (Norwegian and Dala) and the strong imprint of

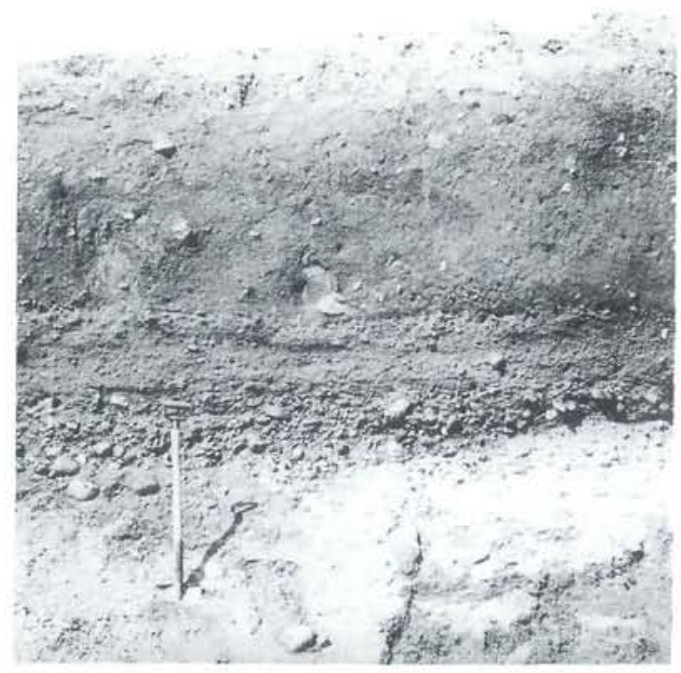

Fig. 65: Mid Danish Till overlying proximal outwash deposits, loc. 59. Grønbjerg. 
Baltic indicators, which characterized the hinterland of the East Jylland Ice border line between. Djursland and the Danish-German border is not demonstrated in the area west and north of Vejle. Moreover, V.Milthers' (1948, p. 134) definition of the East Jylland Ice border line in the area west of Vejle and Kolding as the dividing line between the two main morphological regions of Jylland will much better fit the definition of the Main Stationary Line.

Regarding the Scanian basalts dominating the surface erratics west of the ice border line, it will later be argued, that their presence is dependent upon the exposure of a Baltic (presumably the Lillebælt-) Till, and not, as argued by V.Milthers (1925), as a characteristic component of the icesheet which deposited the Dala-Baltic till during the maximum extension of the last glaciation.

It is therefore suggested, that the western limit of the East Jylland Icesheet is tentatively drawn immediately north and west of Vejle, thus constituting the eastern border of the ice damed lake deposits, which filled the Vejle $\AA$ valley, and the valleys on the plateau west of Grejsdalen.

\section{CONCLUSION}

The three Saalian tills: The Trelde Næs Till, the Ashoved Till, and the Lillebælt Till are present in the deeper lying glacial deposits of area 6 (fig. 105). The surface is dominated by the Mid Danish Till except for the eastern-most part, where the East Jylland Till presumably has its maximum extension east of the ice damed lakes north and west of Vejle. Sandur deposits from the retreat of the ice which reached the Main Stationary Line are present in the valleys between the ice-marginal hills in the western part of the area.

\subsection{AREA 7: RANDS-FREDERICIA-FANळ (locs 66-74, fig. 44) MORPHOLOGY AND LOCATION}

Area 7 is situated around the Fredericia peninsula and westernmost Fyn. The morphology of the area is characterized by an elevated till plane cut by two valleys, 1) The Elbo valley and 2) the most narrow part of the straights of Lillebælt.

Area 7 : RANDS - FREDERICIA - FANE
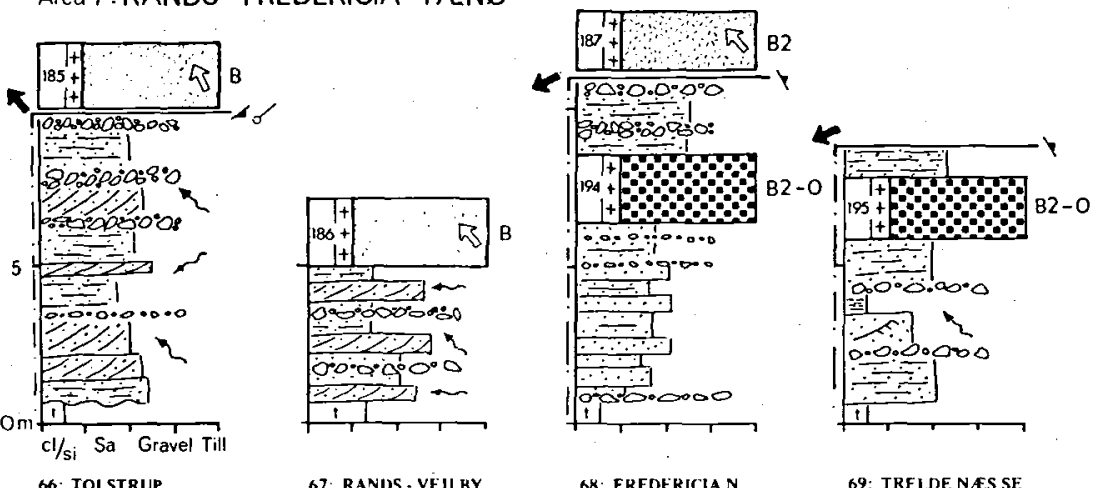

66: TOLSTRUP

67: RANIOS - VEJLHY

SX: FREDERICIA N

69: TRELDE NAS SE

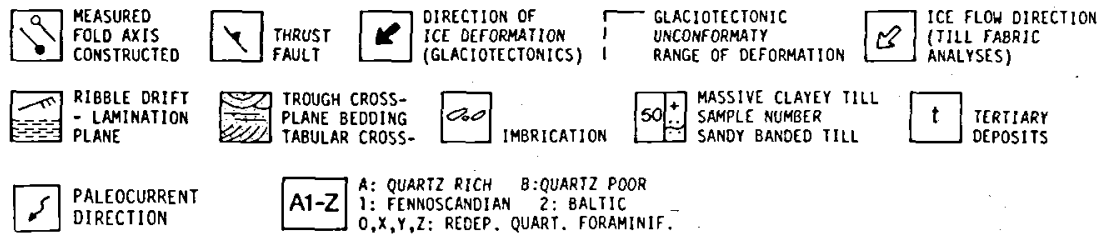

-Fig. 66: Simplified lithological logs, area 7, Rands -Fredericia-Fænø. 
The localities are situated inland in gravel pits and construction sites (locs 66, 67, 68) and along coastal cliffs of Lillebælt $(69,70,71,72,73,74)$. Area 7 also contains two principal localities, 1: Trelde Næs and 3: Røgle Klint.

\section{PREVIOUS INVESTIGATIONS}

V.Nordmann (1927) proposes, on morphological grounds, recessional lines from the East Jylland Ice-sheet that go along the E-W oriented so called Taulov moraine and the N-S oriented Røgle peninsula. Madsen et al. (1928) suggests, that the Taulov moraines mark the northernmost position of a glacier which has advanced through Lillebæit, and is ascribed to the (Lillebælt-) ice marginal stage E: the Bælt stage (fig. 3), which is an independent ice stream younger than the East Jylland Ice.
V.Milthers $(1932,1948)$ connects the Taulov line and the Røgle line across the Middelfart peninsula and further northwards over Trelde Næs to the recessional lines north of Vejle fjord. K.Milthers (1942) presents very few indicator counts from this area. One count in beach gravel on the SE coast of Trelde Næs, with aboūt equal amounts of the three indicator types (Norwegian, Dala, Baltic), is ascribed to the Dala-Baltic ice stream of the last glaciation. -Two counts from fields contain a pronounced domination of Baltic indicators and are ascribed to the Young Baltic phase of the last glaciation.

Nordmann (1958) describes the presence of interglacial fresh water diatomite in several places in the area (Rands Vejlby, Trelde, Fredericia and Vejle), but he gives no indication of the possible

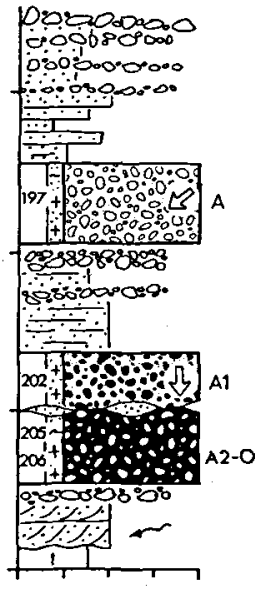

70: SONDERSKOV - SNOCHOS

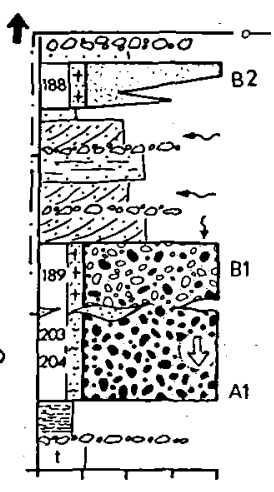

71: GALS KLINT

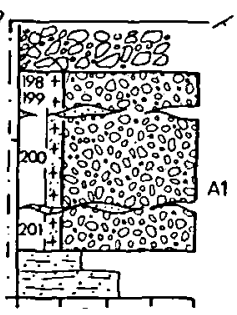

72: HINDSCAVLS
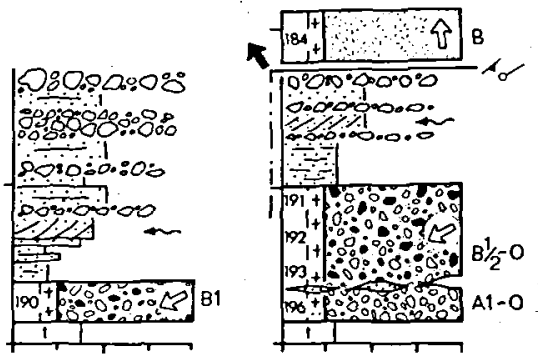

73: KONCEBROEN - MIDDELFART

74: FENO 
age of these deposits. S.Th. Andersen (1965) shows, on the basis of palynological analyses, that the diatomite of Rands Vejlby and possibly also the other neighbouring sites is of Holsteinian age. A floe of Marine Eemian clay is reported from the area of Strib NE of Middelfart (Nordmann 1958).

Referring to the stone counts presented by Madsen et al. (1928) and Madsen and Nordmann (1940), Nordmann (1958) questions the assumed stratigraphic position of the Tellina Clay of Røgle Klint, and with the same reference Nordmann opposed the publication of stone counts from the mapsheet: Fredericia (Nordmann 1958), even though he stated, that tills of different clast composition are present in the area.

\section{STRATIGRAPHY}

Lithological logs from the examined localities of area 7 are shown in fig. 66 and are correlated for the whole area in the glacial stratigraphic data chart (fig. 67). The principal localities Trelde Næs and Røgle Klint are not included but they will be considered later.

The oldest till of the area is separated from Tertiary sand by waterlaid outwash, deposited by south-westward moving palaeocurrents. It is a grey, sandy to clayey, massive and banded, Baltic till with about twice as much quartz as flint and it contains insignificant amounts of re-deposited Quaternary foraminifera. This till of A2-0 composition is in the whole of the region only observed at loc. 70: Snogh $\varnothing \mathrm{j}$, because of which it is named the Snoghøj Till.

The Snoghøj Till is overlain (loc. 70) by a massive and banded, grey; sandy, Fennoscandian till containing roughly equal amounts of quartz and flint with fabrics indicating ice flow from the north, N-(A1): The Trelde Næs Till. Waterlaid outwash (loc. 70) separates it from the overlying, brown, sandy, banded and massive, Fennoscandian till showing equal amounts of quartz and flint, hardly any re-deposited Quaternary foraminifera (locs 72,74) and with a fabric indicating ice movement from the northeast, NE-(A1-0): The Ashoved Till.

It can be deduced from the stratigraphy of the principal locality 3: Røgle Klint that the Ashoved
Till is in turn overlain by the Lillebælt Till, which is present as a grey, massive, clayey, quartz poor, Baltic till with insignificant amounts of re-deposited Quaternary foraminifera, (B2-0) at locs 68 and 69 , where it overlies mostly fine grained outwash, deposited by westward moving palaeocurrents.

The Lillebælt Till and the overlying proximal outwash deposits are thrusted by glaciotectonic deformation from the NE (locs 68,69 ) by an ice sheet, which most probably deposited the brown to grey, clayey, massive, quartz poor, Fennoscandian till (locs $71,73,74$ ) holding a few re-deposited Quaternary foraminifera and with fabrics (locs 73,74 ) indicating ice flow from the northeast, NE-(B2-0): The Mid Danish Till. It is overlain by sand and gravel, deposited by westward moving meltwater streams, which have undergone glaciotectonic deformation from the south and south-east. The sequence (fig. 68) is unconformably overlain by a brown, clayey, massive, quartz poor, Baltic till with fabrics indicating ice flow from the south (loc. 74) and the south-east (locs 66, 68), SSE-(B2): The East Jylland Till. A flow-till subunit of this till has also been subjected to the glaciotectonic deformations from southerly directions (loc. 71).

\section{DISCUSSION}

The present investigation has not been able to confirm the existence or the course of the ice border lines drawn on morphological grounds by V.Milthers and Nordmann. The Røgle peninsula and Trelde Næs do not appear as a young ice marginal zone, in fact, it is highly probable, that the dislocation from north-easterly directions in these coastal cliffs is connected with advancive or readvancive stages of the ice sheet, which deposited the Mid Danish Till. Judging from topographic features, the whole of the area does not seem to present any young ice marginal features (except perhaps for a few $\mathrm{km}$ of the Taulov ridge), on the contrary, the morphology can be characterized as a very gentle or flat till plain disected by pronounced valleys the deepest of which have been transgressed by the sea; Lillebælt.

On the basis of stratigraphic position and clast petrographic content the Snoghøj till is conside- 

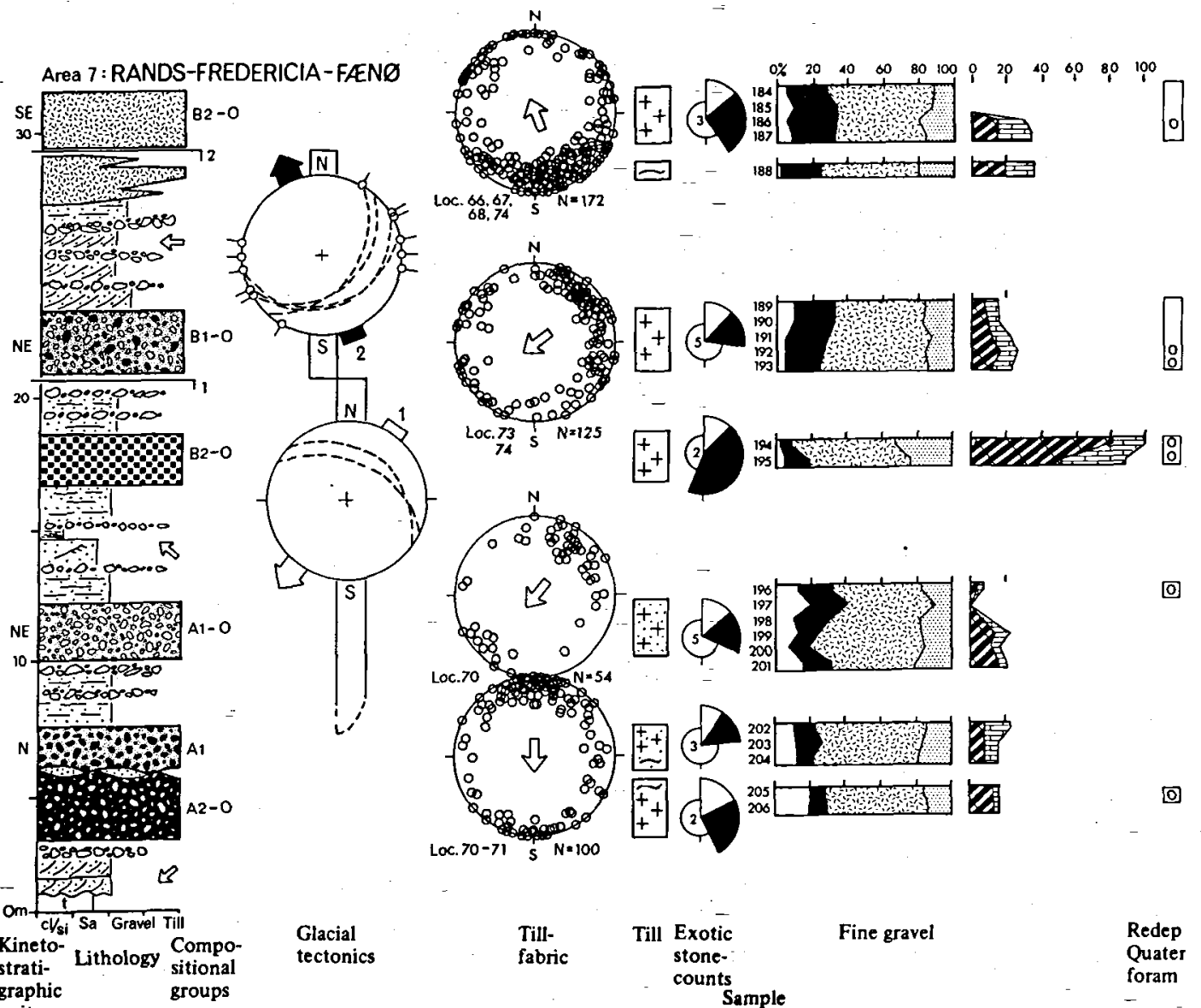

Loc. $66,67^{6,58} \mathrm{~S}, \mathrm{~N}=172$

(1)
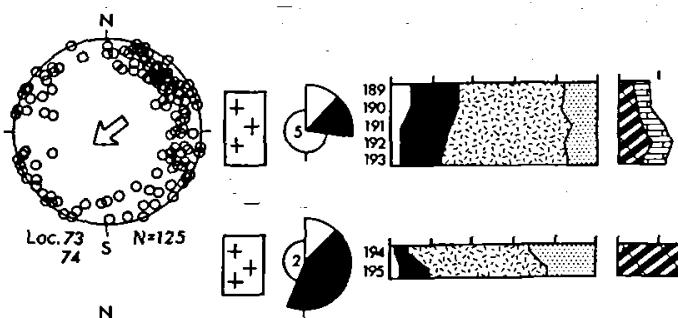

0

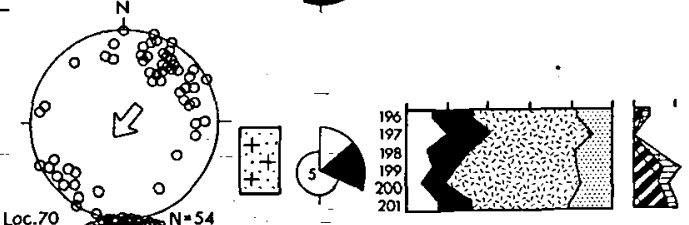

路1
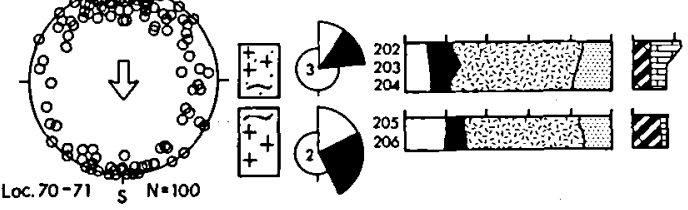

0 units

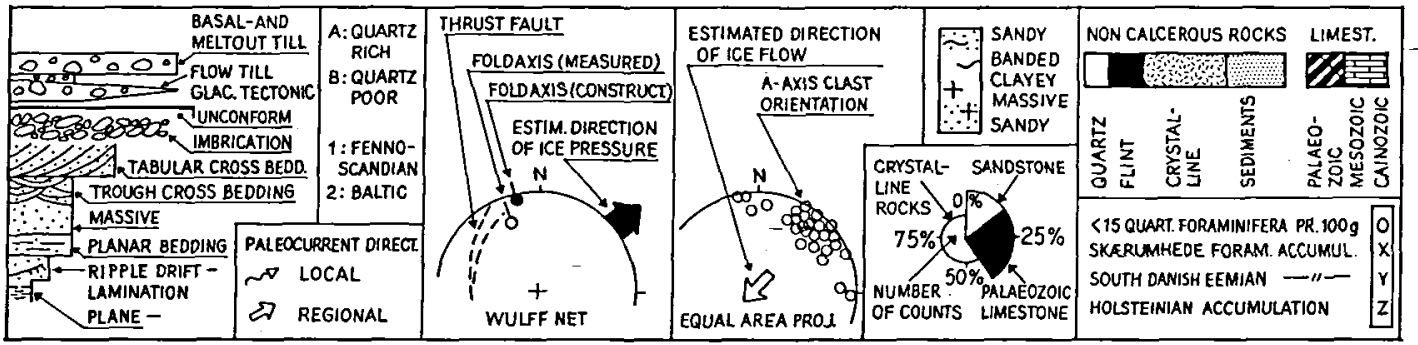

Fig. 67: Glacial stratigraphic data chart, area 7, Rands -Fredericia-Fænø. Till units shown in fig. 43. 
red to be of pre-Saalian age most probably Elsterian, but the Baltic provenance prevents it from being correlated with the other two assumed Elsterian tills (Palsgård till and Sønder Vissing till). Even though the stratigraphic position of the three tills is unknown, it is proposed, that they represent Elsterian tills of much wider distribution deposited by a Norwegian advance, a NE advance and a Baltic advance respectively, and possibly in this order of appearance.

\section{CONCLUSION}

When data from the principal localities 1: Trelde Næs and 3: Røgle Klint is included, 6 till units have been identified (fig. 105). These till units are not only separated by outwash, deposited by generally westward moving meltwater streams; but also by interglacial and/or interstadial deposits.

A Baltic, probably Elsterian till (the Snoghøj Till) is separated by outwash material and Holsteinian lake deposits from the overlying, Saalian, Trelde Næs Till deposited from the north. This is succeeded by an ice advance from the northeast, which deposited the Ashoved Till. The deposition of the Lillebælt till marks the final ice advance of the Saalian and the till is separated from the Weichselian Mid Danish Till by outwash deposits containing re-deposited marine molluscan fragments of Eemian derivation and glaciotectonic unconformities indicating ice deformation from the NE. The Mid Danish Till is overlain by the East Jylland Till which was deposited by an ice stream from the south-south-east.

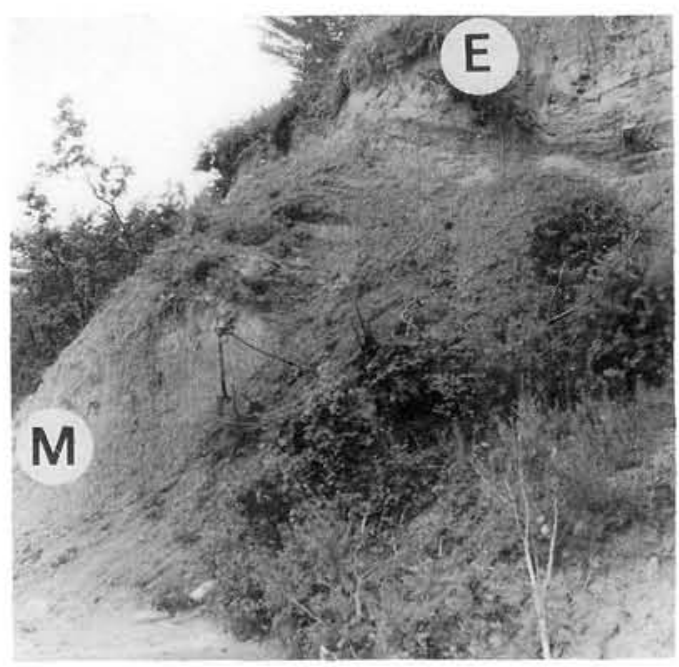

Fig. 68: Mid Danish Till (M) overlain by outwash deposits unconformably overlain by the East Jylland Till (E), loc. 74, Fænø.

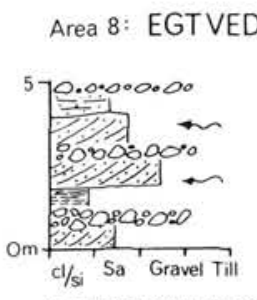

\section{VEJLE}

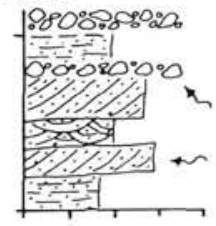

75: KRAGELUND V. BEKKE

76: VERST

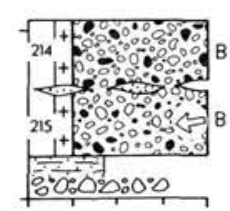

77: EGTVED

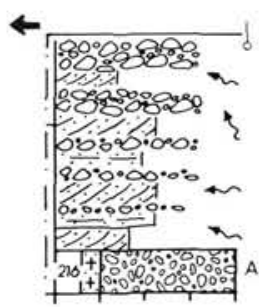

78: BOLLING SKANSE

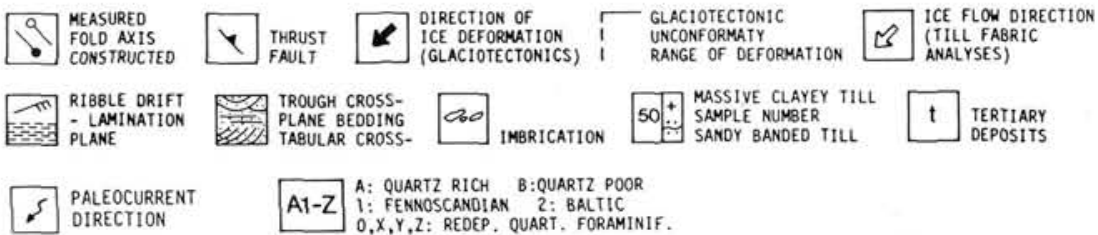

Fig. 69: Simplified lithological logs, area 8, Egtved-Vejle. 
5.8 AREA 8: EGTVED-VEJLE (locs 75-86, fig. 44). MORPHOLOGY AND LOCATION

Area 8 is situated southwest of Vejle, north of Kolding $\AA$-valley and east of the Main Stationary Line. Localities are gravel pits placed in valley sandur deposits (locs 75,76 ), in ice marginal hills (locs $77,78,86$ ) or in the more gentle country (locs $79,80,81,82,83,84,85$ ) disected by the Vejle $\AA$ valley and the Egtved-Kolding valley.

\section{PREVIOUS INVESTIGATIONS}

Nordmann $(1927,1958)$ describes the ice marginal hills south-west of Vejle, and connects this presumed recessional stage of the East Jylland ice sheet with the marginal lines east of the ice damed lake deposits at Vejle.

V.Milthers (1925, 1932, 1948) and K.Milthers (1942) suggest, that the north-south trending ice marginal line- through Egtved, separating the area into the two main morphological regions of Jylland (see also area 6); divides an older part characterized by numerous Scanian basalts in the mated to be the continuation of the East Jylland Ice border going from Hedensted north and west of Vejle and Jelling southward through Egtved to a position west of Lunderskov. Except for a few places where an apparently lower; Baltic till is present, the surface till can according to V.Milthers' (1925) stone counts be characterized as Fennoscandian in clast composition.

\section{STRATIGRAPHY}

Symbolic logs of each locality of the area are shown in fig. 69 and a correlation for the area based on the stratigraphic model is presented in the data chart (fig. 70). The oldest till of area 8 is a brown, sandy, massive, limestone free till with equal amounts of quartz and flint, which is equivalent to the Ashoved Till (loc. 78). It is overlain by proximal outwash material, deposited by westward moving meltwater streams. This sequence is dislocated from easterly directions (loc. 78) and overlain (locs $77,79,80,81,82$ ) by a brown to grey, clayey, quartz poor, Fennoscandian till also

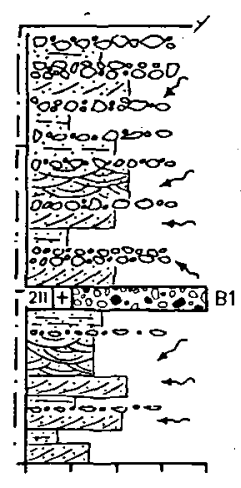

79, 80: ODSTED - VINGSTED

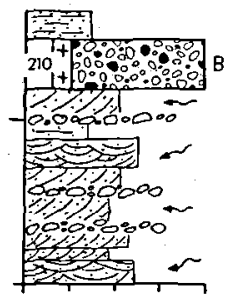

81: NR. VILSTRUP

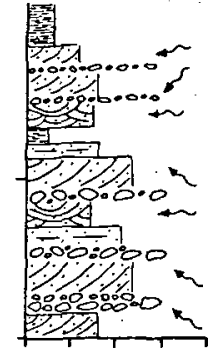

82. 83: VIUF - V. NEBEL

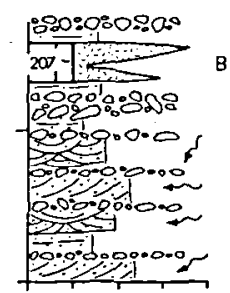

84, 85: LILBALLE - ALMIND

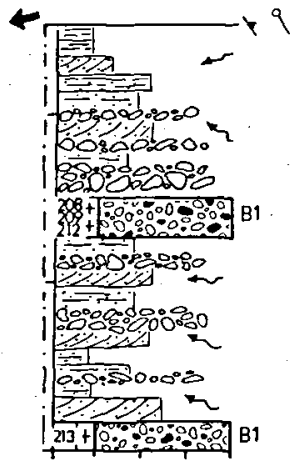

86: HOJEN surface deposits towards the west, and a younger part characterized by an indicator association dominated by Norwegian and Dala rocks and little Baltic material towards the east. This dividing line is presented (V.Milthers 1925) as the younger among several recessional stages from the Main Stationary Line, and the line is esti- present at loc. 86 and with fabric indicating ice flow from and east-north-easterly direction, ENE-(B1): The Mid Danish Till. This till is divisible into two subunits separated by proximal outwash which shows westward directed palaeocurrents (loc. 86). The upper subunit of the Mid Danish Till is overlain by outwash material with a 


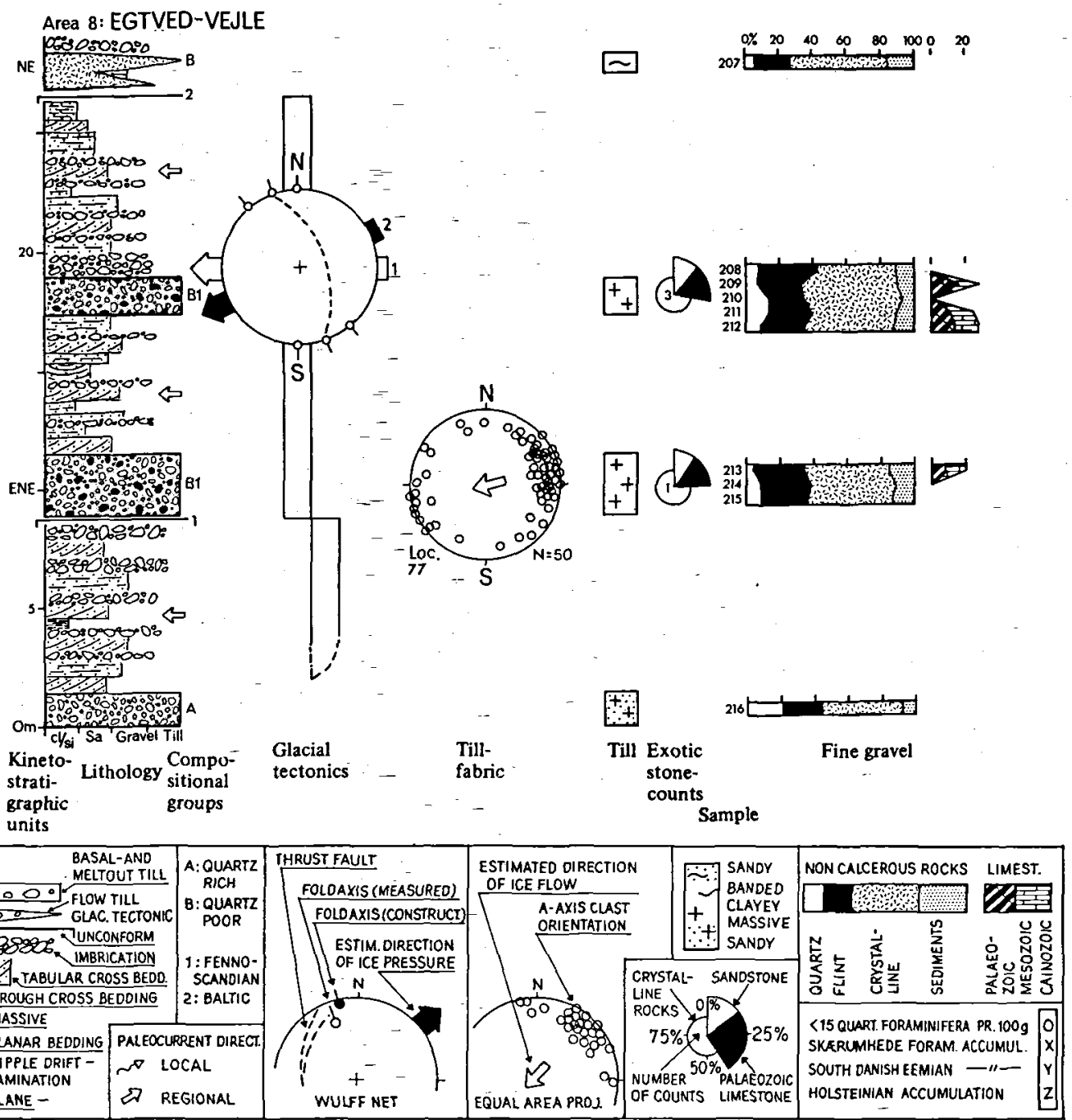

Fig. 70: Glacial stratigraphic data chart, area 8, Egtved -Vejle. Till units shown in fig. 43.

tendency to fine upwards (loc. 86). This is also present at locs $79,80,82,83,84,85$ where it was deposited by westward moving meltwater streams. The sequence has suffered glaciotectonic folding and thrusting from east-north-easterly directions and is overlain by limestone free flow till deposits (loc. 85). These deposits contain Baltic indicators and other rock fragments of Baltic derivation which suggests correlation with the East Jylland Till.

\section{DISCUSSION}

Referring to the description of area 6, it is highly improbable, that the north-south lying recessional ice border through Egtved was formed by the East Jylland ice stream. The indicator counts presented by V.Milthers $(1925,1932)$ and K. Milthers (1942) and Berthelsen (1949) indicate, that the surface deposits of the area covered by the till of the East Jylland Icesheet are characterized by considerable quantities of Baltic indica- 
tors, much more than were found in the area behind the division line described by V.Milthers (1925) and Nordmann (1927). Only the coastal areas east of Hedensted, Vejle and Kolding have a Baltic indicator content as high as the area to the east of the East Jylland Iceborder line around Århus and Horsens.

It is therefore suggested, that the East Jylland Ice border line should be extended southwards from a position between Vejle and the ice damed lake deposits west of the city, through the ice marginal hills at Højen (loc. 86), where the lower and the upper subunits of the Mid Danish Till are dislocated from the ENE, towards the area immediately west of Kolding.

Unfortunately it has not been possible to outline the position of the Main Stationary Line in the area. It is assumed, however, that it could be placed somewhere between locs 75, 76 (east of Bække) and west of loc. 72 (Egtved), because, as shall be argued later, it is the opinion of the present author that the occurrence of the Scanian basalts in the area is not connected with the ice sheet which reached the Main Stationary Line, but is probably associated with an older Baltic ice stream from easterly directions.

\section{CONCLUSION}

Three till units have been identified in area 8 (fig. 96). The oldest is presumably the Ashoved Till overlain by outwash, deposited by westward flowing meltwater streams emerging from the ice sheet, which reached the Main Stationary Line and deposited the Mid Danish Till. A readvance of the ice sheet which deposited the Mid Danish Till reached the area slightly west of Vejle depositing the upper subunit of the Mid Danish Till. Meltwater deposits which overlie the Mid Danish Till, and show westward directed palaeocurrent patterns have also been subjected to the stacking of thrust slices by the East Jylland Icesheet forming the ice marginal hills south of Vejle.
5.9 AREA 9: LUNDERSKOV-KOLDINGHEJLS (locs 87-97, fig. 44). MORPHOLOGY AND LOCATION

The localities in area 9 are situated in the country around Kolding $\AA$ valley, its eastern continuation in the Kolding Fjord, and the coastal areas around the ice marginal hills of Skamlingsbanken. The landscape is dominated by the pronounced valleys around Kolding and Hejlsminde, cutting through a rather smooth till plain upon which several ice marginal ridges are present.

\section{PREVIOUS INVESTIGATIONS}

V.Milthers (1925) extends the ice border lines described in connection with area 8 southward. Milthers suggests that the area between Brørup and west of Lunderskov, which is characterized by the presence of Scanian basalts, has a till cover deposited during the maximum extension of the last glaciation. It is also suggested that the area towards the east which is characterized by a DalaBaltic indicator association with strong mixing of older Norwegian material, is covered with till material belonging to the East Jylland Ice advance.

Jessen et al. (1918) suggests, on the basis of genetic classification of the covering material, that some of the Eemian kettle bogs of Brørup are overlain by till. Strongly supported by V.Milthers' (1925) view on the presence of the Scanian basalt indicators, it is suggested, that the maximum extension of the Weichselian ice sheet runs in a N-S direction through Brørup.

Apart from the Scanian basalts, indicator counts and stone counts (V.Milthers 1925) show, that the area east of Brørup is characterized by a Baltic till underlying the Eemian kettle bogs described by Hartz (1909), Milthers (1925) and Jessen and Milthers (1928). According to Nordmann (1958) Eemian peat bogs and their Baltic substratum have been recognized in the area around Kolding, where they are covered by till or other glacigenetic material and often disturbed by glaciotectonic activity. In the area between Lunderskov and Kolding K.Milthers' counts from outwash gravels overlying the Eemian bogs are dominated by Dala rocks which are ascribed to the melting of the Dala-Baltic ice stream. Further 
eastwards the coastal areas are presumably covered by till material deposited by the Young Baltic, Lillebælt glacier.

Jessen (1935) indicates that the surface till of the southern part of area 9 is characterized by a Baltic clast composition. However, this till can not be distinguished on the basis of stone counts or indicator studies from the lower till of the area, but apparently only the upper till contains re-deposited molluscan fragments of marine Eemian derivation. The north-western part of the area is suggested (Jessen 1935) to be characterized by more Norwegian influenced indicator associations.

\section{STRATIGRAPHY}

Lithological columns of individual localities are shown in fig. 71 and units are presented and correlated for the whole area in the glacial stratigraphic data chart (fig. 72).

The oldest till in the area (locs 93, 97) overlying sandy outwash deposits (loc. 93) is a brown, sandy, massive, Fennoscandian till with small quantities of re-deposited Quaternary foraminifera. It has equal amounts of quartz and flint and shows a fabric (loc. 93) indicating ice movement from the north-east, NE-(A1-0): The Ashoved Till. Fine grained outwash separates it from the overlying grey, clayey, generally massive, quartz

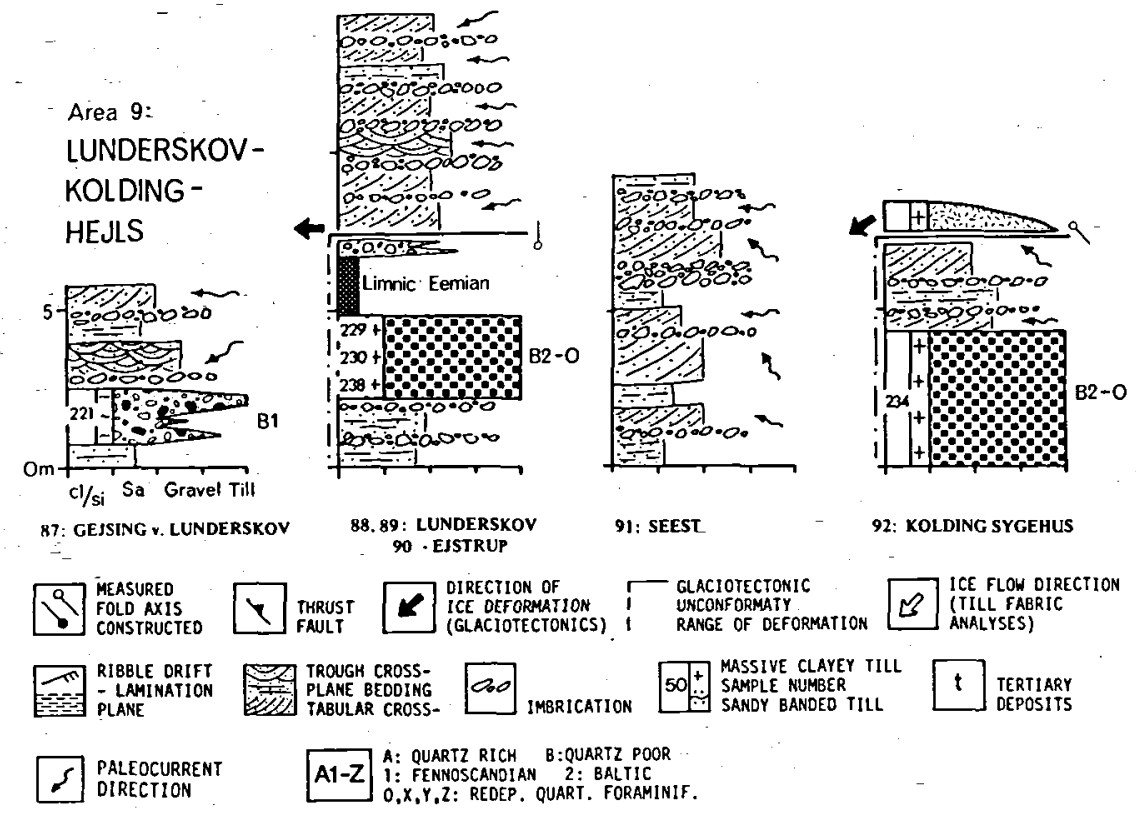

Fig. 71: Simplified lithological logs, area 9, Lunderskov -Kolding-Hejls. 
poor, Baltic till (locs $88,89,90,93,95,96,97$ ). This till is sporadically very rich in Cretaceous/ Tertiary limestone (fig. 73) and generally it shows insignificant quantities of re-deposited Quaternary foraminifera or seldom a Z-accumulation and with fabrics indicating ice movement from easterly directions, E-(B2-0Z): The Lillebælt Till.

The Lillebælt Till is overlain by limnic gyttja and peat deposited in a lake basin at Ejstrup (loc. 90, fig. 26). Samples with a pollen assemblage corresponding to the Eemian zone 4 (S.Th.Andersen 1965) were thermoluminiscence dated (J.Nr. 829027, RIS $\varnothing$ ), and gave an age of 93100 TL years (Kronborg 1983). The limnic deposits, that are covered by solifluction material, and the underlying till have been folded by glaciotectonic deformation from easterly directions. At other localities (locs 95, 96) the Lillebælt Till is overlain by a brown to grey, massive and banded, clayey, quartz poor, Fennoscandian till (also present at loc. 87) occasionally holding a Z/Y-foraminiferal accumulation and with fabric indicating ice flow from the northeast; NE-(B1-ZY): The Mid Danish Till. This is overlain by an outwash sequence, with a tendency to fine upwards, deposited by westward moving meltwater streams. This sequence have undergone glaciotectonic deformation from the north-east and is overlain by a brown, clayey, occasionally limestone free, quartz poor, Baltic till containing a Y-foraminifera accumulation and with fabrics indicating ice flow from the south-east; SE-(B2-Y): The East Jylland Till. This till is overlain by proximal outwash deposits in the eastern part of the area.

\section{DISCUSSION}

The arguments held by V.Milthers (1925) regarding the maximum extension of the ice sheet which reached the Main Stationary Line were opposed by Andersen (1945) who stated, that the Scanian basalts were transported to the area by a Baltic ice stream and that the Dala-Baltic icestream established by V. and K.Milthers never could have existed. It was, however, not until Hansen (1978) published the results of half a centurys work in southern Jylland, that the most westerly maximum extension of the Weichselian ice cover presented by Jessen et al. (1918), V.Milthers (1925) and $\emptyset$ dum (1927) was refuted. Hansen pointed out that 1), the Weichselian cover of the Eemian

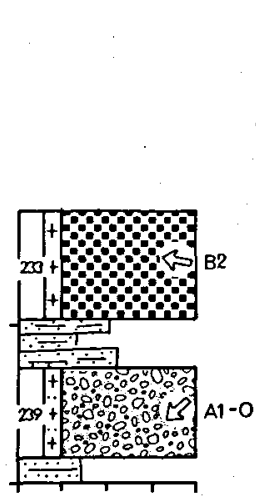

93: ELVG HOJ. NR. BJERT

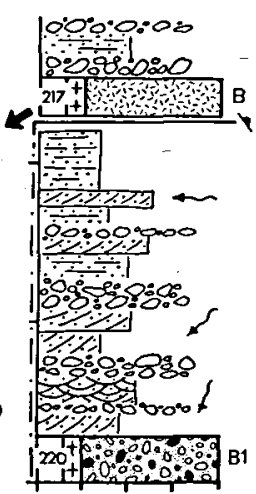

94: GRONNINCHOVED

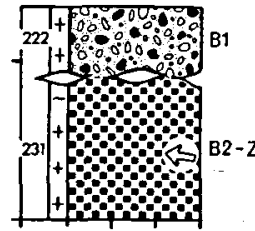

95: MOSEHUSE

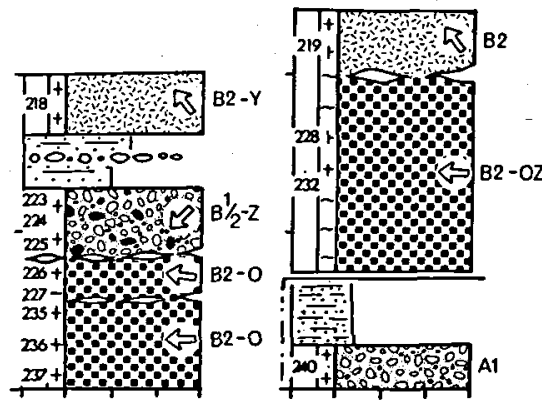

96: KALVEHOJ. HEJLS 97: GRAVENS HOVED 
Area 9: LUNDERSKOV-KOLDING-HEJLS

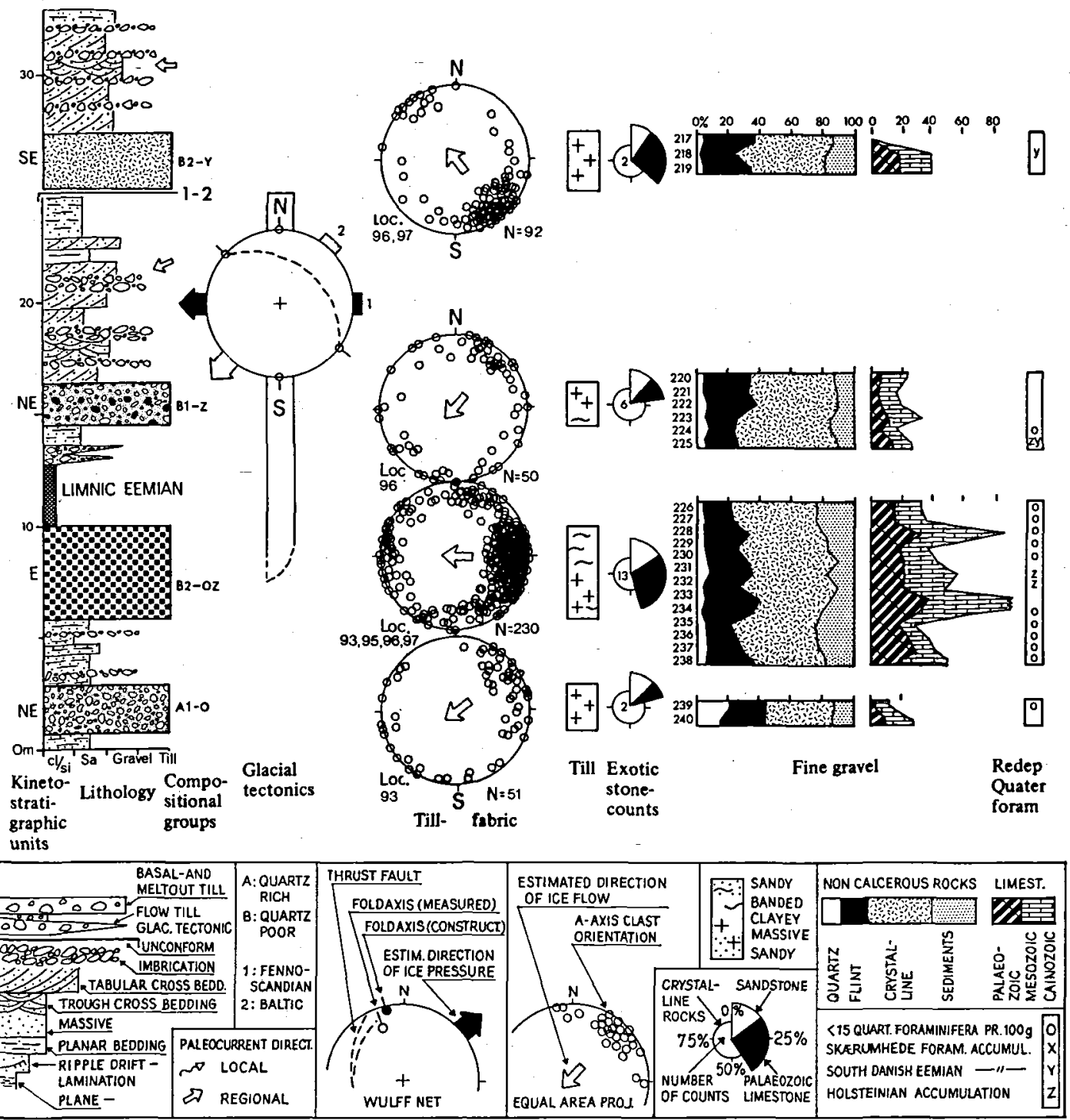

Fig. 72: Glacial stratigraphic data chart, area 9, Lunderskov-Kolding-Hejls. Till units shown in fig. 43. 
peatbogs west of Jels and Vejen is solifluction material and not till, that 2) on morphological grounds the maximum extension of the Weichselian ice cover follows the course of the line dividing Jylland into the two major regions as described by Ussing $(1903,1907)$ respectively east and west of a line through Jels and Vejen, and that 3), the presence of Scanian basalts in the area could hardly be proved to have any relation to the Main Weichselian icesheet. In this connection Hansen referred to indicator counts rich in Scanian basalts (but not as rich as the counts from the Brørup area) published by K.Milthers (1942) from Emmerlev Klev on the west coast of Jylland immediately north of the Danish-German border, where a Baltic till is overlain by undisturbed limnic Eemian deposits.

Gormsen and Hansen (1980) take a standpoint between the classical one and that presented by S.Hansen (1978) by suggesting, that the cover material of the Eemian bogs has been deposited by ice surging from the Main Stationary Line towards the west, although the authors state, that the covering material can not be strictly characterized as either till or solifluction material.

The upper part of the outwash deposited in the Kolding $\AA$ valley and the sandy deposits described from the ice damed lake deposits west of Kolding (Nordmann 1958) were probably deposited in connection with the deglaciation of the icesheet, which deposited the East Jylland Till.

\section{CONCLUSION}

The examined localities of area 9 contain 4 tills interbedded by outwash material, deposited by generally westward flowing meltwater streams (fig. 105). The two older tills are separated from the two younger by limnic, Eemian deposits.

The oldest till is the Ashoved till deposited by an ice sheet from the NE, this is overlain by the Lillebælt Till deposited by a Baltic ice sheet from easterly directions and covered by Eemian peat bogs. The Weichselian tills comprise the Mid Danish Till deposited by an ice sheet from the NE, which probably found its maximum extension along the line proposed by S.Hansen (1978) similar to the line sketched by Ussing (1907). A recessional advance from the NE disturbed the outwash deposits overlying the Mid Danish Till in coastal areas.

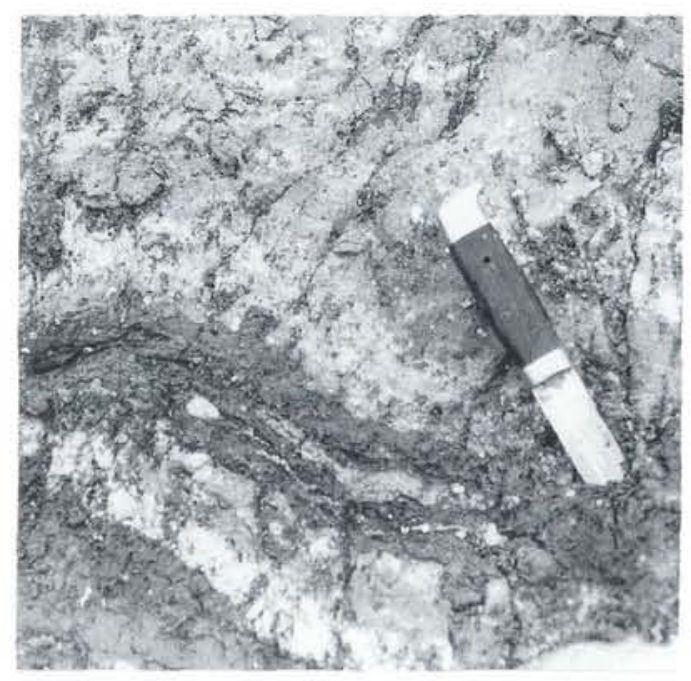

Fig. 73: Incorporated chalk bands and chalk clasts, Lillebalt Till, Joc. 97, Gravenshoved.

The East Jylland Till was deposited by an icesheet from the southeast, which has been found in the coastal parts of the area. On the basis of stonecounts, indicator erratic studies, topographic features and published geological maps, it is suggested that the East Jylland ice border line should be estended from area 8 taking a southerly corse across the Kolding $\AA$ valley immediately east of the ice damed lake deposits described by Nordmann (1958). From here it should be extended southward crossing the late glacial lake basin southwest of Vonsild, to a position at the vertex of the valley sandur at $\varnothing$ dis east of Vamdrup.

\subsection{AREA 10: WESTERN SOUTH-EAST JYLLAND (locs 98-106, fig. 44)}

Area 10 is situated between the Main Stationary Line and the East Jylland Ice border in a north-south trending strip of land between Ødis-Vamdrup and the area south of Vojens. The landscape is characterized by valley sandurs and sandur plains in the west and by the western heads of the valleys typical of eastern Jylland. The localities are all gravel pits, except for loc. 106 which is a motorway construction site. 


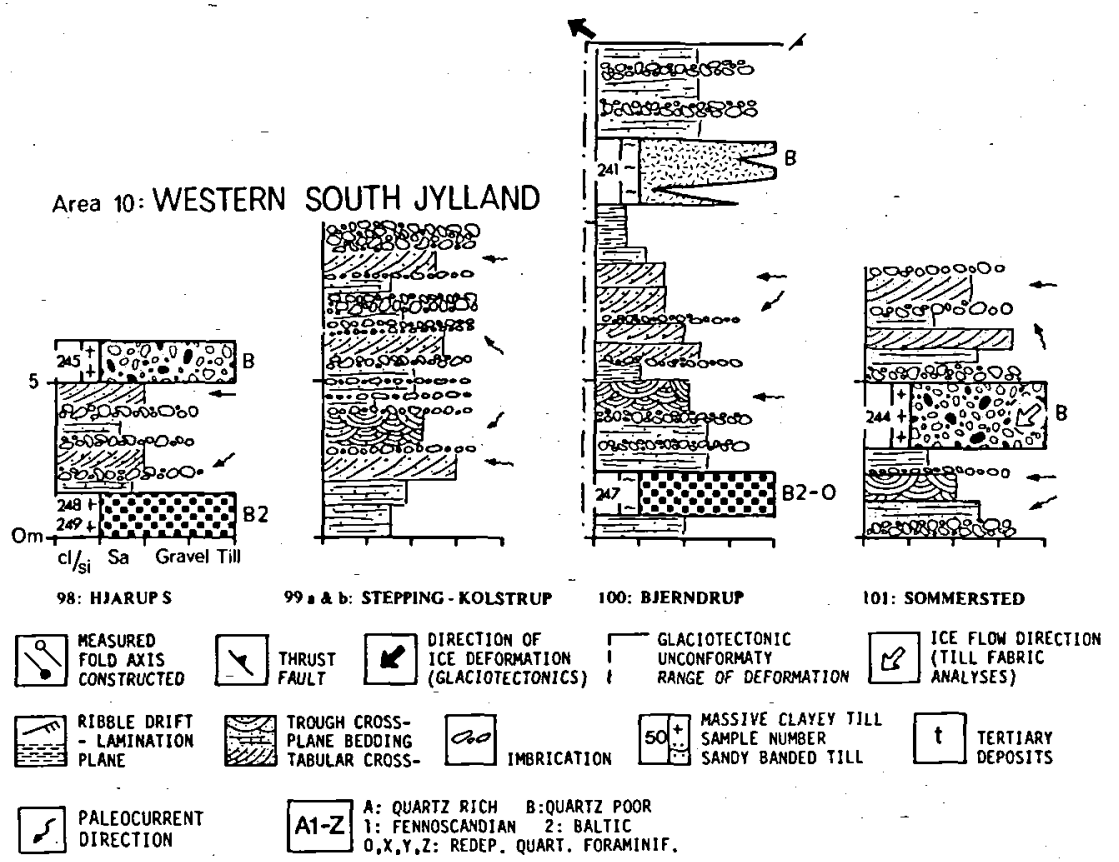

Fig. 74: Simplified lithological logs, area 10, Westem South Jylland.

STRATIGRAPHY (fig. 74, 75)

The oldest till of the area is a grey, massive, clayey, quartz poor, Baltic till with insignificant amounts of re-deposited Quaternary foraminifera, (B2-0): The Lillebælt Till. It is separated by outwash material, with a tendency to fine upwards deposited by westward moving meltwater streams, from the overlying brown to grey, clayey, massive, quartz poor, Fennoscandian till (locs 98, 101, 103, 106). This till contains negligable re-deposited Quaternary foraminifera and fabrics (locs 101, 103) indicates ice flow from the northeast; NE-(B1-0): The Mid Danish Till. It is overlain by a waterlaid sequence, coarsening upwards at locs 99 and 106, deposited by westward flowing meltwater streams. This sequence is overlain by a brown, mostly banded, clayey, quartz poor, Baltic till deposited as flowtill (B2): The East Jylland Till. It is occasionally overlain by proximal outwash material and has undergone glaciotectonic deformation from the south-east and east-north-east.

\section{DISCUSSION AND CONCLUSION}

Three till units interbedded with outwash material has been found in area 10 (fig. 105). The fining upwards sequence overlying the Lillebalt Till is correlated with similar outwash of identical stratigraphic position in area 11 , where it is assumed to have been washed out from the ice sheet which deposited the Ristinge Klint Till. It is overlain by the Mid Danish Till, deposited by an ice sheet from the north-east, which is supposed to have had its maximum extension along the Main Stationary Line indicated by S.Hansen (1978) and discussed under the previous area (9). Between the deglaciation of this icesheet and the advance of the East Jylland Ice sheet waterlaid material was deposited on the sandur flats west of Vojens. Meltwater emerging from the advancing East Jylland Ice cap followed the same course, and the resulting deposits were dislocated by ice pressure from the south-east and east-north-east in the eastern parts of the area, where the East Jylland Ice border is proposed to lie on a northsouth trending line from Poth $\varnothing \mathrm{j}$ by Vedsted (loc. 106) east of Styding (loc. 103) through Bjerndrup (loc. 100) northward to Ødis. 


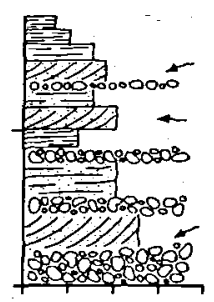

102: TINGVAD

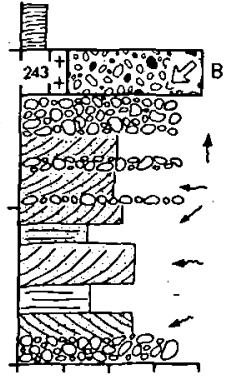

103: STYDING

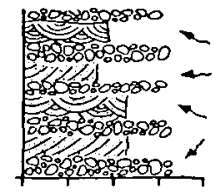

104: VOJENS - SKRYDSTRUP

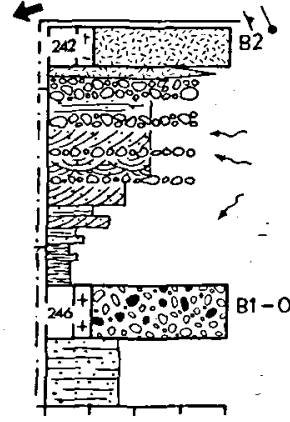

106: VEDSTED MOTORVEJ -
Area 10: WESTERN SOUTH JYLLAND

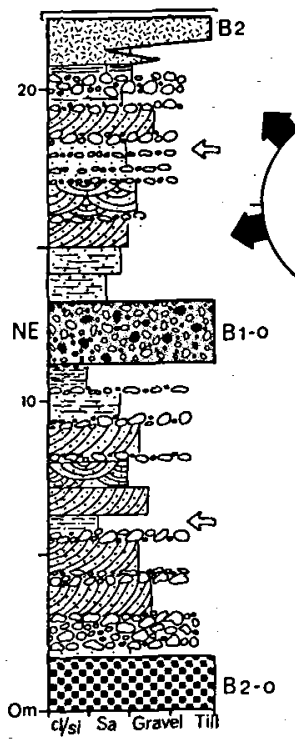

$\begin{array}{ll}\text { Kineto- } & \text { Compo- } \\ \text { strati- } & \text { Lithology } \\ \text { graphic } & \text { groups }\end{array}$

Glacial
tectonics
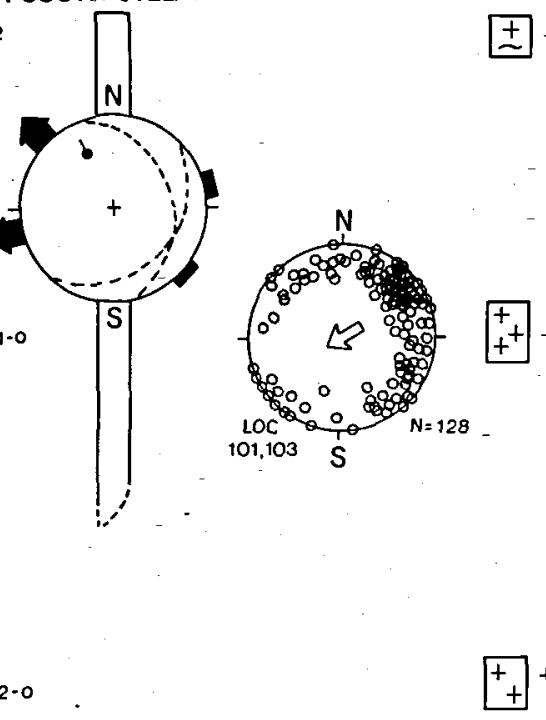

Tilt-

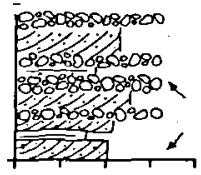

105: OVERJERSTAL E
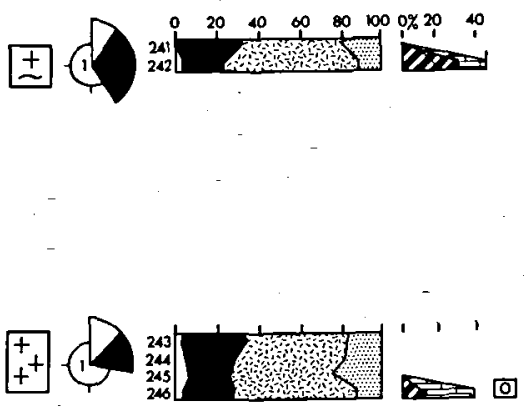

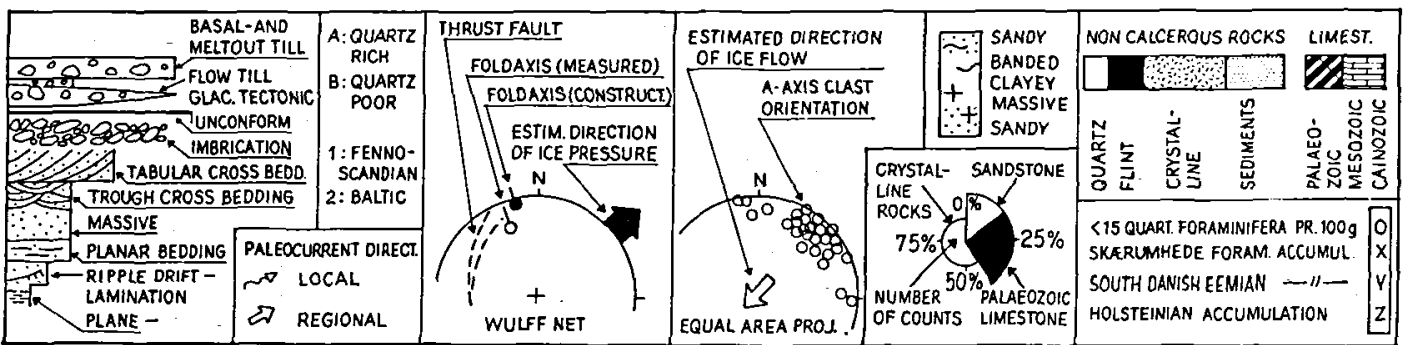

Fig. 75: Glacial stratigraphic data chart, area 10, Western South Jylland. Till units shown in fig. 43. 


\subsection{AREA 11: EASTERN SOUTH JYLLAND (locs 107-115, fig. 44)}

Area 11 comprises the country between Christiansfeld, Haderslev, the coast land to the east and southeast, and the islands of $\AA$ Ar $\varnothing$ and Bars $\varnothing$. The landscape is dominated by valleys through Haderslev and Hoptrup and several ice marginal hills lying on a relatively smooth till covered surface. Localities are placed inland in gravel pits and construction sites (locs 107, 108, 109, 110) and at coastal cliffs by the Lillebælt coast (locs $111,112,113,114,115)$. The area also contains the principal locality 5: Søndervilstrup Strand.

\section{PREVIOUS INVESTIGATIONS}

Jessen (1930) identified three tills interbedded with waterlaid material, on the basis of the contents of Palaeozoic limestone at the coastal cliff of Halk Hoved (loc. 112). A lower Baltic till is unconformably overlain by a Fennoscandian till, at the base of which a glaciotectonic unconformity indicates ice deformation from the northeast. The Upper till is limestone free at the locality in question, however, it is correlated with the youngest till in the area (Jessen 1935) which is of Baltic clast composition and characterized by re-deposited molluscan fragments of marine Eemian derivation from the western Baltic region.

Jessen (1935) correlated the lower Baltic- and the Middle Fennoscandian till of Halk Hoved with the two Weichselian, Baltic- and Fennoscandian tills of Ristinge Klint both of which are interbedded by meltwater deposits. Among other localities S.A.Andersen $(1933,1945)$ uses the till stratigraphy and glaciotectonic setting of Halk Hoved to illustrate the chronology of ice streams during the Weichselian. Andersen indicates, that the Old Baltic ice stream deposited the lower Baltic till, the NE ice deposited the Fennoscandian, middle till and reached the Main Stationary Line, and the Young Baltic ice advance deposited the upper, Baltic till.

K.Milthers (1942) suggests, that the subsurface deposits of the area are dominated by rocks of the Dala-Baltic ice stream with some incorporation of older Norwegian material and overlain by till dominated by Baltic indicators at the surface.

Frederiksen $(1975,1976)$ recently studied the localities called $111,112,113$ in this investigation among other sites along the coast of Lillebælt and concluded, that three tills interbedded with outwash material are present in the area. A lower, Baltic till, containing a Z-foraminiferal accumu-

Area 11: EASTERN SOUTH JYLLAND

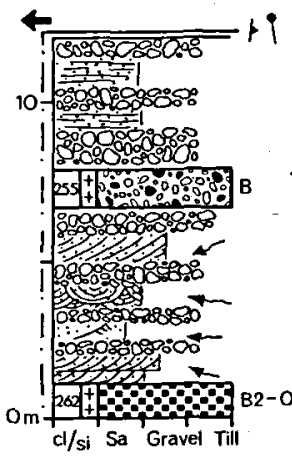

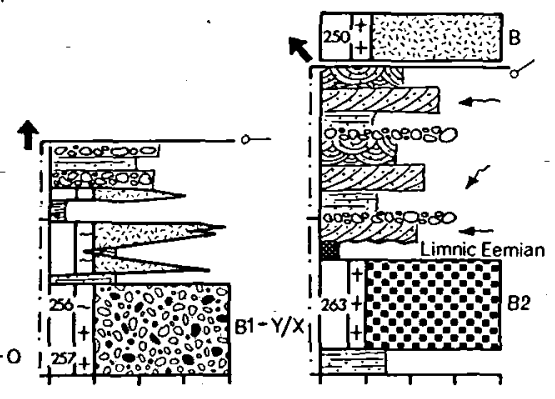

107: CHRISTIANSFELD
108: HJERNDRUP

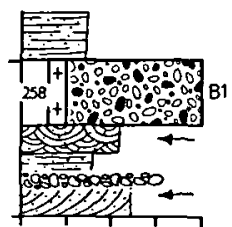

110: HADERSLEV

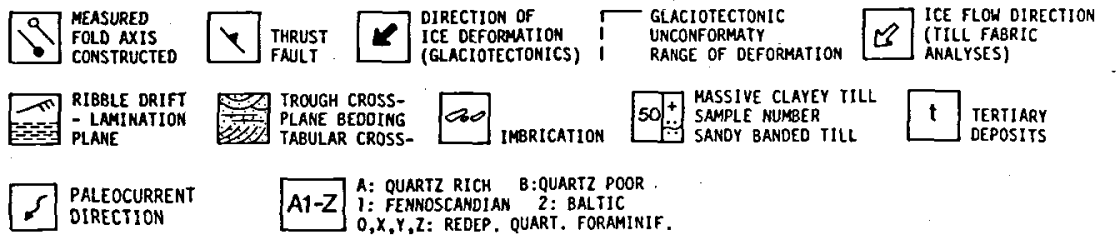

Fig. 76: Simplified lithological logs, area 11, Eastern South Jylland. 
lation and with fabrics indicating ice flow from easterly directions, is estimated to be of late Saalian age. The middle Fennoscandian till containing an X-foraminiferal assemblage and with fabrics indicating ice flow from the NE is assumed to be deposited by the ice sheet, which reached the Main Stationary Line, and the upper, Baltic till containing a Y-accumulation and with fabrics indicating ice flow from the southeast was most probably deposited by the East Jylland Ice sheet.

\section{STRATIGRAPHY}

Omitting the data from the principal locality 5: Søndervilstrup Klint, symbolic locs of each of the examined localities are shown in fig. 76 , and individual units are correlated for the whole area in the glacial stratigraphic data chart (fig. 77).

The oldest till in the area overlying sandy outwash deposits (loc. 109) is a grey, clayey, massive, quartz poor, Baltic till with insignificant that at least pollen zone 7, defined by S.Th.Andersen (1965), is present. In other places the Lillebælt Till is overlain by outwash material (locs $107,110,115)$, at locality 112 developed as a fining upwards sequence, deposited by westward moving meltwater streams. This sequence is glaciotectonically thrusted and folded from northeasterly directions (loc. 112) and unconformably overlain (locs 107, 110, 112, 115) by a brown to grey, massive and banded, quartz poor, Fennoscandian till. This till contains, in some places, a mixture of the $\mathrm{X}$ and $\mathrm{Y}$ foraminiferal accumulations, whilst fabrics indicate ice flow from the northeast; NE-(B1-XY): The Mid Danish Till. At Halk Hoved (loc. 112, fig. 78) this till has undergone glaciotectonic deformation from northeasterly directions. The Mid Danish Till is overlain by proximal outwash and flow-till deposits which have undergone glaciotectonic folding and thrusting from the east (loc. 107, fig. 79), from the south (loc. 108) and from south-easterly di-

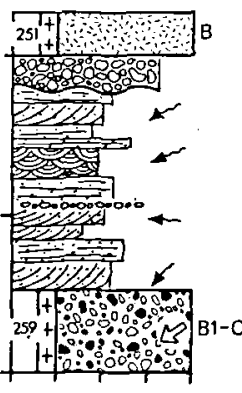

III: KNUDSHOVED

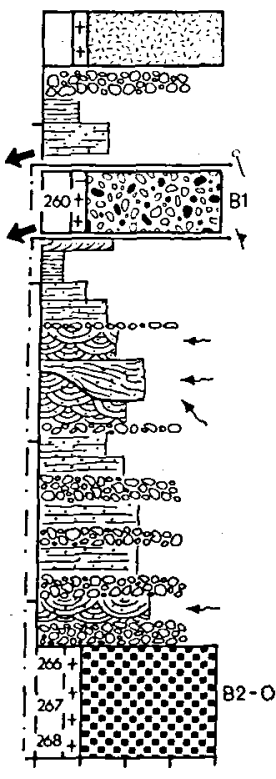

112: HALK HOVEO

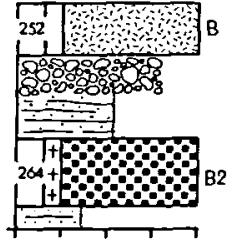

113: RADE HOVED

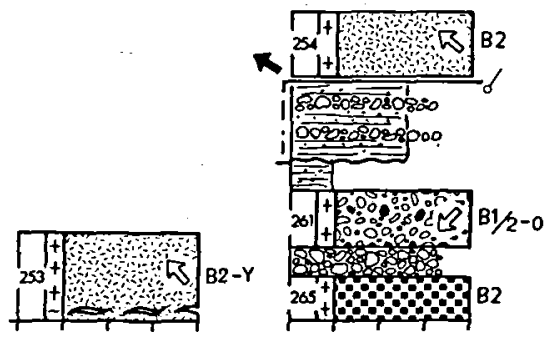

11S: BARSO amounts of re-deposited Quaternary foraminifera (B2-0): The Lillebælt Till. It is overlain by (remobilized?) limnic Eemian deposits which in turn are overlain by waterlaid sand and gravel (loc. 109). Palynological examination of one sample from the limnic Eemian deposits indicated, rections (loc. $\overline{109}, 115)$. The sequence is unconformably overlain by a brown, clayey, massive, quartz poor Baltic till (figs 78,80 ) showing in some samples a Y-accumulation and with fabrics indicating ice flow from the southeast: SE-(B2-Y): The East Jylland Till. 
Area 11: EASTERN SOUTH JYLLAND
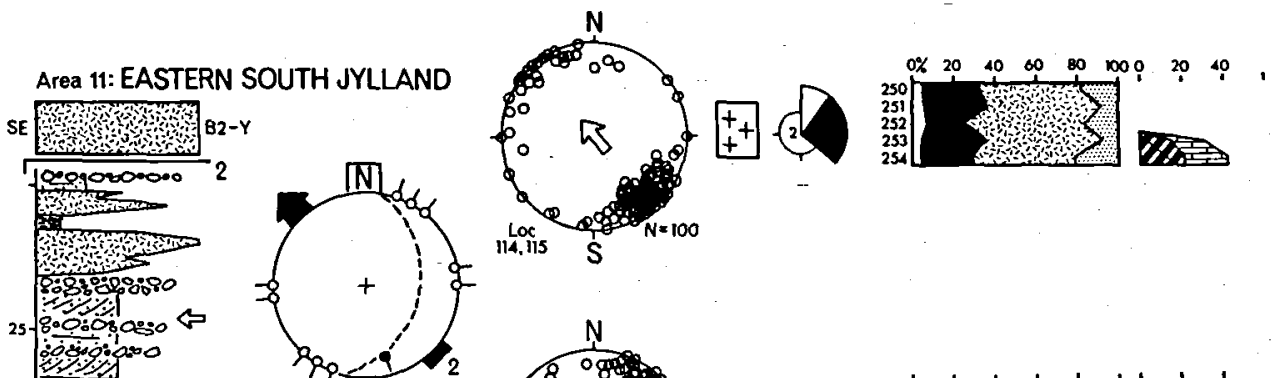

Y
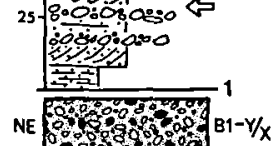

.
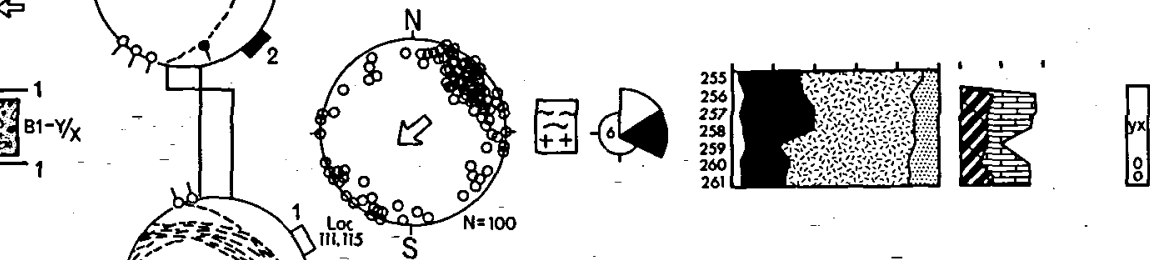

Om $\frac{\mathrm{c} / \mathrm{si}}{\mathrm{Sa} \text { Gravel Til }}$

$82-0$

Kineto- Lithology Compo-

graphic groups

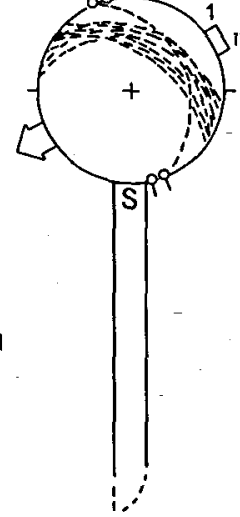

Glacial

tectonics

Till-

fabric
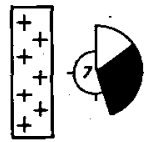

Till Exotic Sample stonecounts

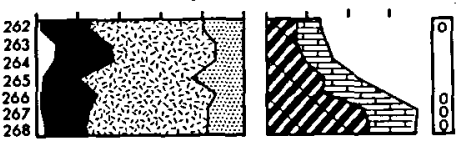

Fine gravel

Redep

Quater foram

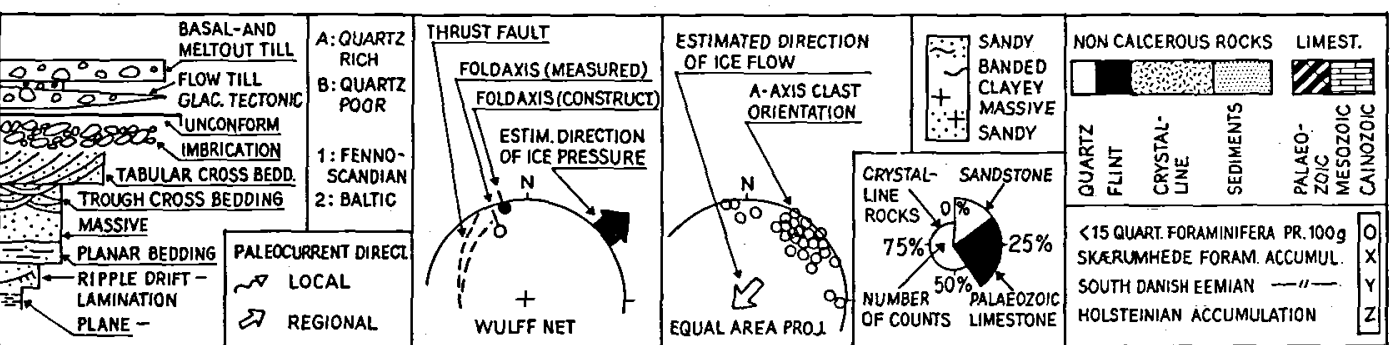

Fig. 77: Glacial stratigraphic data chart, area 11, Eastern South Jylland. Till units shown in fig. 43. 


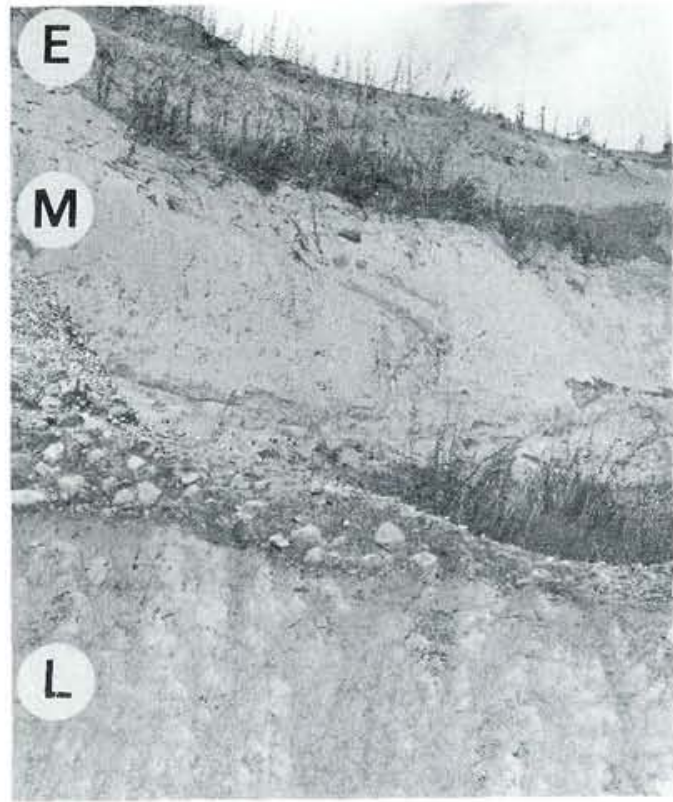

Fig. 78: Lillebrelt Till (L) overlain by outwash deposits. The Mid Danish Till (M) which unconformably overlies this sequence is folded by ice deformation from the NE and overlain by the East Jylland Till (E), loc. 112, Halk Hoved.

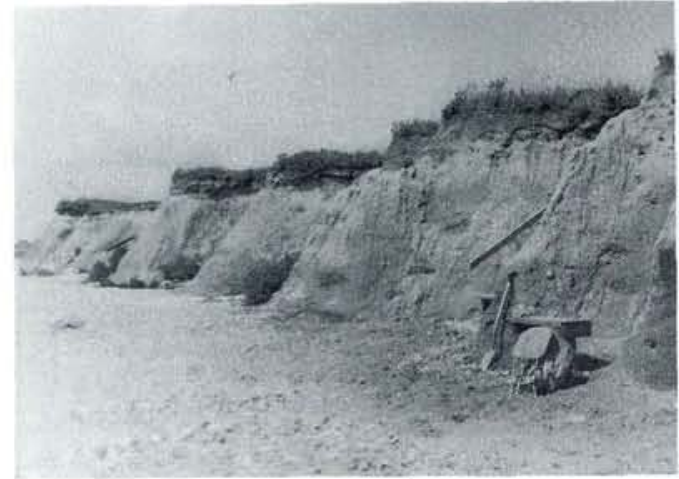

Fig. 80: East Jylland Till, loc. 114, Årø.

\section{DISCUSSION}

The present investigation has fully confirmed the stratigraphic results of Frederiksen $(1973,1976)$, however, some new information has been gathered. The fining upwards sequence overlying the Lillebælt Till is estimated to be of Weichselian age, because it overlies the Eemian material inland and it overlies the Ristinge Klint Till at principal locality 5: Søndervilstrup Strand. The fact that the Ristinge Klint Till only is found at loc. 5, does not indicate, that its extension in confined to this locality, it can very well have a greater distribution in the area. On the Tinglev sandur, (Hansen 1965) morphological evidence of dead

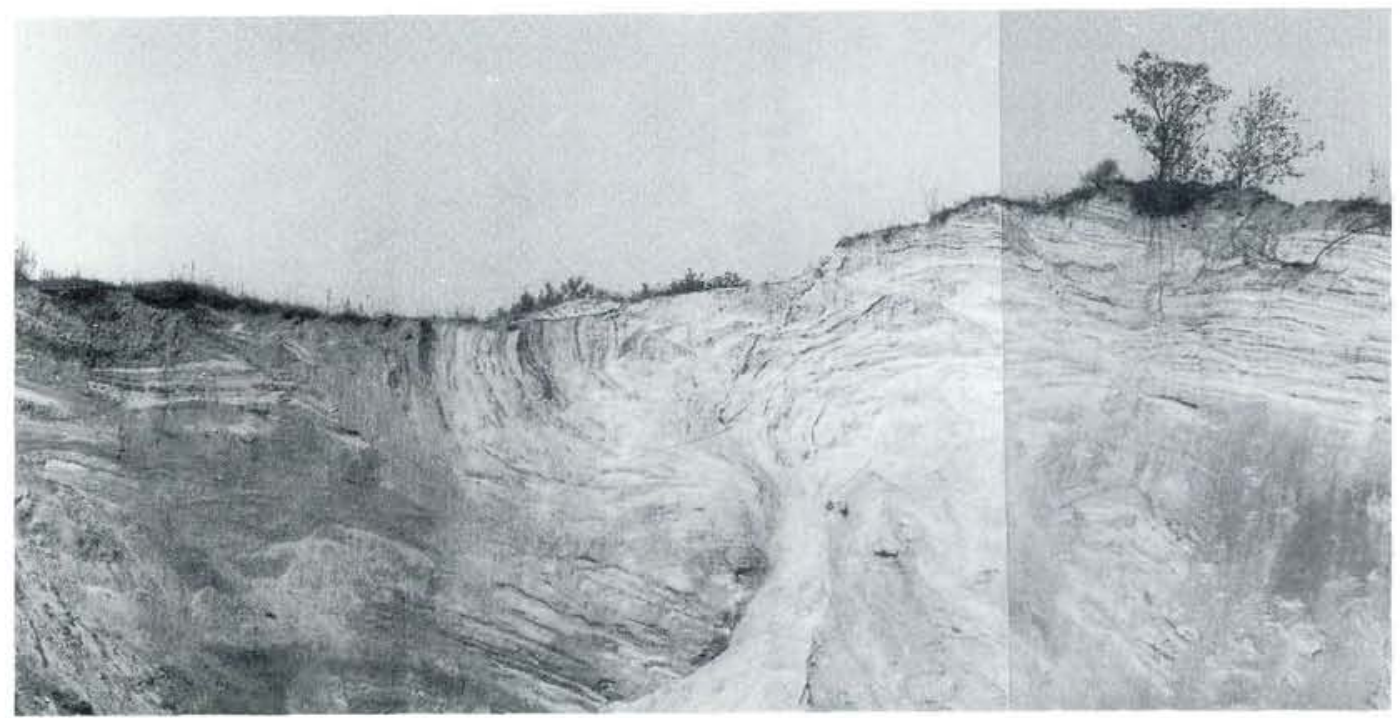

Fig. 79: Sandy and gravely outwash material folded and thrusted from easterly directions in icemarginal hills from the East Jylland Advance, loc. 107, Christiansfeld. 
ice masses present during the deposition of the sandur could suggest, that the ice stream which deposited the Ristinge Klint Till in the coastal areas of the southern Lillebælt, also covered the part of southern Jylland characterized by dead ice topography on the Tinglev sandur. The presence of fragments of Juniperus (Kolstrup \& Havemann 1984) of Pleniglaical age has suggested, that the larger part of the Tinglev Sandur was deposited from the Old Baltic icestream before 49000-42000 BP. This conclusion is, however, not favoured by the present author because, it is not demonstrated that the wood fragments in fact lie in situ, on the contrary, it is higly probable that the material is reworked.

A comparison of morphological features and the ice pressure directional properties of the last ice cover, which probably deposited the East Jylland Till, is assumed here to outline the course of the East Jylland Iceborder line at the inland localities of the area. The line proposed continues from $\emptyset$ dis (area 10) through Ravnbjerg'(loc. 107) west of Christiansfeld where a valley led outwash towards the west (into area 10). From Ravnbjerg the ice border line follows the ridge south-westward through Bjerndrup (loc. 100) and further south eastwards to a point east of Styding and west of Haderslev Dam and from here southward to Poth $\varnothing \mathrm{j}$ by Vedsted (loc. 106) to be connected with the younger of the terminal moraines around Åbenrå.

\section{CONCLUSION}

When taking the stratigraphy of the principal locality 5: Søndervilstrup Strand into consideration, area 11 contains 4 till units interbedded by outwash generally deposited by westward flowing meltwater streams (fig. 105).

The oldest till is the Lillebælt till deposited by a Baltic ice sheet from eastern directions during the late Saalian. It is overlain by limnic Eemian deposits or a podsolic palaeo soil has developed on the surface of the till and in waterlaid sand immediately above it (loc. 5). The Weichselian, Ristinge Klint Till, which overlies the Lillebælt Till at loc. 5 , was deposited by a Baltic icestream succeeded by an icestream from the north-east, which deposited the Fennoscandian, Mid Danish Till. This ice sheet apparently caused glaciotectonic deformation of the Mid Danish Till in the coastal areas during a readvance from north easterly direction. After or during deglaciation of the previous icesheet, the East Jylland Till was deposited by the East Jylland Ice stream in the coastal areas.

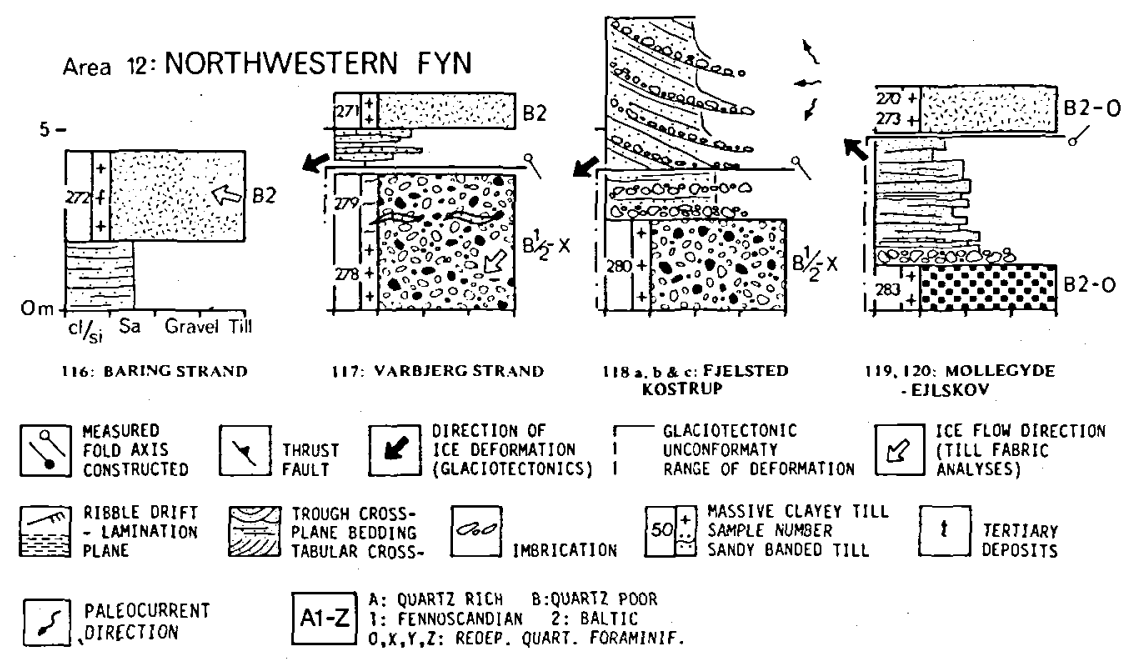

Fig. 81: Simplified lithological logs, area 12, Northwestern Fyn. 
5.12 AREA 12: NORTH-WESTERN FYN (locs 116-125, fig. 44)

Area 12 comprises Æbel $\varnothing$ and the northern part of Fyn between Ejby, Båring Vig, Bogense and Sønders $\emptyset$. The landscape is dominated by the smooth plain of northern Fyn upon which several eskers are situated and towards the south, the more elevated dead ice region of central Fyn is characterized by numerous kames. Localities are placed at coastal cliffs (locs 116, 117) and in inland gravel pits $(118,119,120,121,122,123,124$, 125). Area 12 also contains the principal locality 4: Æbelø.

\section{PREVIOUS INVESTIGATIONS}

Madsen (1900) indicates on the basis of stone counts, that the northern part of Fyn is covered by a Baltic till, although some counts also indicate the presence of Fennoscandian till material. Stone counts from subsurface deposits especially on Fbelø suggest the presence of older till material dominated by Norwegian indicators.

Madsen et al. (1928) suggests, that the Baltic till covering northern Fyn was deposited by the East Jylland Ice sheet, named the D-advance.
The till of the younger, Baltic ice stream is assumed to cover material rich in Norwegian indicators in the northern region, where as, this material constitutes the youngest glacial deposit in the southern region. This material was deposited by the Dala-Baltic icestream, but strongly contaminated by older Norwegian clast material. Based on the frequency of Baltic indicators and morphological features V.Milthers (1932) sketched roughly north-south trending recessional lines of the Baltic ice sheet, as a continuation of similar lines drawn in eastern Jylland.

K.Milthers (1942) ascribes the dead ice landscape in central Fyn to the Dala-Baltic phase, whereas the western lobe of the Baltic ice stream covered the coastal areas towards the west. This ice stream deposited Baltic indicators from the Lillebælt glacier supposedly travelling in a northeasterly direction across the coastal areas of western Fyn.

Smed (1962) studied the glacial morphology of Fyn in great detail dividing the landscape into several distinct morphological regions. Area 12 comprises two such regions. The larger, northern region is characterized by a till plain drumlinized in a ESE-WNW direction upon which, eskers containing Baltic clast material have been formed. The smaller region towards the south is characterized as a till plain partly drumlinized in

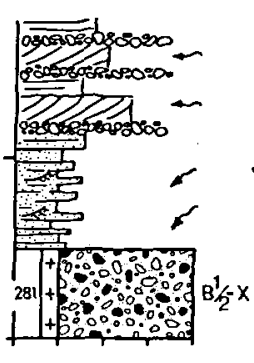

121: HARSLEY MARK

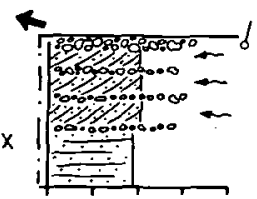

122: SMIDSTRUP

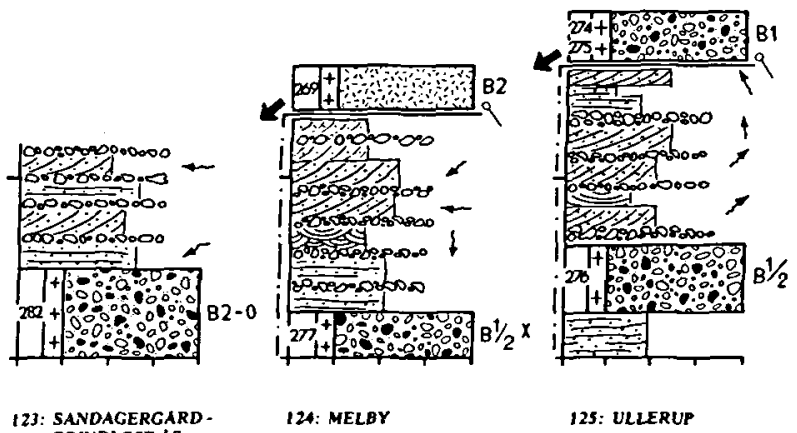

V.Milthers $(1932,1948)$ recognizes two regions of different indicator erratic associations and morphology: 1) a larger northerly till plain dominated by Dala and Baltic indicators and 2) a smaller southerly region dominated by Dala and Norwegian indicators characterized by morphological features developed in dead ice masses. a NE-SW direction, with numerous kames deposited upon the surface. Supported by observations from glacial striations on stratigraphically determined boulder pavements Smed concluded, that the southern region was overridden by a glacier from the NE, which left dead ice masses on central Fyn. This advance was succeeded by the 
Young Baltic, East Jylland ice stream which was responsible for the WNW-ESE drumlinization of the northern region and which deposited a Baltic till and the eskers around Grindløse south of Bogense.

Smed advocated the point of view (in accordance with K. Milthers 1942), that the NE icestream was the last to cover central Fyn and that the two Young Baltic ice streams moving through Lillebælt and Storebælt respectively, were not able to transgress this central area even though the ice streams merged west of Fyn. This standpoint was strongly opposed by Andersen (1963) but no reasonable alternative was forwarded in his critisism of Smeds work.

\section{STRATIGRAPHY}

Omitting the data from principal locality 4: Fbelø lithological columns from each investigated locality are presented in fig. 81 , and units are correlated and presented in fig. 82 for the whole area in the glacial stratigraphic data chart.

The oldest till of area 12 is a grey, clayey, massive, quartz poor, Baltic till (loc. 120) with insignificant amounts of re-deposited Quaternary foraminifera, (B2-0): The Lillebælt Till. This till is not observed in direct contact with the younger, brown to grey, massive and banded, quartz poor partly Fennoscandian partly Baltic till (locs 117 , $118,121,123,124,125)$ which primarily contains an X-foraminiferal accumulation and with a fabric indicating ice-flow from the north east; NE-(B

Area 12: NORTHWESTERN FYN
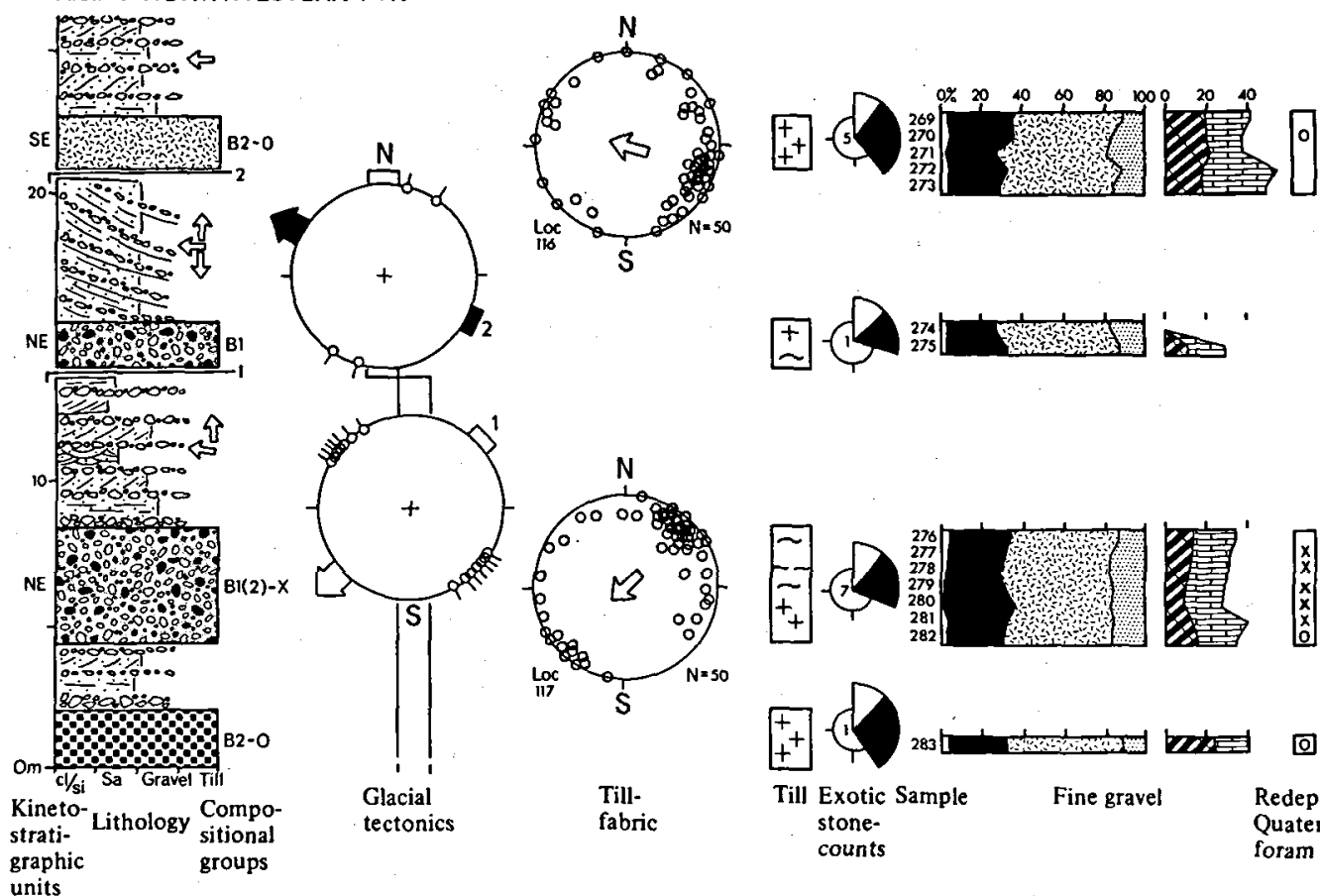

$$
\begin{array}{ll}
\mathrm{cl} / \mathrm{si} & \text { Sa Gravel Till } \\
\text { Kineto- Lithology } & \text { Compo- } \\
\text { strati- } & \text { sitional } \\
\text { graphic } & \text { groups }
\end{array}
$$

Tillunits

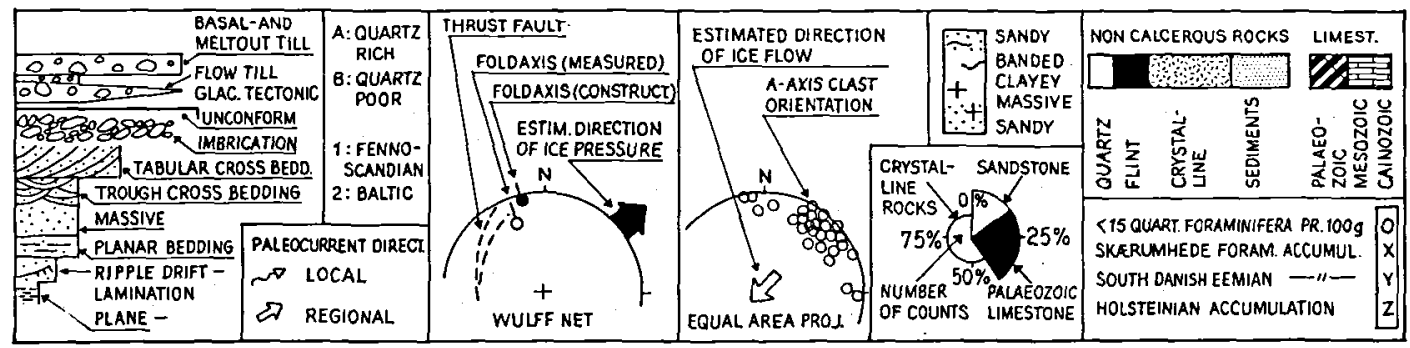

Fig. 82: Glacial stratigraphic data chart, area 12, Northwestern Fyn. Till units shown in fig. 43. 


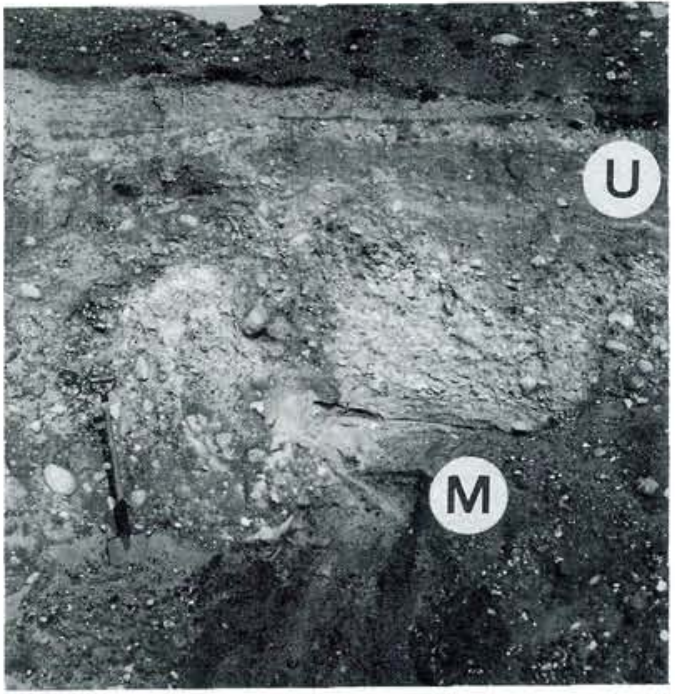

Fig. 83: Mid Danish Till (M) overlain by proximal outwash folded from the NE and overlain by an upper subunit of the Mid Danish Till (U), loc. 125, Ullerup.

1/2-X): The Mid Danish Till. The till forming the core of Grindløse esker (loc. 123) is considered to be part of this till unit. In spite of its high Baltic clast content, which was presumably picked up from an underlying Baltic till unit, several clasts of kinnekulle-diabase have been found in situ and it moreover contains an X-like foraminiferal accumulation even though the content is too small for faunal comparison.

The Mid Danish Till is overlain by proximal outwash material (locs 118, 121, 122, 124, 125) deposited by meltwater streams flowing towards the north and southwest. The outwash and the underlying till have undergone glaciotectonic deformation from the NE (locs 117, 118, 124, 125). This sequence is either unconformably overlain by a brown, massive, quartz poor Fennoscandian till (fig. 83) in the northern part of the area (locs 124, 125); (B1): an upper subunit of the Mid Danish Till; or the dislocated sequence is unconformably overlain by proximal outwash material (locs 118, 121) occasionally found deposited as small deltas (fig. 84) building up some of the kames of the dead ice area of central Fyn. In the coastal areas the Mid Danish Till and the overlying outwash have undergone glaciotectonic deformation from the ESE and are overlain by a brown, massive, quartz poor, Baltic till without notable amounts of re-deposited Quaternary for-

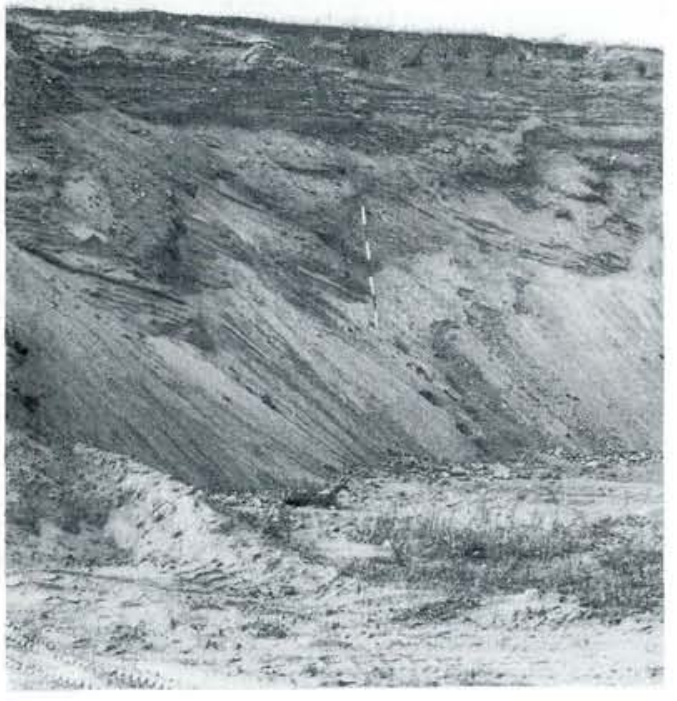

Fig. 84: Deltaic kame deposits overlying the Mid Danish Till, loc. $118 \mathrm{a}$, Fjelsted.

aminifera (locs 116, 117, 119, 124) and with a fabric indicating ice flow from the east-south-east (loc. 116); ESE-(B2-0): The East Jylland Till. The esker near Grindløse and this till were probably deposited from the same icesheet.

\section{DISCUSSION}

The Mid Danish Till seems to show a relatively higher content of Pal.limestone on northern Fyn than found in other parts of the examined region, however it can in most places be identified by its content of re-deposited Quaternary foraminifera with X-accumulation. The Mid Danish Till can be divided into two subunits separated by proximal outwash deposits and glaciotectonic unconformities indicating ice pressure from north-easterly directions. This suggests, that the ice stream which deposited the Mid Danish Till deposited the lower subunit at an early stage and, after a retreat of the ice front, during which proximal outwash was deposited, a readvance caused glaciotectonic deformation from the NE. Thereafter either the upper subunit of the Mid Danish Till or the proximal outwash in kames on central Fyn was deposited in dead ice masses of this ice sheet.

As the East Jylland Till has not been found in the southern part of area 12, and the kames, 
which resulted from the readvance leaving dead ice masses in central Fyn, constitute the youngest and undisturbed glacial deposits in this region, it could be suggested, following Smed (1962), that the East Jylland Ice sheet was confined to the coastal areas of Fyn. However, Andersens (1963) contention, that the dead ice masses of central Fyn were no real obstacle for the Young Baltic Ice stream, cannot been rejected as a result of the present investigation. As it shall be shown in the next chapter (area 13: Southwestern Fyn), the course of the icestream, which deposited the East Jylland Till, was strongly affected by an "obstacle" which resulted in the formation of a converging directional pattern across Fyn, but whether or not the Young Baltic ice stream covered the whole of Fyn is still an open question, however the proposal of Andersen (1963) is favoured from a glaciodynamic point of view.

\section{CONCLUSION}

When the data from the principal locality 4: Ebel $\emptyset$ is included, the area of northern Fyn contains 5 till units interbedded with waterlaid outwash, deposited by generally westward flowing meltwater streams (fig. 105).

The two older tills, only observed at Æbel $\varnothing$, are the Trelde Næs Till and the Ashoved Till. A Baltic till, apparently the Lillebælt Till, constitutes the oldest till observed on the mainland of Fyn which also overlies the older tills at $Æ b e l \varnothing$.
This till is overlain on Fbelø by the older subunit of the Mid Danish Till which was deposited by an early substage of the icesheet, which reached the Main Stationary Line. A recessional advance from the NE caused deformation of the lower subunit and overlying outwash material and led to the deposition of an upper subunit and the sedimentation of kames in its dead ice masses on central Fyn. The East Jylland Till was deposited by an icesheet from the ESE and is found in the coastal areas of area 12 .

\subsection{AREA 13: SOUTHWESTERN FYN (locs 126-135, fig. 44)}

Area 13 is situated on the Lillebælt coast of Fyn and extends from the base of the Fønsskov peninsula south of Middelfart in the north over Assens to Helnæs towards the south. The landscape is dominated by a drumlinized till plain near the coast whilst kames dominate further inland. Localities are placed at coastal cliffs (locs 126, 127, $131,133,135$ ) or in gravel pits (locs 128, 129, 130, $132,134)$. The principal locality 6 : Sønderby Klint is situated within area 13.

\section{PREVIOUS INVESTIGATIONS}

Jessen $(1907,1935)$ recognizes a Baltic till cover and an older substratum, where Norwegian clast material is present in minor quantities. Madsen et al. (1928) suggested, that a glacier moving northward through Lillebælt deposited the upper, Bal-

Area 13: SOUTH WESTERN FYN

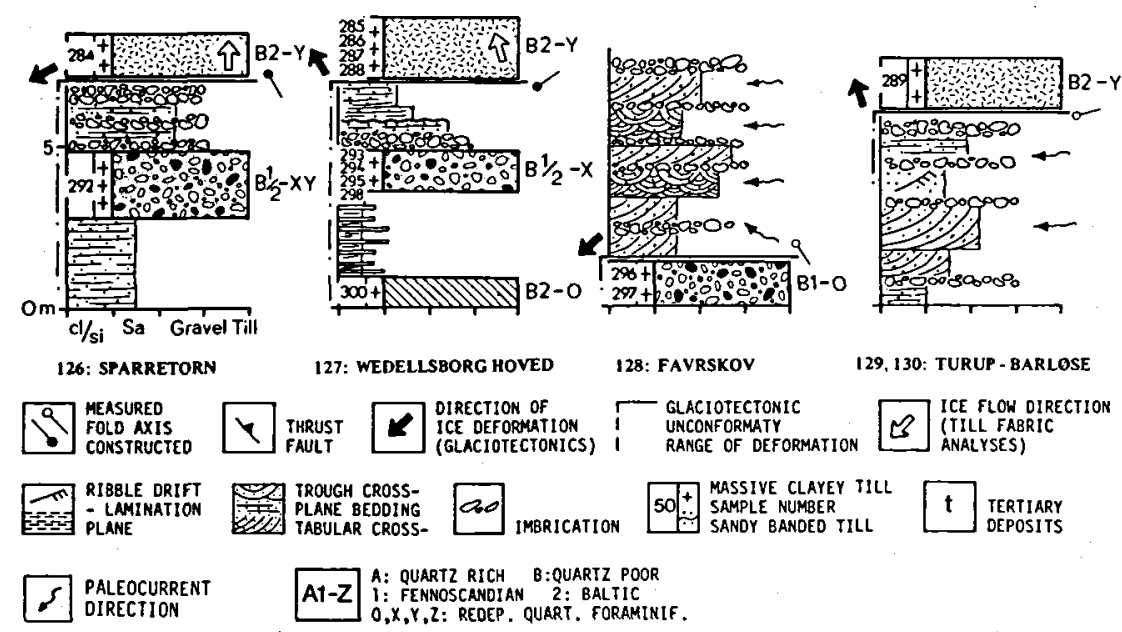

Fig. 85: Simplified lithological logs, area 13, Southwestern Fyn. 
tic till and suggested, that the glacier was confined to the area in which floes of marine Eemian clay are found.

By the use of indicator counts and morphological considerations V.Milthers (1932, 1940, 1948) divided the area into a south-western, coastal region dominated by Baltic indicators in which floes of Eemian clay could be found, and a central region with a pronounced dead-ice topography primarily occupied by kames. This region contains a strong imprint of Norwegian indicators. The border between the landscape left by the Dala-Baltic ice stream in central Fyn, and the coastal area occupied by the purely Baltic ice stream, was drawn along NW-SE trending parallel ridges. These ridges consist of outwash material deposited by westward moving meltwater streams flowing between an inactive ice towards the NE and an active glacier moving through Lillebælt. The same two regions were recognized by K.Milthers (1942) who suggested, that the central region of Fyn was never covered by the Baltic ice stream which advanced through Lillebæit and Storebælt.

Smed (1962) indicated that the coastal area was characterized by a till plane, drumlinized in a roughly NNW-SSE trending direction, and developed by a glacier moving northward through Lillebælt. This plane is separated from the central ferring to glacial striations on boulders covering an esker (Sallinge Ås) deposited by the NE-ice in south-central Fyn he suggests, that the Young Baltic ice stream transgressed the whole of Fyn on its way to the East Jylland Ice border. Andersen proposes, that the ice marginal hills of south-western Fyn were deposited as elongate kames between the dead-ice in the north east and the East Jylland ice sheet under deglaciation in the coastal region. Meltwater from south-west and central Fyn was directed across the Lillebælt and through Kolding $\AA$ valley towards the sandur flats of central Jylland.

\section{STRATIGRAPHY}

Simplified lithological columns of individual localities are shown in fig. 85 and lithostratigraphic units are correlated for the whole area in the glacial stratigraphic data chart (fig. 86).

The oldest till of area $\mathbf{1 3}$ is separated from underlying marine Eemian clay by fine grained waterlaid deposits (loc. 135). It is a brown to grey, massive, quartz poor, Baltic till containing redeposited Quaternary foraminifera of the Y-accumulation; (B2-Y): The Ristinge Klint Till. At loc. 127 this is also characterized by re-deposited molluscan fragments derived from the Cyprina Clay. The till is overlain by primarily fine grained

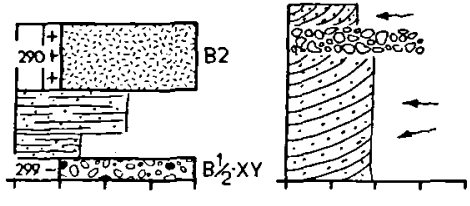

131: ASSENS NORDSTRAND 132: SKYDEBJERG

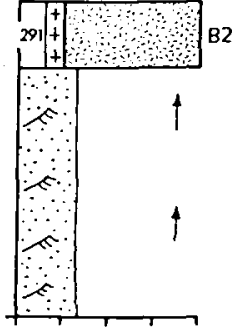

133: HELNAS N

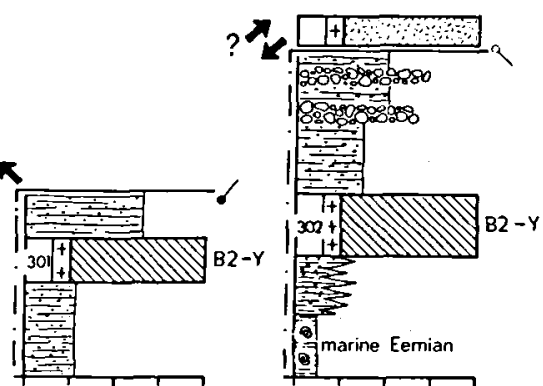

134: SKARUP

135: HELNES S dead-ice region by ice border kames and kame like ice marginal hills which are also present on the plane where they form recessional ice border lines.

Andersen (1963) points out, that there are no traces of an independent Lillebælt glacier, and re- outwash material, deposited by generally northward moving meltwater, which in turn is overlain by a brown to grey, mostly massive, quartz poor Fennoscandian till (fig. 87) with rather large amounts of Baltic clast material (locs 126, 127, $128,131)$ and containing an $\mathrm{X}$-accumulation with 


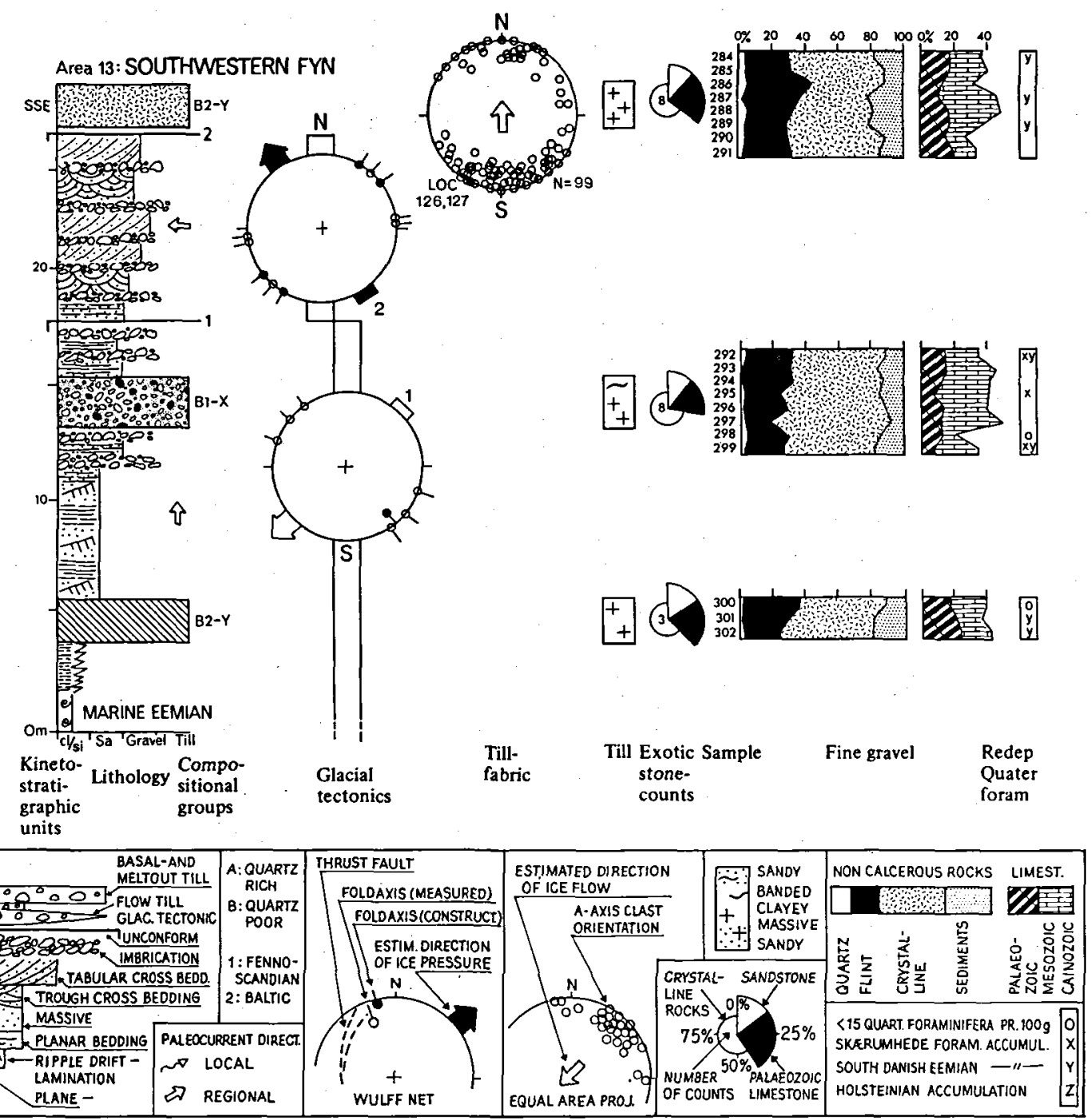

Fig. 86: Glacial stratigraphic data chart, area 13, Southwestern Fyn. Till units shown in fig. 43.

some intermixture of the Y-foraminiferal accumulation; (B1-X/Y): The Mid Danish Till. It is overlain by proximal outwash material which, together with the underlying deposits, has undergone glaciotectonic deformation (locs 126, 128) from the NE. This sequence is unconformably overlain by proximal outwash material deposited by westward flowing meltwater streams (locs 128 , 129, 130) and kame deposits (loc. 132). In the coastal areas this sequence (and older deposits) has undergone glaciotectonic deformation from south-eastern directions and is unconformably overlain by a brown, massive, quartz poor, Baltic till containing a Y-foraminiferal accumulation, and which contains fabrics indicating ice flow from the south; S-(B2-Y): The East Jylland Till.

\section{DISCUSSION}

The Mid Danish Till defined as a NE-till of B1-X composition seems in area 13 (as well as the previously described area 12) to be characterized by an enrichment of Pal.clast material and some traces of the Y-foraminiferal accumulation. This somewhat diverging composition, which at times approaches the values of the Weichselian, Baltic 
tills, is explained by incorporation of a substratum partially composed of the Lillebælt Till, primary Eemian marine deposits and the Ristinge Klint Till. The deformation from the NE of the Mid Danish Till and overlying outwash deposits indicates that the readvance, which led to the deposition of kames in the dead ice masses of central Fyn, transgressed the whole of the island and possibly reached the coastal areas of Jylland at Halk Hoved (loc. 112) and covered parts of the island of Als (Sjørring 1977).

The distribution of the East Jylland Till and its associated glaciotectonic disturbances suggests, that the Young Baltic advance is confined to the coastal regions of Fyn. No conclusive evidence as to whether or not the central part of Fyn was transgressed by the ice sheet has, however, been obtained by the present investigation.

\section{CONCLUSIONS}

Three till units have been recognized in area 13 when the stratigraphy of loc. 6 Sønderby Klint is included (fig. 105).

The whole of the described glacial sequence is ascribed to the Weichselian. The oldest till is the Ristinge Klint Till which is overlain by the Mid Danish Till. A readvance of the ice sheet which deposited this till caused deformation from the $\mathrm{NE}$ and during deglaciation kames were deposited in the central Fyn dead ice masses while, at the same time, the Young Baltic ice sheet deposited the East Jylland till is the coastal areas.

\subsection{AREA 14: MOLS, HELGENAES, TUNØ, NORTH SAMSØ, KYHOLM (locs 136-144,} fig. 44)

Area 14 comprises the coastal areas of southern Mols, the peninsula of Helgenæs, Northern Sams $\emptyset$ and the islands of Tun $\varnothing$ and Kyholm. The landscape consists of two generations of ice marginal hills situated on a rather plane surface, the highest points of which today constitue peninsulas or small islands. All localities are placed at coastal cliff sites; Mols (locs 136, 140, 141), Helgenæs (locs 137, 138, 139), Tunø (locs 142, 143) and Kyholm (loc. 144). The principal locality (loc. 7): North Samsø is situated in the southern part of the area.

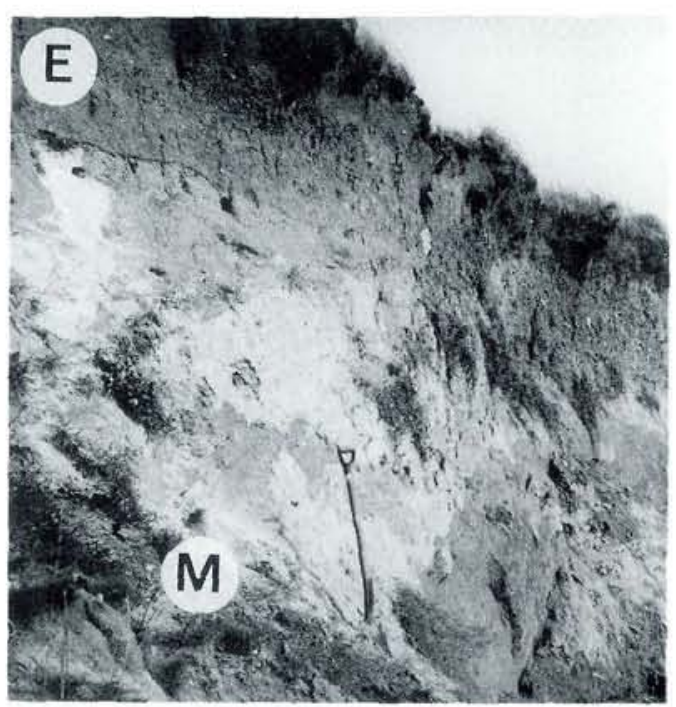

Fig. 87: Mid Danish Till (M) overlying finegrained meltwater deposits and overlain by outwash gravel. The sequence has been folded by ice-deformation from the NE and is unconformably overlain by the East Jylland Till (E), loc. 127, Wedellsborg Hoved.

\section{PREVIOUS INVESTIGATIONS}

Madsen (1897) recognized an upper and a lower till-complex each divisible into two compositional groups; one rich and one poor in Pal.limestone. In the upper complex, the till containing high quantities of Palaeozoic material has low flint quotients and vice versa. Madsen et al. (1928) suggests, with reference to the flint quotient of the surface tills, that the younger till of the area corresponds to till D, deposited by the East Jylland Ice sheet.

Harder (1908) indicates, that the East Jylland Ice border line represents the maximum extension of an independent ice sheet younger than that which reached the Main Stationary Line. The till from this ice sheet is characterized by a Baltic clast composition which however, in the area of Mols seem somewhat contamined by Norwegian indicators.

Based on morphological considerations and the frequency of respectively red and brown Baltic quartzporphyry in indicator counts taken primarily in beach gravel V.Milthers $(1932,1948)$ suggests, that most of the area except for Tun and perhaps Kyholm is dominated by indicators from an East Baltic advance, whereas Tun $\varnothing$ and southern Samsø were overridden at a later stage 


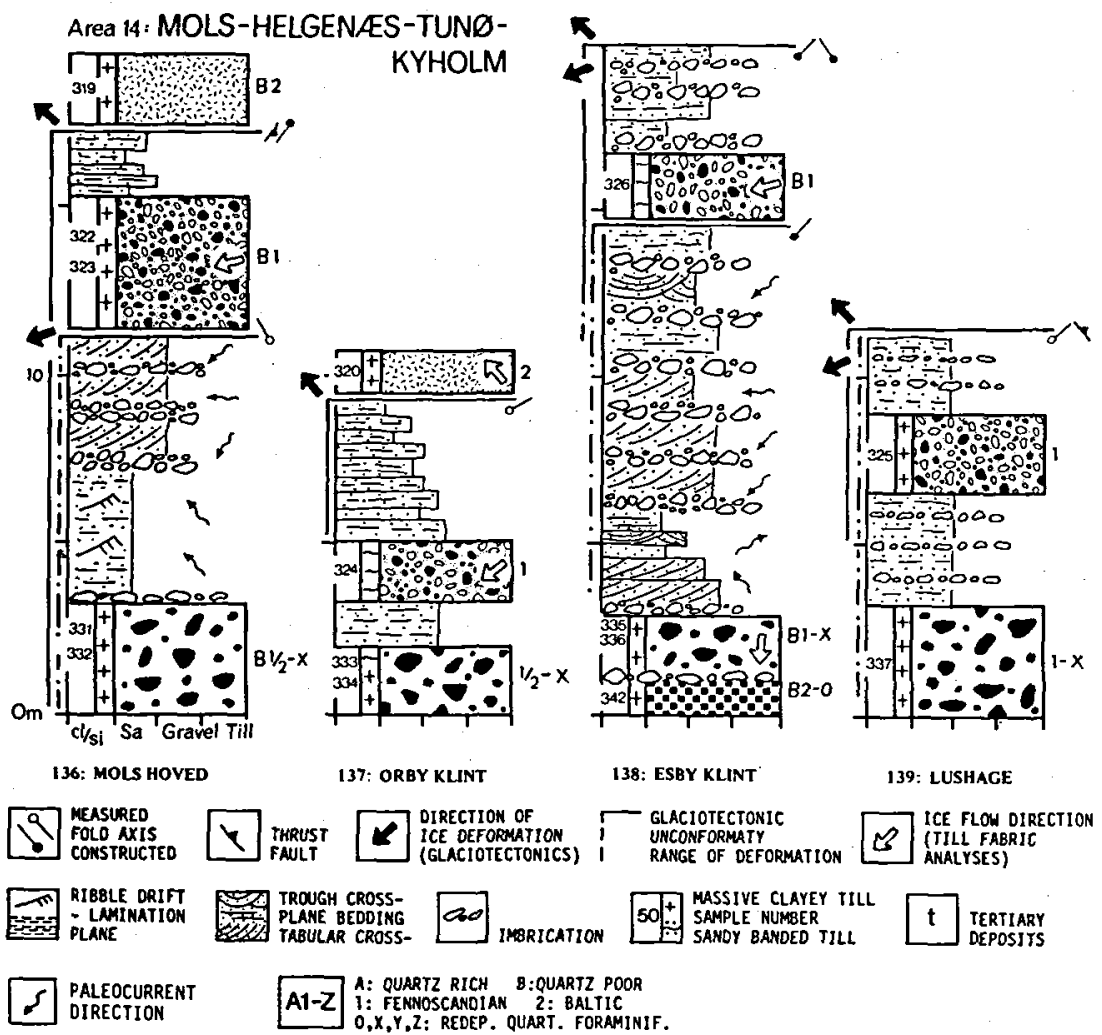

Fig. 88: Simplified lithological logs, area 14, Mols -Helgenæs-Tunø-Kyholm.

by a West Baltic advance. V.Madsen (1931) strongly opposed V.Milthers' morphological arguments. K.Milthers (1942) also using the frequency of baltic quartzporphyries suggests, that an ice sheet from the Baltic region divided when reaching Fyn into a western and an eastern lobe. These he named respectively the Lillebalt- and Storebælt glacier. These two glacier tongues proceeded northwards on either side of Sams $\emptyset$ reaching the East Jylland Ice border zone at Mols.

Thamdrup (1970) indicates the presence of two dislocated tills in the cliff site of Mols Hoved (loc. 136). An older till characterized by Norwegian and Dala indicators was presumably deposited by the ice stream which reached the Main Stationary Line, and the upper till was deposited by the Dala-Baltic advance during the East Jylland stage. The sequence underwent glaciotectonic thrusting from the southeast during the (late) Baltic advance referred to by K. Milthers (1942) as the Lillebælt glacier.
H.W.Rasmussen (1977) finds no evidence for an ice transgression on Mols later than the east Jylland advance and the $\mathrm{V}$-shaped ice marginal hills mentioned by V.Milthers (1932) are interpreted as kames deposited upon older ice marginal ridges.

Houmark-Nielsen (1976 a, b, c, 1980, 1981, 1983c) and Houmark-Nielsen and Berthelsen (1981) presents results of glacial stratigraphic investigations in the area concluding, that four tills interbedded by waterlaid deposits are present. An older (Saalian) Baltic till (the Palaeo-baltic till) is present at several sites and is seen incorporated into a younger, otherwise Fennoscandian till deposited by the first Weichselian ice sheet from the north. It was succeeded by an ice sheet from the north-east, which deposited a Fennoscandian till which was in turn dislocated by readvance of that ice sheet. Finally an ice stream from the SE deposited a Baltic till. 


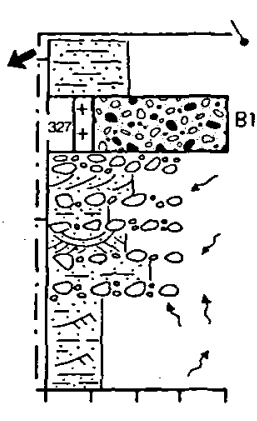

140: FUGLSO STRAND
[41: ELSEGARDE

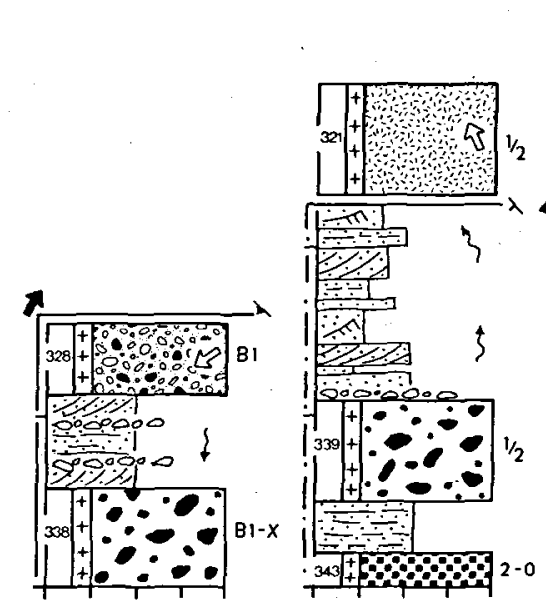

142: TUNO NR. KLINT

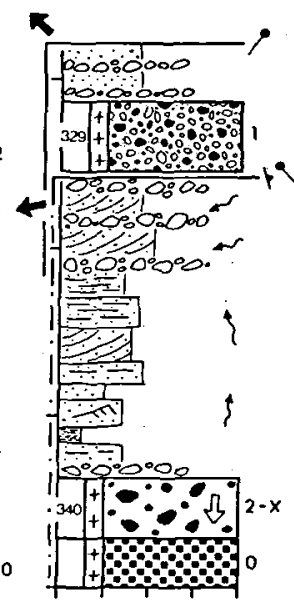

143: TUNO SDR. KLINT

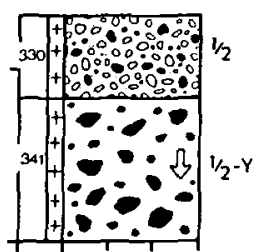

144: KYHOLM

\section{STRATIGRAPHY}

Simplified lithological logs of each locality are shown in fig. 88 and units are presented and correlated for the whole area in the glacial stratigraphic data chart (fig. 89). The oldest till found in the area overlying Tertiary clay is a grey, massive, clayey, limestone rich, quartz poor, Baltic till (locs 138, 142, 143) with insignificant amounts of re-deposited Quaternary foraminifera (B2-0): The Lillebælt Till. In some cases it is separated from younger tills by waterlaid material or a boulder pavement (locs 142, 137) however, on southern Tun $\varnothing$ (loc. 143) the boundary is graditional. The overlying till is a grey, massive, clayey, quartz poor, Fennoscandian till (locs 138, $139,141)$, which at some sites contains a Baltic (locs 143, 144) or intermediate (locs 136, 137, 142) clast composition. It is characterized by an $\mathrm{X}$-foraminiferal accumulation except for loc. 144 where a Y-accumulation is present. Fabric data obtained from all compositional facies indicate ice movement from the north-north-east; NNE-(B1(2)-X): The Kattegat Till (fig. 90). It is overlain by proximal outwash deposits, which grade into fine grained deltaic sediments, deposited by generally northward flowing meltwater streams. These deposits are overlain by proximal waterlaid sand and gravel deposited by southwestward moving meltwaterstreams. This sequence has undergone glaciotectonic deformation from the $\mathrm{NE}$ and, it is unconformably overlain by a brown, banded and massive, quartz poor, Fennoscandian till with fabrics indicating ice flow from the north-east; NE-(B1): The Mid Danish Till. Together with overlying outwash deposits this till has first undergone glaciotectonic deformation from the NE (fig. 90) then disturbed by a younger deformational phase from the SE. This sequence is unconformably overlain by a brown, massive, quartz poor, Baltic till (locs 136, 137,142 ) with fabrics indicating ice flow from the southeast; SE-(B2): The East Jylland Till. 


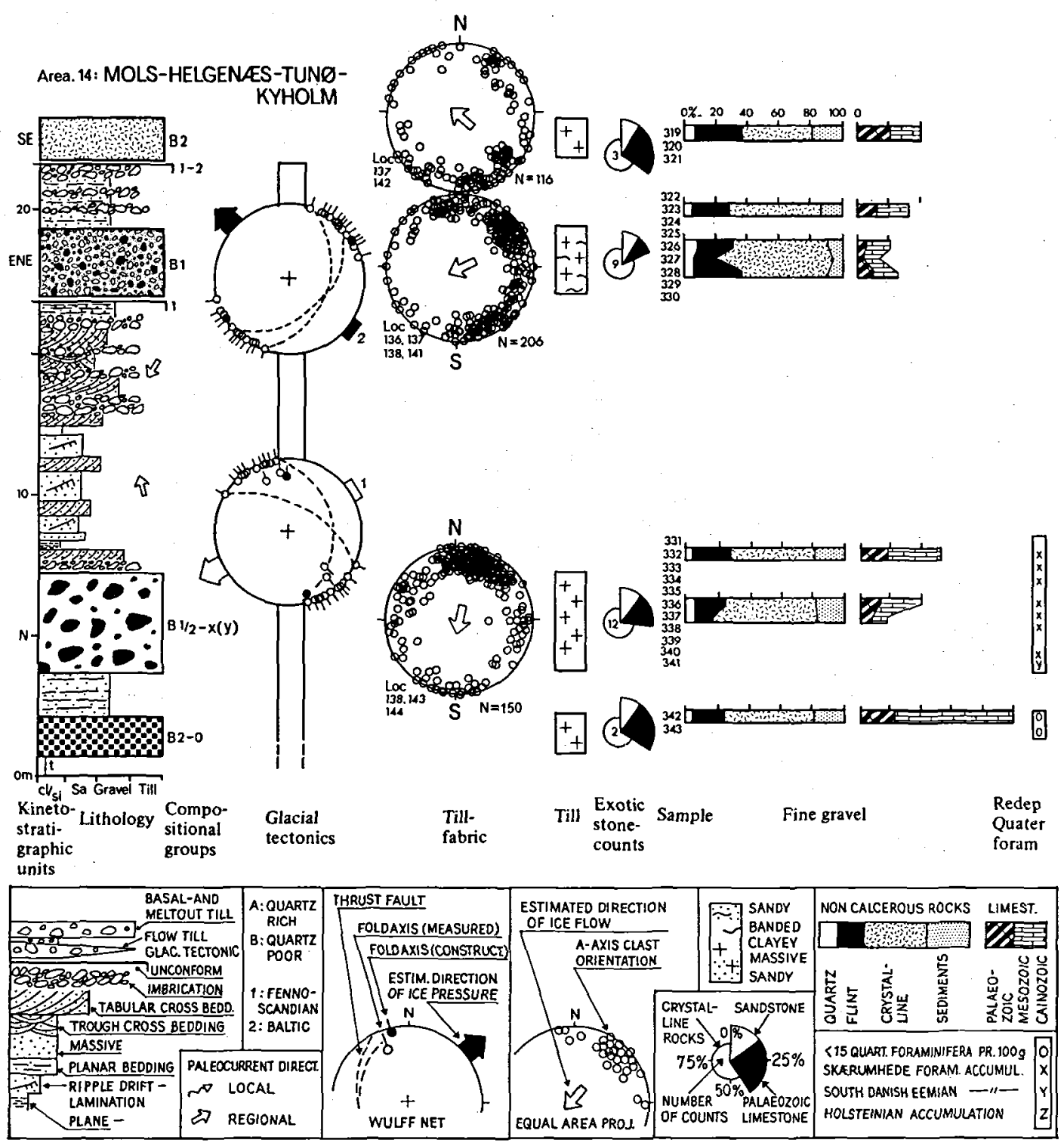

Fig. 89: Glacial stratigraphic data chart, area 14, Mols-Helgenæs-Tunø-Kyholm. Till units shown in fig. 43.

\section{DISCUSSION}

Clast petrographic studies of the Kattegat Till suggests, that strong incorporation of a substratum composed of Baltic material took place in this area and the presence of a Y-foraminiferal assemblage in a sample from loc. 144 indicates, that marine deposits of the Eemian could be situated north of the area in question. However, the overall appearance of the Kattegat Till points towards deposition by an ice stream from the north, which is supported by the large amounts of Norwegian indicators (V.Milthers 1932) especially around Northern Samsø.

Houmark-Nielsen (1980) and Houmark-Nielsen and Berthelsen (1981) proposed, that the fine grained, deltaic outwash material deposited by northward moving meltwater streams interbedding the Kattegat Till and the Mid Danish Till could have been deposited distally from an Old Baltic ice sheet lying south of the area. This hy- 

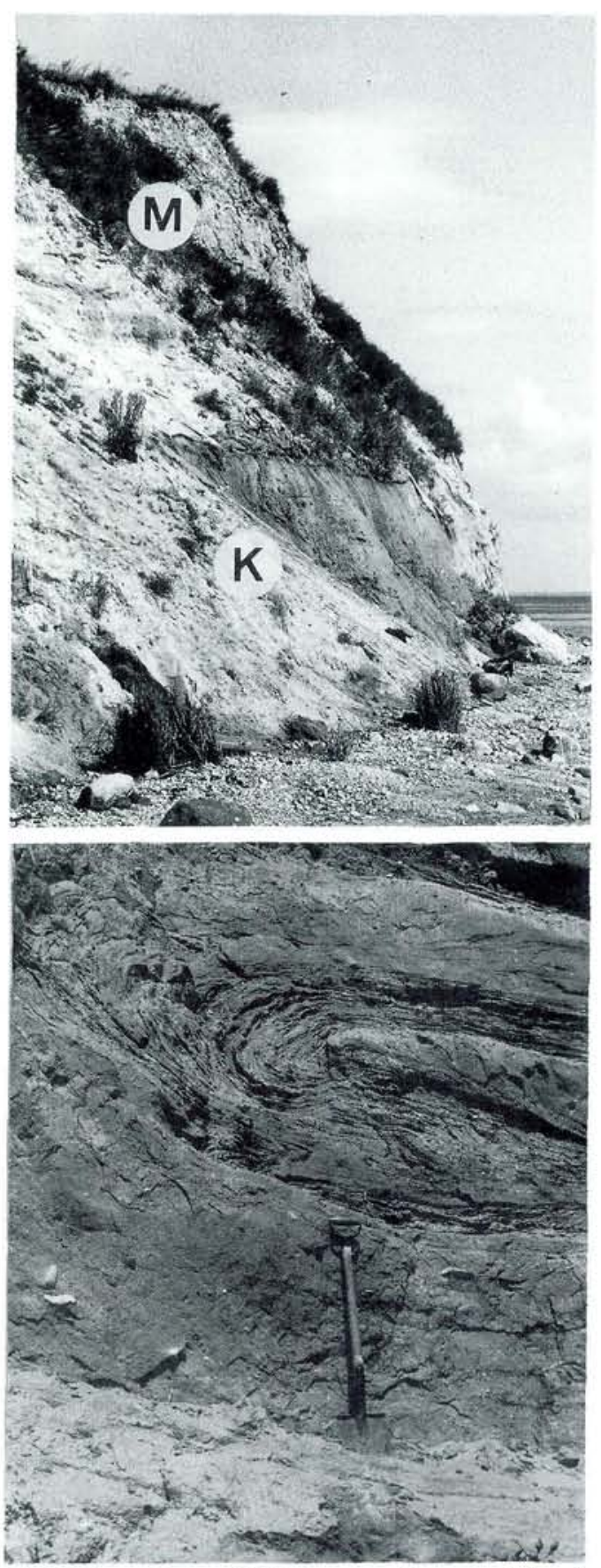

Fig. 90: Upper: Kattegat Till (K) separated by outwash deposits from the Mid Danish Till (M). Lower: Detail of the Mid Danish Till folded by ice-deformation from the NE, loc. 138, Esby Klint. pothesis can however no longer be maintained, because the evidence from loc. 185 , area 19 indicates, that the Ristinge Klint Till, presumably deposited by the Old Baltic advance, underlies the Kattegat Till. On the other hand, the presence of this outwash unit, which has a much wider distribution in the Brelthav region, indicates that the ice free conditions prevailed in the southern Kattegat between the advance from the $\mathrm{N}$ and that from NE.

Studies of glacial morphological features from aerial photographs, with special emphasis placed on the orientation of elongate ridges, indicates a strong agreement in directional properties between ridges and the orientation of glacialtectonic structures from exposed cliff sections (Houmark-Nielsen 1976c, 1983a). Thus it can be established, that the NW-SE oriented hills of Mols, Helgenæs and North Samsø were formed during a readvance of the ice sheet which deposited the Mid Danish Till. Hills with an orientation lying in a NE-SW direction are ascribed to a later phase of ice transgression from the SE during the Young Baltic glaciation. These studies partly confirm the morphological interpretation by V.Milthers (1932) who suggested, that the ice pushed "highlands" of the region are composed of two sets of differently oriented hills, they were however, not contemporary in formation but each is ascribed to an individual ice advance (Houmark-Nielsen 1983a).

\section{CONCLUSION}

In the stratigraphy of area 14 , including the principal locality 7: North Sams $\emptyset$, four till units interbedded with waterlaid deposits are recognized (fig. 105).

The Lillebælt Till constitutes the oldest observed till which is often separated by outwash material from the overlying Kattegat Till. Two units of outwash deposits interbed the Kattegat Till and the Mid Danish Till. A lower, fine grained sequence is deposited by generally northward flowing palaeostreams and an upper, coarse grained sequence deposited by south-westward to westward moving meltwater streams emerging from the advancing ice stream from the NE. This ice sheet deposited the Mid Danish Till and during a readvance caused deformation from the NE as well as forming the older ice pushed ridges of the region. 
Area 15: SOUTH SAMS $\varnothing-$ VEJR $\varnothing$

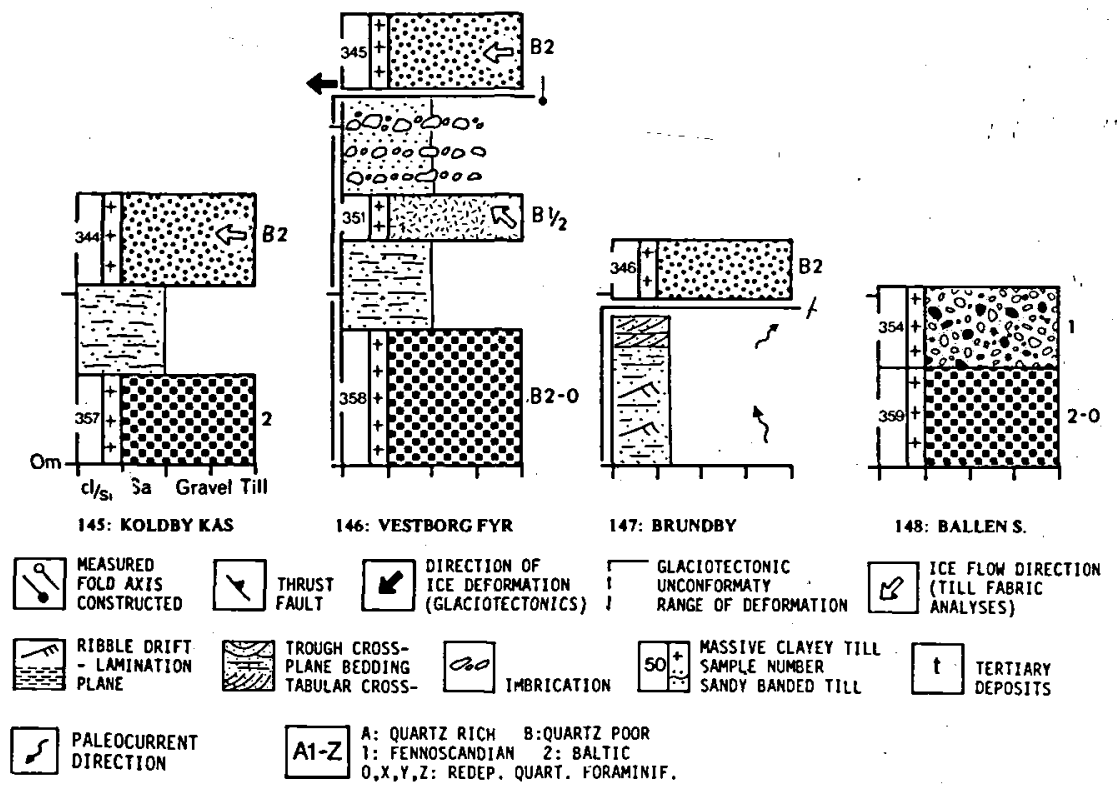

Fig. 91: Simplified lithological logs, area 15, South Samsø -Vejrø.

The East Jylland Till was deposited by the Young Baltic Ice stream advancing from southeastern directions and a readvance of this icesheet (Bælthav re-advance) thrusted and folded the East Jylland Till and older deposits from the south-east in an ice marginal zone cutting North Sams $\varnothing$ in a NE-SW direction.

\subsection{AREA 15: SOUTH SAMSØ-VEJRØ (locs 145-153, fig. 44)}

Area 15 includes the southern part of the island of Sams $\emptyset$ which is characterized by a relatively level till covered surface with elongate kame like hills lying in a roughly NE-SW to N-S trending position: The island of Vejrø is situated east of Sams $\emptyset$ upon the submarine arch-shaped ridge connecting Sams $\emptyset$ and Sejerø. Localities are placed in gravel pits (locs 147, 150, 152) and coastal cliffs (locs 145, 146, 147, 148, 149, 151, 153).

\section{PREVIOUS INVESTIGATIONS}

Madsen (1897) found an upper and a lower till on southern Sams $\emptyset$, both characterized by large quantities of Palaeozoic clast material. The upper till, the flint quotient of which is about half the value of the till covering north Sams $\emptyset$ was, according to Madsen et al. (1928), deposited by an icestream younger than the one reaching the East Jylland Ice border line and hence named the Bælt advance (E). The argument of V.Milthers (1932), that a V-shaped ice border line had its position across southern Sams $\varnothing$, was strongly objected by Madsen (1931). Milthers argued that the border line had inherited its form from earlier stages of the East Jylland ice sheet and was developed during the changing from an Eastbaltic to a Westbaltic icestream. Madsen, however, connected the elongate hills of south Samsø and the Baltic till cover of the island with the position of a glacier lobe in Storebælt (the Bælt advance) east and southeast of Sams $\emptyset$.

Houmark-Nielsen (1980, 1981, 1983c) suggests, that Madsens lower till should be ascribed 


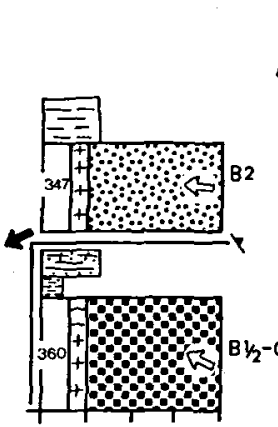

149: VESTERLOKKE

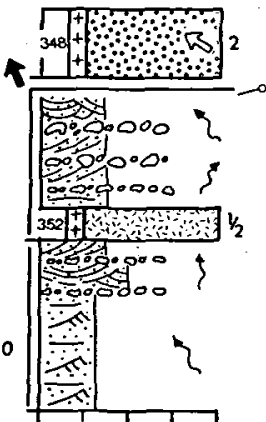

150: RINGEBJERGE

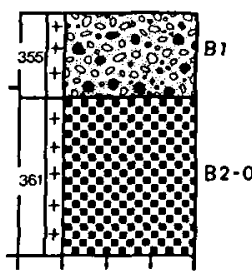

151: SILDEBALLF

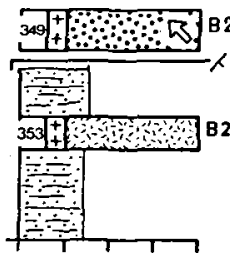

152: GRONHOVED

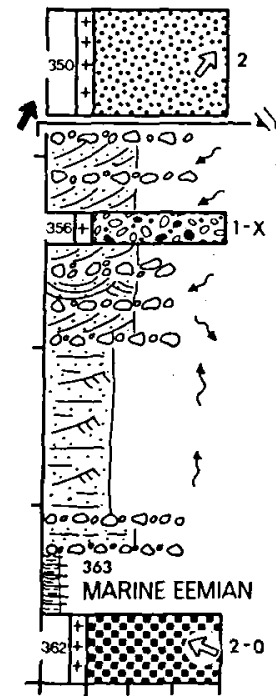

IS3: VEJRG to the Saalian glaciation and concludes, that the Kattegat Till is most probably confined to areas north of South Samsø. The Mid Danish Till deposited by an ice sheet from the NE is not often found in this area and moreover, the East Jylland Till is overlain by a younger Baltic till deposited by the Bælthav readvance.

\section{STRATIGRAPHY (figs 91, 92)}

The oldest till of area 15 , the lower boundary of which is not exposed, is a grey, clayey, massive, quartz poor Baltic till (locs 145, 146, 148, 149, 151,153 ) containing insignificant amount of redeposit Quaternary foraminifera and with fabrics indicating ice movement from a south-easterly direction; SE-(B2-0): The Lillebælt Till. The stratigraphy of the strongly disturbed glacial sequence of loc. 153: Vejrø suggests, that the till is overlain by marine Eemian clay and silt, which in turn is overlain by the previously described lower, fine grained and upper coarse grained waterlaid deposits separating the Kattegat Till and the Mid
Danish Till in area 14. These meltwater deposits are overlain by a brown, massive, clayey, quartz poor, Fennoscandian till at loc. 153 containing an $\mathrm{X}$-foraminiferal accumulation; (B1-X): The Mid Danish Till. Thrust faults indicating ice deformation from the NE, and affecting the Lillebælt Till and overlying waterlaid deposits (loc. 149), are associated with the icestream which deposited the Mid Danish Till.

According to the glacial stratigraphic model, this till should be overlain by the East Jylland Till, but unfortunately this stratigraphic relation has not been found exposed in the present area. However, a brown, massive, quartz poor till (locs $146,150,152)$ of Baltic and intermediate composition with a fabric indicating ice flow from the southeast; (SE-B1/2) is suggested to correspond to the East Jylland Till (fig. 93). It is separated from the overlying till by outwash, deposited by northward flowing meltwater streams and glaciotectonic unconformaties indicating ice pressure from easterly (fig. 93) and south easterly directions. The glaciotectonic thrusting and folding 


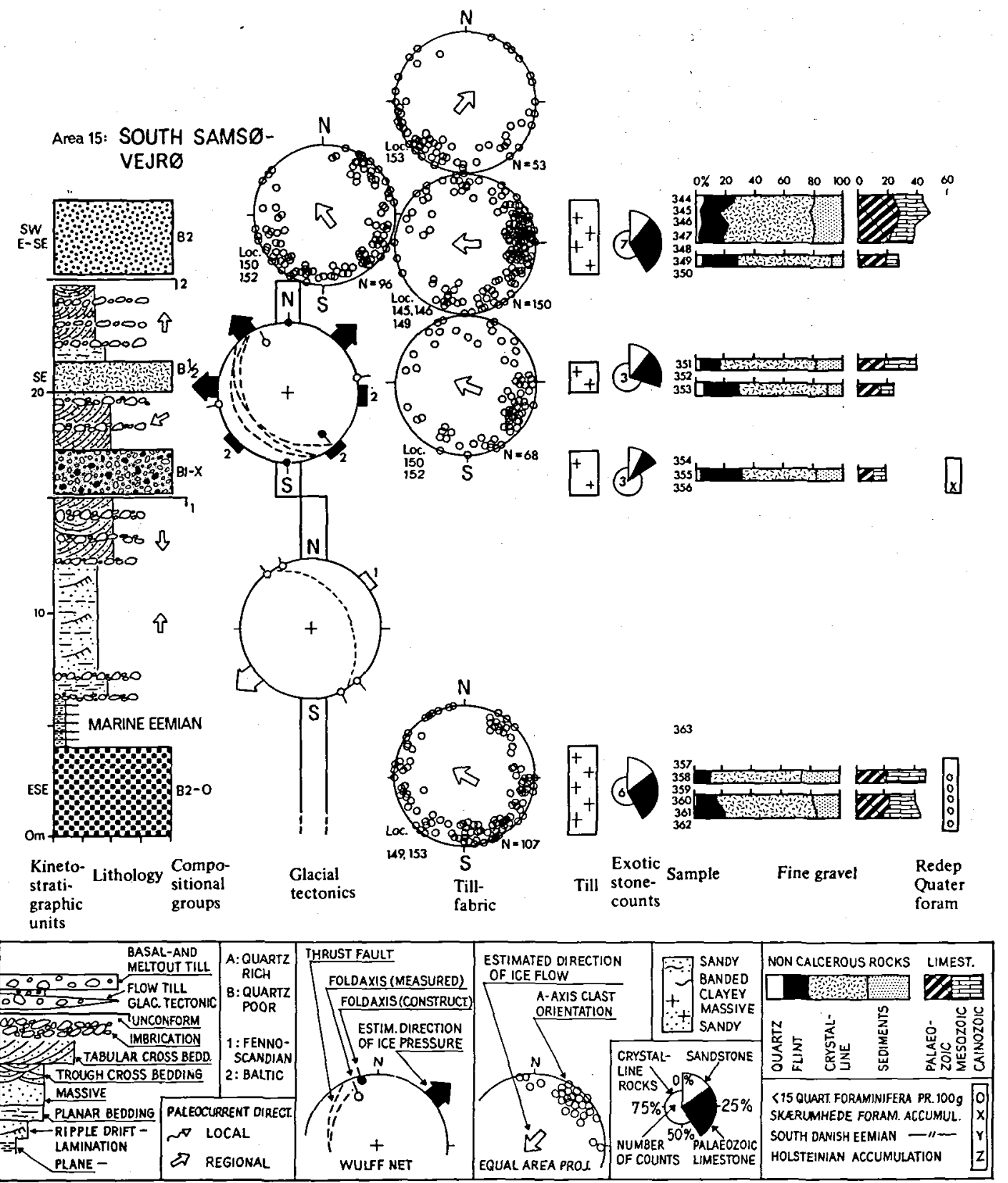

Fig. 92: Glacial stratigraphic data chart, area 15, South Samsø-Vejrø. Till units shown in fig. 43. 


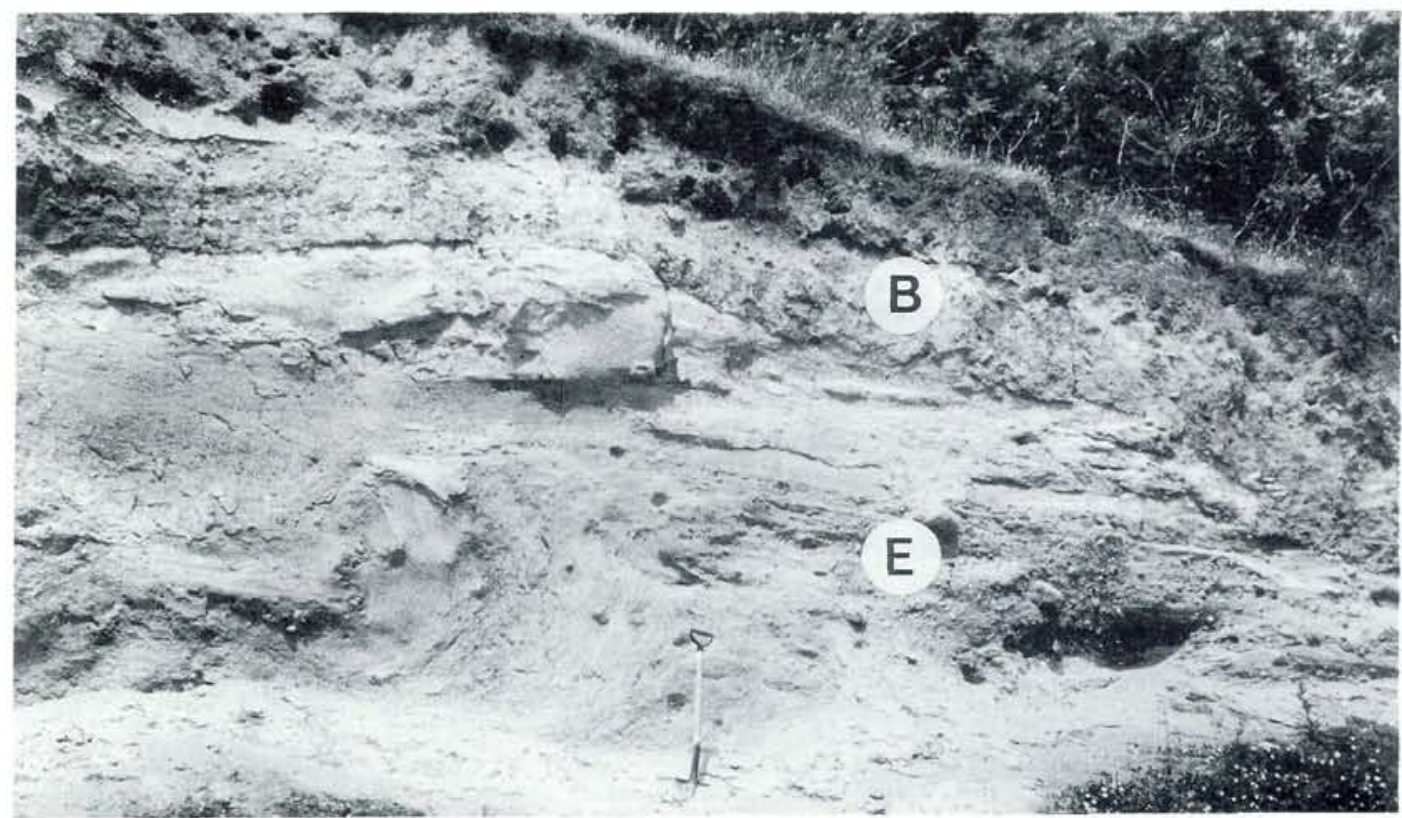

Fig. 93: East Jylland Till (E) overlain by waterlaid sand folded from the east and unconformably overlain by the Brithav Till (B), loc. 146, Vestborg Fyr.

from the southwest at loc. 153 , is also ascribed to the ice sheet which deposited the overlying till. This till is a brown, massive, clayey, quartz poor, Baltic till with fabrics indicating ice flow from the E (locs 145, 146, 149), from the southeast (locs $150,152)$ and from the southwest (loc. 153). This E-SE-SW-till of B2 composition is referred to as the Bælthav Till.

\section{DISCUSSION}

Concerning the Weichselian deglaciation pattern sketched by V.Milthers (1932) and K.Milthers (1942) it must be emphasized, that their interpretation is only to a minor degree based on stratigraphic evidence and depends for the larger part upon the frequency of indicator bounders found mostly in beach gravels or other secondary accumulations. This has already been pointed out by S.A.Andersen (1945). In the northern Lillebælt region, one of the key regions delt with by $\mathrm{V}$. and K.Milthers, it can be shown, that cliff sites often contain two or three Baltic tills and possibly one or two tills of Fennoscandian provenance each presumably deposited by individual icesheets. Therefore, the conclusions presented by V. and
K.Milthers should be regarded with some scepticism. However, indicator counts will often provide important information on the erratic composition of tills present in any cliff site of gravel pit.

The stratigraphic evidence of the present investigation suggests, that the East Jylland Till was deposited by the Young Baltic ice stream which reached the East Jylland Ice border line and that a readvance of this icesheet deposited the Bælthav Till from the E, SE and SW in area 15. The maximum extension of this readvance is proposed to lie between South Samsø and Endelave going in a SW-NE direction through North Sams $\emptyset$ turning eastward and southeastward towards Sejerø.

\section{CONCLUSION}

Four tills interbedded with outwash, deposited by northward and south-westward flowing meltwater currents, are present in area 15 (fig. 105).

The Lillebælt Till is separated from the Mid Danish Till by fine grained, marine Eemian deposits. The Mid Danish Till and its associated glaciotectonic unconformaties, indicating ice press- 


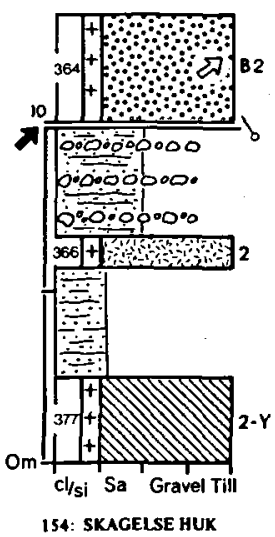

154: SKAGELSE HUK

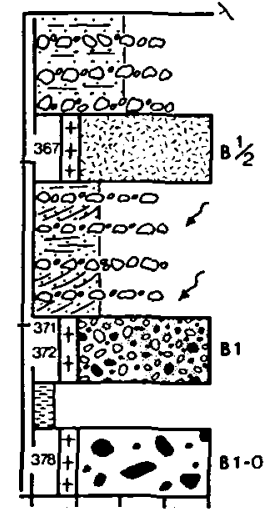

155: ORDRUP NES

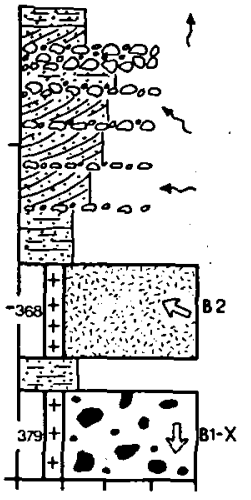

156 : HVIDEKLINT
156 b: SKAMLEBEK

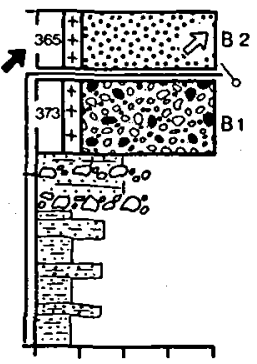

157: KNARBOES KLINT
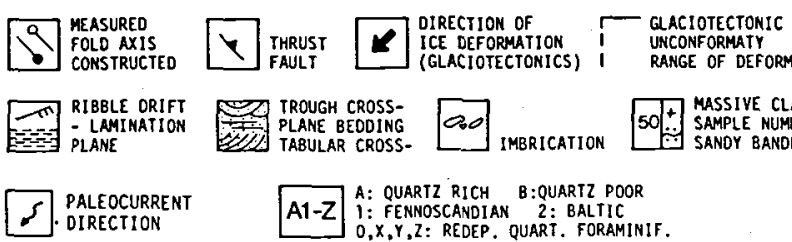
RANGE OF DEFORMATION

C) ICE FLOW OIRECTION GLACIOTECTONICS)
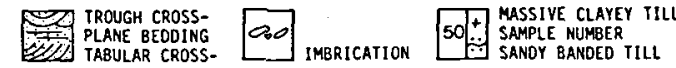
ANALYSES)

\section{A1-Z A: QUARTZ RICH B: QUARTZ POOR} 1: FENNOSCANDIAN 2: BALTIC
$0, X, Y, Z$ : REDEP. QUART. FORAMINIF.

Fig. 94: Simplified lithological logs, area 16, Sejerø Bugt -Saltbæk Vig.

ure from the northeast, is overlain by the East Jylland Till deposited by an ice sheet from the SE. This is succeeded by the Bælthav Till which was deposited during a readvance of the Young Baltic ice stream which had previously reached its maximum extension along the East Jylland Ice border line.

\subsection{AREA 16: SEJERØ BUGT-SALTBEK $V I G$ (locs 154-162, fig. 44)}

Area 16 comprises the coastal areas of NW-Sjælland from Ordrup Næs to the base of the Røsnæs peninsula and the islands of Sejerø and Nekselø. The landscape takes the form of a rather smooth till covered plane upon which submarine ridges forming Neksel $\varnothing$ and Sejer $\varnothing$, and their inland continuation in the form of ice marginal hills are found. Except for loc. 162, which constitutes several gravel pits, all localities are placed along coastal cliffs.

\section{PREVIOUS INVESTIGATIONS}

Rørdam and Milthers (1900) suggest correlation between the surface tills of NW and NE-Sjælland which are both characterized by Fennoscandian and Baltic clast composition. V.Milthers (1900) describes the archshaped hills of Vejrhøj and $\mathrm{R} ø$ snæs as ice marginal hills and the area between them as an interlobate area generated between a western and an eastern ice lobe. V.Milthers (1932) suggests, that the elongated hills of Sejer $\emptyset$ should be interpreted as drumlins formed by movement from the SE by the last ice sheet covering the area.

S.A.Andersen (1964) indicated, that dead ice masses filled the area around Sejerø during the Røsnæs advance; this was also proposed by Gry (1952). During this advance a glacier lying south of Røsnæs deposited outwash material upon the dead ice masses of the former, Young Baltic ice sheet.

Houmark-Nielsen $(1980,1981,1983 c)$ suggests the presence of three Weichselian tills interbed- 


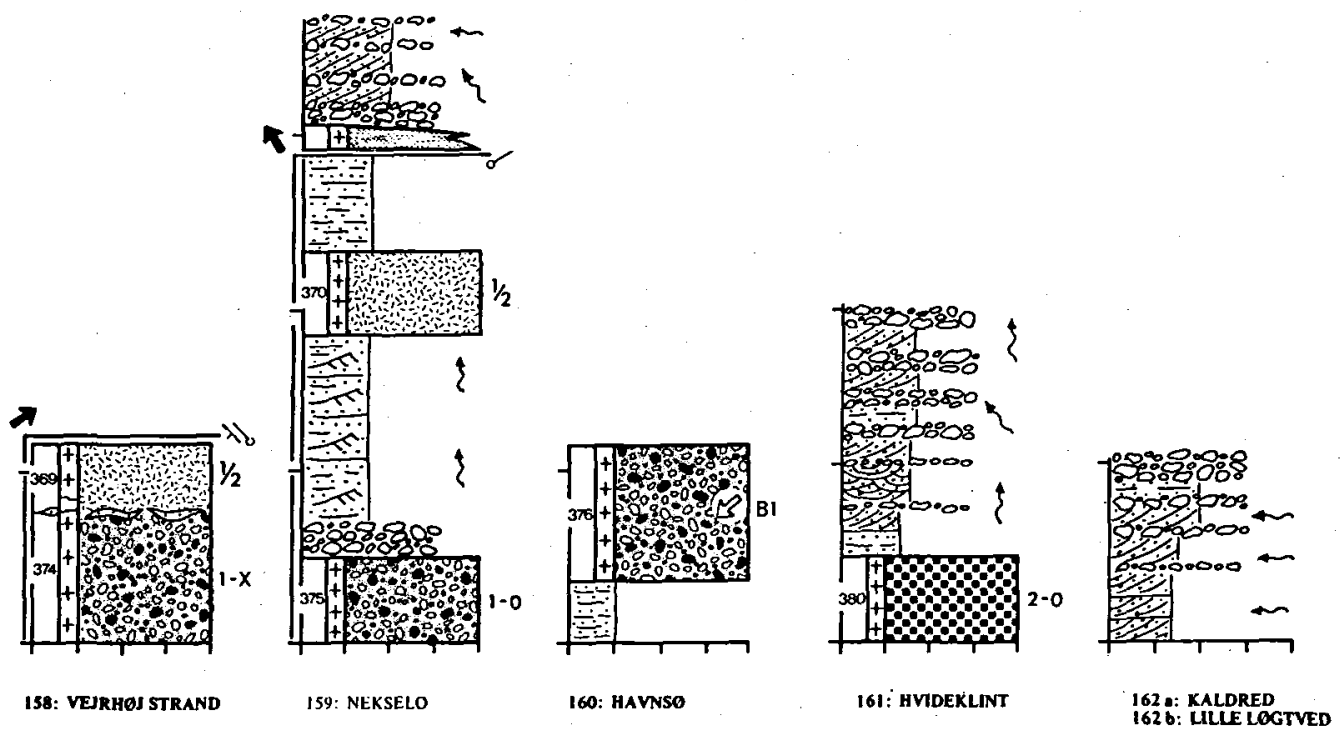

ded with waterlaid deposits in the area; 1) a lower Fennoscandian (and Baltic) till deposited by an ice sheet from the NE which presumably incorporated local bedrock (Baltic till material) to a large extent. 2) the NE advance was succeeded by an advance from southeasterly direction which could have reached the East Jylland Ice border line and deposited a till of intermediate to Baltic clast composition. Finally 3 ) an ice stream (the Balthav advance) deposited a Baltic till from the south west in the western part of the area and from the south east in the eastern part.

\section{STRATIGRAPHY}

Simplified lithological columns from individual localities are shown in fig. 94 and correlated and presented for the whole area in the data chart of fig. 95 .

Two grey, massive, clayey tills of Baltic clast composition constitute the oldest till in the area. In accordance with the stratigraphic model, one with negligable re-deposited Quaternary foraminifera (loc. 161) is correlated with the Lillebælt Till and one containing a Y-foraminiferal accumulation (loc. 154) is correlated with the Ristinge Klint Till. The latter is also found at the principal locality: 8 Kongsh $\varnothing j$ on Sejer $\varnothing$. Still referring to the stratigraphic model the brown to grey, clayey, massive, quartz poor, Fennoscandian till (locs 155, 156) with an X-foraminiferal accumulation and a fabric indicating ice flow from the north (fig. 96); $\mathrm{N}-(\mathrm{B} 1-\mathrm{X})$ is correlated with the Kattegat Till.

This till is overlain by a grey to brown, massive, quartz poor, Fennoscandian till (locs 157, 158, 159,160 ) occasionally containing an X-foraminiferal accumulation and with a fabric indicating ice flow from the north-east; NE-(B1-X): The Mid Danish Till.

Waterlaid outwash, deposited by northward and south-westward directed meltwater streams (locs: 155, 159) separate the Mid Danish Till from the overlying, brown, massive and banded 
Area 16: SEJERØ BUGT-SALTBAEK VIG

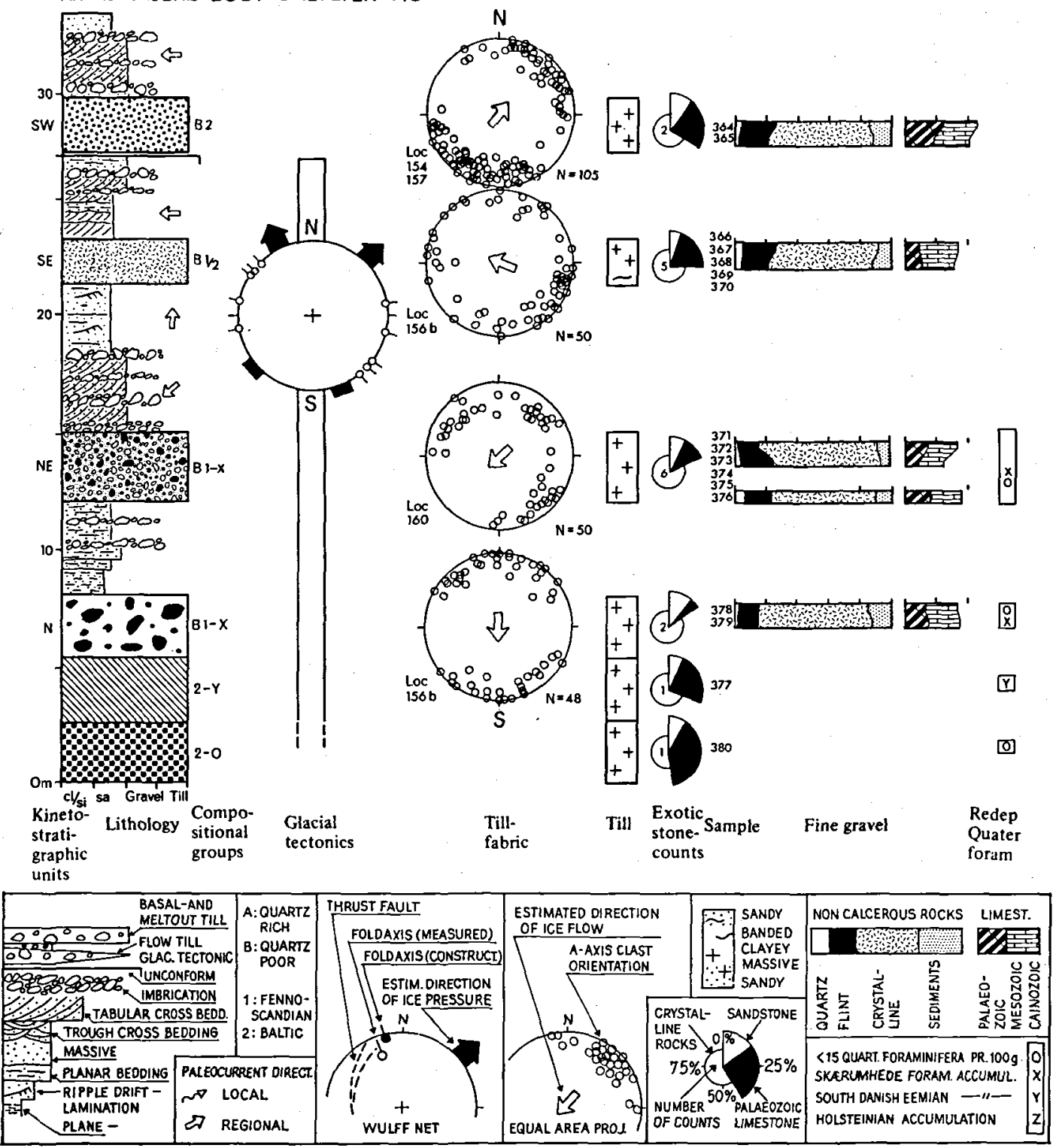

Fig. 95: Glacial stratigraphic data chart, area 16, Sejerø Bug-Saltbæk Vig. Till units shown in fig. 43. 


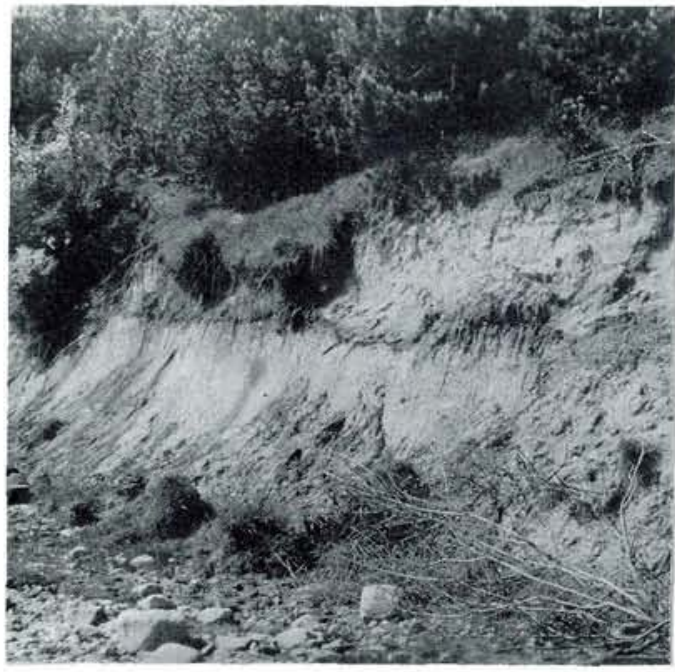

Fig. 96: Kattegat Till overlain by sandy outwash material from the Bælthav Readvance, loc. 156a, Hvideklint.

clayey, quartz poor till of Baltic and intermediate clast composition (locs $154,156,158$ ) with a fabric indicating ice flow from an east-south-easterly direction; ESE-(B/2): The East Jylland Till.

This till is separated by outwash and glaciotectonic unconformities, indicating ice pressure from the SW (locs 154, 157, 158) and the SE (loc. 169), from the overlying brown, massive, clayey, quartz poor, Baltic till (locs 154, 157) with fabrics indicating ice flow from the $\mathrm{SW}$ in the coastal areas; SW-(B2): The Bælthav Till. Waterlaid proximal outwash, deposited by westward moving meltwater streams overlies the Bælthav Till or replace the till laterally.

\section{DISCUSSION}

Unfortunately the stratigraphic relationships between the three older tills have not been found exposed in area 16. It seems possible, however, that the Lillebælt Till is present in the southern part of the area. Apparently the Ristinge Klint Till and the Kattegat Till overlap each other in the area, but their age relationship is only indicated at loc. 185 (area 19) where conditions suggest, that the Kattegat Till is the younger of the two. According to the data from the principal locality 8: (Kongshøj) Sejerø the Ristinge Klint Till overlies limnic deposits of Middle Weichselian age (Sejerø interstadial).
On the coastline north-east of Ordrup Næs the East Jylland Till is overlain by proximal outwash material which coarses upwards and was deposited in front of the classical terminal moraines of NW-Sjælland. It is therefore suggested, that the ice sheet which deposited the younger and the upper, Baltic tills (the Bælthav advance) in area 16 , found its maximum extension along the Vejrhøj ice marginal hills in the coastal area. It is also suggested that its continuation westward along Ordrup Næs follows the submarine ridges and Sejerø towards Sams $\varnothing$. A readvance of the Bælthav ice stream along the Røsnæs peninsula (cf. Berthelsen 1975) towards the Bjergsted area gave rise to the final form of the ice marginal hills of NW-Sjælland and caused deposition of proximal outwash deposits forming the Salbæk Vig sandur.

\section{CONCLUSION}

Apart from the possible presence of the Lillebælt Till, five Weichselian tills, interbedded with waterlaid material, have been observed in area 16 (fig. 105); this includes the data of the principal locality 8 : Kongshøj, Sejerø.

The Ristinge Klint Till and the Kattegat Till are both overlain by the Mid Danish Till which was deposited by an icesheet from the NE. It is overlain by the East Jylland Till which was deposited from the ESE by the Young Baltic ice sheet. A recessional (Bælthav) advance of this ice sheet deposited the Bælthav Till in all but the northeastern part of area 16, where proximal outwash was deposited in front of the ice margin.

\subsection{AREA 17: SJAELLANDS ODDE- NYKØBING (locs 163-171)}

Area 17 is dominated by the roughly north-south trending ice marginal hills of NW-Sjælland. Former islands consisting of glacial deposits have been linked together by Postglacial, marine deposits forming Sjællands Odde towards the west and the Nykøbing-Rørvig peninsula to the east. Localities are placed at coastal cliffs (locs 163, $164,165,167,171)$ and inland gravel pits situated in the ice marginal hills (locs 168, 169, 170). 


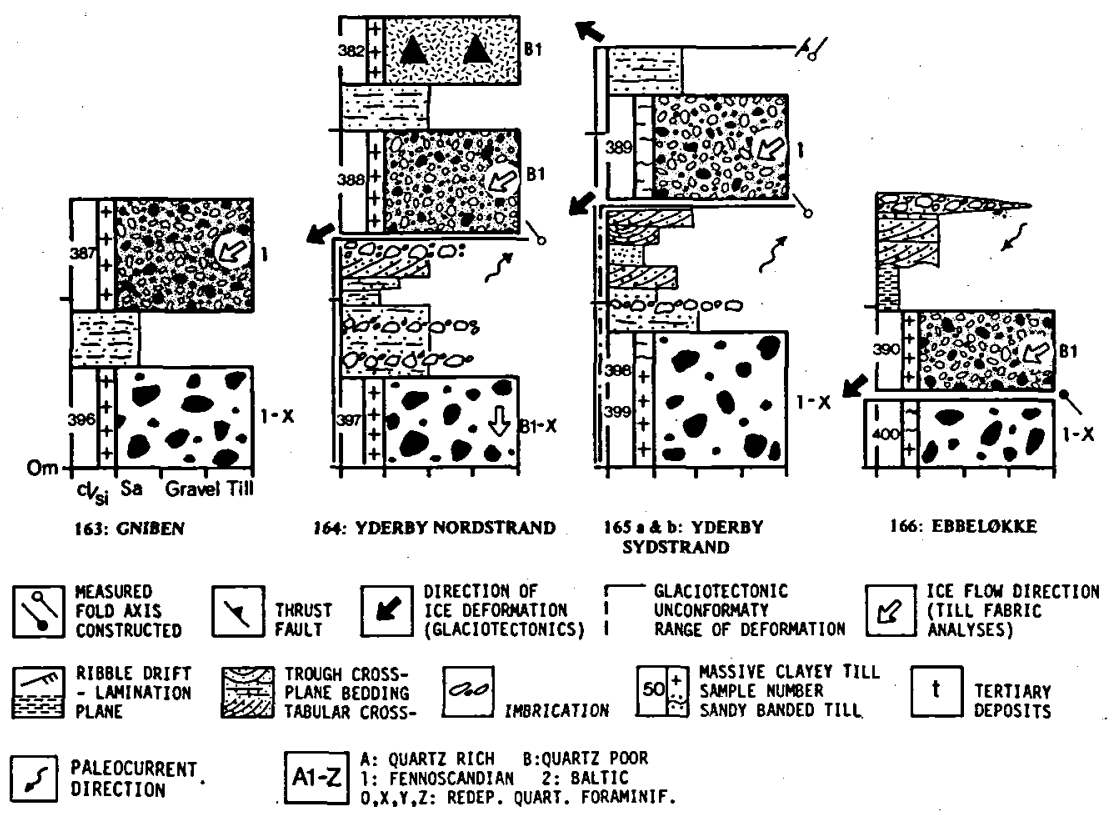

Fig. 97: Simplified lithological logs, area 17, Sjællands Odde-Nykøbing.

\section{PREVIOUS INVESTIGATIONS}

Rørdam and Milthers (1900) present stone counts from the upper till of NW-Sjælland, and suggest that this till was deposited by the Baltic ice sheet which also deposited the upper till of NE-Sjalland. V,Milthers (1900) accounted for the genesis of the elongate $\mathrm{N}-\mathrm{S}$ trending hills of the area by interpreting the "gravel plains" towards the west as an outwash plain. The formation of the hills was ascribed to active glacier push from eastern directions, upon which dump moraines were deposited, and, east of the ridges, the narrow and shallow fjords were interpreted as subglacial depressions.

According to K.Milthers (1942), who counted indicator boulders in beach gravels, it can be concluded, that nowhere in the area can a proponderance of Baltic indicators be found. On the contrary, the counts from Sjællands Odde show a predominance of Norwegian indicators followed by Dala rocks, and with a fair representation of the Kinnekulle diabase from Middle Sweden.

V.Milthers (1948) suggests, that Sjællands Odde constitutes the continuation of the previously described ice marginal zone. Andersen (1950) on the other hand suggests, that the ice marginal zone takes a course eastward towards the coast of NE-Sjælland.

Houmark-Nielsen $(1980,1981,1983 c)$ indicates the presence of four tills separated by outwash deposits in the area. A lower, Fennoscandian till deposited by an ice sheet from the north is overlain by a Fennoscandian till deposited by an ice sheet from the NE. This till is overlain by a Fennoscandian till deposited by an ice stream from easterly directions. Glaciotectonic unconformities on Sjællands Odde, indicating ice pressure from the SE, were associated with this ice advance, which presumably reached the East Jylland ice border line. A Baltic till deposited by an icesheet from south-easterly directions is present behind (east of) the classical ice marginal hills of the area. The internal structure of these hills indicates, that the ice pressure from the E and SE took place after the deposition of the third Fennoscandian till, thus suggesting, that the development of the ice marginal hills and the deposition of the upper, Baltic till took place during the Bælthav re-advance. 


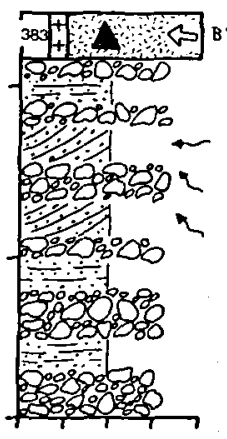

167: KLINTEBJERG

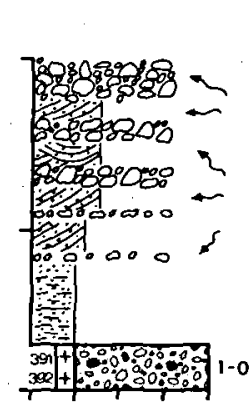

168: HOJBY
168 b: VIG W

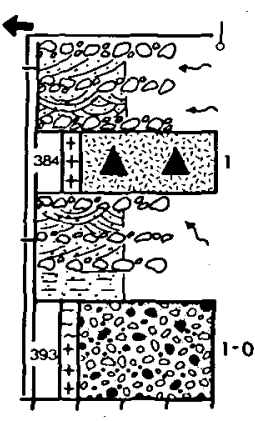

169: HOJBYS

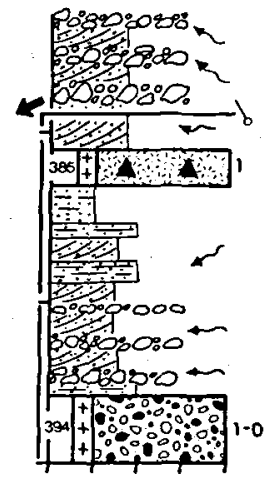

170: ASNES NE

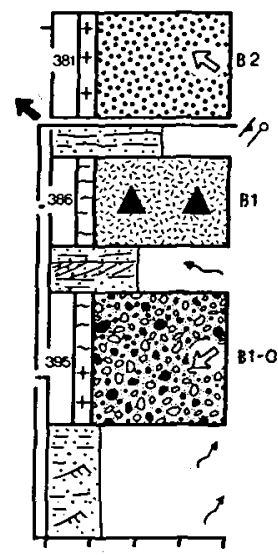

17I: RORVIC S

\section{STRATIGRAPHY}

Simplified lithological columns from individual localities are shown in fig. 97 and correlated and presented for the whole area in the data chart of fig. 98.

The oldest till of the area, the lower boundary of which is not exposed, is a grey, clayey, generally massive, quartz poor, Fennoscandian till (locs $163,164,165,166$ ) containing an $X$-foraminiferal accumulation and with a fabric suggesting ice flow from the north; $\mathrm{N}-(\mathrm{B} 1-\mathrm{X})$ : The Kattegat Till. It is overlain by outwash, deposited by northward moving meltwater streams and separated from the overlying till by glaciotectonic unconformities (locs 164, 165, 166) indicating ice pressure from the NE. The discordant till is a brown to grey, clayey, massive and banded, quartz poor, Fennoscandian till with fabrics indicating ice flow from north-easterly directions and with insignificant amounts of re-deposited Quaternary foraminifera; NE-(B1-0): The Mid Danish Till.

Sandy and gravely outwash material, with a tendency to fine upwards and deposited by west and north-westward moving meltwater streams, separate the Mid Danish Till from the overlying brown, mostly massive, quartz poor, Fennoscandian till which contains a fabric suggesting ice flow from an easterly direction. This E-till of B1 composition corresponds to the North Sjælland Till. In the eastern part of the area (locs 169, 170, 171) the North Sjælland Till is overlain by proximal outwash deposits and superimposed by glaciotectonic structures indicating ice push from the ENE, E and SE. These deposits are unconformably overlain by a brown, massive, clayey, quartz poor, Baltic till (loc. 171) with a fabric indicating ice flow from southeast; SE-(B2): The Bælthav Till. Glaciotectonic structures which affect the Kattegat Till (fig. 99) and the Mid Danish Till (loc. 165) are ascribed to an ice stream transgressing the area from the SE after the deposition of the Mid Danish Till but prior to the deposition of the Brithav Till and the forming of the ice marginal hills of NW-Sjælland.

\section{DISCUSSION}

During the retreat of the ice sheet which deposited the Mid Danish Till deglaciation gave rise to deposition of outwash sediments by north-westward moving meltwater streams. This deglacia- 


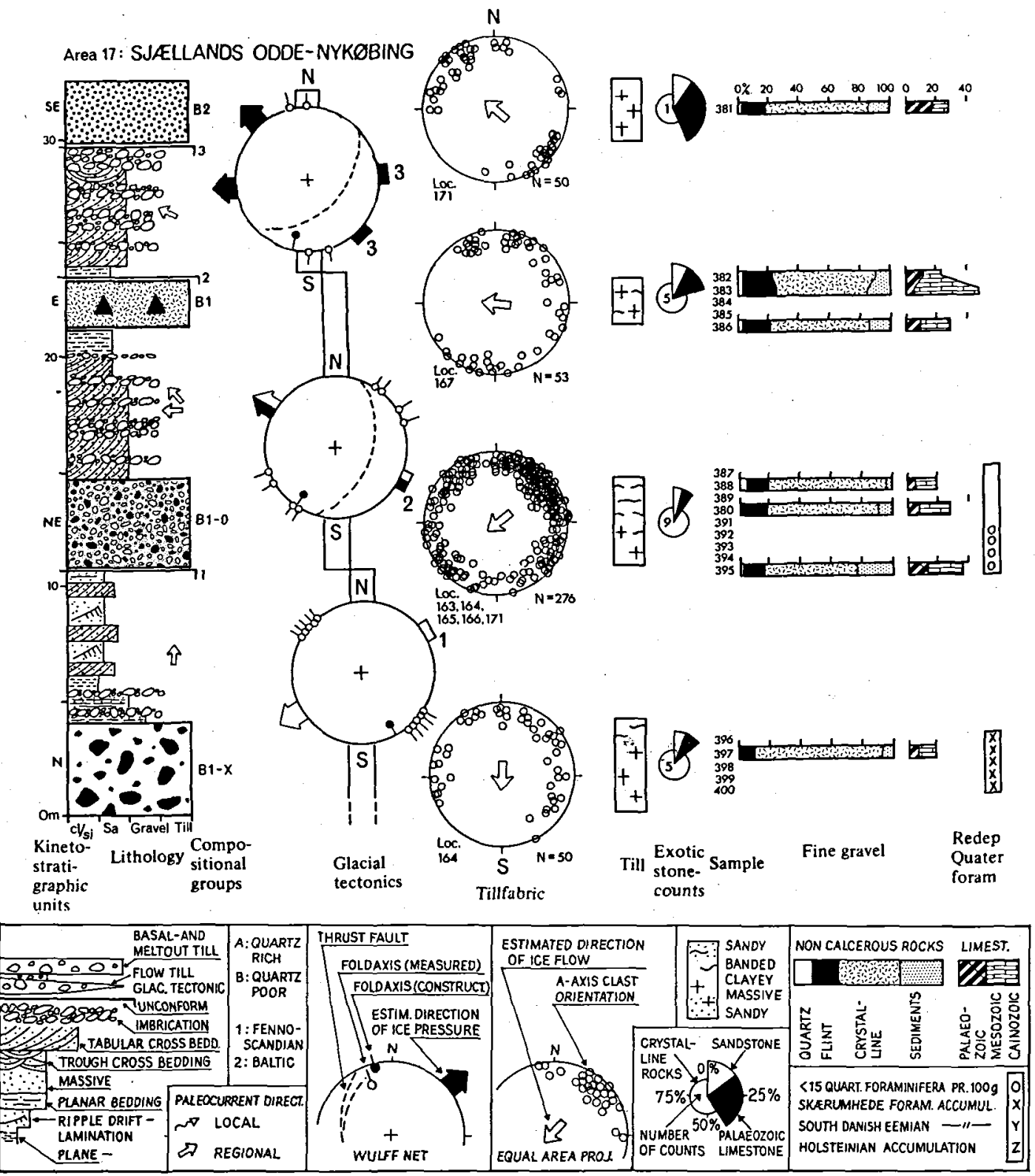

Fig. 98: Glacial stratigraphic data chart, area 17, Sjællands Odde-Nykøbing. Till units shown in fig. 43. 


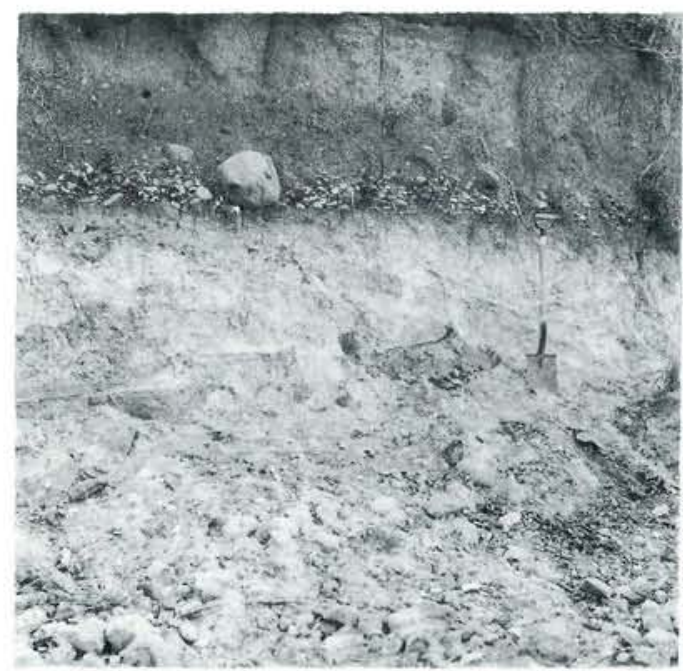

Fig. 99: Kattegat Till folded from the SE and overlain by Postglacial, marine deposits, loc. 165a, Yderby Sydstrand.

tion was interrupted by the transgression of an icesheet which deposited a Fennoscandian till from easterly directions (the North Sjælland Till). Recently (Houmark-Nielsen 1980, 1981, $1983 \mathrm{c}$ ), the deposition of this till from the $\mathrm{E}$ was tentatively connected with the deposition of the East Jylland Till from the SE west of area 17. This was according to the assumption that the ice sheet which reached the East Jylland ice border line on Mols, had its right flank travelling due east across North Sjælland. This ice sheet was assumed to be carrying clast material picked up further upstream outside (NE of) the area in SESweden and the Baltic which is characterized by bedrock mostly composed of Paleozoic limestone rocks. This model for the East Jylland ice sheet is however no longer prefered. This is due primarily to the regional distribution of the younger Fennoscandian and Baltic tills and the directional properties associated with these tills as indicated by the present investigation.

Even though a Baltic till cover has not been found on Sjællands Odde west of the classical ice marginal hills of Odsherred, and the indicator counts of K.Milthers' suggest, that a possible Young Baltic till cover is sparsely represented here, it is suggested, that the icestream, which reached the East Jylland iceborder, transgressed the area from the SE (as recorded at loc. 165 and the previously described area 16) and during deglaciation a readvance deposited the Bælthav
Till. This readvance found it maximum extension along the ice marginal hills of Odsherred.

\section{CONCLUSION}

Four tills interbedded with outwash material deposited by generally north and north-westward flowing meltwater streams have been recognized in area 17 (fig. 105).

The oldest (Kattegat Till) was deposited by an icesheet advancing from northerly directions and was succeeded by a deglaciation phase during which a northward directed meltwater drainage pattern prevailed. The Mid Danish Till was deposited by an ice sheet from the NE; it unconformably overlies the above mentioned deposits, which have undergone glaciotectonic deformation from the NE. Sandy and gravely outwash, deposited by west and north-westward directed meltwater streams, separate this till from the overlying North Sjælland Till which was deposited by an ice sheet from the E and overlain by proximal outwash material deposited by westward flowing meltwater. The outwash deposits was glaciotectonically disturbed from easterly and south-easterly directions by an ice sheet, which deposited the Bælthav Till. Presumably this ice sheet previously occupied the whole of the area during the East Jylland glacial phase. At a later (Bælthav-) stage a readvance caused the formation of the ice marginal hills of NW-Sjælland, which can be connected with those across Storebælt to Samsø.

\subsection{AREA 18: TUSE NAES-HORNSHERRED} (locs 172-180, fig. 44)

Area 18 is located in the central part of North Sjælland comprising the land around Holbæk Fjord, Isefjord and west of Roskilde Fjord. The landscape is characterized by kames and other dead ice topographic features situated on a till covered surface. Localities are placed in coastal cliff sites (locs 173, 175) and at gravel pits and construction sites (locs 172, 174, 176, 177, 178, 179, 180).

\section{PREVIOUS INVESTIGATIONS}

Rørdam $(1893,1899)$ and Rørdam and Milthers (1900) recognized a lower and an upper till separ- 
Area 18: TUSE NAES-HORNSHERRED

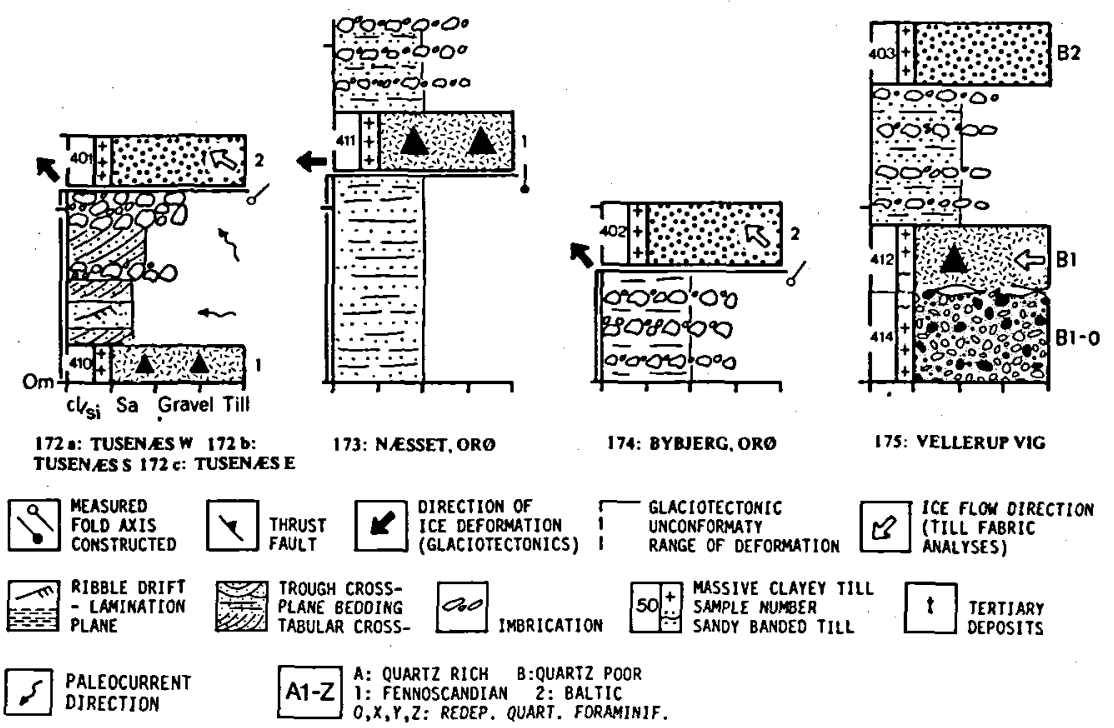

Fig. 100: Simplified lithological logs, area 18, Tuse Næs-Hornsherred.

ated by waterlaid material. Supported by observations of glacially striated bedrock and - boulder pavements in the vicinity of Copenhagen (Rørdam 1899) it was suggested, that an older ice advance from the north and north-east deposited the lower till during the first iceage and a younger ice sheet from the second (last) glaciation deposited the upper till from south easterly and southerly directions.

V.Milthers (1935) suggested, that the lower till was not necessarily deposited by an earlier ice advance than the upper till, and the meltwater deposits interbedding the tills could represent deposition during smaller oscillations of the same icesheet. Andersen (1933) indicates, that the deposition of the Skuldelev esker by meltwater draining northwards was initiated when the Young Baltic ice stream was no longer active.

K.Milthers (1942) suggests the presence of older till material dominated by Norwegian indicators covered with deposits from the Dala-Baltic glacial phase.

Houmark-Nielsen $(1980,1981,1983$ c) suggests the presence of four Weichselian tills interbedded with waterlaid material in the area; three Fennoscandian tills deposited by ice streams from the north, north-east, and east respectively, and overlain by a Baltic till deposited from south easterly directions. The two younger tills were ascribed to two phases of the Young Baltic glaciations: 1) during the older phase an ice stream advanced from the $E$ and is assumed to have reached the East Jylland ice border and 2) a younger phase (the Bælthav phase) in which an ice sheet invaded the area from south-easterly directions and remained south and east of the ice marginal zone of Odsherred.

\section{STRATIGRAPHY}

Simplified lithologic columns from each locality are shown in fig. 100 and correlation and presentation of stratigraphic units for the whole area is shown in the glacial stratigraphic data chart fig. 101.

The oldest till in the area overlies proximal 


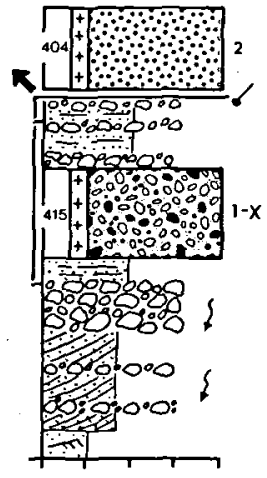

176: KYNIJFLOSL:

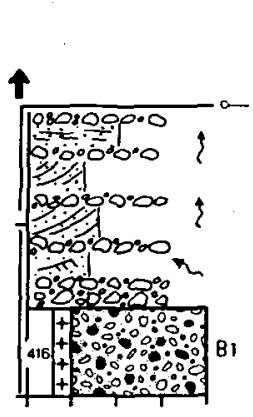

177: KIRKE HYLLINGE

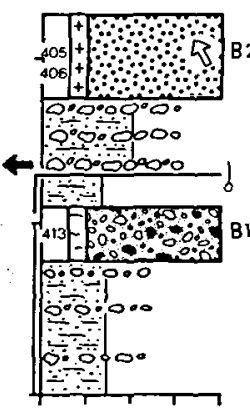

178: SELSO KLINT

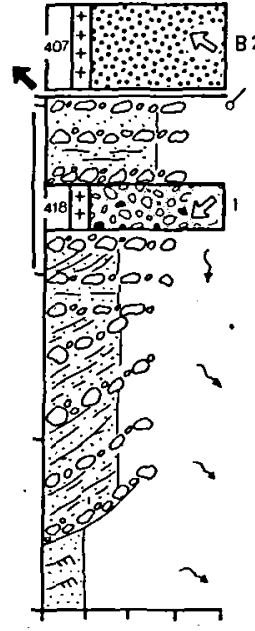

179: KYNDBY

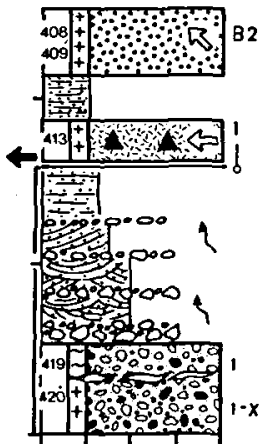

180: LYNGERUP outwash material (locs 176, 178, 179) deposited by southward moving palaeostreams; deltaic deposits at Kyndby (loc. 179) was especially treated from a sedimentological point of view by Clemmensen and Houmark-Nielsen (1981). The till is a grey to brown, clayey, massive and banded, quartz poor, Fennoscandian till (locs 175, 176, $177,178,179,180)$ containing an X-foraminiferal accumulation and with a fabric indicating ice flow from the northeast; NE-(B1-X): The Mid Danish Till. It is overlain by generally coarse grained outwash with a tendency to fine upwards which was deposited by northward flowing meltwater streams. These deposits have been subjected to glaciotectonic disturbances from easterly directions (fig. 33), and are unconformably overlain by a brown, clayey massive, quartz poor, Fennoscandian till (locs 172a, 173, 175, 180) with fabrics indicating ice flow from the east; E-(B1): The North Sjælland Till (fig. 102). It is overlain by proximal outwash material with a tendency to coarsening upwards which was probably deposited by north-westward flowing meltwater streams. This sequence and the underlying deposits have undergone glaciotectonic deformation from southerly and south-easterly directions and is unconformably overlain (locs $172 \mathrm{~b} \& \mathrm{c}$, $174,175,176,178,179,180$ ) by a brown, massive, clayey, quartz poor, Baltic till (fig. 93) with fabrics indicating ice flow from southeasterly directions; SE-(B2): The Bælthav Till.

\section{DISCUSSION}

After a critical review of till fabric diagrams from the lower till of the area (locs 175, 180) shown by Houmark-Nielsen (1980) it seems no longer possible to identify the lower till as that deposited by an ice sheet from the north and to separate it from the till deposited by the NE-ice stream. Because of this and the presence of fairly large quantities of Kinnekulle diabase at the localities in question $(175,180)$, the lower till is correlated with the Mid Danish Till.

The North Sjælland Till was previously regarded as having been deposited by the East Jyl- 
Area 18 TUSENAES-HORNSHERRED

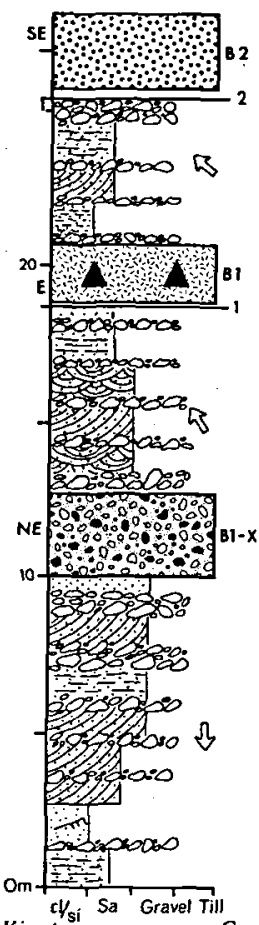

$\begin{array}{ll}\text { Kineto- Lithology } & \text { Comp } \\ \text { strati- } & \text { sition } \\ \text { graphic } & \text { group }\end{array}$ units
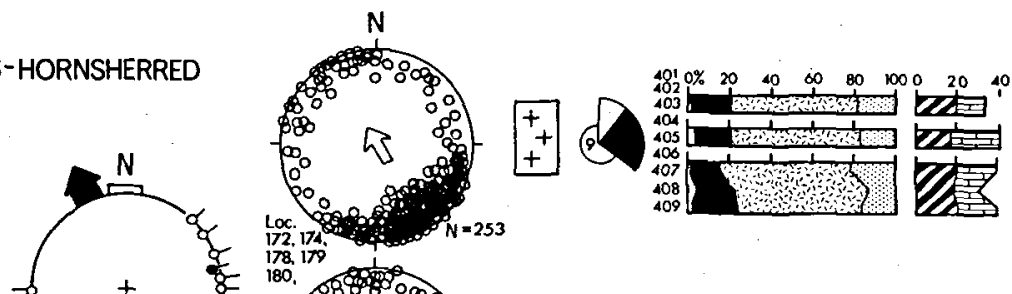

180.
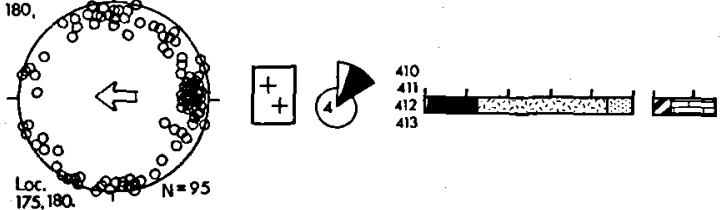

175,180 .
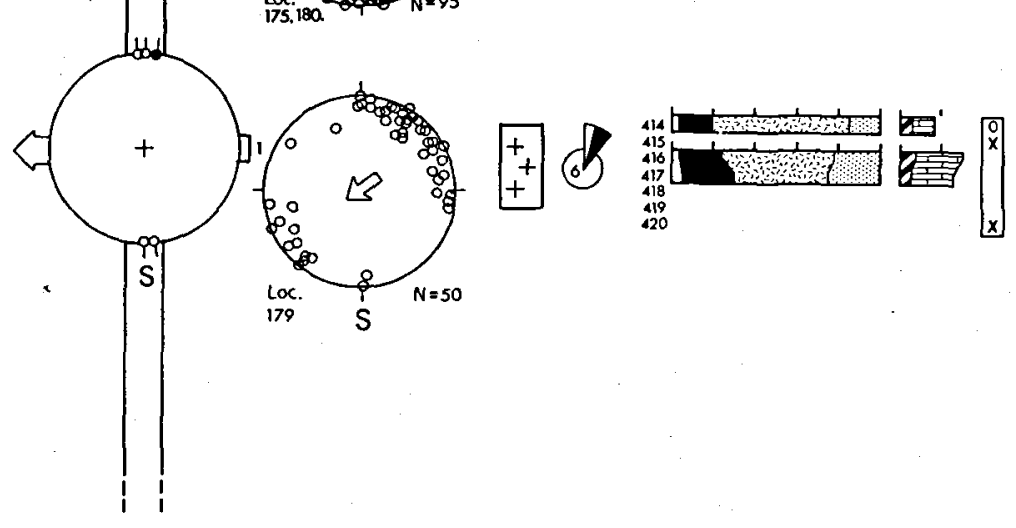

\begin{tabular}{|c|c|c|c|}
\hline \multicolumn{2}{|c|}{$\begin{array}{l}\text { BASAL-AND } \\
\text { MELTOUT TILL }\end{array}$} & $\begin{array}{l}\text { A: QUARTZ } \\
\text { RICH }\end{array}$ & THRUST FAULT \\
\hline \multicolumn{2}{|c|}{$\begin{array}{l}00^{\circ} \circ 00 \text { FLOW THL } \\
00^{\circ} 0^{\circ}=0 \text { GLAC. TECTONIC }\end{array}$} & B: QUARTZ & $\begin{array}{l}\text { FOLDAXIS (MEASURED) } \\
\text { FOLDAXIS (CONSTRUCI }\end{array}$ \\
\hline \multicolumn{2}{|c|}{$\begin{array}{l}\text { SOZZOSOSOE } \text { IMNCONFORM } \\
\text { IMBRICATION } \\
\text { TROUGH CROSS BEODING }\end{array}$} & $\begin{array}{l}\text { 1: FENNO- } \\
\text { SCANDIAN } \\
\text { 2: BALTIC }\end{array}$ & $\begin{array}{l}\text { ESTIM. } \\
\text { OF ICE P }\end{array}$ \\
\hline & \multirow{2}{*}{\multicolumn{2}{|c|}{ PALEOCURRENT OIRECT. }} & \\
\hline PLANAR BEDDING & & & \\
\hline $\begin{array}{l}\text { LAMINATION } \\
\text { PLANE - }\end{array}$ & R & EGAL & $i_{\text {WULFF NET }}^{+}$ \\
\hline
\end{tabular}

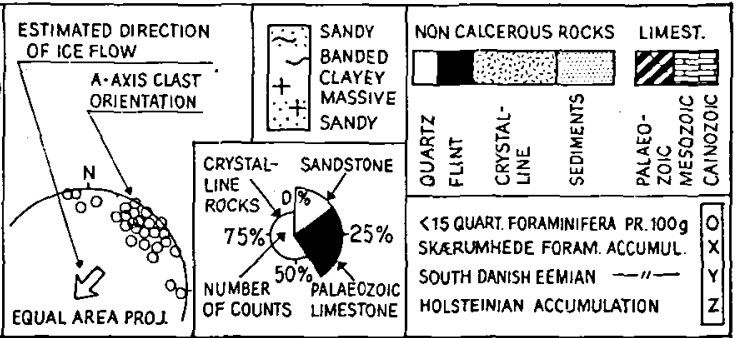

Fig. 101: Glacial stratigraphic data chart, area 18, Tuse Næs-Hornsherred. Till units shown in fig. 43.

land icesheet (Houmark-Nielsen 1980, 1981, 1983a), however, due to its directional properties and Fennoscandian clast composition the till is now regarded as having been deposited by an ice stream after the deposition of the Mid Danish Till but prior to the transgression of the Young Baltic ice sheet.

\section{CONCLUSION}

Three till units interbedded with outwash deposits are present in area 18 (fig. 105).
Southward flowing meltwater streams deposited the lower waterlain sequence during an ice free interval between the ice advance from the north and that from the north-east; the latter of which deposited the Mid Danish Till. The deglaciation of the NE-ice caused the formation of outwash material deposited from northward flowing meltwater streams. A readvance of this ice sheet probably led to the deposition of the North Sjalland Till from the east and was succeeded by the Young Baltic glacial phase, which deposited the Bælthav Till. 


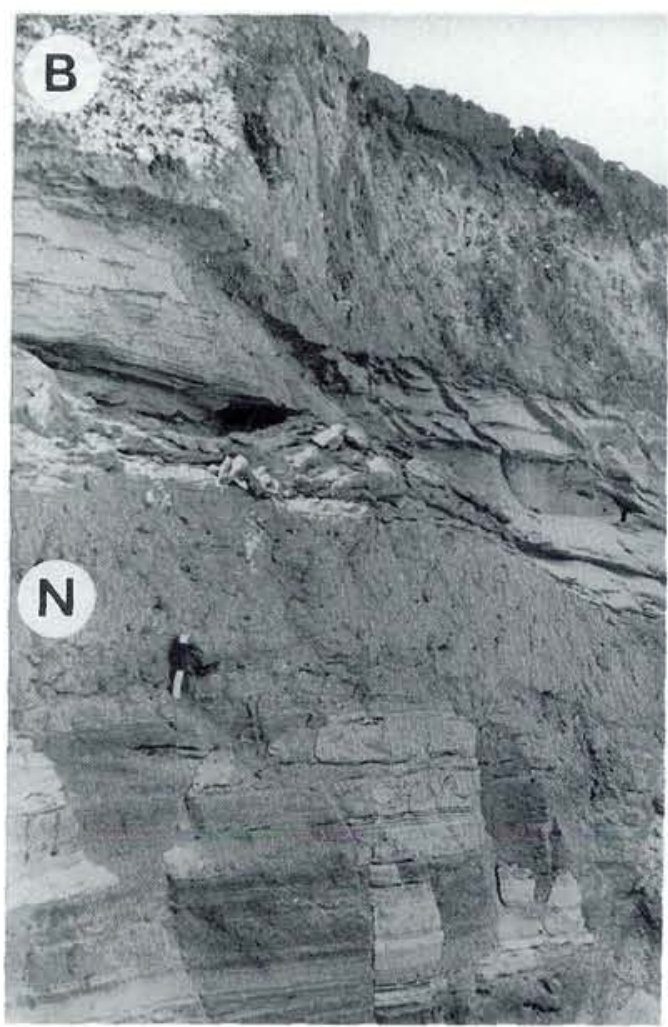

Fig. 102: North Sjælland Till (N) and Bælthav Till (B) separated by finegrained waterlaid material, loc. 180, Lyngerup. See also fig. 42 .

\subsection{AREA 19: FREDERIKSSUND-ARRESØ (locs 181-189, fig. 44)}

Area 19 is situated between Frederikssund in the central part of Roskilde Fjord and Hundested and Tisvildeleje on the Kattegat coast of Halsnæs. The area is characterized by rather hilly country connected by postglacial marine deposits and separated by Roskilde Fjord and Arresø. Localities are placed at coastal cliff sites (locs 181, $185,188,189)$ and gravel pits (locs 182, 183, 184, 186, 187).

\section{PREVIOUS INVESTIGATIONS}

Rørdam (1893) indicate the presence of two till beds, a lower till characterized by Norwegian indicators and molluscan fragments from the older Yoldia clay of Vendsyssel and an upper till characterized by Baltic indicators. The tills are separated by waterlaid material.
Andersen (950) assumes, that those parts of the lower till, which according to Rørdams' (1893) stone counts contain large amounts of Pal. limestone should be correlated with the Old Baltic till of Ristinge Klint.

Petersen and Konradi (1974) and Sjørring (1973, 1974) indicate on the basis of analyses of redeposited Quaternary foraminifera, that the lower till of NE-Sjælland carries a characteristic (X-) accumulation comparable with the foraminiferal fauna found in the arctic zones of the Skærumhede sequence (cf. Bahnson et al. 1974) thus indicating a Weichselian age. Sjørring (1974) and Jensen (1977) show, that a readvance of the ice sheet which deposited the lower till caused deformation of the till and overlying waterlaid material from northerly directions on the Halsnæs peninsula.

In the region immediately east of area 19 Berthelsen (1974) and Rasmussen (1974) suggest the presence of three tills younger than the lower till and deposited by ice streams from the NE, E and SE respectively. Sjørring $(1973,1974)$ and Jensen (1977) suggest, that the ice stream from the E should be regarded as a readvance of the NE-ice. Houmark-Nielsen (1980) disagrees with this theory suggesting, that the ice advance from the $\mathrm{E}$ was part of the Young Baltic glacial phase which reached the East Jylland ice border line. Contrary to Sjørring (1974) and Jensen (1977) Houmark-Nielsen (1980) finds evidence on the Halsnæs peninsula for the presence of a Baltic till deposited from south-easterly directions by an ice sheet younger than that one from the east.

Houmark-Nielsen (1980, 1981, 1983c) suggests, that a supposedly Saalian till (the Palaeobaltic till) is overlain by the so-called Norwegian till of Fennoscandian composition and Weichselian age deposited by an ice-sheet from the north. Fine grained outwash, deposit by northward moving meltwater streams separates this till from the overlying, Fennoscandian NE-till. This is overlain by a Fennoscandian E-till and succeeded by the Bælthav ice-advance, which deposited the upper, Baltic till from south-easterly directions.

\section{STRATIGRAPHY}

Simplified lithological columns of each locality are shown in fig. 103 and units are presented and 

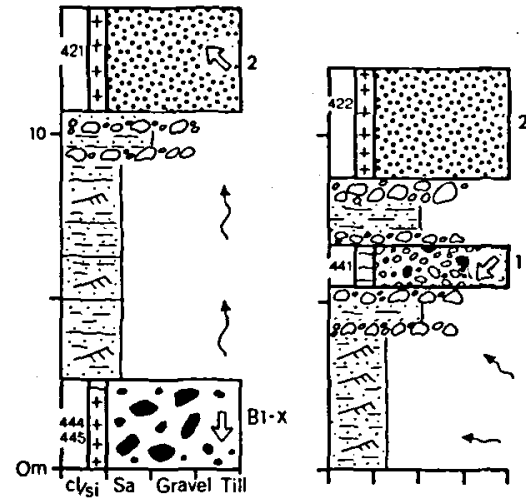

182: HORUP

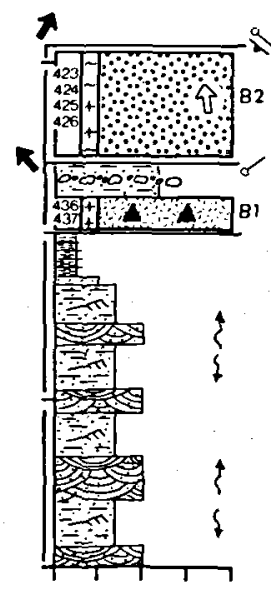

183: OLSTED

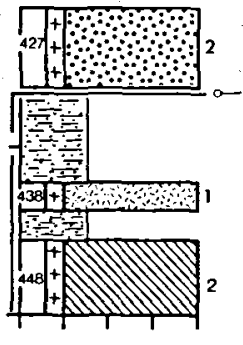

184: LILLE HAVELSE
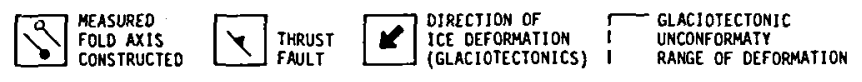

2 ICE FLOW DIRECTION ANALYSES)
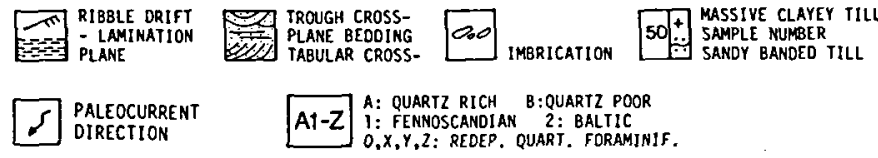
SAMPLE NUMBER

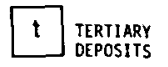

AT-Z A: QUARTZ RICH B:QUARTZ POOR
1: FENNOSCANDIAN 2: BALTIC 1: FENNOSCANDIAN 2: BALTIC
$0, X, Y, Z:$ REDEP. QUART. FORAMINIF.

Fig. 103: Simplified lithological logs, area 19, Frederikssund-Arres

correlated on the glacial stratigraphic data chart (fig. 104).

The oldest till in the area (loc. 185a), overlying sandy meltwater deposits, is a grey, clayey, massive, quartz poor Baltic till containing a Y-foraminiferal accumulation (B2-Y) suggesting, that it could correspond to the Ristinge Klint Till. It has undergone glaciotectonic deformation from a northerly direction. It is presumably older than a grey, clayey, generally massive, quartz poor, Fennoscandian till (locs 181, 185b, 188) with fabrics indicating ice-flow from the north and containing an $\mathrm{X}$-foraminiferal accumulation; N-(B1-X): The Kattegat Till. Apparently this till has undergone glaciotectonic deformation from the north before deposition of the overlying, fine grained outwash. This outwash was deposited first by southward later northward flowing meltwater streams. This sequence is unconformably overlain by a grey, clayey, massive and banded, quartz poor, Fennoscandian till (locs 182, 186a, 189) with fabrics indicating ice flow from the north-east and containing an X-accumulation; NE-(B1-X): The Mid Danish Till. It is overlain by proximal outwash, deposited by south west moving palaeostreams and unconformably overlain by a brown, banded and massive, clayey, quartz poor, Fennoscandian till (locs 183, 185a, 186a) with fabrics indicating ice flow from easterly directions; E-(B1): The North Sjælland Till.

Proximal outwash deposits, overlying the North Sjælland Till and older deposits in the area, have undergone glaciotectonic deformation from the south-east and the south (locs 183, 186). These are unconformably overlain by a brown, banded and massive, clayey, quartz poor, Baltic till (locs 181, 182, 183, 184, 186, 187, 188, 189) with fabric indicating ice flow from southeasterly and southerly directions SSE-(B2): The Balthav Till. This till has been folded and thrusted by icepressure from a south-south-westerly direction (loc. 183).

\section{DISCUSSION}

Houmark-Nielsen (1980) indicated that the socalled Palaeo-baltic till was present in the area, however, renewed investigation of the foraminiferal accumulation from the Baltic till at Kulhuse (loc. 185a) suggests that ii can be characterized as 


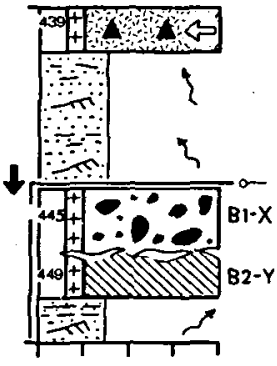

185: KULHUSE N
185: KULHUSE

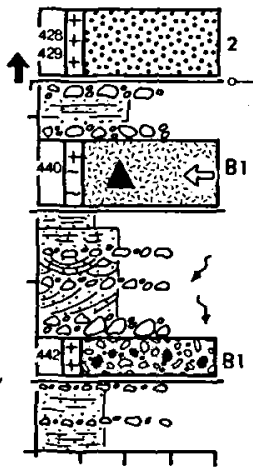

186: AUDERODN 186 b: AUDEROD
186:: ANNISSI:

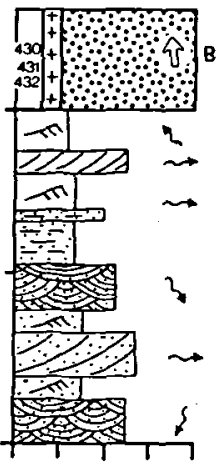

187: ARKENAKKE

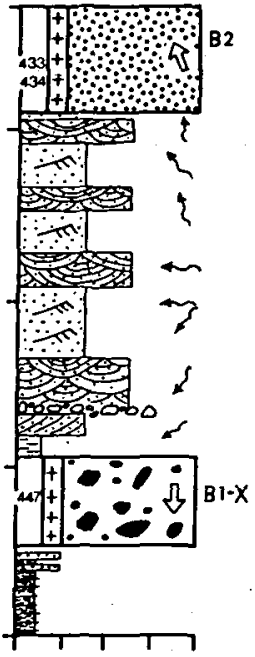

188 :: NODEBO HUSE 188 b: HYLLINGEBJERG a Y-accumulation; because of which it is correlated with the Ristinge Klint Till. In consequence of this correlation, it must be suggested, that the Fennoscandian till found further south (loc. 185b) was deposited by the same ice sheet which dislocated the Ristinge Klint Till from the north (at loc. 185a) and apparently also caused deformation of the Kattegat Till during a readvance recorded $1.5 \mathrm{~km}$ towards the NW at Lynæs, Halsnæs (Jensen 1977). This readvance presumably caused the development of a large Gilbert-type delta in the central part of Hornsherred at Kyndby (Clemmensen \& Houmark-Nielsen 1981).

The Mid Danish Till is only sparsely represented in the area, however, at some sites it is overlain by the North Sjælland Till. The latter till contains a Fennoscandian clast composition and shows a westward directed pattern of movement and must therefore be regarded as having been deposited either by a readvance of the NE-ice or an independent ice stream having no connection with the Young Baltic phase as already stated by Sjørring (1974).

The Bælthav Till was deposited by the Young
Baltic ice sheet, it has not been possible however to recognize the two phases found in the Sams $\varnothing$ and Sejerø areas. The two deformational phases recorded at loc. 183 and separated by the deposition of the Bælthav Till could however be interpreted as the result of a glacier advance followed by a regressive advance after the deposition of the Bælthav Till.

\section{CONCLUSION}

Five Weichselian tills interbedded with outwash material have been identified in area 19 (fig. 105).

The oldest is the Ristinge Klint Till overlain by the Kattegat Till both of which have been dislocated by an ice sheet readvance from the north. Fine grained waterlaid deposits separate these tills from the Mid Danish Till, which in turn is overlain by the North Sjælland Till. This till is overlain by the Balthav Till sporadically glaciotectonically disturbed by a readvance of the Young Baltic icesheet. 
Area 19: FREDERIKSSUND-ARRES $\varnothing$
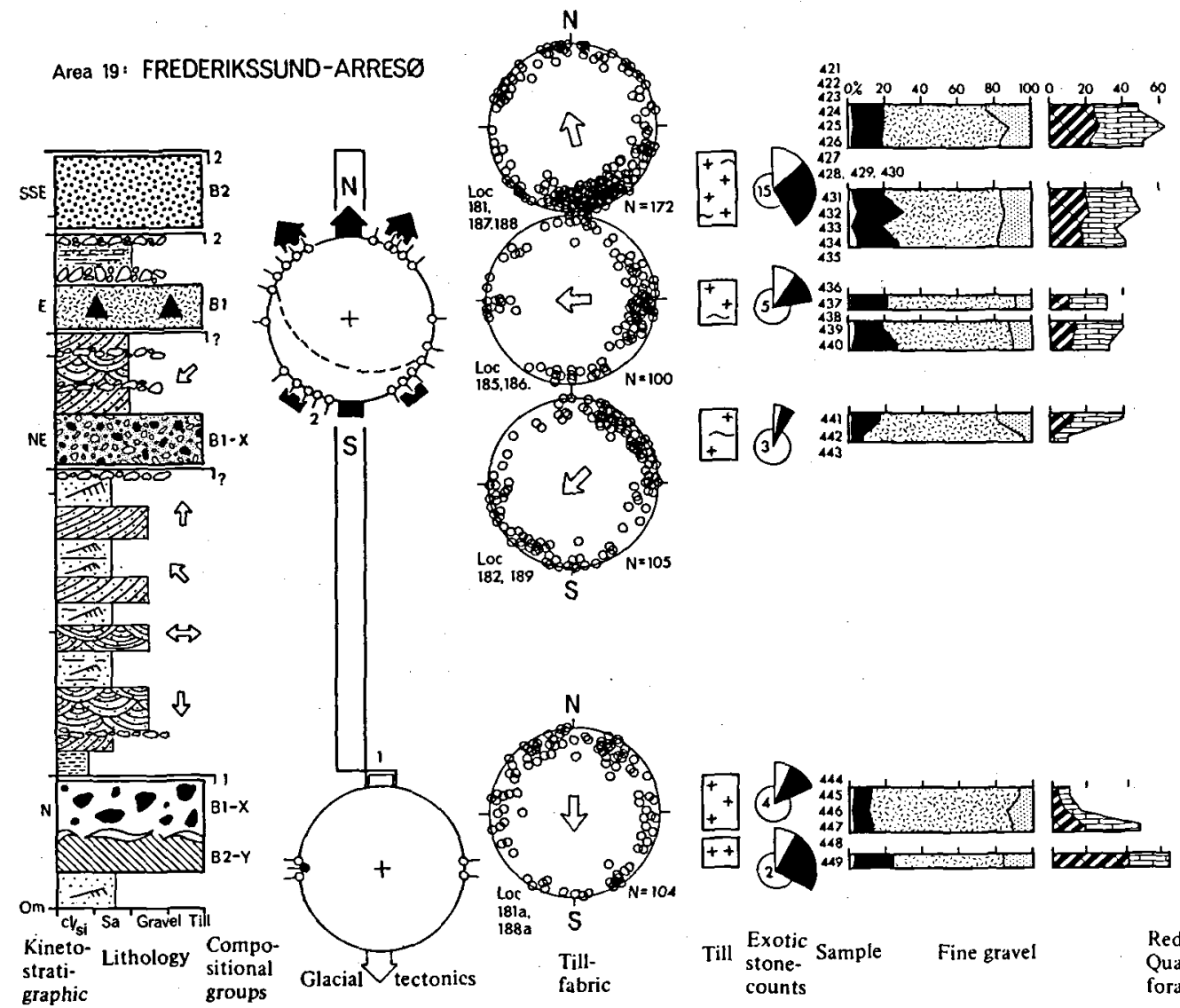

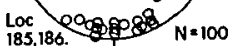
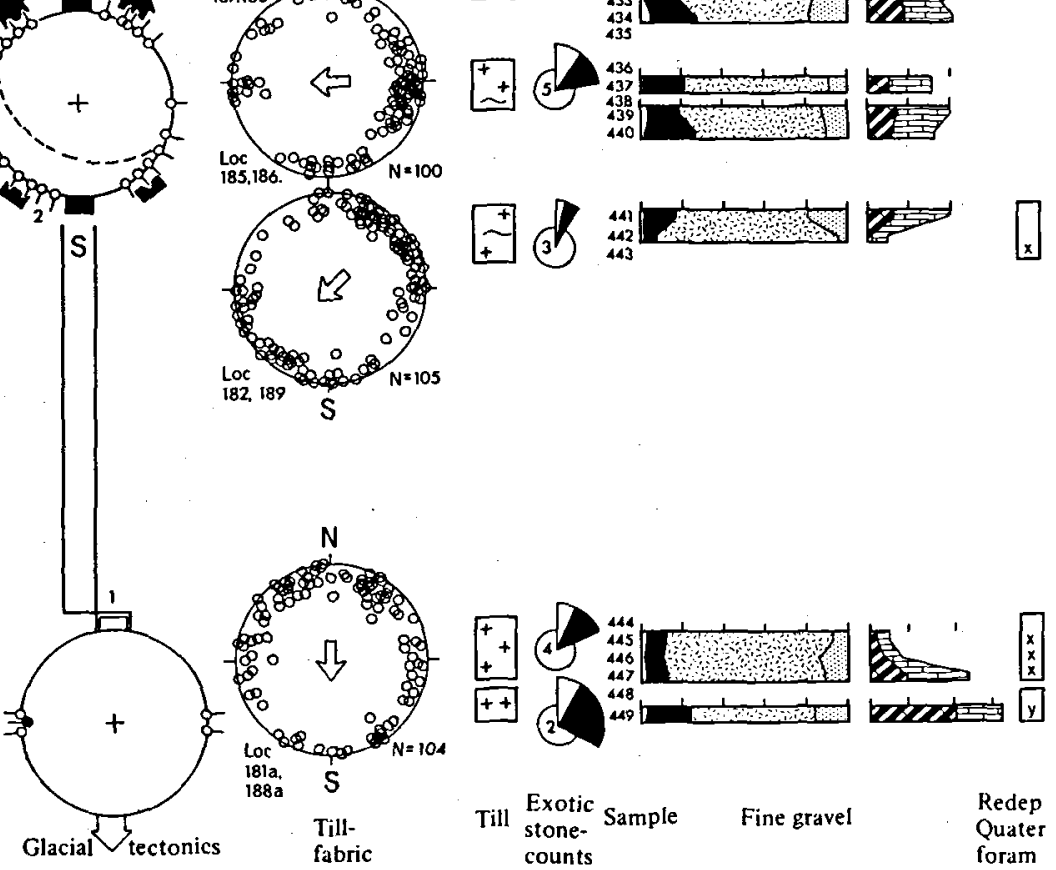
units

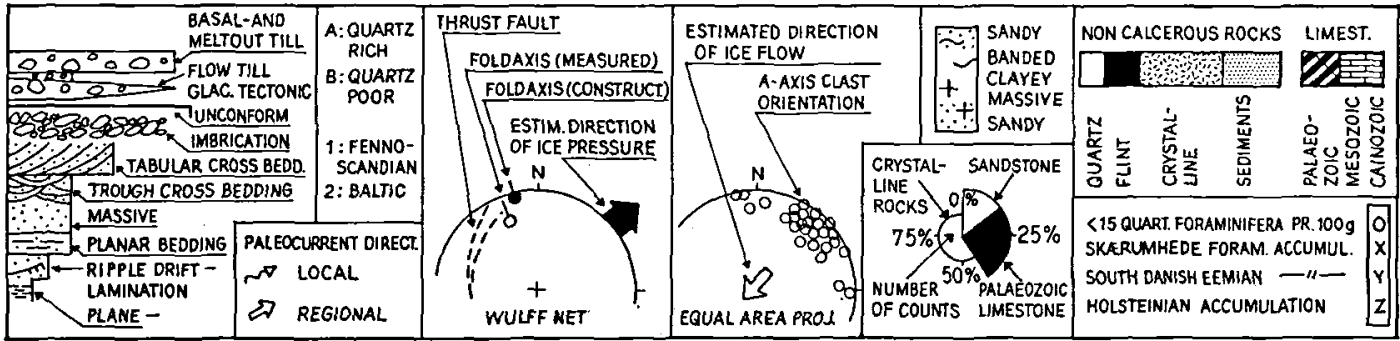

Fig. 104: Glacial stratigraphic data chart, area 19, Frederikssund-Arresø. 


\section{PLEISTOCENE STRATIGRAPHY IN THE CENTRAL PART OF DENMARK}

This section deals with the lithostratigraphic description of till units found in the examined region. Post-Holsteinian till units are formally erected into Formations on the basis of lithology and boundaries, moreover the historical record, the mapped distribution and the possible age will be considered.

Maps present distribution, directional elements and glaciotectonic boundaries for each of the described till units. Special emphasis is placed on the presentation of clast petrographic properties and directional elements. Especially the latter feature is strongly related to the advance, standstill and deglaciation pattern of the ice sheets, which deposited individual till units. Therefore not only the distribution of units and their internal directional elements are pictured, but also the presence of glaciotectonic unconformaties indicating the direction of glacier deformation related to the ice stream which deposited a certain till unit, is shown.

A lithostratigraphical scheme covering the examined 19 areas and their contained principal localities within the central Danish region is shown in fig. 105. 12 lithostratigraphic till units have been identified covering the Elsterian-, the Saalian and the Weichselian glaciations respectively. Till units are interbedded with glaciofluvial or -lacustrine outwash sediments. Age determinated and biostratigraphically classified interglacial-interstadial deposits separate deposits of each of the glacials.

Erected Till Formations are extended to cover informal till units described from extraregional, Danish localities as well as tills found outside the country.

\subsection{LITHOSTRATIGRAPHIC CLASSIFICATION OF TILL FORMATIONS}

\section{SØNDER VISSING TILL}

This till is named Sønder Vissing till after the locality at which it is found. There is apparently no historical record in the literature of this till within the examined region.

\section{TYPE SECTION}

The Sønder Vissing Sand quarry (loc. 33, figs 44, 51) close to Sønder Vissing between Silkeborg and Skanderborg is the only locality, at which the Sønder Vissing Till has been observed.

\section{LITHOLOGY}

Sønder Vissing Till is brown, very sandy and massive and more than $2 \mathrm{~m}$ thick (fig. 106). A fine gravel analysis shows a little less than twice as much quartz than flint ( $42 \%$ and $26 \%$ ). Apparently the original limestone content has been removed by decalcification. The till is also characterized by numerous indicator erratics of the Oslo district found in situ. Due to the limited exposure no textural properties have been attributed to this till.

\section{BOUNDARIES}

Sønder Vissing Till is bound upwards by Trelde Næs Till (fig. 106) and it is separated from Tertiary quartz sand and -gravel by less than $2 \mathrm{~m}$ of glaciofluvial material containing a pronounced ventifacted horizon, of pebbles and stones.

\section{DISTRIBUTION}

Even though the Sønder Vissing Till has only been found at one locality, its distribution is thought to be much wider than the region examined.

$A G E$

Till units of certified pre-Holsteinian age in the examined region have similar quartz/flint relationships to the Sønder Vissing Till. The overlying till at the type section (Trelde Næs Till) has proved to relate to the earliest Saalian advance. It is therefore reasonable to assume that the $\mathbf{S} \varnothing n$ der Vissing Till was deposited during the Elsterian glaciation, even though a greater age can not entirely be ruled out.

\section{CORRELATION}

Since the lithological properties and the bounding conditions of the $\$ ø$ nder Vissing Till are not known in detail, correlation with other pre-Hol- 


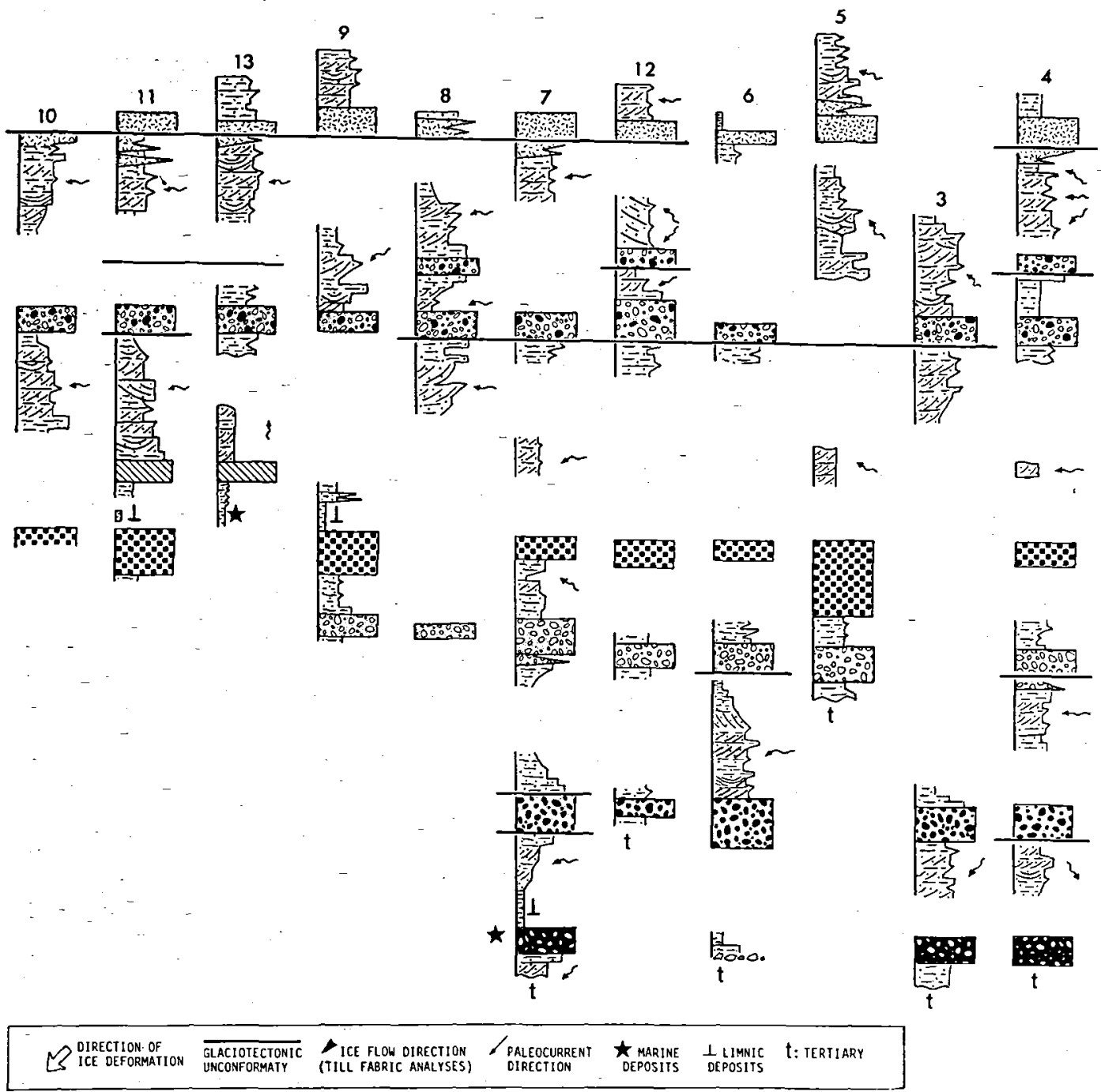

Fig. 105: Stratigraphic scheme of Pleistocene deposits in the central part of Denmark. 
STOREBALT NORTHSJALLAND NE

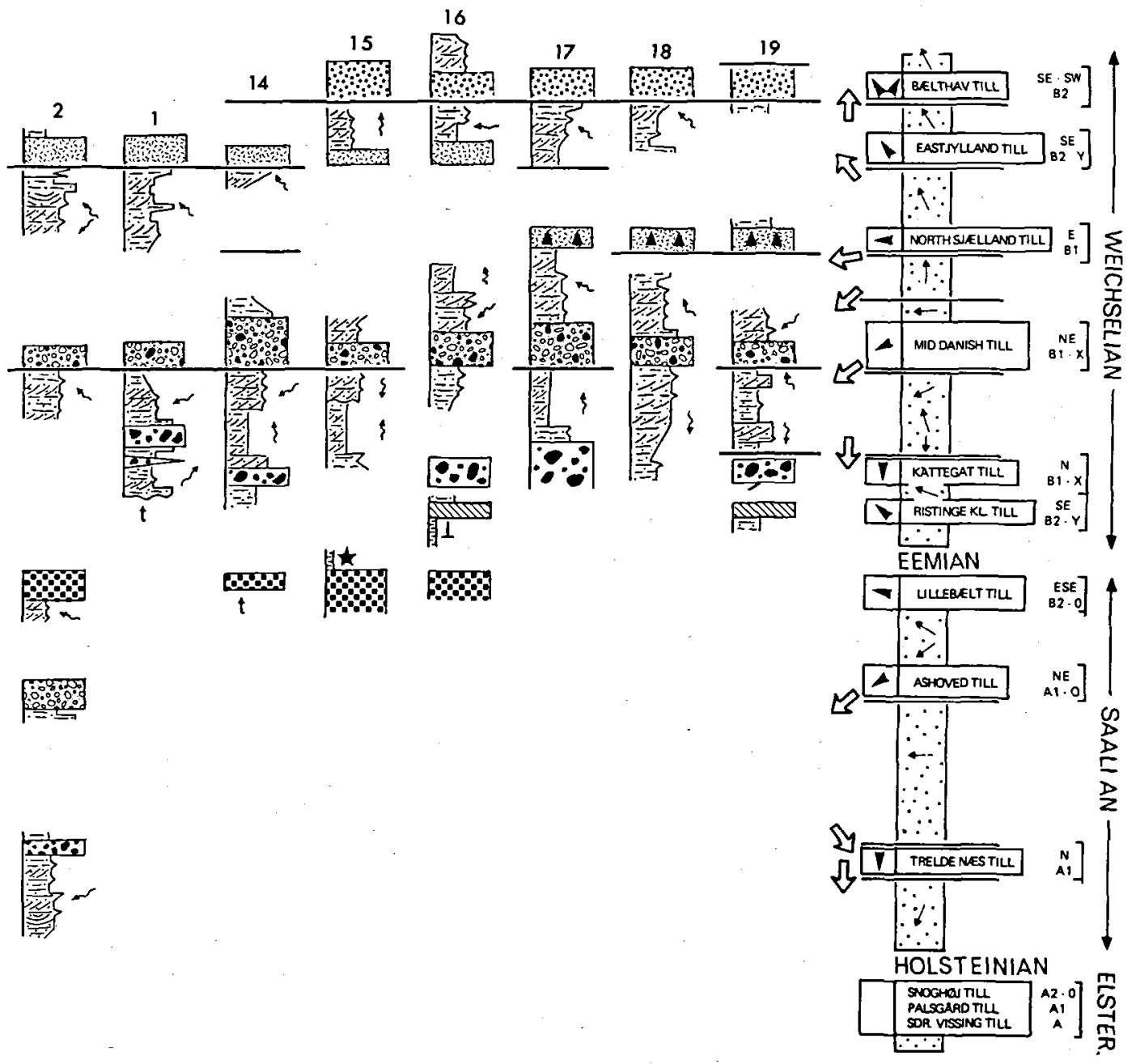




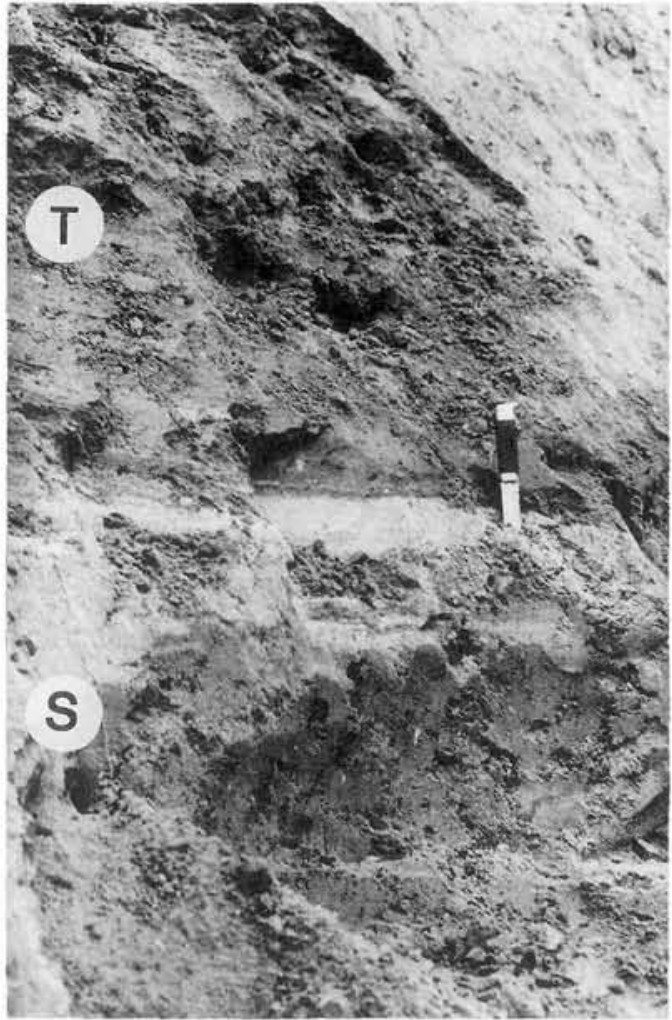

Fig. 106: Sønder Vissing Till (S) overlain by meltwater sand and gravel and Trelde Nas Till (T), loc. 33, Sønder Vissing.

steinian tills is somewhat speculative. However, it can be concluded, that on the basis of fine gravel analyses and when compared with similar counts made by Ehlers (1978), tills of supposed Elsterian age have been found in western Jylland (Sjørring \& Frederiksen 1980). Based on observations of Oslo indicators associated with such tills Sjørring (1981) suggests, in accordance with the older literature (cf. Madsen et al. 1928), the presence of a Norwegian till of Elsterian age in West Jylland. The Sønder Vissing Till is therefore correlated with this Norwegian till. Unfortunately, it is not possible to correlate the Sønder Vissing Till with any tills of suggested Elsterian age described from the central part of Jylland (Kronborg 1983).

The Sønder Vissing Till can, on the same rather loose grounds, be correlated with the lower, Norwegian till of the Elsterian described from northern Germany (Ehlers et al. 1984).

\subsection{PALSGÅR TILL}

This till is named Palsgård Till after the manor adjacent to the type section (loc. 2, Ashoved).

\section{HISTORY}

At Trelde Næs (loc. 1) Hartz and Østrup (1899) recognized a grey, clayey till bed underlying interglacial lake deposits, that are of the Holsteinian Interglacial (S.Th.Andersen 1965, 1967, pers.comm.). Madsen et al. (1928) and Madsen and Nordmann (1940) correlated till A (lowermost till) at Røgle Klint (loc. 3) with the till underlying marine Holsteinian deposits in the Esbjerg area. Sjørring and Frederiksen (1980) suggest, on the basis of the fine gravel analysis, that the pre-Holsteinian till at Trelde Næs and Till A at Røgle were deposited during the Elsterian.

\section{TYPE SECTION}

Ashoved (loc. 2, figs 7, 12): Where the till and its upper boundary is well exposed in a cliff section.

\section{REFERENCE SECTION}

Trelde Næs (loc. 1, fig. 8): Here a pre-Holsteinian age is demonstrated in a well exposed cliff section.

\section{LITHOLOGY}

The Palsgård Till is more than $2 \mathrm{~m}$ in thickness, grey, clayey to sandy and it appears both banded and massive (fig. 107). Fine gravel analyses show about twice as much quartz than flint $(29-20 \%$ and $17-9 \%$ respectively) and exotic stone counts (loc. 2, fig. 13) revealed Fennoscandian clast provenance ( $16 \%$ Pal.limestone). In addition several Kinne- diabase indicators were found in situ. Due to the strongly disturbed nature of the till no textural properties are included in this description.

\section{BOUNDARIES (fig. 105)}

Apart from waterlaid outwash material, the Palsgård Till is upward bound by the Trelde Næs Till. Glaciotectonic unconformaties indicating ice pressure from the north and associated with the deposition of the Trelde Næs Till, may also constitute the upper boundary (locs 1: Trelde Næs, 2: Ashoved). At the former locality the till is overlain by limnic Holsteinian deposits. Assuming corrrespondance between Palsgård Till and the 
lower till (Till A) at Røgle, the Tellina clay may also constitute the upper boundary.

The lower bounding unit is composed of Tertiary clay (locs $1 \& 2$ ).

\section{DISTRIBUTION}

Because the till is only found in very few localities, its exact distribution can not be outlined, however, it is estimated that it has a much wider distribution than the area of the examined region. As the clast provenance of the till is Fennoscandian and it contains associated Middle Swedish indicators (Kinne- diabase) is it suggested, that the Palsgård Till was deposited by an ice stream from north-easterly directions.

\section{$A G E$}

As the presumably, oldest Saalian till (Trelde Næs Till) overlies the Palsgård Till at localities where this till is found and because it underlies limnic Holsteinian deposits at Trelde Næs (loc. 1), it is estimated that the Palsgård Till has a preHolsteinian age. Even though the till rests on Tertiary clay, and interglacial/interstadial deposits of Harreskovian or early Elsterian age have not been found to underlie the till, an Elsterian age is proposed. However, a greater age can not entirely be excluded.

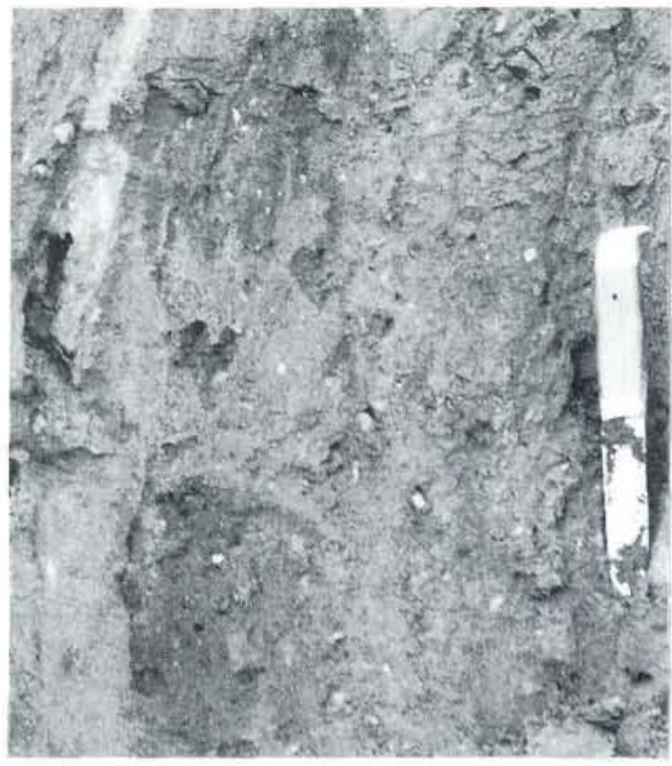

Fig. 107: Palsgård Till, loc. 2, Ashoved. (See also fig. 14).

\section{CORRELATION}

On the basis of the data presented above, it has been difficult to correlate Palsgård Till with extraregional till units of presumed Elsterian age described in the literature.

North of the examined region the Palsgård Till is tentatively correlated with the lower till of Rugård on the east coast of Djursland (Kronborg \& Knudsen 1985); in spite of the extreme low quartz content and very high values of flint contained in this assumingly pre-Holsteinian till.

\subsection{SNOGHØJ TILL}

This till is named after the hamlet of Snoghøj in Jylland immediately west of the old Lillebæltbridge south of Fredericia. The till has apparently not previously been described in the literature from the examined region. However, V.Milthers (1939) mentions the presence of a Baltic, preHolsteinian till in the Brande area, central West Jylland.

\section{TYPE SECTION}

Loc. 70: Sønderskov-Snoghøj (figs 44,66 ) is the only site at which the Snoghøj Till has been observed.

\section{LITHOLOGY}

The Snoghøj Till is more than $2 \mathrm{~m}$ thick, grey to brown, clayey and both massive and banded (fig. 108 ). Fine gravel analyses show about $20 \%$ quartz and less than 10\% flint (fig. 67). Exotic stone counts demonstrate Baltic clast provenance ( $25 \%$ Pal.limestone). The till has not been found to contain re-deposited Quaternary foraminifera in noteworthy quantities.

\section{BOUNDARIES (fig. 105)}

The Snoghøj Till is upward bound by the Trelde Næs Till. Waterlaid outwash material separates it from underlying Tertiary deposits.

\section{DISTRIBUTION}

Because the Snoghøj Till is exposed at just one site, its distribution within the examined region is highly ambigous. However, the till in question can be compared with extra-regional till units, on which grounds its distribution must lie far beyond the examined region. It is suggested, on the basis of clast composition, that the Snoghøj Till was deposited by a Baltic ice stream. 


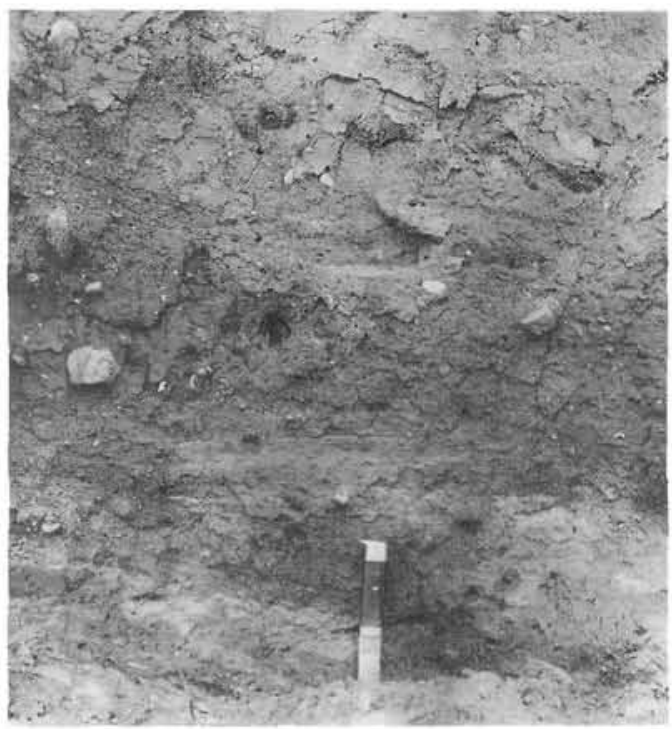

Fig. 108: Snoghøj Till, loc. 70, Sønderskov-Snoghøj.

\section{$A G E$}

The Snoghøj Till is overlain by the presumably oldest Saalian till, and its quartz/flint relationship equals that of other tills older than the Trelde Næs Till, therefore, a pre-Saalian age is suggested. Even though it could have been deposited during older glaciations, it seems most reasonable to propose an Elsterian age for the Snoghøj Till.

\section{CORRELATION}

Even though lithostratigraphical data are sparse, Snoghøj Till is correlated with the Baltic, quartzrich and flint-poor till supposedly deposited by an icesheet from easterly directions in western Jylland during the Elsterian (V.Milthers 1939, Sjørring 1981). In addition, the till is tentatively correlated with the till deposits of Baltic composition appearing at the surface in the so-called Baltic enclave (V.Milthers 1955) in western, central Jylland, which, according to Sjørring (1983), most probably belong to the Elsterian.

The Snoghøj Till is also correlated with the proposed pre-Holsteinian till largely containing twice as much quartz than flint and deposited by an ice sheet from easterly directions described from Gyldendal in the western Limfjord region (Jensen \& Knudsen 1984).

Outside the country the Snoghøj Till could cor- respond to the Elsterian till of Eastbaltic facies (Younger Elsterian till) mentioned by Ehlers et al. (1984). This till supposedly covers large parts of the countries along the south coast of the Baltic Sea.

\subsection{TRELDE NAS TILL FORMATION}

The till is named the Trelde Næs Till after the type section located at Trelde Næs (loc. 1) north of Fredericia.

\section{HISTORY}

Hartz and Østrup (1899) mentioned the presence of a till overlying the interglacial, lake deposits of Trelde Næs. Madsen (1900) recognized a lower dark, Fennoscandian till at Ashoved (loc. 2) and Æbelø (loc. 4) and ascribed the dominance of Norwegian indicators in recent beach gravels to have been derived from this till. Rørdam (1909) correlated the Fennoscandian, "Norwegian", till of North Sjælland characterized by re-deposited molluscan fragments from the Older Yoldia clay, with the lower tills of Ashoved and Æbelø. V.Milthers (1932) confirmed Madsens interpretation of the clast composition of the lower tills of Ashoved and Æbel $\varnothing$ by systematic indicator counts in beach gravels.

K.Milthers (1942) ascribed the dominance of Norwegian indicators to the presence of a possibly late Saalian or early Weichselian till of Norwegian origin at the cliff sites just mentioned. Madsen et al. (1928) and Madsen and Nordmann (1940) suggest on the basis of the flint quotient, that till A of Røgle Klint was deposited during the Elsterian and till B during the Saalian; both tills show a Fennoscandian clast composition.

Nordmann (1958) indicated, that the till overlying the limnic, interglacial deposits at Trelde Næs was strongly disturbed by ice pressure from the west. At Stjær (loc. 27) Kronborg (1983) described a (lower) sandy, brown till assumed to be deposited by an ice sheet from northerly directions and overlain by a NE-till. The N-till is named the Søbyvad till and is supposed to be of Elsterian age.

\section{TYPE SECTION}

Trelde Næs (loc. 1, figs 7,8). In a well exposed cliff section strongly disturbed by glaciotectonic activity the Trelde Næs till and its bounding units are readily accessible for study. 

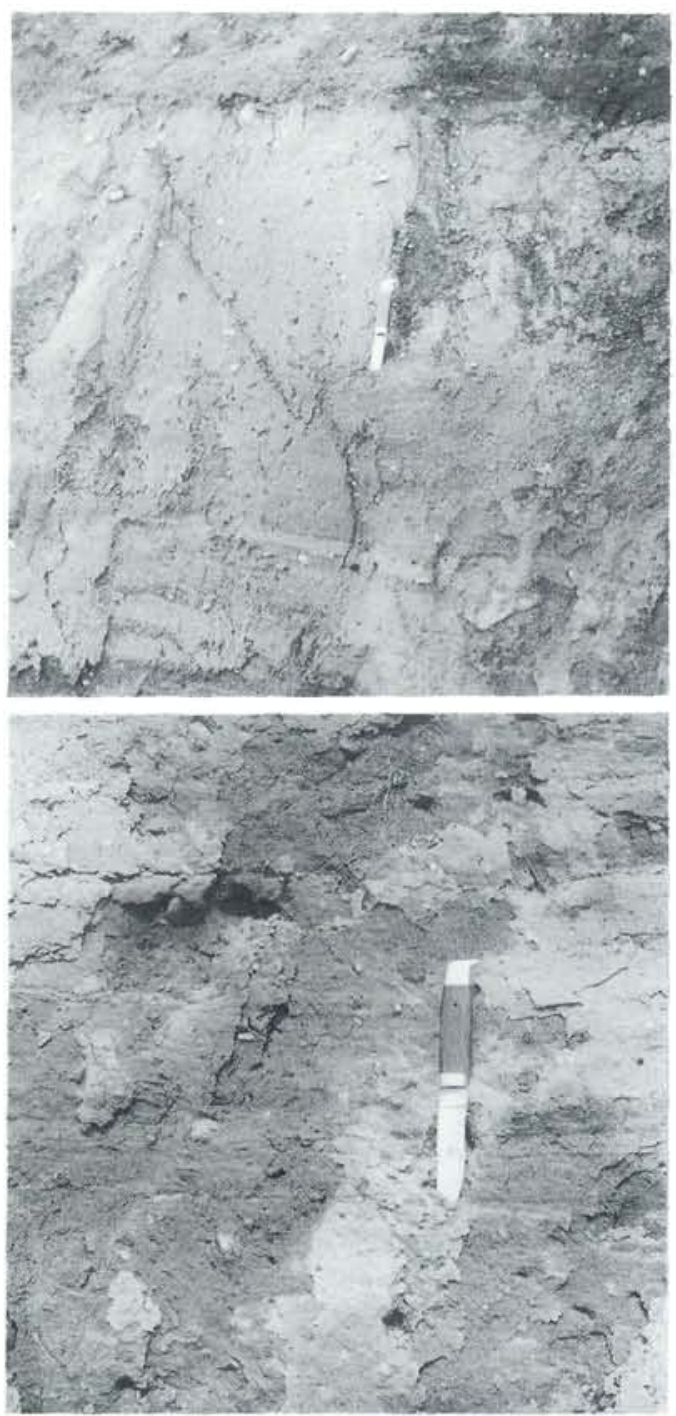

Fig. 109: Trelde Nas Till, loc. 1, Trelde Nas (upper), loc. 2 , Ashoved (lower).

\section{REFERENCE SECTIONS}

Ashoved (loc. 2, figs 7, 12) and Æbelø (loc. 4, figs 7,23 ), where the upper boundary is exposed. Sønder Vissing (loc. 33) and Snoghøj (loc. 70) where the lower boundary to glaciogenetic deposits is exposed.

\section{LITHOLOGY}

Trelde Næs Till (fig. 109), which ranges in thickness between 3-5 meters, is brown or blackish to grey, sandy and often banded. Fine gravel analyses show roughly equal amounts of quartz and flint $(9-29 \%)$ with an average of $18 \%$ each, and stone counts demonstrate Fennoscandian clast composition with an average of $12-15 \%$ Pal.limestone (fig. 110). A few samples analysed contained insignificant quantities of re-deposited Quaternary foraminifera. The Trelde Næs Till seems to be characterized by erratics of the Oslo District and other rocks of northerly provenance such as cemented fragments of ash bearing diatomite (Fur Formation: Pedersen \& Surlyk 1983 ) and the so-called "flint conglomerate" (Ødum 1968, Sjørring \& Frederiksen 1980). These associated rocks and indicator erratics can be found in situ, but they appear more frequently in beach gravels or gravel pits where the Trelde Næs till is exposed.

Measurements of clast orientation revealed north- and north-westward dipping longitudinal and mixed fabrics, indicating deposition by a glacier from northerly directions.

\section{BOUNDARIES (fig. 105)}

Usually Trelde Næs Till is bound upwards by the Ashoved Till (locs 1, 3, 4, 27, 70). They are often separated by waterlaid outwash material deposited by meltwaterstreams that reveal generally south westerly palaeoflow directions. At Trelde Næs a glaciotectonic unconformity indicating ice deformation from the NW constitutes the upper

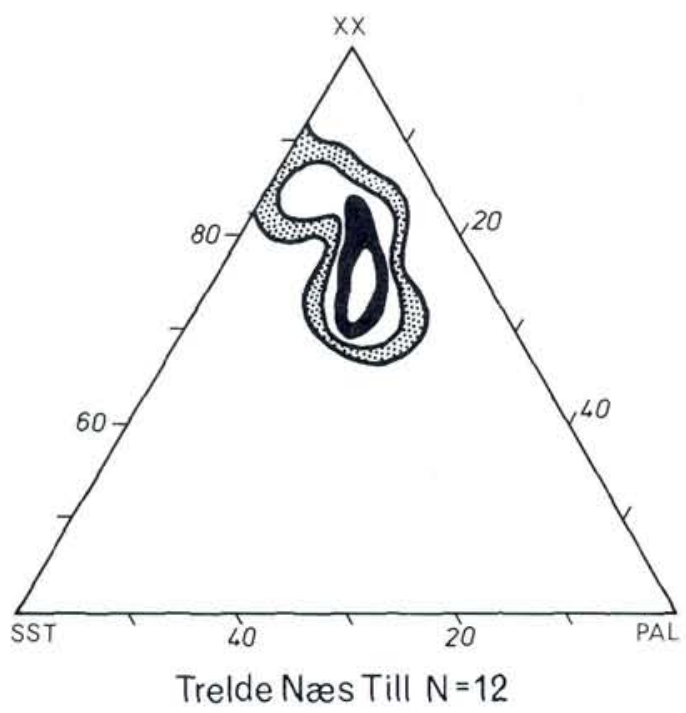

Fig. 110: Exotic stone counts $(6-60 \mathrm{~mm})$ Trelde Nas Till. Contour interval $2.5 \% . x x=$ crystalline rocks, $\mathrm{sst}=$ sandstone, Pal. $=$ Palaeozoic limestone. For reference see fig. 132. (Tabel 1). 


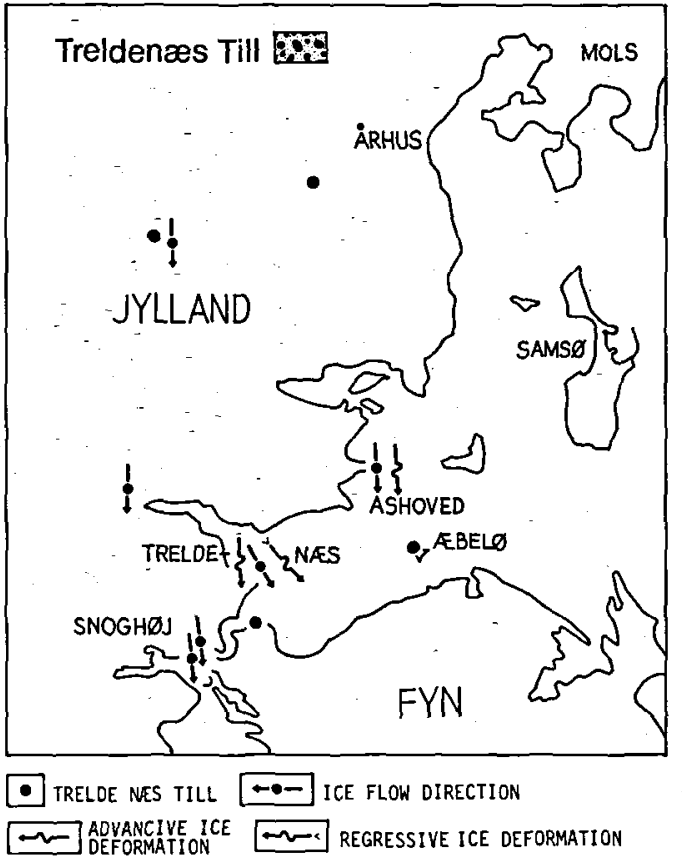

Fig. 111: Distribution of Trelde Næs Till and associated fabric analyses and glaciotectonic unconformaties. For scale see fig. 44.

boundary; whereas in a few cases younger till units overlie the till.

The lower boudnary lies at the transition between the till and the upper part of sandy, waterlaid outwash material overlying limnic, Holsteinian lake sediments at loc. 1, area 7 (fig. 105). In other cases the previously described Sønder Vissing Till, the Palsgård till or the Snoghøj till constitute the immediately underlying till deposits. At locs 1: Trelde Næs, and 2: Ashoved, area 7 (fig. 105) the lower boundary is marked by a glaciotectonic unconformity indicating ice pressure from northerly directions. At Røgle (loc. 3, area 7), the Tellina clay could constitute the lower boundary.

\section{DISTRIBUTION}

The distribution of the Trelde Næs Till is shown in fig. 111. The till is found in the western part of the region, but it is estimated to be of a much wider distribution, covering more than the whole of Denmark. Directional properties of the till and associated glaciotectonic disturbances indicate deposition connected with the passage of an icesheet from northerly directions. A local(?) readvance from a northwesterly direction has been re- corded by a glaciotectonic unconformaty at loc. 1.

\section{$A G E$}

A post-Holsteinian age is demonstrated at loc. 1: Trelde Næs. Furthermore the till is overlain by the Ashoved till which in turn is overlain by the pre-Eemian Lillebælt Till. Because of this, a possible early Saalian age is suggested for the Trelde Næs Till.

\section{CORRELATION}

Trelde Næs Till corresponds to some tills showing the so-called Drenthe fine gravel spectrum described by Sjørring and Frederiksen (1980). In the western part of Jylland it is correlated with the till referred to as the older Saalian till of Norwegian provenance (V.Milthers 1939, Sjørring 1981); as well as the lower, N-till (Søbyvad Till) described from central Jylland by Kronborg (1983).

\subsection{ASHOVED TILL FORMATION}

This till is named Ashoved Till after the type section located at Ashoved (loc. 2) on the east coast of Jylland between Vejle Fjord and Horsens Fjord.

\section{HISTORY}

Madsen et al. (1928) and Madsen and Nordmann (1940) demonstrated, that till B of Røgle Klint, which overlies the Tellina clay, is of Fennoscandian clast composition and a Saalian age was suggested. Kronborg (1983) described a sandy to clayey till, deposited by an ice stream from the eastnortheast named Haar till overlying a $\mathrm{N}$-till both of presumably pre-Eemian age.

\section{TYPE SECTION}

Ashoved (loc. 2, figs 7, 12): The Ashoved Till is accessible for-study in an apparently undisturbed condition, and the lower bounding till unit is also present in this well exposed cliff section.

\section{REFERENCE SECTIONS}

Røgle Klint (loc. 3, fig. 15): Here the upper bounding unit is exposed. Snogh $\varnothing$ j (loc. 70, fig. 66) and Rhoden Strand (loc. 52, fig. 58) where respectively the lower bounding till unit and the upper bounding till can be studied in less well exposed cliff sections. 


\section{LITHOLOGY}

The Ashoved Till, which has an average thickness of about $3 \mathrm{~m}$, is a brown to grey, sandy and clayey, both banded and massive till (fig. 112). Fine gravel analyses show roughly equal amounts
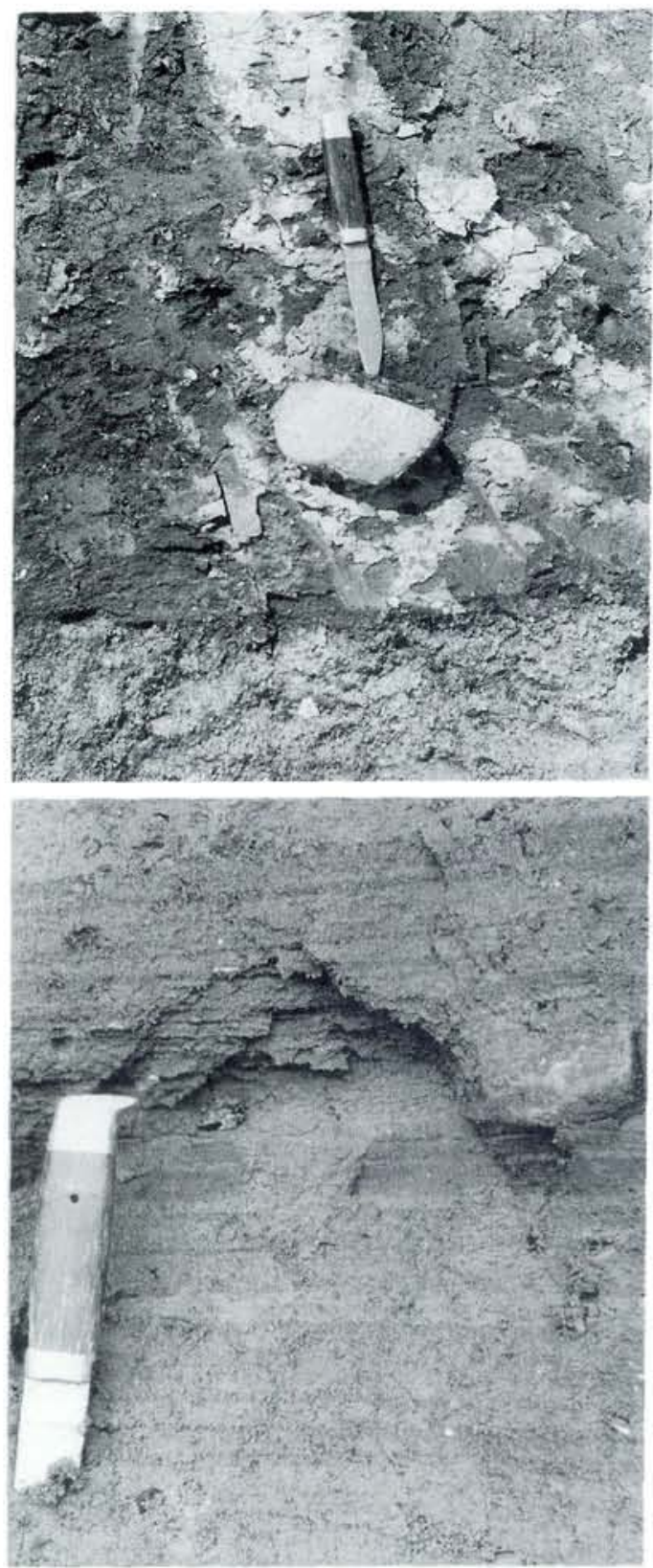

Fig. 112: Ashoved Till. Massive-weakly banded subfacies with in situ kinnediabase overlying Trelde Nas Till (upper), loc. 2, Ashoved, banded and sandy subfacies (lower), loc. 52, Rhoden Strand.

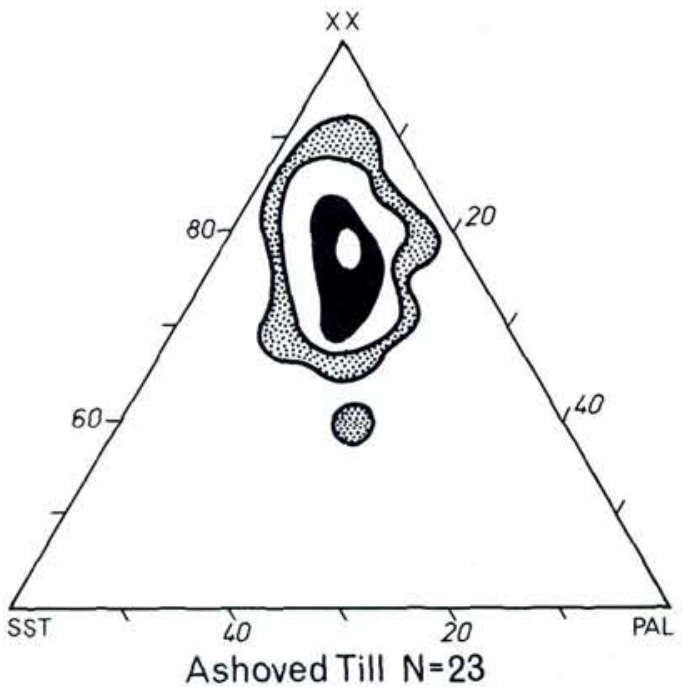

Fig. 113: Exotic stone counts, Ashoved Till. Further explanation fig. 110.

of quartz and flint (18\%), even though values approaching pre-Holsteinian tills do appear. The exotic clast composition demonstrates Fennoscandian provenance $(2-22 \%$ Pal. limestone, fig. $113)$, and the till does not seem to contain redeposited Quaternary foraminifera in notable quantities, except for one sample from loc. 4 (Æbelø) which contains a Z-accumulation. At several localities $(2,4,93)$ Middle Swedish indicators (Kinne-diabase) have been found in situ in the till, and it seems likely, that whenever the Ashoved Till is exposed in cliff sections Kinnediabase and other rock types from south western Sweden and the Kattegat area (dark garnet-amphibolite and Katholm erratics) are present among beach gravels.

Clast orientation measurements revealed longitudinal and mixed, NE-ward dipping till fabrics indicating deposition by an ice sheet from north easterly directions.

\section{BOUNDARIES (fig. 105)}

The Ashoved Till is bound upwards by the Lillebælt Till (locs 3, 4, 52, 93, 97), omitting possible waterlaid material interbedding the tills. Even younger (Weichselian) tills may immediately overlie the Ashoved Till (locs 2, 27, 39, 74) or glaciotectonic unconformities related to Weichselian ice advances may strongly affect the till (locs $3,4,27,39,61)$. 


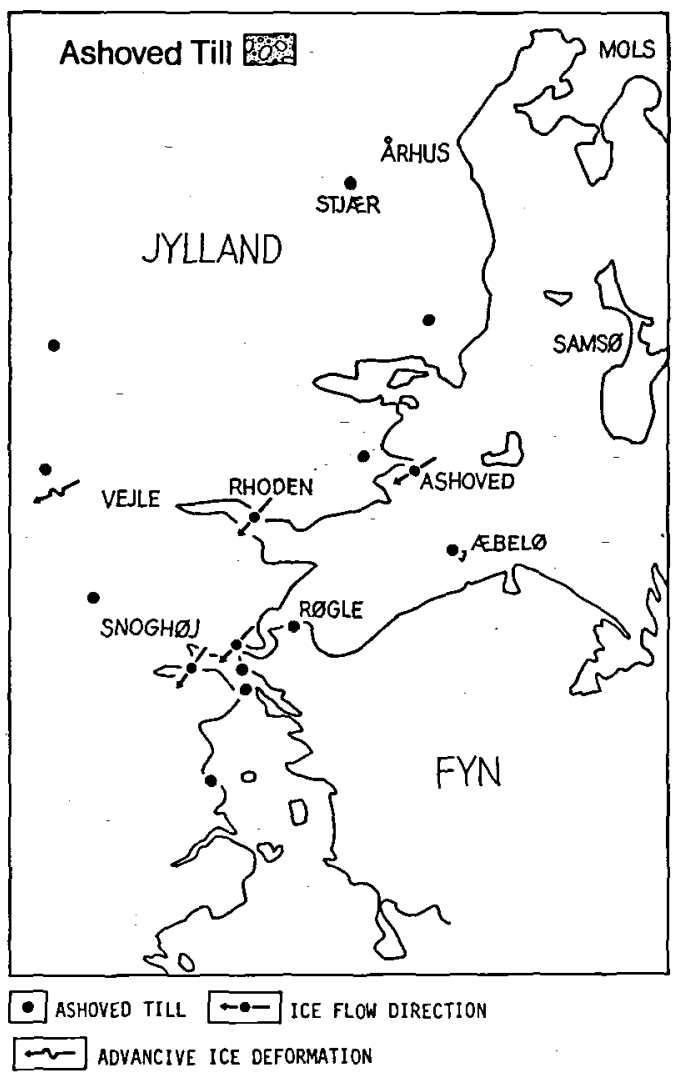

Fig. 114: Distribution of Ashoved Till and associated fabric analyses and glaciotectonic unconformaties.

The lower boundary consists in a few cases of glaciotectonic unconformities indicating ice deformation from the NE (locs 45, 57) or the Ashoved Till may overlie the Trelde Næs Till (locs 2, $4,27,70$ ) or older deposits.

\section{DISTRIBUTION}

The Ashoved Till has been found in the western part of the examined region, where it most frequently crops out along the coastal cliffs of Lillebælt. The distribution of the till is (fig. 114), however, estimated to go far beyong this area. Directional elements and provenance dependent compositional properties suggest deposition by a Fennoscandian ice sheet transgressing the central Danish region from northeasterly directions.

\section{$A G E$}

Due to the stratigraphic position between the post-Holsteinian Trelde Næs Till and the pre-
Eemian Lillebælt Till, a (possibly mid-) Saalian age is proposed for the Ashoved Till.

\section{CORRELATION}

On the basis of stratigraphic position, lithology and directional properties the Ashoved Till apparently corresponds to a number of extra-regional tills. On the island of Als, Sjørring (1977), described a sandy, "chalk poor", Fennoscandian till of Saalian age referred to as a "Drenthe" type till overlain by a Baltic "Warthe" till type. This sandy till and some other sandy, Fennoscandian tills of similar stratigraphic position, containing equal amounts of quartz and flint also referred to as Drenthe tills, described from western Jylland (Sjørring \& Frederiksen 1980) are correlated with the Ashoved Till. There is in the literature, however, no other means than the contents of Norwegian and Middle Swedish indicator erratics by which the Drenthe tills of western Jylland may be separated into individual units comparable to either Trelde Næs Till or Ashoved Till.

Correlation with the area north of the examined region suggests that most probably the Ashoved Till would be equivalent to the pre-Eemian till deposited by an icesheet from the NE which is described by Larsen et al. (1977) and Kronborg (1983) from several localities in the eastern and middle part of Jylland including loc. 27 (Stjær, fig. 48). This till is named Haar till (Kronborg 1983).

The Ashoved Till is tentatively assumed to correspond to the so-called older Saalian till described from northern Germany (Ehlers 1981, Ehlers et al. 1984) and deposited by the Main Drenthe ice stream from northeasterly directions.

\subsection{LILLEBALLT TILL FORMATION}

This till is named Lillebælt Till becuase it is most frequently exposed in the coastal areas of Lillebælt.

\section{HISTORY}

The lower, Baltic till of south Samsø and $Æ b e l \varnothing$ was recognized by V.Madsen $(1897,1900)$, who however, made no attempt to set the till in relation to other subsurface tills in the area. Hartz (1909) observed a till beneath an Eemian kettle bog at Ejstrup (loc. 90) and V.Milthers (1925) correlated this till with the till underlying the Ee- 
mian bogs at Brørup. Milthers concluded, that the till is clayey, of Baltic clast composition and often rich in Cretaceous-Paleocene limestone. Madsen et al. (1928) and Madsen and Nordmann (1940) described the Baltic clast composition of till C at Røgle Klint; which overlies a sandy, limestone poor till (B) and is overlain by outwash material containing re-deposited, Eemian molluscan fragments. A Weichselian age was suggested.

By comparing percentages in the clast content of Pal. limestone Jessen (1930) suggests, that the lower, Baltic till of Halk Hoved, which was deposited prior to an ice transgression from the NE, should be correlated with the "thin" (Weichselian) Baltic till of Ristinge Klint. Frederiksen's (1973, 1976) glacial stratigraphic studies of the lower till at Halk Hoved, indicate, that the Baltic till characterized by re-deposited Quaternary foraminifera of Holsteinian origin, was deposited by an ice sheet from easterly directions, most probably in the late Saalian. Houmark-Nielsen (1980) suggests, that the apparently pre-Eemian, lower, Baltic till of southern Samsø and adjacent islands should be informally named the Palaeobaltic till and suggested it to be of late Saalian age.

\section{TYPE SECTION}

Søndervilstrup Strand and Halk Hoved (loc. 5, fig. $7 \&$ loc. 112, fig. 44). The two cliff sections, a little less than $10 \mathrm{~km}$ apart, provide the largest, thickest and most well exposed sections through the till in the examined region.

\section{REFERENCE SECTIONS}

Ejstrup (loc. 90, fig. 7) and Vejrø (loc. 153, fig. 44) where the upper boundary is exposed, Æbelø (loc. 4, fig. 7), Rhoden (loc. 52, fig. 44), Gravens Hoved (loc. 97, fig. 44) where the lower boundary is exposed and Røgle Klint (loc. 3, fig. 7), where the till is present in a strongly dislocated, composite glacial sequence.

\section{LITHOLOGY}

The Lillebælt Till (figs 19, 26, 28, 115) which has an average thickness of 3-4 metres, is most often bluish grey with more brown variations in colour when weathered. It is clayey and usually massive. Clast composition is characterized by low values of quartz $(0-10 \%)$ and high values of flint (20$40 \%$ ) in the fine gravel fraction and large amounts of Pal.limestone (15-50\% with an aver-

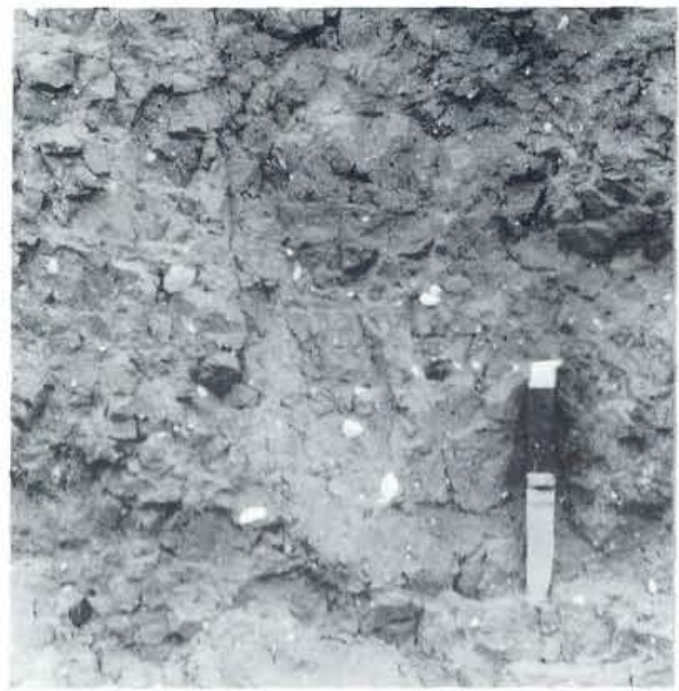

Fig. 115: Lillebalt Till, loc. 112, Halk Hoved. See also figs 19 and 73 .

age of $28 \%$ ) in the exotic stone counts (fig. 116). The Lillebælt Till carries in situ - or beach gravels along cliff sites where the till is exposed contain a wide range of Baltic indicator erratics and rockfragments especially derived from Palaeozoic sources in the Southern Baltic region. Locally a subfacies appears extremely rich in Cretaceous limestone (fig. 73). The till contains only very limited quantities of re-deposited Quaternary

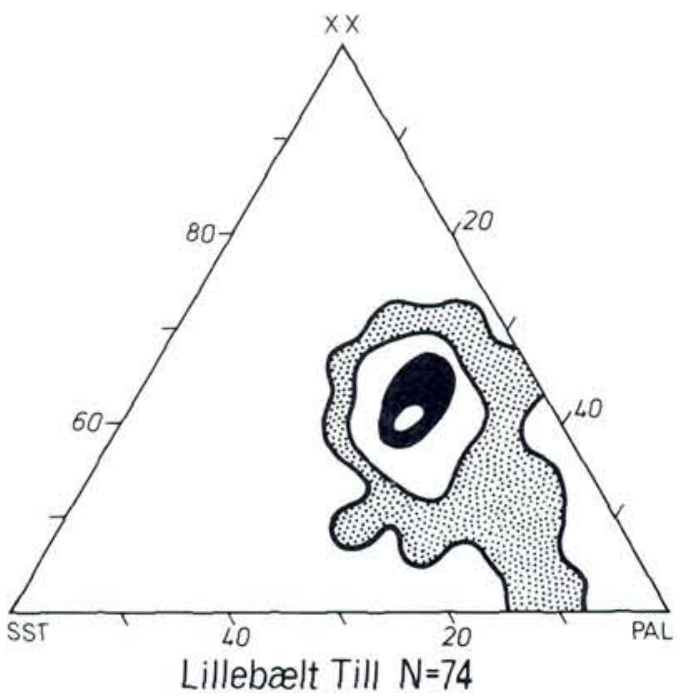

Fig. 116: Exotic stone counts, Lillebxit Till. Further explanation fig. 110. 


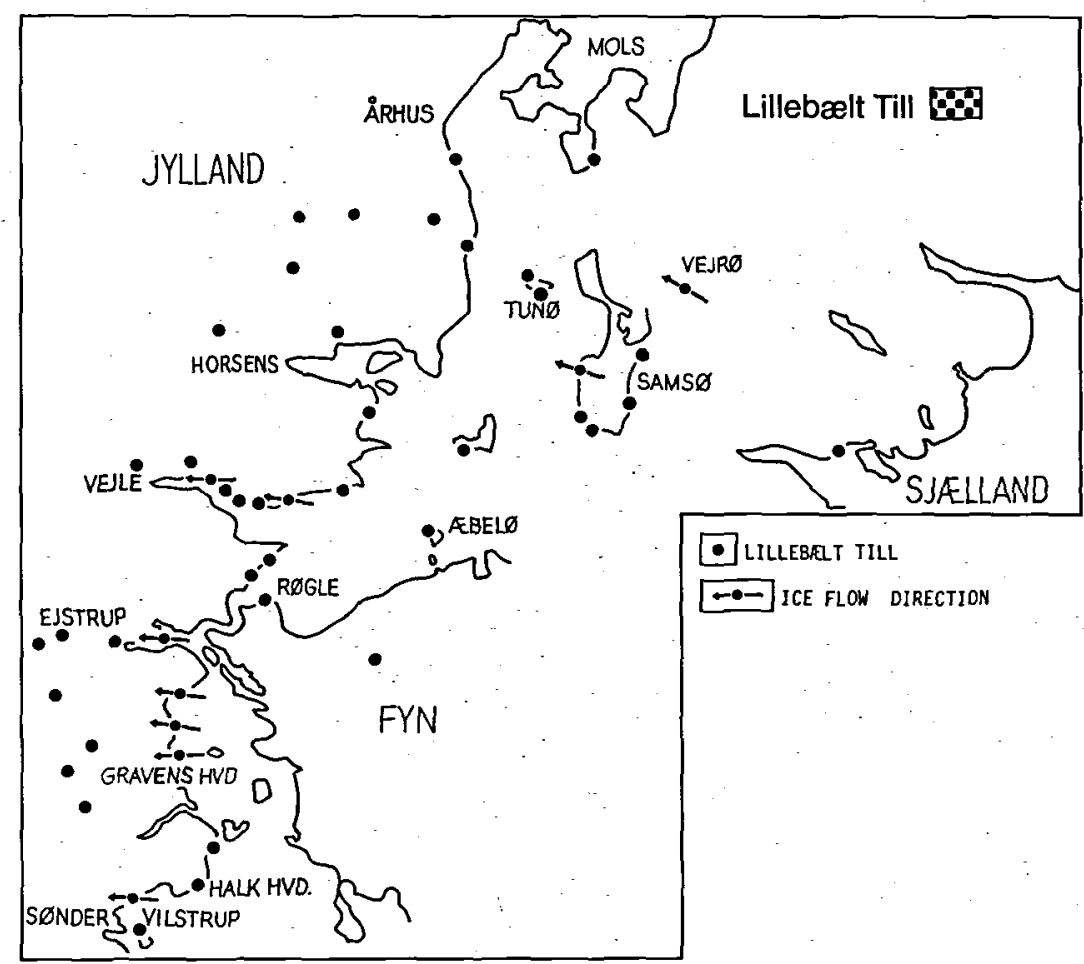

Fig. 117: Distribution of Lillebælt Till and associated fabric analyses.

foraminifera. Another compositionally different subfacies of the Lillebælt Till appears to be present in area 5 (fig. 58). It comprises the clayey, grey, lower third of the till (at locs 51,54) and differs because of its low content of Palaeozoic and younger limestones and a slightly higher quartz content. This unit is assumed to represent a poorBaltic subfacies of the Lillebalt Till characterized by reworked local glacigenetic clast material.

The directional properties of clast show consistent eastward to east-south-eastward dipping, longitudinal fabrics indicating deposition by a glacier flowing in a direction from the east towards the west.

\section{BOUNDARIES (fig. 105)}

Apart from waterlain outwash interbedding the till units the Lillebælt Till is bound upwards by limnic Eemian deposits (locs 90, 109) or marine Eemian clay and silt (loc. 153). In the southern part of the examined region the till is overlain by the Ristinge Klint Till (loc. 5) or outwash material assumed to be deposited by the icesheet, which laid down this till (locs 3, 112). In the northern part of the central Danish region the Lillebælt Till is overlain by the Kattegat Till (locs $138,142,143)$. Throughout the western region it is often overlain by the Mid Danish Till or bound upwards by glaciotectonic unconformities indicating ice deformation from the NE related to the ice advance which deposited the Mid Danish Till.

The lower boundary is marked by the underlying Ashoved Till (locs 3, 4, 52, 93, 97) or more rarely the Trelde Næs Till (loc. 64) or the Tertiary clay (loc. 68).

Apparently hardly any glaciotectonic unconformaties are associated with the Lillebælt Till.

\section{DISTRIBUTION}

The distribution of the Lillebælt Till is shown in fig. 117. Directional properties suggest the passage from the E and ESE of an inland ice sheet, the marginal zone of which was extended far west of the examined region.

\section{$A G E$}

Because the oldest deposit overlying the Lillebælt Till consists of limnic Eemian peat and gyttja or 
marine Eemian clay, and the youngest till bed underlying it is the post-Holsteinian Ashoved Till, the Lillebælt Till is estimated to be of late Saalian age and deposited by the youngest ice sheet of this glacial.

\section{CORRELATION}

On the basis of lithology and stratigraphic position the Lillebælt Till can be correlated with a number of extra-regional till units.

In south-western Jylland a quartz poor, Baltic till underlying limnic Eemian deposits at Emmerlev Klev named a Warthe till-type (Sjørring \& Frederiksen 1980) and a very limestone rich subfacies of this till described further inland (Hansen 1965, Sjørring 1981a) is correlated with the Lillebælt Till. The Baltic supposedly late Saalian till overlain by marine Eemian deposits exposed in the cliff at Sarup, Als (Sjørring 1977) is also correlated with the Lillebalt Till.

Jessen et al. (1910) and K.Milthers (1942) indicate the presence of a supposed Baltic till beneath a marine Eemian-Weichselian marine sequence at Skærumhede. Along with the Baltic till beneath a marine Early-Middle Weichselian sequence at Holmstrup (Petersen \& Buch 1974) both "pre-Skærumhede" tills are correlated with the Lillebælt Till. This correlation however is contrary to Wennberg (1949) and Petersen (1984), who suggested an Early- to early Middle Weichselian age for the tills at Skærumhede and Holmstrup (West Sjælland) respectively. Jacobsen (1981) and Nielsen (1980) describe lower till units of Baltic clast composition from Falster and Korsør ascribed to the late Saalian which, along with a Baltic, Warthe type till from the western Limfjord region (Jensen \& Knudsen 1984) and the clayey, limestone rich SE-till containing a Zforaminiferal accumulation named the Hinnerup Till (Kronborg 1983, Kronborg \& Knudsen 1985) is correlated with the Lillebælt Till. Sjørring (1983) sketched a possible distribution for the Warthe till-type in western Jylland leaving parts of west-central Jylland uncovered by this till.

Outside Denmark the Lillebælt Till is correlated with the so-called Warthe- or Younger Saalian tills of Germany (Ehlers \& Stephan 1983, Ehlers et al. 1984) and with the Ramslid Till in Skåne, southern Sweden (Lagerlund 1980).

\subsection{RISTINGE KLINT TILL FORMATION}

This till is named the Ristinge Klint Till after the location of the type section at Ristinge Klint on south-western Langeland (fig. 3). The till has not previously been described from the examined region. S.A.Andersen (1945) and Berthelsen (1973) referred to the till as the Old Baltic Till.

\section{HISTORY}

Overlying marine Eemian clay (named Cyprina clay) at Ristinge Klint, Madsen et al. (1908) and Madsen (1916) recognized two dislocated tills separated by waterlaid outwash deposits and thus this glacial sequence was ascribed to the last glaciation (Weichselian). The lower of the tills (till C) was (Madsen 1916) characterized as a ca. $1 \mathrm{~m}$ thick till bed with Baltic rock fragments. Madsen et al. (1928) connected till C with the Main Weichselian advance, the maximum extension of which lies along the Main Stationary Line.

Jessen's (1930) correlation between till C (at Ristinge) and the lower till of Halk Hoved using the content of Pal. limestones was cited by Andersen (1945) who stated, that the thin, Baltic till of Ristinge Klint was deposited by an Old Baltic ice stream separated in time by deposition of waterlaid sand and gravel from the Main Weichselian advance, which invaded the country from the NE. K.Milthers (1959) mentions the presence of till $\mathrm{C}$ in Ristinge Klint, however, it does not appear in his description of the chronology of Weichselian ice streams in the area around southern Fyn. On the basis of Rørdams' (1893) stone counts, Andersen (1950) suggested the presence of the Old Baltic till in the coastal areas of NESjalland.

Ehlers (1979) and Sjørring et al. (1982) confirm the Baltic clast provenance of the till at Ristinge from fine gravel analysis and add the fact, that it is characterized by low contents of quartz and intermediate flint quantities. According to Sjørring et al. (1982) the number of re-deposited Quaternary foraminifera is very limited and the thin till shows fabrics, which indicate ice flow from south-easterly directions. Berthelsen (1973), Sjørring (1981b) and Houmark-Nielsen (1981) correlate the Old Baltic till at Ristinge Klint with various post-Eemian till units in the southern and eastern part of the country.

Houmark-Nielsen and Kolstrup (1981) described a Baltic subfacies of the NE-till overlying 
limnic deposits of Hengelo age (Sejerø interstadial), but it was not recognized as an independent till unit at that time.

\section{TYPE SECTIONS}

1) Ristinge Klint (fig. 3). The classical locality for studies of this till and its relationship to other glacial and interglacial deposits. Units are readily accessible in this well expose cliff section (cf. Sjørring et al. 1982).

2) Sønderby Klint (loc. 6, fig. 7). A well exposed coastal cliff face with a complex Eemian and Weichselian stratigraphy; here Ristinge Klint Till is situated within the examined region.

\section{REFERENCE SECTIONS}

Søndervilstrup Strand (loc. 5, fig. 7) where the lower bounding unit of glacigenetic origin (Lillebælt Till) and the upper bounding unit (Mid Danish Till) is well exposed. Kulhuse (loc. 185a, fig. 44) where the upper boundary characteristic of the north-eastern part of the region is occasionally exposed. Sejerø (loc. 8, fig. 40) where the till assumingly overlies limnic deposits of the Pleniglacial, Sejerø Interstadial.

\section{LITHOLOGY}

Ristinge Klint Till, which ranges in thickness between $1 / 2-2 \mathrm{~m}$, is grey to reddish brown. It is

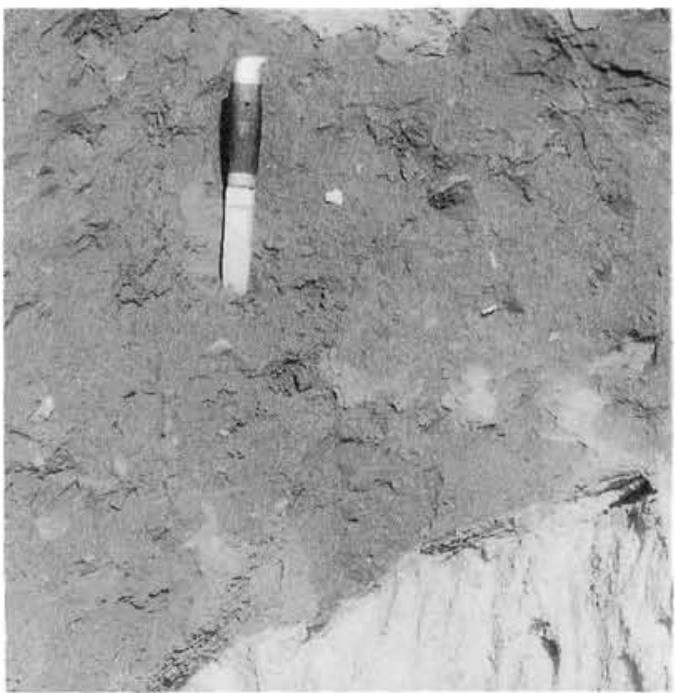

Fig, 118: Ristinge Klint Till unconformably overlying sandy waterlaid deposits, loc. 6. Sønderby Klint. (Note in situ shell fragments from the Cyprina clay).

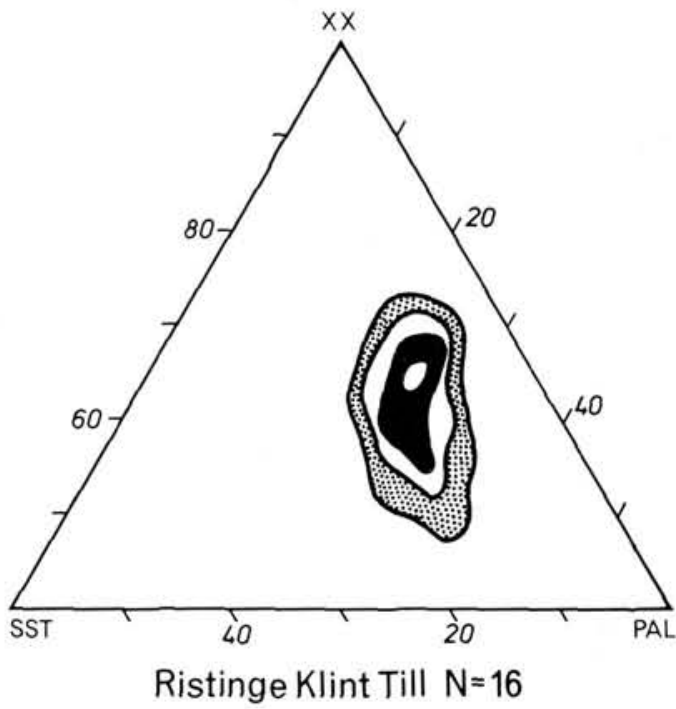

Fig. 119: Exotic stone counts, Ristinge Klint Till. Further explanation fig. 110 .

clayey and appears both massive and banded (fig. 118). The fine gravel content shows low quantities of quartz (less than $10 \%$ ) and intermediate values of flint (10-30\%). Stone counts (fig. 119) indicate Baltic clast composition $(20-40 \%$ Pal. limestone with an average of $25-30 \%$ ) and it is characterized by molluscan fragments and a Yforaminiferal accumulation most probably derived from marine Eemian sources. It should be noted, that the quantity of re-deposited Quaternary foraminifera has been found to be too low for faunal comparison at Ristinge Klint ( $\mathrm{Sj} \varnothing \mathrm{r}$ ring et al. 1982).

Clast orientation measurements revealed one longitudinal south-eastward dipping fabric (loc. 5) suggesting deposition by an ice sheet from south-easterly directions.

\section{BOUNDARIES (fig. 105)}

Apart from fine grained waterlain material over and underlying the Ristinge Klint till the upper boundary in the southern and central part of the examined region is made up of glaciotectonic unconformities indicating deformation by an ice sheet from the NE (locs 5, 6) and it may be overlain by the Mid Danish Till (locs 5, 6, 8, 127). In the north-eastern part (loc. 185a) a glaciotectonic unconformity indicating ice pressure from the $\mathrm{N}$ constitute the upper boundary. 


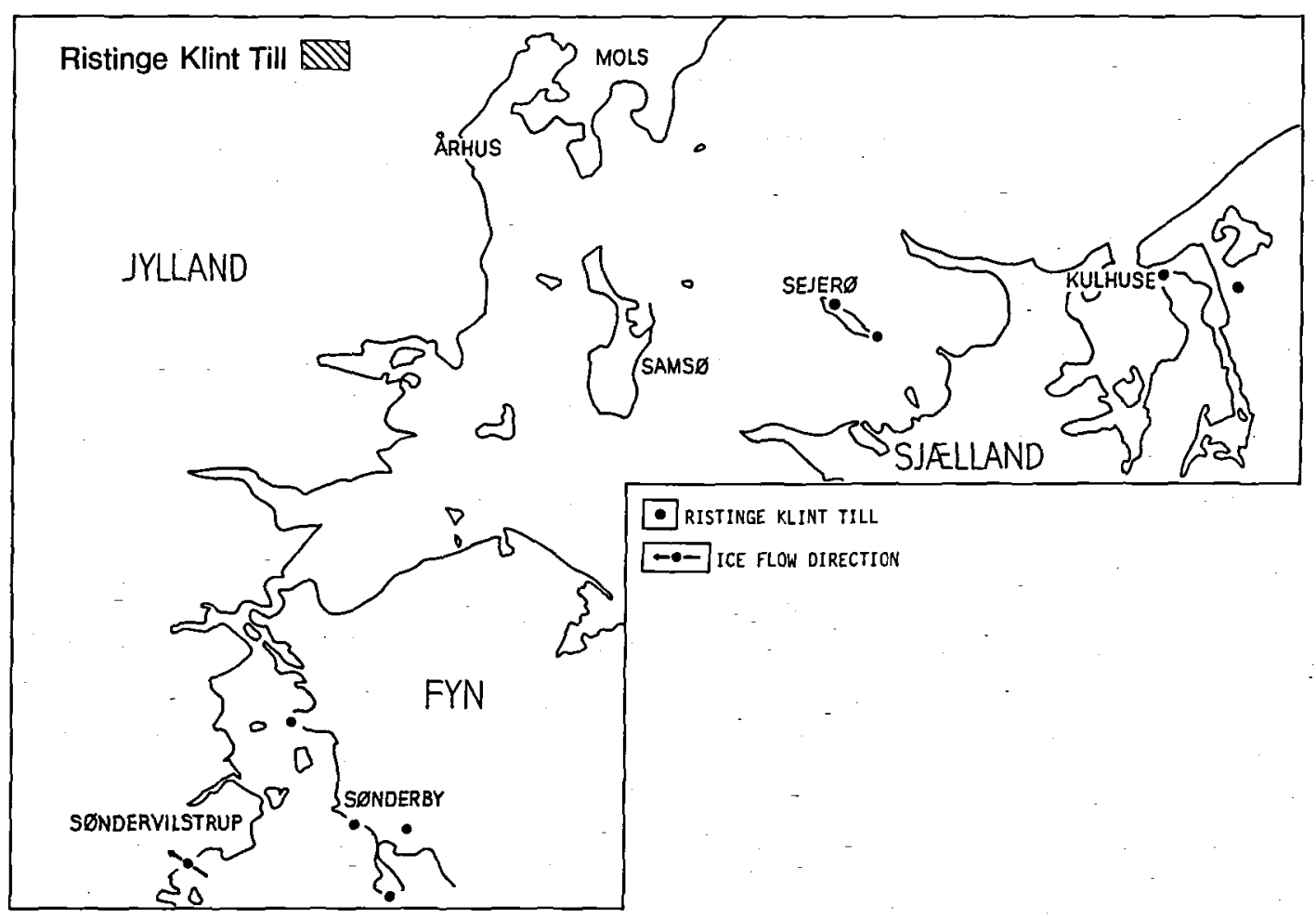

Fig. 120: Distribution of Ristinge Klint Till and associated fabric analysîs.

The lower boundary in the southern part of the examined regions is placed where it supposedly overlies laminated clay, silt and sand underlain by limnic or marine Eemian deposits (locs 6, 135). In other instances (loc. 5) it may rest immediately upon the Lillebælt Till. Limnic deposits of the Sejer $\emptyset$ Interstadial apparently underlie Ristinge Klint Till at Sejerø (loc. 8).

\section{DISTRIBUTION}

The Ristinge Klint Till is only found in a few localities in the southern and eastern part of the examined region (fig. 120). If a clear stratigraphical indicating of its post Eemian age can not be demonstrated it only differs radically from the Lillebælt Till as the content of re-deposited Quaternary foraminifera. The position of its maximum extension can not be outlined, but it might well be extended further westwards and possibly also north-westwards, than the position of the localities where the till has been found, seem to indi- cate. The Ristinge Klint Till was deposited by a Baltic ice stream possibly from south-easterly directions as suggested by clast petrography and directional properties.

\section{$A G E$}

A post Eemian age prior to the NE-advance is demonstrated from-the classical type section at Ristinge Klint as well as from Sønderby Klint. The apparent underlying of deposits from the Sejer $\varnothing$ Interstadial on Sejer $\emptyset$ suggests an age younger than $36800 \mathrm{BP}$. The Ristinge Klint Till is presumably older than the ice advance from the north which deposited the Kattegat-Till, the age of which is estimated to be younger than the Middle Weichselian zone $\mathrm{C}$ of the Skærumhede sequence dated to an age of $34000 \mathrm{BP}$ (LykkeAndersen 1982). It is therefore suggested, that the age of the Ristinge Klint Till should be found within the late Middle Weichselian, younger than the Hengelo Interstadial. 


\section{CORRELATION}

The Ristinge Klint Till corresponds to the lower, dislocated, Baltic till at Strandegårdens Dyrehave, southeastern Sjælland (Petersen \& Konradi 1974) and Als (Sjørring 1977) where it overlies marine Eemian deposits and is superimposed by glacialtectonic structures indicating ice deformation from the NE. It can also be correlated with other Baltic tills having similar upper boundaries at Kors $\emptyset r$ (Nielsen 1980), Southwest Møn (Aber 1979, Berthelsen et al. 1977) and Falster (Jacobsen 1981). East of $\emptyset$ resund it is not clear whether the Ristinge Klint Till corresponds to the Allarp Till or the lower Baltic facies of the DalbyBräcke tills of SW-Skåne (Lagerlund 1980, Berglund \& Lagerlund 1981).

\subsection{KATTEGAT TILL FORMATION}

This till unit is named Kattegat Till because it crops out in the coastal areas of southern Kattegat. Rørdam (1909) named it the Norwegian Till.

\section{HISTORY}

Rørdam (1893) described the "lower till" of NESjælland as a clayey, grey till containing limited amounts of Baltic clast material, and abundant re-deposited shell-fragments apparently derived from the Older Yoldia clay of Vendsyssel. It is characterized by indicator erratics, primarily of the Oslo district, but also from the western part of Middle Sweden. These indicator boulders are readily apparent in beach gravels along cliff sections where the lower till is exposed. Rørdam (1909) named it the "Norwegian Till" after its dominating indicator boulder erratic content, and it was proposed, that the till had been deposited during the first glacial by a "Norwegian" ice stream. According to Rørdam the Norwegian till is separated from the "upper till" of NE-Sjalland, presumably deposited during the last (e.g. Weichselian) glaciation by amber and twig bearing sand and gravel containing fragmented shell material of the same derivation as the lower till.

Madsen (1897) recognized the dominant representation of Norwegian indicators in beach gravels on North Sams $\emptyset$ and Helgenæs, but no attempt was made to compare these observations with those of Rørdam. With the initiation of renewed glacial stratigraphic studies at Hundested in particular and around North Sjælland in general (Sjørring 1973, 1974), Rørdams view of a proposed northerly heretage for the lower till was confirmed. Structural studies, stone counts, and foraminiferal analyses in till-stratigraphic research (Sjørring 1973, 1974, Konradi 1973, Petersen \& Konradi 1974, Rasmussen 1973, 1974) defined the Norwegian till as a dense and massive till, which also appears as stratified clast bearing clay and it was characterized by 1) a Fennoscandian clast composition and 2) by a re-deposited foraminiferal accumulation similar to the fauna found in the Portlandia artica zone of the Skærumhede sequence. The latter feature would consequently suggested a Weichselian age and the Norwegian till supposedly underlies deposits of the Main Weichselian advance.

Fabric measurements either show a random clast orientation (Rasmussen 1974) or they suggest ice flow from northern directions (HoumarkNielsen 1976c, Jensen 1977). The Norwegian till is over- and underlain by sandy waterlaid deposits and in the eastern part of the examined region it is commonly disturbed by ice pressure from the north; assumed to be caused by a readvance of the icesheet, which deposited the till (Sjørring 1973, 1974, Jensen 1977). Berthelsen (1974) describes how the "blue boulder clay" (= Norwegian till) in a liquifacted state became remobilized and intruded overlying deposits as a consequence of later glacier loading.

Sjørring $(1975,1983)$ suggests, that the Norwegian ice stream, which deposited the till, covered larger parts of Northern Jylland and the coastal areas of northernmost Sjalland.

Houmark-Nielsen $(1980,1981)$ recognized the Norwegian till in the larger part of the northern Bælthav region and characterized it as a Weichselian till mainly of Fennoscandian clast composition deposited by an icestream from the North prior to the Main Weichselian advance from the NE. On indirect stratigraphical evidence it was suggested, (Houmark-Nielsen 1976b, 1976c, 1980, Houmark-Nielsen \& Berthelsen 1981), that the Norwegian till was deposited before the Old Baltic ice sheet advanced over the southern parts of the country.

Nielsen (1985) suggests, on the basis of shallow seismic investigations, that the Norwegian till is present over large areas of the sea-floor in the southern part of Kattegat. 


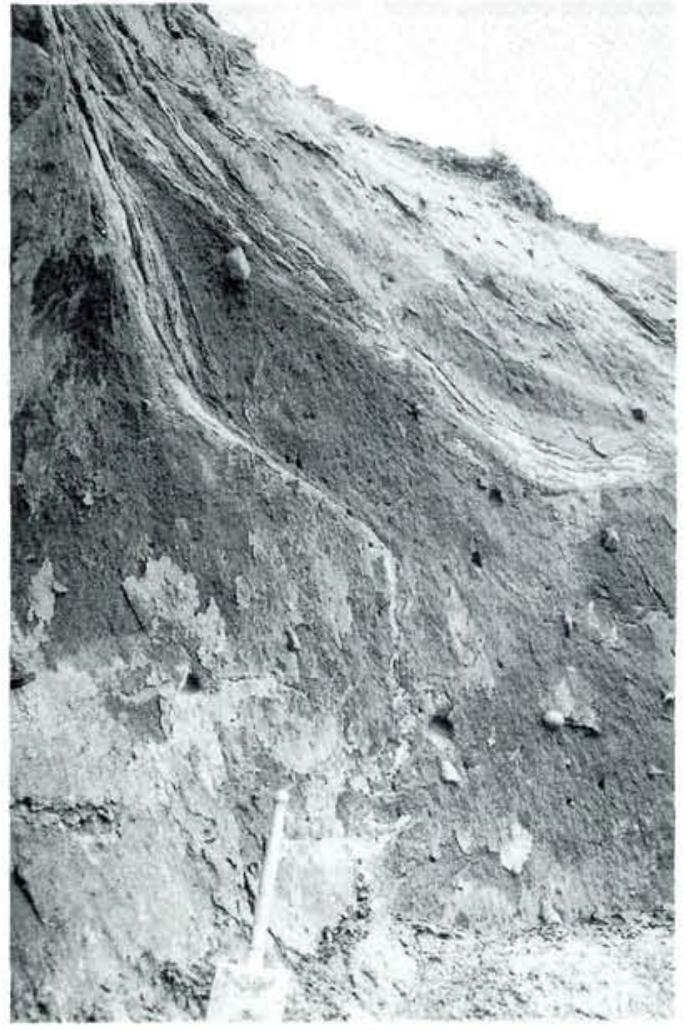

Fig. 121: Kattegat Till folded by ice-deformation from the north, Hundested, Photo: S.Sjørring.

\section{TYPE SECTION}

Hundested Klint (fig. 44). This well exposed section was examined by Rørdam (1893) and Sjørring (1974) and even though only the upper, glaciotectonic boundary is exposed here, it is, from a historical point of view, a classical locality for study of this till.

\section{REFERENCE SECTIONS}

North Sams $\varnothing$ (loc. 7, fig. 7) where the Kattegat Till and the upper bounding units can be studied.

Esby Klint (loc. 138, fig. 44) where the lowerand upper boundary can be studied.

\section{LITHOLOGY}

The Kattegat Till is less than $4 \mathrm{~m}$ thick, mostly grey and clayey. It appears both massive are banded (fig. 121). Fine gravel analyses show very limited amounts of quartz and limited to intermediate quantities of flint. Stone counts indicate Fennoscandian provenance (with an average of about $15 \%$ Pal.limestone (fig. 122)) even though higher values appear, probably due to local incorporation of older Baltic till material. It is characterized by occasionally rich $\mathrm{X}$-foraminiferal accumulations derived from the Early- to Middle Weichselian Skærumhede deposits.

In several instances indicators of the Oslo district have been found in situ, together with shell fragments which originated in the Older Yoldia clay as already noted by Rørdam (1893). Clast orientation measurements revealed longitudinal fabrics indicating ice flow from northerly directions.

\section{BOUNDARIES (fig. 105)}

Apart from outwash material deposited locally or within a regional, northward flowing system of meltwater streams and lakes the Kattegat Till is bound upwards by the Mid Danish Till. Glaciotectonic disturbances indicating ice push from the NE (locs 7, 136, 138, 164, 166) and more easterly directions (Sjørring 1973, 1974, Jensen 1977) associated with the advance and readvance of the Main Weichselian ice sheet superimposes the Kattegat Till. Glaciotectonic unconformities indicating ice deformation from the north (Sjørring 1973, 1974, Jensen 1977) ascribed to a readvance of the ice stream which deposited the Kattegat Till may also constitute the upper boundary.

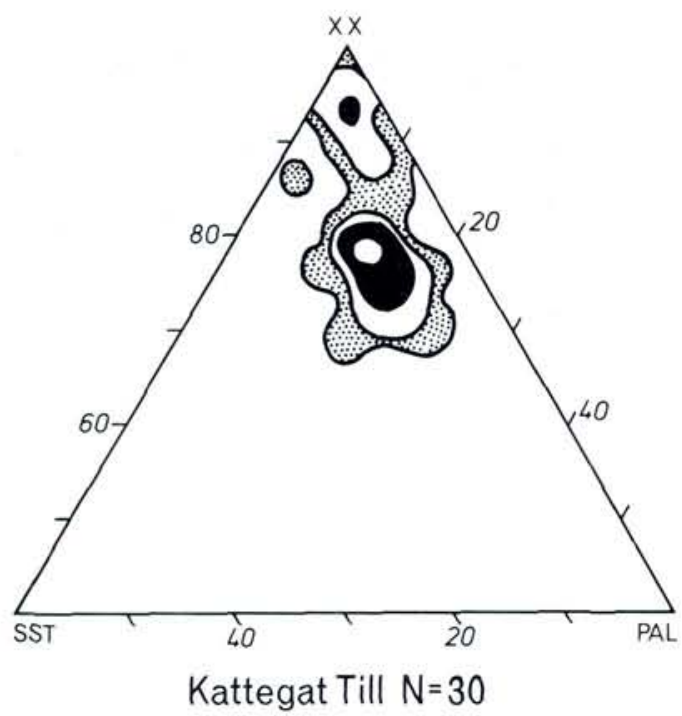

Fig. 122: Exotic stone counts, Kattegat Till. Further explanation fig. 110 . 


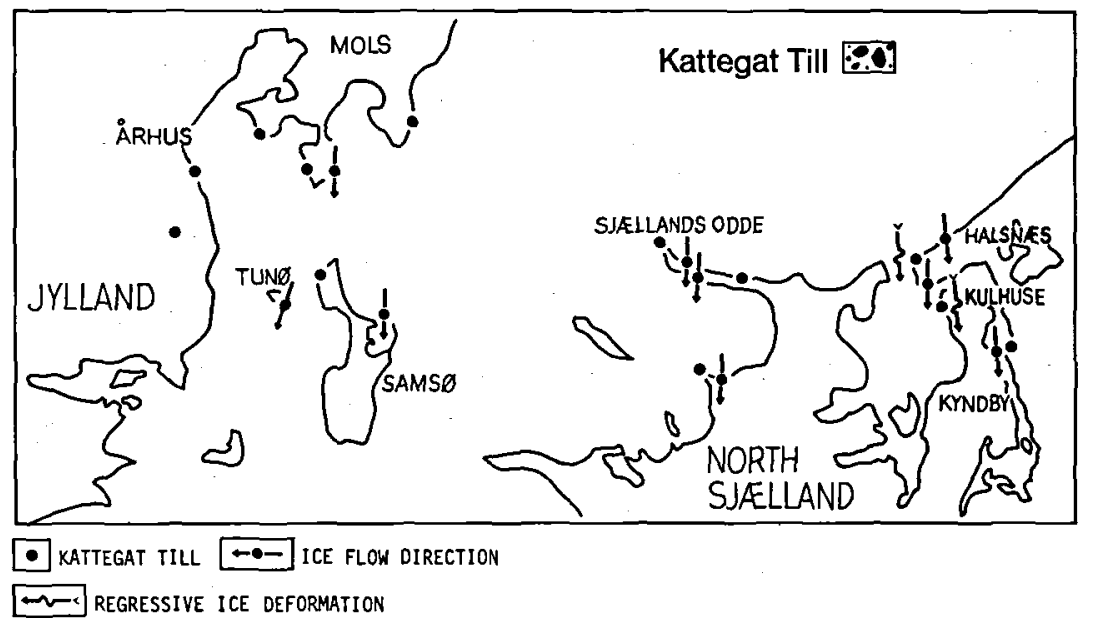

Fig. 123: Distribution of Kattegat Till and associated fabric analyses and glaciotectonic unconformaties.

The lower bounding till unit is rarely exposed, but the Lillebælt Till (locs 138, 142, 143) is occasionally present beneath the Kattegat Till. However, the Ristinge Klint Till apparently underwent glaciotectonic deformation from a northerly direction at Kulhuse immediately south of the area containing the Kattegat Till type section (loc. 185a). Even though stratigraphical observations can not put forward evidence, it is suggested, that in a common area of distribution (NE-Sjælland) Kattegat Till is expected to overlie Ristinge Klint Till.

\section{DISTRIBUTION}

The Kattegat. Till is only found in the coastal areas of the northern part of the examined region (fig. 123), because of which it is assumed, that the maximum extension of the (Norwegian-) ice sheet, which deposited the Kattegat Till from the $\mathrm{N}$, lies within the examined region. This assumption is supported by evidence from the literature dealing with the central parts of Sjælland (Petersen \& Buch 1974, Jacobsen 1985) where no "Norwegian till" is present. Great quantities of outwash material deposited as a large-scale Gilbert type delta (loc. 179), Kyndby (fig. 44) (Clemmensen \& Houmark-Nielsen 1981) and glaciofluvial deposits (Himmelev formation, Jacobsen 1985) in the area between Roskilde and Halsnæs originated during the retreat of this ice sheet. It has not so far been possible to relate any present glaciomorphological features to this Norwegian advance.
$A G E$

A post Eemian age is suggested, because the $\mathrm{Ka}$ ttegat Till contains an X-accumulation of re-deposited Quaternary foraminifera derived from the boreo-artic Portlandia arctica zone of the Skærumhede sequence in which Middle Weichselian Interstadials have been recognized (Knudsen \& Lykke-Andersen 1982). The Eemian-Middle Weichselian sequence at Skærumhede has been interpreted as representing a complete marine succession (Bahnson et al. 1974) on which grounds it is assumed (cf. Konradi 1973), that glaciers did not transgress the North Danish area until after deposition of the uppermost zones of the Skærumhede sequence / Older Yoldia clay (zones C-A/II-I); the older zone has been given radiocarbon ages of around 34000 years BP (Knudsen \& Lykke-Andersen 1982). Since the Main Weichselian glacial phase is estimated to have taken place around 24000-20000 years BP (cf. Petersen 1984, Rasmussen \& Petersen 1980), is it suggested, in accordance with the possible age relation to the supposedly underlying Ristinge Klint Till, that the Kattegat Till was deposited during the time interval 34000-20000 BP probably closer to the youngest date, as also proposed by Berthelsen (1979).

\section{CORRELATION}

Outside the examined region descriptions of tills units, which could correspond with the Kattegat Till are very sparse. The Kattegat Till is correlated with the so called "blue-boulderclay" of NE-Sjælland described by Berthelsen (1974), 
Rasmussen (1974), Schuldt (1981) and Sjørring (1973).

Evidence based mainly on morphology and indicator erratic counts revealed, that deposits characterized by Norwegian indicators dominate the northern parts of Djursland (Bahnson 1984, K.Milthers 1942). Even though these dpeosits are regarded as either being younger than the Main Weichselian advance (Bahnson 1984) or of preEemian age (K. Milthers 1942) little stratigraphical evidence has yet been brought forward concerning these "Norwegian" deposits. They could, however, be related to the ice sheet that deposited the Kattegat Till. Possibly the Kattegat Till corresponds to the upper till from Rugård (Kronborg \& Knudsen 1985) containing similar re-deposited Quaternary foraminifera and clast petrographic properties.

Sjørring (1983) mentions, that a till of similar lithology as the Kattegat Till has been osberved just south of the Main Stationary Line, where the line crosses the North Sea coast of Jylland.

Outside the country the Kattegat Till is correlated with the Ålaboda Till of the Ven-Glumslöv area (Skåne) and the Smedstorp Till of western Skåne as also suggested by Adrielsson (1984), Lagerlund (1980) and Berglund and Lagerlund (1981).

\subsection{MID DANISH TILL FORMATION}

This till is named the Mid Danish Till, because it is found at almost all localities in the whole of the central Danish region. Previously the till has been referred to as the NE-till (S.A.Andersen 1945, 1957, Berthelsen 1973).

\section{HISTORY}

Prior to the publication of-a "Summary of the Geology of Denmark" (Madsen et al. 1928) lithological and stratigraphical descriptions of the till, deposited by the ice sheet which reached the Main Stationary Line, had been rather insufficient or lacking.

Madsen et al. (1928) proposed, that till $C$ was deposited by the Main Weichselian ice sheet, and it was described on a regional scale according to its flint-quotient and bounding till units (see chapter 1). A "key locality" in Madsens' correlation was Ristinge Klint, where till $D$ (Madsen 1916) is characterized by limited quantities of Palaeozoic clast material (Fennoscandian pro- venance) when compared to the (Baltic) Weichselian till (C) underlying this "thick till" (D).

At Halk Hoved, Jessen (1930), recognized a till of Fennoscandian clast provenance deposited by an ice stream which also was responsible for the stacking of an older glacial sequence into NNE'dipping thrust slices. In addition, Jessen (1930) correlated the middle (NE-) till of Halk Hoved with the thick (Fennoscandian) till of Ristinge Klint, from which glacial striations on boulder pavements, indicating ice movement from the NE, had been recognized.

S.A.Andersen (1933) recommended, along similar lines of thought as Jessen (1930), that correlation of till units should be based on their content of Baltic/Nonbaltic clast material, associated indicator boulder erratics and the pattern of glacier movement that could be deduced from glaciotectonic deformations and, glacial striations on bedrock or boulder pavements. Andersen suggested, that the ice stream whic reached the Main Stationary Line came from the NE. The ice stream deposited a NE-till of Fennoscandian clast provenance also characterized by indicator boulders from Middle Sweden (Kinne- diabase).

The concept of the NE-ice being the Main Weichselian ice stream, which deposited the Fennoscandian NE-till in the central and southern parts of Denmark, was further outlined by Andersen $(1945,1957,1966)$, who with these papers contributed to the foundation of modern glacial stratigraphic research in Denmark.

Smed (1962) recognized a NE-SW oriented glacial striated boulder pavement connected to a till unit overlain by a (Young) Baltic till at Lindø, northeast of Odense, Fyn (fig. 3), and he related the former mentioned till to the ice advance from the NE, which produced the dead ice landscape of central Fyn.

Thamdrup (1970) described a NE-till at Mols Hoved (loc. 136), but it was interpreted as having been deposited by an early East Jylland ice stream, following the pattern of the Weichselian glacial evolution, formulated by K.Milthers (1942) and Wennberg (1949).

From various available stratigraphic sources Berthelsen (1973) outlined the distribution of the Weichselian NE-till and its relation to the Main Stationary Line in the eastern part of Denmark.

Sjørring (1974) correlated the upper till at Halsnæs, with the till laid down by the NE-ice. 


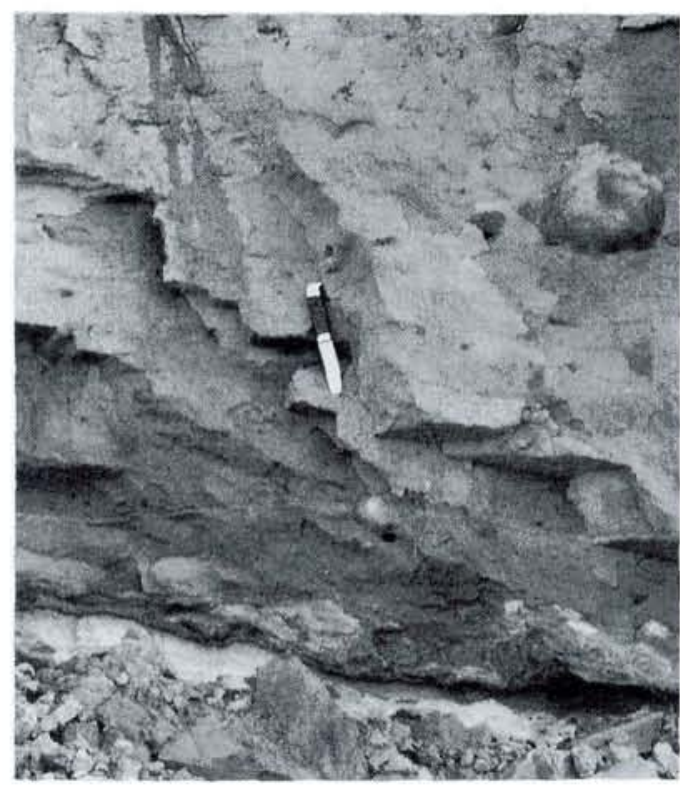

Fig. 124: Mid Danish Till, loc. 6, Sønderby Klint. See also figs 39 and 65 .

Berthelsen (1974) and Rasmussen (1974) recognized the NE-till and associated glaciotectonic unconformities at the base of the till in NE-Sjælland.

From Holmstrup, West Sjælland (fig. 3) Petersen and Buch (1974) described a Fennoscandian till overlying interstadial, marine deposits comparable to the upper part of the Portlandia arctica zone of the Older Yoldia clay and which contained re-deposited foraminifera from these deposits, thus they ascribed the till to the ice advance from the NE.

Frederiksen (1976) described the NE-till from the south-eastern part of Jylland (cf. loc. 112, Halk Hoved). He related this Fennoscandian till, containing an $\mathrm{X}$-foraminiferal accumulation, overlying glaciotectonic unconformaties indicating ice deformation from the NE and covered by the Young Baltic till, to the Main Weichselian advance.

Houmark-Nielsen (1976b,c, Houmark-Nielsen \& Berthelsen 1981) described a Weichselian, Fennoscandian NE-till, which was bound by glaciotectonic unconformaties indicating ice deformation from the NE, at Northern Sams $\emptyset$ and adjacent islands, and related it to the ice stream from the NE, which reached the Main Stationary Line. Houmark-Nielsen (1980, 1981, 1983c) mapped the distribution of the Weichselian, Fen- noscandian NE-till and its associated glaciotectonic unconformaties indicating ice deformation from the NE in the northern Bælthav region. The NE-till, which contains an average of $10 \%$ Pal. limestone clasts (ranging from $0 \%$ to $25 \%$ ) and an X-foraminiferal accumulation was on the background of previous investigations related to the Main Weichselian ice stream.

\section{TYPE SECTIONS}

1) Ristinge Klint (fig. 3). Here the Mid Danish Till is described from a principal locality in the vicinity of the examined region in terms of Fennoscandian clast provenance, associated NE-SW oriented striated boulder pavements and upper and lower bounding Baltic till units. The locality has recently been described by Sjørring et al. (1982).

2) Northern Sams $\varnothing$ (loc. 7, fig. 7). Along the cliffs of Northern Sams $\emptyset$ the Mid Danish till, its bounding Fennoscandian and Baltic till units and its associated waterlaid outwash deposits and glaciotectonic unconformaties appears in very well exposed sections.

\section{REFERENCE SECTIONS}

1) Sønderby Klint (loc. 6, fig. 7). Here the Mid Danish Till, its bounding till units and associated glaciotectonic unconformities, characteristic of the southern part of the examined region, is exposed.

2) Mols Hoved (loc. 136, fig. 44). Here the Mid Danish Till, its bounding till units and associated glaciotectonic unconformities, characteristic of the northern part of the examined region, is exposed.

3) Lyngerup (loc. 180, fig. 44). Here the Mid Danish Till and its upper bounding till unit and glaciotectonic unconformities associated with the overlying Fennoscandian till are described from a gravel pit, which is no longer accessible to study.

\section{LITHOLOGY}

The Mid Danish Till, which ranges in thickness between 1 and $4 \mathrm{~m}$, is grey to brown, it is mostly clayey and usually it appears massive (figs 39, 65, 124), but banded variaties do occur.

Fine gravel analysis revealed small quantities of quartz (less than 10\%) and intermediate to high values of flint $(15-40 \%)$. Exotic stone counts demonstrate Fennoscandian clast provenance 


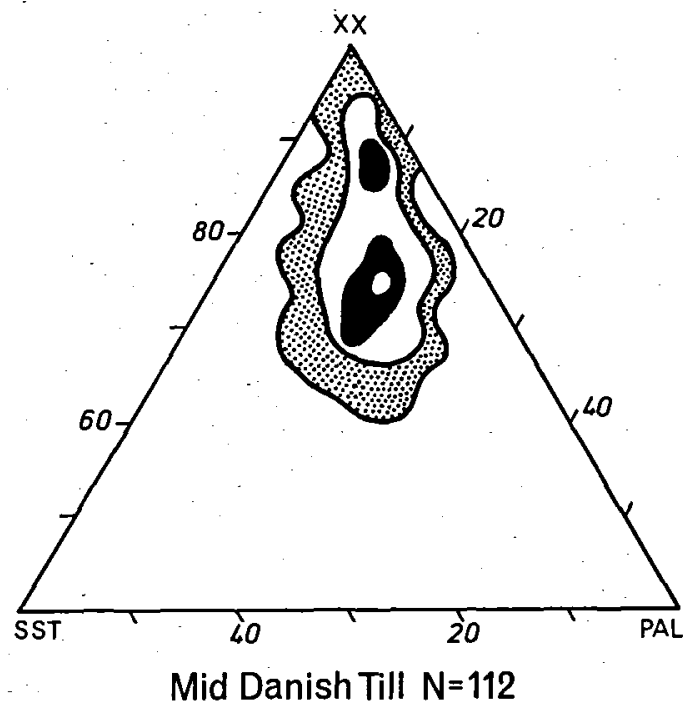

Fig. 125: Exotic stone counts, Mid Danish Till. Further explanation fig. 110 . (fig. 125), showing an average of $10-15 \%$ Pal. limestone. Lower values occur mainly in the northern and eastern part of the examined region $(0-10 \%)$, as well as higher quantities of Baltic clast material $(15-25 \%)$ is found predominantly in the southern and central parts. At a number of localities Kinne-diabase and the so called $\mathrm{Ka}$ tholm erratics have been found "in situ", and these provenance dependent rock fragments are also found in beach gravels together with dark garnet-amphibolites at coastal cliffs, where the Mid Danish Till is exposed.

The till is often characterized by re-deposited Quaternary foraminifera of the X-accumulation derived from parts of the Portlandia arctica zone of the Older Yoldia clay. In some instances in the southern part of the examined region, the till contains a Y-accumulation derived from Eemian sources (Cyprina clay), or a mixture of the two (X-Y) accumulations is found. In rare cases the till may show a Z-foraminiferal accumulation.

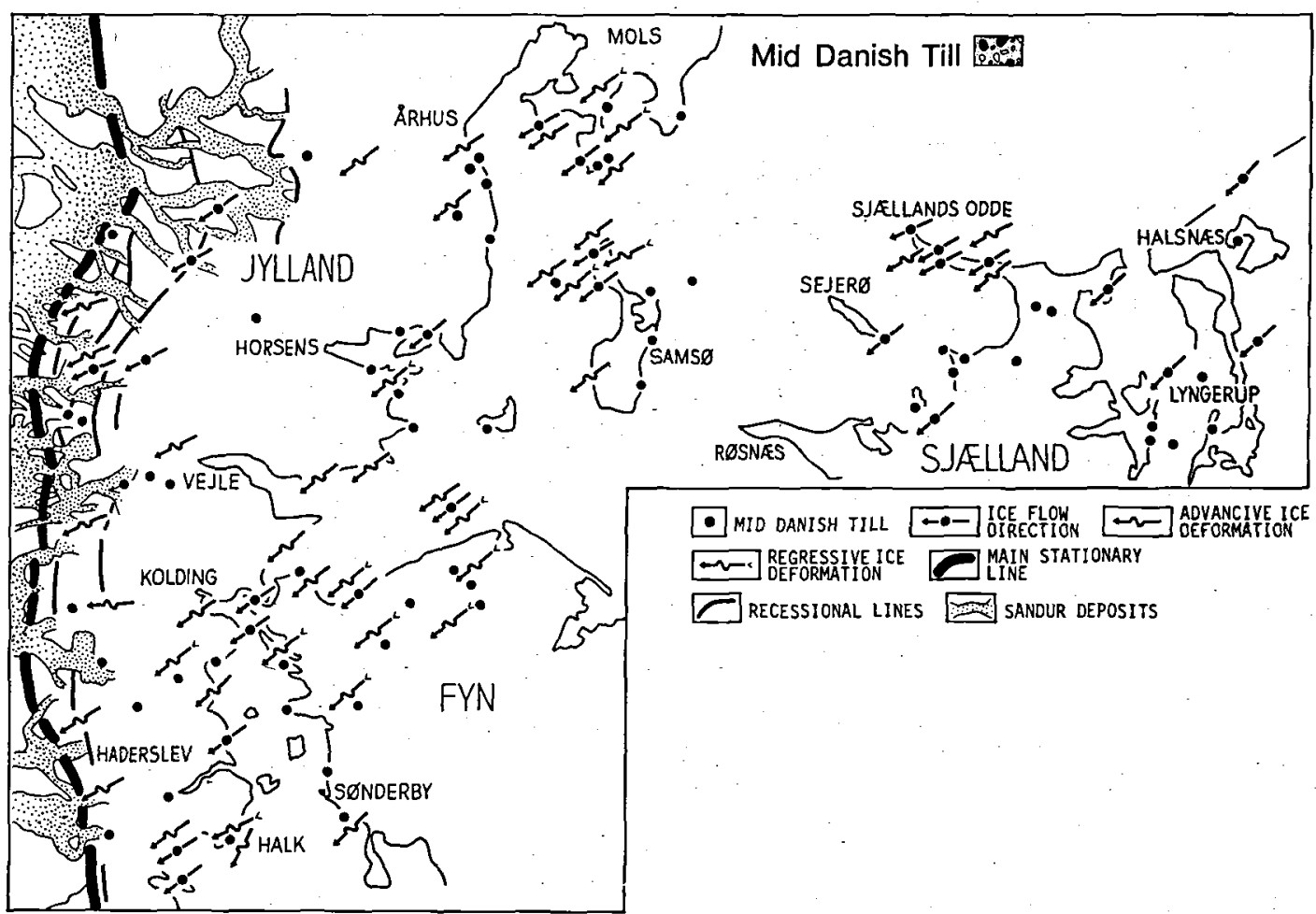

Fig. 126: Distribution of the Mid Danish Till and associated fabric analyses, glaciotectonic unconformaties, ice -marginal positions and sandur deposits. 
Clast orientation measurements show, that most fabrics are longitudinal or mixed, and only at few localities have transverse fabrics been recognized. Fabrics indicate deposition by an ice sheet moving in south-westerly directions.

\section{BOUNDARIES (fig. 105)}

Disregarding possible waterlaid outwash material, the Mid Danish Till is bound upwards by the East Jylland Till in the western part of the examined region, whereas the North Sjælland Till overlies it in the eastern part. Glaciotectonic unconformities indicating ice deformation from 1) the NE (related to readvances of the NE-ice during general retreat), 2) the $\mathrm{E}$ (youngest readvance of the NE-ice on Sjælland) or 3) SE to $S$ (advance of the Young Baltic icestream) may also constitute the upper boundary.

Often, the lower boundary is placed at the base of the till, where it is marked by glaciotectonic unconformities indicating ice deformation from north-easterly directions. In the southern region, the Mid Danish Till overlies the Ristinge Klint Till and it overlies the Kattegat Till towards the north and east.

\section{DISTRIBUTION}

The Mid Danish Till is found at almost all localities in the examined region (fig. 126), and the presence of the till is often accompanied by glaciotectonic unconformities indicating ice deformation from north-easterly directions developed either during the advance of the NE-ice sheet or during general retreat. The western limit of the Mid Danish Till appears to be marked by the Main Stationary Line (fig. 126), even though the deduced directions of glacier movement, especially in the northern sector, are not orientated quite perpendicular to the stationary line. In areas $4,8,11,12$ and 13 major readvances caused the formation of glaciotectonic structures and related landforms, which revealed a pattern of glacial retreat towards the NE interrupted by readvances.

\section{$A G E$}

The stratigraphic position of the Mid Danish Till at Ristinge Klint and Sønderby Klint (loc. 6) demonstrate Weichselian age, and the till is youn- ger than the Ristinge Klint - and Kattegat tills and older than the North Sjælland - and East Jylland tills respectively. A late Middle Weichselian age is suggested, and in accordance with results of absolute dated interstadial material (cf. Petersen 1984) an age of approximately 24000$20000 \mathrm{BP}$ is proposed.

\section{CORRELATION}

Correspondance with extra-regional, Fennoscandian, NE-tills of Weichselian age with similar boundaries as the Mid Danish Till can be demonstrated throughout the greater part of Denmark that was glaciated during the Weichselian. Till units comparable to the Mid Danish Till and/or glaciotectonic unconformities indicating ice pressure from north-easterly directions found in the stratigraphical record has been described from a large number of areas: Møn (Aber 1979, Berthelsen et al. 1977), Falster (Jacobsen 1981), Lolland (Andersen 1957, Fredericia 1979), South Sjælland (Jacobsen 1981, Petersen \& Konradi 1974), Storebælt (Berthelsen 1975, Jacobsen 1976, Nielsen 1980, Petersen 1973, Rasmussen 1975, Ussing \& Madsen 1897), Middle Sjælland (Jacobsen 1985, Petersen \& Buch 1974), NESjælland (Berthelsen 1973, 1974, Rasmussen 1974), Southern Lillebælt (Sjørring 1977, Sjørring et al. 1982), East- and Middle Jylland (Fårup Till: Kronborg 1983, Larsen et al. 1977), Viborg area (Rasmussen \& Petersen 1980), Northern Limfjord (Gry 1979) and Western Limfjord (Jensen \& Knudsen 1984).

Outside the country the Mid Danish Till is correlated with the Västernäs Till from eastern Øresund (Ven-Glumslöv area: Adrielsson 1984) and the NE-till facies of the Dalby-Bräcke-Sallerup tills of Skåne (Berglund \& Lagerlund 1981, Lagerlund 1980, Ringberg et al. 1984).

In accordance with Andersen (1966) the western limit of the Mid Danish Till is marked by the Main Stationary Line, which accordingly corresponds to the limit of the Frankfurt Stage of nortern Germany.

In Schleswig-Holstein the till disturbed by the Fehmarn advance has tentatively been correlated with the NE-till (Stephan et al. 1983), even though principal dificulties in correlation based on deduced directional pattern of movement and 


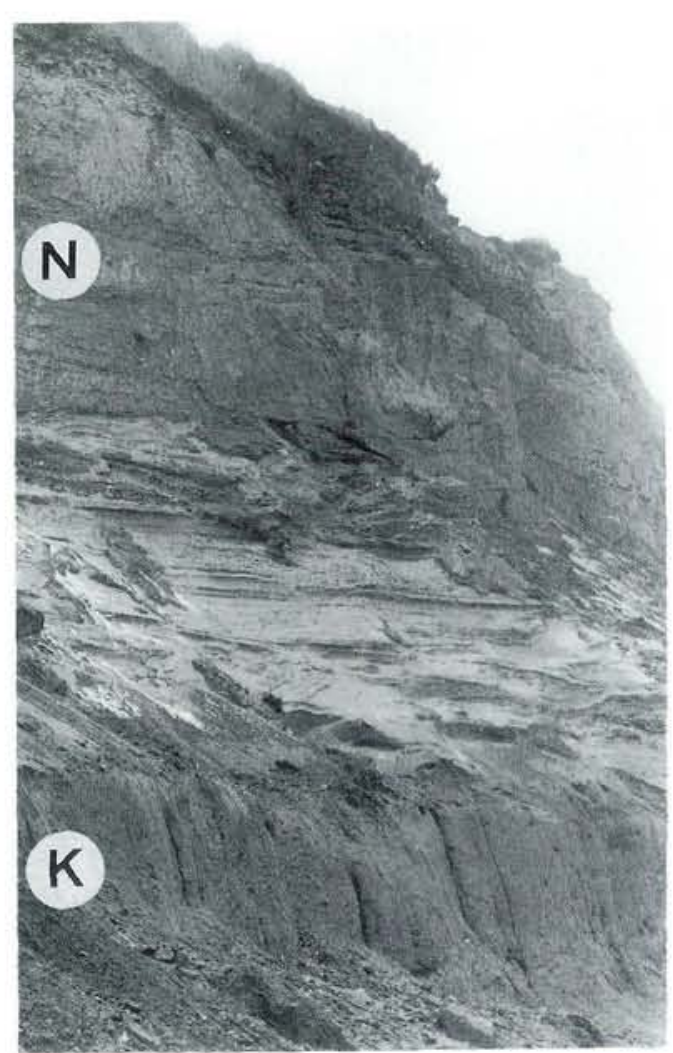

Fig. 127: North Sjalland Till (N) overlying finegrained waterlaid material and the Kattegat Till (K), Hundested.

clast petrography should be mentioned as stated by Stephan et al. (1983).

\subsection{NORTH SJAELLAND TILL FORMATION}

This till unit is named the North Sjælland Till because it is apparently confined to this part of the examined region.

\section{HISTORY}

Rørdam (1893) defined the upper till of North Sjælland as a Dala-Baltic till, however, stone counts (Rørdam 1893) revealed the presence of both Fennoscandian and Baltic clast material within this unit.

Sjørring $(1973,1974)$, using stratigraphical and structural analyses concluded, that the upper till of the Hundested area is of Fennoscandian clast provenance. It was deposited by an ice sheet from easterly directions, which most probably caused the formation of N-S' orientated ice shoved ridges in NE-Sjælland.
SE of Hundested at Lynæs Jensen (1977) confirmed Sjørrings observations and presented a till fabric analysis from the upper till, which revealed a strong longitudinal fabric indicating deposition by an ice stream flowing in a direction from east to west.

Houmark-Nielsen $(1980,1981,1983 \mathrm{c})$ mapped this E-till in the central parts of North Sjælland. The till is of Fennoscandian clast provenance, and it is underlain by the NE-till and overlain by a Young Baltic till. The E-till was assumingly a non-Baltic equivalent to the Young Baltic till from the western part of the Bælthav region and it was suggested, that both tills had been deposited by the ice stream, which reached the East Jylland Iceborder Line.

\section{TYPE SECTIONS}

Hundested Klint and Store Karlsminde Klint (Lynæs) the latter lying about $3 \mathrm{~km} \mathrm{SE}$ of Hundested (fig. 44). Here the till and its associated glaciotectonic unconformaties have previously been described (Sjørring 1974, Jensen 1977).

\section{REFERENCE SECTIONS}

Lyngerup (loc. 180, fig. 44). In this recently (1983) closed gravel pit, the North Sjælland Till, its associated glaciotectonic unconformity at the base of the till and the lower and upper bounding units were accessible to study.

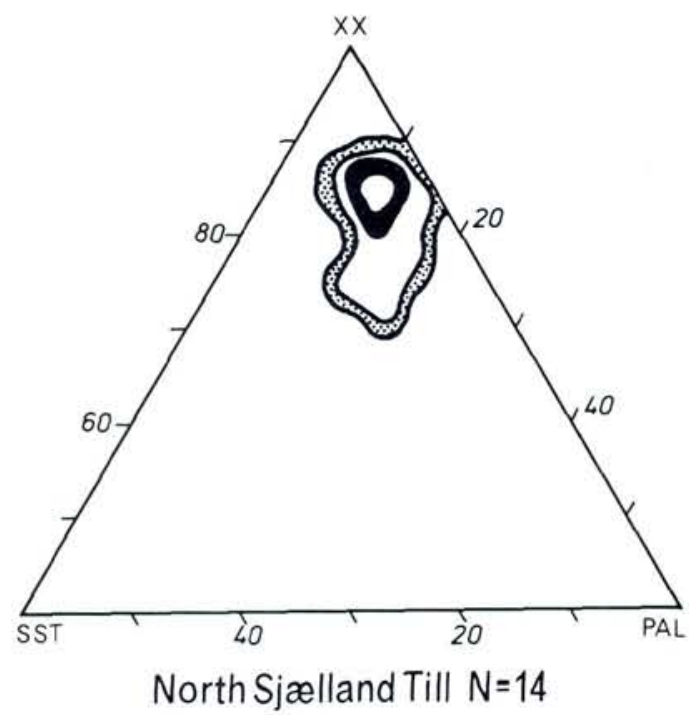

Fig. 128: Exotic stone counts, North Sjalland Till. Further explanation fig. 110. 


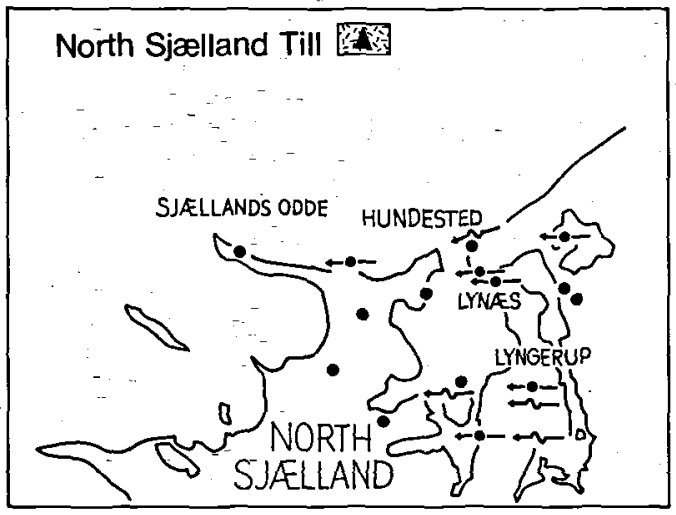

- north suflland till $\because$ ice flow direction

$\sim$ ADVANCIVE-ICE DEFORMATION

Fig. 129: Distribution of the North Sjælland Till and associated fabric analyses and glaciotectonic unconformaties.

\section{LITHOLOGY}

The North Sjælland Till is usually brown, about 1 $m$ thick and massive (fig. 127), however, banded variaties of greater thickness do occur. Fine gravel analyses show little quartz $(0 \%-6 \%)$ and intermediate quantities of flint $(20 \%)$. Exotic stone counts démonstrates Fennoscandian provenance (5\%-20\%-Pal.limestone) with an average of about $10 \%$ (fig. 128).

Clast orientation measurements revealed longitudinal or mixed fabrics indicating deposition by an ice sheet flowing from easterly directions.

\section{BOUNDARIES (fig. 105)}

The North Sjælland Till is separated from bounding till units by waterlaid outwash material. It is bound upwards by the Bælthav Till and it overlies the Mid Danish Till. Often glaciotectonic unconformities at the base of the till indicating ice deformation from the east constitute the lower boundary.

\section{DISTRIBUTION}

The North Sjælland Till is confined to the eastern section of the examined region (fig. 129), and its western limit-is, on somewhat speculative grounds, placed somewhere in the Storebalt region. It is suggested, that the till was deposited during a readvance from easterly directions during deglaciation of the Main Weichselian ice sheet. The formation of the younger recessional ice pressed structures and morphological el- ements, that are related to the Main Weichselian glaciation found in the Mols-Helgenæs-North Samsø area (Houmark-Nielsen 1980; 1983c), could possibly have been caused by this readvance at its maximum extension.

\section{$A G E$}

Because it overlies the Mid Danish Till a Weichselian age younger than $20000 \mathrm{BP}$ is indicated for the North Sjælland Till. It is overlain by a till of the Young Baltic glacial phase, which on indirect evidence is dated to about $14000 \mathrm{BP}$. Therefore an age of $16000-15000$ years BP is suggested for the North Sjælland Till.

\section{CORRELATION}

With the present data available it has only been possible to correlate the North Sjælland till with tills from two localities situated in the vicinity of the area of distribution. The previous correspondance to the Young Baltic till in the western part of the Bælthav region (Houmark-Nielsen 1980, $1981,1983 \mathrm{c}$ ) is no longer regarded as valid. This is because, firstly, all directional properties differ too greatly and secondly, the change from Fennoscandian to Baltic clast provenance in the northern Storebælt area is now regarded to be too abrupt and pronounced to be explained by local incorporation of older Baltic till material.

On the basis of its stratigraphic position, clast provenance and deduced directional elements, the North Sjælland Till is correlated with the massive E-till, which overlies (NE-) push structures and a banded till supposedly deposited by the NE-ice stream, described from Dragstrup (NE-Sjælland) by Rasmussen (1974).

The North Sjælland Till is also correlated with the upper till (c) of Fennoscandian clast provenance overlying a glaciotectonic unconformaty indicating ice pressure from the east described by Petersen and Buch (1974) from Holmstrup, even though this till is ascribed by these authors to the Young Baltic ice advance.

\subsection{EAST JYLLAND TILL FORMATION}

This till is named East Jylland Till, because it is found in south-eastern Jylland and on adjacent islands towards the south and east. Furthermore, the maximum extension of the ice sheet, which deposited the till, is defined by the East Jylland Ice border line. 


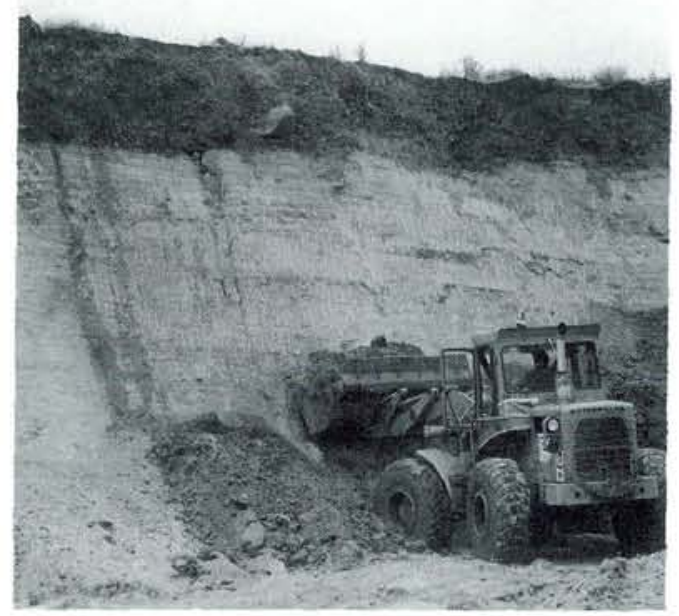

Fig. 130: East Jylland Till, loc. 11, Randlev. See also figs 62 and 93.

The Baltic surface-till in east Jylland and the ice advance, which reached the East Jylland Ice border, have previously been referred to as till D/D advance (Madsen et al. 1928) or the Young Baltic till/Young Baltic advance or SE-till/SE-advance (Andersen 1945, 1957, 1966, Berthelsen 1973). Houmark-Nielsen (1980) informally used the term East Jylland Till (Østjysk moræne) to indicate the till deposited by the Young Baltic advance in Jylland.

\section{HISTORY}

Harder demonstrated the Baltic clast composition of the youngest till in East Jylland deposited by the ice stream, that reached the East Jylland Ice border line.

Stone counts from the youngest till, which covers Fennoscandian tills south and east of the area examined by Harder (Jessen 1907, 1930, 1935) and Madsen $(1897,1900)$ also demonstrate Baltic clast provenance. Thus, the till is also present in more upstream areas on the mainland and east of Jylland (Southern Jylland, Fyn, Samsø, Helgenæs).

Madsen et al. (1928) described the youngest till of eastern Jylland in terms of the flint quotient and named it till D, and consequently the East Jylland Ice border line was termed line D.

Contradictory to V.Milthers (1932) and
K.Milthers (1942) Berthelsen (1949) demonstrated, that the hinterland of the East Jylland Ice border consists of one homogeneous indicator association indicating, that just one Baltic ice advance had covered eastern Jylland after the retreat from the Main Stationary Line.

Thamdrup (1970) showed, by the use of structural analyses, that a NE-till and underlying deposits at Mols Hoved had undergone glaciotectonic thrusting and folding from a south-easterly direction, presumably by the ice sheet which gave rise to the final layout of the east Jylland Ice border on Mols.

Frederiksen $(1975,1976)$ showed, that the East Jylland till was deposited from south-easterly directions on the east coast of southern Jylland and, that as well as the Baltic clast provenance it was also characterized by re-deposited Quaternary foraminifera derived from Eemian sources in the southern part of Denmark.

Sjørring $(1973,1974)$ found no trace of a Young Baltic till in the Hundested area, Northeast Sjælland. Further eastwards a Young Baltic till deposited from southerly to south-easterly directions (Berthelsen 1973, Berthelsen et al. 1976, Rasmussen 1974) overlies Fennoscandian tills deposited by ice sheets from northeasterly to easterly directions.

Houmark-Nielsen $(1980,1981$, Houmark-Nielsen \& Kolstrup 1981) described the presence of two Young Baltic till-beds with diverging directional properties on southern Sams $\emptyset$ and Sejerø. It was suggested, that the lower of the two was deposited by the East Jylland advance and the upper by the Bælthav advance, which respectively reached the East Jylland Ice border and the ice border lines in northern Storebælt. The Young Baltic tills and their directional properties in the area covered by the so-called Lillebælt glacier (Madsen et al. 1928: E advance) was related to the Bælthav advance (Houmark-Nielsen 1981) in an attempt to present old as well as new information on the glacial stratigraphy east of the Main Stationary Line.

\section{TYPE SECTIONS}

Sønderby Klint (loc. 6, fig. 7) and Mols Hoved (loc. 136, fig. 44). In these two well exposed cliff sections the East Jylland Till, its associated glaciotectonic unconformaties and lower bounding till units are found. 


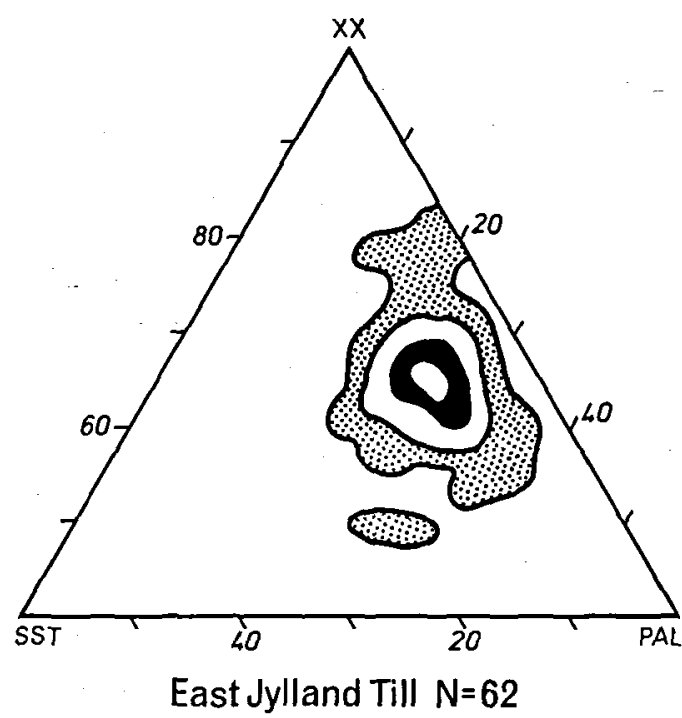

Fig. 131: Exotic stone counts, East Jylland Till. Further explanation fig. 110 .

\section{REFERENCE SECTIONS}

Vestborg Fyr (loc. 146, fig. 44). Here on the southern tip of Sams $\varnothing$ the East Jylland Till and its upper bounding Baltic till unit and a glaciotectonic unconformaty related to the latter unit is present.

Nim-Hvirring (locs 16, 17, 18, fig. 39). Here the East Jylland Till, its associated glaciotectonic unconformaties and transitional, waterlaid facies, which laterally replace the till, are exposed in gravel pits along a segment of the East Jylland Ice border.

\section{LITHOLOGY}

The East Jylland Till is clayey, brown to grey and usually between 1-2 $\mathrm{m}$ in thickness. It appears both banded and massive (figs 35, 130). Fine gravel analyses show little quartz (less than 10\%) and intermediate quantities of flint (20\%). Exotic stone counts reveal baltic clast provenance with an average of $25 \%-30 \%$ Pal.limestone ranging from $15 \%$ to $40 \%$ (fig. 131). In the northern

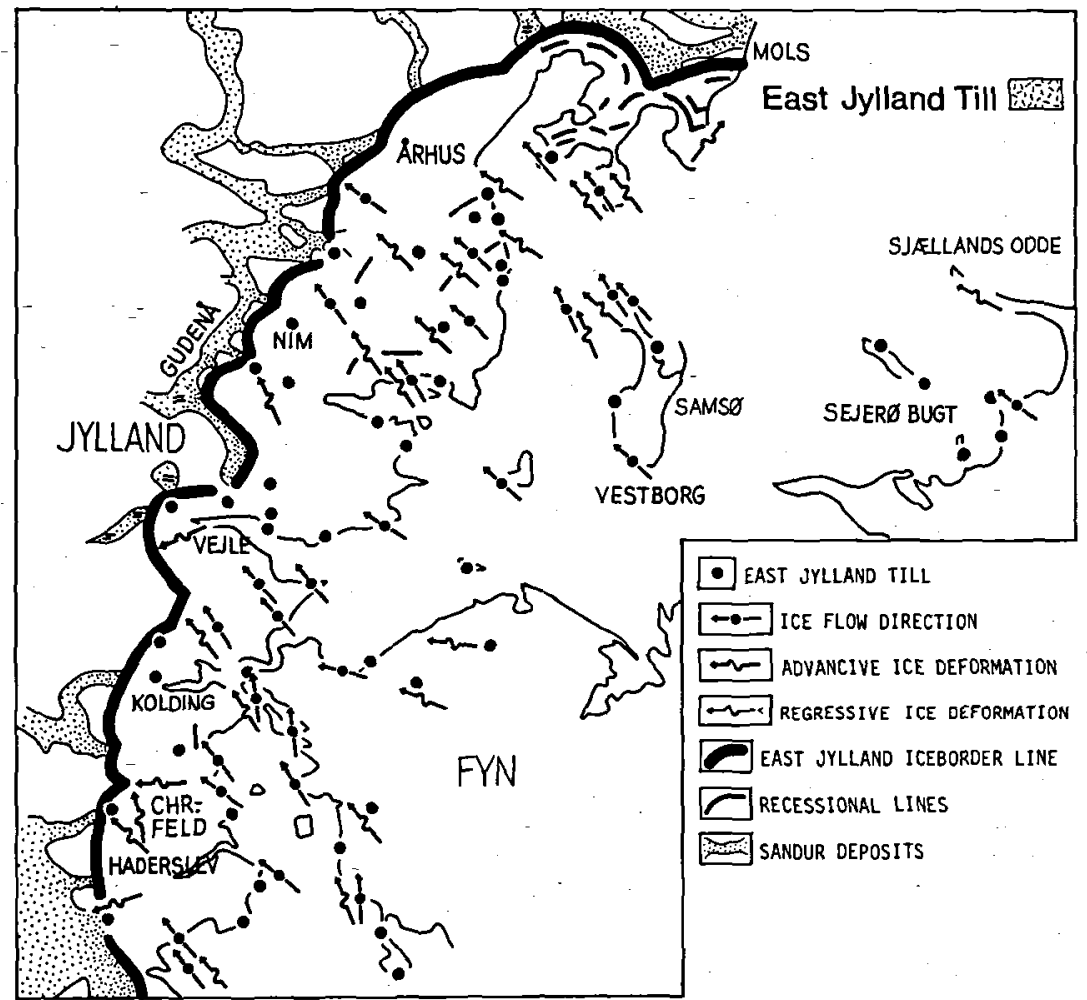

Fig. 132: Distribution of the East Jylland Till and associated fabric analyses, glaciotectonic unconformaties, ice-marginal positions and sandur deposits. 
Storebælt area values approaching Fennoscandian provenance do occur, however, these values are still much richer in Pal.clast material than the underlying Mid Danish till at these localities.

In the southern part of the examined region the till is also characterized by re-deposited molluscan fragments and Quaternary foraminifera of the Y-accumulation, derived from Eemian sources situated in the southern part of the country.

Analyses of clast orientation revealed longitudinal and mixed fabrics indicating deposition of an ice sheet from south-easterly directions, even though local directions from the south and the east have been noted.

\section{BOUNDARIES (fig. 105)}

On the mainland of Jylland and western Fyn no upper bounding till unit has been observed, thus in this part of the examined region the East Jylland Till constitutes the youngest till deposit. From descriptions of the geological map sheets Haderslev (Jessen 1935) and Fredericia (Nordmann 1958) it has been shown, that the upper till is in places covered with Late Weichselian limnic deposits.

On Sams $\emptyset$ and in the Sejerø Bugt area the upper bounding till unit is the Bxlthav Till, glaciotectonic unconformities related to the Balthav advance may also constitute the upper boundary.

The lower bounding till-unit in the western part of the examined region is usually the Mid Danish Till even though the till may directly overlie older glacial (fig. 9) - or even Tertiary deposits. Glaciotectonic unocnformities at the base of the till indicating ice pressure from easterly over south-easterly to southerly directions may constitute the lower boundary.

The till may be laterally replaced by ice marginal deposits (debris flows and proximal waterlaid material) towards the west along the East Jylland Ice border (Houmark-Nielsen 1983a).

In the eastern part of the region or slightly beyond it the East Jylland Till is assumed to be laterally replaced by the Balthav Till, even though such a transition has not been observed.

\section{DISTRIBUTION}

The East Jylland Till is usually found in the western part of the examined region (Jylland, Fyn, Samsø, Sejerø) and only very occasionally found on western Sjælland (fig. 132). Its maximum extension lies along the East Jylland ice border line, away from which meltwater streams from the central and northern sector of the iceborder carried outwash material towards the north and westwards in the southern sector.

The directional pattern shows general glacier movement from south-easterly directions with more merging directions on the lee side (northwestern side) of Fyn. Close to the ice margin local, diverging flow patterns are found.

\section{$A G E$}

The east Jylland Till is older than the Late Weichselian deposits which cover the till in local depressions in eastern Jylland. Therefore a late Middle Weichselian age is proposed. Radiocarbon datings of a mammuth tusk embedded in the sandur deposits formed in front of the East Jylland Ice border at Rosmus on Djursland (Petersen 1984) revealed an age around $13240+760 /$ -690 BP. Petersen (1984, pers.comm.) argued, that this dating indicates the age of the East Jylland Iceborder, because the mammuth tusk is found in the highest elevated and proximal parts of the outwash plain deposited during the maximum extension of the East Jylland ice. Deposition on the sandur apparently took place prior to the transition to a dead ice phase; a phase that was active on Mols as indicated by Rasmussen (1977) and possibly also recorded west and north of Egernsund, southernmost Jylland (Jessen 1945).

It has been suggested that northward flowing outwash, draining the East Jylland ice, merged in the Ålborg area with the Younger Yoldia sea around 14000 BP (Berthelsen 1973). Petersen (1984) suggests, that the maximum transgression of the Younger Yoldia Sea and the formation of the east Jylland Ice border were synchronous events, which took place around $13500 \mathrm{BP}$.

As similar ages have been reported from shell material deposited in front of the Halland coastal moraines (Berglund \& Lagerlund 1981), which the present author has estimated to be slightly younger than the Balthav readvance, and as this readvance of the Young Baltic ice sheet (Bælthav adv.) covered eastern Denmark and parts of western Skane later than the East Jylland advance, it is suggested that the East Jylland Till and the terminal moraines in eastern Jylland 
should be given an age of about $14000 \mathrm{BP}$ rather than the younger age proposed by Petersen (1984).

\section{CORRELATION}

The East Jylland Till is correlated with the socalled Højvang Till of the Arhus area (Kronborg 1983) which was presumably deposited by the East Jylland Ice advance.

The East Jylland Till is also connected to extra regional Baltic tills and their associated underlying glaciotectonic unconformities indicating ice pressure from south-easterly to easterly directions. They overlie Fennoscandian NE-tills and are in turn overlain by Baltic till-units or have been affected by glaciotectonic disturbances from south-easterly or southerly directions. Such till units or glaciotectonic unconformities are described from Als (Sjørring 1977), Ristinge Klint (Sjørring et al. 1982), Omø (Jacobsen 1976) and Korsør (Nielsen 1980). Even though directional properties do differ, the middle till of Hindsholm (supposedly deposited from southwesterly directions, Rasmussen 1975) could also have been deposited by the East Jylland ice advance.

It can be discussed, whether the next upper Baltic till of Omø (Jacobsen 1976) or LollandFalster (Sjørring 1981b) was deposited by the East Jylland Ice advance or the Bælthav readvance. It is however, suggested, that the east Jylland Till in the southern part of Denmark as well as in the eastern part of the examined region is replaced laterally by the Balthav Till, and that the latter till can also be divided into subunits deposited by local readvances during general deglaciation.

\subsection{BAELTHAV TILL FORMATION}

This till unit is named Bælthav Till, because it is found in the Bælthav region (Lillebælt-Storebælt$\emptyset$ resund). Its maximum extension on Sjælland is marked by the pronounced marginal moraines around Odsherred, whereas its position in the Storebælt is marked by arch shaped shoals on the seabed, the highest parts of which form islands (Sams $\varnothing$, Vejrø, Sejer $\varnothing$ ). This outline in Storebælt has previously been referred to as the E-line (Madsen et al. 1928) formed during the Bælt advance (E-advance).

\section{HISTORY}

V.Madsen (1897) and Ussing and Madsen (1897) characterized the upper till of southern Sams $\varnothing$ and Hindsholm as Baltic, because of the large quantities of Pal.limestone clasts found in the till.

Rørdam (1893) and Rørdam and Milthers (1980) suggest, that the upper till of north Sjælland was deposited by a Baltic ice stream, even though published stone counts suggest a more complex depositional history. This till was correlated with the upper, Baltic tills of South Sams $\varnothing$ and Hindsholm. During deglaciation of the Baltic ice stream outstanding recessional ice marginal moraines were formed in Odsherred (V.Milthers 1900) and other N-S' trending ridges in NE-Sjælland (Gribskov Line, V.Milthers 1916) were also ascribed to the retreat of this Baltic ice sheet.

Madsen et al. (1928) suggested, that the Bælt advance (E-advance) covered almost the whole of Sjxlland and the maximum extension of this Baltic ice sheet in Storebælt was supposed to be marked by the islands of Sams $\emptyset$ and Sejerø.

According to Berthelsen $(1973,1974)$ and Rasmussen (1974) the Baltic, SE-till constitutes the youngest of the "upper tills" described by Rørdam (1893). Sjørring (in Berthelsen et al. 1976) has shown, that the Young Baltic advance dislocated the Strø Bjerge "esker" (NE-Sjalland) from southerly directions and deposited a Baltic till in the area between Roskilde Fjord and Arresø, however, Sjørring $(1973,1974)$ finds no evidence of a Young Baltic ice transgression around Hundested.

Houmark-Nielsen (1980, 1981, 1983c) sketched the distribution of the Baltic surface till in the northern Bælthav region and concluded, that the till could be informally named the S/SEtill or Bælthav till and that it was deposited by the Bælthav advance. The maximum extension of this advance, which was regarded as an ice stream independent of the East Jylland Advance, lies along the marginal moraines of Odsherred and could be followed through Sejerø Bugt and northern Samsø southward towards Hindsholm. Houmark-Nielsen (1981) correlated this advance with the outline of the Balt Stage (E-line) sketched by Madsen et al. (1928).

\section{TYPE SECTION}

Loc. 8: Sejerø, fig. 7. Here the Bælthav Till, its bounding units and an associated glaciotectonic 


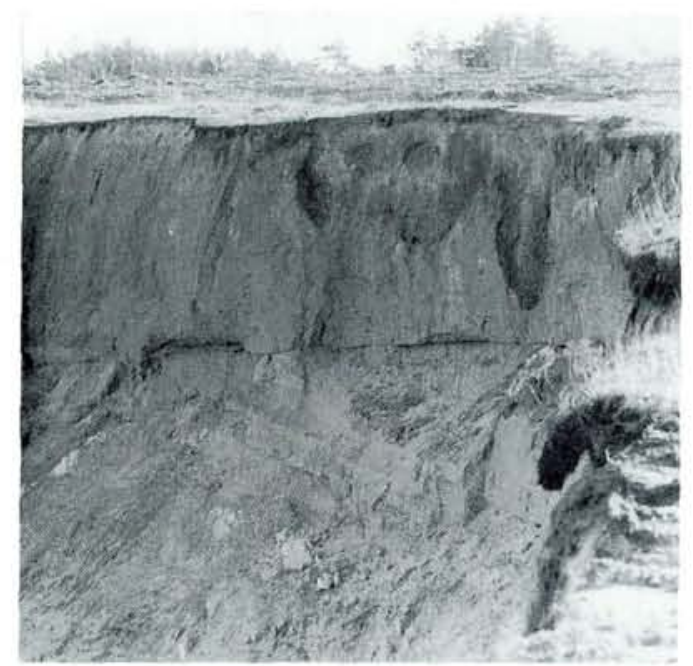

Fig. 133: The Balthav Till, loc. 187, Arrenakke. See also fig. 62.

unconformity is seen in an occasionally well exposed cliff section.

\section{REFERENCE SECTIONS}

Loc. 146: Vestborg Fyr, fig. 44. Here the lower bounding unit characteristic of the western part of the examined region and a glaciotectonic unconformity related to the Bælthav re-advance is readily accessible for study in an, at times, well exposed cliff section.

Loc. 180: Lyngerup, fig. 7. Here the lower bounding till unit characteristic of the eastern part of the examined region was accessible to study in an abandoned gravel pit.

\section{LITHOLOGY}

The Bælthav Till is brown, clayey, mostly massive and up to $3 \mathrm{~m}$ in thickness (figs 102,133). Fine gravel analyses show little quartz (less than $6 \%$ ) and intermediate quantities of flint (15$25 \%$ ). Exotic stone counts demonstrate Baltic provenance with an average of $30 \%$ Pal.limestone (fig. 134).

Clast orientation measurements revealed longitudinal and mixed fabrics indicating ice movement from eastern over southern to southwestern directions.

\section{BOUNDARIES (fig. 105)}

The Bælthav Till is bound upwards by late Middle Weichselian deglaciationsediments (Hou-
mark-Nielsen \& Lagerlund 1987), or Late Weichselian-Flandrian deposits cover the till in depressions. Thus the Bælthav Till constitutes the youngest Weichselian Till related to a glacier advance in the eastern part of the examined region.

The lower boundary consists of glaciotectonic unconformities indicating ice pressure from the $\mathrm{E}$, the SE, the S and the SW; and the Bælthav Till overlies the East Jylland Till in the central part of the examined region and the North Sjælland Till towards the east.

The till laterally changes into coarse waterlaid outwash material along the terminal moraines of Odsherred and it is assumed laterally to coincide with the East Jylland Till in western North Sjælland.

\section{DISTRIBUTION}

The distribution of the Bælthav Till and its associated glaciotectonic unconformaties are confined to the northern Storebælt region and northern Sjælland except for Sjællands Odde (fig. 135). The till was apparently deposited by two great glacier-lobes, one in Storebælt and one on Sjælland. The western and northern limit of the till and associated directional elements is estimated to lie west of South Samsø, through North Sams $\emptyset$, north of Sejerø and through the Odsherred ice marginal moraines northwards into $\mathrm{Ka}$ -

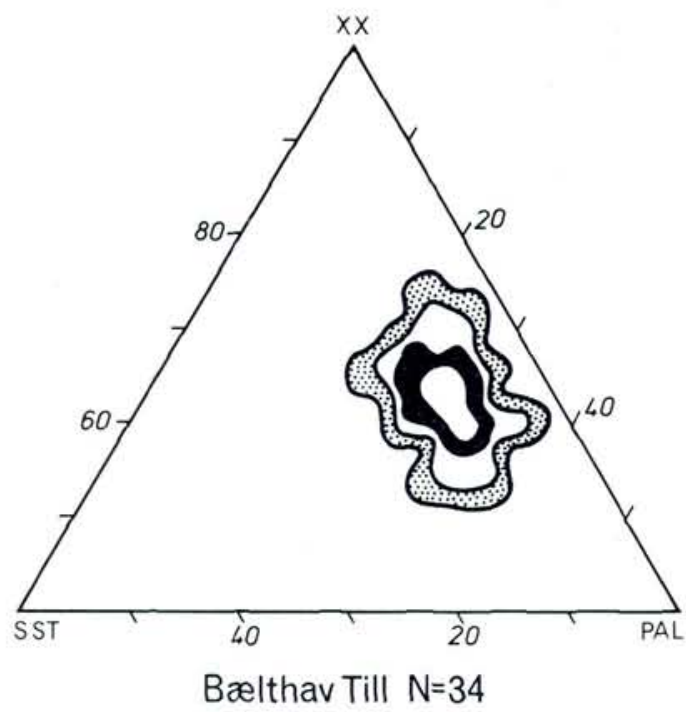

Fig. 134: Exotic stone counts, Balthav Till. Further explanation fig. 110 . 


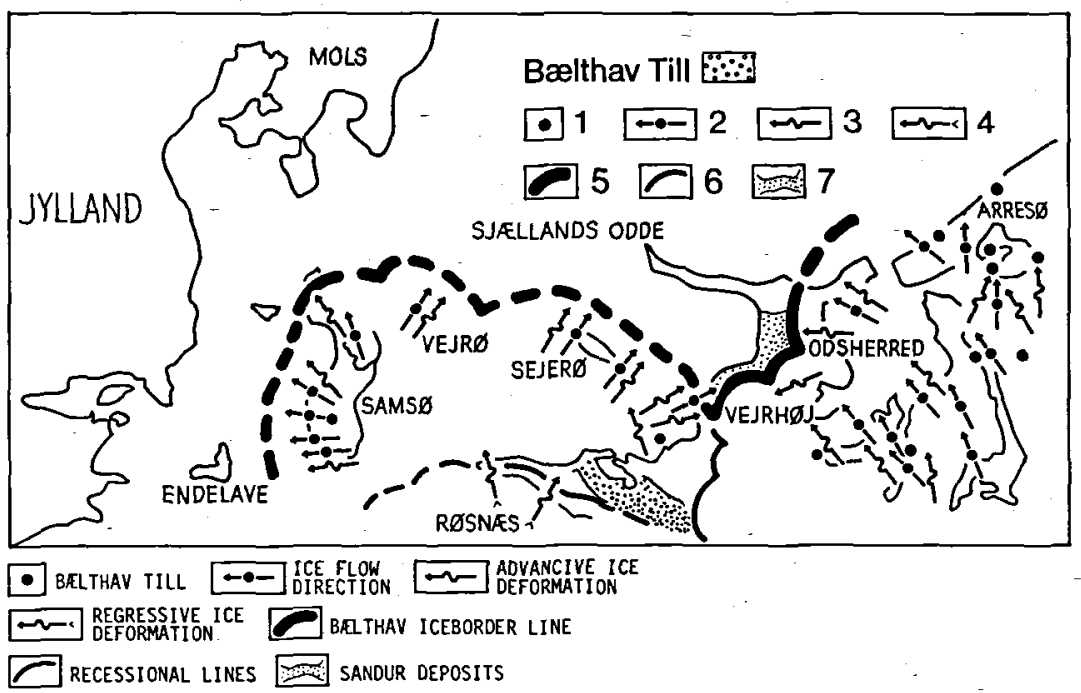

Fig. 135: Distribution of the Bælthav Till and fabric analysis, glaciotectonic unconformaties, ice-marginal positions and sandur deposits.

ttegat and can be drawn in accordance with Houmark-Nielsen $(1980,1983 c)$. Recessional advances which reached Røsnæs and the area south of Lammefjord are also shown in fig. 135.

\section{$A G E$}

The existence of undisturbed limnic material deposited during the Bølling Interstadial (early Late Weichselian) in the south-eastern part of the country (Møn, Kolstrup 1982) indicates, that deglaciation of the Young Baltic ice sheet had been active before, and was progressing during the very beginning of the Late Weichselian and, that here after no ice advances transgressed the Danish region. Therefore, a very late Middle Weichselian age is indicated for the Bælthav Till.

Owing to the lack of datings from the area in Denmark covered by the Bælthav Till, ages obtained from southernmost Sweden are used to determine a possible age. Even though conflicting evidence as to the deglaciation pattern and the nature of till deposition around the end of the Middle Weichselian in Skåne does exist (cf. Berglund \& Lagerlund 1981, Duphorn et al. 1979, Ringberg et al. 1984) a tentative age determination is attempted.

Berglund and Lagerlund (1981) related the Young Baltic advance and readvances to the deposition of the upper Baltic facies of the DalbyBräcke tills prior to 13300 BP. Duphorn et al. (1979) and Ringberg (1984) argued to the con- trary that the so called Low Baltic ice advance transgressed south-western Skåne after $13200 \mathrm{BP}$ and deposited the younger (low-) Baltic till (Sunnanå Till, Ringberg 1984) from westerly directions and correlated this advance with the Bælthav advance. It is, however, argued by Lagerlund (1980) and Houmark-Nielsen and Lagerlund (1987) that the till presumably related to the Low Baltic advance ( $=\emptyset$ resund-Low Baltic glacier) in fact was not deposited by an active glacier but can be characterized as a subaqueous partly ice-rafted till.

On the background of the mentioned correlation (Berglund \& Lagerlund 1981) it is suggested, that an age slightly older than $13500 \mathrm{BP}$ should be applied to the Bælthav Till, thus, the present author prefers the interpretation of Berglund and Lagerlund (1981) and Lagerlund et al. (1983). However it must be kept in mind, that the Bælthav readvance eventually led to the deposition of the uppermost Baltic diamicton found in Skåne during its deglaciation.

\section{CORRELATION}

The Bælthav Till is correlated with the upper Baltic till of North Sjælland (Berthelsen 1973, 1974, Rasmussen 1974), from the rest of Sjælland (Berthelsen 1975, Jacobsen 1984, Nielsen 1980, Petersen 1973) and adjacent islands (Berthelsen et al. 1977, Fredericia 1979, Jacobsen 1976, 1981), 
eastern Fyn (Madsen 1902, Rasmussen 1975, Ussing \& Madsen 1897) and Ristinge Klint (Sjørring et al. 1982) even though this upper till is limestonefree at the latter locality. Also the upper Baltic till on Als (Sjørring 1977) is correlated with the Bælthav Till.

The correlation of the Bælthav Till with the Baltic till deposited by the so called Lillebralt glacier in the area between Kolding and Als (Houmark-Nielsen1981) has been shown not to be valid. This is because in the whole of the Lillebælt region north of Als only one Young Baltic till has been observed, where as south and east of Als two Young Baltic tills or glaciotectonic disturbances related to two Young Baltic ice advances have been observed (Jacobsen 1976, Sjørring 1977, Sjørring et al. 1982).

From the Ven-Glumslöv area in the eastern Øresund region and from western Skåne the Bxlthav Till is correlated with the Laebrink Till ${ }^{-}$ (Adrielsson 1984) and the upper Baltic facies of the Dalby-Bräcke - and Sallerup-Limhamn tills (Berglund \& Lagerlund 1981, Lagerlund 1980, Ringberg et al. 1984) respectively.

\section{REGIONAL STRATIGRAPHY OF PLEISTOCENE TILL FORMATIONS}

Till Formations erected in the present investigation are correlated with extra-regional, glacial stratigraphic till-units, and related to biogenetically classified interglacial/interstadial material, absolute datings and morphological elements from areas in the vicinity of the examined region. By this comparison a schematic NE-SW' oriented cross section through an about $300 \mathrm{~km}$ wide sector covering central Denmark and strecting from the Øresund and southern Kattegat southwestwards through the examined region to the Danish-German borderland can be presented (fig. 139). The outline of this cross-section is based on observations from the central Danish region (present investigation) supplied with data from southern Jylland (Jessen 1922, 1925, Jessen \& Milthers 1928, Kolstrup \& Haveman 1984, V. Milthers 1939, Sjørring \& Frederiksen 1980, Sjørring 1981), Fyn (Rasmussen 1975, Smed 1962, Ussing \& Madsen 1897), northern and central Sjælland (Berthelsen 1973, 1974, 1975, H. Lykke-Andersen 1979, Petersen 1973, Petersen \& Buch 1974, Petersen \& Konradi 1974, Rasmussen 1973, Schuldt 1981, Sjørring 1973, 1974, $\emptyset$ dum 1933) and Øresund (Adrielsson 1984, Berglund \& Lagerlund 1981, Houmark-Nielsen \& Lagerlund 1987, Lagerlund 1980, Rasmussen 1973). More general stratigraphic descriptions and classifications combined with geomorphological maps dealing with the larger part of southern Denmark are also considered (S. Th. Andersen 1965, 1967, Hansen 1965, Mangerud et al. 1974, Smed 1982).

\section{THE ELSTERIAN}

Except for the Palsgård Till (fig. 136, a1) the preSaalian tills: Sønder Vissing Till (fig. 136, a) and Snoghøj Till (fig. 136, a2) can be correlated with Norwegian and Baltic tills from southern Jylland (Sjørring \& Frederiksen 1980, Sjørring 1981) and Germany and the Netherlands (Ehlers et al. 1984). Ehlers et al. points out, that the Baltic-ice is responsible for deposition of the younger of the two tills. Such stratigraphic evidence has not been demonstrated from Denmark, but the above mentioned age relationship is favoured by Sjørring $(1981,1983)$ when observations made by 
V.Milthers (1939) in the Brande area are considered. Here a Baltic till is situated beneath deposits of limnic Holsteinian and the Baltic Till presumably constitutes the youngest pre-Holsteinian Till.

Tills a, a1 and a2 (fig. 136) are ascribed to the Elsterian glaciation, even though they have not been found to overlie deposits of the Hareskovian (Cromerian?) Interglacial described by S.Th.Andersen (1965). The lack of descriptions of positively pre-Hareskovian tills prevents such tills from being distinguished from Elsterian tills on the basis of lithology alone.

During the Elsterian glaciation Norwegian, Middle Swedish and Baltic ice advances presumably invaded the examined region in the mentioned order of appearance.

\section{THE SAALIAN}

Marine- and Limnic Holsteinian deposits situated respectively around the west coast of Jylland e.g. at Tornskov and around Vejlby in the Lillebælt area (S.Th. Andersen 1963, 1965, 1967) separate Elsterian and Saalian deposits. According to the present investigations, the Saalian comprises 3 till units (fig. 136, b-d) referred to as Trelde Næs Till, Ashoved Till and Lillebælt Till respectively. Till units are interbedded with mainly glaciofluvial material.

Investigations in south western Jylland (Sjørring \& Frederiksen 1980, Sjørring 1981, 1983) report one older Saalian till (called Drenthe type), however indicator boulder accumulations associated with two source areas (Oslo region and western Middle Sweden) are recognized in connection with the outcropping of older Saalian tills (K.Milthers 1942). In Schleswig-Holstein Ehlers et al. (1984) recognizes one older Saalian till of middle Swedish provenance deposited by an ice stream from northeasterly directions possibly corresponding to the ice stream which deposited the Ashoved Till. This could suggest, that the maximum extension of the Trelde Næs Till lies somewhere between the Danish-German border and the southern part of Schleswig-Holstein.

The younger Saalian Till (fig. 136, d), Lillebælt Till, is found in almost the whole of the area covered by the cross section. It is overlain by marine Eemian deposits in westernmost Jylland, around southern Fyn and Lillebælt and in the Sams $\emptyset$ area. Limnic Eemian deposits in southern Jylland and -Fyn (S.Th.Andersen 1965, 1967, Hansen 1965, Milthers 1940, Sjørring 1977, 1981, Sjørring \& Frederiksen 1980) cover the till and marine Early- to Middle Weichselian interstadial deposits (Petersen \& Buch 1974, Ødum 1933) apparently overlie the Lillebælt Till in northern and central Sjælland even though Petersen (1984) proposes a Weichselian age for the till at Holmstrup.

A glaciotectonically disturbed Drenthe type till containing a fossil soil horizon on its surface has been reported from Oksbøl by Sjørring (1977) and Sjørring \& Frederiksen (1980). It is suggested (Sjørring \& Frederiksen 1980, Sjørring 1983) that the development of the fossil soil at Oksbøl took place during the so-called Treene Interglacial prior to the deposition of Warthe tills in Schleswig-Holstein. The Treene Interglacial is, however, only recognized as fossil soil horizons and until lithostratigraphic evidence has been recorded, sceptisism does occur as to the existence of this interglacial (Ehlers et al. 1984).

The three described till units of the Saalian glaciation (fig. 136, b-d) were respectively deposited by the Norwegian Saale advance from northerly directions, the Middle Saalian advance from north-easterly directions, and the Paleobaltic advance from easterly- and south-easterly directions.

\section{THE WEICHSELIAN}

During the Weichselian glaciers invaded Denmark generally from northerly-, northeasterly-, easterly-, and southeasterly- to southerly directions. It is proposed, that all major ice-advances took place in the later half of the Middle Weichselian.

Thus, the present paper follow the definition of this substage as given by Mangerud et al. (1974), which implies that the Middle Weichselian-Late Weichselian boundary is placed at $13000 \mathrm{BP}$.

An alternative age for that boundary lying at 25000 BP has been proposed by Mangerud and Berglund (1978). These authors claim, that a division with only 3000 years for the Late Weichselian is disharmonious in relation to the almost 100.000 years duration of the Weichselian glacial. It is also advocated that a $25000 \mathrm{BP}$ boundary is useful both with respect to separating earlier glacial phases from the maximum Weichselian glaciation and to obtain correspondance with the 


\section{SW JYLLAND FYN SEJERø KATTEGAT NE LILLEBELLT SAMS $\varnothing$ SJELLAND $\varnothing R E S U N D$}

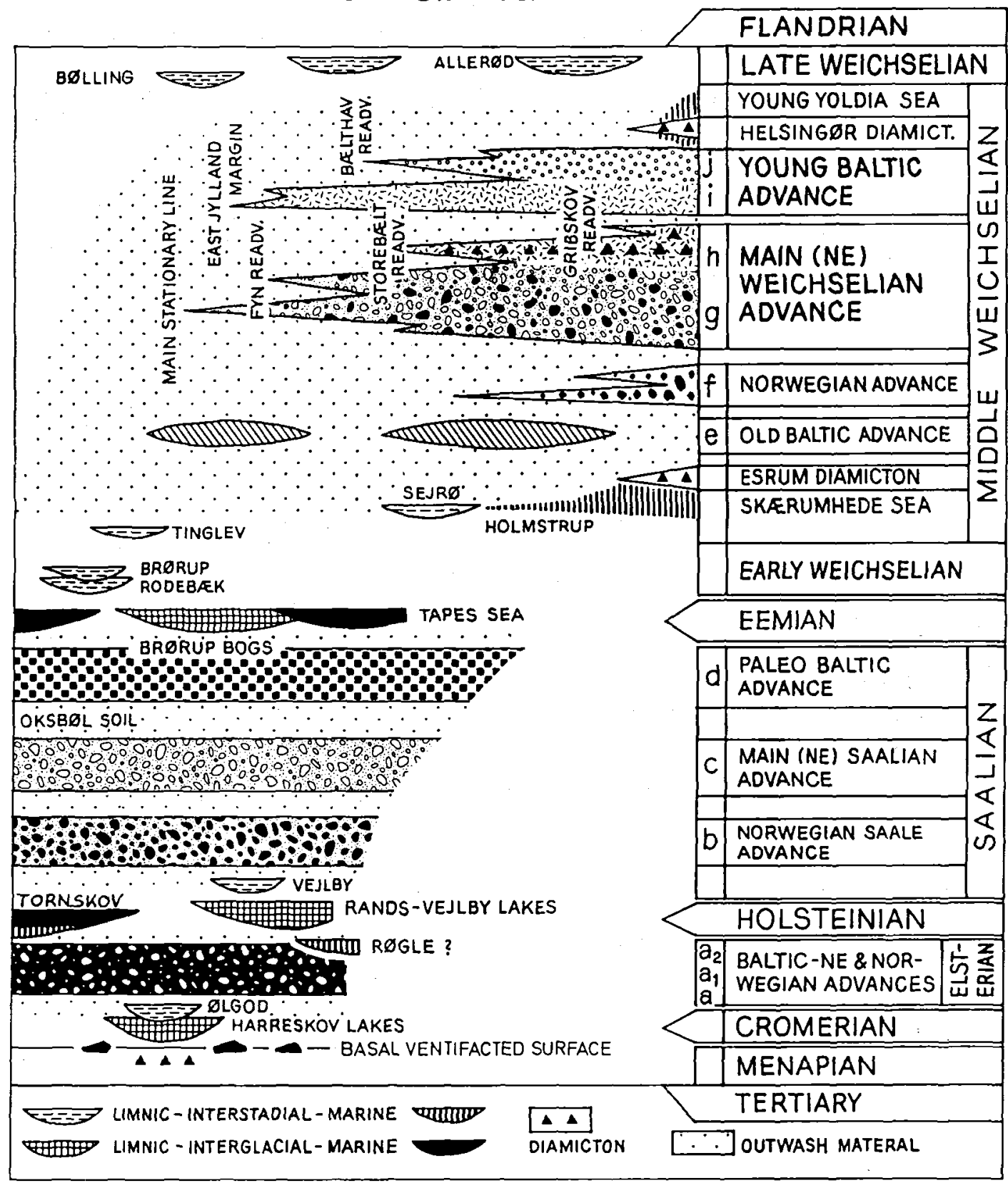

Fig. 136: Event stratigraphic scheme in a SW-NE oriented section across central Denmark between the Danish-German borderland and the Øresund and Kattegat. Till units are related to Pleistocene stages, substages and glacier advances. 
boundaries of the last glaciation in the British Isles and on the North American continent. This matter has previously been discussed by S.Th.Andersen (1979).

When the present author all the same favours the $13000 \mathrm{BP}$ boundary it is for the following reasons. First of all this boundary has a long historical record in Danish geological litterature, and it is placed around the time when glaciation ceased and was succeeded by a pronounced climatic amelioration that gave way for the Bølling and Allerød Interstadials, which according to Mangerud, et al. (1974) coincide with the lower boundary of the traditional Late-Glacial in northwestern Europe. Secondly the 13000 BP boundary should be much easier to recognize lithostratigraphically, to test through absolute dates and to classify biostratigraphically in type sections than the $25000 \mathrm{BP}$ boundary. This is primary because terrestrial or marine deposits from the time just prior to the maximum Weichselian glaciation seems to be very scarcely represented in Denmark and absolute datings of deposits from this period are performed on re-deposited mainly biogenetic material (Petersen 1984). Dates tend to suggest, that $20000 \mathrm{BP}$ marks a radical change in environment rather than $25000 \mathrm{BP}$. To conclude this discussion, it should be mentioned, that the desire of Mangerud \& Berglund to relate respectively an older and a younger Weichselian glacial phase each to an individual substage is readily fullfilled without changing the age of the Middle/ Late Weichselian boundary. Thus, in the countries covered by the Scandinavian icesheet a Middle Weichselian glacial maximum is recognized to have taken place around $22000 \mathrm{BP} 18000 \mathrm{BP}$ (Mangerud 1981, Lundqvist 1981, Berglund \& Lagerlund 1981, Hirvas et al. 1981, Krasnov 1978, Chebotareva \& Makarycheva 1981, Drozdowski 1980, Kozarski 1980, Mojski 1985, Eissmann \& Müller 1979, Ehlers 1983, Sjørring 1983, Petersen 1984). Likewise, an Early Weichselian maximum is supposedly recognized around 60000 BP - 50000 BP (Mangerud 1981, Lundqvist 1981, Hirvas et al. 1981, Krasnov 1978, Drozdowski 1980, Mojski 1985).

Six Weichselian lithostratigraphic till units (fig. $136, e-j$ ) have been identified in open exposures in the central parts of Denmark. Their directional patterns and compositional features suggest, that they were deposited by four major glacier trans- gressions separated by intervals of glaciofluvialand periglacial activity. The existence of an earlier (still Middle-) Weichselian glacier advance prior to those mentioned is suggested by the presence of a glacial diamictite (Esrum diamictite, fig. 136) found in borings in the deepest part of the Esrum-Alnarp valley on northern Sjalland (Schuldt 1981).

Middle Weichselian interstadial deposits underlie exposed Weichselian tills on Sejerø (Houmark-Nielsen \& Kolstrup 1981) or separate them from older (Baltic) till material at Holmstrup on north-western Sjælland (Petersen \& Buch 1974).

The oldest till unit: the Esrum diamictite (fig. 136) is described by Schuldt (1981). Because of its content of specific re-deposited Middle Weichselian foraminifera it is believed to be younger than the zone IV of the Skærumhede II boring (Bhanson et al. 1974), which according to Knudsen and Lykke-Andersen (1982) indicates a postMoershoofd age (post 47000-40000 BP). The Esrum diamictite is supposed to have been deposited by an ice sheet from northerly directions (Schuldt 1981). However, its genesis must be regarded with some sceptism since the till is only observed in borings. The overlying Esrum sand is equivalent to the Grävie sand (Schuldt 1981), which according to Berglund and Lagerlund (1981) constitutes part of the Gärslöv Beds underlying the Allarp- and Dalby Tills. The Ristinge Klint Till (fig. 136, e) is suggestingly correlated either with the Baltic, Allarp Till or the lower Baltic facies of the Dalby Till thus indicating, that the Esrum diamictite and the Gärslöv beds was deposited before the Ristinge Klint Till. This supports the tentative age relationship between the Ristinge Klint Till and the Sejer $\emptyset$ Interstadial beds, where it is suggested, that the Ristinge Klint Till was deposited after the Hengelo Interstadial (post $36000 \mathrm{BP}$ ).

On the contrary, Petersen $(1984,1985)$ suggests, that it is the Old Baltic, Weichselian till (= Ristinge Klint Till) and not a Saalian Baltic Till (= Lillebælt Till) that constitutes the substratum for the marine Middle Weichselian beds at Holmstrup. However, the pre-Middle Weichselian till at this site is not underlain by Early Weichselianor Eemian deposits, in fact it overlies Tertiary clay. It is moreover not characterized by a $\mathrm{Y}$ foraminiferal assemblage, but it contains only limited quantities of Quaternary foraminifera 
(Petersen \& Buch 1974, p. 73). This makes a Saalian age more probable. On this account is must be concluded, that neither the stratigraphy of the Holmstrup claypit nor the Baltic composition of a till can be taken as evidence for an Early Weichselian, "Old Baltic" icestream in Denmark.

Although no direct stratigraphic evidence as to the age relationship between the Ristinge- and Kattegat Tills has yet been demonstrated, the icestream which deposited the Kattegat Till (fig. $136, f)$ apparently caused glaciotectonic deformation of the Ristinge Klint Till in northern Sjalland. For this reason, it is suggested that the Ristinge Klint Till was deposited prior to the Kattegat Till. The distribution of the Ristinge Klint Till and the Kattegat Till is rather uncertain, however, it is assumed, that the former is confined to the south-eastern half of the country, whereas the latter is confined to northern and middle part of Denmark. The tills were deposited by the Old Baltic- and the Norwegian advances respectively from south-easterly- and northerly directions.

The Mid Danish Till (fig. 136, g) is found in the whole of the country east of the Main Stationary Line. It was deposited by the Main Weichselian ice advance probably around $20000 \mathrm{BP}$ from northeasterly directions and it overlies the Kattegat Till - and is overlain by the North Sjalland Till in the northeastern part of the examined region. During the decay of this ice sheet readvances covered parts of the examined region presumably between $20000 \mathrm{BP}$ and $15000 \mathrm{BP}$. An older readvance (Fyn Readvance) transgressed Fyn and the eastern parts of Jylland and dislocated the previously deposited Mid Danish Till and formed the central dead ice deposits on Fyn. The North Sjælland Till is separated from the former till by waterlaid outwash material. The North Sjælland Till was deposited from easterly directions presumably by a younger readvance (Storebælt Readvance) of the Main Weichselian ice sheet. It is suggested, that the Mid Danish Till and the North Sjælland Till merge into a single till unit in the north-eastern part of Sjælland or the Øresund region. The North Sjælland Till is confined to the area east of Storebælt. An even younger readvance is assumed to have formed the N-S trending so-called Gribskov ice marginal hills in NE-Sjælland.

The East Jylland- and the Balthav Tills (fig. $136, i-j)$ were deposited by the Young Baltic ice- sheet generally from south-easterly directions most probably between 14000 and $13500 \mathrm{BP}$. They overlie the Mid Danish Till towards the west and the North Sjalland Till in the eastern part of the country. At an early stage of maximum extension along the East Jylland Ice border the East Jylland Till was deposited in the area west of Sjelland. Shortly after a readvance of the Young Baltic ice sheet (Bælthav readvance) deposited the Bælthav Till in the eastern parts of the examined region and around $\emptyset$ resund and successive readvances formed terminal moraines southward through Storebælt.

In the Øresund region the Bxlthav Till and its equivalents in Skåne is overlain by droped and dumped diamict material (Helsing $ø$ r diamicton: Houmark-Nielsen \& Lagerlund 1987) deposited in connection with a late Middle Weichselian transgression (Adrielsson 1984, Lagerlund \& Berglund 1981). In central NE-Sjælland Young Baltic tills are overlain by limnic deposits (Allerød Interstadial) and deposits of the Bølling Interstadial presumably cover these tills on Møn (Kolstrup 1982). In the whole of the region covered by the cross section Late Weichselian (post 13000 BP, Mangerud et al. 1974) deposits locally overlie the younger of the previously described Weichselian till units. 


\section{GLACIAL HISTORY OF THE CENTRAL PARTS OF DENMARK}

The following account covers the glacial history of the Pleistocene of Denmark primarily as deduced from the present investigation in the central Danish region. It is supplemented by information from adjoining areas comprising the country dealt with in the schematic stratigraphic cross section of southern Denmark (fig. 136). The history of the eastern part of Denmark is compiled from Houmark-Nielsen (1981, 1983c, Jacobsen 1981a, 1981b, 1985, Krüger 1969, Kronborg \& Knudsen 1985, Sjørring et al. 1982). The account of central and northern Jylland is taken from Gry (1979), Jensen \& Knudsen (1984), Kronborg (1983), Rasmussen \& Petersen (1980), and western Jylland from Sjørring \& Frederiksen (1980). Regions of neighbouring countries (especially Skåne and Schleswig-Holstein) are also considered in order to present a more comprehensive outline. Data from northern Germany are compiled from Ehlers \& Stephan (1983), Ehlers (1983), Ehlers et al. (1984), Eissmann \& Müller (1979), Hurtig (1979), Stephan \& Menke (1977) and Stephan et al. (1983), and summarized for southern Sweden from Adrielsson (1984), Berglund \& Lagerlund (1981), Lagerlund (1980), Lagerlund et al. (1983) and Ringberg (1984).

The Elsterian, the Saalian and the Weichselian glaciations are described (fig. 136) in terms of chronology, directional properties, ice-distribution and deposits of glaciers and meltwater supplemented by information from descriptions of interstadial deposits. Interglacial periods are only described in general terms, based mainly on the presentation given by S.Th. Andersen (1965, 1967).

\subsection{A PRE-ELSTERIAN GLACIATION}

Deposits of pre-Elsterian glaciations have not been recognized for certain in the central Danish region. However, S.Th.Andersen $(1965,1967)$ argued that the interglacial deposits at Harreskov (central Jylland) are older than the Holsteinian; they possibly constitute a younger part of the Cromerian Interglacial complex. Between the Harreskovian Interglacial deposits and beds of Tertiary clay, glaciolacustrine and glaciofluvial deposits overlie a clayey glacial diamicton (S.Th.
Andersen 1967). This suggest that during a preElsterian glaciation, possibly the Menapian an ice sheet deposited a till; it is not unlikely, that the ventifacted, mainly quartzite- and quartzitic sandstone rock and boulder horizons found between the Tertiary deposits and the older tills in the examined region comprise residual till material of pre-Elsterian derivation.

According to S.Th.Andersen (1967) pre-Harreskovian till deposition was followed by sedimentation of glaciofluvial material around Harreskov and Ølgod in central Jylland. During the close of this glaciation local depressions were filled with meltwater clay and solifluction material.

\section{THE HARRESKOVIAN INTERGLACIAL}

During the Harreskovian Interglacial some of these local depressions were filled with lake marl and diatomaceous gyttja in the area of west-central Jylland. Pollen analysis (S.Th.Andersen $1965,1967,1969$ ) indicates that an open vegetation was succeeded by temperate, deciduous forest. As the calcareous soil was leached, coniferous forests took over and by the end of the Harreskovian open vegetation again replaced the forests.

\subsection{THE ELSTERIAN GLACIATION}

Elsterian glacigenetic deposits comprise very quartz-rich tills of Norwegian, Middle Swedish and Baltic provenance, possibly deposited in this order, and found at just a few localities within the central Danish region.

At Ølgod, deposits of the Harreskovian Interglacial are overlain by solifluction material interbedded with two limnic gyttja horizons representing the Ølgod I- and Ølgod II Interstadials (S.Th.Andersen 1965, 1967). During the Ølgod I Interstadial the temperate forest reclaimed the area, whereas at the time of the Ølgod II Interstadial a less pronounced climatic amelioration allowed only an open vegetation to re-occur.

Outwash sand and-gravel, overlying the solifluction material and interstadial deposits was probably deposited by meltwater streams emerging from the first Elsterian ice sheet (Norwegian Elster Advance). This invaded the country from the north and deposited the sandy Sønder Vissing Till (fig. 136a) which is characterized by large amounts of Norwegian indicators. This ice ad- 
vance apparently terminated east of the Netherlands (Wee 1983) and left prominent terminal moraines on the north German lowlands, where it deposited till and outwash material rich in Norwegian indicators (Ehlers et al. 1984, V.Milthers 1909).

Whether or not the Norwegian Elster Advance and the advance which deposited the Elsterian sandy to clayey till of Middle Swedish composition: i.e. the Palsgård Till (fig. 136a.1), were separated by interstadial conditions is uncertain, neither is the distribution of this Middle Elsterian Advance known in any detail.

It is most likely, however, that the latter advance was succeeded by a Baltic ice stream, which deposited the clayey Snoghøj Till (fig. 136a.2) and the older Baltic tills of southwest Jylland (Sjørring 1981, 1983), the Brande area (V. Milthers 1939) and western Limfjord (Jensen \& Knudsen 1984). This Baltic Elster Advance probably terminated in northern Germany and the North Sea. At the end of the Elsterian a marine transgression reached the North Sea coast by the Ribe-Esbjerg area (cf. S.Th.Andersen 1963, 1965, 1967, Madsen et al. 1928) and the western Limfjord region (Jensen \& Knudsen 1984) and marine clay containing an arctic foraminiferal fauna was deposited. Pollen successions comparable to limnic inland deposits at Tornskov can be found throughout this marine series that cover in time the late Elsterian and most of the Holsteinian (S.Th.Andersen 1963, 1965, 1967).

Madsen et al. (1928) and Madsen \& Nordmann (1940) . suggested that the Tellina clay of Røgle Klint was deposited contemporaneously with the lower part of the Yoldia clay at Esbjerg. The marine clay at Røgle has an arctic and poor molluscan fauna deposited in a glacio-marine environment (Madsen et al. 1928)). The assignment of the Tellina clay to the transition between the late Elsterian and the early Holsteinian is favoured by Knudsen (1966); however, there are still insufficient micropaleontological knowledge concerning the Tellina clay, (Feyling-Hanssen \& Knudsen (1979).

Simultaneously with the on-coming transgression, meltwater clay was washed down into local depressions in eastern Jylland (S.Th.Andersen $1965,1967)$ and the Brande area (V.Milthers 1939) and into larger basins in the western Limfjord area (Jensen 1985). These basins and lakes were later to be filled with limnic and marine Holsteinian deposits. According to Jensen (1985) the meltwater clay could very well be equivalent to the so called Lauenburg clay from northern Germany (cf. Ehlers et al. 1984).

\section{THE HOLSTEINIAN INTERGLACIAL}

The transgression reached its peak during the Holsteinian Interglacial and marine clay with a boreal foraminiferal fauna was deposited by the sea in the Ribe-Esbjerg - and western Limfjord regions (cf. Knudsen \& Feyling-Hanssen 1976, Jensen \& Knudsen 1984, Kundsen 1986) as well as in the western part of Kattegat (Kronborg \& Knudsen 1985, Knudsen 1986).

In central and eastern Jylland around the Trelde Næs-Rands-Vejlby area local depressions were filled with limnic deposits consisting mainly of lake marl and diatomite. Palynological investigations (S.Th.Andersen 1965, 1967, V.Milthers 1939) have revealed a characteristic plant succession, apparently developed on lime-poor or sour soils. Herbaceous vegetation was succeeded by an open vegetation, that developed into mostly coniferous, temperate forests which, by the end of the Holsteinian, were again succeeded by herbaceous vegetation.

\subsection{THE SAALIAN GLACIATION}

Three major ice advances separated in time by deposition of glaciofluvial material dominate the Saalian.

The Saalian glaciation was initiated with the final infilling of the previously mentioned lake basins. Solifluction material alternating with two limnic beds of the Vejlby I - and Vejlby II Interstadials are recognized in the Rands Fjord area (S.Th.Andersen 1965, 1967). The interstadials are characterized by an open, almost temperate forest vegetation.

Glaciofluvial sand and gravel locally filled the lake basin at Trelde Næs and formed a sandur cover deposited by west- to southward-moving meltwater streams which flowed over large parts of central and southern Jylland (fig. 105, Sjørring \& Frederiksen 1980). These waterlaid deposits, referred to as the "Norwegian" gravel by V.Milthers (1939), probably emerged from the first Saalian ice advance.

This Norwegian Saale Advance deposited a sandy, quartz-rich, Fennoscandian till: the Trelde 
Næs Till (Fig. 136b), with a readily-apparent Norwegian indicator erratic content and other characteristic rock fragments of northerly provenance. These include flint conglomerate and late Paleocene, ash-bearing diatomite (Fur Formation) previosly referred to as Moler. Recently Sjørring (1983) advocated that the flint conglomerate- and rhombporphyry-bearing Drenthe type till constitutes the older of the Saalian tills of western Jylland.

The Norwegian Saale Advance invaded the country from northerly directions and probably terminated south of the Danish-German borderland, although some disagreement exists as to the transgression of this ice stream into SchleswigHolstein (Ehlers et al. 1984).

During the retreat of the Norwegian Saale Advance a readvance (locally?) from north-western directions dislocated the Trelde Næs Till and older deposits in the Vejle Fjord area. During the final withdrawal of this ice sheet glaciofluvial material was deposited by westward moving meltwater streams (fig. 105) before the arrival of the Middle Saalian ice sheet.

The Middle Saalian Advance commenced with the deposition of finegrained glaciofluvial material and as the glacier approached, ending up with proximal outwash deposits and flow till sediments. The Middle Saalian ice sheet invaded the country from north-easterly directions, and deposit the sandy, quartz-rich, Ashoved Till (fig. 136c), which is characterized by Fennoscandian clast composition and associated Middle Swedish indicators (Kinnediabase) and rock fragments from the Fennoscandian border zone in Kattegat (Katholm erratics) as well as by re-deposited Holsteinian foraminifera.

The advance from the NE of the Saalian glaciation is most probably equivalent to the Older Saalian glacial phase in northern Germany (Ehlers et al. 1984, Eissmann \& Müller 1979) and the Saalian Stadial III (Wee 1983), which deposited the till of the Drenthe Formation and covered the larger part of the Netherlands (Zagwijn 1963).

The deglaciation of this ice sheet was accompanied by deposition of the glaciofluvial materal observed at several places in the central Danish region. In the Esbjerg area a podsolic paleosoil (Oksbøll Soil, fig. 136), which developed between the Drenthe and Warthe advances (Sjørring 1981a, 1983), could possibly indicate a cli- matic amelioration before the Younger Saalian (Paleobaltic) Advance. Recent investigations of pre-Eemian marine deposits (Knudsen \& LykkeAndersen 1982) containing an arctic foraminiferal fauna tend to suggest that interstadial conditions prevailed in north Jylland before (or during) deposition of the pre-Eemian Baltic till complex recorded in the Skærumhede I boring (Jessen et al. 1910).

The youngest of the Saalian glaciers that covered Denmark was the Paleobaltic Advance. It invaded the central Danish region from easterly to east-south-easterly directions and deposited a clayey, quartz-poor, chalk-rich, till named the Lillebælt Till (fig. 136d). This is characterized by Baltic indicator erratics and Palaeozoic sandstone, limestone and shale fragments. Apparently, Scanian basalt indicator erratics are also associated with the Lillebælt Till.

Even though documentation is lacking it is not unlikely, that the Paleobaltic Advance terminated in western Jylland as proposed by Sjørring (1983, p. 174), however, terminal moraines are not found in west-central Jylland. The presence of a "Warthe" till around the western Limfjordand the Skærumhede areas (Jensen \& Knudsen 1984, Jessen et al. 1910) as well as in the area south of Esbjerg (Sjørring \& Frederiksen 1980), suggests that the Paleobaltic Advance went at least as far to the NW as the present North Sea coast of northern Jylland and transgressed the present marsh-land between the Esbjerg-Ribe area and the northern part of Schleswig-Holstein.

It has been noted, that correlation of Saalian tills across the Danish-German borderland is quite troublesome and it is recognized, that two different concepts of Saalian stratigraphy have been put forward in the German literature (cf. Ehlers et al. 1984). However, it is suggested that, in spite of being represented as one bed of till in Denmark, the Paleobaltic Advance presumably corresponds to the Middle- and Younger Saalian Advances that invaded northern Germany from north-easterly and easterly directions (Ehlers \& Stephan 1983, Ehlers et al. 1984) and the Younger Saalian till mentioned by Eissmann \& Müller (1979). At the maximum extension of this ice sheet terminal moraines were built up in Lower Saxony between the rivers Weser-Aller and the Elbe. During the Younger Saalian glaciation, which is regarded by the present author as a read- 
vance of the former Baltic ice sheet, glaciers reached western and central Schleswig-Holstein and the area immediately west of Hamburg.

The deglaciation of the Paleobaltic ice sheet led to the development of vast, dead-ice landscapes in southern and central Jylland (Jessen \& Milthers 1928). The formation of a large number of kettle holes draped by and partly filled with meltwater clay and solifluction material (S. Th. Andersen 1967, Hartz 1989, Jessen \& Milthers 1928, Madsen 1916), marks the end of the Saalian glaciation.

\section{THE EEMIAN INTERGLACIAL}

During the Eemian, a marine transgression inundated low lying parts of the country and inevitably the distribution of the Tapes Sea (fig. -136) became somewhat comparable to the present land and sea configuration. In more elevated areas limnic deposits were sedimented in lake basins. S.Th.Andersen $(1957,1961,1965,1967)$ and Jessen \& Milthers (1928), especially investigated the "bog field" around Brørup, where more than 12 undisturbed interglacial peat bogs had been mapped within an area of less than $4 \mathrm{~km}^{2}$ (V.Milthes 1925).

Palynological analyses of the Brørup Bogs (fig. 136) (S. Th. Andersen 1965, 1967) indicate, that the previous sedimentation of meltwater clay and solifluction material at the beginning of the Eemian had been followed by gyttja sedimentation. Around lakes, open vegetation was relatively quickly replaced by dense deciduous, temperate forests. As the lakes grew over and the soil was leached, coniferous forests dominated the vegetation, which by the end of the Eemian had again become open, before this was succeeded by herbaceous vegetation.

In the Lillebælt region at Stensigmose Klint and Ristinge Klint (Jessen \& Milthers 1928, Konradi 1976 , Madsen et al. 1908, Sjørring et al. 1982, Surlyk 1980) marine Cyprina clay overlies limnic and brackish Early Eemian deposits. Boreo-Lusitanic marine clay deposited in a relatively shallow environment is most frequently found in the coastal areas of southern Jylland and southwestern Fyn. It is also occasionally found in the Sams $\emptyset$ area and more often in south-eastern Sjælland (S.Th.Andersen 1967, Houmark-Nielsen 1980, Lykke-Andersen 1979), whereas deep water deposits are found in northern Jylland (Knudsen \& Lykke-Andersen 1982). According to Knudsen and Lykke-Andersen (1982) BoreoLusitanic marine ecological conditions of the Turritella terebra Zone (Skærumhede sequence) changed into a shallow Boreal environment during a late Eemian/Early Weichselian regression.

\subsection{THE WEICHSELIAN GLACIATION}

In south-central Jylland the Weichselian glaciation was initiated by deposition of sandy, leached solifluction material into the already existing lake basins around Brørup and Ejstrup. During the Early Weichselian, two periods of climatic amelioration called the Rodebæk ( $=$ Amersfoort) and Brørup Interstadials are represented by gyttja and peat deposits (S.Th.Andersen 1961, 1965, 1967). An open, temperate, coniferous vegetation characterizes these interstadials. Finally the "Brørup kettle bogs" were filled with solifluction material, thus most of the terrestrial Early Weichselian is dominated by artic tundra vegetation in a presumably dry, polar climate as demonstrated from Skåne, southern Sweden (cf. Berglund \& Lagerlund 1981).

An apparently continuous marine sedimentation of the Skrrumhede sequence (Bahnson et al. 1974) suggests, that several Interstadials can be recognized in these artic sea beds. Knudsen \& Lykke-Andersen (1982) argued that the Brørup Interstadial possibly constitutes the upper parts of the Turritella terebra - or Abra nitida Zones.

\section{THE MIDDLE WEICHSELIAN}

The Middle Weichselian is characterized by deposition of limnic- and marine interstadial sediments, coversands, glaciofluvial-glaciolacustrine material and eventually till deposits.

During the Moershoofd and Hengelo Interstadials an open vegetation characterized by Juniperus growth around Tinglev, southern Jylland (Kolstrup \& Havemann 1984) and a Herbaceous vegetation developed on Sejerø (Houmark-Nielsen \& Kolstrup 1981), but generally a high arctic "mammoth-steppe" vegetation characterized the Middle Weichselian of southern and central Denmark (Petersen 1984) as well as Skåne (Berglund \& Lagerlund 1981).

According to Lykke-Andersen (1981, 1982, Knudsen \& Lykke-Andersen 1982) Middle Weichselian Interstadials can be traced in the Skærumhede sequence by changes in foraminiferal faunas in the Portlandia arctica zone. $\varnothing$ dum 
(1933) indicates that northern Sjælland was subjected to a transgression from the north by the Skærumhede Sea (fig. 136). Petersen (1984) estimated the transgression to have taken place in the time between the Moershoofd- and Hengelo Interstadials, and shell-bearing clay with arctic to boreoarctic, foraminiferal faunas characterize the Middle Weichselian marine deposits of Holmstrup, north-western Sjælland (Petersen \& Buch 1974). Diamictic deposits from northeastern Sjælland containing a poorer, but similar, foraminiferal fauna called the Græsted clay (Petersen \& Konradi 1974) have also been included in the primary marine deposits (Lykke-Andersen 1979).

The first recorded Weichselian till deposition was supplied from northerly directions; presumably the so-called Esrum diamictite was laid down (fig. 136) later than the Moershoofd Interstadial (Schuldt 1981). It is not clear whether the Esrum diamicton was deposited from an active glacier or by drop and dump from drifting icebergs. However, its sedimentation could be connected with the later stages of the Middle Weichselian transgression previously mentioned. By the time of regression of the Skærumhede Seal withdrawal of icesheet, the Esrum sand (Schuldt 1981) was deposited in the Esrum-Alnarp valley draining the Baltic into the Kattegat depression as proposed by Lagerlund (1980). It is not unlikely that fine grained deposits found beneath the Ristinge Klint Till were deposited simultaneously with the Esrum Sand. East of Øresund the Gärdslöv core in the Alnarp valley revealed terrestrial, limnic sediments deposited during interstadial conditions between $35000 \mathrm{BP}$ and 20000 BP.

\subsection{AGE OF THE FIRST WEICHSELIAN GLACIATION IN DENMARK}

Opposite viewpoints have been presented regarding a possibly Early Weichselian glaciation in the southern margin of the areas covered by the Scandinavian icesheet during the last glaciation.

In the lower Vistula region (Drozdowski 1980, Mojski 1985) and on the Valdai Russian plain (Krasnov 1977) several authors have suggested the existence of an Early Weichselian glaciation. However, opposing arguments have also been published. Chebotareva \& Makarycheva (1981) and Kozarski (1980) report respectively of an early "Iceless Valdai" and a non-glaciated Pleni Vistulian. Thus, these authors concluded that glaciers did not reach western Russia or the Great Polish Lowland until late in the Middle Weichselian. In northern Germany Eissmann \& Müller (1979) find no evidence of an Early Weichselian stadial and east of Øresund in Skåne Berglund \& Lagerlund (1981) suggest, that from the start of the Early, through most of the Middle Weichselian until about 20000 BP the environment was characterized by arctic tundra vegetation and polar deserts occasionally interrupted by subarctic woodlands during interstadials.

It must be argued, that even though an Early Weichselian ice sheet could have existed in the Baltic region as far south as northeastern Poland, glaciers did not necessarily reach Denmark, although this has been proposed by Petersen (1984, 1985). The evidence cited by Petersen in favour of an Early Weichselian glaciation in Denmark will briefly be considered. First of all, as stated earlier, the presence of a Baltic till overlying Tertiary clay and situated beneath Middle Weichselian marine deposits at Holmstrup (western Sjælland) does not indicate an Early Weichselian age for the till. Secondly, Juniperus fragments of the Moershoofd Interstadial on the Frøslev fan of the Tinglev sandur (southern Jylland), which is suggested by Kolstrup \& Havemann (1984) to postdate deposition of larger parts of the outwash fan, has not convincingly been demonstrated to appear in situ. In fact it is highly probable that reworking of the wood fragments took place in connection with the sedimentation of the sandur fan, thus the existence of Middle Weichselian wood fragments in the fan sediments is not an indication of an Early Weichselian glaciation.

Thirdly, thermoluminescence dating of waterlaid sand overlying limnic Eemian deposits at Hollerup (north-central Jylland) revealed ages around 67.000 TL-years (Kronborg 1983). This supposed meltwatersand is estimated to relate to the Old Baltic Advance (Petersen 1984, 1985), even though the reliability of other TL-datings on outwash material is quite troublesome. As an example meltwater sand presumably deposited during the interval between the Main Weichselian Advance and the East Jylland Advance at two sites has been TL-dated (Kronborg 1983). Outwash material overlying limnic Eemian deposits at Ejstrup (loc. 90) and meltwater sand overlying 
the Sejer $\varnothing$ Interstadial, the Ristinge Klint Till and the Mid Danish Till at Sejerø (loc. 8) respectively gave dates around $117000 \mathrm{TL}$-years and 31000 TL-years. Being considerably older than expected from other dated material the TL-datings on glaciofluvial material must still be regarded with great sceptisism.

As a conclusion it must be stressed that the arguments put forward in favour of an Early Weichselian glaciation in Denmark are rather insufficient. On the contrary it is proposed that the Sejerø Interstadial antedates the Old Baltic Advance as shown by the present investigation. However, this documentation is not as solid as could be desired, therefore, the age of the Old Baltic Advance must still be regarded as an open question even though an age younger than postHengelo Interstadial is favoured by the present author.

\subsection{THE OLD BALTIC ADVANCE}

Deposits from the oldest Weichselian ice advance recognized from open exposures constitutes the Ristinge Klint Till (fig. 136e). The Old Baltic Advance deposited a quartz-poor, clayey till containing Baltic indicator erratics and re-deposited Eemian foraminifera most probably later than the Sejer $\varnothing$ (= Hengelo) Interstadial. The Old Baltic advance apparently covered most of Sjælland, the southern and central Storebxlt region, southern Fyn and southeastern Jylland. Slightly modified this distribution corresponds to the outline proposed by Sjørring $(1975,1983)$. Glaciofluvial outwash material deposited by west- to northward flowing meltwater streams found in the middle and southern part of the central Danish region and overlain by the Mid Danish Till or its associated glaciotectonic unconformities probably emerged from the Old Baltic ice sheet.

Ice of the Old Baltic Advance invaded southeastern Denmark from south-easterly to easterly directions (cf. Berthelsen et al. 1977, Sjørring 1977, Sjørring et al. 1982) and according to S.A.Andersen (1966) and Sjørring (1977) it is highly probable that this ice-sheet corresponds to the Brandenburg glacial stage described from northern Germany (cf. Hurtig 1969).

\subsection{THE NORWEGIAN ADVANCE}

Apparently succeeding the Old Baltic Advance, an ice stream from northerly directions transgressed the northern Bælthav region, north-east- ern Sjzlland and northwestern Skåne (Adrielsson 1984, Berthelsen 1974, Houmark-Nielsen 1976a, 1976b, 1976c, 1980, 1981, Lagerlund \& Berglund 1981, Rasmussen 1973, 1974, Schuldt 1981, Sjørring 1973, 1974). The Norwegian advance deposited a clayey, quartz poor, Fennoscandian till the Kattegat Till (fig. 136f) containing Norwegian indicators and characterized by molluscan fragments and re-deposited Quaternary foraminifera derived from Older Yoldia clay/Upper Skærumhede sequence. A possible distribution of the Norwegian Advance is sketched by Sjørring $(1975,1983)$, who on published and unpublished grounds suggested that the Norwegian Advance terminated in the region along the eastwest oriented part of the Main Stationary Line and in the northern parts of Sams $\varnothing$ and Sjælland and north-western Skåne.

Glaciolacustrine redeposition of its till material (Houmark-Nielsen 1976a, 1976b, 1976c, 1980, Jensen 1977, Sjørring 1973, 1974) suggests that deglaciation of the Norwegian ice sheet was in operation before a readvance from northerly directions reached the coastal areas of northern Sjælland (Jensen 1977, Sjørring 1973, 1974). During the withdrawal of this readvance glaciodeltaic- and glacio-fluvial material deposited by south- and westward moving meltwater streams was deposited south of the glaciated area covered by the readvance on Sjælland (Houmark-Nielsen 1980, Clemmensen \& Houmark-Nielsen 1981, Jacobsen 1985).

The final deglaciation of the Norwegian ice sheet gave way to the deposition of mainly fine grained, fluvial and deltaic deposits over large areas in the northern part of the central Danish region (Houmark-Nielsen 1980) and the Øresund region (Glumslöv Member: Adrielsson 1984)). Northward-directed palaeocurrents prevailed and it is suggested that deposition took place in an ice-free interphase between the Norwegian and the Main Weichselian advances. Hence, the palaeocurrent patterns reflect a regional outlet drainage trend of water flow from the Baltic depression, which could have been occupied by (stagnant?) Old Baltic ice, through the Danish straits into the Kattegat basin.

\subsection{THE MAIN WEICHSELIAN ADVANCE}

In the central Danish region the initiation of a renewed ice transgression is marked by the deposi- 


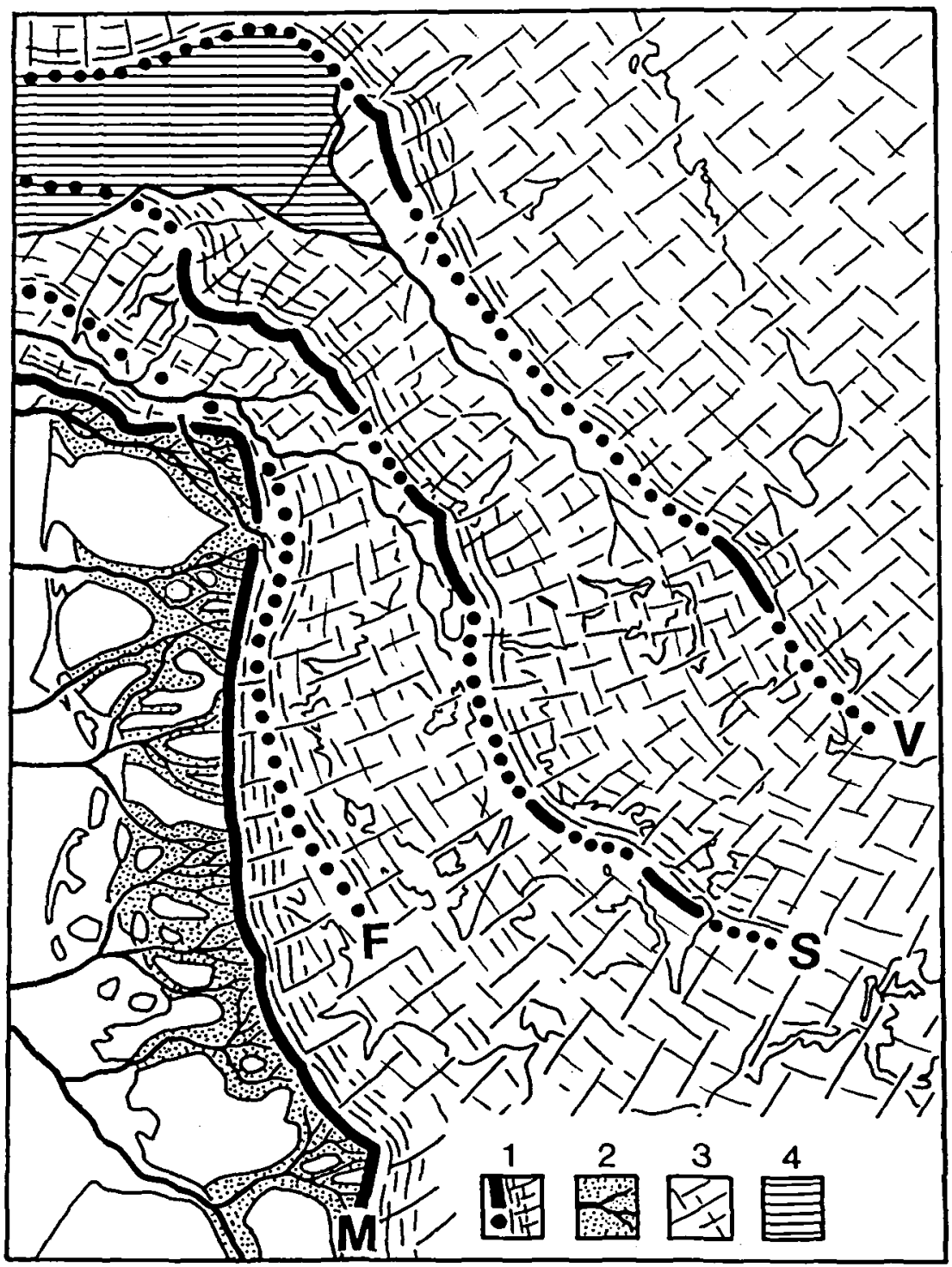

Fig. 137: Main Weichselian Glaciation. 1: Ice-marginal position, 2: Sandur deposits and possible course of meltwater rivers, 3: Flow lines, 4: Estimated distribution of the Younger Yoldia Sea, 5: Pre-Weichselian deposits. Morphological elements and ice-margins compiled after Hurtig (1969), Smed (1980, 1982) and Woldstedt (1935). M = Main Weichselian Advance, Main Stationary Line, F = Fyn-Westein Limfjord Readvance, S = Storebælt-North Jylland Readvance, $\mathrm{V}=$ Vendsyssel-Gribskov Readvance.

tion of coarse grained outwash material deposited by generally westward flowing meltwater streams and overlying the above-mentioned fine grained deposits. Absolute dated biogenetic material found in outwash deposits laid down in front of the advancing Main Weichselian Icesheet suggests that this advance possibly crossed Den- mark slightly before 20000 BP (Berthelsen 1979, Rasmussen \& Petersen 1980, Petersen 1984).

The Main Weichselian Advance invaded the country from the NE and terminated along the Main Stationary Line (fig. 137). It deposited the Mid Danish Till (fig. 136g); a quartz-poor, clayey, Fennoscandian till with associated Middle 
Swedish indicators, Kattegat erratics and re-deposited Quaternary foraminifera derived from the Older Yoldia clay/Upper Skærumhede sequence. In other parts of the country this till is referred to as the NE-till, a term already used by S.A. Andersen (1966). During the maximum extension of the Main Weichselian Advance, the larger part of the sandur plains of western and central Jylland were formed by generally westward flowing meltwater streams. According to S.A.Andersen (1966) and Sjørring (1977) the Main Weichselian advance is assumed to correspond to the Frankfurt advance in northern Germany.

As the NE-ice withdrew from Denmark, several readvances disturbed till and outwash material deposited by the Main Weichselian Advance and till beds and waterlaid outwash material were deposited, whilst at the same time forming roughly NW-SE oriented terminal moraines and ice-pressed ridges. Most probably all this occurred during the time interval 20000-15000 BP. In the following description a tentative presentation of the deglaciation pattern of the Main Weichselian ice-sheet will be presented.

\section{THE FYN - WESTERN LIMFJORD READVANCE}

The active Main Weichselian ice sheet probably withdrew to the area around Storebælt before a readvance from the NE crossed Fyn (Fig. 137). It is assumed to have terminated in a zone reaching the coastal areas of south-easternmost Jylland over the Vejle-Silkeborg area then connected with the second and third iceborder stages in the development of the sandur plains in northern Jylland described by Ussing $(1903,1907)$. When the readvance stagnated, isolated ice masses were left on Fyn, where the melting of these ice masses resulted in formation of the central Fyn dead-ice landscape.

\section{THE STOREBALT - NORTH JYLLAND READVANCE}

As the active ice sheet reached a position east of Roskilde Fjord, proglacial drainage patterns were directed northwards through the central Danish region prior to the Storebælt-North Jylland Readvance (fig. 137). This readvance transgressed northern Sjælland from easterly directions and deposited the Fennoscandian, North
Sjælland Till (fig. 136h). In other parts of the country a more northeasterly ice flow direction is thought to have prevailed (Aber 1979, Jacobsen 1981a, 1985).

The readvance from the NE caused the formation of the older generation of prominent ice shoved ridges on Mols and northern Sams $\varnothing$ in the northern Bælthav region (Houmark-Nielsen $1976 \mathrm{~b}, 1980$, 1983). Towards the south this recessional zone can probably be traced on Hindsholm (Rasmussen 1975) and south-eastwards over Omø (Jacobsen 1976) and through northern Falster (Jacobsen 1981a,b). In northern Jylland the terminal moraines around the Randers-Hobro area (corresponding to stage 5: Ussing 1903, 1907) can be followed into the Limfjord. Here it cuts through northern Mors, where it is assumed to turn northward through Hannæs towards Bulbjerg as sketched by Gry (1979). It is, however, uncertain which role the prominent icepressed ridges around Hanklint and Hunborg in the western Limfjord region (Gry 1940) play in this connection, they could perhaps be related to the previous Norwegian icestream.

\section{VENDSYSSEL - GRIBSKOV READVANCE}

According to Hansen (1965) the formation of the terminal moraines in Vendsyssel (fig. 137) was contemporaneous with the beginning of the transgression of the Younger Yoldia Sea. The start of this transgression has been dated to 15000 to $14500 \mathrm{BP}$ (Petersen 1984). Before the final withdrawal of the Main Weichselian ice sheet from the Danish region the Younger Yoldia Sea transgressed into the Kattegat basin. A readvance caused the formation of the so-called Gribskov ice marginal hills from northeasterly directions on NE-Sjælland (fig. 137). The Gribskov readvance probably interconnects with the Vendsyssel terminal moraines and it is tentatively extended along the southern coast of Scania. Because the Younger Yoldia clay on Las $\varnothing$ has been dated to an age of around 14000-13500 BP (Krog \& Tauber 1974), the Vendsyssel-Gribskov readvance is estimated to be older than $14000 \mathrm{BP}$.

\subsection{THE YOUNG BALTIC ADVANCES}

It is not known how far into the Kattegat the Younger Yoldia Sea transgressed prior to the Young Baltic Advances. However, Adrielsson (1984) presents data indicating that the trans- 


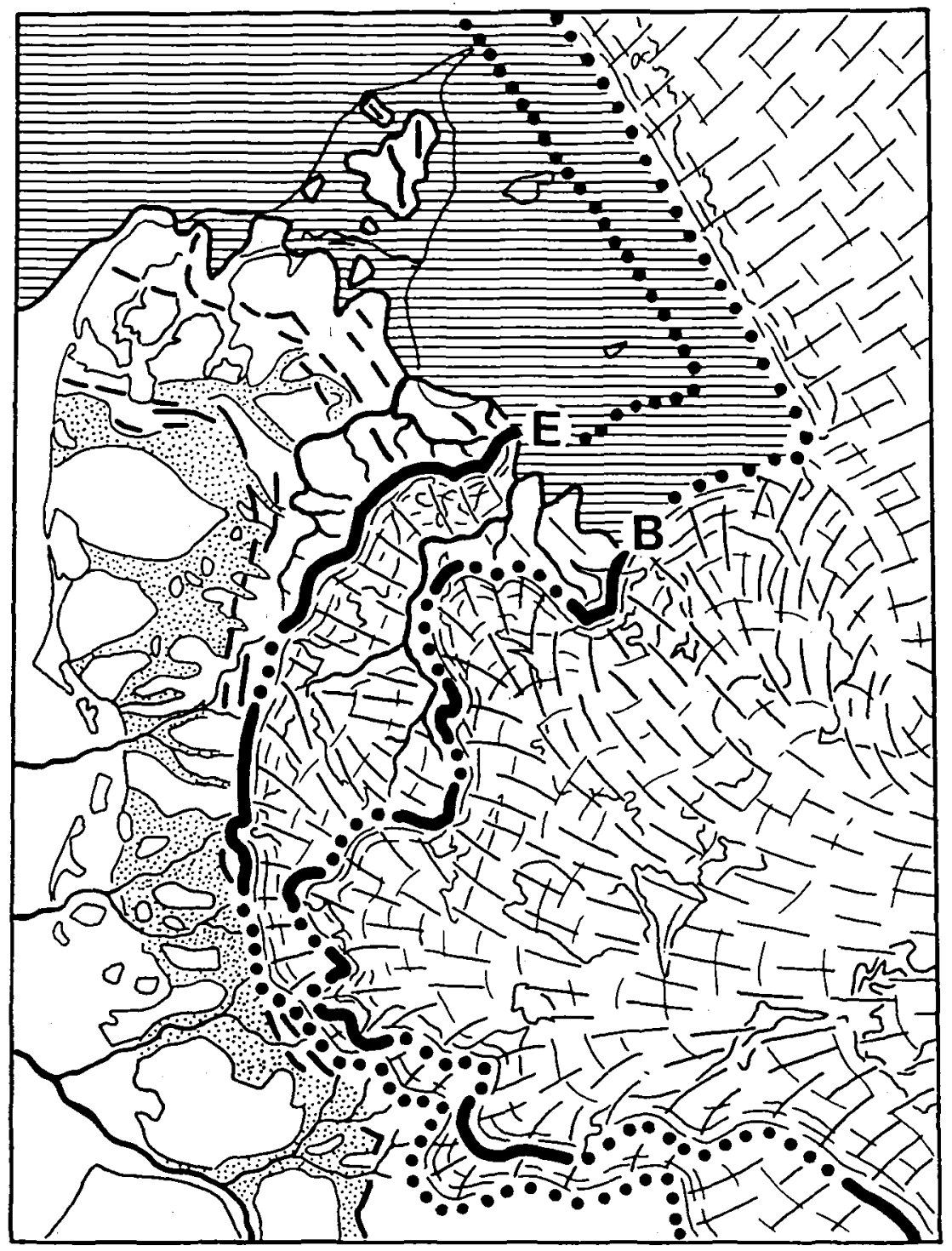

Fig. 138: Weichselian Young Baltic Glaciation. $E=$ East Jylland Advance, $B=$ Balthav Readvance. Further explanation fig. 137.

gression reached the northern Øresund region before and progressed during, the Young Baltic Advance (East Jylland Advance and Balthav Readvance).

\section{THE EAST JYLLAND ADVANCE}

The first Young Baltic ice stream, called the East Jylland Advance, terminated along the East Jylland Ice border line and its southern extension, as shown in the present investigation (fig. 138). The icesheet invaded eastern Denmark and western Skåne generally from south-easterly directions and deposited a quartz poor, clayey, Baltic till (East Jylland Till, fig. 136i) with associated Baltic indicators and re-deposited Quaternary foraminifera of Eemian derivation. Outwash material was deposited either as valley sandurs in central and north Jylland (Gudenå Sandur) or as northward draining sandur plains on Djursland (Tirstrup sandur). On the sandur plains of southern 
Jylland drainage was directed westwards across the peninsula.

During the maximum of the East Jylland Advance the ice-margin probably turned eastward from Djursland on the east coast of Jylland (cf. S.A.Andersen 1933, Berthelsen 1973). Here the present author assumes that the glacier calved into the Younger Yoldia Sea, which occupied the larger parts of the Kattegat basin. Between Anholt and Kullen the ice edge merged with the main body of the retreating "Fennoscandian" NE-ice sheet situated east of Læsø.

In accordance with S.A.Andersen (1966) and Sjørring (1977) the East Jylland Advance is thought to be connected with the Pommerian advance in northern Germany (cf. Hurtig 1979). The deposition of the upper Baltic facies of the Dalby-Sallerup tills (Berglund \& Lagerlund 1981, Ringberg et al. 1984) most probably took place during Young Baltic advances.

Petersen (1984) proposed that the East Jylland Advance peaked during the latest part of the Middle Weichselian (around $13300 \mathrm{BP}$ ). According to Berglund \& Lagerlund (1981) and Lagerlund et al. (1983), western Skåne was largely deglaciated around $13300 \mathrm{BP}$, which is after deposition of the upper Baltic facies of the Dalby Till. To the present author it seems highly improbable that the deglaciation of the Young Baltic Icesheet in western Skåne could be contemporaneous with its maximum limit of activity along the northern part of the East Jylland iceborder on Mols. In consequence the $\mathrm{C}-14$ dating published by $\mathrm{Pe}$ tersen (1984) must be evaluated with caution. It is therefore suggested, that the East Jylland Advance and $B æ l$ thav readvance took place between 14000-13500 BP. However, reliable datings are lacking from the area covered by the Young Baltic glaciers in Denmark.

\section{THE BALTHAV READVANCE}

The active Young Baltic glacier retreated to a position east of Fyn and north of the Kattegat coast of NE-Sjælland before the Bælthav Readvance crossed north western Sjælland, Storebælt, southern and eastern Fyn and south-eastern Jylland generally from south-easterly directions (fig. 138). A quartz poor, clayey, Baltic till (Bælthav Till, fig. 136j) with associated Baltic indicators was deposited. In the region examined outwash drainage patterns were directed northward. That meltwater streams could flow across central Jylland at this stage is thought to be rather improbable. An alternative, northward directed outwash route is proposed, being consequently responsible for the erosion of the deeper parts of Lillebælt and Storebælt (fig. 138).

Shortly before the maximum transgression of the Younger Yoldia Sea, the Bælthav Readvance terminated along and formed an ice marginal zone (fig. 138) marked by the ice-damed lakes of Egernsund (southeast Jylland) and Stenstrup (southern Fyn) continuing east of the sandur flats on northeastern Fyn. The ice margin followed a course northward across northern Sams $\varnothing$ and eastwards through the classical terminal moraines of NW-Sjalland (Odsherred), turning northward into Kattegat. It is suggested that the Balthav Readvance could correspond to the so-called activity limit A (Lagerlund et al. 1983) which marks the joining of the Bælthav ice margin and the NEice margin just NW of Halland Åsen in the southeasternmost part of Kattegat. A tentative correlation between the ice-marginal features along the coast of Halland and the latest Young Baltic Readvance across North Sjælland has been suggested by Berglund (1979). However, Lagerlund et al. (1983) suggests that the deglaciation phase along the Halland coastal moraines should be extended southeastwards through central Skåne, thus being contemporaneous with the deposition of the Lund-Jonstorp Tills in a subaqueous environment.

As proposed by Stephan et al. (1983) the Fehmern advance could correspond to the Bælthav readvance. During the Bælthav readvance the Younger Yoldia Sea transgressed into the deeper parts of the northern Bælthav. Prior to deglaciation the transgression had reached the northern coasts of Sjalland (cf. Nielsen \& Nielsen 1985) and penetrated deeply into the $\emptyset_{\text {re- }}$ sund region (Adrielsson 1984, Lagerlund 1980, Ringberg 1984). During deglaciation of the Bælthav Readvance recessional positions of the central part of the ice stream are marked by the pronounced arch-shaped terminal moraines through Storebælt (cf. S.A.Andersen 1927, Berthelsen 1975, Petersen 1973). The further decay of the ice sheet eventually led to sedimentation of the Lund/Jonstorp Tills in Skåne and equivalent deposits (Helsingør Diamicton) in NE-Sjælland (Houmark-Nielsen \& Lagerlund 1987). This most 
probably occurred in connection with the maximum transgression of the Younger Yoldia Sea in Kattegat. Dead-ice masses were launched as drifting icebergs and glacial debris was dropped and dumped giving rise to subaqueous icerafted tills like the Helsing $\varnothing r$ diamicton.

\subsection{THE LATE WEICHSELIAN}

During the Late Weichselian the final melting of dead ice masses from the former Middle Weichselian glacier advances took place. The Late Weichselian (Mangerud et al. 1974) covers deposition during the Bølling-, Allerød Interstadials, ranging in time between 13000 and 10000 BP.

Shortly after 13000 BP the active ice front had retreated to a position in the southernmost parts of Småland (south central Sweden) (Lagerlund et al. 1983) and during the first climatic optimum (Bølling) an open vegetation had invaded of the country (cf. Iversen 1954, 1967, Kolstrup 1982). Dead ice masses may still have occurred locally, but it is uncertain for how long time such remnants existed in Denmark. Villumsen (1973) and V.Milthers (1935) suggest that dead ice remnants in eastern Jylland and northern Sjælland melted during or after the Allerød Interstadial.

\section{CONCLUDING REMARKS}

Studies of Quaternary deposits in the central part of Denmark have revealed, that data from relatively few principal localities (less than 10 ) is sufficient to outline a glacial-stratigraphic model for the region. On the other hand, a large number of localities (in the present case around 200) evenly scattered within the examined region are required to map the distribution and regional directional elements of till-stratigraphic units.

The present investigation shows that within the examined region exposed sections of Pleistocene deposits range in thickness from less than $3 \mathrm{~m}$ to more than $50 \mathrm{~m}$ in composite exposures (fig. 16) and that even large hiati are frequently recorded in the stratigraphic columns. Any Pleistocene deposit, or, to a lesser extent underlying Tertiary sediments, may constitute the immediate subsurface deposits in areas affected by strong glaciotectonic activity. It is shown that tills make up less than $40 \%$ of the thickness of both tills and waterlaid outwash material. By far the largest part of the outwash material interbedded between till units is regarded as having been deposited under subaerial conditions. Thus, they may show structures developed in a periglacial environment. Inter-till, waterlaid deposits have large, lateral distribution and the observed regional palaeoflow directions are governed by pre-existing topographic features such as valleys, lake basins, dead ice masses and regional embayments (cf. Berthelsen 1973, Houmark-Nielsen 1980, Houmark-Nielsen \& Berthelsen 1981, Larsen et al. 1977, Selsing 1981).

The concept of subaerial deposition of waterlaid material interbedding till units in Denmark is supported by the environmental reconstruction covering Middle Weichselian deposits in the eastern Øresund region (Adrielsson 1984). The present author notes in accordance with S. A. Andersen (1957), Berthelsen (1973) and Sjørring (1977) that except for local dead ice masses, relatively ice-free conditions with subaerial sedimentation prevailed between the major Weichselian ice advances and readvances.

A poly-glacial evolution as described above seems not only to be the case with the Weichselian, but it is estimated with some confidence also to apply to earlier glaciations. Evidence of soilforming processes (Sjørring 1981), or of deposi- 
tion of thick and extensively distributed outwash sediments laid down in the time between glacier advances during the Elsterian and the Saalian, have been noted by the present investigation as well as previous works (cf. Ehlers et al. 1984, Kronborg 1983, Sjørring 1981, Sjørring \& Frederiksen 1980).

The course of the Weichsleian-, the Saalianand probably also the Elsterian glaciations across Denmark seems to follow a directional pattern in which northerly ice advances originating in the southern part of Norway were replaced by northeasterly advances crossing southwestern Sweden. The final stage consists of south-easterly advances through the Baltic depression. With modifications, the above-mentioned clockwise movement of ice-flow directions is reflected in the change of indicator erratics of tills and striations on bedrock and boulder pavements and was recognized early in the Danish literature (cf. Milthers 1909).

The path of repeated, cyclic, clockwise changes in direction of ice advances, divisible into the 3 phases mentioned above, has recently been expressed in the light of previous investigations for the parts of northern Germany that were covered by successive, pre-Weichselian, Scandinavian ice caps (Ehlers 1981, Ehlers et al. 1984).

From the present investigation it is demonstrated that during the Saalian in Denmark, one single and extensive cyclic change in directional pattern of the ice streams occurred. Several cycles of clockwise changes as estimated by Ehlers (1981) and Ehlers et al. (1984) have, however, not been demonstrated in the region examined. In Denmark the Saalian is recorded by three major ice advances each representing an independent glacial stage: an early Norwegian, succeeded by a Middle (NE) advance crossing western Sweden bringing the Saalian to an end with a (Palaeo-) Baltic advance. The three advances were separated in time at least by the deposition of proglacial outwash material.

The present study seems to indicate the presence of at least four stages of glacial evolution within the Middle Weichselian of Denmark. However, the Old Baltic advance seems to anticipate this "trinity" of a simple cyclic glaciation during the later half of the Middle Weichselian. The last glaciation proceeded with the Norwegian ice advance, which was followed by the Main
Weichselian advance from the NE, and subsequently succeeded by the Young Baltic advance. Apparently, Weichselian glacier advances took place within a time span of less than 20000 years.

Fundamentally different glaciation models have been brought forward to elucidate the cyclic change in directional pattern of Scandinavian ice sheets in general and to explain or expel the presence of Baltic ice streams in particular.

Despite published evidence on Young Baltic glaciotectonic activity Overweel (1977) rejected the idea that Baltic glaciers travelled across Denmark and western Skåne during the Weichselian. The scattering of Baltic indicator erratics supposedly arose primarily from ice-rafting through a proglacial lakebasin linking the Baltic with the Skagerrak and Kattegat.

In accordance with the classical outline as well as more recent publications, Ehlers (1981) and Ehlers et al. (1984) discussed the possibility that migration of the ice-divide owing to an eastward shifting of the glaciation centre constitutes the primary cause of the clockwise change recorded in the periphery of the ice sheet. Another factor mentioned is a possible negative mass balance in the western parts of the ice-sheet developed owing to rapid melting in near coastal regions towards the end of each glaciation.

A different glaciation model is presented by Lagerlund (1980). One or more marginal domes situated in the periphery of the ice-sheet are thought to develop and decay independently of a large central dome. Thus, for the Weichselian it is suggested that the existence of Norwegian and Baltic ice streams is brought about by surging of marginal domes situated in the western and southern rim of the Scandinavian ice-sheets that affected the Danish - and surrounding regions.

Boulton et al. (1985) present a modern, computerized model for the Scandinavian ice-sheet during the last glaciation. A Fennoscandian icestream crossed Denmark from northeasterly directions and terminated along the Main Stationary Line. Thus, this model clearly pictures the behaviour of the icesheet during the Main Weichselian advance. Excluding the influence of marginal domes as presented by Lagerlund (1980), Boulton et al. find their model unable to reproduce Baltic icestreams that will cross western Skåne, Denmark and Schleswig-Holstein.

Regardless of the reliability of either glaciation 
model, it is considered by the present author that the above-mentioned clockwise changes in the directional pattern reflects a fundamental trend in the evolution of consequtive Scandinavian icesheets. It is also suggested that whatever attempts are made to model the evolution of Scandinavian ice sheets, the fundamental and repeated changes of direction of ice advances as recorded by glacial stratigraphic studies should be taken into consideration.

To bring the discussion to an end it must be concluded that Norwegian and Baltic icestreams apparently only exist when glaciers from central Sweden are not occupying the Kattegat and the western Baltic depressions. Baltic and Norwegian icestreams are supposed to have been brought about by an interaction between the evolution of a main (central) icedome and local factors at the fringes of the icesheet.

The evolution of the central dome, which is likely to produce the clockwise change of movement, is to a large extent governed by global climatic changes, regional land/sea configurations and the overall topography of Scandinavia that give rise to the migration of the icedivides. Also, changes in bedrock composition may influence the behaviour of icesheets. Local factors in the periphery may strengthen or suppress the course of icestreams. Primarily, local climatic changes may trigger the building of marginal domes and alternations in bedrock/ice temperature, glacierinduced, morphological modifications, such as proglacial depressions and other isostatic responses, neotectonic movements and eustatic fluctuations, will govern the course of surging glaciers that flow from the pre-Cambrian and $\mathrm{Pal}$ aeozoic Fennoscandian shield out upon the soft, mostly Cainozoic Northeuropean lowlands.

\section{ACKNOWLEDGEMENTS}

Gratitude is expressed to the Danish Natural Science Research Council and the University of Copenhagen for the granting of scholarships which made up the financial foundation for the present investigation. In addition, the Danish Natural Science Research Council is thanked for financial support in connection with the compilation, the linguistic revision and the publication of the manuscript. The Carlsberg Foundation is thanked for making it possible to finish writing this thesis. I want to express my thanks to colleagues at the Institute of General Geology (University of Copenhagen) for discussions and comments on the manuscript.

The Institute of General Geology readily placed field equipment, transportation media, Iaboratory- and office facilities at my disposal.

John Frederiksen (Danish State Railways) and Karen Louise Knudsen (Institute of Geology, University of Aarhus) are thanked for the examination of Quaternary foraminifera in selected samples. Svend Funder (Geological Museum, University of Copenhagen), Kurt Jacobsen (Ribe Amtskommune) and the Geobotanical department (Geological Survey of Denmark) kindly performed pollen analyses and Christian Kronborg (Institute of Geology, University of Aarhus) willingly made TL-datings at selected localities. Comments on parts of the manuscript were given by Peter Banham (Department of Geology, University of London) and Geoffrey Thomas (Department of Geography, University of Liverpool).

Rene Madsen and Guta Lis (Institute of General Geology) gave the drawings their finish and Pernille Andersen (Institute of General Geology) patiently and without hesitation typed several editions of the manuscript. 


\section{DANSK SAMMENDRAG}

Der er opstillet en glacialstratigrafisk model for det centrale Danmark (fig. 43) med et kombineret sæt af såvel klassiskesom moderne glacialstratigrafiske metoder anvendt på 10 hovedlokaliteter (fig. 7). Modellen danner grundlaget for en regional Kvartær stratigrafi fremkommet ved gennemgang af ca. 200 andre lokaliteter. De er jævnt fordelt i den unders $₫$ gte region og samlet i 19 områder. Regionen omfatter Jylland $ø$ st for Hovedopholdslinien mellem Århus og Haderslev, Mols samt Sams $\emptyset$, Sejerø. og Nordsjælland vest for Roskilde Fjord (fig. 44). På baggrund af den opstillede Kvartærstratigrafi kan en række morænebænke etableres som lithostratigrafiske till-enheder (fig. 105).

Till-enheder eller morænebænke aflejret direkte af den Skandinaviske indlandsis udgør den ene af de to hovedfacies, der kan erkendes fra Kvartæret omkring det midtdanske område. Imidlertid udgør den anden hovedfacies, nemlig smeltevandsdannelser, sammen med overgangstyper af langt ringere udbredelse foruden interglaciale eller interstadiale marine og limniske aflejringer, mere end halvdelen af Kvartærets mægtighed.

Morænebænke afsat direkte i forbindelse med afsmeltningen af en iskappe er formelt klassificeret som Formationer. De adskiller sig fra de øvrige aflejringer ved at vise regional ensartethed med hensyn til mægtighed, lithologi, istektonisk betingede grænser, udbredelse og til en vis grad også granulometri. Dette muliggør korrelation ved hjxlp af egenskaber, der afspejler de respektive iskappers udbredelse og bevægelsesmonstre $\mathrm{i}$ overensstemmelse med det kinetostratigrafiske princip. Endvidere er andre lithologiske karaktertrak anvendt ved korrelation.

De lithologiske egenskaber kan have lokal- eller regional betydning og omfatter både texturelle og petrografiske karakterer. Till-fabric analyser $i$ bund- $o g$ ablation tills vil ofte vise isstrømmes lokale flyderetning såfremt klasterne ikke har været udsat for postsedimentær reorientering eller gravitativt betinget flydning har forårsaget omlejring af morænematerialet.

Petrografiske studier af hhv. klaster og matrix muliggør klassiffcering af tills ud fra deres lokalt opblandede materiale og indholdet af fjerntransporterede elementer. For at lette sammenligning med moderne beskrivelser eller aldre især danske arbejder er sten- og grusanalyser udført på fraktionerne 3-5 mm efter den hollandske fingrustællingsmetode og i fraktionen 6-60 mm efter den klassiske danske stentællingsmetode. Mens det lokale klastmateriale bl.a. kan karakterisere morænebænke ud fra deres indhold af kvarts og flint (fig. 5) kan tills ud fra det fjerntransporterede materiale karakteriseres af hhv. fennoskandiske og baltiske sten- og grus selskaber (fig. 5). De fjerntransporterede elementer formodes at afspejle et regionalt isstrømningsmønster hhv. direkte fra den skandinaviske halvø eller gennem Østersøbakkenet.

Matrix's indhold af omlejrede Kvartære foraminiferer, der kan sammenlignes med kendte interglaciale eller interstadiale faunaselskaber anvendes primart som en legitim lithologisk karakter, men kan også give et muligt skøn over en given till-enheds maksimumalder.

Morænebænkenes grænser er undersøgt med specielt henblik på glacialtektoniske diskordanser, idet disse primært kan give oplysning om den lokale isbevagelsesretning og samtidig fungere som ledehorisonter $\mathrm{i}$ den opstillede lagfølge indenfor store dele af den unders $\varnothing$ gte region. I stærkt ispresforstyrrede sekvenser vil en glacialtektonisk analyse ofte yde de vigtigste bidrag til forståelsen af den stratigrafiske opbygning og enhedernes relative aldersforhold på en given lokalitet.

Till-bænkenes udbredelse er kortlagt, og deres relation til kendte interglaciale- eller interstadiale aflejringer, der kan absolut dateres eller klassificeres biostratigrafisk, er bestemt, ligesom der er foreslået korrelation med till-enheder fra andre egne af Danmark såvel som Skåne og Slesvig-Holstein.

\section{LITHOSTRATIGRAFI}

I den centraldanske region er der opstillet 12 till-formationer (figs $2,96,105$ ) afsat under de tre sidste istider.

Elster istiden er repræsenteret af 3 kvartsrige og flintfattige till-enheder (Sønder Vissing Till, Palsgård Till og Snoghøj Till), hvoraf den sidste er baltisk, mens de øvrige har fennoskandisk klast sammensatning og er desuden karakteriseret af hhv. norske og mellem- til vestsvenske ledeblokke.

Saale istiden omfatter tre enheder (Trelde Næs Till, Ashoved Till og Lillebælt Till), hvoraf den sidstnævnte er baltisk, kvartsfattig og flint- og kridtrig, mens de to æeldre viser omtrent samme mængde kvarts og flint og har fennoskandisk klastsammensætning med tilhørende ledeblokke fra hhv. Olso-egnen og Vest- og Mellemsverige. De tre till-enheder er afsat af tre forskellige iskapper fra hhv. nordlige, nordøstlige og til slut fra ostlige retninger.

Til Weichsel istiden henføres seks kvartsfattige till-enheder, hvoraf den ældste (Ristinge Klint Till) sandsynligvis aflejredes efter 36800 BP. Denne baltiske till-enhed aflejredes af en iskappe fra en sydøstlig retning. Den overlejredes af tre enheder med fennoskandisk klastsammensatning (Kattegat Till, Midtdanske Till og Nordsjalland Till) med associerede norskeeller vest- og mellemsvenske ledeblokke afsat af iskapper fra hhv. nordlige-, nordøstlige- og østlige retninger. De to yngste enheder (Østjylland Till og Balthav Till) er baltiske og aflejredes af den Ung Baltiske iskappe der overskred Øeme og Østjylland fra sydøstlige retninger sandsynligvis omkring 14000 BP.

De opstillede till-enheder er korreleret med till-aflejringer beskrevet fortrinsvis fra det sydvestlige Jylland og det nordlige $\emptyset$ resundsområde, og de er forsøgt afbildet i hæendelses-stratigrafisk profil, der gennemskærer Danmark i en NØ-SV'lig retning (fig. 136). Ud fra deres indbyrdes stratigrafiske placering, tilhørende bevægelsesmønstre og indholdet af fjerntransporteret materiale er till-enhederne sat i forbindelse med regionale isfremstød fra Elster, Saale og Weichsel istiderne.

\section{GLACIAL HISTORIE}

Den xlđste, registrerede till-enhed er påvist i boringer og overlejres af aflejringer fra Harreskov-mellemistiden, hvilket antyder, at en iskappe dakkede Danmark forud for denne interglacial. Under den efterfølgende Elster istid aflejredes limniske dannelser under de to Ølgod (I \& II) Interstadialer, hvorefter iskapper fra det sydnorske, mellemsvenske og baltiske område aflejrede hhv. Sønder Vissing Till, Palsgård till og Snoghøj Till sandsynligvis i den nævnte rækkefølge. I forbindelse med afsmeitningen af det yngste Elster fremstød aflejredes vidt udbredte finkornede smeltevandsdannelser $i$ det vestlige og nordlige Jylland. Marine-aflejringer afsattes under den efterfølgende transgression i Holstein mellemistiden, samtidig med aflejringen af søkalk, kiselgur og andre limniske sedimenter i mindre søbassiner i det centrale Jylland.

Sale istiden indledtes med to korterevarende varmeperioder (Vejlby Interstadialerne), hvorefter de tidligere søbassiner opfyldtes af flydejord og senere af grus og sand afsat af vest- og sydgående smeltevandsstrømme foran en fremrykkende iskappe. Dette Norske Saale fremstød deformerede sit underlag fra nordlige retninger og aflejrede Trelde Næs Till. Under isens afsmeltning forårsagede et lokalt genfremstød forstyrrelser $\mathrm{i}$ den allerede aflejrede till. Vestgående smeltevandsstrømme aflejrede herefter sand $0 \mathrm{~g}$ grus forud for det Midterste Saale fremst $\varnothing$ d, der overskred Danmark fra det vestlige Mellemsverige og aflejrede Ashoved Till.

Sandede aflejringer afsattes af vestgående smeltevandsstrømme inden det yngste Saale isfremstød, kaldet det Paleobaltiske fremstød, overskred landet fra Østersøområdet og aflejrede Lillebælt Till. 
I isolerede lavninger på denne morænes overflade aflejredes under Eem mellemistiden limniske sedimenter $i$ kedelmoser $i$ det centrale Jylland. Havet opfyldte de lavereliggende områder omkring Sydvestjylland, Lillebælt og $\emptyset$ stesøen og afsatte $\mathrm{Cy}$ prinaleret på relativt lavt vand, mens det marine ler afsattes på betydeligt st $\varnothing$ rre dybder omkring Vendsyssel.

Mens havspejlet atter sænkedes, afsattes tidligt $i$ Weichsel istiden limniske dannelser $i$ de tilbageblevne søbassiner under to korte varmeperioder (Rodebxk- og Brorup Interstadialerne). I Midtweichsel transgrederede det Aldre Yoldiahav gennem Kattegat mod syd ind over Sjalland, mens der på højereliggende arealer aflejredes limniske dannelser af begrænset udbredelse under Moershoofd- og Hengelo Interstadialerne.

Under den efterfølgende regression kunne den såkaldte Esrum-diamiktit være aflejret. Herefter fyldtes Esrum-Alnarp dalen og andre lavereliggende egne af fluviatil sedimenter fra Øs. tersøen, inden den Gammelbaltiske isstrøm overskred de sydlige- og østlige dele af landet og aflejrede Ristinge Klint Till.

Samtidig med eller umiddelbart efter afsmeltningen af den Gammelbaltiske is overskred den Norske Weichsel isstrøm de nordlige dele af landet og aflejrede Kattegat Till. Efter bortsmeltningen af den Norske is herskede relativt isfrie tilstande i Danmark og nordgående smeltevandsstrømme aflejrede finkornede materialer med stor udbredelse ved drænering fra Østersøen.

Under Hovednedisningens fremrykning fra det vestlige Mellemsverige kort før $20000 \mathrm{BP}$ aflejredes grovkornede flodaflejringer af vestgående smeltevandsstrømme. Hovedfremstødet eller NØ-isen nảede Hovedopholdslinien (fig. 137) under sin største udbredelse og aflejrede den Midtdanske Till. Under NØ-isens generelle afsmeltning blev smeltevandets afstrømningsretning efterhånden tvunget nordud under en række genfremst $\varnothing$ d. Ved disse genfremstød dannedes bl.a. det centralfynske dødisområde (Fyn-Vestlimfjord genfremstødet, fig. 136), de markante israndszoner $i$ de midterste dele af landet (Storebælt-Nordjylland genfremstødet, fig. 136), hvorunder Nordsjalland Till afsattes, samt israndsdannelserne i det nordøstlige Danmark (Vendsyssel-Gribskov genfremstødet, fig. 136). I forbindelse med det yngste genfremst $ø$ d nåede den "senglaciale" transgression Vendsyssel, hvorefter det Yngre Yoldiahav bredte sig foran den vigende $N \emptyset$-is dybt ind $i$ Kattegat.

Den Ungbaltiske iskappe overskred Danmark under den yngre Yoldia transgression og nåede omkring $14000 \mathrm{BP}$ under det Østjyske fremstød sin største udbredelse langs den Østjyske israndslinie (fig. 138), og aflejringen af den Østjyske Till fandt sted. Under den generelle afsmeltning forårsagede et genfremstød før 13500 BP (Bælthav genfremstød, fig. 138) den endelige udformning af Odsherredbuerne, de nordsamske randmorænebakker, israndsdannelserne på Øst- og Sydfyn og Broagerland samt aflejringen af Bælthav Till. Under den fremadskridende afsmeltning udmodeleredes israndsstrø- gene i og omkring Storebælt, bælternes dybe render, og det Yngre Yoldiahav nåede de nordsjallandske kystegne og den skånske Øresundskyst. Med indledningen til Bølling Interstadialet omkring $13000 \mathrm{BP}$ var den Ungbaltiske isstrøm overgået til dødis, og større dele af de tidligere isdækkede områder blev taget $\mathrm{i}$ besiddelse af en sparsom vegetation ved overgangen til Senweichsel.

\section{KONKLUSION}

Det må formodes, at de respektive isstrømme i Weichsel-, Saale- og sandsynligvis også Elster istiden i hvert fald delvist overskred det danske område efter et overordnet cyklisk bevxgelsesm ønster. De ofte vidt udbredte smeltevandsdannelser, der mellemlejrer de enkelte till-bænke, er efter alt at dømme aflejret under subaeriske forhold i et periglacialt miljø mellem de enkelte isstrømme. En given nedisningscyklus kan indledes med nordlige isstrømme, efterfølges af nordøstlige og østlig- og afsluttes med isstrømme fra det baltiske område.

Under Weichsel istiden synes det cykliske nedisningsforløb at være ufuldstændigt. Forud for den cyklus der førte til aflejring af hhv. Kattegat Till, Midtdanske Till, Nordsjælland Till samt $\emptyset$ stjyske- og Balthav Till, afsattes Ristinge Klint Till under det gammelbaltiske fremstød. Weichsel istiden fortsatte med det Norske isfremstød, som blev afløst af Hovedfremstødet. Det gav efter sin afsmeltning plads for den Ungbaltiske nedisning.

For Saale istidens vedkommende synes de stratigrafiske studier at afsløre én større cyklus, hvorunder først Trelde Næs Till, derefter Ashoved Till og til slut Lillebalt Till aflejredes under hhv. det Norske Saale fremstød, det Midterste (NØ-) Saale fremstød og det Paleobaltiske fremstød. På trods af manglende stratigrafiske vidnesbyrd må det formodes, at aflejringen af Sønder Vissing Till, Palsgård Till og Snoghøj Till også under Elster istiden foregik efter samme overordnede nedisningsmønster.

Det cykliske nedisningsforløb, som synes at præge de tre yngste glaciationer, er formodentlig et resultat af udviklingen i en stor, centralt beliggende, Skandinavisk iskappe. Globale klimatiske forhold samt fordelingen af højland, lavland og havområder kan give ophav til en vandring af isdeleren og en differentieret afsmeltning $i$ randen af den centrale ismasse. Lokale forhold omkring iskappens periferi som f.eks. andrede cyklonbaner, isostatiske udligninger, endringer $\mathrm{i}$ isbundens temperatur og beskaffenhed kan tænkes at gribe forstyrrende ind $i$ et "forudbestemt" nedisningsforløb. Opbygningen af marginale isdomer synes til en vis grad at styre udbredelsen af Norske og Baltiske isstrømmes passage af det danske område. Disse synes at finde sted mens hovedstrømmen fra Mellemsverige er smeltet tilbage til en position langs med den Fennoskandiske randzone. 


\section{References}

Aber, J. 1979: Kineto-stratigraphy at Hvidekiint, Møn, Denmark and its regional significance. Bull. Geol. Soc. Denmark, vol. 28, 81-93.

Adrielsson, L. 1984: Weichselian Lithostratigraphy and Glacial Environments in the Ven-Glumslöv Area, Southern Sweden. LUNDQUA-Thesis, vol. 16, $120 \mathrm{p}$.

Andersen, S.A. 1927: Storebalt i Nutid og Fortid. Geol. Fören. Stockh. Förh. 49, 427-437.

Andersen, S. A. 1933: Det danske Landskabs Historie. Danmarks Geologi $i$ almenfatteligt omrids. Levin \& Mundsgaard, Copenhagen, 111-124.

Andersen, S. A. 1945: Isstr $\not$ mmenes retning over Danmark i den sidste Istid, belyst ved ledeblokunders $\emptyset$ gelser. Kritiske bemærkninger til K. Milthers: Ledeblokke og Landskabsformer i Danmark (DGU II, No. 69) $\mathrm{m}$. svar og gensvar. Meddr dansk geol. Foren., vol. 10, 594-615.

Andersen, S. A. 1950: Rågeleje Egnens Geologi. Meddr dansk geol. Foren., vol. 11, 543-577.

Andersen, S. A. 1957: Lolland i den sidste istid. Meddr dansk geol. Foren., vol. 13, 225-235.

Andersen, S. A. 1963: Om Fyns glaciale terrænformer og deres opståen. Kritik af P. Smed: (Studier over den fynske øgruppes glacial landskabsformer. Meddr dansk geol. Foren., vol. 15, 1962) med gensvar. Meddr dansk geol. Foren., vol. 15, 223-229.

Andersen, S. A. 1964: Grusgravene i bakkerne ved Kalundborg. Meddr dansk geol. Foren., vol. 15, 359-367.

Andersen, S. A. 1966: En fremstilling af Danmarks Kvartærgeologi. Anmeldelse og vurdering af S. Hansen: The Quaternary of Denmark. In: The Quaternary, vol. 1, K. Rankama (edit.) Interscience Publishers. 1965. Meddr dansk geol. Foren., vol. 16, 214-233.

Andersen, S. Th. 1957: New Investigations of Interglacial Fresh-water deposits. Eiszeitalter u. Gegenwart 8, 181-186.

Andersen, S. Th. 1961: Vegetation and its Environment in Denmark in the Early Weichselian Glacial (Last Glacial). Danm. geol. Unders. II, No. 61,175 p.

Andersen, S. Th. 1963: Pollenanalysis of the Quaternary Marine Deposits at Tornskov in South Jylland. Danm. geol. Unders. IV Vol. 4, No. 8, 23 p.

Andersen, S. Th. 1965: Interglacialer og Interstadialer i Danmark. Meddr dansk geol. Foren., vol. 15, No. 4, 486-506.

Andersen, S. Th. 1967: Istider og mellemistider. In: Nørrevang \& Meyer (edit.): Danmarks Natur. Vol. 1. Politiken, Copenhagen, 199-250.

Andersen, S. Th. 1969: Interglacial vegetation and soil development. Meddr dansk geol. Foren., vol. 19, 90-102.

Andersen, S. Th. 1979: The subdivision of the Quaternary of Norden: a comment. Boreas, Vol. 8, 74-75.

Baartman, J. C. \& Christensen, O. B. 1975: Contributions to the interpretation of the Fennoscandian Border Zone. Danm. geol. Unders. II, No. 102, 31.

Bahnson, H. 1973: Lithological investigations in some Danish boulderclay profiles. Bull. Geol. Inst. Univ. Upps. 5, 93109.

Bahnson, H. 1984: Lithological and Stratigraphical Investigations of Types of Till in Northern Djursland, Jutland, Denmark. Striae, vol. 20, 21-26.

Bahnson, H., Petersen, K. S., Konradi, P. B. \& Knudsen, K. L. 1974: Stratigraphy of Quaternary deposits in the Skarumhede II boring: lithology, molluscs and foraminifera. Damm. geol. Unders., Årbog 1973, 27-62.

Berglund, B. 1979: The deglaciation of southern Sweden 1350010000 BP. Boreas, vol. 8, 89-118.

Berglund, B. E. \& Lagerlund, E. 1981: Eemian and Weichselian stratigraphy in South Sweden. Boreas, vol. 10, 323362.
Berthelsen, A. 1949: Nogle ledebloktallinger på Horsensegnen. Meddr dansk geol. Foren., vol. 11, 449-455.

Berthelsen, A. 1971: Fotogeologiske og feltgeologiske undersøgelser i NV-Sjælland. Dansk geol. Foren., Årsskrift for 1970, 64-69.

Berthelsen, A. 1973: Weichselian ice advances and drift successions in Denmark. Bull. Geol. Inst. Univ. Upps., 5, 21-29.

Berthelsen, A. 1974: Nogle forekomster af intrusivt moræneler i NØ-Sjælland. Dansk geol. Foren., Årsskrift for 1973, 118-131.

Berthelsen, A. 1975: Geologi på Røsnæs. Eskursionsfører No. 3, VARV, 78. p.

Berthelsen, A. 1978: The methodology of kineto-stratigraphy as applied to glacial geology. Bull. geol. Soc. Denmark, vol. 27, Special Issue, 25-38.

Berthelsen, A. 1979: Contrasting views on the Weichselian glaciation and deglaciation of Denmark. Boreas, vol. 8, 125132.

Betthelsen, A., Konradi, P., Petersen, K. S., Rasmussen, L. A. \& Sjørring, S. 1976: Guide til NORDQUA-ekskursion til Sjalland, Falster og Møn, 24-27 maj. Inst. for almen Geologi, Københavns Univ., 30 p.

Berthelsen, A., Konradi, P. \& Petersen, K. S. 1977: Kvartære lagfølger og strukturer i Vestmøns klinter. Dansk geol.Foren., Årsskrift for 1976, 93-99.

Boulton, G. S., Smith, G. D., Jones, A. S. \& Newsome, J. 1985: Glacial geology and glaciology of the last mid-latitude ice sheets. J. geol. Soc. London, vol. 142, 447-474.

Buch, A. 1955: De marine, interglaciale lag ved Inder Bjergum. Meddr dansk geol. Foren.; vol. 12, 593-632.

Chebotareva, N. S. \& Makarycheva, I. A. 1981: Paleogeography of the Treeless stage of the Valdai Russian Plain. Quart. Stud. Pol., 3, 15-20.

Clemmensen, L. \& Houmark-Nielsen, M. 1981: Sedimentary features of a Weichselian glaciolacustrine delta, Kyndby, North Sjælland, Denmark. Boreas, vol. 10, 229-245.

DeGeer, G. 1884: Om den skandinaviska landisens andra utbredning. Sver. Geol. Unders. Ser. C, No. 68, 33 p.

Drosdowski, E. 1980: Chronostratigraphy of the Vistulian Glaciation on the lower Vistula river. Quart. Stud. Pol., 2, 13-20.

Duphorn, K., Stay, B. \& Stiller, D. 1979: Deglaciation of the Bara Basin near Malmö, Sweden, Boreas, vol. 8, 141-144.

Ehlers, J. 1978: Die quartäre morphogenese der Harburger Berge und ihre Umgebung. Mitt. Geogr. Gesellschaft in Hamburg, 68, $181 \mathrm{p}$.

Ehlers, J. 1979: Fine gravel analysis after the Dutch method as tested out on Ristinge Klint, Denmark. Bull. geol. Soc. Denmark, vol. $27,157-165$.

Ehlers, J. 1981: Different till types in North Germany and their origin. In: Evenson, E. B., Schlüchter, Ch. \& Rabassa, J. (edit.): Tills and Related Deposits. Proceedings of the INQUA Symposia on the genesis and lithology of Quaternary deposits USA. 1981, Argentina 1982, A. A. Balkema, Rotterdam, 68-80.

Ehlers, J. 1983: The glacial history of north-west Germany. In: Ehlers, J. (edit.): Glacial deposits in Northwest-Europe. A. A. Balkema, Rotterdam, 229-238.

Ehlers, J. \& Stephan, H-J. 1983: Till fabric and ice movement. In: Ehlers, J. (edit.): Glacial deposits in northwest Europe. A. A. Balkema, Rotterdam, 267-274.

Ehlers, J., Meyer, K-D. \& Stephan, H-J. 1984: Pre-Weichselian glaciations in Northwest Europe. Quaternary Science Reviews, vol. $3,1-40$.

Eisemann, L. \& Müller, A. 1979: Leitlinien der Quartärentwicklung im Norddeuthschen Tiefland. Z.geol. Wiss. Berlin $7,4,451-462$.

Feyling-Hanssen, R. \& Knudsen, K. L. 1979: Foraminiferer og deres betydning i skandinavisk geologi. Dansk Natur Dansk Skole Årsskrift for 1979, 3-47. 
Francis, E. A. 1975: Glacial sediments: a selected review. In: Wright, A. E. \& Mosely, F. (edits), Ice ages: ancient and modern. Geol. Jour., Spec. Issue 6, 43-68.

Fredericia, J. 1979: Kvartargeologisk, sedimentologisk undersøgelse ved Birket, $N V$-Lolland. Unpubl. cand. thesis. Inst. General Geology, University of Copenhagen, $248 \mathrm{p}$.

Frederiksen, J. K. 1975: Glacialtektoniske og -stratigrafiske undersøgelser $i$ udvalgte områder $i$ det sydlige Danmark. Unpubl. prize essay, Univ. Copenhagen.

Frederiksen, J. K. 1976: Hvad de sønderjyske klinter fortæller. VARV, 1976, No. 2, 35-45.

Frederiksen, J. K. 1982: Græstedlerets foraminiferer i østdanske moræneaflejringer. Dansk geol. Foren., Arsskrift for 1981, 65-71.

Glen, J. W., Donner, J. J. \& West, R. G. 1957: On the mechanism by which stones in till become reoriented. Am. Jour. Science, vol. 255, 194-205.

Gormseñ, K. \& Hansen, H. C. S. 1980: Isfremstød over interglacial mose ved Rødding. Dansk Geoteknik A/S, Publ. No. 8, 12 p.

Gry, H. 1940: De istektoniske Forhold i Molerområdet. Meddr dansk geol. Foren., vol. 9, No. 5, 586-627.

Gry, H. 1952: Eskursion til Kalundborg-egnen (ref.). Meddr dansk geol. Foren., vol. 12, 322-323.

Gry, H. 1979: Beskrivelse til Geologisk Kort over Danmark. Kortbladet Løgstør. Danm. geol. Unders. I, No. 26.

Hansen, S. 1965: The Quaternary of Denmark. In: Rankama (edit.) The Quaternary. Vol. 1, Interscience Publishers, $1-90$.

Hansen, S. 1978: Sidste nedisnings maksimum-udbredelse i Syd og Midtjylland (A. V. Nielsen edit.). Danm. geol. Unders., Årbog 1976, 139-152.

Harder, P. 1908: En østjydsk Israndslinie og dens Indflydelse paa Vandløbene. Danm. geol. Unders. II, No. 19, 227 p.

Hartz, N. 1909: Bidrag til Danmarks tertizere og diluviale Flora. Danm. geol. Unders. II, No. 20, 292 p.

Hartz, N. \& Østrup, E. 1899: Danske Diatome. jord-Aflejringer og deres Diatomeer. Danm. geol. Unders. II, No. 9, $81 \mathrm{p}$.

Hirvas, H., Korpela, K. \& Kujansuu, R. 1981: Weichselian in Finland before 15000 BP. Boreas, vol. 10, 423-431.

Holm, L. 1981: Heavy mineral distribution in Weichselian drift successions in eastern Denmark. Bull. geol. Soc. Denmark, vol. 30, 1-10.

Holmes, C. D. 1941: Till Fabric. Bull. geol. Soc. Am., vol. 52, 1299-1354.

Houmark-Nielsen, M. 1976a: En glacialstratigrafisk oversigt fra Nordsamsø og Tunø. Dansk geol. Foren., Årsskrift for $1975,11-13$.

Houmark-Nielsen, M. 1976b: Nordsamsøs Istidsnekrolog. VARV, 1976, No. 3, 89-96.

Houmark-Nielsen, M.-1976c: En glacialstratigrafisk undersøgelse af klinterne på Nordsamsф og Tun $\phi$. Unpubl.cand. thesis. Inst.General Geol., University of Copenhagen, 107 p.

Houmark-Nielsen, M. 1980: Glacialstratigrafien omkring det nordlige Balthav. Unpubl. lic. thesis, Inst.General Geol., University of Copenhagen, $194 \mathrm{p}$.

Houmark-Nielsen, M. 1981: Glacialstratigrafi i Danmark øst for Hovedopholdslinien. Dansk geol. Foren., Årsskrift for $1980,61-76$

Houmark-Nielsen. M. 1983a: Depositional features of a late Weichselian outwash fan, central East Jylland, Denmark. Sedimentary Geology, vol. 36, 51-63.

Houmark-Nielsen, M. 1983b: The compositional features of Danish glacial deposits. In: Ehlers, J. (edit.): Glacial deposits in northwest Europe. A. A. Balkema, Rotterdam, 199-202.

Houmark-Nielsen, M. 1983c: Glacial stratigraphy and morphology of the northern Bælthav region. In: Ehlers, J. (edit.):
Glacial deposits in northwest Europe. A. A. Balkema, Rotterdam, 211-217.

Houmark-Nielsen, M. \& Berthelsen, A. 1981: Kineto-stratigraphic evaluation and presentation of glacial-stratigraphic data, with examples from northern Samsø, Denmark. Boreas, vol. 10, 411-422.

Houmark-Nielsen, M. \& Kolstrup, E. 1981: A radiocarbon dated Weichselian sequence from Sejerø, Denmark. Geol. Fören. Stockh. Förh., vol. 103, Pt. 1, 73-78.

Houmark-Nielsen, M. \& Lagerlund, E. 1987: The Helsingør Diamicton. A late Middle Weichselian subaqueus till from the northern Øresund region. Bull. geol. Soc. Denmark, vol. 36 (in press).

Humlum, O., Krüger, J. \& Sjørring, S. 1978: Danmark i sidste istid: En diskussion. Naturens Verden 1978, 272-286.

Hurtig, T. 1969: Zum letzglazialen Abschmelzmechanismus im Raume des Baltischen Meers (Map of icemarginal positions). Geogr. Zeitschrift, Beihefte 22, Franz Steiner Verlag, Wiesbaden.

International Subcommission on Stratigraphic Classification (ISSC) 1976: International Stratigraphic Guide (H. D. Hedberg, edit.): John Wiley \& Sons, New York, 200 p.

Iversen, J. 1954: The late-glacial flora of Denmark and its relation to climate and soil. Danm. geol. Unders. II, No. 80, 87 p.

Iversen, J. 1967: Naturens udvikling siden sidste istid. In: Nørrevang \& Meyer (edit.): Danmarks Natur, vol. 1, Politiken, Copenhagen, 345-373.

Jacobsen, E. M. 1976: En morænestratigrafisk unders $\emptyset$ gelse af klinterne på Omø. Dansk geol. Foren., Årsskrift for 1975, 15-17.

Jacobsen, E. M. 1981a: Weichselian till stratigraphy in borings from northern Falster, Denmark. Boreas, vol. 10, 403-409.

Jacobsen, E. M. 1981b: Some glaciotectonic features from the southern part of Sjælland, Denmark. Abstract. INQUA \& IGCP 73/1/24. Field meeting in Denmark, May 1981, "Glacial Tectonics", 8 p.

Jacobsen, E. M. 1985: En råstofgeologisk kortlagning omkring Roskilde. Dansk geol. Foren., Årsskrift for 1984, 65-78.

Jensen, J. B. 1985: Sen-Elster smeltevandsler - en mulig ledehorisont $\mathrm{i}$ det vestlige Jylland. Dansk geol. Foren., Årsskrift for 1984, 21-35.

Jensen, J. B. \& Knudsen, K. L. 1984: Kvartarstratigrafiske undersøgelser ved Gyldendal og Kås Hoved i det vestlige Limfjordsområde. Dansk geol. Foren., Årsskrift for 1983, 35-54.

Jensen, V. 1977: Store Karlsminde Klint, materialer og strukturer. Dansk geol. Foren., Årsskrift for 1976, 47-55.

Jessen, A. 1899: Beskrivelse til geologisk kort over Danmark. Kortbladene Skagen, Hirtshals, Frederikshavn, Hjørring og Løkken. Danm. geol. Unders. I, No. 3, 368 p.

Jessen, A. 1907: Beskrivelse til geologisk kort over Danmark. Kortbladet Skamlingsbanke. Danm. geol. Unders. I, No. $12,99 \mathrm{p}$

Jessen, A. 1918: Vendsyssels Geologi. Danm. geol. Unders. V, No. 2,195 p.

Jessen, A. 1922: Beskrivelse til geologisk kort over Danmark. Kortbladet Varde. Danm. geol. Unders. I, No. 14, 105 p.

Jessen, A. 1925: Beskrivelse til geologisk kort over Danmark. Kortbladet Blaavandshuk. Danm. geol. Unders. I, No. 16, $76 \mathrm{p}$.

Jessen, A. 1930: Klinten ved Halk Hoved. Danm. geol. Unders. IV, vol. 2, No. $8,26 \mathrm{p}$.

Jessen, A. 1931: Lonstrup Klint. Danm. geol. Unders. II, No. $49,142 \mathrm{p}$.

Jessen, A. 1935: Beskrivelse til geologisk kort over Danmark. Kortbladet Haderslev. Danm. geol. Unders. I, No. 17, 95 p.

Jessen, A. 1945: Beskrivelse til geologisk kort over Danmark. 
Kortbladet Sønderborg. Danm. geol. Unders. I, No. 20, $91 \mathrm{p}$.

Jessen, A., Madsen, V., Milthers, V. \& Nordmann, V. 1918: Brørup-Mosernes Lejringsforhold. Danm. geol. Unders. IV, vol. 1, No. 9, 44 p.

Jessen, A., Milthers, V., Nordmann, V., Hartz, N. \& Hesselbo, A. 1910: En boring gennem kvartære lag ved Skærumhede. Danm. geol. Unders. II, No. 25, 175 p.

Jessen, K. \& Milthers, V. 1928: Stratigraphical and Paleontological Studies of Interglacial Fresh-water Deposits in Jutland and Northwest Germany. Danm. geol. Unders. II, No. 48,380 p.

Knudsen, K. L. 1986: Foraminiferal biostratigraphy of the north Jutland-Kattegat area through Middle- and Upper Pleistocene time. Abstract to the seminar in Quaternary geology, University of Aarhus, sept. 4-7, 1986.

Knudsen, K. L. \& Feyling-Hanssen, R. 1976: Ergebnisse der foraminiferanalyse zur Quartärstratigraphie in Skandinavien. Eiszeitalter u. Gegenwart 27, 82-92.

Knudsen, K. L. \& Lykke-Andersen, A-L. 1982: Foraminifera in Late Saalean, Eemian, Early and Middle Weichselian of the Skærumhede I boring. Bull. geol. Soc. Denmark, vol. 30, 97-109.

Kolstrup, E. 1982: Late-glacial pollendiagrams from Hjelm and Draved Mose (Denmark) with a suggestion of the possibility of drought during the Earlier Dryas. Rev. Paleobot. Palynol., vol. 36, 35-63.

Kolstrup, E. \& Havemann, K. 1984: Weichselian Juniperus in the Froslev alluvial fan (Denmark). Bull. geol. Soc. Denmark, vol. 32, 121-131.

Konradi, P. B. 1973: Foraminiferas in some Dansih glacial deposits. Bull. Geol. Inst. Univ. Upps., 5, 173-175.

Konradi, P. B. 1976: Foraminifera in Eemian deposits at Stensigmose, southern Jutland. Danm. geol. Unders. II, No. $105,57 \mathrm{p}$.

Kozarski, S. 1980: An outline of Vistulian stratigraphy and chronology of the Great Poland Lowland. Quart. Stud. Pol., 2, 21-35.

Krasnov, I. I. 1978: Stratigraphische Korrelation der Quartãrablagerungen in ostlichen Gebiet der fennoskandischen Vereisungen. Z. geol. Wiss., Berlin 9, 69-79.

Kronborg, C. 1983: Glacialstratigrafien i Øst-og Midtiylland. Unpubl. lic. thesis, Geol.Inst., University of Aarhus, 259 p.

Kronborg, C. \& Knudsen, K. L. 1985: Om kvartæret i Rugård: En foreløbig undersøgelse. Dansk geol. Foren., Årsskrift for $1984,37-48$.

Krüger, J. 1969: Landskabsformer i sydlige Sjælland. Geogr. Tidsskrift, vol. 68, 105-212.

Krüger, J. 1970: Till fabric in relation to direction of icemovement. Geogr. Tidsskrift, vol. 69, 73-109.

Lagerlund, E. 1980: Lithostratigrafisk indeling av Västskånes Pleistocen och en ny glaciationsmodell för Weichsel. Univ. of Lund, Dept. of Quat. Geol., Report 21, 120 p.

Lagerlund, E., Knutsson, G., Åmark, M., Hebrand, M., Jönsson, L-O., Karlgren, B., Kristiansson, J., Möller, P., Robinson, J. M., Sandgren, P., Terne, T. \& Waldemarsson, D. 1983: The deglaciation pattern and dynamics in south Sweden. A preliminary report. $L U N O Q U A$ Report 24,7 p.

Larsen, G., Jørgensen, F. H. \& Priisholm, S. 1977: The stratigraphy, structure and origin of glacial deposits in the Randers area, eastern Jutland. Danm. geol. Unders. II, nr. $111,36 \mathrm{p}$.

Larsen, G., Kronborg, C. \& Bender, H. 1979; Det Midtjyske søhøjland. Geologi. Amtsfredningskontoret, Aarhus Amt, 14-27.

Larsen, G., Liboriussen, J. \& Villumsen, A. 1972: Kvartærgeologiske undersøgelser på kortbladet Randers. Dansk geol. Foren., Årsskrift for $1971,27-40$.
Lindsay, J. F. 1970: Clast fabric of till and its development. Jour. Sed. Pet., vol. 40, No. 2, 629-641.

Lundqvist, J. 1981: Weichselian in Sweden before 15000 BP. Boreas, vol. 10, 395-402.

Lykke-Andersen, A-L. 1974: Foraminiferal investigations of some Danish tills (transl.). Lecture held at a meeting in the Geol. Soc. Denmark, March 26, 1974.

Lykke-Andersen, A-L. 1981: En ny C-14 datering fra Ældre Yoldia Ler i Hirtshals Kystklint. Dansk geol. Foren., Årsskrift for $1980,1-5$.

Lykke-Andersen, A-L. 1982: Nogle nye C-14 dateringer fra Fldre Yoldia Ler i Hirtshals Kystklint. Dansk geol. Foren., Årsskrift for 1981, 119-121.

Lykke-Andersen, H. 1968: Is og Landskab. Terrænet syd for Aarhus i søgelyset. VARV 1968, No. 1, 17-25.

Lykke-Andersen, H. 1979: Nogle undergrundstektoniske elementer $\mathrm{i}$ det danske Kvartær. Dansk geol. Foren., Årsskrift for 1978, 1-6.

Madsen, V. 1897: Beskrivelse til Geologisk Kort over Danmark. Kortbladet Samsø. Danm. geol. Unders. I, No. 5, 87 p.

Madsen, V. 1900: Beskrivelse til Geologisk Kort over Danmark. Kortbladet Bogense. Danm. geol. Unders. I, No. 7, $112 p$.

Madsen, V. 1902: Beskrivelse til Geologisk Kort over Danmark. Kortbladet Nyborg. Danm. geol. Unders. I, No. 9, $182 \mathrm{p}$.

Madsen, V. 1916: Ristinge Klint. Danm. geol. Unders. IV, vol. 1, No. 2, 32 p.

Madsen, V. 1921: Terrainformene paa Skovbjerg Bakkeø. Danm. geol. Unders. IV, vol. 1, No. 2, 24 p.

Madsen, V. 1931: Diskussion om V. Milthers' Foredrag om Ledeblokke og Israndsstadier i det centrale Danmark. Meddr dansk geol. Foren., vol. 8, 139-142.

Madsen, V., Jessen, K. \& Nordmann, V. 1928: Oversigt over Danmarks Geologi. Danm. geol. Unders. V, No. 4, 78142.

Madsen, V., Nordmann, V. \& Hartz, N. 1908: Eem-Zonerne. Studier over Cyprinaleret og andre Eem-Aflejringer i Danmark, Nord-Tyskland og Holland. Danm. geol. Unders. II, No. 17,302 p.

Madsen, V. \& Nordmann, V. 1928 (in V. Madsen edit.): Guide for the Excursions in Denmark. Danm. geol. Unders. V, No. $5,18-20$.

Madsen, V. \& Nordmann, V. 1940: Kvartæret i Røgle Klint ved Lillebælt. Danm. geol. Unders. II, No. 58, 142 p.

Mangerud, J. 1981: The Early and Middle Weichselian in Norway: a review. Boreas, vol. 10, 381-393.

Mangerud, J., Andersen, S. Th., Berglund, B. \& Donner, J. J. 1974: Quaternary startigraphy of Norden, a proposal for terminology and classification. Boreas, vol. 3, 109-128.

Mangerud, J. \& Berglund, B, E. 1978: The subdivision of the Quaternary of Norden: a discussion. Boreas vol. 7, 179181.

Marcussen, I. 1974: Stentxllingsmetoden, ledeblokanalysen og glacialstratigrafi - en kritisk vurdering. Dansk geol. Foren., Årsskrift for 1973, $20-42$.

Marcussen, I. \& Østergaard, T. 1977: Danmark i sidste istid. Naturens Verden 1977, 367-375.

Marcussen, I. \& Østergaard, T. 1978: Danmarks istidslandskaber - en ny teori for deres dannelse. Naturens Verden 1978, 53-61.

Milthers, K. 1942: Ledeblokke og Landskabsformer i Danmark. Danm. geol. Unders. II, No. 69, 137 p.

Milthers, K. 1952: Stenene og det danske landskab. J. Fr. Clausen, Copenhagen (second edit.), $46 \mathrm{p}$.

Milthers, K. 1959: Beskrivelse til Geologisk Kont over Danmark. Kortbladene Fåborg, Svendborg og Gulstav. A: Kvartære aflejringer. Danm. geol. Unders. I, No. 21-A, 112 p. 
Milthers, V. 1900: Randmoræner. In: Rørdam, K. \& Milthers, V. 1900: Beskrivelse til Geologisk Kort over Danmark. Kortbladene Sejrø, Nykjøbing, Kalundborg og Holbæk. Danm. geol. Unders. I, No. 8, 69-83.

Milthers, V. 1908: Beskrivelse til Geologisk Kort over Danmark. Kortbladene Faxe og Stevns Klint. Danm. geol. Unders. I, No. 11, $291 \mathrm{p}$.

Milthers, V. 1909: Scandinavian Indicator-Boulders in Quaternary Deposits. Danm. geol. Unders. II, No. 23, 153 p.

Milthers, V. 1913: Ledeblokke i de skandinaviske Nedisningers sydvestlige Grænseegne. Dansk geol. Foren. Bd. 4, 115182.

Milthers, V. 1925: Beskrivelse til Geologisk Kort over Danmark. Kortbladet Bakke. Danm. geol. Unders. I, No. 15, $175 \mathrm{p}$.

Milthers, V. 1932: Israndens Tilbagerykning fra $\emptyset$ stjylland til Sjelland-Fyn, belyst ved Ledeblokke. Danm. geol. Unders. IV, vol. 2, No. 9, 59. p.

Milthers, V. 1935: Nordøstsjallands Geologi. Danm. geol. Unders. V, No. 3 (second edit.), 192 p.

Milthers, V. 1939: Beskrivelse til Geologisk Kort over Danmark. Kortbladet Brande. Danm. geol. Unders. I, No. 18, $163 \mathrm{p}$.

Milthers, V. 1940: Beskrivelse til Geologisk Kort over Danmark. Kortbladet Vissenbjerg. Danm. geol. Unders. I, No. 19, $143 \mathrm{p}$.

Milthers, V. 1948: Det danske Istidslandskabs Terrænformer og deres Opståen. Danm. geol. Unders. III, No. 28, 233 p.

Milthers, V. 1955: Et vestjysk istidsområde. Meddr dansk geol. Foren., vol. 13, 206-216.

Mojski, J.E. 1985: Geology of Poland. Vol. 1, Stratigraphy, Part 36. Cainozoic, Quaternary. Publishing House: Wydawnictwa Geologiczne, Warzawa 1985, 246 p.

Nielsen, P. E. 1980: Kvartærgeologiske undersøgelser i Korsør området. Dansk geol. Foren., Årsskrift for 1979, 55-62.

Nielsen, P. E. \& Houmark-Nielsen, M. 1983: Till Fabric. In: Ehlers, J. (edit.): Glacial deposits in northwest Europe, A. A. Balkema, Rotterdam, 207-209.

Nielsen, P. E. \& Nielsen, E. M. 1985: Hvad skjuler Kattegat. VARV 1, 1985, 3-7.

Nordmann, V. 1922: Det marine Diluvium ved Vognsbøl. Danm. geol. Unders. IV, vol. 1, No. 14, 24 p.

Nordmann, V. 1927: Israndslinier paa Kortbladet Fredericia. Meddr dansk geol. Foren., vol. 7, 171-177.

Nordmann, V. 1928: La position stratigraphique des dépôts d'Eem. Danm. geol. Unders. II, No. 47, 81 p.

Nordmann, V. 1958: Beskrivelse til Geologisk Kort over Dánmark. Kortbladet Fredericia. A. Kvartare aflejringer. Danm. geol. Unders. I, No. 22A, 125 p.

Nordmann, V., Jessen, K. \& Milthers, V. 1923: Quartärgeologische Beobachtungen auf Sylt. Meddr dansk geol. Foren., vol. 6, No. 15, 40 p.

North American Commission on Stratigraphic Nomenclature 1983: North American Stratigraphic Code, A.A.P.G. Bull., 67, 5, 841-875.

Overweel, C. J. 1977: Distribution and transport of Fennoscandian indicators. Thesis Wangeningen, Scripta Geol. 43, 117 p.

Pedersen, G. \& Surlyk, F. 1983: The Fur Formation, a late Paleocene ash-bearing diatomite from northern Denmark. Bull. geol. Soc. Denmark, vol. 32, 43-65.

Petersen, K. S. 1973: Tills in dislocated drift deposits on the Røsnæs peninsula, northwestern Sjæelland, Denmark. Bull. Geol. Inst. Univ. Upps., vol. 5, 41-49.

Petersen, K. S. 1978: Applications glaciotectonic analysis in geological mapping of Denmark. Danm. geol. Unders., Årbog 1977, 53-61.

Petersen, K. S. 1984: Stratigraphical position of Weichselian Tills in Denmark. In: Königsson, L-K. (edit.): Ten Years of Nordic Till Research. Striae, vol. 20, 75-78.
Petersen, K. S. 1985: The Late Quaternary History of Denmark. The Weichselian Icesheets and Land/Sea Configuration in the Late Pleistocene and Holocene. Journal of Danish Archaeology, vol. 4, 7-22.

Petersen, K. S. \& Buch, A. 1974: Dislocated tills with Paleogene and Pleistocene marine beds. Tectonics, lithology, macro- and microfossils. Danm. geol. Unders., Årbog 1973, 63-91.

Petersen, K. S. \& Konradi, P. B. 1974: Lithologisk og palxontologisk beskrivelse af profiler i Kvartæret på Sjælland. Dansk geol. Foren., Årsskrift for 1973, 47-56.

Rasmussen, H. W. 1977: Geologi på Mols. Rapport udarbejdet for Fredningsplanudvalget for Århus Amt. Danm. geol. Unders. Series A, No. 4, 21 p.

Rasmussen, L. Aa. 1973: The Quaternary stratigraphy and dislocations on Ven. Bull. Geol. Inst. Univ. Upps., 5, 37-39.

Rasmussen, L. Aa. 1974: Om moræenestratigrafi i det nordlige Øresundsområde. Dansk geol. Foren., Årsskrift for 1973, 132-139.

Rasmussen, L. Aa. 1975: Kinetostratigraphic glacial drift units on Hindsholm, Denmark. Boreas, 4, 209-217.

Rasmussen, L. Aa. \& Petersen, K. S. 1980: Resultater fra DGUs genoptagne kvartærgeologiske kortlagning. Dansk geol. Foren., Årsskrift for 1979, 47-54.

Richter, K. 1933: Gefüge und Zusammensetzung des Norddeutchen Jungmoränengebietes. Ab. Geolog.-Pal. Inst. Greifswald, hf. XI, 1-63.

Ringberg, B. 1984: Beskrivning till jordartskartan Helsingborg SO. Sver, geol. Unders. Serie Ae, No. 51, 21-124.

Ringberg, B., Holland, B. \& Miller, U. 1984: Till Stratigraphy and Provenance of the Glacial Chalk Rafts at Kvarnby and Ängdala, Southern Sweden. Striae, vol. 20, 79-90.

Rørdam, K. 1893: De geologiske Forhold i det nordostlige Sjalland. Danm. geol. Unders. I, No. 3, 110 p.

Rørdam, K. 1899: Beskrivelse til Geologisk Kort over Danmark. Kortbladene Kjøbenhavn og Roskilde. Danm. geol. Unders. I, No. 6, 108 p.

Rørdam, K. 1909: Geologi og Jordbundslaere, vol. I \& II. Nordisk Forlag, Copenhagen.

Rørdam, K. \& Mitthers, V. 1900: Beskrivelse til Geologisk Kort over Danmark. Kortbladene Sejrø, Nykjøbing, Kalundborg og Holbæk. Danm. geol. Unders. I, No. 8, 143 p.

Schuldt, J. 1981: Om Esrum dalens geologi. Dansk geol. Foren., Årsskrift for 1980, 77-81.

Schwan, J. \& Rizema, W. 1982: Till variation in a Weichselian glacial section along the coast of southwest Funen, Denmark. Geol. Mijnbouw 61, 163-171.

Schwan, J. \& van Loon, A. J. 1979: Structural and sedimentological characteristics of a Weichselian kame terrace at Sønderby Klint, Funen, Denmark. Geol. Mijnbouw 58, 305-319.

Selsing, L. 1981: Stress analysis on conjugate normal faults in unconsolidated Weichselian glacial sediments from Brorfelde, Denmark. Boreas, vol. 10, 275-279.

Sjørring, S. 1973: Some problems in the till stratigraphy of the northeastern part of Sjaelland. Bull. Geol. Inst. Univ. Upps. 5, 31-35.

Sjørring, S. 1974: Klinterne ved Hundested. Dansk geol. Foren., Årsskrift for 1973, 108-117.

Sjørring, S. 1975: Isen kom, isen gik. VARV 1977, vol. 1, 9-11.

Sjørring, S. 1977: The glacial stratigraphy of the island of Als, southern Denmark. Z. Geomorph. N. F., Suppl.Bd. 27, 1-11.

Sjørring, S. 1981a: Pre-Weichselian Till Stratigraphy in Western Jutland, Denmark. Meded. Rijks. Geol. Dienst, vol. 34, $62-68$.

Sjørring, S. 1981b: The Weichselian till stratigraphy in the southern part of Denmark. Quaternary Studies in Poland, 3, 103-109.

Sjørring, S. 1983: The glacial history of Denmark. In: Ehlers, J. 
(edit.): Glacial deposits in north-west Europe. A. A. Balkema, Rotterdam, 163-179.

Sjørring, S. \& Frederiksen, J. 1980: Glacialstratigrafiske observationer i de vestjyske bakkeøer. Dansk geol. Foren., Årsskrift for 1979, 63-77.

Sjørring, S., Nielsen, P. E., Frederiksen, J., Hegner, J., Hyde, G., Jensen, J. B., Mogensen, A. \& Vortisch, W. 1982: Observationer fra Ristinge Klint, felt- og laboratorieunders $\phi$ gelser. Dansk geol. Foren., Årsskrift for 1981, 135-149.

Smed, P. 1962: Studier over den fynske øgruppes glaciale landskabsformer. Meddr dansk geol. Foren., vol. 15, No. 1, $1-74$.

Smed, P. 1980: Isens afsmeltning fra Danmark i sidste istid. In: Smed, P.: Det fynske landskab (second edit.) 1980, Geografforlaget, Brenderup, DK-5464, 11.

Smed, P. 1982: Landskabskort over Danmark. Mapsheets 1-4. Geografforlaget, Brenderup, DK-5464.

Stephan, H-J., Kabel, C. \& Schlüter, G. 1983: Stratigraphical problems in the glacial deposits of Schleswig-Holstein. In: Ehlers, J. (edit.): Glacial deposits in Northwest Europe, A. A. Balkema, Rotterdam, 305-320.

Stephan, H-J. \& Menke, B. 1977: Untersuchungen über den Verlauf der Weichsel - Kaltzeit in Schleswig-Holstein. $Z$. Geomorph. N. F. Suppl. Bd. 27, 12-28.

Surlyk, F. 1980: Geology of the European countries, vol. 1, Denmark. Dunod, Paris, 42-50.

Thamdrup, K. 1970: Klinterne ved Mols Hoved, en kvartærgeologisk undersøgelse. Meddr dansk geol. Foren., Årsskrift for $1969,2-8$.

Torell, O. 1872: Undersökningar öfver istiden del 1 - Kungl. Vet. Akad. Förh. Stockholm, 1-44.

Torell, O. 1873: Undersökningar öfver istiden del 2 - Kungl. Vet. Akad. Förh. Stockholm, 47-64.

Ussing, N. V. 1899: Danmarks Geologi i almenfatteligt Omrids. Danm. geol. Unders. III, No. 2, First edit., 372 p.

Ussing, N. V. 1903: Om Jyllands Hedesletter og Teorierne for deres dannelse. Overs. $K$. danske Videnskb. Selsk. Forh., 1903, No. 2, 99-165.
Ussing, N. V. 1907: Om Floddale og Randmoræener i Jylland. Overs. K. danske Vidensk. Selsk. Forh., 1907, No. 4, 161213.

Ussing, N. V. 1913: Danmarks Geologi i almenfattigt Omrids. Danm. geol. Unders. III, No. 2 (P. Harder, third edit.), $372 \mathrm{p}$.

Ussing, N. V. \& Madsen, V. 1897: Beskrivelse til Geologisk Kort over Danmark. Kortbladet Hindsholm. Danm. geol. Unders. I, No. 2, 87 p.

Villumsen, A. 1973: Geochemical and sedimentological investigations of the Rosenholm Depression. Danm. geol. Unders. II, No. 100,66 p.

Wee, M. W. Ter 1983: The Saalean glaciation in the northern Netherlands. In: Ehlers, J. (edit.): Glacial deposits in northwest Europe, A. A. Balkema, Rotterdam, 405-412.

Wennberg, G. 1943: Eisströme über Schonen während der letzten Eiszeit. Medd. Lunds Geol. Min. Inst., No. 104, 28 p.

Wennberg, G. 1949: Differentialrörelser i indlandsisen. Sista istiden i Danmark, Skåne og Östersjön. Medd. Lunds Geol. Min. Inst., No. 114, 201 p.

Woldstedt, P. 1935: Geologisch-morphologischen Übersichtskarte des norddeutschen Vereisungsgebietes. Preuss. Geol. Landesanst. 33 p.

Woldstedt, P. 1954: Das Eiszeitalter. Grundlinien einer Geologie des Quartärs. 1, 1954; II, 1958. Stuttgart.

Zagwijn, W. H. 1963: Pleistocene stratigraphy in the Netherlands, based on changes in vegetation and climate. Verh. Ned. Geol. Mijnb. Gen. Geol. Ser., No. 21-2, 173-196.

$\emptyset$ dum, H. 1927: Bemærkninger om Vestgrænsen for den sidste Nedisning i Nordslesvig (ref.). Meddr dansk geol. Foren., vol. 7,171 .

$\emptyset$ dum, H. 1933: Marint Interglacial på Sjælland, Hven, Møn og Rygen. Danm. geol. Unders. IV, vol. 4, No. 10, 5-23.

Ødum, H. 1968: Flintkonglomeratet i Jylland. Tertiærformation og ledeblok. Meddr dansk geol. Foren., vol. 18, 1-32. 
EXOTIC STONE COUNTS FINE GRAVEL COUNTS

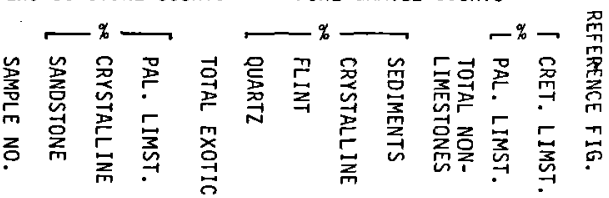

$\begin{array}{rrrrrrrrrrrrr}1 & & & & & 5 & 25 & 55 & 15 & 416 & & & \\ 2 & & & & 15 & 17 & 52 & 16 & 487 & & & \\ 3 & 8 & 85 & 7 & 225 & 19 & 18 & 55 & 8 & 332 & 5 & 5 & 110 \\ 4 & & & & & 21 & 22 & 42 & 15 & 227 & 1 & 1 & \\ 5 & & & & & 20 & 21 & 48 & 11 & 324 & & & \\ 6 & & & & & 15 & 13 & 53 & 19 & 312 & & 1 & \\ 7 & & & & & 15 & 17 & 54 & 14 & 360 & 1 & 2 & \\ 8 & & & & & 20 & 19 & 50 & 11 & 267 & & & \\ 9 & & & & & 29 & 17 & 44 & 10 & 305 & 3 & 1 & \\ 10 & & & & & 23 & 14 & 46 & 17 & 603 & 1 & 2 & \\ 11 & & & & & 28 & 10 & 46 & 15 & 412 & 2 & 1 & \\ 12 & & & & & 5 & 30 & 56 & 9 & 212 & & & \\ 13 & 7 & 80 & 13 & 188 & 8 & 24 & 54 & 14 & 351 & 8 & 13 & 125 \\ 14 & 8 & 79 & 13 & 126 & 19 & 17 & 49 & 6 & 316 & 7 & 4 & 113 \\ 15 & 14 & 72 & 14 & 161 & 19 & 19 & 47 & 15 & 330 & 7 & 6 & 113 \\ 16 & 21 & 65 & 14 & 111 & 13 & 14 & 54 & 19 & 296 & 8 & 7 & 113 \\ 17 & 13 & 73 & 14 & 317 & 15 & 14 & 54 & 17 & 345 & 10 & 5 & 110 \\ 18 & 18 & 65 & 16 & 92 & 18 & 15 & 49 & 18 & 346 & 14 & 3 & 110 \\ 19 & & & & & 16 & 16 & 52 & 17 & 400 & 10 & 10 & \\ 20 & & & & & 16 & 15 & 49 & 21 & 360 & 9 & 6 & \\ 21 & 11 & 70 & 19 & 73 & 21 & 12 & 47 & 20 & 410 & 12 & 9 & \\ 22 & 10 & 78 & 12 & 208 & 20 & 12 & 53 & 15 & 303 & 13 & 9 & \\ 23 & 6 & 77 & 16 & 191 & 20 & 9 & 55 & 16 & 209 & 11 & 4 & \\ 24 & 16 & 67 & 17 & 108 & 9 & 21 & 58 & 12 & 306 & 12 & 19 & 125 \\ 25 & 10 & 74 & 16 & 160 & 3 & 25 & 57 & 15 & 291 & 14 & 18 & 125 \\ 26 & 11 & 69 & 20 & 94 & 5 & 28 & 52 & 15 & 194 & 16 & 29 & 116 \\ 28 & 9 & 61 & 29 & 129 & 6 & 20 & 55 & 19 & 475 & 22 & 21 & 116 \\ 29 & 14 & 59 & 28 & 138 & 7 & 19 & 53 & 22 & 229 & 23 & 20 & 116 \\ 30 & 13 & 60 & 26 & 160 & 5 & 18 & 57 & 20 & 292 & 27 & 23 & 116 \\ 31 & 15 & 63 & 22 & 158 & 7 & 27 & 49 & 17 & 290 & 31 & 24 & 116 \\ 32 & 15 & 64 & 21 & 172 & 6 & 17 & 53 & 24 & 226 & 22 & 12 & 116 \\ 33 & 17 & 58 & 26 & 90 & 5 & 21 & 52 & 22 & 310 & 27 & 18 & 116 \\ 34 & 12 & 79 & 9 & 116 & 18 & 23 & 46 & 13 & 252 & 6 & 10 & 113 \\ 35 & 14 & 80 & 5 & 77 & 21 & 18 & 49 & 11 & 297 & 3 & 12 & 113 \\ 36 & 12 & 80 & 8 & 148 & 20 & 22 & 48 & 10 & 284 & 7 & 8 & 113 \\ 37 & 16 & 70 & 14 & 128 & 17 & 16 & 55 & 12 & 254 & 9 & 4 & 113 \\ 38 & 15 & 75 & 10 & 92 & 18 & 21 & 49 & 12 & 288 & 4 & 5 & 113 \\ 39 & 12 & 78 & 10 & 140 & 23 & 13 & 56 & 9 & 263 & 8 & 4 & 113 \\ 40 & & & & & 27 & 14 & 50 & 9 & 258 & & & \\ 11 & & & & & 25 & 14 & 44 & 17 & 350 & & & \end{array}$
$\begin{array}{rrrrrrrrrr}39 & 12 & 78 & 10 & 140 & 23 & 13 & 56 & 9 & 283 \\ 40 & & & & & 27 & 14 & 50 & 9 & 258 \\ 41 & & & & & 25 & 14 & 44 & 17 & 350\end{array}$

$\begin{array}{lllllllllllll}42 & 12 & 70 & 18 & 227 & 11 & 10 & 60 & 19 & 294 & 12 & 7 & 110\end{array}$ $\begin{array}{lllllllllllll}43 & 15 & 74 & 11 & 148 & 15 & 15 & 51 & 18 & 210 & 8 & 10 & 110\end{array}$

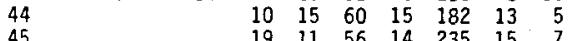

$\begin{array}{lllllllllllll}46 & 12 & 68 & 20 & 123 & 4 & 23 & 56 & 17 & 257 & 17 & 21 & 131\end{array}$ $\begin{array}{lllllllllllll}47 & 11 & 61 & 27 & 71 & 2 & 24 & 51 & 23 & 298 & 29 & 20 & 131\end{array}$ $\begin{array}{lllllllllllll}48 & 7 & 85 & 8 & 72 & 3 & 29 & 48 & 20 & 267 & 7 & 24 & 125\end{array}$ $\begin{array}{lllllllllllll}49 & 8 & 79 & 13 & 142 & 4 & 18 & 61 & 17 & 289 & 13 & 17 & 125\end{array}$ $\begin{array}{lllllllllllll}50 & 10 & 67 & 23 & 130 & 1 & 25 & 50 & 24 & 338 & 33 & 20 & 116\end{array}$ $\begin{array}{lllllllllllll}51 & 16 & 63 & 21 & 117 & 3 & 33 & 56 & 8 & 256 & 19 & 22 & 116\end{array}$ $\begin{array}{lllllllllllll}52 & 6 & 64 & 30 & 163 & 4 & 34 & 46 & 17 & 281 & 24 & 16 & 116\end{array}$ $\begin{array}{lllllllllllll}53 & 7 & 48 & 44 & 187 & 4 & 30 & 49 & 17 & 271 & 30 & 17 & 116\end{array}$ $\begin{array}{lllllllllllll}54 & 12 & 72 & 16 & 188 & 13 & 14 & 57 & 15 & 402 & 16 & 7 & 113\end{array}$ $\begin{array}{lllllllllllll}55 & 10 & 76 & 14 & 160 & 14 & 13 & 56 & 17 & 299 & 13 & 10 & 113\end{array}$ $\begin{array}{lllllllllllll}56 & 22 & 68 & 10 & 96 & 17 & 22 & 47 & 14 & 329 & 4 & 41 & 113\end{array}$ $\begin{array}{lllllllllllll}57 & 12 & 76 & 12 & 115 & 17 & 15 & 54 & 14 & 355 & 11 & 2 & 110\end{array}$ $\begin{array}{lllllllllllll}58 & 12 & 66 & 22 & 167 & 3 & 18 & 64 & 15 & 238 & 23 & 11 & 131\end{array}$ $\begin{array}{lllllllllllll}59 & 13 & 62 & 25 & 173 & 3 & 20 & 59 & 18 & 319 & 19 & 17 & 131\end{array}$ $\begin{array}{lllllllllllll}60 & 13 & 71 & 16 & 139 & 4 & 16 & 61 & 18 & 401 & 12 & 27 & 125\end{array}$ $\begin{array}{lllllllllllll}61 & 9 & 73 & 18 & 80 & 5 & 24 & 56 & 15 & 218 & 10 & 19 & 125\end{array}$ $\begin{array}{lllllllllllll}62 & 11 & 69 & 20 & 115 & 3 & 28 & 62 & 7 & 208 & 17 & 21 & 125\end{array}$ $\begin{array}{lllllllllllll}63 & 14 & 57 & 29 & 110 & 2 & 13 & 66 & 20 & 342 & 27 & 17 & 119\end{array}$ $\begin{array}{lllllllllllll}64 & 17 & 53 & 30 & 83 & 6 & 26 & 52 & 16 & 307 & 17 & 12 & 119\end{array}$ $\begin{array}{lllllllllllll}65 & 12 & 60 & 28 & 172 & 2 & 20 & 54 & 24 & 331 & 24 & 7 & 119\end{array}$ $\begin{array}{lllllllllllll}66 & 10 & 50 & 40 & 60 & 3 & 18 & 64 & 15 & 344 & 28 & 22 & 116\end{array}$ $\begin{array}{lllllllllllll}67 & 12 & 64 & 24 & 104 & 4 & 22 & 56 & 18 & 246 & 24 & 18 & 116\end{array}$ $\begin{array}{lllllllllllll}68 & 13 & 53 & 34 & 152 & 3 & 18 & 59 & 19 & 223 & 18 & 16 & 131\end{array}$ $\begin{array}{lllllllllllll}69 & 20 & 48 & 32 & 124 & 1 & 28 & 52 & 19 & 341 & 24 & 20 & 131\end{array}$ $\begin{array}{lllllllllllll}70 & 7 & 59 & 34 & 267 & 4 & 29 & 54 & 14 & 297 & 22 & 16 & 131\end{array}$ $\begin{array}{lllllllllllll}71 & 10 & 79 & 11 & 67 & 4 & 33 & 50 & 13 & 329 & 4 & 29 & 125\end{array}$ $\begin{array}{lllllllllllllll}72 & 11 & 74 & 15 & 37 & 3 & 39 & 38 & 20 & 318 & 8 & 29 & 125\end{array}$ $\begin{array}{rrrrrrrrrrrrr}73 & 15 & 73 & 12 & 83 & 8 & 32 & 40 & 21 & 217 & 9 & 34 & 125\end{array}$
EXOTIC STONE COUNTS FINE GRAVEL COUNTS

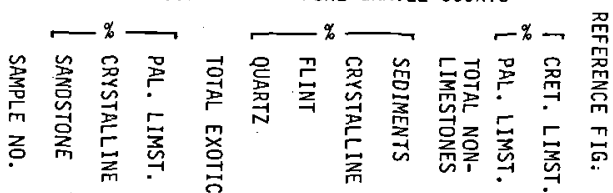

$\begin{array}{lllllllllllll}75 & 10 & 72 & 18 & 114 & 4 & 22 & 58 & 16 & 311 & 14 & 18 & 125\end{array}$ $\begin{array}{rrrrrrrrrrrrr}76 & 9 & 76 & 15 & 117 & 3 & 26 & 46 & 25 & 204 & 8 & 20 & 125 \\ 77 & 12 & 72 & 16 & 95 & 4 & 31 & 51 & 14 & 318 & 11 & 24 & 125\end{array}$

$\begin{array}{lllllllllllll}78 & 13 & 72 & 15 & 72 & 8 & 29 & 44 & 19 & 312 & 5 & 33 & 125\end{array}$

$\begin{array}{lllllllllllll}79 & 14 & 72 & 14 & 153 & 7 & 35 & 46 & 11 & 405 & 8 & 30 & 125\end{array}$

$\begin{array}{rrrrrrrrrrrrr}80 & 14 & 70 & 16 & 210 & 9 & 27 & 58 & 6 & 286 & 9 & 13 & 125\end{array}$

$\begin{array}{rrrrrrrrrrrrr}81 & 13 & 70 & 17 & 100 & 8 & 29 & 53 & 11 & 279 & 11 & 11 & 125\end{array}$

$\begin{array}{llllllllllll}82 & 22 & 75 & 3 & 62 & 20 & 18 & 48 & 14 & 392 & 3 & 3\end{array}$

$\begin{array}{rrrrrrrrrrrrr}83 & 17 & 57 & 26 & 58 & 3 & 26 & 54 & 16 & 292 & 16 & 15 & 119\end{array}$ $\begin{array}{lllllllllllll}84 & 12 & 61 & 27 & 131 & 6 & 28 & 54 & 12 & 299 & 14 & 12 & 119 \\ 85 & 11 & 65 & 24 & 109 & 2 & 20 & 56 & 22 & 208 & 22 & 16 & 119\end{array}$ $\begin{array}{lllllllllllll}86 & 10 & 65 & 25 & 135 & 5 & 22 & 60 & 14 & 246 & 20 & 20 & 119\end{array}$ $\begin{array}{lrlllllllllll}87 & 9 & 69 & 22 & 138 & 2 & 24 & 60 & 13 & 243 & 17 & 26 & 119\end{array}$ 88

89

$\begin{array}{lllllllllllll}91 & 10 & 60 & 30 & 229 & 5 & 19 & 59 & 17 & 210 & 19 & 12 & 131\end{array}$ $\begin{array}{lllllllllllll}92 & 14 & 58 & 28 & 155 & 4 & 28 & 51 & 17 & 360 & 17 & 12 & 131\end{array}$ 93

$\begin{array}{lllllllllllll}94 & 15 & 62 & 23 & 223 & 4 & 29 & 50 & 17 & 271 & 17 & 12 & 131\end{array}$

$\begin{array}{lllllllllllll}95 & 7 & 66 & 17 & 59 & 4 & 24 & 51 & 22 & 255 & 9 & 28 & 125\end{array}$

$\begin{array}{lllllllllllll}96 & 8 & 78 & 14 & 78 & 4 & 28 & 54 & 14 & 286 & 6 & 12 & 125\end{array}$

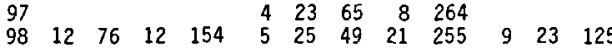

$\begin{array}{lllllllllllll}99 & 10 & 73 & 17 & 111 & 3 & 22 & 55 & 20 & 326 & 13 & 38 & 125\end{array}$

$\begin{array}{lllllllllllll}100 & 12 & 77 & 11 & 183 & 5 & 35 & 54 & 8 & 288 & 10 & 16 & 125\end{array}$

$\begin{array}{lrrrrrrrrrrrr}101 & 6 & 76 & 17 & 75 & 3 & 30 & 54 & 13 & 248 & 13 & 17 & 122\end{array}$

$\begin{array}{rrrrrrrrrrrrr}.102 & 13 & 76 & 10 & 99 & 6 & 25 & 56 & 13 & 340 & 12 & 24 & 122 \\ 103 & 8 & 79 & 13 & 80 & 6 & 26 & 52 & 17 & 242 & 8 & 26 & 122\end{array}$

$\begin{array}{lllllllllllll}104 & 9 & 79 & 12 & 138 & 3 & 21 & 64 & 12 & 264 & 8 & 15 & 122\end{array}$

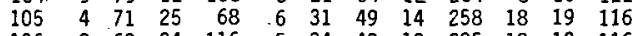

$\begin{array}{lllllllllllll}106 & 8 & 68 & 24 & 116 & 5 & 34 & 49 & 12 & 285 & 18 & 12 & 116\end{array}$

$\begin{array}{lrlllllllllll}107 & 9 & 54 & 37 & 151 & 4 & 28 & 50 & 18 & 276 & 29 & 24 & 116\end{array}$

$\begin{array}{lllllllllllll}108 & 14 & 60 & 27 & 165 & 2 & 13 & 67 & 18 & 313 & 24 & 32 & 116\end{array}$

109

$\begin{array}{rrrrrrrrrrrrr}110 & & & & & 4 & 19 & 59 & 9 & 300 & & & \\ 111 & 6 & 70 & 25 & 335 & 3 & 26 & 52 & 19 & 310 & 23 & 20 & 131\end{array}$

$\begin{array}{rrrrrrrrrrrrr}112 & 11 & 60 & 29 & 88 & 5 & 24 & 54 & 17 & 312 & 20 & 21 & 131 \\ 113 & 12 & 66 & 22 & 164 & 6 & 30 & 50 & 14 & 301 & 21 & 19 & 131\end{array}$

$\begin{array}{lllllllllllll}114 & 10 & 56 & 34 & 99 & 13 & 31 & 48 & 7 & 376 & 16 & 15 & 131\end{array}$

$\begin{array}{lllllllllllll}115 & 13 & 62 & 25 & 238 & 7 & 26 & 50 & 17 & 296 & 21 & 19 & 131\end{array}$

$\begin{array}{lrlllllllllll}116 & 8 & 59 & 33 & 436 & 2 & 34 & 51 & 13 & 321 & 19 & 18 & 131\end{array}$

$\begin{array}{lrrrrrrrrrrrr}117 & 12 & 80 & 8 & 136 & 8 & 29 & 49 & 14 & 218 & 8 & 26 & 125\end{array}$

118

$\begin{array}{lllllllllllll}119 & 7 & 59 & 34 & 135 & 4 & 19 & 59 & 9 & 300 & 34 & 8 & 116\end{array}$

$\begin{array}{lllllllllllll}120 & 16 & 51 & 32 & 47 & 7 & 24 & 55 & 14 & 304 & 29 & 20 & 116\end{array}$

$\begin{array}{lllllllllllll}121 & 17 & 61 & 22 & 111 & 15 & 23 & 46 & 16 & 366 & 11 & 20 & 116\end{array}$

123

.124

125

126

127

128

129

130
131

132

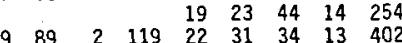

$\begin{array}{rrrrr}22 & 31 & 34 & 13 & 402 \\ 8 & 24 & 59 & 9 & 245\end{array}$

$0 \quad 10 \quad 110$

$\begin{array}{llllll}9 & 23 & 58 & 10 & 336\end{array}$

$\begin{array}{llllll}10 & 22 & 55 & 13 & 319\end{array}$

$\begin{array}{lllll}11 & 24 & 52 & 13 & 225\end{array}$

$\begin{array}{lllll}5 & 27 & 55 & 13 & 455\end{array}$

$\begin{array}{llllll}25 & 27 & 42 & 5 & 384\end{array}$

22. $24 \quad 44 \quad 10 \quad 272$

$\begin{array}{lllll}20 & 29 & 40 & 11 & 310\end{array}$

$\begin{array}{llllll}42 & 26 & 26 & 6 & 388\end{array}$

$\begin{array}{lllllllllllll}133 & 10 & 68 & 23 & 132 & 8 & 24 & 49 & 19 & 215 & 18 & 37 & 131\end{array}$

$\begin{array}{lllllllllllll}134 & 8 & 67 & 25 & 100 & 6 & 24 & 56 & 14 & 312 & 19 & 28 & 131\end{array}$

$\begin{array}{lllllllllllll}135 & 12 & 63 & 25 & 128 & 6 & 23 & 49 & 22 & 375 & 22 & 23 & 131\end{array}$

$\begin{array}{lllllllllllll}136 & & & & & 4 & 31 & 50 & 15 & 361 & & & \\ 137 & 10 & 69 & 21 & 164 & 3 & 37 & 48 & 12 & 345 & 12 & 32 & 131\end{array}$

$\begin{array}{lllllllllllll}138 & 24 & 49 & 27 & 88 & 5 & 21 & 47 & 26 & 281 & 16 & 18 & 131\end{array}$

$\begin{array}{lllllllllllll}139 & 11 & 67 & 22 & 141 & 7 & 21 & 45 & 17 & 248 & 17 & 21 & 131\end{array}$

$\begin{array}{lllllllllllll}140 & 8 & 85 & 8 & 92 & 3 & 29 & 54 & 14 & 277 & 8 & 22 & 125\end{array}$

$\begin{array}{lllllllllllll}141 & 11 & 73 & 16 & 93 & 3 & 28 & 52 & 17 & 355 & 11 & 19 & 125\end{array}$

$\begin{array}{lllllllllllll}142 & & & & & 3 & 27 & 57 & 13 & 274 & & & \\ 143 & 9 & 71 & 21 & 204 & 4 & 28 & 52 & 16 & 323 & 17 & 23 & 125\end{array}$

$\begin{array}{lllllllllllll}144 & 12 & 74 & 14 & 165 & 5 & 24 & 49 & 22 & 447 & 6 & 24 & 125\end{array}$

$\begin{array}{lllllllllllll}145 & 11 & 70 & 19 & 137 & 2 & 22 & 57 & 19 & 241 & 12 & 27 & 125\end{array}$

$\begin{array}{lrrrrrrrrrrrr}146 & 9 & 69 & 22 & 82 & 9 & 17 & 53 & 21 & 367 & 18 & 23 & 116\end{array}$

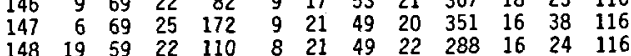

Fig. 139: Tabel 1: Clast petrography of till samples featuring exotic stone counts $(6-60 \mathrm{~mm})$ and fine gravel counts $(3-5 \mathrm{~mm})$. 
EXOTIC STONE COUNTS FINE GRAVEL COUNTS

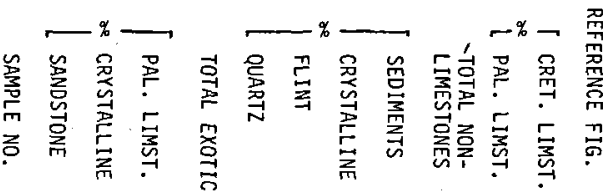

$\begin{array}{lllllllllllll}149 & 25 & 49 & 26 & 182 & 6 & 14 & 45 & 35 & 310 & 25 & 15 & 116\end{array}$ $\begin{array}{lllllllllllll}150 & 20 & 58 & 22 & 165 & 8 & 18 & 52 & 21 & 515 & 11 & 7 & 116\end{array}$ $\begin{array}{lllllllllllll}151 & 7 & 80 & 13 & 250 & 18 & 19 & 50 & 13 & 371 & 6 & 2 & 113\end{array}$ $\begin{array}{rlllllllrllll}152 & & & & & 19 & 18 & 51 & 12 & 512 & & & 113 \\ 153 & 6 & 85 & 9 & 187 & 16 & 19 & 56 & 9 & 268 & 5 & 1 & 113\end{array}$ $\begin{array}{lllllllll}154 & & & & 23 & 23 & 46 & 7 & 271\end{array}$

$\begin{array}{lllllllllllll}155 & 7 & 58 & 36 & 80 & 6 & 33 & 51 & 10 & 301 & 11 & 14 & 131\end{array}$ $\begin{array}{lllllllllllll}156 & 10 & 64 & 26 & 126 & 5 & 25 & 51 & 19 & 338 & 15 & 17 & 131\end{array}$ $\begin{array}{lllllllllllll}157 & 6 & 68 & 26 & 130 & 9 & 22 & 51 & 21 & 309 & 19 & 16 & 131\end{array}$ $\begin{array}{lllllllllllll}158 & 9 & 63 & 28 & 262 & 10 & 21 & 52 & 17 & 223 & 13 & 19 & 116\end{array}$ $\begin{array}{lllllllllllll}159 & 12 & 63 & 25 & 102 & 6 & 19 & 54 & 21 & 236 & 26 & 26 & 116\end{array}$ $\begin{array}{lllllllllllll}160 & 17 & 56 & 27 & 150 & 4 & 24 & 57 & 15 & 311 & 30 & 64 & 116\end{array}$ $\begin{array}{lllllllllllll}161 & 12 & 46 & 42 & 106 & 6 & 29 & 51 & 15 & 294 & 29 & 90 & 116\end{array}$ $\begin{array}{lllllllllllll}162 & 14 & 59 & 28 & 140 & 7 & 26 & 52 & 16 & 270 & 15 & 19 & 116\end{array}$ $\begin{array}{lllllllllllll}163 & 7 & 60 & 34 & 147 & 4 & 20 & 55 & 21 & 260 & 19 & 28 & 116\end{array}$ $\begin{array}{lllllllllllll}164 & 10 & 65 & 25 & 119 & 6 & 21 & 58 & 15 & 248 & 21 & 14 & 116\end{array}$ $\begin{array}{lllllllllllll}165 & 11 & 58 & 32 & 92 & 5 & 26 & 52 & 17 & 280 & 25 & 27 & 116\end{array}$ $\begin{array}{lllllllllllll}166 & 18 & 47 & 35 & 104 & 11 & 22 & 53 & 13 & 327 & 18 & 21 & 116\end{array}$

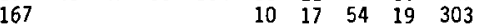

$\begin{array}{rrrrrrrrrrrrr}168 & 20 & 65 & 15 & 123 & 9 & 21 & 64 & 16 & 460 & 12 & 14 & 116\end{array}$ $\begin{array}{lllllllllllll}169 & 12 & 71 & 17 & 201 & 12 & 25 & 50 & 14 & 388 & 14 & 14 & 116\end{array}$ $\begin{array}{lllllllllllll}170 & 8 & 89 & 3 & 176 & 19 & 18 & 52 & 11 & 381 & 2 & 3 & 113\end{array}$ $\begin{array}{lllllllllllll}171 & 14 & 80 & 6 & 95 & 21 & 17 & 54 & 8 & 315 & 5 & 9 & 113\end{array}$

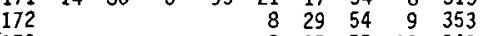
$\begin{array}{lrrrrr}173 & 8 & 25 & 55 & 12 & 340 \\ 174 & 10 & 18 & 59 & 13 & 248\end{array}$

$\begin{array}{lrllll}175 & 8 & 24 & 57 & 11 & 287\end{array}$

$\begin{array}{lrrrrr}176 & 8 & 26 & 54 & 13 & 285 \\ 177 & 9 & 27 & 55 & 9 & 303\end{array}$

$\begin{array}{lllllllllllll}178 & 14 & 63 & 23 & 108 & 5 & 31 & 52 & 12 & 306 & 20 & 12 & 116\end{array}$ $\begin{array}{lllllllllllll}179 & 18 & 56 & 25 & 110 & 9 & 16 & 59 & 16 & 255 & 26 & 17 & 116\end{array}$ $\begin{array}{llllll}180 & 23 & 25 & 41 & 11 & 314\end{array}$

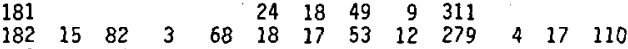
$\begin{array}{lllllllllllll}183 & 14 & 84 & 2 & 37 & 21 & 25 & 43 & 11 & 270 & 1 & 18 & 110\end{array}$ $\begin{array}{llllllll}184 & 5 & 23 & 61 & 11 & 343\end{array}$

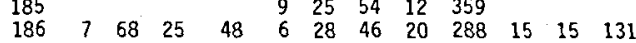
$\begin{array}{lllllllllllll}187 & 11 & 62 & 27 & 159 & 8 & 25 & 51 & 16 & 231 & 14 & 20 & 131\end{array}$ $\begin{array}{lllllllllllll}188 & 18 & 57 & 25 & 136 & 2 & 23 & 55 & 20 & 292 & 19 & 17 & 131\end{array}$ $\begin{array}{lllllllllllll}189 & 13 & 77 & 10 & 48 & 11 & 22 & 51 & 16 & 388 & 7 & 8 & 125\end{array}$ $\begin{array}{lllllllllllll}190 & 19 & 64 & 17 & 53 & 10 & 23 & 50 & 17 & 242 & 10 & 5 & 125\end{array}$ $\begin{array}{lllllllllllll}191 & 6 & 77 & 17 & 309 & 5 & 25 & 53 & 17 & 268 & 12 & 11 & 125\end{array}$ $\begin{array}{lllllllllllll}192 & 17 & 62 & 21 & 134 & 3 & 25 & 56 & 16 & 217 & 17 & 11 & 125\end{array}$ $\begin{array}{lllllllllllll}193 & 9 & 73 & 18 & 56 & 5 & 20 & 60 & 15 & 304 & 12 & 11 & 125\end{array}$ $\begin{array}{lllllllllllll}194 & 13 & 47 & 40 & 83 & 3 & 6 & 59 & 32 & 186 & 86 & 20 & 116\end{array}$ $\begin{array}{lllllllllllll}195 & 10 & 39 & 50 & 155 & 5 & 15 & 57 & 23 & 378 & 51 & 38 & 116\end{array}$ $\begin{array}{llllllllllllll}196 & 12 & 71 & 17 & 76 & 14 & 19 & 50 & 17 & 297 & 4 & 4 & 113\end{array}$

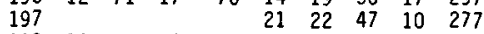

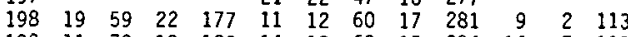
$\begin{array}{lllllllllllll}199 & 11 & 70 & 19 & 102 & 14 & 12 & 60 & 15 & 284 & 16 & 7 & 113\end{array}$ $\begin{array}{lllllllllllll}200 & 16 & 66 & 18 & 180 & 9 & 11 & 67 & 14 & 281 & 12 & 5 & 113\end{array}$ $\begin{array}{lllllllllllll}201 & 4 & 78 & 18 & 229 & 18 & 16 & 46 & 20 & 258 & 18 & 3 & 113\end{array}$ $\begin{array}{lllllllllllll}202 & 9 & 80 & 11 & 173 & 11 & 12 & 64 & 14 & 314 & 8 & 15 & 110\end{array}$ $\begin{array}{lllllllllllll}203 & 5 & 83 & 12 & 238 & 12 & 15 & 56 & 17 & 264 & 8 & 8 & 110\end{array}$ $\begin{array}{lllllllllllll}204 & 14 & 70 & 16 & 340 & 12 & 9 & 60 & 19 & 247 & 9 & 7 & 110\end{array}$ $\begin{array}{llllllllllll}205 & 17 & 60 & 23 & 251 & 20 & 10 & 57 & 13 & 435 & 15 & 3\end{array}$

$\begin{array}{llllllllllll}206 & 13 & 60 & 27 & 256 & 19 & 10 & 59 & 13 & 385 & 15 & 3\end{array}$

$\begin{array}{llllllll}207 & 5 & 21 & 56 & 17 & 382\end{array}$

$\begin{array}{llllll}208 & 7 & 35 & 46 & 12 & 234\end{array}$

$\begin{array}{lllllllllllll}209 & 9 & 71 & 20 & 188 & 6 & 25 & 58 & 11 & 432 & 16 & 11 & 125\end{array}$

$\begin{array}{lllllllllllll}210 & 18 & 71 & 11 & 77 & 13 & 21 & 57 & 9 & 385 & & 11 & \\ 211 & 18 & 74 & 17 & 194 & 8 & 26 & 59 & 12 & 391 & 10 & 14 & 125\end{array}$

$\begin{array}{lrrrrrrrrrrrr}212 & 9 & 74 & 17 & 194 & 8 & 26 & 53 & 13 & 362 & 13 & 15 & 125\end{array}$

$\begin{array}{lllllllllllll}213 & 8 & 76 & 16 & 172 & 4 & 30 & 50 & 16 & 276 & 8 & 12 & 125\end{array}$

214

215

$\begin{array}{lllll}8 & 30 & 50 & 13 & 283\end{array}$

$\begin{array}{llllll}9 & 27 & 50 & 14 & 224\end{array}$

$\begin{array}{lllll}20 & 23 & 48 & 9 & 290\end{array}$

$\begin{array}{lllllll}217 & \quad & 3 & 34 & 49 & 14 & 211\end{array}$

$\begin{array}{lllllllllllll}218 & 18 & 58 & 24 & 96 & 3 & 20 & 59 & 18 & 241 & 18 & 18 & 131\end{array}$

$\begin{array}{lllllllllllll}219 & 8 & 65 & 27 & 97 & 4 & 31 & 46 & 19 & 330 & 18 & 19 & 131\end{array}$

$\begin{array}{lllllllllllll}220 & 10 & 77 & 13 & 103 & 4 & 32 & 53 & 11 & 334 & 8 & 15 & 125\end{array}$

$\begin{array}{lllllllllllll}221 & 16 & 77 & 7 & 96 & 4 & 30 & 56 & 10 & 218 & 4 & 11 & 125\end{array}$

$\begin{array}{rrrrrrrrrrrrr}222 & 11 & 84 & 5 & 74 & 7 & 32 & 51 & 10 & 361 & 7 & 13 & 125 \\ 223 & 7 & 76 & 18 & 181 & 6 & 20 & 61 & 14 & 341 & 12 & 22 & 125\end{array}$
EXOTIC STONE COUNTS FINE GRAVEL COUNTS

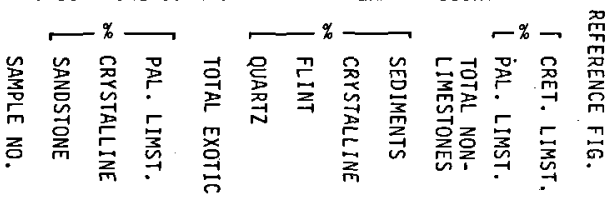

$\begin{array}{lllllllllllll}224 & 11 & 74 & 15 & 162 & 7 & 19 & 60 & 14 & 304 & 12 & 20 & 125\end{array}$ $\begin{array}{lllllllllllll}225 & 11 & 70 & 19 & 84 & 7 & 21 & 59 & 12 & 217 & 15 & 15 & 125\end{array}$ $\begin{array}{lllllllllllll}226 & 16 & 57 & 25 & 114 & 5 & 17 & 55 & 22 & 250 & 18 & 16 & 116\end{array}$ $\begin{array}{lllllllllllll}227 & 20 & 60 & 20 & 176 & 6 & 19 & 52 & 23 & 318 & 15 & 19 & 116\end{array}$ $\begin{array}{llllllllllllll}228 & 11 & 41 & 48 & 147 & 6 & 30 & 46 & 17 & 312 & 33 & 52 & 116\end{array}$ $\begin{array}{lllllllllllll}229 & 16 & 64 & 21 & 229 & 5 & 20 & 58 & 17 & 294 & 18 & 18 & 116\end{array}$ $\begin{array}{lllllllllllll}230 & 11 & 62 & 26 & 114 & 6 & 27 & 56 & 10 & 383 & 21 & 21 & 116\end{array}$ $\begin{array}{lllllllllllll}231 & 16 & 58 & 26 & 67 & 8 & 29 & 45 & 18 & 267 & 22 & 33 & 116\end{array}$ $\begin{array}{lllllllllllll}232 & 14 & 61 & 25 & 127 & 4 & 24 & 62 & 10 & 368 & 21 & 25 & 116\end{array}$ $\begin{array}{lrlllllllllll}233 & 8 & 43 & 49 & 88 & 5 & 36 & 44 & 15 & 279 & 37 & 87 & 116\end{array}$ $\begin{array}{lllllllllllll}234 & 11 & 63 & 26 & 79 & 3 & 34 & 41 & 21 & 261 & 30 & 36 & 116\end{array}$ $\begin{array}{lllllllllllll}235 & 18 & 54 & 28 & 129 & 7 & 16 & 54 & 23 & 309 & 17 & 11 & 116\end{array}$ $\begin{array}{lllllllllllll}236 & 17 & 53 & 30 & 127 & 9 & 18 & 52 & 21 & 213 & 25 & 12 & 116\end{array}$ $\begin{array}{lllllllllllll}237 & 11 & 53 & 36 & 81 & 8 & 20 & 50 & 22 & 237 & 28 & 14 & 116\end{array}$ $\begin{array}{lllllllllllll}238 & 13 & 63 & 24 & 106 & 4 & 32 & 49 & 16 & 234 & 19 & 30 & 116\end{array}$ $\begin{array}{lllllllllllll}239 & 13 & 85 & 2 & 96 & 21 & 23 & 45 & 12 & 253 & 3 & 9 & 113\end{array}$ $\begin{array}{lllllllllllll}240 & 12 & 76 & 12 & 82 & 15 & 19 & 53 & 13 & 271 & 10 & 17 & 113\end{array}$

$\begin{array}{lllllllllllll}241 & & & & & 1 & 32 & 49 & 18 & 261 & & & \\ 242 & 9 & 61 & 31 & 75 & 3 & 20 & 62 & 14 & 330 & 21 & 19 & 131\end{array}$ $\begin{array}{lllllll}243 & 4 & 31 & 49 & 16 & 320\end{array}$ $\begin{array}{llllll}244 & 5 & 25 & 53 & 17 & 310 \\ 245 & 7 & 21 & 49 & 23 & 310\end{array}$

$\begin{array}{lllllllllllll}246 & 12 & 69 & 19 & 139 & 4 & 24 & 60 & 12 & 361 & 11 & 23 & 125\end{array}$ $\begin{array}{lrlllllllllll}247 & 9 & 70 & 22 & 111 & 4 & 28 & 52 & 16 & 284 & 17 & 19 & 116\end{array}$ $\begin{array}{lllllllllllll}248 & 19 & 57 & 24 & 64 & 6 & 27 & 51 & 16 & 218 & 21 & 18 & 116\end{array}$ $\begin{array}{lllllllllllll}249 & 15 & 61 & 24 & 169 & 5 & 29 & 57 & 9 & 320 & 22 & 18 & 116\end{array}$ 250

251

$\begin{array}{llllllllrllll}253 & 14 & 57 & 29 & 108 & 5 & 31 & 56 & 8 & 318 & 15 & 16 & 131\end{array}$ $\begin{array}{lllllllllllll}254 & 7 & 67 & 27 & 191 & 4 & 26 & 49 & 21 & 309 & 22 & 20 & 131\end{array}$ 255

$\begin{array}{lllll}256 & 11 & 68 & 21 & 72\end{array}$

$\begin{array}{lllll}257 & 13 & 69 & 18 & 157\end{array}$

$\begin{array}{lllll}258 & 16 & 67 & 17 & 85\end{array}$

$\begin{array}{lllll}259 & 19 & 68 & 13 & 161\end{array}$

$\begin{array}{llllll}260 & 14 & 70 & 16 & 101\end{array}$

$\begin{array}{llllll}261 & 9 & 72 & 19 & 142\end{array}$

$\begin{array}{lrlllllllllll}262 & 9 & 61 & 30 & 116 & 2 & 24 & 44 & 20 & 326 & 15 & 12 & 116\end{array}$ $\begin{array}{lllllllllllll}263 & 19 & 54 & 27 & 108 & 10 & 27 & 50 & 13 & 342 & 15 & 15 & 116\end{array}$ $\begin{array}{lllllllllllll}264 & 17 & 61 & 22 & 64 & 9 & 29 & 48 & 14 & 392 & 20 & 12 & 116\end{array}$ $\begin{array}{lllllllllllll}265 & 7 & 56 & 37 & 93 & 2 & 19 & 54 & 25 & 234 & 18 & 16 & 116\end{array}$ $\begin{array}{lllllllllllll}266 & 12 & 47 & 40 & 98 & 2 & 29 & 56 & 13 & 271 & 27 & 29 & 116\end{array}$ $\begin{array}{lllllllllllll}267 & 11 & 61 & 28 & 132 & 2 & 24 & 56 & 18 & 318 & 38 & 36 & 116\end{array}$ $\begin{array}{lllllllllllll}268 & 19 & 48 & 33 & 90 & 3 & 21 & 57 & 19 & 306 & 39 & 33 & 116\end{array}$ $\begin{array}{lllllllllllll}269 & 12 & 66 & 22 & 217 & 2 & 31 & 56 & 11 & 412 & 20 & 21 & 116\end{array}$ $\begin{array}{lllllllllllll}270 & 12 & 63 & 25 & 186 & 2 & 31 & 53 & 17 & 244 & 17 & 22 & 131\end{array}$ $\begin{array}{lllllllllllll}271 & 9 & 55 & 36 & 105 & 2 & 34 & 45 & 19 & 318 & 22 & 16 & 131\end{array}$ $\begin{array}{lllllllllllll}272 & 10 & 64 & 26 & 90 & 3 & 29 & 56 & 12 & 301 & 18 & 36 & 131\end{array}$ $\begin{array}{lllllllllllll}273 & 13 & 58 & 28 & 269 & 3 & 23 & 57 & 17 & 264 & 20 & 17 & 131\end{array}$ 274

$\begin{array}{llllll}3 & 24 & 56 & 17 & 304\end{array}$

$\begin{array}{lllll}275 & 13 & 72 & 15 & 209\end{array}$ $\begin{array}{llllll}276 & 10 & 67 & 23 & 164\end{array}$ $\begin{array}{rrrrr}277 & 12 & 69 & 19 & 58 \\ 278 & 8 & 73 & 19 & 183\end{array}$ $\begin{array}{lllll}279 & 15 & 67 & 18 & 103\end{array}$ $\begin{array}{lllll}280 & 14 & 66 & 20 & 211\end{array}$ $\begin{array}{lllll}281 & 11 & 67 & 21 & 116\end{array}$ $\begin{array}{llllll}282 & 15 & 62 & 23 & 156\end{array}$ $\begin{array}{lllll}283 & 14 & 57 & 30 & 163\end{array}$

$\begin{array}{lllll}284 & 6 & 67 & 27 & 129\end{array}$

$\begin{array}{lllll}285 & 8 & 69 & 23 & 112\end{array}$

$\begin{array}{lllll}286 & 13 & 65 & 22 & 1110\end{array}$

$\begin{array}{llllll}287 & 19 & 61 & 20 & 36\end{array}$ $\begin{array}{lllll}288 & 15 & 63 & 22 & 47\end{array}$

$\begin{array}{lllll}289 & 13 & 63 & 24 & 159\end{array}$

$\begin{array}{lllll}290 & 7 & 68 & 25 & 149\end{array}$ $\begin{array}{lllll}291 & 11 & 58 & 31 & 162\end{array}$ $\begin{array}{rrrrr}292 & 10 & 69 & 21 & 149 \\ 293 & 16 & 64 & 20 & 77\end{array}$ $\begin{array}{lllll}293 & 16 & 64 & 20 & 77 \\ 294 & 15 & 62 & 19 & 90\end{array}$ $\begin{array}{llllllll}31 & 54 & 13 & 247 & 14 & 28 & 125\end{array}$ $\begin{array}{lllllllllllll}295 & 7 & 82 & 11 & 74 & 3 & 22 & 60 & 15 & 360 & 8 & 13 & 125\end{array}$ $\begin{array}{lllllllllllll}296 & 14 & 72 & 15 & 72 & 3 & 24 & 55 & 18 & 380 & 8 & 26 & 125\end{array}$ $\begin{array}{rrrrrrrrrrrrr}297 & 11 & 72 & 17 & 136 & 2 & 28 & 59 & 11 & 274 & 14 & 26 & 125 \\ 298 & 15 & 68 & 18 & 93 & 3 & 25 & 63 & 9 & 316 & 12 & 36 & 125\end{array}$ 
EXOTIC STONE COUNTS FINE GRAVEL COUNTS

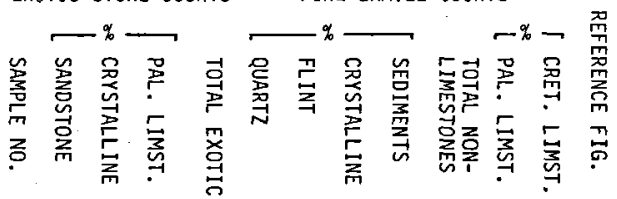

$\begin{array}{lllllllllllll}299 & 4 & 77 & 19 & 114 & 5 & 25 & 55 & 14 & 409 & 13 & 9 & 125\end{array}$

$\begin{array}{lllllllllllll}300 & 9 & 69 & 22 & 137 & 2 & 35 & 52 & 11 & 347 & 18 & 22 & 119\end{array}$

$\begin{array}{lllllllllllll}301 & 15 & 62 & 23 & 93 & 2 & 28 & 52 & 18 & 291 & 21 & 16 & 119\end{array}$

$\begin{array}{lllllllllllll}302 & 15 & 61 & 24 & 275 & 3 & 22 & 56 & 19 & 384 & 24 & 19 & 119\end{array}$

$\begin{array}{lllllllllllll}303 & 0 & 80 & 20 & 170 & 3 & 28 & 53 & 16 & 208 & 18 & 14 & 131\end{array}$

$\begin{array}{lllll}304 & 5 & 75 & 20 & 251\end{array}$

$\begin{array}{lllllllllllll}305 & 0 & 89 & 11 & 423 & 6 & 31 & 50 & 15 & 300 & 9 & 11 & 125\end{array}$

$\begin{array}{lllllllllllll}306 & 2 & 88 & 9 & 150 & 4 & 34 & 55 & 7 & 206 & 11 & 13 & 125\end{array}$

$\begin{array}{lllllllllllll}307 & 5 & 90 & 5 & 302 & 5 & 32 & 47 & 16 & 291 & 7 & 21 & 125\end{array}$

$\begin{array}{lllllllllllll}308 & 3 & 85 & 12 & 403 & 2 & 32 & 49 & 17 & 320 & 9 & 14 & 125\end{array}$

$\begin{array}{lllllllllllll}309 & 5 & 85 & 10 & 580 & 6 & 36 & 47 & 11 & 309 & 11 & 17 & 125\end{array}$

$\begin{array}{lllllllllllll}310 & 3 & 89 & 8 & 127 & 6 & 26 & 55 & 14 & 268 & 8 & 19 & 122\end{array}$

$\begin{array}{lllllllllllll}311 & 9 & 77 & 14 & 75 & 6 & 22 & 61 & 10 & 235 & 7 & 18 & 122\end{array}$

$\begin{array}{lllllllllllll}312 & 3 & 89 & 8 & 60 & 8 & 24 & 57 & 11 & 289 & 5 & 20 & 122\end{array}$

$\begin{array}{lllll}313 & 2 & 86 & 12 & 600\end{array}$

$\begin{array}{lllll}314 a & 14 & 56 & 30 & 124\end{array}$

$\begin{array}{lrrrrrrrrrrrr}316 \mathrm{~b} & 10 & 68 & 22 & 437 & 2 & 19 & 61 & 18 & 215 & 17 & 30 & 131 \\ 3 & 40 & 4 & 16 & 65 & 15 & 287 & 16 & 23 & 131\end{array}$

$\begin{array}{lllllllllllll}317 \mathrm{a} & 5 & 78 & 16 & 166 & 3 & 25 & 53 & 20 & 253 & 13 & 23 & 125\end{array}$

$\begin{array}{lllllllllllll}317 \mathrm{~b} & 8 & 75 & 17 & 96 & 3 & 22 & 60 & 14 & 328 & 12 & 17 & 125\end{array}$

$\begin{array}{lllllllllllll}318 a & 12 & 67 & 21 & 149 & 2 & 15 & 65 & 17 & 231 & 23 & 19 & 119\end{array}$

$\begin{array}{lllllllllllll}318 \mathrm{~b} & 14 & 51 & 35 & 65 & 3 & 17 & 61 & 19 & 301 & 25 & 24 & 119\end{array}$

$\begin{array}{lllllllllllll}319 & 5 & 68 & 27 & 216 & 6 & 30 & 45 & 19 & 277 & 21 & 19 & 131\end{array}$

$\begin{array}{lllll}320 & 6 & 63 & 31 & 118\end{array}$

$\begin{array}{llllll}321 & 10 & 71 & 19 & 159\end{array}$

$\begin{array}{lllll}322 & 11 & 72 & 17 & 258\end{array}$

$\begin{array}{rrrrr}323 & 8 & 84 & 8 & 254 \\ 324 & 5 & 80 & 15 & 216\end{array}$

$\begin{array}{rrrrr}325 & 4 & 94 & 2 & 346\end{array}$

$\begin{array}{rrrrr}326 & 10 & 83 & 7 & 116 \\ 327 & 4 & 90 & 6 & 305\end{array}$

$\begin{array}{lllll}327 & 4 & 90 & 6 & 305 \\ 328 & 9 & 82 & 9 & 381\end{array}$

$\begin{array}{llllll}329 & 11 & 78 & 11 & 176\end{array}$

$\begin{array}{lllll}330 & 21 & 61 & 18 & 171\end{array}$

$\begin{array}{llllll}331 & 5 & 76 & 19 & 139\end{array}$

$\begin{array}{lllll}332 & 7 & 70 & 23 & 126\end{array}$

$\begin{array}{lllll}333 & 9 & 76 & 15 & 144\end{array}$

$\begin{array}{lllll}334 & 6 & 70 & 23 & 137 \\ 335 & 4 & 92 & 4 & 300\end{array}$

$\begin{array}{rrrrr}335 & 4 & 92 & 4 & 300 \\ 336 & 12 & 74 & 14 & 169\end{array}$

$\begin{array}{llllll}337 & 15 & 69 & 16 & 63\end{array}$

$\begin{array}{lllll}338 & 9 & 80 & 11 & 114\end{array}$

$\begin{array}{lllll}339 & 11 & 71 & 18 & 171\end{array}$

$\begin{array}{lllll}340 & 14 & 61 & 25 & 109\end{array}$

$\begin{array}{lrlll}341 \quad 8 & 72 & 20 & 161\end{array}$

$\begin{array}{lllll}342 & 18 & 63 & 19 & 192\end{array}$

$\begin{array}{lllll}343 & 2 & 65 & 33 & 183\end{array}$

$\begin{array}{lllll}344 & 8 & 60 & 32 & 145\end{array}$

$\begin{array}{lllll}345 & 6 & 60 & 34 & 162\end{array}$

$\begin{array}{lllll}346 & 10 & 64 & 26 & 415\end{array}$

$\begin{array}{lllll}347 & 10 & 62 & 28 & 140\end{array}$

$\begin{array}{lllll}348 & 12 & 63 & 25 & 563\end{array}$

$\begin{array}{lllll}349 & 7 & 65 & 28 & 380\end{array}$

$\begin{array}{lllll}350 & 16 & 54 & 30 & 146\end{array}$

$\begin{array}{lllll}351 & 11 & 68 & 21 & 708\end{array}$

$\begin{array}{lllll}352 & 11 & 67 & 22 & 505\end{array}$

$\begin{array}{lllll}353 & 11 & 68 & 21 & 381\end{array}$

$\begin{array}{rrrrr}354 & 2 & 94 & 4 & 266\end{array}$

$\begin{array}{rrrrr}355 & 5 & 86 & 9 & 247\end{array}$

$\begin{array}{lllll}355 & 11 & 78 & 11 & 177\end{array}$

$\begin{array}{lllll}357 & 8 . & 62 & 30 & 176\end{array}$

$\begin{array}{lllll}358 & 13 & 56 & 31 & 117\end{array}$

$\begin{array}{lllll}359 & 16 & 60 & 24 & 176\end{array}$

$\begin{array}{lllll}360 & 12 & 69 & 19 & 160\end{array}$

$\begin{array}{lllll}361 & 12 & 60 & 28 & 206\end{array}$

$\begin{array}{lllll}362 & 17 & 58 & 25 & 213\end{array}$

$\begin{array}{lllll}364 & 11 & 63 & 26 & 172\end{array}$

$\begin{array}{lllll}365 & 10 & 69 & 21 & 97\end{array}$

$\begin{array}{lllll}366 & 7 & 66 & 26 & 200\end{array}$

$\begin{array}{lllll}367 & 6 & 75 & 19 & 428\end{array}$

$\begin{array}{lllll}368 & 5 & 72 & 23 & 210\end{array}$

$\begin{array}{lllll}369 & 3 & 70 & 17 & 125\end{array}$

$\begin{array}{lllll}370 & 4 & 78 & 17 & 420\end{array}$

$\begin{array}{rrrrr}371 & 5 & 88 & 8 & 189 \\ 372 & 2 & 91 & 7 & 83\end{array}$

$\begin{array}{llllllll}4 & 23 & 60 & 13 & 287 & 13 & 20 & 125\end{array}$

125

$\begin{array}{llllllll}5 & 12 & 77 & 6 & 222 & 2 & 10 & 125\end{array}$

$\begin{array}{rrrrrrrr}7 & 24 & 62 & 7 & 272 & 6 & 15 & 125 \\ 4 & 32 & 56 & 9 & 318 & 10 & 15 & 125\end{array}$

125

$\begin{array}{llllllll}3 & 24 & 54 & 19 & 280 & 18 & 34 & 122\end{array}$

122
122

$\begin{array}{llllllll}4 & 20 & 58 & 18 & 297 & 14 & 24 & 122\end{array}$

$\begin{array}{llllllll}2 & 11 & 71 & 18 & 214 & 4 & 10 & 122\end{array}$

122

122

$\begin{array}{llllllll}4 & 31 & 43 & 22 & 256 & 22 & 79 & 116\end{array}$

$\begin{array}{llllllll}6 & 20 & 54 & 20 & 312 & 24 & 19 & 134\end{array}$

$\begin{array}{llllllll}3 & 13 & 60 & 23 & 247 & 28 & 20 & 134\end{array}$

$\begin{array}{llllllll}4 & 18 & 57 & 21 & 246 & 26 & 12 & 134 \\ 2 & 17 & 60 & 21 & 210 & 21 & 16 & 134\end{array}$

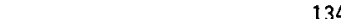

$\begin{array}{llllllll}5 & 24 & 59 & 12 & 225 & 19 & 8 & 134\end{array}$

$\begin{array}{llllllll}3 & 14 & 65 & 18 & 289 & 18 & 22 & 131\end{array}$

$\begin{array}{llllllll}6 & 24 & 59 & 11 & 208 & 16 & 10 & 131\end{array}$

$\begin{array}{llllllll}4 & 28 & 56 & 12 & 218 & 11 & 9 & 125\end{array}$

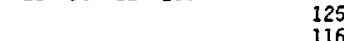

$\begin{array}{llllllll}3 & 9 & 62 & 26 & 292 & 22 & 27 & 116\end{array}$

$\begin{array}{llllllll}2 & 13 & 67 & 18 & 274 & 24 & 17 & 116\end{array}$

$\begin{array}{llllllll}1 & 20 & 63 & 16 & 260 & 21 & 24 & 116\end{array}$

$\begin{array}{llllllll}4 & 22 & 60 & 14 & 194 & 24 & 22 & 134\end{array}$

$\begin{array}{llllllll}2 & 19 & 68 & 11 & 284 & 18 & 23 & 134\end{array}$

$\begin{array}{llllllll}5 & 21 & 67 & 8 & 206 & 8 & 26 & 131\end{array}$

$\begin{array}{llllllll}4 & 17 & 67 & 12 & 198 & 10 & 21 & 131\end{array}$

131
131
125
EXOTIC STONE COUNTS FINE GRAVEL COUNTS

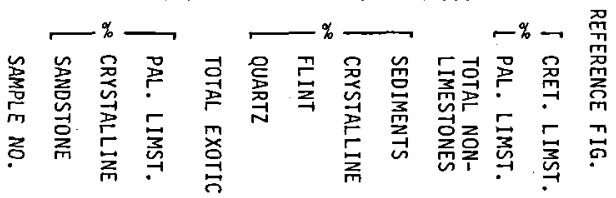

$\begin{array}{lllllllllllll}373 & 4 & 87 & 9 & 242 & 4 & 21 & 78 & 7 & 211 & 8 & 16 & 125\end{array}$

$\begin{array}{lllllllllll}374 & 4 & 84 & 12 & 410 & & 78 & 211 & 8 & 16 & 125\end{array}$

$\begin{array}{rrrrrrrrrrrrr}375 & 16 & 76 & 8 & 286 & & & & & & & & \\ 376 & 5 & 87 & 8 & 147 & 6 & 17 & 67 & 10 & 207 & 15 & 20 & 125\end{array}$

$\begin{array}{llllllllllllll}377 & 7 & 68 & 25 & 129 & & & & & 10 & 207 & 15 & 20 & 125\end{array}$

$\begin{array}{lllllllllllll}378 & 11 & 87 & 2 & 230 & 2 & 14 & 70 & 14 & 358 & 8 & 21 & 121\end{array}$

$\begin{array}{lllllllllllll}379 & 10 & 79 & 11 & 213 & 2 & 14 & 72 & 12 & 217 & 10 & 20 & 121\end{array}$

$\begin{array}{lrrrr}380 & 8 & 53 & 39 & 215\end{array}$

$\begin{array}{lllll}381 & 9 & 59 & 32 & 199\end{array}$

$\begin{array}{llllll}382 & 8 & 83 & 8 & 108\end{array}$

$\begin{array}{llllll}383 & 2 & 87 & 11 & 150\end{array}$

$\begin{array}{lllll}384 & 11 & 75 & 14 & 175\end{array}$

$\begin{array}{llllll}385 & 7 & 78 & 15 & 186\end{array}$

$\begin{array}{rrrrr}386 & 8 & 80 & 12 & 115 \\ 387 & 2 & 96 & 2 & 445\end{array}$

$\begin{array}{llllll}388 & 4 & 92 & 4 & 344\end{array}$

$\begin{array}{rrrrr}389 & 0 & 98 & 2 & 82 \\ 390 & 3 & 88 & 9 & 475\end{array}$

$\begin{array}{lllll}390 & 3 & 88 & 9 & 475 \\ 391 & 4 & 89 & 7 & 125\end{array}$

$\begin{array}{llllll}392 & 7 & 79 & 14 & 541\end{array}$

$\begin{array}{lllll}393 & 3 & 94 & 3 & 690\end{array}$

$\begin{array}{lllll}394 & 6 & 86 & 8 & 602\end{array}$

$\begin{array}{lllll}395 & 3 & 88 & 9 & 105 \\ 396 & 2 & 92 & 5 & 184\end{array}$

$\begin{array}{lllll}397 & 2 & 96 & 2 & 354\end{array}$

$\begin{array}{llll}398 & 1 & 96 & 3 \cdot 141\end{array}$

$\begin{array}{llllll}399 & 8 & 78 & 14 & 673\end{array}$

$\begin{array}{lllll}400 & 8 & 80 & 12 & 77\end{array}$

$\begin{array}{lllll}401 & 11 & 64 & 25 & 252\end{array}$

$\begin{array}{lllll}402 & 6 & 71 & 23 & 474\end{array}$

$\begin{array}{lllll}403 & 11 & 68 & 21 & 210\end{array}$

$\begin{array}{lllll}404 & 4 & 72 & 24 & 312\end{array}$

$\begin{array}{lllll}405 & 7 & 73 & 20 & 294\end{array}$

$\begin{array}{lllll}406 & 12 & 66 & 22 & 222\end{array}$

$\begin{array}{lllll}407 & 7 & 65 & 28 & 273\end{array}$

$\begin{array}{lllll}408 & 12 & 63 & 25 & 126\end{array}$

$\begin{array}{lllll}409 & 7 & 72 & 21 & 208\end{array}$

$\begin{array}{lllll}410 & 5 & 87 & 8 & 236\end{array}$

$\begin{array}{rrrrr}411 & 8 & 85 & 8 & 191 \\ 412 & 5 & 82 & 13 & 564\end{array}$

$\begin{array}{lllll}413 & 2 & 85 & 12 & 146\end{array}$

$\begin{array}{rrrrr}413 & 2 & 86 & 12 & 146 \\ 414 & 3 & 85 & 2 & 189\end{array}$

$\begin{array}{lllll}415 & 5 & 86 & 9 & 459\end{array}$

$\begin{array}{lllll}416 & 5 & 85 & 10 & 311\end{array}$

$\begin{array}{lllll}418 & 2 & 95 & 3 & 179\end{array}$

$\begin{array}{lllll}418 & 2 & 95 & 3 & 179 \\ 419 & 4 & 88 & 8 & 245\end{array}$

$\begin{array}{lllll}420 & 3 & 96 & 1 & 450\end{array}$

$\begin{array}{lllll}421 & 14 & 56 & 30 & 189\end{array}$

$\begin{array}{lllll}422 & 10 & 65 & 25 & 241\end{array}$

$\begin{array}{lllll}423 & 11 & 53 & 36 & 149\end{array}$

$\begin{array}{lrlll}424 & 8 & 62 & 30 & 116\end{array}$

$\begin{array}{lllll}425 & 18 & 45 & 37 & 93\end{array}$

$\begin{array}{lllll}426 & 10 & 58 & 32 & 116\end{array}$

$\begin{array}{lllll}428 & 13 & 62 & 25 & 160\end{array}$

$\begin{array}{lllll}429 & 12 & 60 & 28 & 206\end{array}$

$\begin{array}{rrrrr}430 & 8 & 60 & 32 & 114\end{array}$

$\begin{array}{lllll}431 & 12 & 58 & 30 & 101\end{array}$

$\begin{array}{lllll}432 & 6 & 67 & 27 & 114\end{array}$

$\begin{array}{lllll}433 & 16 & 65 & 19 & 257\end{array}$

$\begin{array}{llllll}434 & 11 & 68 & 21 & 84\end{array}$

$\begin{array}{lllll}435 & 7 & 66 & 27 & 203\end{array}$

$\begin{array}{lllll}436 & 13 & 74 & 13 & 160\end{array}$

$\begin{array}{lllll}437 & 12 & 71 & 17 & 152\end{array}$

$\begin{array}{lllll}438 & 11 & 73 & 16 & 172\end{array}$

$\begin{array}{llllll}439 & 9 & 84 & 7 & 150\end{array}$

$\begin{array}{lllll}440 & 9 & 85 & 6 & 140 \\ 441 & 5 & 87 & 8 & 188\end{array}$

$\begin{array}{lllll}441 & 5 & 87 & 8 & 188\end{array}$

$\begin{array}{lllll}442 & 3 & 97 & 0 & 199 \\ 443 & 4 & 88 & 8 & 114\end{array}$

$\begin{array}{rrrrr}443 & 4 & 88 & 8 & 114 \\ 444 & 13 & 70 & 17 & 223\end{array}$

$\begin{array}{rrrrr}445 & 4 & 94 & 2 & 112\end{array}$

$\begin{array}{lllllllllllll}446 & 2 & 98 & 0 & 290 & 2 & 8 & 82 & 7 & 219 & 4 & 6 & 122\end{array}$

$\begin{array}{rrrrrrrrrrrrr}446 & 2 & 98 & 0 & 290 & 2 & 7 & 77 & 14 & 306 & 8 & 9 & 122 \\ 447 & 5 & 77 & 18 & 156 & 3 & 13 & 73 & 11 & 183 & 19 & 29 & 122\end{array}$

$\begin{array}{lllll}448 & 8 & 64 & 27 & 217 \\ 449 & 7 & 70 & 23 & 477\end{array}$ $\begin{array}{llllllll}2 & 16 & 67 & 14 & 249 & 18 & 10 & 134\end{array}$

$\begin{array}{llllllll}3 & 20 & 67 & 10 & 292 & 11 & 12 & 128\end{array}$

$\begin{array}{llllllll}3 & 23 & 59 & 15 & 202 & 6 & 42 & 128\end{array}$

$\begin{array}{llllllll}3 & 18 & 64 & 14 & 304 & 10 & 19 & 128\end{array}$

$\begin{array}{llllllll}6 & 14 & 77 & 3 & 269 & 6 & 14 & 125\end{array}$

125
125
125

$\begin{array}{llllllll}3 & 14 & 60 & 23 & 270 & 14 & 23 & 125\end{array}$

122
122

122

$\begin{array}{lllllll}19 & 61 & 18 & 214 & 20 & 14 & 134\end{array}$

$\begin{array}{llllllll}4 & 16 & 64 & 16 & 196 & 18 & 24 & 134\end{array}$

$\begin{array}{llllllll}2 & 14 & 63 & 21 & 274 & 22 & 18 & 134\end{array}$

$\begin{array}{llllllll}4 & 19 & 65 & 12 & 219 & 19 & 12 & 134\end{array}$

$\begin{array}{lllllll}21 & 60 & 16 & 234 & 20 & 20 & 134 \\ & & \end{array}$

$\begin{array}{llllllll}2 & 24 & 63 & 11 & 263 & 10 & 21 & 128\end{array}$

$\begin{array}{llllllll}4 & 16 & 66 & 14 & 211 & 6 & 11 & 125\end{array}$

$\begin{array}{lllllllll}3 & 21 & 65 & 11 & 250 & 8 & 23 & 125\end{array}$

$\begin{array}{llllllll}5 & 26 & 55 & 14 & 181 & 6 & 21 & 125\end{array}$

125
125

125

134

$\begin{array}{llllllll}1 & 19 & 56 & 24 & 254 & 25 & 24 & 134\end{array}$

$\begin{array}{llllllll}3 & 16 & 71 & 10 & 219 & 28 & 36 & 134 \\ 2 & 17 & 64 & 17 & 291 & 22 & 30 & 134\end{array}$

134

134

134
134

$\begin{array}{llllllll}1 & 19 & 64 & 16 & 257 & 20 & 25 & 134\end{array}$

$\begin{array}{llllllll}5 & 26 & 55 & 14 & 204 & 21 & 29 & 134 \\ 2 & 16 & 56 & 16 & 170 & 16 & 20 & 134\end{array}$

$\begin{array}{llllllll}5 & 23 & 54 & 18 & 168 & 18 & 25 & 134\end{array}$

$\begin{array}{llllllll}1 & 20 & 69 & 10 & 226 & 11 & 21 & 128\end{array}$

$\begin{array}{llllllll}4 & 15 & 68 & 12 & 228 & 15 & 26 & 128\end{array}$

$\begin{array}{llllllll}5 & 22 & 63 & 10 & 281 & 12 & 20 & 128\end{array}$

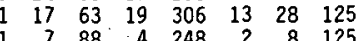

125

$\begin{array}{llllllll}3 & 19 & 62 & 16 & 249 & 42 & 23 & 119\end{array}$ $\begin{array}{llllllll}2 & 17 & 73 & 8 & 200 & 8 & 21 & 125\end{array}$

$\begin{array}{llllllll}0 & 10 & 83 & 7 & 191 & 7 & 12 & 122\end{array}$ 


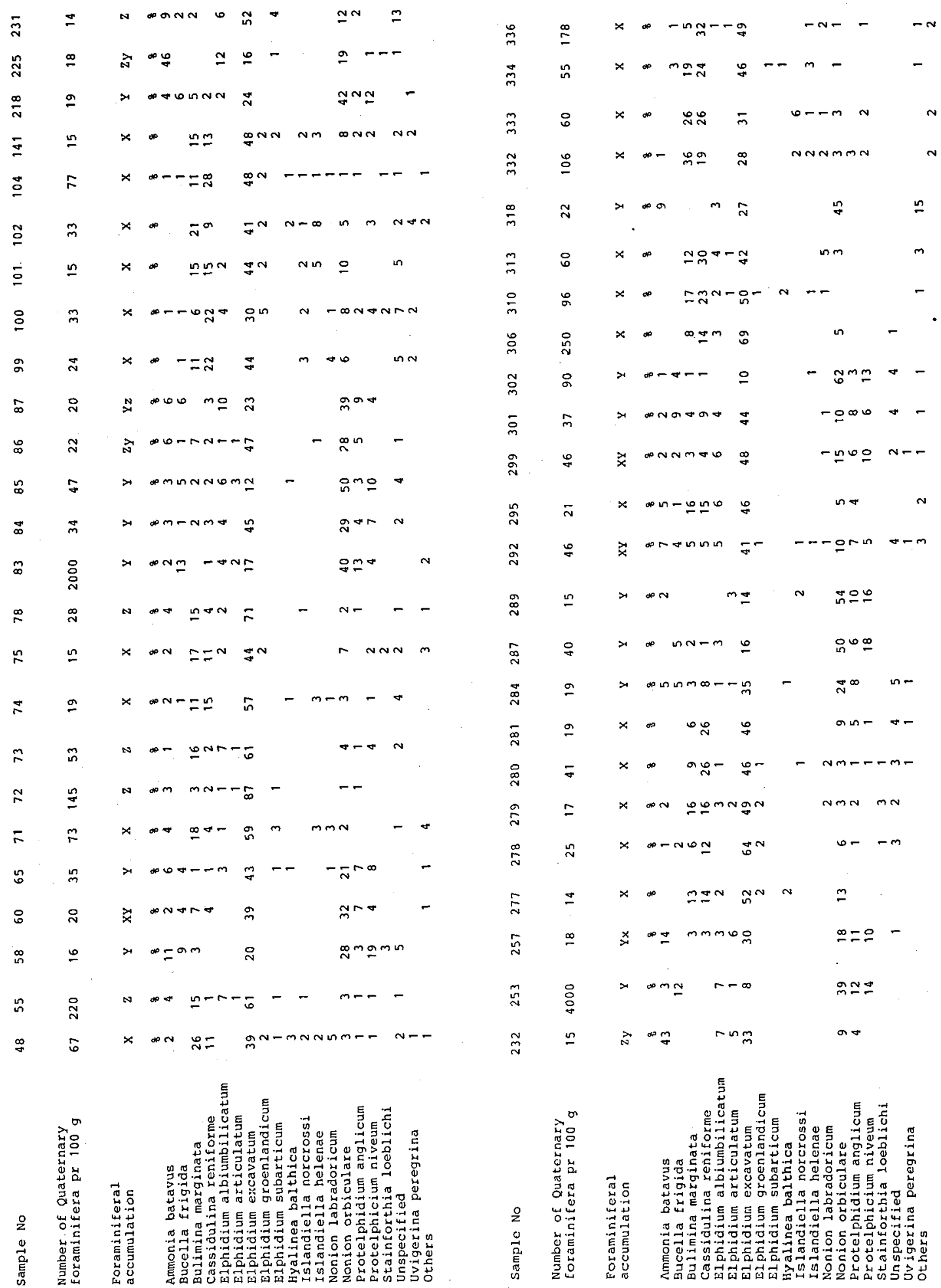

Fig. 140: Tabel 2: Contents of redeposited Quaternary foraminifera from till samples. 


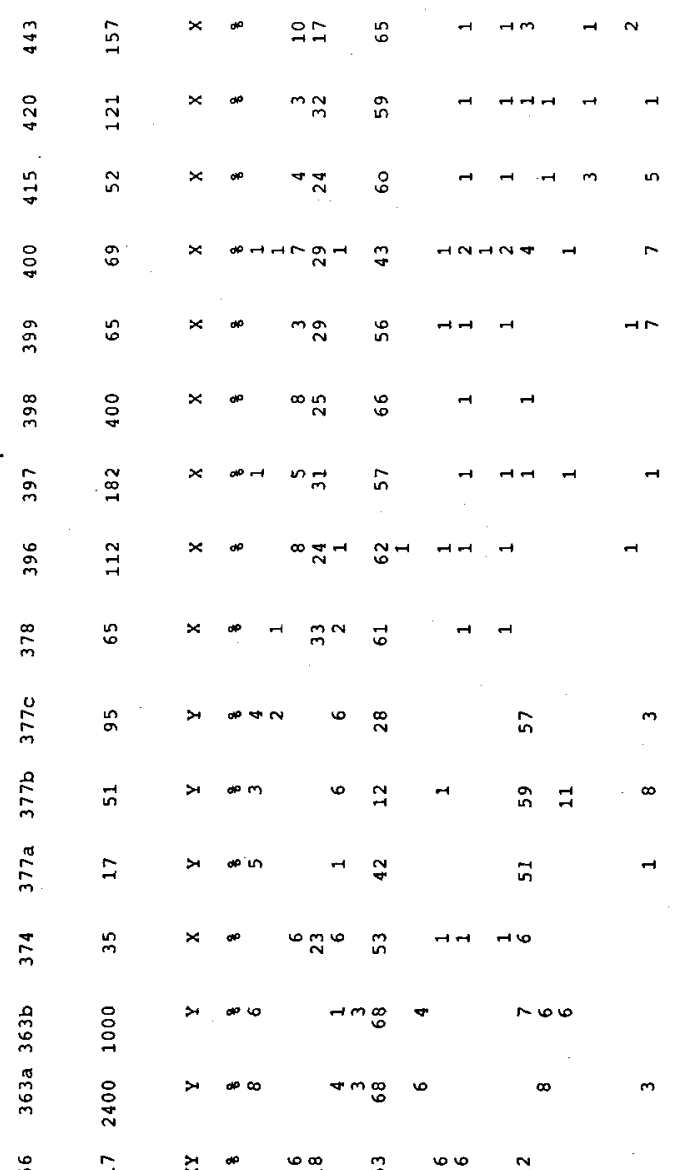

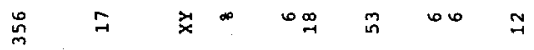

丽

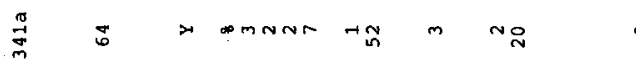

$\stackrel{m}{m} \times \stackrel{m}{m} \underset{\infty}{ }$

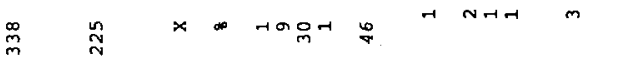

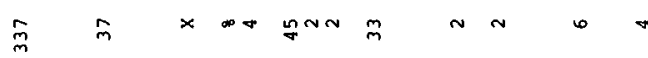

$x \rightarrow$ -

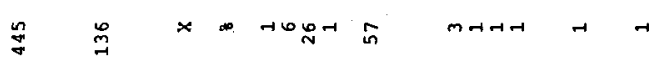
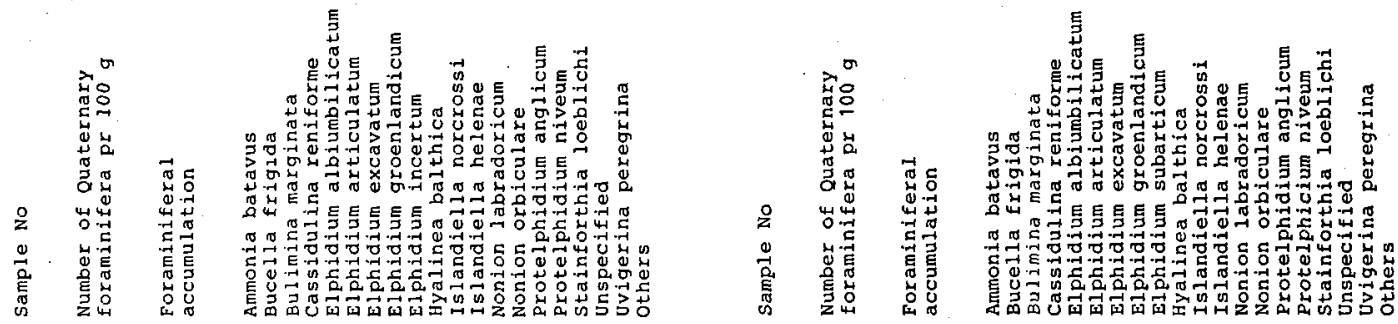
ดิ

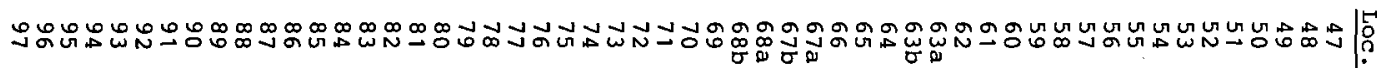
.

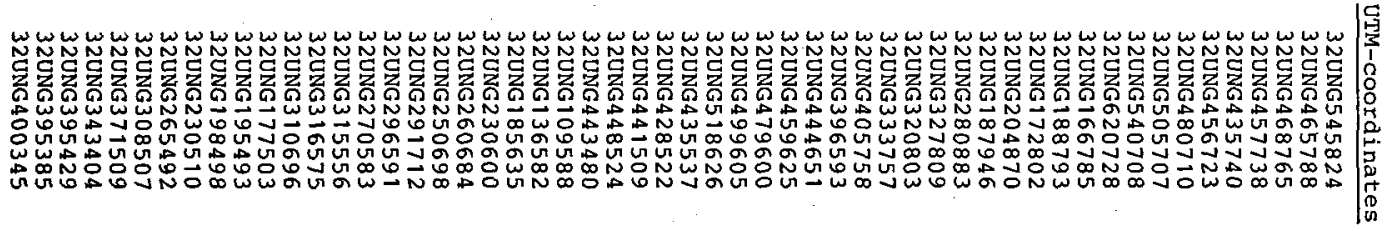

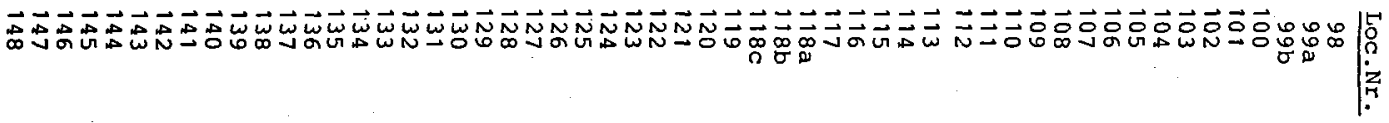

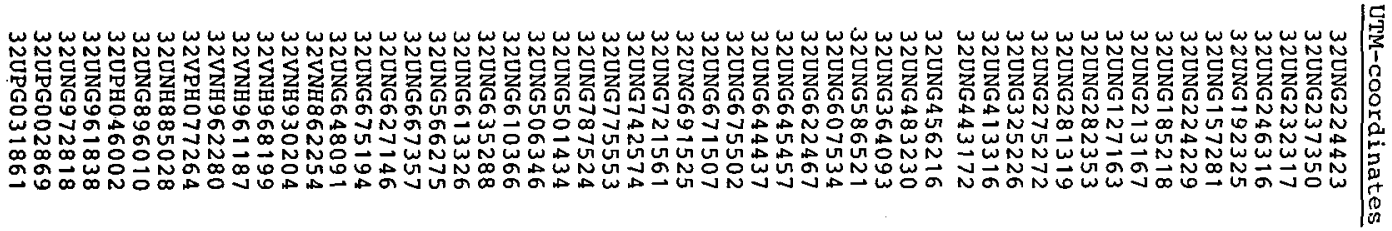

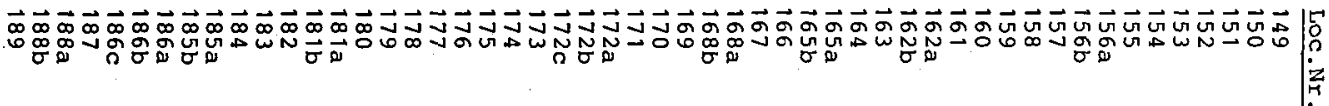

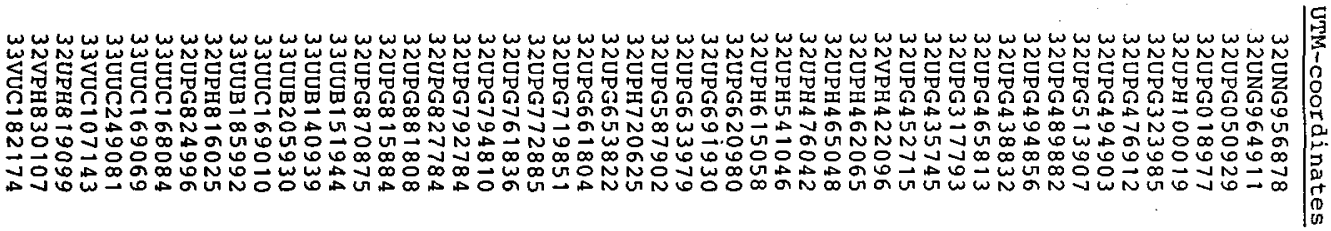

